

\section{THIS BOOK IS A PART OF THE LIBRARY OF $=$}
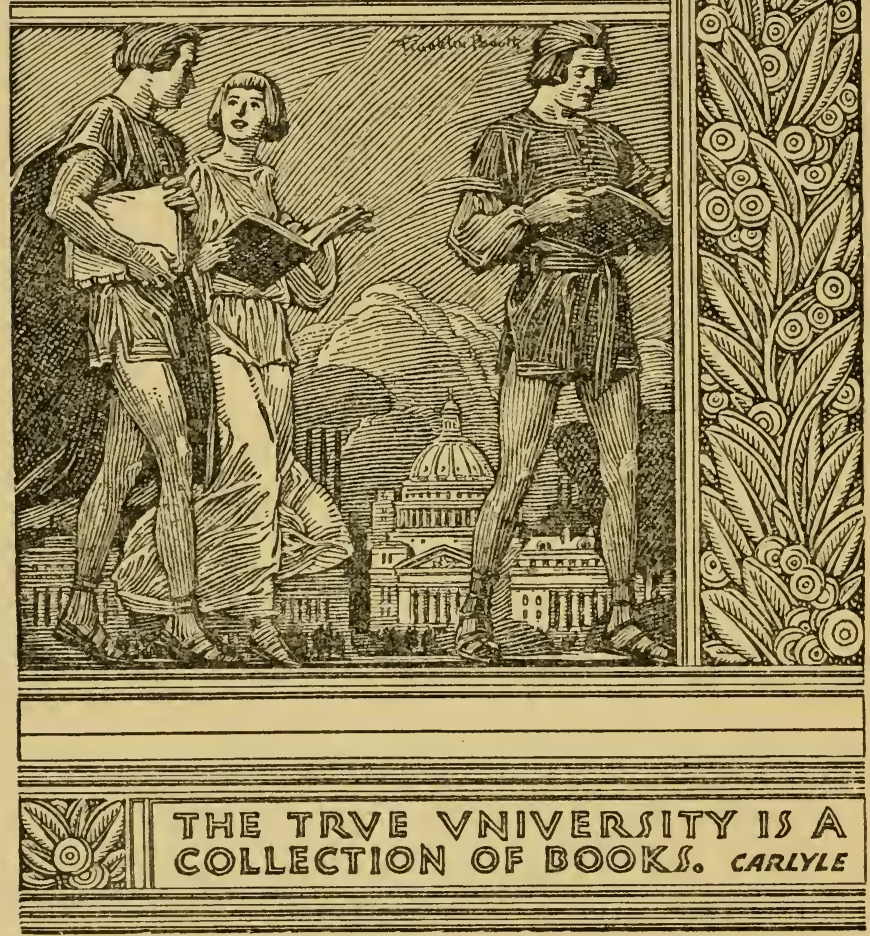

THE FUNGI 


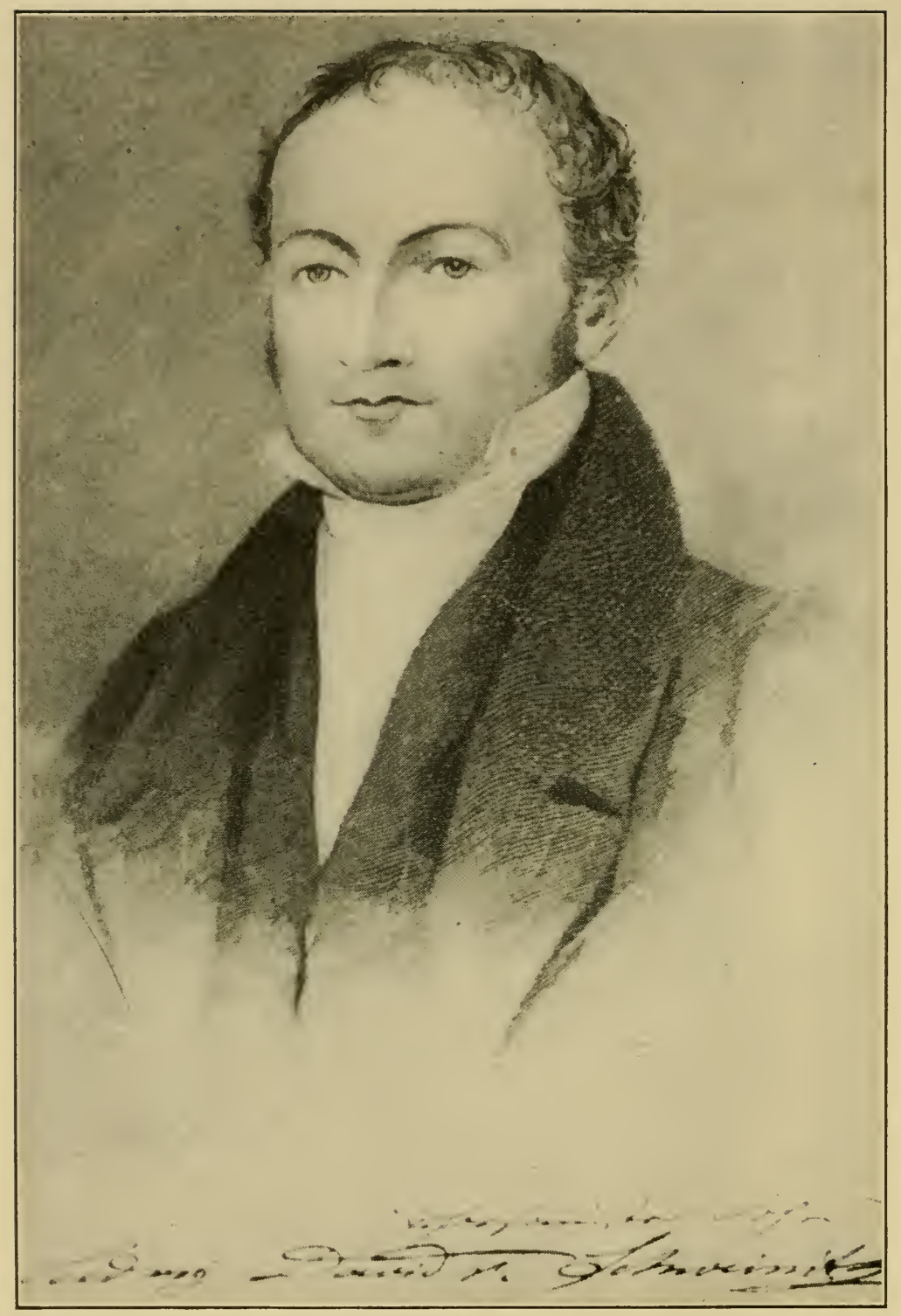

The father of American mycology. 


\title{
THE FUNGI
}

IN TWO VOLUMES

\author{
Volume I
}

By Frederick A. Wolf and Frederick T. Wolf DEPARTMENT OF BOTANY DUKE UNIVERSITY

DEPARTMENT OF BOTANY VANDERBILT UNIVERSITY

New York: JOHN WILEY \& SONS, Inc.

Chapman \&a Hall, Limited

London 


\section{Copyright, 1947}

BY

Johy WILEY \& Sows, INC.

All Rights Reserved

This book, or any part thereof, must not be reproduced in any form without the written permission of the publishers. 


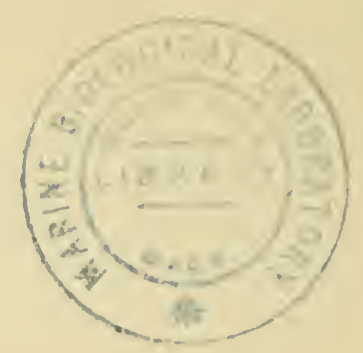

This treatise on fungi is intended as a reference and textbook. Its content falls naturally into two portions. The first portion, included in Volume I, is a consideration of the developmental morphology and taxonomy of fungi and is basic to any comprehensive study of the fungi. The second portion, included in Volume II, deals more specifically with the activities of fungi. It must be borne in mind, however, that we have attempted throughout the treatise to stress the need for more emphasis on problems relating to fungus activities.

Much of the mycological teaching and research of the past has centered around taxonomy and classification. Some emphasis has necessarily been placed on morphology and cytology, but this phase of inquiry has been largely an adjunct to taxonomy and classification. It is, of course, essential that one should be able to name a given fungus correctly, to place it in a suitable packet, and to arrange it in some phylogenetic category in an herbarium. This should, however, not be the end, as it all too commonly is, but rather the beginning of interest in the particular fungus. It would appear to be much more stimulating if, after having received a more or less "formal" introduction to a fungus, one were to turn his attention to its activities. To determine what a fungus does and how it does it and to attempt to approximate an answer to why it reacts in a certain manner have always appealed to us as of more concern than its name. The primary purpose of Volume II is therefore to direct attention away from time-honored and well-beaten paths of mycological thinking and to focus it on this different point of view.

To stress the activities of fungi with a minimum of consideration to taxonomic aspects has been no easy task. It has required, first of all, a fusion of the mycological concepts of two generations. This in itself was a departure from tradition; although it presented very real difficulties, they have not been insurmountable. Another disconcerting factor which entered into the considerations of how to emphasize the problems of fungus behavior 
was that, as all older mycologists appreciate, much which was once regarded as truth has been and is being supplanted. To unlearn seems no less difficult a task than to learn. It must be remembered, too, that it is a prodigious task to become conversant with new truths, which must be sifted from voluminous mycological literature.

Information about a particular fungus is conveyed most satisfactorily if one is able to orient it as to its structure and its relationship with other species. This orientation is best achieved by using its name understandingly. For each order and family, the barest essentials of morphology and development are given. So far as possible, species of economic importance have been chosen for this purpose.

Certain families have been omitted, mainly because they are so little known. This deficiency may incite adverse criticism, some of which is conceded to have real merit. A conscious effort has been made to de-emphasize phylogeny, so that the teacher with definite convictions on relationships among fungi will not be handicapped or inhibited by our opinions, expressed or implied. The value of present-day interpretations of phylogeny among fungi, in our opinion, still remains largely open to question.

In some instances the most acceptable binomials have not been used; instead we have used the name employed by the writer of the report cited. This practice should not create any serious difficulties for the person interested in synonomy. Except in a few instances, we have not cited the authority for the binomials employed, for two reasons: (1) the correct authority can be had from Saccardo's Sylloge Fungorum or from some monograph, and (2) valuable space is saved throughout by these omissions.

We have arbitrarily chosen to give no consideration to lichens. Mycologists may eventually agree that they should be dispersed among the Eurotiales, Sphaeriales, Hypocreales, Hysteriales, inoperculate Discomycetes, and other groups. It seems to us that, if and when this is done, it will be the result of overemphasis of the morphology of reproductive structures and of underemphasis of a very specialized structure, the lichen thallus. It would appear that the structure of the thallus and its correlated, sym- 
biotic, fungus-alga relationship are of much more importance than the morphology of reproductive parts. If it is borne in mind that this specialized thallus makes possible specialized functional relationships, it is appreciated that the lichen thallus is neither an alga nor a fungus, but is a lichen. Moreover one can best appreciate the possible complexities that may arise in this specialized dual relationship by consideration of such a species as Strigula complanata. Its algal component, Cephaleuros virescens, widely parasitizes the foliage of broad-leaved evergreens in tropical and subtropical regions and may be found living happily apart from the pyrenomycetous component. On the other hand, the two may form a lichen, and each component may reproduce itself in its own characteristic fashion.

Most of the illustrations are adapted from those of others. If the author of the original drawing has not been mentioned, the omission is unintentional. The degree of magnification is not stated for the reason that the drawings are intended only to convey some idea of appearance and relationship of parts.

It is intended that the illustrations and explanatory legends will serve to help define terms and thus to provide an understanding of the general morphology of representative genera or species. References to illustrations are omitted from the text. In this way all explanations occur as legends and remain concise.

Nearly all the drawings and graphs are the result of our own efforts, ably supplemented by those of Mary H. Wolf. Certain cuts, drawings, and photographs were, however, provided by others; and, even though their sources are mentioned in the legends, we herewith acknowledge again, with grateful appreciation, these kindnesses. We are indebted also to Dr. L. E. Wehmeyer, who carefully read the entire manuscript, for his criticisms and suggestions and to Mrs. Fred T. Wolf for assistance in proofreading and indexing.

These volumes are dedicated to Lewis David de Schweinitz (1780-1834), a distinguished pioneer in American mycology, whose achievements were the results of a labor of love during the spare moments of an otherwise all-too-busy life that was consecrated to official duties in the Moravian church. His bestknown contribution, Synopsis Fungorum in America Boreali Media Degentium, lists 3098 species of North American fungi, 
approximately 1200 of which had not previously been described. Were this his only accomplishment, it would constitute an everenduring monument and an inspiration to students of fungi in all parts of the world. His wood-cut picture, appearing as the frontispiece, was supplied by his great-granddaughter, Dr. Adelaide L. Fries, and it is our special pleasure to acknowledge this courtesy.

F. A. Wolf

F. T. Wolf

February, 1947 


\section{CONTENTS}

1. THE FOUNDING OF MYCOLOGY .

2. ISOLATION AND CULTIVATION OF FUNGI .

Isolation methods, 15. Cultivation, 21. Implications, 27.

3. CLASSIFICATION AND TAXONOMY OF FUNGI

The classes of fungi, 34. The orders of fungi, 35 .

4. THE MYXOMYCETES

5. THE PHYCOMYCETES

Chytridiales, 63. Doubtful Chytrids, 74. Lagenidiales, 74. Blastocladiales, 77. Monoblepharidales, 83. Leptomitales, 88. Saprolegniales, 92. Pythiales, 98. Albuginales, 105. Peronosporales, 108. Mucorales, 116. Entomophthorales, 128. Doubtful Zygomycetes, 133. Eccrinales, 134.

6. THE ASCOMYCETES

Hemiascomycetes, 139. Endomycetales, 140. Taphrinales, 146. Euascomycetes, 150. Plectomycetes, 152. Eurotiales, 152. Myriangiales, 163. Erysiphales, 171. Pyrenomycetes, 179. Dothideales, 180. Hypocreales, 186. Sphaeriales, 198. Laboulbeniales, 233. Hemisphaeriales, 236. Hysteriales, 243. Discomycetes, 245. Helotiales (Inoperculates), 251. Ostropales, 267. Pezizales (Operculates), 268. Tuberales, 272.

7. THE BASIDIOMYCETES .

Heterobasidiomycetes, 284. Dacryomycetales, 284. Tremellales, 287. Aúriculariales, 291. Ustilaginales, 299. Uredinales, 309. Sori and spore forms, 315. Heteroecism, 328. Sexuality of the Uredinales, 332. The Mycoplasm hypothesis, 333. Specialization, 334. Classification of Uredinales, 335. Important species of rusts, 335. Homobasidiomycetes, 341. Hymenomycetes (Agaricales), 341. Exo-

$$
62129 \text { i. }
$$


basidiaceae, 341. Thelephoraceae, 343. Clavariaceae, 345. Hydnaceae, 346. Polyporaceae, 347. Agaricaceae, 353. Gastromycetes, 364. Hymenogastrales, 367. Podaxales, 369. Sclerodermatales, 372. Lycoperdales, 374. Phallales, 377. Nidulariales, 380.

8. THE DEUTEROMYCETES (FUNGI IMPERFECTI) . 383 Sphaeropsidales, 390. Melanconiales, 392. Moniliales, 394. Mycelia Sterila, 401.

AUTHOR INDEX • . . . . . . . . . . 405

SUBJECT INDEX . . . . . . . . . • • . 412 


\section{Chapter 1}

\section{THE FOUNDING OF MYCOLOGY}

Mycology, the study of fungi, had its beginning along with the study of other kinds of living organisms. Knowledge concerning fungi, however, has advanced somewhat more slowly than that of seed plants and larger animals. Nevertheless, if the influence of discoveries in any particular field of biology upon those in other fields is traced, it is apparent that the findings in each field have tended to promote a parallel advance in every other phase of biologic knowledge. Despite this fact, knowledge of microbic life lagged from the beginning of historic time until at least well into the nineteenth century.

Phenomena connected with the nature, origin, and development of fungi remained for a long time completely invested in superstition and mysticism. No doubt even in prehistoric times man had, through tests of their edibility, some familiarity with such larger kinds of fungi as mushrooms and puffballs, and he may have concerned himself with philosophical musings on their nature. Abundant evidence, dating back to the beginning of historical records, shows man's interest in fungi. For several reasons, however, appreciation of their true nature was gained very slowly. In the first place, self-constituted authority was revered for nearly 2000 years, records indicate, in all matters pertaining to church, state, and secular education. Under such a regimen experimentation was prohibited and might be attempted only at the risk of severe punishment, or even execution, if the offender was apprehended. Even today, the influence of the teachings and beliefs of "authorities" on advances in science is still very potent. Perhaps, however, the time will come when facts in science, no matter by whom they are brought to light, will themselves be "authority," and self-constituted human authorities will dominate thinking to a lesser degree. In the second place, microscopic aids to vision began in 1590 with 
Zacharias Janssen's compound microscope. This microscope and those made during the succeeding period of approximately 200 years were little more than toys or objects of curiosity. Third, there had early come into being a belief that microscopic life originated by spontaneous generation. According to this theory, all sorts of non-living materials might become transformed into living matter, an idea that dominated biologic thinking from the time of ancient Greek civilization until the classic researches of Pasteur in approximately 1860. The experiments of Pasteur confirmed in part the observations of Leeuwenhoek, Redi, Spallanzani, and others and established once and for all that living creatures give rise to other living things like themselves. It should be clearly comprehended, however, that these workers did not settle the problem of the origin of life. Fourth, fermentations were long held to be purely chemical decompositions, a concept fostered by Berzelius and Liebig. A series of researches, culminating in those of Pasteur, however, established that the agencies which induce fermentations are living microbes.

There were no doubt other factors which militated against the development of mycology, but all of them contributed in some manner to the impact of the four just discussed. In the brief historical sketch that follows passing mention is made of the more important, landmarks in the development of presentday concepts of mycology.

EARLy ACQUAINTANCE with FUNGi. Man's early knowledge of the higher plants, the beginnings of which are lost in antiquity, undoubtedly centered around their use for food and medicine. The same stimuli may be assumed to have prompted man to employ fungi similarly, and the knowledge thus gained was certainly transmitted to others. The preservation and widespread dissemination of such information, however, were seriously handicapped until the fifteenth century, when printing came into use.

Abundant evidence from the writings of the Greeks and the Romans shows that they were able to distinguish edible and poisonous mushrooms. The high esteem in which they held these plants is indicated by a painting, identified as representing Lactarius deliciosus, found buried beneath volcanic ash among the ruins of Pompeii. Biblical accounts indicate a familiarity among the people of that time with the diseases of crop plants, 
notably with cereal rusts, the cause of which they ascribed to offended deities. The Romans, in fact, instituted festivals to appease these deities, for by so doing they hoped to avert from

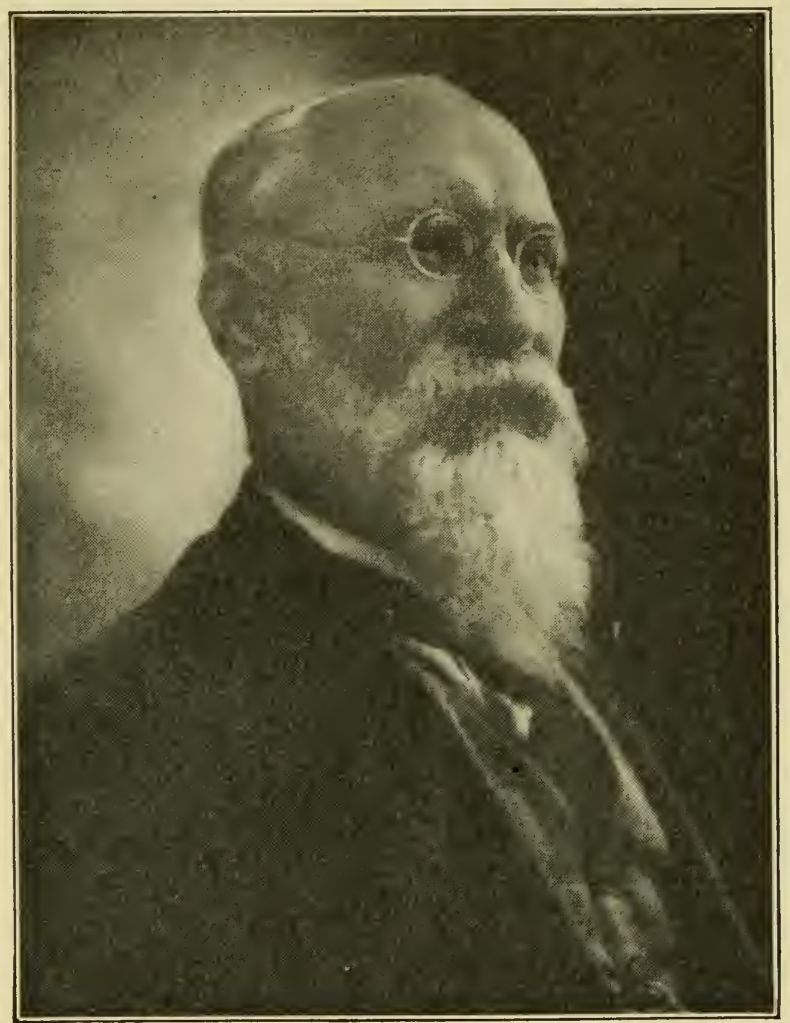

Fig. 1. Professor Carlos Spegazzini (1858-1926), the foremost student of South American fungi. His studies, while professor of botany at the National University of La Plata, Buenos Aires, Argentina, were primarily taxonomic and dealt with approximately 4000 species.

their grain crops the ravages of disease. During the period of about 1000 years after the fall of the Roman Empire in A.D. 476 little was accomplished to increase man's knowledge of fungi.

Preniodern kNowledge of FUngi. The invention of printing marks the beginning of a period when interest in plants was renewed and greatly stimulated, and special consideration was given to the identification of food and medicinal plants. As a conse- 
quence, herbalists collected, described, and made illustrations of not only seed plants but also many fungi. Among these early herbalists was Bauhin, who in 1623 listed in his Pinax Theatri Botanici nearly 100 species of fungi. Generic and specific names, as now employed, had not yet come into usage, so that under his group name Fungus are included species belonging in Agaricaceae, Polyporaceae, Boletaceae, Clavariaceae, Auriculariaceae, Lycoperdaceae, Phallaceae, and Pezizaceae. His Agaricum Fungus includes sessile Polyporaceae; and his Tubera, truffles and related forms.

In Tournefort's Elémens de Botanique (1694) the fungi are arranged in the following 6 groups: (1) Fungus, including all centrally stalked agarics, boletes, and polypores; (2) Boletus, including Clathrus, Morchella, and Phallus; (3) Agaricus, including Auricularia and all laterally attached polypores; (4) Lycoperdon, including the various Lycoperdaceae and certair slime molds; (5) Coralloides, including the coral fungi and other branched fungi; and (6) Tubera, including subterranean fungi.

Mention should also be made of the results of Hooke's observations on fungi, recorded and illustrated in Micrograpbia and presented to the Royal Society in 1667. Two of the microfungi carefully studied by him were undoubtedly Phragmidium, a rose rust, and the common mold, Mucor. He decided that both were plants but held to the idea that they were generated by the plant tissues.

The outstanding student of fungi of this period was Micheli, whose classical Nova Plantarum Genera, published in 1729, stands as a monument to his botanical devotion and zeal. He used such group names as Clathrus, Clavaria, Geaster, Lycoperdon, Phallus, and Tuber, and his illustrations and descriptions are so accurate that specific identifications can be made. In his classification Boletus includes members of the Genus Morchella, as now understood; and Puccinia, as he used it, includes Gymnosporangium. He devoted special attention to the larger fungi, grouping them into Fungi lamellati (Agaricaceae), Fungi porosi (Polyporaceae), Fungi ramosi (Clavariaceae), and Fungi pulverentes (puffballs). He also cultivated a number of microfungi in approximately pure culture. These fungi included species of Botrytis and Rhizopus, whose developmental cycle from "seed" he traced, thus proving that each fungus produces its own kind. 
The next landmark in progress was Linnaeus' Species Plantarum, published in 1753. This work is mentioned, not because it contributed to a better understanding of fungi, but because it established the binomial system, whereby each plant was given a generic and a specific name. Linnaeus assembled the thendescribed fungi under the Class Cryptogamia Fungi.

Modern history of fungi. After Linnaeus' Species Plantarum there occurred a period, which may be said to extend to the present day, in which mycology was mainly concerned with the collection and description of fungi. Although the larger, more conspicuous fungi received major attention at first, the microscope was early used to determine morphologic characteristics not discernible to the unaided eye. Specimens were preserved, exchanged, and assembled in herbaria. As a result of these practices some workers conducted monographic studies of certain groups, but unfortunately their knowledge of fungi was restricted too closely to those found in herbaria. Such students, as a consequence of this monastic seclusion, possessed little knowledge of the habitats, life histories, or range of variation of fungi, and therefore they described many new genera and species on the basis of minor, inconsequential differences.

A few of the older, more important works of this period may be mentioned. Of these, Bulliard's Champignons de France (1791) is outstanding. It contains descriptions and accurate drawings of many of the microfungi, especially Discomycetes, Pyrenomycetes, Mucorales, and Mycetozoa. There followed the taxonomic treatises of Persoon, his Synopsis Methodica Fungorum, in 1801, and his comprehensive Mycologia Europaea, a three-volume work that appeared between 1822 and 1828 . He divided the fungi into 2 classes, 6 orders and 71 genera and was the first to establish a usable system for the classification of fungi.

Probably the fundamental contribution of all time to mycologic knowledge is Elias Fries's Systema Mycologicum, consisting of three volumes published between 1821 and 1832. The Systema is the basis of our present-day system of classification and constitutes the starting point of classification of many major groups of fungi.

At the same time that Fries, working in Sweden, was laying the foundation for the classification of fungi, pioneer work in North America was being carried out by de Schweinitz, who 
richly deserves the title, Father of American Mycology. He collected about 3000 species of fungi in North Carolina and Pennsylvania, 1200 of which he described as new in Synopsis Fungorum Carolinae Superioris and in Synopsis Fungorum in America Boreali Media Degentium.

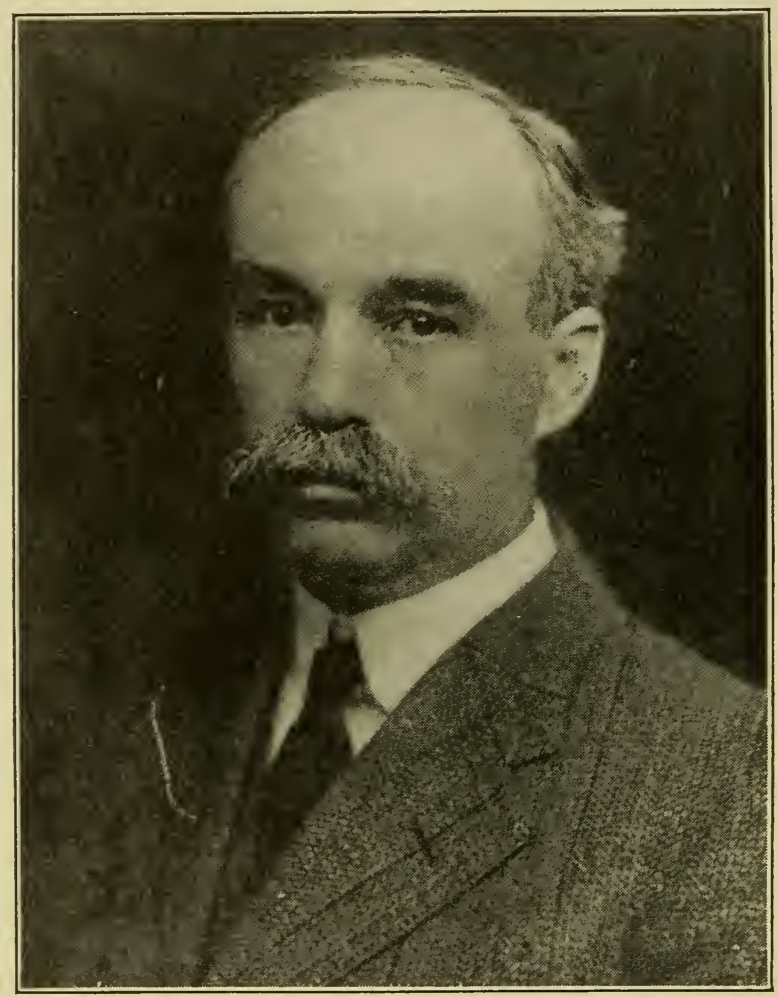

Fig. 2. Professor George F. Atkinson (1854-1918), under whose guidance at Cornell University many mycologists were trained. His researches primarily involved problems in developmental morphology and taxonomy of fungi.

Corda's Icones Fungorum Hucusque Cognitorum, appearing in six volumes published from 1837 to 1854, contains drawings and descriptions of all fungi found in Austria and known to Corda. Of a similar nature, the Tulasne brothers' Selecta Fungorum Carpologia, published in 1861 to 1865 in three volumes, remains unequalled and unsurpassed in beauty of illustrations. 
Mention should be made also of such other excellent and indispensable treatises of a purely taxonomic and classificatory nature as those of Patouillard (1887), Quélet (1888), Cooke (1871-1883), Massee (1892-1895), and Bresadola (1927-1932), as well as Engler and Prantl's Die natïrlichen Pfanzenfamilien, Rabenhorst's Kryptogamen Flora, the Sydows' Monographia Uredinearum, Oudemans' Enumeratio Systematica Fungornm, and Seymour's Host Index of the Fungi of North America. This list of essential works is incomplete without Saccardo's Sylloge Fungorum, which now comprises twenty-five volumes, the first having appeared in 1882. This work purports to contain brief descriptions in Latin of all known fungi, about 80,000 species, only an occasional description being inadvertently omitted.

Concepts of origin of fungi. Throughout the period extending to the middle of the nineteenth century the theory of spontaneous generation dominated all explanations of the origin of microscopic life. Fungi were supposed to be generated by the substratum upon which they were found; it seemed impossible to overcome the influence of this ancient dogma. Persons interested in the classification of fungi continued meanwhile to describe and name them as separate entities. Observations that fungi occur on the surface of living seed plants continued to be recorded, and proofs of the ability of fungi to produce disease accumulated. Fontana's observations (1767) on Puccinia granninis convinced him that the rust is an independent plant that probably produces "seed." Prévost (1807) proved that the "globules" in bunted wheat are the spores of the pathogen. Nevertheless Unger (1833), among others, insisted that the tissues of the plant underwent a metamorphosis to become the fungus. The evidence of Prévost, Fontana, and other workers, in its entirety, failed to shake the foundation of belief in spontaneous generation. The change in point of view came primarily as the result of the brilliant and convincing experiments of Pasteur, in which he demonstrated that microbes are air-borne, that they reproduce, giving rise to others like themselves when grown in culture, and that their activities induce fermentations.

During the period in which Pasteur was making these revolutionary experiments that led to the discoveries of microbes as causal agencies of human and animal diseases, the foundations of knowledge regarding fungi as the cause of plant diseases were 
also laid, especially by Berkeley (1837), Kühn (1858), de Bary (1866), Hartig (1874), Woronin (1878), and Brefeld (1884-

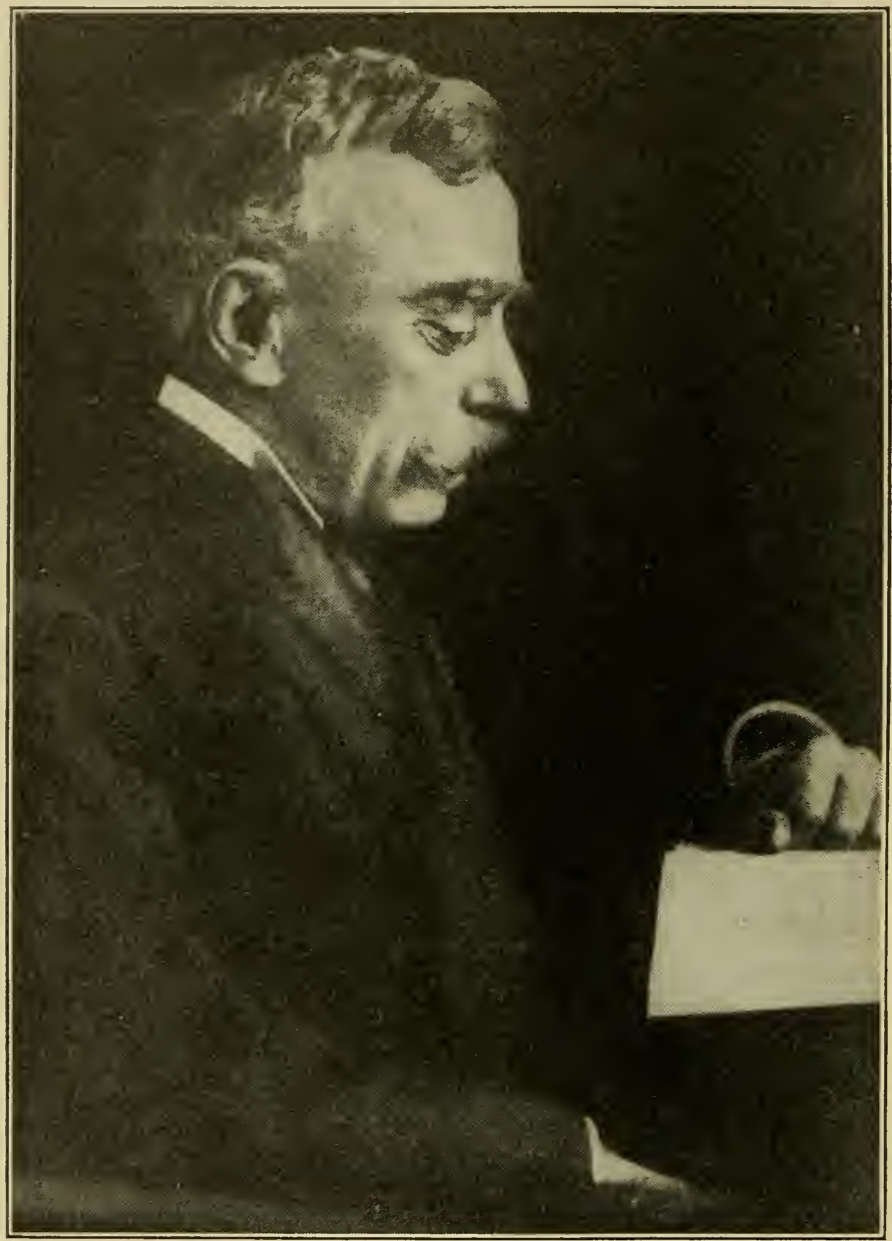

Fig. 3. Professor William G. Farlow. (1858-1926), the first to occupy a chair of cryptogamic botany in the United States. His influence, although centered at Harvard University, radiated widely, for he and his students have been a major influence in guiding the course of mycological development.

1912). These investigators established such now generally accepted facts as that Phytopbthora infestans is causally related to late blight of potatoes, that the aecia on barberry are genetically 
related to the rust on wheat, that the hyphae in wood are the assimilatory stage of the conks which form at the surface of standing trees or logs, that Plasmodiophora brassicae causes club root of crucifers, and that different cereal smuts accomplish infection at definite critical periods only. This type of research stimulated an appreciation of the economic importance of fungi and led to wide interest in applied mycology and plant pathology. A summary of this work is contained in Whetzel's History of Phytopathology (1918).

As an outgrowth of the establishment of the fact that microbes cause fermentations came Hansen's researches on the morphology and physiology of yeasts and the assemblage of studies on the industrial usage of fungi in Lafar's Technische Mykologie (1904-1907). This phase of mycologic interest, in its recent developments, is more fully discussed in Chapter 4, Volume II, where its results are briefly summarized.

Change in approach to study of Fungi. Gross morphologic similarities and differences constituted the bases for groupings in the early attempts to classify fungi. Then, as microscopes came into use as aids in elucidating details of structure, more and more attention was devoted to microscopic features. Characteristic structural features found by examination with the microscope were employed increasingly to supplement those observable by the unaided eye, but for a long time the purpose of such studies, as the numerous monographs that have appeared indicate, was purely taxonomic and classificatory. Gradually there came into being an appreciation of detailed structure and a grasp of its importance, as portrayed in Bulliard's Champignons de France and the Tulasnes' Selecta Fungorum Carpologia. This new point of interest eventually resulted in de Bary's Morphologie und Physiologie der Pilze, Flechten, und Myxomyceten (1866), which mycologists everywhere regard as a basic work in the study of fungi. In it developmental morphology is emphasized, and the taxonomic approach may with fairness be said to be deemphasized. At any rate, the investigations by de Bary and similar studies by his students have securely established the morphologic approach to mycologic knowledge, where the primary interest remains to this day. In fact, de Bary is universally conceded to be the father of modern mycology. 
In general, much of recent mycological investigation has not digressed too widely from the paths laid out by de Bary. Some of the recent contributions are recorded in the chapters that

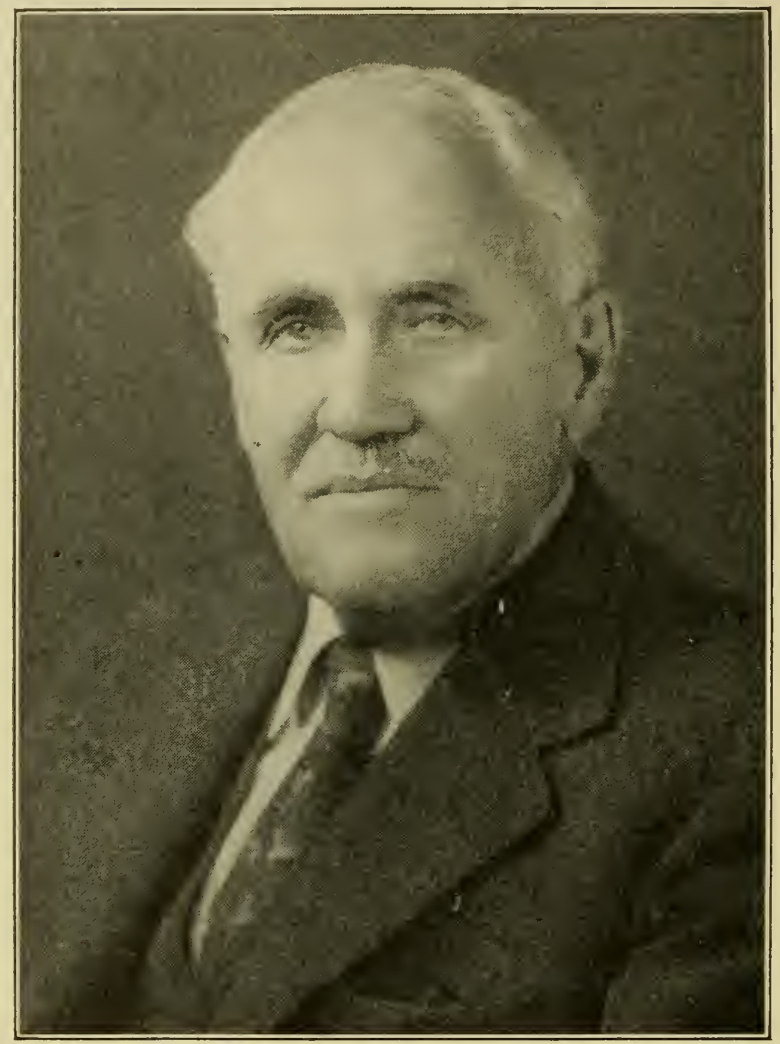

Fig. 4. Professor Robert A. Harper (1862-1946). His researches and those of his students at the University of Wisconsin and Columbia University on cytology and morphology are fundamental in the entire field of mycology.

follow; to avoid repetition, it seems best not to discuss them at this point. The impact of certain ones upon current mycologic thinking, however, has been of great significance, and attention is directed therefore to a few of the more noteworthy contributions. They include:

1. Mycorrhizae and their structure, by Frank.

2. The need for "bios" in nutrition of yeasts, by Wildiers. 
3. Plus and minus strains of black molds, by Blakeslee.

4. Cytology of the ascus, by Harper.

5. The function of rust pycniospores (spermatia), by Craigie.

6. Self-sterility and cross-fertility in Pleurage, by Ames.

7. Microconidia (spermatia) and fertilization in Sclerotinia, by Drayton.

8. Clamp connections among Hymenomycetes, by Kniep and Bensaude.

9. Genetics of yeasts, by Lindegren.

10. Production of new races of rusts and smuts. by Stakman and his associates.

11. The mycoplasm hypothesis, by Eriksson.

12. The genetics of Neurospora, by Dodge.

Several investigators, however, have blazed entirely new mycologic trails. Among these are: (1) Buller, whose Researches on Fungi explains how the principles of physics may be used to further an understanding of the structure and function of fungi; (2) Sabouraud, whose researches, described in Les Teignes, are basic to an understanding of the skin fungi (Dermatophytes) and other fungi that are pathogenic to man; (3) Wehmer in Germany, Raistrick and his associates in Great Britain, Chrzaszcz and his associates in Poland, and Ivanoff and his associates in Russia, whose contributions stress the ability of fungi to synthesize a variety of chemical products of industrial use; and (4) Fleming and his associates, best known for their work in penicillin, from which study has come the use of antibiotics of microbial origin.

The origins of plant pathology, as Chapter 18, Volume II, will point out, are in mycology, and the two subjects have much in common in recent researches. Unfortunately, however, their interdependence is not fully appreciated, and work in each field would undoubtedly be strengthened if mycologists and plant pathologists were conversant with basic facts in both fields.

In summary, this brief historical account has established that mycology began with taxonomy and classification, the basic point of departure in any field of biology. Gradually the morphologic point of view, supplementing taxonomy, developed. At the same time it became established that certain fungi are pathogenic, and as an outgrowth emphasis has been placed in increasing proportions upon the economic and industrial aspects of fungal activity. 
Truth in mycology has emerged slowly. Students in this field of learning keenly appreciate that "those who seek for gold dig up much earth, perchance to find a little."

\section{LITERATURE CITED}

Bary, Anton DE, Morphologie und Physiologie der Pilze, Flechten, und Myxomyceten. Engelmann, Leipzig. 1884. (Translated by Garnsey. Clarendon Press. 1887.)

Bauhis, Gaspard, Pinax theatri botanici. xviii +522 pp. Ludovicius Rex, Basel. 1623.

BeRKELEY, M. J., Introduction to cryptoganic botany. 1857.

BREFeld, Oscar, Untersuchungen aus dem Gesammtgebiet der Mykologie, Hefte 6-15. Heinrich Schöningh, Münster. 1884-1912.

Bresadola, J., Iconographia mycologica, Vols. 1-24, Milan. 1927-1932.

Bulliard, P., Histoire des champignons de la France. 386 pp. Paris. 17911798.

Сооке, M. C., Handbook of British fungi, with full descriptions of all the species and illustrations of all the genera, Vols. I-II. Macmillan and Company, London. 1871-1883.

Corda, A. C. I., lcones fungorum bucusque cognitorum, Vols. I-VI. J. G. Calve (Vols. I-IV) and F. Ehrlich (Vols. V-VI). 1837-1854.

Engler, A., ANd K. Prantl, Die natürlichen Pflanzenfamilien. I. Teil, Abteil. 1: 1-513, 1897. I. Teil, Abteil. 1**: 1-570, 1900. Engelmann, Leipzig.

Fontana, Felice, "Observations on the rust of grain, in Lucca, 1767," Phytopath. Classics, 2. 40 pp. 1932. (Translated by P. P. Pirone.)

Fries, Elias, Systema mycologicum, sistens fungorum ordines, genera, et species bucusque cognitas, Vols. I-III. Ernest Mauritius, Griefswald. 1821-1832.

Hartig, Robert, Wichtige Krankheiten der Waldbäume. 127 pp. Julius Springer, Berlin. 1874.

НоOKE, RовеRт, Micrographia, or some physiological descriptions of minute bodies made by magnifying glasses, with observations and inquiries thereupon. 246 pp. J. Allestry, London. 1667.

Küнк, Julıus, Die Krankbeiten der Kulturgerwächse, ilsre Ursachen und ibre Verbütung. 312 pp. 1858.

Lafar, Franz, Technische Mykologie, Vols. I-V. Gustav Fischer, Jena. 1904-1914. (Translated by Salter, 1903-1910).

Linnaecs, Carl, Species plantarum. $\mathrm{x}+1200$ pp. L. Salvius, Stockholm. 1753.

Massee, George, British fungus flora, a classified textbook of mycology. Vols. I-IV. Geo. Bell and Sons, London. 1892-1895.

Micheli, P. A., Nova plantarum genera. xxii +234 pp. Bernardi Paperini, Florence. 1729.

Oudemans, C. A. J. A., Enumeratio systematica fungorum, Vols. I-V. Martin Nijhoff, The Hague. 1919-1924. 
Patouillard, N., Les Hyménomycètes d'Europe. Anatomie générale et classification des champignons supérieurs. 166 pp. Paul Klincksieck, Paris. 1887.

Persoon, C. H., Synopsis methodica fungorum. xxx +706 pp. H. Dieterich, Göttingen. 1801.

Mycologia Europaea, Vols. I-III. 852 pp. Jacob Palm, Erlangen. 18221828.

PRÉvost, B., Memoir on the immediate cause of bunt or smut of wheat, and of several other diseases of plants, and on preventives of bunt. 80 pp. 1807. (Translated by G. IV. Keitt.)

Qú́let, Lucien, Flore mycologique de la France et des pays limitrophes. xviii + 492 pp. O. Doin, Paris. 1888.

Rabenhorst, L., Kryptogamen Flora von Deutsclaland, Oesterreich und der Schweiz, Vols. I-X. Edward Kummer, Leipzig. 1884-1920.

Saccardo, P. A., Sylloge fungorum ommium bucusque cognitorum, Vols. 1-25. 1882-1931.

Schwernitz, L. D. DE, "Synopsis fungorum in America boreali media degentium," Trans. Am. Phil. Soc. Pbiladelphia, 4: 141-318, 1831.

Synopsis fungorum Carolinae superioris. 105 pp. 1918.

Seymour, A. B., Host index of the fungi of North America. xiii $+732 \mathrm{pp}$. Harvard University Press. 1929.

Sydow, P. ANd H., Monograpbia Uredinearum, Vols. I-III. Gebrüder Bornträger, Leipzig. 1904-1915.

Tournefort, JosePH P. DE, Élémens de botanique, ou methode pour connâitre les plantes, I. 562 pp. L'Imprimiere royale, Paris. 1694.

Tulasne, L. R. And C., Selecta fungorum carpologia, Vols. I-III. 792 pp. Typographie Impériale, Paris. 1861-1865.

Unger, Franz, Die Exantheme der Pflanzen und einige mit diesen verwandete Krankbeiten der Gewächse, pathogenetisch und nosographisch dargestellt. 421 pp. Gerold, Wien. 1833.

Whetzel, H. H., An outline of the bistory of phytopathology. $130 \mathrm{pp}$. IV. B. Saunders Co., Philadelphia. 1918.

Woronin, M., "Plasmodiophora brassicae, the cause of cabbage hernia," Jabrb. wiss. Botan., 11:548-574, 1878. (Reprinted in Pbytopatbol. Classics, no. 4. 32 pp. 1934. Translated by Charles Chupp.) 


\section{Chapter 2}

\section{ISOLATION AND.CULTIVATION OF FUNGI}

The isolation and cultivation of fungi in pure culture constitute an essential procedure in studies involving their structure, developmental history, pathogenesis, and physiological activities. A student of fungi must appreciate at the outset, however, that, even though pure culture techniques are useful in the enrichment of knowledge, the results of such studies of responses and activities in artificial environments always require judicious interpretation. The underlying reasons for this fact, which generally are not sufficiently emphasized, are that fungi may be quite abnormal when grown on substrata entirely unlike those encountered in nature, and of necessity they react abnormally when entirely separated from the associative effects of other organisms. These influences might be expected to be more pronounced among pathogenic species, having restricted host relations, than among saprophilous species. It should also be borne in mind that in nature pure cultures seldom occur and, if they do, are not maintained for appreciable periods.

Many different procedures have been developed for isolating fungi in pure culture. The choice of method is conditioned by several factors, among them being the kind of fungus, the stage of development of the fungus, the kind of culture (monosporic or gross) which is desired, the judgment of the investigator, and finally the degree of manual skill, dexterity, and painstaking devotion to detail which the investigator possesses. In some studies it is essential to secure monosporic cultures. Monosporic isolates, however, may be "half fungi," if the fungus is heterothallic or also if it is hermaphroditic, and at the same time self-incompatible and hence self-sterile. It may be advantageous to make a considerable number of isolations, using as sources material obtained from different areas or from different host species, in order prop- 
erly to appreciate and evaluate the variation that exists within the given species of fungus.

\section{ISOLATION METHODS}

In all the methods that are described in the following account the ubiquitous presence of contaminants is presupposed. For this reason culture media, glassware, scalpels, needles, forceps, and other laboratory materials and apparatus must be sterilized before being used. The atmosphere of laboratories always contains bacteria and spores of fungi, and they may contaminate plates of media during pouring or planting, or during the transfer of cultures. In order to avoid contamination from this source, isolations and transfers are sometimes made by use of special transfer hoods or culture chambers. Their use, however, is unnecessary and constitutes a form of "self-inflicted inquisition" or "purposeless purgatory," since contamination may be avoided in the open laboratory if reasonable care is exercised.

Surface disinfection. Isolation from diseased tissues or from the interior of fruit bodies of the larger fungi is usually accomplished by planting bits of tissues directly on the surface of agarpoured plates or of tubes of slanted agar. Generally it is advantageous to disinfect the surface of such tissues before using fragments for planting, for the reason that contaminants occur at the surface. With care the action of the disinfectant may be limited to destruction of those organisms at the surface.

Surface disinfection may be accomplished by the use of: (a) $95 \%$ alcohol applied for a few seconds and removed by flaming or by washing; (b) $1: 1000$ solution of $\mathrm{HgCl}_{2}$ applied for 15 to 45 seconds and removed by washing; (c) a solution of calcium hypochlorite applied for about 1 minute and removed by washing; (d) a $50 \%$ solution of $\mathrm{H}_{2} \mathrm{O}_{2}$ applied for 15 seconds to 5 minutes and removed by washing. In all cases washing consists in placing the tissues for about 5 minutes in several changes of sterile water, thus removing the disinfectant. It is entirely possible with thick or massive tissues to obviate surface disinfection, for instead the outer tissues may be removed with a sterilized scalpel. The underlying tissues can then be transferred directly to the surface of appropriate media. After incubation, transplants can be made from the marginal growth of colonies. 
SPORES AS inoculun. If the fungus to be isolated produces spores in sufficient abundance, concentrated suspensions of spores in water can be made and either of two general methods of isolation can be employed: (1) the streak method, or (2) the dilution method.

The streak method is the oldest and simplest procedure. A needle, bearing a loopful of spores suspended in water, can be

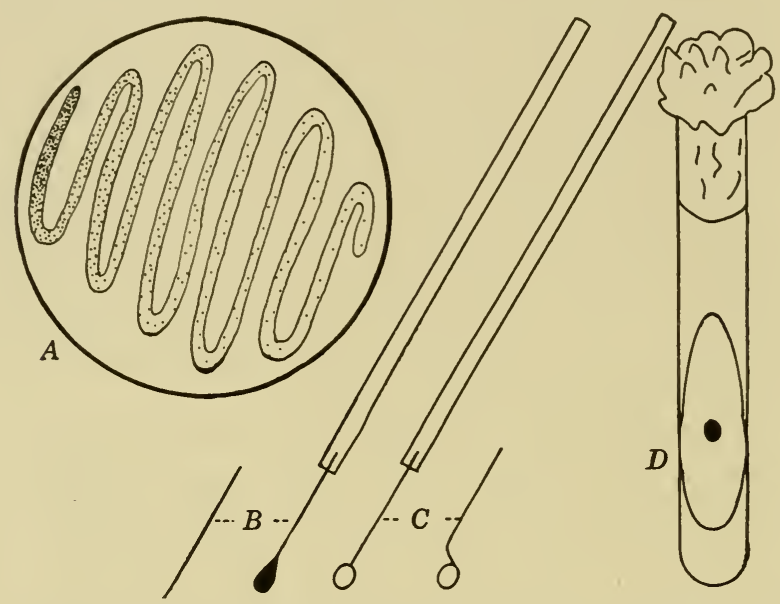

FIG. 5. Materials used in isolating single spores by streaking. $A$. Poured agar plate over whose surface a droplet containing spores in suspension has been spread with a zigzag stroke. $B$. Needle with flattened tip employed to pick up disk of agar, bearing a spore, cut out by means of loop $C$.

$D$. Disk, with adhering spore transferred to slanted tube of agar.

spread with a zigzag stroke over the surface of a hardened agar plate, care being taken not to break the surface of the agar. In this way most of the spores are brushed off at first, but toward the end of the stroke a few remain. When these few germinate, the colonies are discrete and may be transferred intact to fresh media.

If tubes of sterile water are available, a series of increasingly less concentrated suspensions of spores can be made as a first step in isolation by the dilution method. The proper amount of dilution is entirely a matter of choice. A small quantity of inoculum from the first tube should be placed in a tube of melted agar cooled to about $45^{\circ} \mathrm{C}$. The contents of this tube should be 
poured immediately into a Petri dish. Similarly poured plates should be made from the remainder of the series of suspensions. After incubation some of the Petri dishes may bear a few widely separated colonies that are suitable for transfer to other media.

With either of these methods difficulties may be encountered in separating the desired fungus from bacterial contaminants. Several techniques have been developed to overcome this difficulty. The fungus may be of a type that will leave the bacteria behind as it grows away from the original inoculum. Advantage may be taken of this fact by cutting off portions of the hyphal tips when making transfers to new substrata. In other studies the medium upon which the inoculum was first planted or the medium in subcultures may be acidulated with a drop of 25 or $50 \%$ lactic acid. By this means media may be so acidified as to inhibit bacterial growth and at the same time to permit the fungus to grow at the usual rate.

Brown (1924) described a procedure which applies generally in freeing fungal cultures from bacteria. Its basis is the fact that hyphae tend to penetrate the medium. After the colonies have grown for 1 to 5 days, the medium is cut through with a sterile knife in advance of the growing colony. The colony can then be inverted, and bits of material from the undersurface can be carefully cut away in making transfers. The same principle underlies a method recently successfully employed by Raper (1937) in isolating species of Achlya. He fused glass beads $1 / 3$ to $1 / 2 \mathrm{~mm}$ in diameter on one rim of a van Tieghem ring and placed the beaded rim downward in a Petri dish. Agar was poured into the dish to bring the medium well up on the ring. The mixed inoculum was placed inside the ring, and as growth proceeded the hyphae extended under the ring and into the agar lying beyond. The bacteria, howerer, remained confined within the ring. The hyphae outside the ring therefore provided inoculum for pure cultures.

Monosporic isolations. Numerous methods are available for single-spore isolations of fungi. The techniques involved have been assembled in a recent report by Hildebrand (1938). Among these methods may be mentioned those of Barber (1914), Edgerton (1914), Keitt (1915), LaRue (1920), Dunn (1924), Brown (1924), Hanna (1924, 1928), and Ezekiel (1930). With each technique, practice greatly facilitates successful operation. That 
of Barber (1914) is among the early methods employing micromanipulation. He used a microscope equipped with special mechanical devices to control the movement of capillary pipettes by means of which spores suspended in liquids were picked up for transfer.

Edgerton (1914) also used capillaries attached to the substage to pick up the spores. The upper end of the capillary tube was sealed. Looking through the microscope, the operator lowered the capillary point until it came into contact with the spore in suspension. A drop of ether was then applied to the closed end of the capillary, causing the spore to be drawn up into the capillary. The spore could be expelled subsequently onto the surface of a Petri-dish culture by gently heating the closed end of the capillary.

The methods employed by Keitt (1915), LaRue (1920), Dunn (1924), and Ezekiel (1930) were basically quite similar. The spores were separated in agar plates by the streak method or the dilution method. LaRue then located the spore in the agar or upon its surface by direct microscopic examination. When he had found the spore, he lowered a special marker on the nosepiece to cut out a disk of agar containing the desired spore and then transferred this disk with a flattened needle. Ezekiel located the spore to be isolated by inverting the bottom half of the Petri dish, selected the spore or sporeling, and with India ink marked its position on the bottom of the dish. The dish was next righted, and a disk of agar immediately above the marked area was cut out and removed. If the dot of ink is placed while the operator is looking through the microscope, it can be accurately located. This method has much to commend it, especially if spores are well spaced and if it is desired to make numerous isolations.

Brown (1924) employed a mechanical appliance to bring a capillary tube near the hyphal tips in a colony arising from germination of a well-isolated spore. The tips were then drawn into the capillary and expelled upon another plate. After a day or two on the new medium the tips were well spaced, and a single hyphal tip could be cut off.

Hanna (1924), in isolating single spores of Hymenomycetes, placed a generous fragment of the hymenial surface on a sterile microscopic slide, permitting the basidiospores to be discharged. After discharge, and during observation through the microscope, 
he brought a needlepoint, held in the hand, near a spore. The spore could be seen to attach itself to the needle and could then be planted on agar to permit germination and subsequent growth.

Other isolation techniques. In isolating aquatic fungi, notably Saprolegniales, a small quantity of swarm spores or encysted spores may be suspended in water and put into an atomizer. Some of these spores may then be forced through the atomizer, so that they are deposited in tiny droplets on the surface of agar plates. Here they germinate, and marked sporelings can be transferred to slanted tubes of agar.

The isolation of Chytridiales may require a more elaborate technique. Couch (1939) recently isolated certain chytrids, including Rbizidiomyces apopbysatus, Rbi opbidium carpophilum, and $R$. multiporum. He placed the materials containing these chytrids, namely, decaying leaves and grass, in distilled water to which activated charcoal had been added. Into this were placed, as bait, boiled bits of corn leaves or grass blades. After 2 or 3 days the bait was examined, and, if chytrids occurred within the tissues, the fragment of leaf was washed in a strong stream of water. A fragment containing chytrids was then excised and placed in a drop of water in a Petri dish. With the aid of a binocular single sporangia were dissected out and placed in a fresh drop of water baited with a fresh bit of leaf fragment, and again a single sporangium could be dissected out and dragged over agar to free it from bacteria, or zoospores could be picked up by means of capillary pipettes. Eventually pure cultures could be isolated by these procedures. Berdan (19+1) employed this procedure in isolating Cladochytrium byalinum in pure culture on agar.

The ascospores are explosively discharged by many species of Pyrenomycetes and Discomycetes. Advantage may be taken of this fact in isolating them in pure culture. The tissues, bearing perithecia or apothecia, should be placed in the tops of inverted poured plates of agar. Bits of wet paper toweling or other absorbent paper placed beneath the plant tissues will serve to keep the tissues moist, provide a high relative humidity, and bring the fruit bodies sufficiently near the surface of the agar above to be within range of the ascospores when discharged. If proper conditions are provided, the ascospores on expulsion, singly or en masse, adhere to the agar, and are free from con- 
taminants. By means of this simple procedure they essentially isolate themselves in pure culture. If an attempt is made to isolate these same species occurring in decaying leaves and twigs by using macerated tissues as inoculum, there is difficulty in separating the organism sought from protozoa, bacteria, and other fungi present.

In isolating Hymenomycetes advantage may be taken of their

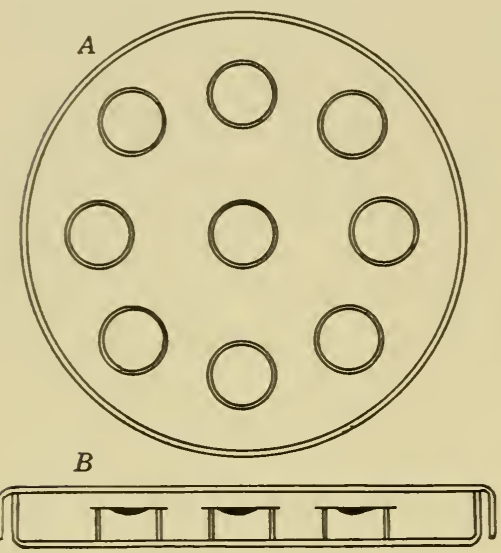

FIG. 6. Diagrammatic arrangement of Van Tieghem cells attached within Petri dish, for repeated observations on germination of spores and subsequent development. $A$. Surface view. $B$. Side view. ability to discharge their basidiospores. In such studies the spores to be used as inoculum can best be collected on a sterile microscopic slide. By methods previously described they can then be transferred directly to agar tubes or plates. Instead of this procedure the sporophores may be placed above the surface of agar plates, so that the basidiospores can fall upon the surface of the agar.

One of the difficulties that attend efforts to isolate plantpathogenic fungi is early occupation of lesions by secondary invaders, both bacteria and fungi. Under these conditions special techniques may be required to isolate the primary organism. This situation is exemplified by a study of the citrus melanose pathogen, Diaporthe citri. When infected leaves, fruits, or twigs were dipped into alcohol and flamed, and lesions were excised and planted on agar, the pathogen soon became overgrown by Colletotrichum gloeosporioides unless subcultures were made as soon as hyphae appeared [Bach and WVolf (1928)]. Similarly other species of fungi may act as "weeds" and stifle the growth of the organism to be isolated.

Observation of pure cultures. Two essentially different procedures are available for the study of pure cultures: ( $a$ ) cultivation in test tubes or in Petri dishes, or $(b)$ cultivation in hanging 
drops. Each has its advantages and disadvantages. With the first method the cultures can be kept indefinitely, and subcultures can be made at such intervals as maintenance of viability demands. Observations are necessarily intermittent. With the second method cultivation in van Tieghem cells makes continuous observations possible as growth proceeds. Although usually the period of observation is limited to a few hours, by governing atmospheric humidity and availability of oxygen in van Tieghem cultures the period may be extended, and much information regarding the developmental history of the fungus may be gained.

\section{CULTIVATION}

The substrata upon which fungi are cultivated in the laboratory are called media. Many different kinds of media have been compounded or synthesized. All are made up according to standard specifications, which are usually included in laboratory manuals. Although these media may contain all the essential food substances, namely, carbohydrates, proteins, fats, amino acids, vitamins, minerals, air, and water, none of them constitutes an ideal substratum. Their deficiency is evidenced by the fact that the mycologist has thus far been unable by use of artificial media to cultivate certain fungi, notably the rusts, downy mildews, and powdery mildews. Furthermore, numerous fungi remain sterile in culture, others cannot be induced to complete their normal developmental cycle in the test tube, and some are manifestly teratological. For these reasons many different kinds of media not listed as standard are continually being devised and tested. The mycologist realizes all too keenly that there is no one best medium. The ideal medium is, perforce, most nearly like the substratum on which the specific fungus occurs in nature. Until more fundamental knowledge has been acquired regarding the nutrition of fungi, the investigator will continue to depend upon empirical methods for their artificial cultivation.

On the basis of their composition, media may be regarded as of two kinds: synthetic (mineral) and non-synthetic (organic), and they may be either liquid or semisolid. Agar in the proportion of about $2 \%$ is used almost exclusively in making the media semisolid. 
Fungi generally grow best in media abundantly supplied with carbohydrates. Another requisite is that the $p \mathrm{H}$ be within the range of 5 to 6 .

Since carbohydrates and proteins are decomposed by heat, especially if the medium is acid or alkaline, they should be sterilized separately and added to the other constituents, care being taken to prevent contamination.

Agar media enriched by the addition of fruit juices may not solidify unless the fruit juices are sterilized separately and then aseptically added after the constituents have been cooled to about $50^{\circ} \mathrm{C}$. Wolf and Shunk (1921) demonstrated that, if agar or gelatin media are cooled before being made acid or alkaline, they will jellify at hydrogen- or hydroxyl-ion concentrations far greater than those permitting growth of microorganisms.

In manuals [Rawlins (1933), Riker and Riker (1936)] containing formulae for compounding various kinds of media may be found instructions regarding such essential matters as clearing of media, filtration, adjustment of reaction, and sterilization. For this reason these subjects will not be given consideration here.

Most kinds of organic media contain meat extract and peptone as essential constituents. The meat extract supplies mainly the ash constituents, organic nitrogen, and certain organic acids. Peptone supplies decomposable proteins that can be cleaved by many fungi to yield essential amino acids. When media containing these materials are enriched by the addition of plant substances extracted by boiling, like those from potatoes, corn meal, or fresh beans, they constitute satisfactory substrata for the cultivation of a large number of different species of fungi. Such media, in fact, are widely used in mycological and phytopathological laboratories.

Mineral nutrient media have a more limited usage than organic media. They are employed especially in physiological studies of the suitability of a single carbohydrate, amino acid, or mineral. A mixture of mineral salts in liquid cultures or jellified with agar furnishes the basis for such media.

In the cultivation of certain groups of fungi specific media have come to be used quite generally. Members of the Saprolegniales and related orders, for example, are commonly cultivated on boiled hempseeds placed in water. The Polyporaceae and Thelephoraceae usually grow well and may be made to fruit 
on malt agar or on sterilized sawdust or blocks of wood. Etter (1929), using a mixture of malt liquid, wood powder, corn meal and starch in flasks, secured typical pileate sporophores of such species as Lentinus lepideus, Pleurotus ostreatus, Coprinus atramentarius, C. micaceus, Polyporus perennis, P. farlowii, Ganoderma curtisii, and Trametes peckii.

The incorporation of extracts from various fruits and vegetables into media may also stimulate fruiting by wood-rotting fungi, but the sporophores on such substrata are sometimes abnormal. Long and Harsch (1918) used such media in studies with wood-rotting species and concluded that the nature of the substrate is of minor importance in stimulating the formation of sporophores. They secured fruiting on plant-extract media by the following species: Daedalea juniperina, Fomes applanatus, $F$. pinicola, $F$. roseus, $F$. robineae, $F$. texanus, Irpex lacteus, Lenzites saepiaria, Pleurotus ostreatus, Polyporus anceps, P. cinnabarinus, $P$. dryophilus, $P$. farlowii, P. obtusus, P. sulphureus, Polystictus birsutus, $P$. versicolor, Trametes peckii, and $T$. serialis.

The studies by Badcock (1943) indicate, moreover, that the nature of the substrate is a vital factor in the production of sporophores in culture. He used sawdust as a basic material supplemented by readily available nutrients. As additional factors there should be a plentiful supply of moisture in the substratum, an atmosphere of high relative humidity, and exposure to diffuse light of moderate intensity. Under these conditions Badcock secured fructifications of 82 of the 92 species tested.

The spores of many species, notably of the downy mildews, powdery mildews, and rusts, can be germinated in water, where they will continue to grow until their reserve of stored food is exhausted. Even though development is determinate under these artificial conditions, observations of growth changes in water contribute materially to the sum total of useful information. For example, the oospores of downy mildews are notoriously refractory to germination, and hence an understanding of the necessary environmental conditions, except for a few species, has not been achieved. Hiura (1930), however, described a method for germinating the oospores of Sclerospora graminicola. A layer of moistened cotton is placed in the top of a Petri dish and another in the bottom, ample space being left between the layers. Moist 
filter paper is then placed lightly in the bottom part, and on it are sprinkled small amounts of well-macerated tissues containing oospores. Blocks of $2 \%$ agar on which spore powder is sprinkled can be substituted for moist filter paper. Using this

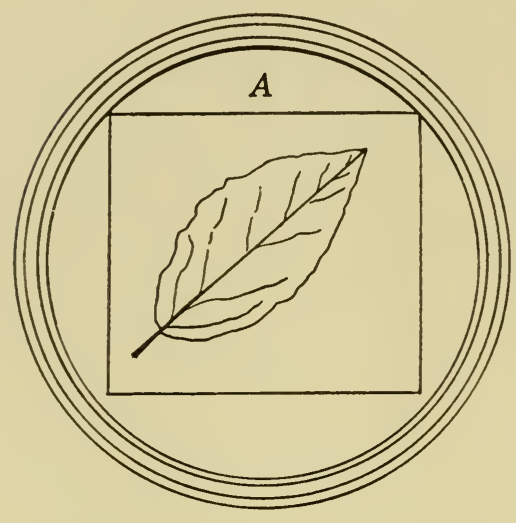

$B$

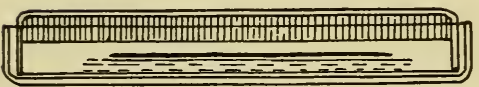

Fig. 7. Schematic arrangement to show method for isolating Ascomycetes that forcibly expel their ascospores. $A$. Poured agar plates, surface view, over infested leaf that rests upon pad of moist filter paper; $B$, side view. The tissues in which the ascocarps are embedded are elevated on the pad to permit the spores, when discharged, to reach the agar surface above them. procedure, Hiura was able to study phenomena of infection, as circumscribed by temperature and moisture [Hiura (1935)].

In the artificial cultivation of various fungi of the downy and powdery mildews and the rusts it is necessary to transfer them from living plants to living plants growing in a more or less controlled environment. Determination of heteroeciousness in rusts is for the most part accomplished by such techniques. Clinton and McCormick (1924), however, floated green leaves on water in Petri dishes and by this procedure successfully accomplished infection by 28 species of rusts from 12 genera.

Experiences with Peronospora tabacina indicate that it can be maintained in culture on living tobacco plants, provided the inoculated plants are maintained in an artificial environment in which the temperature does not exceed $65^{\circ} \mathrm{F}$, the relative humidity is at the point of saturation, and the light is diffuse. Under such conditions crops of sporangia have been produced during every month of the year. Presumably other downy mildews would behave similarly in a suitable artificial environment.

Maintenance of cultures. Much can be learned about a given fungus if it is maintained in pure culture on a chosen 
medium, regardless of the nutritional defects of that substrate and of whether the organism is pathogenic or saprogenic in its natural state. First of all, a modicum of skill and good judgment is required to keep a fungus alive by transfer at sufficiently frequent intervals. Not only must it be kept alive, but also as a result of manipulation and examination each fungus will come to be recognized as having a distinctive appearance. If, then, numerous isolates of that species are assembled and their appearance on different substrates is compared, it will be evident that characteristic differences between isolates exist. Some isolates may reproduce more abundantly than others, their mycelia may differ in color, the mycelial mass may vary in laxness or floccoseness and also in growth rate or in other features that do not lend themselves well to description. Eventually the observer is forced to conclude that each individual isolate must be regarded as a specimen, and that the species consists of an assemblage of closely related individuals.

The frequency of subculturing will depend upon several factors, including (1) the peculiarities of the fungus, (2) the culture medium, and (3) the temperature and humidity of the storage cabinet. Fungi that produce sclerotia, such as Rhizoctonia solani and Sclerotium rolfsii, will remain alive for several years even though the medium has dried up and shrunken to a corneous mass.

The result of transfer of mycelium or spores from old cultures that are thoroughly desiccated may indicate that the culture is dead. It may be possible, however, to revive such an old culture by flooding its surface with a liquid medium and then incubating for a day or two before again attempting to subculture.

Species that produce spores in such abundance that spore clouds may be formed even when the culture is jarred only slightly are difficult to maintain in a state of purity, and they may become contaminants in the whole culture collection unless the utmost care and faultless technique are employed during subculturing. Monilia sitopbila and members of the genera Aspergillus, Penicillium, Mucor, and Trichoderma are included in a group having this peculiarity.

If the temperature of the culture cabinet can be maintained at about $20^{\circ} \mathrm{C}$, most species of fungi need be transferred only two or three times a year. Even when transfers are infrequently 
made, however, the task of subculturing becomes onerous, a situation which constitutes an argument for the establishment and maintenance of "bureaus of culture collections." With certain species it may be found advantageous to incubate them for a few days at a temperature favorable for rapid development and then to place them in storage at $10^{\circ} \mathrm{C}$.

Efforts to retard the drying out of the medium by the use of paraffin on the cotton stoppers or of waxed paper caps or rubber thimbles are quite uniformly unsuccessful because they promote contamination. Spores lodged in or on the cotton stoppers are thereby provided with sufficient moisture to permit them to germinate and the organism to employ the cotton fibers as a nutrient substrate.

Because of lack of detailed knowledge regarding the nutritional requirements of fungi, a choice of culture medium is quite arbitrary. Potato agar, bean agar, corn-meal agar, wort agar, malt agar, and Sabouraud's agar are among those commonly used to maintain cultures.

Some fungi appear to require comparison with type cultures for certain identification. This situation becomes complex in dealing with an organism which does not remain true to type. In culture, certain fungi gradually vary in mycelial color, texture of the colony, and in sporulation or other characters. Moreover, others gradually lose their vigor, dwindling until they become so depauperate and so different from their appearance when first isolated as to be unrecognizable as the same species. Some mutate without known reason and become clearly distinct in appearance from normal colonies. Finally, some pathogenic fungi lose virulence in culture, and no basis has been established for restoring their aggressiveness. On the other hand, others, such as Tapbrina deformans and Ustilago zeae, have been maintained in culture for years without apparent loss of virulence. Until more basic knowledge can be gained of the influence of nutritional and environmental factors each mycologist who maintains fungi in culture must be guided largely by his own experiences in cultivating them.

Another serious difficulty that will be encountered sooner or later by anyone who maintains cultures of fungi is infestation by mites. These pests devour the fungi and, in crawling from one 
culture to another, contaminate all of them. Mites cannot be excluded no matter how tight the stoppers are. To guard against infestation the strictest vigilance and the most stringent sanitary measures must be employed at all times. Before infestation is widespread, fumigation with carbon tetrachloride or pyridine can be effectively employed. These chemicals are allowed to evaporate from shallow dishes placed in the culture cabinets. After 3 or 4 days a second fumigation is necessary because the egg stage and an encysted stage of the young mite are more resistant to vapors of these chemicals than are adult mites. All cultures should be transferred early after fumigation.

\section{IMPLICATIONS}

Certain principles underlie the techniques of isolation and cultivation of fungi. Following routine directions and procedures may cause failure to isolate or to grow a specific fungus artificially. Failure may be attributable to use of the improper kind of substrate. Fungi should be expected to respond in a most nearly normal manner if food and environmental influences approximate those that they encounter in their natural habitat. It is of course impossible in many studies to duplicate these conditions artificially, but a knowledge of these facts about a given fungus may prevent loss of time in attempts to isolate it and misinterpretation of results of its responses when grown in culture. It follows, therefore, that the fungus in culture may be quite pathologic and that a study of its physiology in culture may in reality be a study of its pathology.

\section{LITERATURE CITED}

Bach, W. J., and F. A. Wolf, "The isolation of the fungus that causes citrus melanose and the pathological anatomy of the host," J. Agr. Research, 37: 243-252, 1928.

BADCOCK, E. C., "Methods for obtaining fructifications of wood-rotting fungi in culture," Trans. Brit. Mycol. Soc., 26: 127-132, 1943.

BARBer, M. A., "The pipette method in the isolation of single microorganisms and in the inoculation of substances into living cells," Pbilippine J. Sci., B, 307-360, 1914.

Berdan, Helen B., "A developmental study of three saphrophytic chytrids. I. Cladochytrium byalinum, sp. nov.," Am. J. Botany, 28:422-438, 1941. 
Brown, WV., "Two mycological methods. I. A simple method of freeing fungal cultures from bacteria. II. A method of isolating single strains . of fungi by cutting out a hyphal tip," Amn. Botany, 38:401-404, 1924.

Clinton, G. P., And F. A. McCormick, "Rust infection of leaves in Petri dishes," Comn. Agr. Expt. Sta. Bull., 260:475-501, 1924.

Couch, J. N., "Technic for collection, isolation, and culture of chytrids," J. Elisha Mitchell Sci. Soc., 55: 208-214, 1939.

Dunn, M. S., "The micro-loop. A rapid method for isolating single spores," Ploytopatbology, 14: 338-340, 1924.

Edgerton, C. W., "A method of picking up single spores," Pbytopatbology, 4: $115-117,1914$.

Etter, Bessie E., "New media for developing sporophores of wood-rot fungi," Mycol., 21: 197-203, 1929.

Ezekiel, W. N., "Modified procedure with the Keitt single-spore method," Plbytopatbology, 20: 583-586, 1930.

Hanna, IV. F., "The dry-needle method of making monosporous cultures of Hymenomycetes and other fungi," Ann. Botany, 38: 791-795, 1924.

"A simple apparatus for isolating single spores," Plbytopatbology, 18: 1017$1021,1928$.

Hildebrand, E. M., "Techniques for the isolation of single microorganisms," Botan. Rev., 4:627-664, 1938.

Hiura, M., "A simple method for the germination of oospores of Sclerospora graminicola," Science, n.s., 72:95, 1930.

"Mycological and pathological studies on the downy mildew of Italian millet," Gifu Imp: College Research Bull., 35: 121-283, 1935.

Keitr, G. W., "Simple technique for isolating single-spore strains of certain types of fungi," Phytopathology, 5: 266-269, 1915.

LARue, C. D., "Isolating single spores," Botan. Gaz., 70:319-320, 1920.

Long, W. H., and R. M. Harsch, "Cultures of wood-rotting fungi on artificial media," J. Agr. Research, 12: 33-82, 1918.

RAPER, J. R., "A method of freeing fungi from bacterial contamination," Science, n.s., 85:342, 1937.

Rawlins, T. E., Phytopathological and botanical research methods. 156 pp. John Wiley and Sons, New York. 1933.

Rıker, A. J. ANd R. S., Introduction to research on plant diseases. 117 pp. J. S. Swift Co. 1936.

Wolf, F. A., ANd I. V. Shunk, "Solid culture media with a wide range of hydrogen-ion or hydroxyl-ion concentration," J. Bact., 6: 325-330, 1921. 


\section{Chapter 3}

\section{CLASSIFICATION AND TAXONOMY OF FUNGI}

If the fungi are among the "simplest of organisms" or the "humblest of plants," as some writers maintain, their classification should not present any great difficulties. As far as the first phrase is concerned, however, the student is ultimately forced to conclude that there is nothing simple about fungi except our knowledge of them. And as for their "humbleness"-well, that is only the estimation of man, and who would gainsay that he is among the humblest of animals? Moreover so many problems arise in classifying fungi that volumes have already been written on this subject.

It is of primary importance in dealing with any group of biological materials that they be organized or classified and named; otherwise all is chaos. "By the classification of any series of objects," Huxley says, "is meant the actual or ideal arrangement together of those things which are alike and the separation of those which are unlike, the purpose of the arrangement being, primarily, to disclose the correlations or laws of union of properties and circumstances and, secondarily, to facilitate the operations of the mind in clearly conceiving and retaining in memory the characters of the objects in question."

All classifications of fungi are man-made, and none is without flaws. Comparison of them indicates that, as more information has been obtained, the systems of classification which have from time to time been proposed have become increasingly more adequate and comprehensive. The ideal classification has not yet been proposed, however, and indeed it could be perfected only after a vast amount of intensive study, much more than has been accomplished to date or that has likelihood of being accomplished within the next few centuries. When such a classification is perfected, it should accurately reveal morphological similarities and differences between any and all species and hence should 
indicate their evolutionary position and genealogical relationship. Such a system could appropriately be designated the natural system. In lieu of a natural system, purely artificial or predominantly artificial systems are in general use.

In any scheme of classification the worker must deal with units, each of which must have a designation, such as phylum, class, order, family, genus, and species. Definition of these terms is a vexatious academic problem upon which systematists are not in accord but have a variety of opinions.

Nomenclature. As a natural consequence of attempts by different persons to apply rames to plants and of difficulties attendant on printing and exchanging information on this subject, the same organism of ten came to bear more than one name. This situation of course could lead only to confusion. Moreover a name at first was either a single word or a brief descriptive phrase. Since the publication of Linnaeus' Species Plantarum in 1753, however, each species bears two names, the first being that of the genus to which it belongs, and the second being that of the species. Subsequently, as new organisms were described, the principle of priority came to be accepted in determining the proper binomial. According to this principle, the oldest binomial used is the accepted one. If this principle is regarded as sacrosanct and its strict application is insisted upon in spite of general usage and common sense, there is little chance of establishing stability in nomenclature, especially for certain old and well-known genera. Other problems in nomenclature meanwhile arose, and the machinery for their settlement was created at the International Congress of Paris in 1900. The codes and rules agreed upon by committees then and at subsequent International Congresses constitute a working basis for the solution of all such problems. A composite statement of these international rules was published as a supplement to The Journal of Botany (British and Foreign) for June, 1934, and should be carefully perused by all biologists.

Among the facts important to mycologists in these rules are: (a) the nomenclature of the Myxomycetes begins with Linnaeus' Species Plantarum, 1753; $(b)$ the nomenclature of the Uredinales, Ustilaginales, and Gastromycetes begins with Persoon's Synopsis Methodica Fungorum, 1801; and (c) the nomenclature of all other fungi is based on Fries's Systema Mycologicum, 1821-1832. 
The starting point of classification of all Basidiomycetes, except the Tremellineae, is Volume 1 (1821) of the Systema. The classification of the Tremellineae and of the Discomycetes begins in Volume 2, Part 1 (1822). The classification of the Pyrenomycetes and Sphaeropsidaceae starts in Volume 2, Part 2 (1823); that of the Phycomycetes and Hyphomycetes, in Volume 3, Part 2 (1832).

The generic name is a noun or substantive, the initial letter of which is always capitalized; the species name is adjectival, agrees in gender with the generic name, is either nominative or genitive in case, and normally is not capitalized. Some specific names are bestowed in honor of persons or places, and some authorities capitalize all such names, whereas others consistently begin them with a lower-case letter. Accord in this matter is of little real consequence, certainly not to the extent of fancying that an anthill is a mountain. It is quite unfortunate, however, that generic names of hosts have been used as specific names, especially of pathogenic fungi, for the reason that experimentation reveals a wide host range for some species. In consequence many such specific names must eventually be reduced to synonymy. For the purpose of precision the name of the person who first published the binomial follows the name of the organism. If the name is subsequently changed, this fact is indicated by placing in parentheses the name of the person who published the first description and following it immediately with the name of the person who changed the name.

One excellent rule requires the description of all species in Latin. Latin has the advantages of being a dead language, of being exact in meaning of terms, and of being a tool of all scholars. Objections to its employment would vanish like "a cloud of mist smitten by the sun" if the objector were compelled to translate descriptions of fungi from the Arabic, Slavic, or some of the less frequently encountered Oriental languages.

Another very important provision in the rules deals with the naming of fungi with pleomorphic life cycles. Naturally the different states or stages of the same species have been given different names. It has been agreed that pleomorphic fungi can bear only one binomial, and the earliest name given to the perfect form, beginning with Persoon's Synopsis or Fries's Systema, is the accepted one. The perfect form is indicated to be that 
which ends in the ascus stage in Ascomycetes, in the basidium in Basidiomycetes, and in the teliospore in Uredinales and Ustilaginales.

Changes in systems of classification. An appreciation of the need for changes in nomenclature and taxonomy that may arise in the classification of fungi can be gained if it is borne in

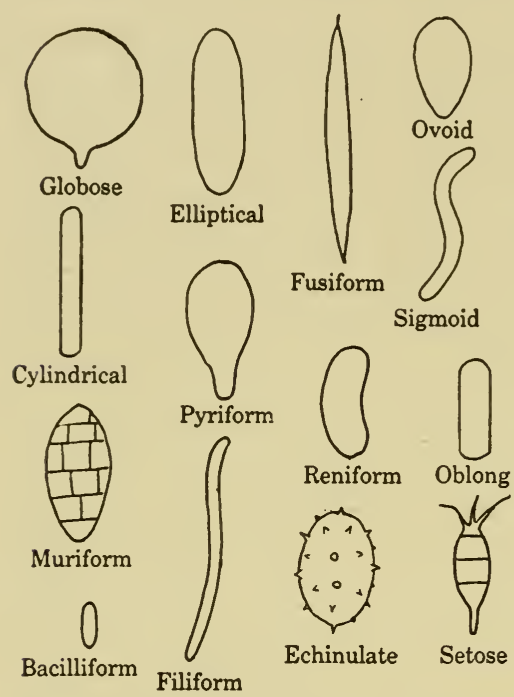

FIG. 8. Types of spores and the terms used to designate each kind. mind that 10 genera containing fewer than 100 species are included in Linnaeus' Species Plantarum, and that now, according to Saccardo's Sylloge Fungorum, there are approximately 5000 genera containing more than 80,000 named species.

Linnaeus included in Cryptogamia Fungi 27 species of Agaricus, 12 of Boletus, 4 of Hydnum, 2 of Phallus, 3 of Clathrus, 2 of Elvela, 8 of Peziza, 8 of Clavaria, 9 of Lycoperdon, and 11 of Mucor.

In Synopsis Methodica Fungorum Persoon divided all fungi into 2 classes, Angiothecium and Gymnothecium.

These two classes included 6 orders and 71 genera.

In Fries's Systema Mycologicum expansion and changes were provided for by grouping the fungi into four classes: Coniomycetes, Hyphomycetes, Gastromycetes, and Hymenomycetes, and then further dividing these classes. The Coniomycetes, for example, were eventually subdivided into Ordo I, Tubercularini; Ordo II, Stilbosporei; Ordo III, Sporodesmiei; and Ordo IV, Hypodermii seu Entophyti. At the present time it is estimated that more than 50 orders have come to be recognized.

On the basis of Saccardo's Sylloge Fungorum the fungi are classified into the following classes: Schizomycetes, Myxomycetes, Phycomycetes, Ascomycetes, Basidiomycetes, and the form-class Deuteromycetes or Fungi Imperfecti. Bisby and Ainsworth (1943) report that the approximate number of Myxo- 
mycetes is 450, of Phycomycetes 1000, of Ascomycetes 12,120, Basidiomycetes 13,430, and Fungi Imperfecti 10,500, making a total of 37,500 species. They further indicate that only about one-third of all species have been described. So far as information warrants, in all present-day systems the division of each of these classes into orders, families, tribes, and similar subdivisions indicates phyletic relationships and evolutionary developments, the simplest being placed first and the more complex following in an ascending series. All of them therefore are ordinarily regarded as natural systems, but there remains much in classification that is arbitrary or has been devised by man for his mental convenience, and hence is purely artificial. For example, the Agaricaceae are divided into tribes on the basis of color of spores en masse, tribal names being Leucosporae, Rhodosporae, Phaeosporae, Ochrosporae, and Melanosporae. Similarly color, shape, and septation of spores, either as separate characters or in combination, especially among the Ascomycetes and Deuteromycetes, furnish the basis for such groupings as Amerosporae, Allantosporae, Hyalodidymae, Phaeodidymae, Hyalophragmeae, Phaeophragmeae, Dictyosporae, Scolecosporae, and Helicosporae.

Any system of classification is successful only if its use will enable the worker to identify an unknown organism conveniently and accurately and at the same time relate it to known organisms. Years must still elapse, however, before the vast expanse of ignorance will be sufficiently carefully charted to enable the student to know that he has closely approximated a natural system. Meanwhile evidence will have accumulated to clarify the question of whether the fungi are a monophyletic series derived from filamentous green algae, whether they are a polyphyletic assemblage derived from different groups of green and red algae, or whether they are a distinct phylum derived from protozoan ancestry. This third hypothesis, voiced by Martin (1941), appears to fit present-day facts most nearly.

Although many systems of classification have been proposed, the few examples which have been mentioned indicate the evolution of present-day systems. Certain investigators would now exclude bacteria and slime molds from the Fungi. Many would separate the Fungi from the Algae, giving each a coordinate 
rank as a phylum. The reasons for these proposals need not be stressed.

Keys are useful as aids in the identification of fungi, but in the present imperfect state of knowledge no generally satisfactory keys are possible. Those of Clements and Shear (1931) are based upon Saccardo's groupings. The recent ones by Martin

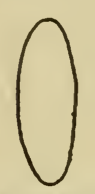

Amerospore Didymospore

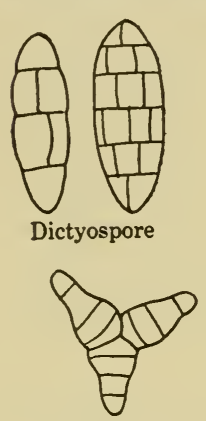

Staurospore

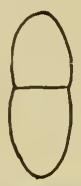

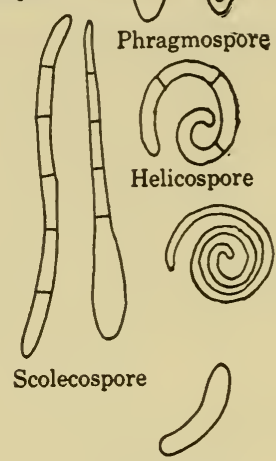

Allantospore

FIg. 9. Artificial groupings within families are based in part upon shape of spores and septation. The names given apply to the characteristics of spores. satisfactory. Exceptions will be encountered, and it must be appreciated that the taxonomic position of many species has not yet been established with finality. This conclusion is all too apparent even among groups of fungi that have been excellently monographed or are best known.

\section{THE CLASSES OF FUNGI}

1. Vegetative or assimilatory stage plasmodial Class Myxomycetes 4

1. Vegetative or assimilatory stage usually filamentous

2. Mycelium usually non-septate throughout Class Phycomycetes 11

2. Mycelium septate throughout 
3. Spores of perfect or sexual stage borne in asci

Class Ascomycetes 21

3. Spores of perfect or sexual stage borne on basidia

Class Basidiomycetes 34

3. Lacking asci and basidia but usually possessing asexual spores

Class Fungi Imperfecti 43

\section{THE ORDERS OF FUNGI}

\section{Class Mrxomycetes}

4. True plasmodium not formed, swarm spores amoeboid but not flagellate

5. Swarm spores retaining individual identity, encyst at tip of mass

Order Acrasiales

5. Swarm spores connected by long pseudopodia into chains or nets

Order Labyrinthulales

4. True plasmodium formed, swarm spores amoeboid and flagellate

6. All parasitic on vascular plants Order Plasmodiophorales

6. Saprophytic

7. Spores borne externally on thallus, each producing eight swarm cells on germination

Subclass Exosporeae (Myxogastres, in part)

7. Spores borne within fructification, each producing one or two swarm cells on germination

Subclass Endosporeae (Myxogastres, in part) 8

8. Spores in mass typically violaceous or black, lime present or absent

9. Peridium, capillitium, or both calcareous

Order Physarales

9. Neither peridium nor capillitium calcareous, lime usually present on stipe and columella Order Stemonitales

8. Spores in mass typically pallid, yellow, brown, or rosy, lime never present

10. True capillitium lacking or only scantily developed

Order Liceales

10. Capillitium well developed, thread-like, sculptured

Order Trichiales

\section{Class Phycomycetes}

11. Mycelium lacking or poorly developed (a rhizomycelium), entire thallus or its parts functional in reproduction

12. Thallus microscopic, unicellular, becoming a single sporangium, a sorus of sporangia, or a gametangium; sexual reproduction unknown or of various kinds; zoospores uniciliate or biciliate

Subclass Archimycetes 13 
13. Mycelium lacking, or consisting of delicate rhizoid-like threads Order Chytridiales 14

14. Mycelium lacking, thallus at first naked and amoeboid; holocarpic, parasitic Suborder Myxochytridineae

14. Mycelium of delicate threads, thallus with cell wall from the first, sterile and fertile portions distinct

Suborder Mycochytridineae

13. Mycelium a chain of cells, each a functional sporangium, antheridium, or oogonium; zoospores biciliate

Order Lagenidiales

11. Mycelium well developed, for the most part remaining vegetative; reproductive parts separated from assimilatory by septa 15

15. Sporangia of two kinds: thin-walled and thick-walled, resistant; sexual reproduction lacking or involving fusion of motile gametes forming motile zygote; zoospores uniciliate

Order Blastocladiales

15. Thin-walled sporangia only; sexual spores thick-walled 16

16. Gametangia dissimilar; fertilization heterogamous to form oospore, asexual spores motile Subclass Oomycetes 17 17. Antherozoids and zoospores uniciliate

Order Monoblepharidales

17. Antherozoids absent; fertilization tube extends from antheridium to oosphere

18. Oospheres 1 to several in each oogonium, periplasm absent; zoospores biciliate, commonly diplanetic

Order Saproleginales

18. Oospheres 1 in each oogonium, periplasm present; zoospores biciliate

19. Thallus aquatic, saprophytic, arbusculate, branches constricted Order Leptomitales

19. Thallus aquatic, not arbusculate nor constricted, parasitic, zoospores extruded in a vesicle Order Pythiales

19. Thallus terrestrial, parasites on seed plants; sporangia germinating by zoospores or germ tube; oospores within host Order Peronosporales

16. Gametangia morphologically similar, fertilization isogamous to form zygospore; asexual spores conidia

Subclass Zygomycetes 20

20. Saprophytes; sporangia from one to many-spored; conidia not forcibly liberated Order Mucorales

20. Mostly parasites on insects; conidia forcibly discharged; zygospores formed within hosts

Order Entomophthorales 


\section{Class Ascomycetes}

21. Asci not aggregated in ascocarps, that is, naked and formed singly or in loose clusters

Subclass Hemiascomycetes 22

21. Asci aggregated, enclosed in well-developed ascocarps

Subclass Euascomycetes 23

22. Saprobic, ascus formed directly from zygote, mycelium not well developed, cells usually bud

Order Endomycetales (Saccharomycetales)

22. Strictly parasitic on vascular plants, apical cells become asci, mycelium not well developed, budding very common

Order Taphrinales (Exoascales)

23. Ascocarps lack definite ostioles, hence are cleistothecia 24

24. Asci irregularly arranged

Plectomycetes 25

25. Stroma lacking, asci filling interior of ascocarp

Order Eurotiales (Aspergillales)

25. Stroma present, asci borne singly in locules

Order Myriangiales

24. Asci regularly arranged Order Erysiphales (Perisporiales)

23. Ascocarps provided with ostioles or cupulate, asci arranged in parallel series

26. Ascocarps with neck-like ostioles, hence perithecia

27. Perithecia borne on a receptacle, minute parasites on insects and arachnids

Order Laboulbeniales

27. Perithecia not borne on a receptacle

28. Perithecia globose, ostiole typically circular in cross-section

29. Perithecia borne singly or in a stroma, black or dark colored

30. Perithecia provided with definite wall

Order Sphaeriales

30. Differentiated perithecial walls lacking, asci borne in stromatic locules

Order Dothideales

29. Perithecia borne singly or in a stroma but always bright colored-red, yellow, purple

Order Hypocreales

28. Perithecia elongated with a slit-like ostiole

Order Hysteriales

28. Perithecia dimidiate, opening with a pore or irregular rift

Order Hemisphaeriales

26. Ascocarps wide open, discoid, hence apothecia

31. Asci inoperculate

Discomycetes 31

32. Apothecia superficial, mostly small, fleshy, or waxy

Order Helotiales

32. Apothecia innate, mostly small, carbonaceous

Order Phacidiales 
31. Asci operculate

33. Apothecia epigeic, variable in size, fleshy; stalk inconspicuous

Order Pezizales

33. Apothecia epigeic; large, fleshy; stalk prominent Order Helvellales

33. Apothecia hypogeic, fleshy, remaining closed Order Tuberales

\section{Class Basidiomycetes}

34. Basidia septate longitudinally or transversely, or arising from a teliospore or probasidium; or if non-septate, basidiocarp gelatinous; basidiospores commonly bud on germination

35. Basidiocarp lacking, basidia arising from teliospores

36. Teliospore (chlamydospore) on germination produces tubes (basidia) septate or not, bearing sessile sporidia that bud

Order Ustilaginales

36. Teliospore on germination produces tubular four-celled basidium, each cell bearing a single sporidium on a sterigma; sporidia produce germ tube on germination

Order Uredinales

35. Basidiocarp present, mostly gelatinous

37. Basidia septate

38. Septations transverse

Order Auriculariales

38. Septations longitudinal, two- or four-divided

Order Tremellales

37. Basidia non-septate, with two blunt terminal sterigmata

Order Dacryomycetales

34. Basidia always non-septate, cylindrical or broadly clavate; probasidium lacking; basidiospores usually form hyphae on germination

Subclass Homobasidiomycetes 39

39. Hymenium exposed before maturity of spores

Order Agaricales (Hymeniales)

39. Hymenium remaining closed or opening only after basidiospores have been liberated from basidia (Gastromycetes)

40. Hymenium present and lining labyrinthiform chambers of gleba

41. Gleba fleshy or waxy or sometimes slimy and fetid at maturity, but if so not exposed

Order Hymenogastrales

41. Gleba fleshy, borne on lower surface of centrally stipitate pileus-like structure, angiocarpous or gymnocarpous

Order Podaxales

41. Gleba fleshy or waxy or slimy and fetid and always exposed at maturity

Order Phallales

41. Gleba powdery and dry at maturity

Order Lycoperdales 
40. Hymenium lacking or indistinct

42. Glebal chambers at maturity not separating from peridium nor from each other; gleba powdery and dry

Order Sclerodermatales

42. Glebal chambers enclosed within peridioles which serve as disseminules

Order Nidulariales

\section{Class Fungi Imperfecti}

43. Conidia produced in globose, cupulate, or hysteroid pycnidia

Order Sphaeropsidales (Phomales, Phyllostictales)

43. Conidia not formed in pycnidia

44. Fructification consisting of a plane stromatic layer of closely compacted conidiophores, an acervulus, usually innate

Order Melanconiales

44. Fructification consisting of separate conidiophores or loosely compacted conidiophores, forming synnemata or sporodochia

Order Moniliales (Hyphomycetes)

43. Conidia lacking

Mycelia Sterila

\section{LITERATURE CITED}

Bisby, G. R., ANd G. C. Ainsworth, "The numbers of fungi," Trans. Brit. Mycol. Soc., 26: 16-19, 1943.

Clements, F. E., and C. L. Shear, The genera of fungi. iv + 496 pp. H. V. Wilson Co., New York. 1931.

Fifth International Botanical Congress, 1930, "International rules of botanical nomenclature." 39 pp. (Published as supplement to J. Botany, June, 1934.)

Fries, Elias, Systema mycologicum, Vols. I-III. Ernest Mauritius, Griefswald. 1821-1832.

Linvaeus, Carl, Species plantarum. 1200 pp. L. Salvius, Stockholm. 1753. Martin, G. W., "A key to the families of fungi exclusive of the lichens," Univ. Iowa Studies, 17:83-115. University of Iowa, Iowa City. 1936. "Outline of the fungi," Univ. Iowa Studies, 28. $64 \mathrm{pp}$. University of Iowa, Iowa City. 1941.

Persoon, C. H., Synopsis metbodica fungorum. xxx +706 pp. H. Dieterich, Göttingen. 1801.

Saccardo, P. A., Sylloge fungorum omnium bucusque cognitorum, Vols. 1-25. 1882-1931. 


\section{Chapter 4}

\section{THE MYXOMYCETES}

The Myxomycetes, or slime molds, are fungus-like organisms which, in their vegetative or assimilatory phase, consist of a naked, multinucleate mass of protoplasm called a plasmodium, and in their reproductive phase consist of encased spores. Their relationship to fungi and to animals has long been a much-discussed subject, as is indicated by the name Mycetozoa, which is frequently applied to them. Such early workers as Micheli and Fries placed them among the puffballs, and it is easily understandable that such well-known species as Lycogala epidendrum and Fuligo septica should have been regarded as puffballs.

The development of a slime mold is typified by that of $F$. septica. It is cosmopolitan, and its fruit bodies may be found on $\operatorname{logs}$, around stumps, or on lawns and flowerbeds. They are yellowish, tawny, cushion-like structures about 3 to $6 \mathrm{~cm}$ in largest diameter and 2 to $3 \mathrm{~cm}$ thick. The cortex is friable, foamy, and calcareous. The interior is filled with violaceous, spherical spores with knotted threads (capillitia) interspersed. The spores are usually disseminated by winds. In moist weather the spore walls open to emit swarm cells (myxamoebae), which ingest bacteria and fungus spores, assimilate them, and grow to become a large, multinucleate, naked mass of protoplasm (plasmodium). The plasmodium moves in amoeboid fashion to the surface of the substratum and in its entirety becomes a fruit body (aethalium). Each nucleus is invested with a wall during the transformation of a plasmodium into an aethalium, and the inert materials (leftovers) become the cortex and capillitium.

Present-day knowledge of the slime molds began with a series of studies by de Bary covering a period of 10 years, which were assembled in his monograph in 1864 . He early observed that the spores of Hemitrichia vesparium give rise not to germ tubes, as do those of fungi proper, but to amoeboid flagellates. For 
this reason he gave slime molds the name Mycetozoa and placed them outside the plant kingdom. Meantime Cienkowski (1863, 1863a) turned his attention to this group, and as an outcome of his studies, together with those of de Bary, thoroughly established the fact that spores of slime molds germinate by the formation of swarm cells, that these swarm cells fuse to initiate the plasmodium (apparently this term was first employed by Cienkowski), and that the plasmodium eventually ceases to grow and becomes transformed into the fructification.

A series of taxonomic treatises on this group have appeared, beginning with that of Rostafinski (1873), a pupil of de Bary. His studies are the basis of present-day classification. Then followed the classification of Massee (1892) and the monograph of Lister (1894), which has undergone two revisions by his daughter. Meanwhile a treatise by Macbride (1899) of the North American slime molds appeared and was completely revised in 1934 [Macbride and Martin (1934)]. In the present account the Myxomycetes are regarded as including the three orders, Acrasiales, Labyrinthulales, and Plasmodiophorales, that are outside the subclass of true slime molds, Myxogastres. This is done arbitrarily and not on the basis of evidence of relationship to the Myxobacteriales, the flagellate Protozoa, or the Myxochytridiales. Acrasiales. The Acrasiales comprise a group of approximately 20 species that occur on dung and on decaying leaves and wood. There is reason to believe that they are of general occurrence in soils containing organic matter of any sort. They are characterized by abrupt separation into vegetative and fruiting stages. On germination their spores produce naked amoeboid cells, called myxamoebae. Each cell is uninucleate and, in the presence of available food (bacteria), is capable of giving rise to an indefinite number of cells like itself. Dictyostelium discoideum, as observed by Raper (1940), typifies the developmental structure of this order. He found that each amoeboid cell remains a distinct entity and that the cells aggregate, without fusing, to constitute the pseudoplasmodium. That they are all separate may be shown, as Raper demonstrated, by placing a pseudoplasmodium in water. As growth proceeds, the pseudoplasmodium becomes a cylindrical body that migrates as a unit throughout the substratum or over its surface. Eventually it becomes transformed into a fruiting structure, a sporocarp, con- 
sisting of a basal disk that supports a stalk which in turn is surmounted by the spore mass. The construction of the sporocarp is a communal enterprise. How this division of labor among so many distinct entities is directed and controlled remains entirely unexplained. The sporocarp of $D$. discoideum is always of the same pattern. Similarly, whatever the pattern is for each other species, it is always the same.

Skupienski (1920) maintained that the amoeboid cells fuse in pairs, a phenomenon that is known to occur among the true slime molds. It seems highly probable that Skupienski is correct as regards fusion among Acrasiales, but this point requires confirmation.

The ability of pseudoplasmodia to maintain their specific identities is strikingly demonstrated by the experiments of Raper and Thom (1941). They crushed and thoroughly mixed the pseudoplasmodia of Dictyostelium discoideum and D. purpureum, and of D. discoideum and Polysphondylium purpureum, and from each pair of the mixture typical sorocarps of each species were eventually organized. If these investigators withheld food (bacteria), the colonies resulting from a mixture of pseudoplasmodia of the two species of Dictyostelium produced sorocarps in which were combined the characters of each species. The combinations were not hybrids, however, but physical mixtures.

The body of the fructification or sorocarp consists of inert material, and the living portion becomes encysted as multinucleate, walled spores that accumulate in a globular body at the tip of the mass.

The Acrasiales were monographed by Olive (1902) and include three families, the Guttulinaceae, Acrasiaceae, and Dictyosteliaceae, differing mainly in structure of the sorocarps. The best-known member is the Genus Dictyostelium, investigated by Pinoy (1907), Skupienski (1920), and Raper (1937, 1940). Raper grew Dictyostelium discoideum and D. mucoroides on a variety of agar media in "pure-mixed culture" with various species of bacteria, especially Escherichia coli and Serratia marcescens. Cohen (1939) grew D. discoideum in pure culture and in "two-membered" cultures. These species commonly utilize bacteria as food, as was first indicated by Pinoy (1907), and as other slime molds are known to do. They continue to ingest bacteria so long as bacteria are available and environmental factors are 
favorable. Raper (1940) found that 20 to $24^{\circ} \mathrm{C}$ is the optimum temperature and that $p \mathrm{H} 5.5$ to 7.0 is a favorable reaction for $D$. discoideum. Decreased relative humidity, increased temperature, and change in light promote fruiting.

In summary, the Acrasiales are distinct from the slime molds proper in that the swarm cells lack flagella, are not known to fuse, and hence do not form true plasmodia but form pseudoplasmodia instead.

LABYrinthulales. The Labyrinthulales are an aberrant, littleknown group, mostly parasitic on algae of both fresh-water and marine species, Cladophora and Vaucheria being common hosts. They consist of naked, amoeboid cells connected by pseudopodial processes to form chains or nets, long ago described by Zopf as "net plasmodia." Each net plasmodium increases in size by the formation of new cells. Spores arise by rounding up and encystment of the cells. On germination a single, naked, amoeboid cell is liberated from each spore. These essential features were early determined by Cienkowski (1867).

Recently Dangeard (1932) described reproduction of another kind, occurring by formation from the net plasmodium of a hollow sphere of cells aggregated around debris within the host cell. From each cell of the sphere 4 to 8 naked swarm cells escaped by rupture of the wall. This number of swarmers coming from each cell indicates that sexuality and reductional division may be involved in this reproductive process.

Attention has been focused on the Labyrinthulales in recent years because of the outbreak of a disease, called "wasting disease," of Zostera marina. This is a marine seed plant of enormous importance as a source of food for wild ducks, geese, and other water fowl and for many marine animals. Associated with diseased plants is Labyrintbula macrocystis, which is regarded by some workers as the causal agent of the wasting disease. The reports by Renn (1936) and Young (1938) will acquaint the reader with evidences of its parasitism and with the status of this problem.

Plasmodiophorales. The members of this order, containing approximately only a score of species, are all endoparasites of vascular plants. They involve roots and underground stems and cause the formation of excrescences or galls. Upon disintegration of the host tissues the spores are liberated in the soil. The 
germinating spore then liberates a naked, amoeboid swarmer provided with a pair of unequal flagella, anteriorly attached, as shown by Ledingham (1934), Karling (1942), and others. Woronin (1878) in his classical studies of Plasmodiophora brassicae and Cook and Schwartz (1930) described a single anterior flagellum, which is clearly erroneous. The swarm cells are said to fuse in pairs, settle on the epidermis or root hairs, and effect entrance as naked, amoeboid zygotes. Actual fusion of swarm cells in living material among Plasmodiophorales has been observed only in Spongospora subterranea. Once this parasitic relationship has become established, the zygote increases in volume, with accompanying increase in number of nuclei, to become a naked plasmodium. As the host cells divide, the plasmodium may be cut in two and may appear in each daughter cell.

All divisions in the same plasmodium are simultaneous [Cook (1928) ]. Finally, just before sporulation, meiosis takes place, and the uninucleate spores are walled off and remain separate or adhere in groups characteristic of the genus or species. In Plasmodiophora and Ligniera the spores remain separate in the host cells; in Tetramyxa they cling in tetrads; in Spongospora they remain in a spongy mass; in Sorosphaera they form a hollow sphere; and in Sorodiscus they aggregate into two layers.

Plasmodiophora brassicae, the cause of club root of cabbage and other cruciferous plants, is the best-known member of the Plasmodiophorales, especially from the studies of Woronin (1878), Maire and Tison (1909, 1911), Lutman (1913), Schwartz (1914), Chupp (1917), Cook (1928), and Cook and Schwartz (1930). Little that is new has been added, however, to the findings by Woronin, so accurate were his observations and so painstaking his attention to details. The swarm cell loses its flagella during penetration, which is accomplished, according to Chupp (1917), by piercing the wall of the root hair. Then the nucleus divides repeatedly, and after 2 or 3 days the plasmodium is of a size to cleave into uninucleate protoplasts. Each protoplast next becomes enclosed in a wall and functions as a gametangium, forming 4 to 8 swarmers [Cook and Schwartz (1930)]. These swarmers fuse in pairs, initiating the plasmodium, which increases in size, with repeated simultaneous divisions of its nuclei. Meanwhile the invaded cells become hypertrophied. All nuclear di- 
visions are equational except the penultimate one [Lutman (1913), Cook and Schwartz (1930), and Cook (1933)].

Spongospora subterranea, the cause of powdery scab of potato tubers and of lesions on the underground portions of tomato stems, is the only other species of this order that is of economic importance. It has been known in Europe for approximately 100 years and was apparently introduced from the Andean home of the potato.

The spores of $S$. subterranea germinate readily, each forming a single uninucleate amoeba. Infection is accomplished at or near the "eyes." Some workers have maintained that infection is accomplished by separate amoebae, but Kunkel (1915) presented evidence that invasion comes from the action of a plasmodium (zygote). Osborn (1911), on the other hand, has described uninucleate amoebae in young potato cells. His studies show the manner of enlargement of plasmodia and the formation of the sponge-like mass of spores. While proof of sexuality is lacking, there is evidence that nuclei fuse and that reductional division occurs just before sporulation.

Information concerning Sorosphaera can be gained from the report of Blomfield and Schwartz (1910), concerning Ligniera from the report of Cook (1926), and concerning Sorodiscus from the report of Wernham (1935).

Generic differences among the Plasmodiophorales are insufficient and too slight in taxonomic value to incline Palm and Burk (1933) to retain the six usually recognized genera. On the other hand, Cook (1933) in his taxonomic treatment of the group recognizes 6 genera and 14 species. He emphasizes the importance of fusion of swarm cells by their anterior end among Plasmodiophorales rather than by their posterior end, as occurs in the slime molds proper. Karling (1942) employs 8 genera in his monograph of the order, which includes a complete host index and bibliography.

Maire and Tison (1909) stressed the point that the Plasmodiophorales are a distinct group, an opinion with which most mycologists are in accord, but whether they should be placed phylogenetically between the Sporozoa and the Myxogastrales or considered primitive chytrids remains a controversial question.

Myxogastres. This subclass comprises the orders Physarales, Stemonitales, Liceales, and Trichiales. It includes about 400 spe- 
cies of true slime molds. As their name implies, they were first placed among the Gastromycetes and, in fact, were so retained by Fries. Their most common habitat is rotten logs or wood and decaying leaves. Many possess unusual architectural beauty and vividly striking colors. The majority of known species grow in temperate regions and are quite cosmopolitan. Some, however, appear to be restricted to the tropics.

The slime molds are characterized by having, in their assimilatory phase, naked, amoeboid, multinucleate plasmodia that are quite mobile and that vary in size from microscopic units to masses several centimeters in diameter. These plasmodia are hyaline and white, yellow, orange, red, violet, blue, green, or brown. The colors are imparted by anthracene pigments, and a change in reaction results in a change of color. The plasmodia occur largely within or beneath decaying vegetation, but at the time of reproduction they migrate to the exposed surface of the substrate or creep up on near-by green herbs or the bases of trees. The migration of the plasmodium never fails to charm the observer. In his Systema Mycologicum Fries writes, "At one time I deposited the plasmodium of Diachaea in my hat and within the space of an hour it had covered the greater part of it with its elegant white network. ... I find nothing more wonderful than slime molds in all the world of plants."

The fructifications are of several general types, all possessing an outer membranous covering of inert material, the peridium. If the entire plasmodium becomes transformed, as in Fuligo septica, into a fructification without the delimitation of separate sporangia, the reproductive structure is of the type termed an aethalium. If the plasmodium aggregates at the loci of a few of the larger veins and retains somewhat the netted form of the plasmodium, as in Hemitrichia serpula, the fructification is termed a plasmodiocarp. If the plasmodium becomes separated into grouped, erect clusters of fructifications of definite form, with remnants of inert material remaining at the base, the fructifications are termed sporangia. Sporangia are of many patterns, some being marvels of delicacy and intricacy.

Fruiting may be induced by exhaustion of nutriment [Camp (1937)]. Doubtless other environmental influences stimulate transformation of the plasmodia into fructifications. 
Spore germination. De Bary (1864), it has previously been stated, first noted that on germination swarm cells, rather than germ tubes, emerge from the spore membranes. Jahn (1905) ob-
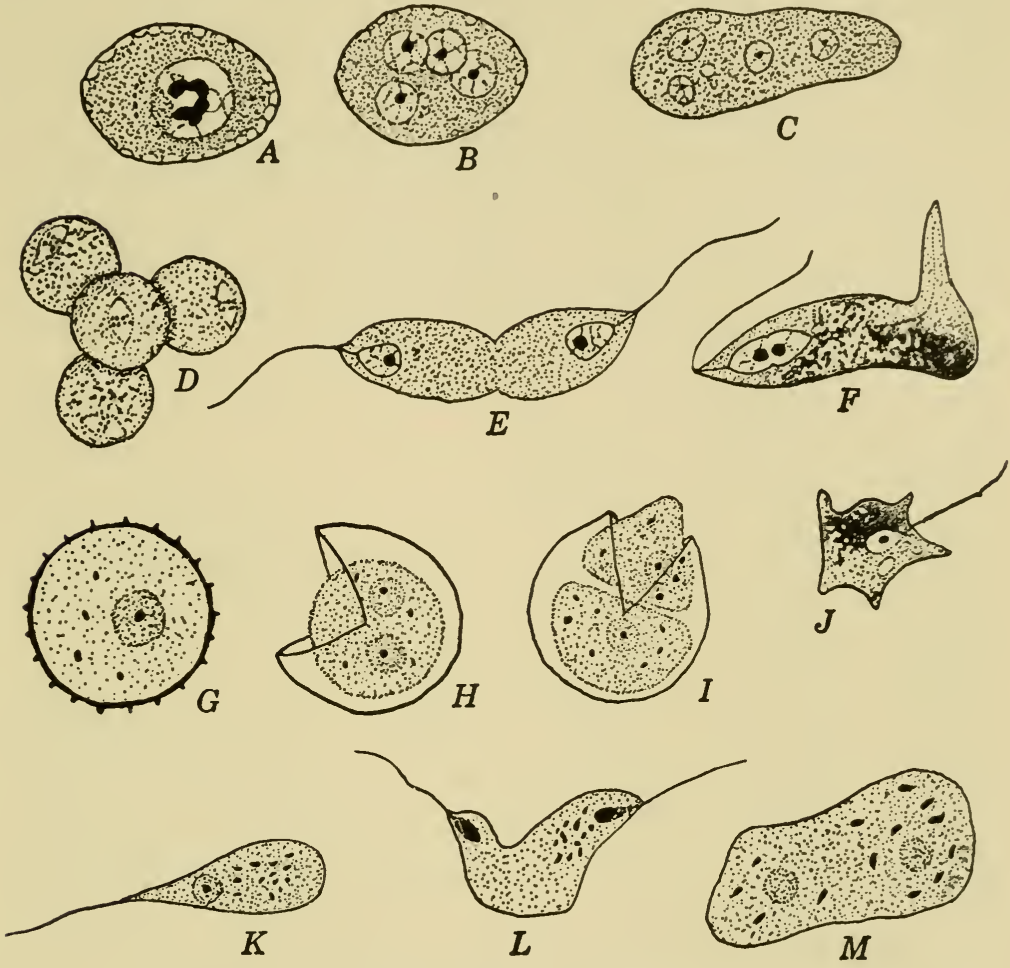

Fig. 10. Types of spore germination and initiation of plasmodia among slime molds. (Adapted from Gilbert.) $A$ to $F$. Ceratiomyxa fructiculosa. $A$, uninucleate spore; $B$, the same spore, which has become four-nucleate; $C$ and $D$, segmentation into four bodies; $E$ and $F$, fusion of cells to form plasmodium. $G$ to $M$. Physarım polycepbalum. $G$, uninucleate spore; $H$ and $I$, the wall has ruptured, the nucleus has divided, and the swarm cells have begun to emerge; $J$ and $K$, motile swarm cells; $L$, fusion of swarm cells; $M$, plasmodium.

served that the membrane may be cracked open in some species, whereas in others a circular, jagged pore is formed. In either case, he believed, rupture resulted from increased osmotic pressure. The change of stored glycogen within the spore into osmotically active sugar resulted in increased osmotic pressure. 
Skupienski (1920), on the other hand, believed that enzyme action did not in any way account for increased osmotic pressure. After observing germination among 56 species Gilbert (1928) expressed the opinion that local enzyme action may soften the wall in species whose membrane opens by a jagged pore, as in Dictydiaethalium plumbeum. The wedge-shaped cleft characteristic of the other type of opening is typified by Fuligo septica.

As in the germination of spores of other organisms, environmental factors exert a controlling influence. Nearly all species germinate best in decoctions of the substrata on which they naturally occur. Smart $(1937,1938)$ found that all but four of the 70 species and varieties which he employed could be made to germinate in water alone.

Some slime molds retain their viability for incredibly long periods. Smith (1929) germinated the spores of 21 species after they had remained in the laboratory for periods of 5 to 35 years. Some are capable of immediate germination, as are Arcyria demudata, Dictydium cancellatum, Dictydiaethalium plumbeum, and Fuligo septica. .Others, such as Hemitricbia serpula, do not germinate until they have aged a year or more.

There are two types of germination among Myxogastres, each characteristic of the subclass, Exosporae or Endosporae, of this order to which the species belongs. A few species of Ceratiomyxa comprise the first subclass, and all other species the second.

In Ceratiomyxa the spores (protospores) on delimitation contain a single nucleus, but at maturity they become four-nucleate by two equational divisions. Upon germination the entire content emerges as an amoeboid, naked body or as a four-lobed mass in which the nuclei again divide, and the protoplast then separates into eight uninucleate portions, each a flagellate, pyriform swarm cell. These swarmers fuse in pairs to form the zygote, which increases in volume to become the plasmodium. Just before the delimitation of protospores, reductional division is accomplished as shown by Jahn (1908) and verified by Gilbert (1935).

In the Endosporae, many of which have been studied, the spores on germination form 1 to 4 swarm cells. Gilbert (1928b) studied 18 species, finding that Badbamia lilacina, B. magna, Physarum connatum, Leocarpus fragilis, and Mucilago spongiosa form 1 to 4 swarm cells and that Physarum compressum, P. leu- 
copus, $P$. serpula, and $P$. virescens form 1 to 2 swarm cells. Each swarm cell is amoeboid on emergence, but soon an anterior flagellum develops. The swarmers fuse in pairs by apposition of their posterior ends [Howard (1931)], and nuclear fusion soon follows. As the plasmodium increases in size, the fusion nucleus repeatedly divides equationally and simultaneously.
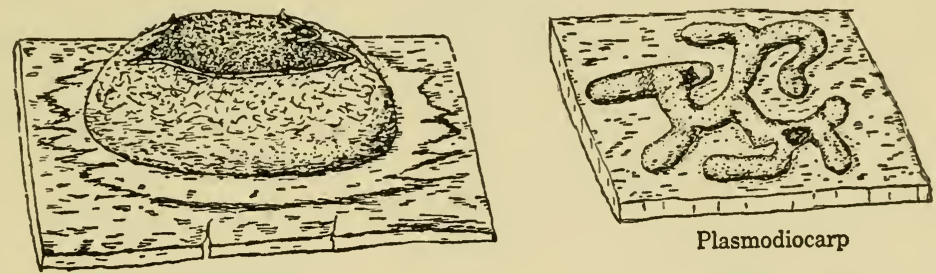

Aethalium
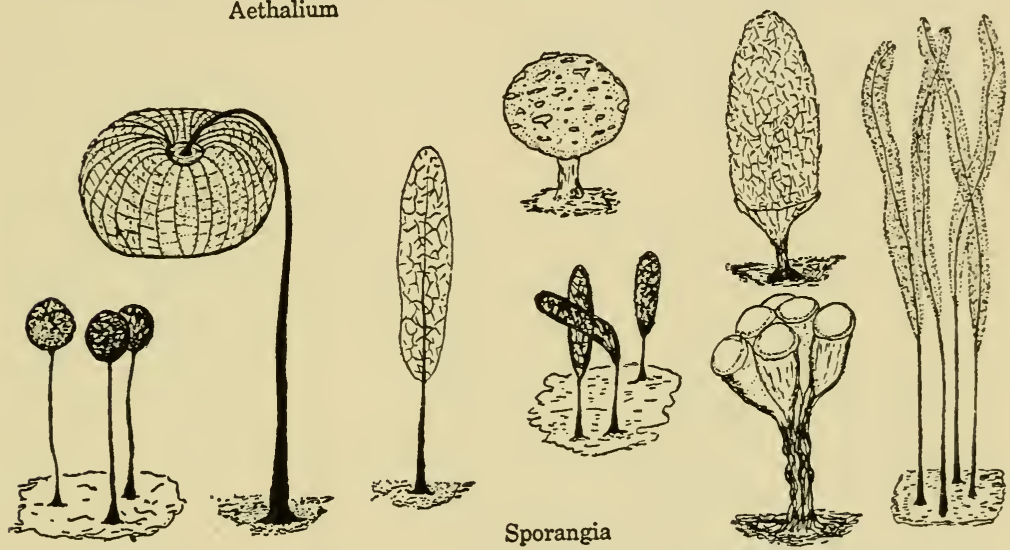

FIg. 11. Types of fructification among slime molds. Aethalium, as in Fuligo septica, the entire plasmodium becoming a sporocarp; plasmodiocarp, as in Hemitrichia serpula, plasmodium somewhat reticulate; sporangia, as in most species, plasmodium becoming separated into groups of fructifications.

In Physarum polycephalum from 20 to 40 minutes is required for the completion of mitosis [Howard (1932)]. There is lack of accord concerning the exact point at which reduction division occurs. It may take place just before cleavage of the plasmodium into spores, or the spore may be diploid, in which case 3 of the 4 nuclei arising by meiosis within the spore may disintegrate.

Feeding habits. The plasmodia ingest a variety of materials, even those which are utterly useless as food. In nature they 
subsist largely on fungi and bacteria. Lister early noted that Badbamia utricularis can attack living species of Corticium. Skupienski (1920) recorded the fact that Didymium difforme utilizes the spores of such common molds as Aspergillus and Penicillium, as well as yeasts and bacteria. Gilbert (1928b) supplied the swarm cells of twenty species of Myxomycetes with spores of certain Agaricaceae, Polyporaceae, Mucorales, Pyrenomycetes, Discomycetes, and Fungi Imperfecti, and found that all could be used by each of the slime molds, provided that the spores were not too large to be engulfed by the swarmer. He used Arcyria denudata, A. incarnata, Badbamia magna, B. lilacina, Comatrichia typhoides, Dictydiaetbalium plumbeum, Didymium nigripes var. xanthopus, Enteridium splendens, Fuligo septica, Hemitricbia clavata, H. vesparium, Leocarpus fragilis, Lycogola epidendrum, Physarum viride, Reticularia lycoperdon, Stemonitis ferruginea, S. fusca, S. splendens var. flaccida, and Trichia floriformis.

Howard and Currie (1932) grew various agarics and polypores on agar media fortified with decoctions of corn, rolled oats, potatoes, or Vicia faba and found that 21 species of slime molds were parasitic upon the mycelia of the various Hymenomycetes.

By making a series of motion pictures of feeding plasmodia at intervals of 5 to 10 minutes and then projecting them at the usual rate, Howard was able to show that the plasmodium flows and recedes as do the waves on a beach, and in so doing breaks into fragments the fungal hyphae or hymenomycete sporophores upon which it is feeding.

Artificial culture. Several methods have been devised whereby slime molds can be grown and maintained in artificial culture. Many workers have cultivated them on the sporophores of Hymenomycetes. Howard (1931) noted that Physarum polycephalum could digest a large pileus of Amanita muscaria within 24 hours. He utilized oat agar as a medium for artificial cultures, placing near the edge of the dish a fragment of plasmodium of $P$. polycephalum. After the plasmodium migrated from its original place of lodgment, a fragment was transferred to another dish, and by means of several transfers the plasmodium was essentially freed from contaminants. Camp (1936) placed the plasmodial or sclerotial fragments of this same species on a gauze or 
filter paper, kept moist by capillarity, in a damp chamber. Pulverized rolled oats were sprinkled sparingly over the mobile plasmodium. After feeding on the oats, the plasmodium spread to

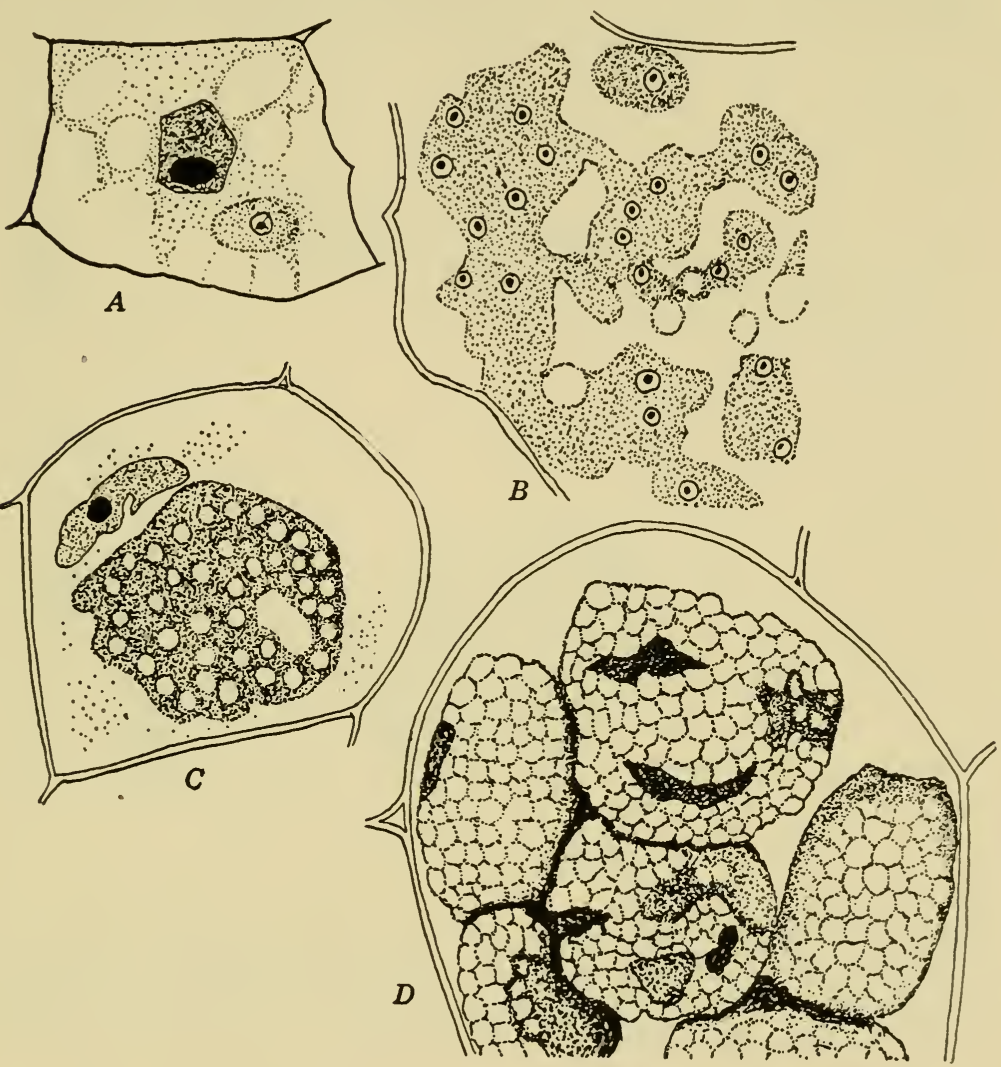

Fig. 12. Stages in growth of plasmodium and transformation into masses of spores in Spongospora subterranea within cells of potato tuber. (Adapted from Osborn.) $A$. Young plasmodium. $B$. Multinucleate plasmodium at a somewhat later date. C. Aggregation of plasmodium before spore formation. D. Mature soral masses of spores.

the walls of the culture vessel, where it could be removed and daily started anew.

CAPILlitial FORMATION. The capillitium and sporangial wall are constituted of inert material deposited by the plasmodium during transformation into the fructification. Capillitial forma- 
tion has been studied by Harper and Dodge (1914) and by Bisby (1914), among others. True capillitium in Physarella mirabilis and Stemonitis fusca [Bisby (1914)] arises during sporangial cleavage among tubular spaces formed from invaginations. The plasma membrane lining these spaces progressively deposits sub-

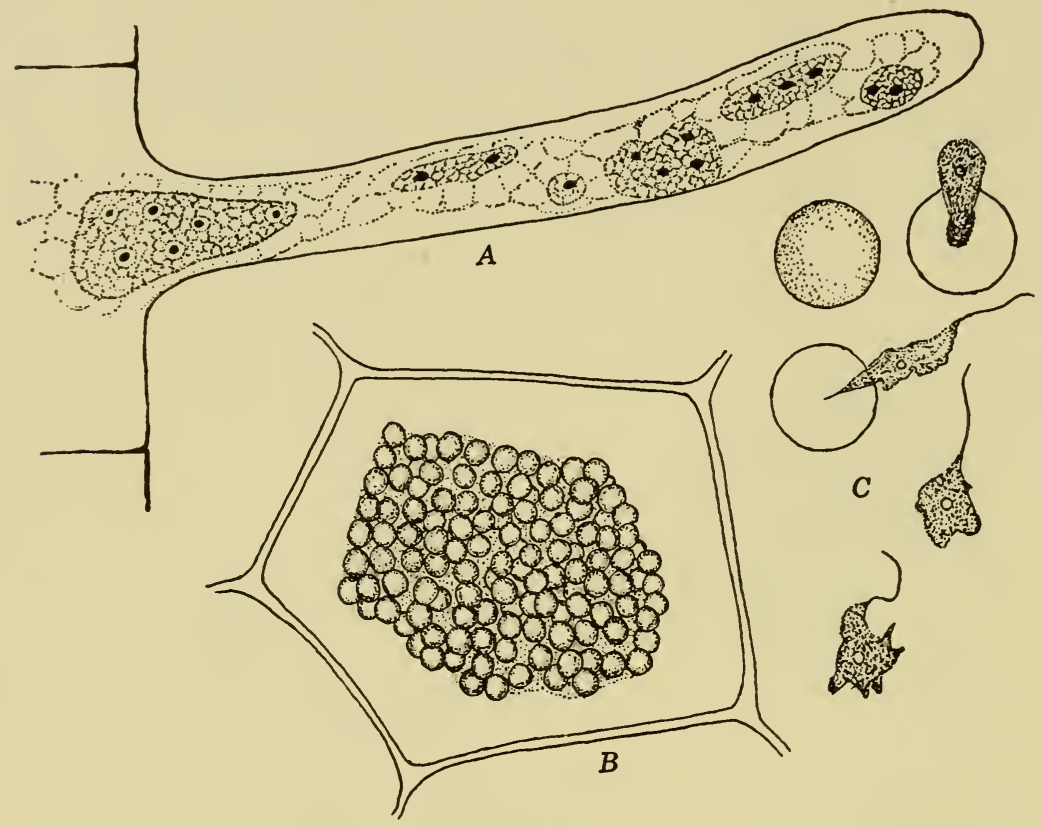

Fig. 13. Plasmodiophora brassicae. A. Young plasmodia within root hair. $B$. Mass of spores that have come from mature plasmodium. $C$. Stages in germination of spores and escape of myxamoebae. ( $A$ and $B$ after Chupp, $C$ after Woronin.)

stance that becomes the walls of capillitial threads. In S. fusca these threads are continuous with the sporangial wall and with the columella. Some genera, such as Enteridium and Lycogala, form pseudocapillitia, which are products of protoplasmic degeneration.

In Comatrichia and Lamproderma the capillitium, as in Stemonitis, is continuous with the columella. In Hemitrichia and Arcyria the capillitial threads are elaborately provided with spines and spiral thickenings. In Badhamia there is a network of lime-containing tubes; in Physarum the lime is aggregated into 
knots. Other genera, such as Licea and Cribraria, possess no capillitium.

Classification. The classifications that have been proposed, including those of Lister (1925), Jahn (1928), and Macbride and Martin (1934), are all highly artificial. Different ordinal names are given by each worker. Color of spores and presence of capillitium and of lime are given great emphasis in ordinal groupings. Genera apparently closely related are often widely separated, as must happen when characters whose significance is not yet evaluated are employed in classification. In spite of these limitations identification is not a difficult task, and the group must be regarded as very inviting to the taxonomist.

Iniplications. The many unsolved problems concerning Myxomycetes are clearly stated in a recent review by Martin (1940). These problems involve, among other factors, the question of whether plasmodia fuse, the sexuality of representative genera (only a few of which have been studied), the uncertainty whether + and - swarmers exist, the nature of the pigments and of color changes in plasmodia, the stimulus of fruiting, morphogenic mechanisms, the factors governing endemism, the causes of protoplasmic streaming and of amoeboid movement, and the relationship of slime molds to other organisms.

\section{LITERATURE CITED}

Bary, Axton de, Die Mycetozoen (Scbleimpilze). Ein Beitrag zur Kenntnis der niedersten Organismen. Leipzig. 1864.

Bisby, G. R., "Some observations on the formation of the capillitium and the development of Physarella mirabilis and Stemonitis fusca," Am. J. Botany, 1:274-288, 1914.

Blomfield, J. E., and E. T. Schwartz, "Some observations on the tumors of Veronica chamaedrys caused by Sorosphaera veronicae," Ann. Botany, 24: 35-43, 1910.

Camp, W. G., "A method of cultivating myxomycete plasmodia," Bull. Torrey Botan. Club, 53:205-210, 1936.

"The fruiting of Physartm polycephalum in relation to nutrition," Am. J. Botany, 24: 300-303, 1937.

Chupp, Charles, "Studies on clubroot of cruciferous plants," Cornell Agr. Expt. Sta. Bull., 387: 421-452, 1917.

Cienkowski, L., "Zur Entwickelungsgeschichte der Myxomyceten," Jalorb. wiss. Botan., 3: 325-337, 1863. 
"Das Plasmodium," Jabrb. wiss. Botan., 3: 400-441, 1863a.

"Über den Bau und die Entwickelung der Labyrinthuléen," Arch. mikroskop. Anat. Entwicklungsmech., 3:274, 1867.

Cohen, A. L., "Nutrition of the Myxomycetes. I. Pure culture and twomembered culture of myxomycete plasmodia," Botan. Gaz., 101: 243275, 1939.

Cook, WV. R. I., "The genus Ligniera Maire and Tison," Trans. Brit. Mycol. Soc., 11: 196-213, 1926.

"The methods of nuclear division in the Plasmodiophorales," Ann. Botany, 42: 347-377, 1928.

"A monograph of the Plasmodiophorales," Arch. Protistenk., 80: 179-254, 1933.

Cook, IV. R. I., and E. J. Schwartz, "The life history, cytology, and method of infection of Plasmodiophora brassicae Woron., the cause of finger-and-toe disease of cabbages and crucifers," Pbil. Trans. Roy. Soc. London, Ser. B, 218: 283-314, 1930.

DANgeARD, P. A., "Observations sur la famille des Labyrinthulées et sur quelques autres parasites du Cladophora," Botaniste, 24: 217-258, 1932.

Gilbert, F. A., "Feeding habits of the swarm cells of the myxomycete Dictydiaetbalium plumbeum," Am. J. Botany, 15:123-131, 1928.

"A study of the method of spore germination in Myxomycetes," Am. J. Botany, 15: 345-352, 1928a.

"Observations on the feeding habits of the swarm cells of Myxomycetes," Am. J. Botany, 15:473-484, 1928 b.

"Factors influencing the germination of myxomyceteous spores," Am. J. Botany, 16: 280-286, 1929.

Gilbert, H. C., "Critical events in the life history of Ceratiomyxa," Am. J. Botany, 22: 52-74, 1935.

Harper, R. A., and B. O. Dodge, "The formation of capillitium in certain Myxomycetes," Amn. Botany, 28: 1-18, 1914.

Howard, F. L., "Laboratory cultivation of myxomycete plasmodia," Am. J. Botany, 18:624-628, 1931.

"The life history of Physarum polycepbalum," Am. J. Botany, 18: 116132, 1931a.

"Nuclear division in plasmodia of Physarum," Ann. Botany, 46:461-477, 1932.

Howard, F. L., AND M. E. CurRIE, "Parasitism of myxomycete plasmodia on the sporophores of Hymenomycetes," J. Arnold Arboretum, 13: 270-284, 1932.

JAHN, E., "Myxomycetenstudien. IV. Die Keimung der Sporen," Ber. deut. botan. Ges., 23:489-497, 1905.

VII. "Ceratiomyxa," Ber. deut. botan. Ges., 26A: 242-252, 1908.

"Myxomycetes." In Engler and Prantl, Die natïrlicben Pflanzenfamilien, 2nd ed., 2: 304-329. 1928.

Karling, J. S., Plasmodiopborales. ix +144 pp. Published by the author, New York. 1942. 
Kunkel, L. O., "A contribution to the life history of spongospora subterranea," J. Agr. Research, 4: 265-278, 1915.

Ledingham, G. A., "Zoospore ciliation in the Plasmodiophorales," Nature, 133: 534, 1934.

Lister, A., A monograph of the Mycetozoa. London. 1894. 2nd ed., revised by G. Lister, 1911. 3rd ed., 1925. Wheldon and Wesley, Ltd., London.

Lutman, B. F., "Studies on club-root. I. The relation of Plasmodiophora brassicae to its host and the structure and growth of its plasmodium," Vermont Agr. Expt. Sta. Bull., 175: 1-27, 1913.

Macbride, T. H., The Nortb American slime molds. The Macmillan Co., New York. 1899. 2nd ed., 1922.

Macbride, T. H., and G. IV. Martin, The Myxomycetes. 339 pp. The Macmillan Co., New York. 1934.

Maire, R., ANd A. Tison, "La cytologie des Plasmodiophoracees et la classe des Phytomyxinae," Ann. Myc., 7: 226-253, 1909.

"Nouvelles recherches sur les Plasmodophoracees," Ann. Myc., 9: 226246, 1911.

Martin, G. IV., "The Myxomycetes," Botan. Rev., 6: 356-388, 1940.

Massee, George, A monograph of the Myxogastres. London. 1892.

Olive, E. WV., "Monograph of the Acrasieae," Proc. Boston Soc. Nat. Hist., 30: 451-513, 1902.

Osborn, T. G. B., "Spongospora subterranea (Wallroth) Johnson," Ann. Botany, 25: 327-341, 1911.

PALM, B. T., AND Myrle Burk, "The taxonomy of the Plasmodiophoraceae," Arch. Protistenk., 79: 263-276, 1933.

Pinoy, Ervest, "Role des bactéries dans le developpement de certains Myxomycètes," Amn. Inst. Pasteur, 21: 622-656, 686-700, 1907.

RAPER, K. B., "Growth and development of Dictyostelium discoideum with different bacterial associates," J. Agr. Research, 55:289-316, 1937.

"Pseudoplasmodium formation and organization in Dictyostelizmn discoideum," J. Elisha Mitcbell Sci. Soc., 56: 241-282, 1940.

Raper, K. B., and Charles Thom, "Interspecific mixtures in the Dictyosteliaceae," Am. J. Botany, 28: 69-78, 1941.

Renn, C. E., "The wasting disease of Zostera marina," Biol. Bull., 70: 148$158,1936$.

Rostafinski, J. T., Versuch eines Systems der Mycetozoan. Inaugural dissertation, Strassburg. 1873.

Schwartz, E. J., "The Plasmodiophoraceae and their relationship to the Mycetozoa and the Chytrideae," Amm. Botany, 28:227-240, 1914.

Skupienski, F. X., Recherches sur le cycle evolutif des certains Myxomycètes. 81 pp. Thesis, Imprimerie M. Flinikowski, Paris. 1920.

SMART, R. F., "Influence of certain external factors on spore germination in the Myxomycetes," Am. J. Botany, 24: 145-159, 1937.

"The reactions of the swarm cells of Myxomycetes to nutrient materials," Mycol., 30: 254-264, 1938. 
S.rith, E. C., "Longevity of myxomycete spores," Mycol., 21: 321-323, 1929. IVernham, C. C., "A species of Sorodiscus on Heteranthera," Mycol., 27: 262-273, 1935.

Voronin, M., "Plasmodiophora brassicae, the cause of cabbage hernia," Jabrb. wiss. Botan., 11:548-574, 1878. (Reprinted in Phytopatbol. Classics, no. 4. 32 pp. 1934. Translated by Charles Chupp.)

Youxg, E. L., "Labyrinthula on Pacific Coast eel grass," Can. J. Research, Sec. C, 16: 115-117, 1938. 


\section{Chapter 5}

\section{THE PHYCOMYCETES}

Phycomycetes fascinate the observer mainly for the reason that so many of them can be induced to carry on all their activities fully exposed to microscopic view. As their name indicates, the Phycomycetes are algal fungi. They might better be regarded as the sporangial series of fungi and hence designated Sporangiomycetes. Early students of this group and even some modern workers regard the Phycomycetes as degenerate algae. Those who hold this belief assume that by loss of chlorophyll and consequent loss of ability to elaborate food, algae may have become fungi. The merits of this assumption need not be discussed at this point, but it may be pointed out that this belief emphasizes morphological resemblances between algae and fungi and ignores almost completely physiological differences.

The Phycomycetes include approximately 300 genera and more than 1500 species. They constitute a very diversified assemblage, ranging from species whose entire thallus consists of a microscopic spherical cell to those with a conspicuous, filamentous, branched thallus. Some are strictly parasitic, living on algae, ferns, seed plants, and other fungi, and at the opposite extreme some are wholly saprophytic. Some are aquatic, some amphibious, some terrestrial.

The thallus. The assimilatory portions of this group as a whole are coenocytic; that is, they are non-septate and multinucleate. Septations commonly are formed, however, in connection with the development of reproductive structures. They may also appear in old hyphae, such as those in Mucor, Saprolegnia, and Phytophthora, the segments becoming chlamydospores or gemmae. Septations regularly appear in young thalli of certain other genera, for example, Basidiobolus, Allomyces, and Entomophthora. 
Among Phrcomrcetes of the simplest structure. those presumed to be the most primitive. the entire coenocrte is the enlarged body of the spore. which may at maturity become transformed into a single sporangium. as occurs in the Olpidiaceae. In the Synchytriaceae the thallus fragments become a sorus or cluster of sporangia. Organisms in which the entire thallus is modified into a fructification. as it is in the Olpidiaceae and Sinchitriaceae, are spoken of as holocarpic. If. on the other hand. the thallus is differentiated into sterile and fertile portions. it is eucarpic. Eucarpic thalli with a single reproductive rudiment are monocentric; with more than one. polycentric. The Rhizidiaceae possess discoid, bulbous, or tenuously branched rhizoids by means of which nutrients are absorbed. Among the Cladochytriaceae the assimilatory portion is mycelioid at first but is quite eranescent and is erentually-transformed into reproductive structures. All the higher Phicomycetes, on the other hand possess richly branched thalli that course over or throughout the substrata. "The parasitic species among them are trpicallyintracellular or else are intercellular. absorption of food in intercellular species being accomplished by haustoria, as in the Albuginacese and the Peronosporaceae.

THE sportivgici. Aserual reproduction among most Phycomrcetes is accomplished by sporangiospores that are borne endogenously within sporangia. They are formed by clearage of the contents of the sporangium and may be either motile or non-motile. depending mainly upon the species. Motile spores are commonly called zoospores or planospores; non-motile spores. aplanospores.

In aquatic species the zoospores are emitted and swim away in the water. In terrestrial species, such as those of the Peronosporacee and Albuginaceae, the sporangia are detachable and are dispersed in toro, mainly by air currents; whereas in other species. for example. those of the Mucorales. the sporangia burst and the sporangiospores are themselres disseminated.

Shape of sporangia is rather generally employed as a generic character in this group. In some genera. such as Leptolegnia. the sporangia are little different from the regetative hyphae. In Saprolegnia, Achlya and Dictyuchus they are broadly clarate; in Olpidium. Mucor. Thamnidium, and Choanephora, spherical; in Phytophthora, Pỵthium, and Pỹthiopsis, pyrriform. 
Among filamentous species the sporangia are usually formed terminally, a single sporangium constituting the terminus of the hypha. In Albugo, Syncephalis, and Piptocephalis the sporangia appear as chains. In Blakeslea the sporangia are aggregated over the surface of the head-like tips of the sporangiophores.

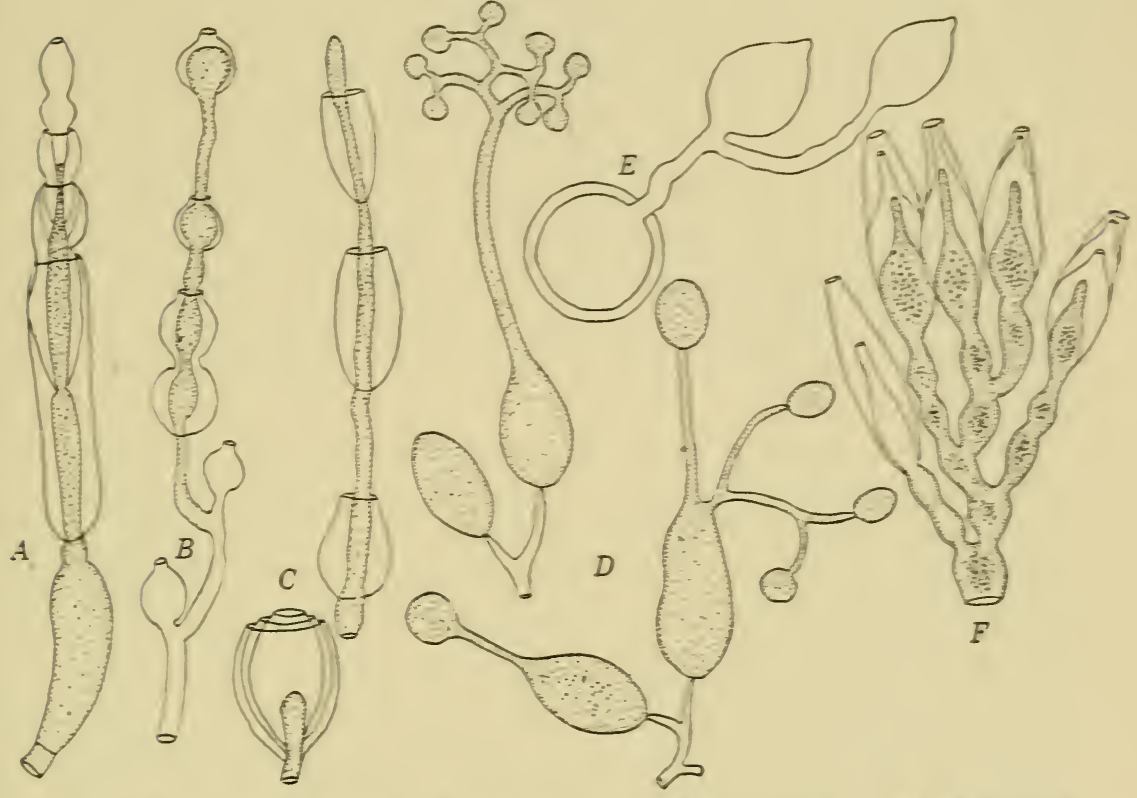

Fig. 14. Repetitional derelopment among Phycomycetes. A. Repeated formation of sporangia, each within the one preriously formed, in Syprolegnis monoicy. (After Pringsheim.) B. Sporangial proliferation to form chains of sporangia in $P_{y}$ tlizim prolifenm. (After Butler.) C. Nest-like and chain ithe sporangia in Pyzbiomorpha gonapodioifes. (Aiter Petersen.) D. Sporangium of Petonospora asbaina proliferating to become diminutive sporangiophore or to form one or more secondary sporangia. E. Sporangial renewal in Plytopltbors pzlwitorz from geminating oospore. (After de Bary.) F. Proliferation of sporangiz in Gonopolyz prolifera.

REPETITIONAL OR PROLIFERATIVE DEVELOPMENT OF SPORAYGLA AND SPORES. Sporangial proliferation is of usual occurrence among certain species of the higher Phycomycetes. It is accomplished by seriate formation of sporangia at the apex of the reproductive hypha. Proliferation may be an entirely normal procedure, but in some species it is apparenty an abnormality. By 
repeated growtn through the base of the old empty sporangium the fertile hyphae may give rise to a chain of sporangia, as occurs in Pytbium proliferm or in Pythiomorpha gonapodioides. If the axis does not elongate, the successively formed sporangia remain one within the other in a nest-like arrangement. In another type of proliferation, exhibited by Acblya racemosa and Phytophtbora infestans, the new branches arise laterally immediately below the sporangium and near the tip of the fertile hypha, and a sympodially arranged series of sporangia is thereby produced.

Sporangiospores may also proliferate, giving rise to series of successively smaller spores, sporangia, or sporangiophores. Repetitional development of this type has been recorded for Acblya racemosa, Pytbium proliferum, P. diacarpum, Phytophtbora phaseoli, P. cactorum, P. infestans, and Dictyuchus sp. by various workers and for Peronospora tabacina by Wolf and MicLean (1940).

Another manifestation of what appears to be the same phenomenon is exhibited by the Saprolegniales and is known as diplanetism. In certain genera of this order two motile or planetic stages are a more or less fixed character. The zoospores are pyriform in the first motile stage and, after encystment, emerge a second time and are reniform.

Sexual spores. Diversity in the sexual process is as great among Phycomycetes as in the asexual processes. The thallus arising from a single spore may produce both kinds of gametes, that is, may be homothallic. Instead thalli from two spores, each producing only one kind of gamete, may be required for zygote formation; that is, the species is heterothallic. The gametangia are differentiated in most genera, but in a few instances they are undifferentiated cells. Two morphologically similar gametes may fuse (isogamy) or the gametes may be quite dissimilar (heterogamy). This feature is the basis for separating the Phycomycetes into the subclasses Zygomycetes (isogamous) and Oomycetes (heterogamous). Some species regarded as Oomycetes, however, are isogamous, as are Synchytrium endobioticum and Olpidium viciae, and similarly some species regarded as Zygomycetes, such as Zygorbynchus heterogamus, have unlike gametes. Both gametes may be flagellated, as in Allomyces arbuscula and $A$. javanicus; the male gamete only may be flagel- 
lated, as in Monoblepharis; or the gametes may be brought into contact by passage of the male gamete through a fertilization tube into the oogonium. In Polyphagus both gametes pass into a swelling in the fertilization tube, and this swelling becomes transformed into the zygote membrane. In Rbizopus nigricans the two gametangia become transformed into the zygote wall. In the Saprolegniales and Peronosporales the antheridial contents flow into the oogonium, and the oogonial wall remains as a cyst for the developing oospores.

Both gametes may be uninucleate, as they are in Synchytrium and Monoblepharis. In other species one gamete is uninucleate and the other multinucleate, and in still others, as in the Mucorales and some species of Albugo, both are multinucleate.

Organs of loconiotion of zoospores. Among aquatic Phycomycetes motility is induced by organs called cilia. The studies of Couch (1941) show that there are two distinct structural types of cilia: the "whip-lash" type and the "tinsel" type. The whiplash type consists of a long, quite rigid, basal portion, the handle, and a short, thin, upper portion, the lash. The tinsel type consists of a central axis, from which extend short lateral hairs. Among true chytrids the whip-lash cilium is situated posteriorly. The zoospore may rotate on its own axis, as seen by dark-field illumination, and the cilium will then appear alternately as a single and a double image. If the image is single, the cilium is undulating in a plane vertical to the observer; if it is double, in a plane horizontal to the observer. In Rbizidiomyces apophysatus there is a single anterior tinsel cilium. In species of Olpidiopsis, Lagenidium, Saprolegnia, and Pythium, with biciliate zoospores, the anterior cilium is of the tinsel type and the posterior cilium of the whip-lash type.

Classification. The most recent comprehensive monograph of aquatic Phycomycetes is that of Sparrow (1943). In it are descriptions of 475 species and 10 varieties, belonging in 112 genera. It does not include the Peronosporales, as described in this book, nor the Mucorales and Entomophthorales, all species of which are terrestrial. Sparrow's excellent treatise will serve for years as a taxonomic handbook for students of aquatic fungi. The number of flagella and the place of their attachment are basic in the separation of orders in his keys. 
In the present account the Phycomycetes are divided into 11 orders: Chytridiales, Lagenidiales, Blastocladiales, Monoblepharidales, Leptomitales, Saprolegniales, Pythiales, Albuginales, Peronosporales, Mucorales, and Entomophthorales. Some workers do not recognize all these as of ordinal rank, although no one questions that all are Phycomycetes. Some students would include in addition the Endogonales and Eccrinales, but the classification of both of these orders in the Phycomycetes remains of doubtful justification.

Origin of the Phycomycetes. There are three points of view among botanists regarding the origin of the Phycomycetes. The first of these, which is the oldest, is that they are degenerate algae and that consequently in classifications they should be included among the Algae. Some of the workers who hold to this concept treat the Phycomycetes and Algae as taxonomically distinct, largely as a matter of convenience. This viewpoint was elaborated by Professor Charles E. Bessey.

The second point of view is that the Algae and Fungi have evolved as two parallel series, a phylogenetic approach advocated by Professor G. F. Atkinson. For the student who is interested in phylogeny the evidence and arguments for and against both of these opposed viewpoints are succinctly presented in a paper by Atkinson (1909).

The third viewpoint is that the Phycomycetes are derived from the Protozoa and should be placed in a phylum distinct from the Algae. Arguments for the validity of any of these points of view rest seemingly upon somewhat the same sort of foundation as do those for political or religious beliefs.

\section{LITERATURE CITED}

Atkinson, G. F., "Some problems in the evolution of the lower fungi," Ann. Mycol., 7: 441-472, 1909.

Couch, J. N., "The structure and action of the cilia in some aquatic Phycomycetes," Am. J. Botany, 25: 704-713, 1941.

Sparrow, F. K., Aquatic Pbycomycetes, exclusive of the Saprolegniaceae and Pytbium. $\mathrm{xx}+785 \mathrm{pp}$. The University of Michigan Press. 1943.

Wolf, F. A., and Ruth M. McLean. "Sporangial proliferation in Peronospora tabacina," Phytopatbology, 30: 264-268, 1940. 


\section{CHYTRIDIALES}

The Chytridiales, commonly called chytrids, include parasitic and saprophytic fungi that are mainly aquatic. They occur on
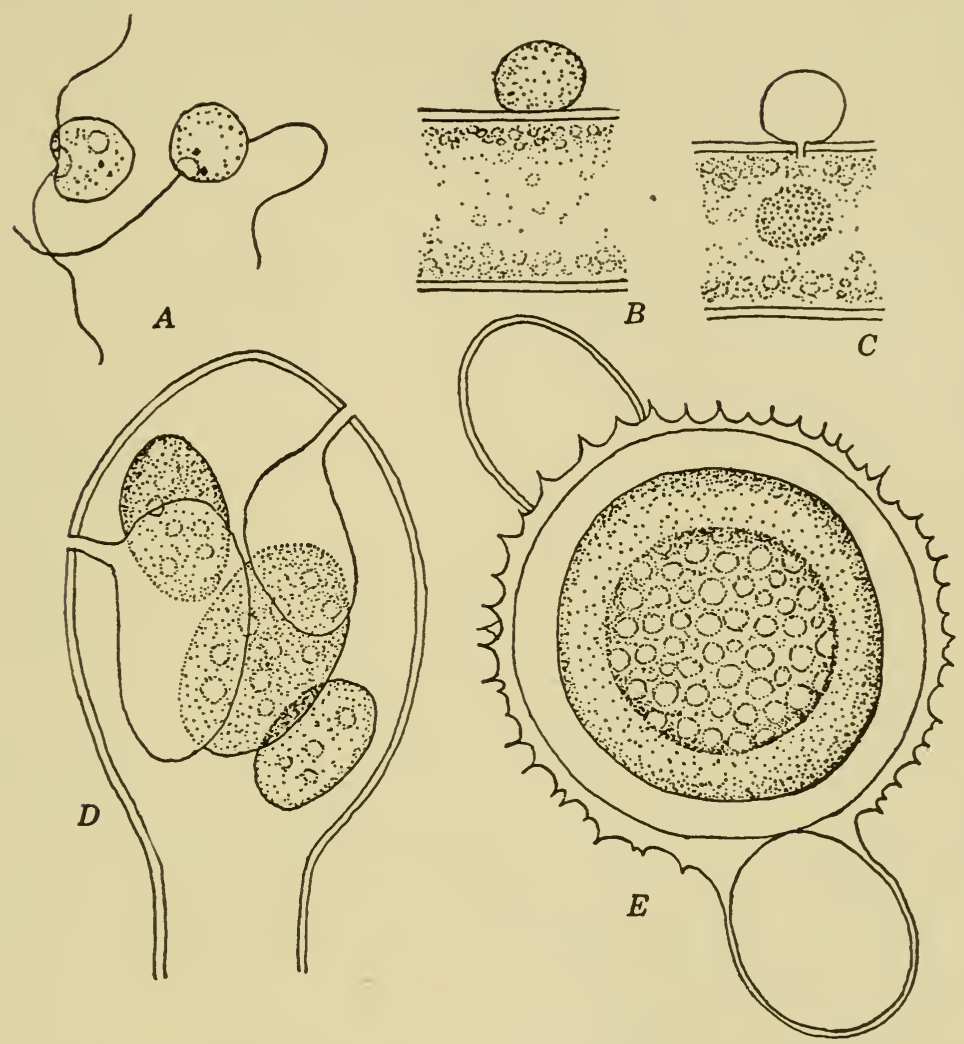

Fig. 15. Stages in the development of Olpidiopsis. $A$. Biciliate zoospores. $B$. Encysted stage that has settled upon a filament of Aphanomyces. C. Migration of protoplast from cyst into filament of Aphanomyces. $D$. Swollen tip of host hypha containing several zoosporangia, two of which have formed exit tubes for escape of zoospores. $E$. Mature oospore of

O. luxurians with two empty antheridia attached. (After Barrett.)

fresh water algae, other aquatic fungi, microscopic animals, and decaying tissues of seed plants. Some few marine species have been described. A few are important pathogens on seed plants. The feature of primary importance in the order is the produc- 
tion within sporangia of anteriorly uniflagellate zoospores. Unfortunately this feature is not easy to determine.

Sparrow (1943) divides the chytrids into two groups, Inoperculatae and Operculatae. The sporangia of the Operculatae open by means of a lid or operculum, while those of the Inoperculatae lack this device to free the uniflagellate zoospores. The Inoperculatae include the Olpidiaceae, Achlyogetonaceae, Synchytriaceae, Phlyctidiaceae, Rhizidiaceae, Cladochytriaceae, and Physodermataceae; the Operculatae include the Chytridiaceae and Megachytriaceae.

The thallus either (1) is naked at first (plasmodial), later becoming walled, and is entirely transformed into a sporangium or a cluster (sorus) of sporangia, or else (2) is walled from the first and differentiated into a vegetative and a fertile portion. The vegetative portion is a delicate, branched structure of rhizoidal appearance and has been appropriately designated a rhizomycelium. Among older systems of chytrid classification and on the basis of these two types of thalli the Chytridiales are divided into the suborders Myxochytridiales and Mycochytridiales. In the Myxochytridiales are the Olpidiaceae, Synchytriaceae, and (doubtfully) Woroninaceae; in the Mycochytridiales, the Rhizidiaceae, Cladochytriaceae, and Hyphochytriaceae.

Among the older taxonomic treatises are those of Schroeter (1892) and von Minden (1911). Although these two works are basic, numerous species have been described subsequently, and these publications, especially the ones by Scherffel (1925) and Sparrow (1935, 1943), and the numerous reports by Couch. should be consulted in connection with the taxonomy of chytrids.

Occurrence and cultivation. A large proportion of the reports on chytrids have been concerned with the description of new species. Although many occur on algae, flowering plants, and other fungi, some are free-living in the soil. Recent evidence [Whiffen (1941)] from growth in culture on cellulose indicates that they may function in cellulose decomposition in the soil. Inability to isolate chytrids in pure culture has been a material obstacle in the acquisition of knowledge of their activities. For a time Sparrow (1931) cultivated Cladochytrium nowakowskii, mixed with bacteria, on bacto-corn-meal agar. Butler and Humphries (1932) grew Catenaria anguillulae, parasitic on the 


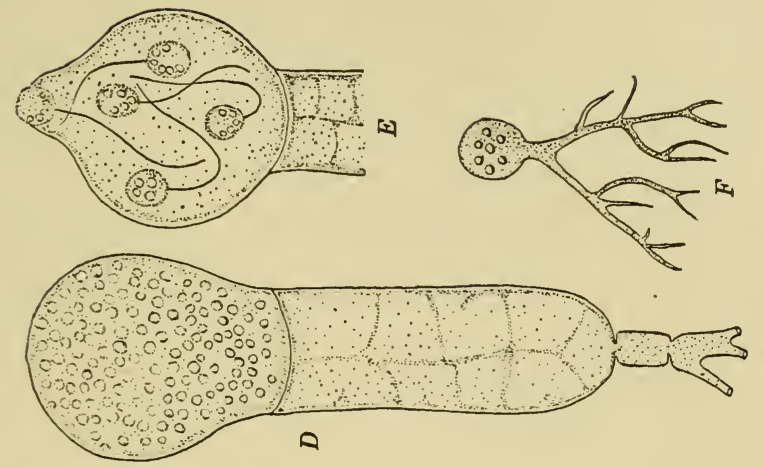

ค๐

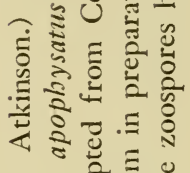

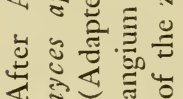

ङ

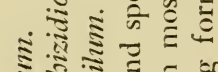

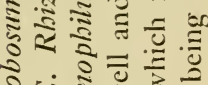

总 $0 \stackrel{8}{0}$ 它

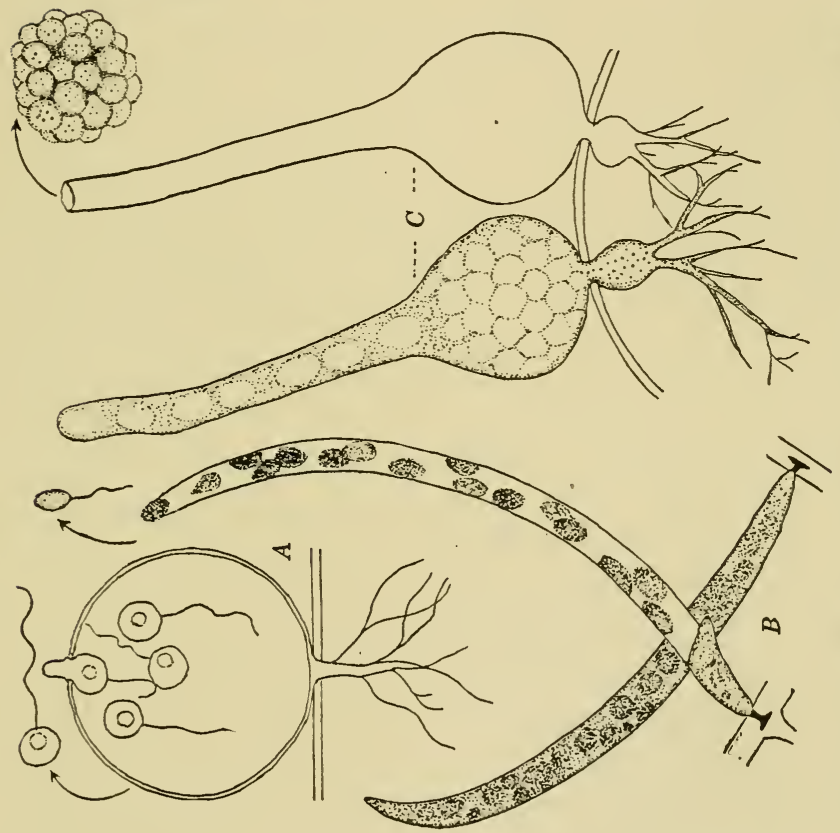

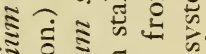

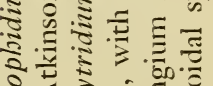

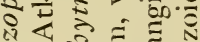

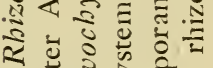

पू के के

४岁它的的

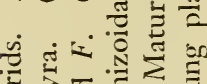

क⿺辶一兀

บ. पु की च मे

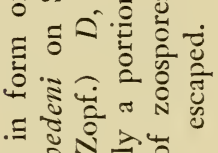
Nㅜㅎㅇ

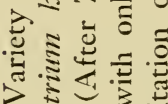

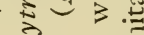

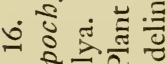

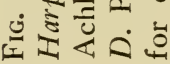


ova of liver fluke of sheep, on boiled fluke eggs and on $0.25 \%$ agar fortified with fluke-ova extract. Karling (1938) grew Catenaria sphaerocarpa on cooked root tips of corn and onion. In pure culture on 3\% plain agar Couch (1939) isolated Rbizidiomyces apophysatus, Rbizopbidium carpopbilum, and $R$. multiporum and cultivated them through several transfers. Cox (1939), using the same technique as Couch, isolated Clavochytridium stomopbilum. Whiffen (1941) grew Nepbrochytridium aurantium on boiled leaves of corn and on filter paper. The fact that these investigators have succeeded to a certain degree in cultivating some of the chytrids has contributed materially to understanding their activities and stimulating interest in them.

Reproduction. In some species two types of sporangia are developed: thin-walled, or temporary, sporangia and thickwalled, or resting, sporangia. The latter type is capable of hibernating and probably arises after fusion of gametes. The sporangiospores, except in the Woroninaceae, are uniflagellate. Cytological details are largely wanting and, among the few species that have been examined, are quite contradictory. Nuclei have been described as arising by amitosis, nuclear budding, and fragmentation. Cell-plate formation has been described as it occurs during cell division (delimitation of spores). Others have concluded that cell division arises either by progressive cleavage of the sporangium or by fragmentation of the protoplast. Meiosis has been described in connection with only a single species. Among the cytological studies dealing with reproduction are those of Curtis (1920) on Synchytrium endobioticum, Kusano (1930) on Synchytrium fulgens, Karling (1937) on Cladocbytrium replicatum, and McLarty (1941) on Olpidiopsis achlyae.

Olpidiaceae. The Olpidiaceae include approximately 50 species, of which Olpidium brassicae, parasitic on the roots of various seedlings, including cabbage and tobacco, is typical of the family. Its uniciliate swarm spores settle upon the host, creep over its surface in amoeboid fashion, come to rest, and produce a thin wall. This wall is soon pierced by a narrow pore, the host wall is also penetrated, and the spore content escapes. Then the naked protoplast enlarges, and finally a wall is formed around the mature thallus. At this point the entire thallus becomes a sporangium; that is, it is holocarpic. During this process the content of the thallus cleaves into a group of zoospores that 
escape to the exterior through an exit tube. According to $\mathrm{Ku}$ sano (1912), motile biflagellate zygotes arise in $O$. viciae by fusion in pairs of zoospores (gametes). The zygotes soon come to rest and produce a wall, and their contents escape into the host to become thick-walled, resting sporangia. Presumably the first divisions of the zygote nuclei are reductional.

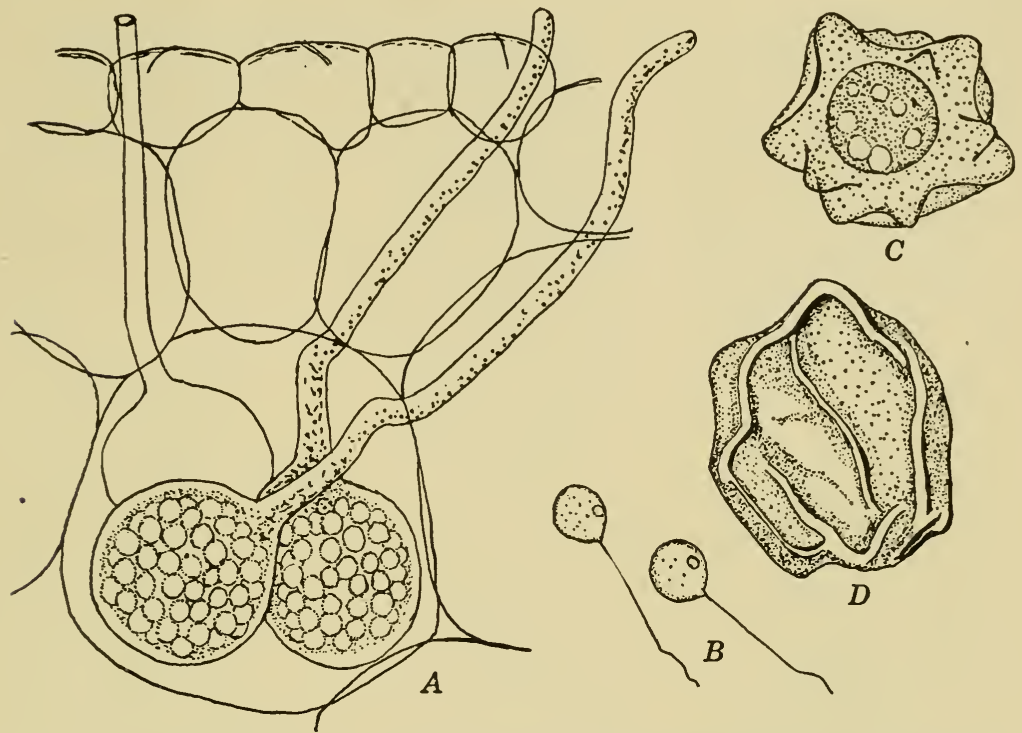

Fig. 17. Olpidium brassicae from roots of cabbage seedlings. A. Sporangia. $B$. Zoospores. $C$ and $D$. Mature resting spores. ( $A$ and $B$ after Woronin, $C$ and $D$ after Bensaude.)

Synchytriaceae. Approximately 75 species comprise the Synchytriaceae. Nearly all are parasitic on seed plants, causing excrescences. Two species, Synchytrium vaccinii, on the leaves and fruits of cranberry, and $S$. endobioticum, on potato tubers, are of especial interest. The latter causes excrescences to form, whence the name potato wart. These excrescences vary from small growths the size of a pea to enlargements exceeding the size of the tuber from which they arise. The disease was first discovered in upper Hungary and is now known to occur throughout Europe and Great Britain; it appeared in the United States in 1918. The causal organism was given the name Chrysopblyctis endobiotica by Schilberszky (1896). 
In section of diseased tissues it may be noted that the outer host cells are occupied by the pathogen in the vegetative phase. It is an unwalled protoplast (plasmodium) that is able to penetrate host-cell walls, meanwhile increasing in volume. This protoplast then forms a wall about itself and cleaves into a cluster (sorus) of sporangia. These sporangia are of two kinds: thin-
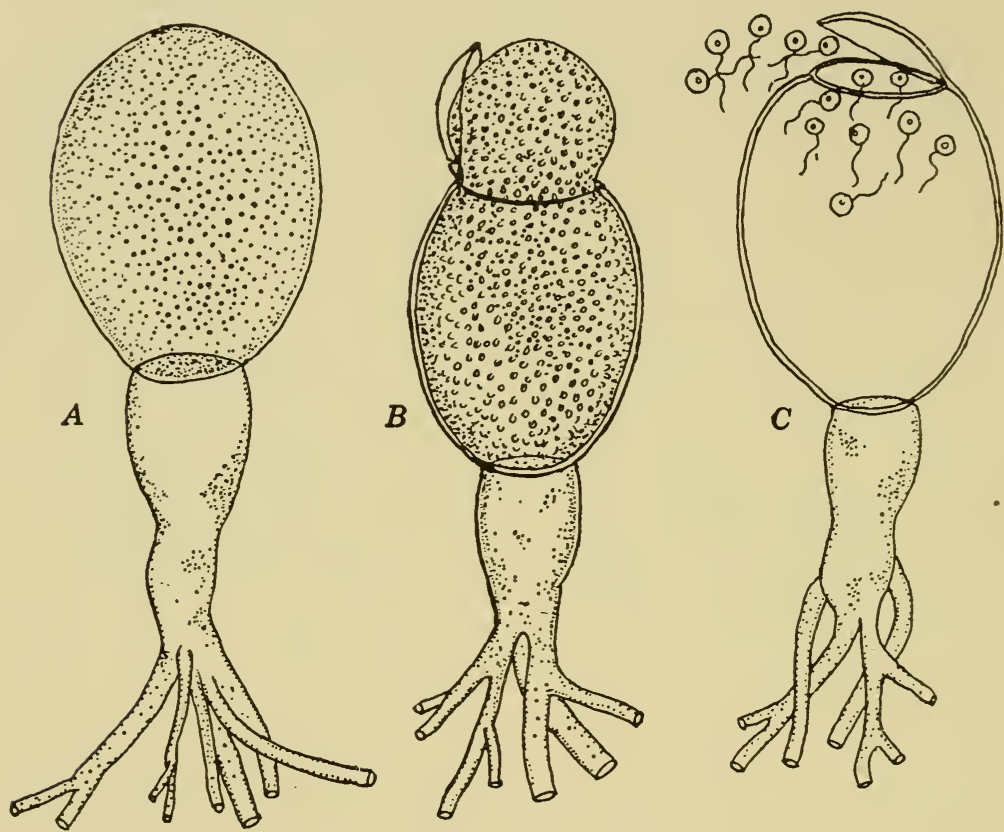

FIG. 18. $A$ to $C$. Stages in liberation of zoospores by Macrochytrium botrydioides. (After ron Minden.)

walled ones that can germinate at once, and thick-walled ones, called resting sporangia, that can germinate only after a period of dormancy. Under favorable conditions each kind of sporangium organizes within itself numerous uniciliate swarm spores that escape into the soil. Swarm spores have an actively amoeboid movement and behave either as swarm spores or as gametes. These single or mated swarm spores are able to initiate new infections by penetrating the "eyes" of the young tubers.

Studies by Percival (1910) and Curtis (1921) contain detailed accounts of the structure and developmental history of Synchytrium endobioticum. 
Woronisaceae. This family is represented by 15 species of endoparasites of Saproleginales and Pythiales. They differ from all other chytrids in that their zoospores are biflagellate. Olpidiopsis and Rozella commonly cause the hyphae of Saprolegnia, Achlya, and Allomyces to be swollen. Asexual spores, formed in ellipsoidal sporangia, are emitted through exit tubes. Thickwalled, spiny oospores arise by migration of multinucleate protoplasts from small antheridia into multinucleate oogonia formed on closely juxtaposed thalli. Sexuality in Olpidiopsis saprolegniae was studied by Barrett (1912) and Diehl (1935), in O. huxurians by Barrett (1912), and in O. achlyae by McLarty (1941). The germination of the oospores has not been observed.

Sparrow (1943) places Olpidiopsis in the Lagenidiales, Rozella in the Olpidiaceae, and Woronina in the Plasmodiophorales. This fact shows that the Woroninaceae, as formerly understood, are not chytrids and are not a group of similar forms. In fact, in a recent study, Karling (1942) monographed a heterogeneous group of 80 biflagellate species, which he divided more or less arbitrarily into five families: Woroninaceae, Ectrogellaceae, Olpidiopsidaceae, Sirolpidiaceae, and Lagenidiaceae. The fact that these species possess a pair of flagella, whereas all chytrids are uniflagellate, constitutes an adequate basis for regarding them as non-chytrids. He therefore regards them as a distinct group of Phycomycetes and does not place all of them in a single order.

RHIzidiaCEAE. The Rhizidiaceae constitute a group of approximately 100 species, mostly ectoparasites. They possess globular or elongated plant bodies attached by rhizoidal branches. They may be found on various algae, both marine and freshwater species, and upon aquatic fungi and insects. The bestknown species occur on Spirogyra, Oedogonium, and various desmids and diatoms. Rbizophidium pollinis-pini is common on pollen grains floating in water.

The swarm cells are uniflagellate and may function either as asexual spores or as gametes. Couch's (1935) account of sexuality in $R$. ovatum states that the male gamete settles on a filament of Stigeoclonium and attaches itself by a delicate rhizoid. Soon thereafter a female gamete becomes attached to the male, both increase in volume, the protoplasmic content of the male cell passes over to the female cell, and the two nuclei unite. The zygote formed is capable of germination within a few days. 
In Polyphagus euglenae, frequent on Euglena that forms a green film on puddles in pigsties and corrals, a conjugation tube is formed between the uninucleate gametangia. A swelling ap-

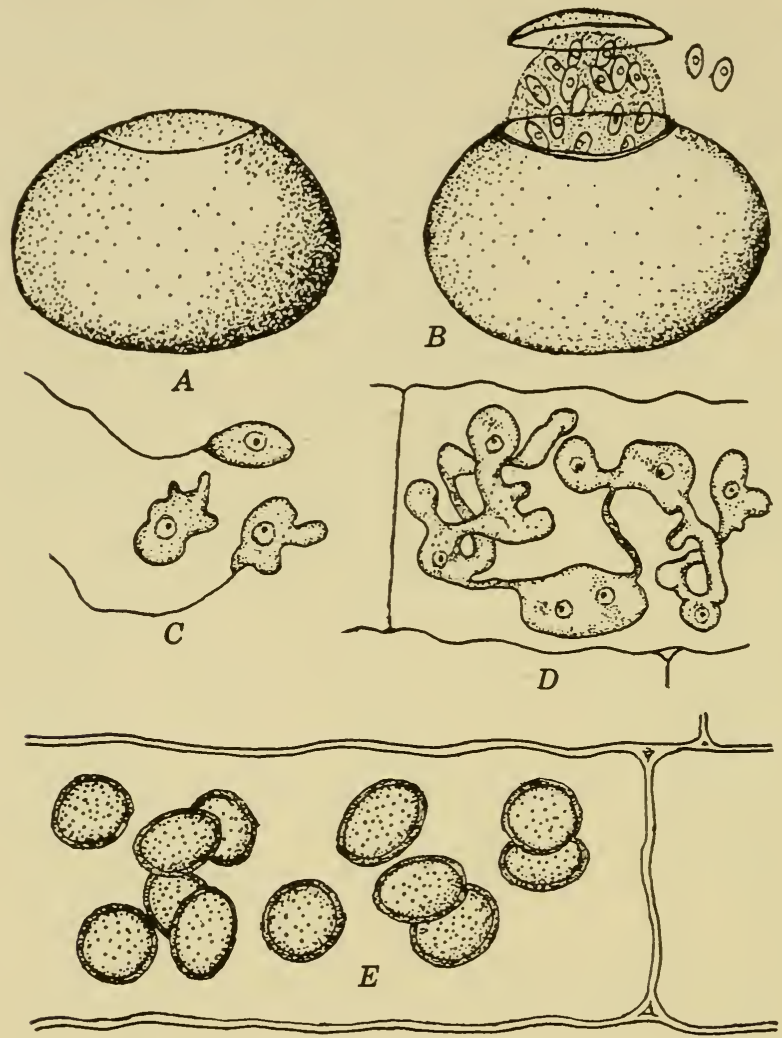

Fig. 19. Physoderma zeae-maydis, causing brown spot on corn. A. Mature resting sporangium, surface view, with circumscissile lid from which zoospores escape, as in B. C. Amoeboid zoospores provided with a single flagellum. D. Rhizomycelium within epidermis of corn. E. Segmentation of rhizomycelium to form thick-walled resting sporangia.

pears on the conjugation tube, into which the protoplasts migrate. A spiny, thick-walled zygote, which remains dormant for a few months, results. On germination a tube is formed; into it the two nuclei migrate and fuse; nuclear division follows; and many swarm cells are set free to repeat the developmental cycle. 
Cladochytriaceae. This small family contains species parasitic on algae, aquatic seed plants, and such economic plants as corn, beets, and alfalfa. It is characterized by the possession of
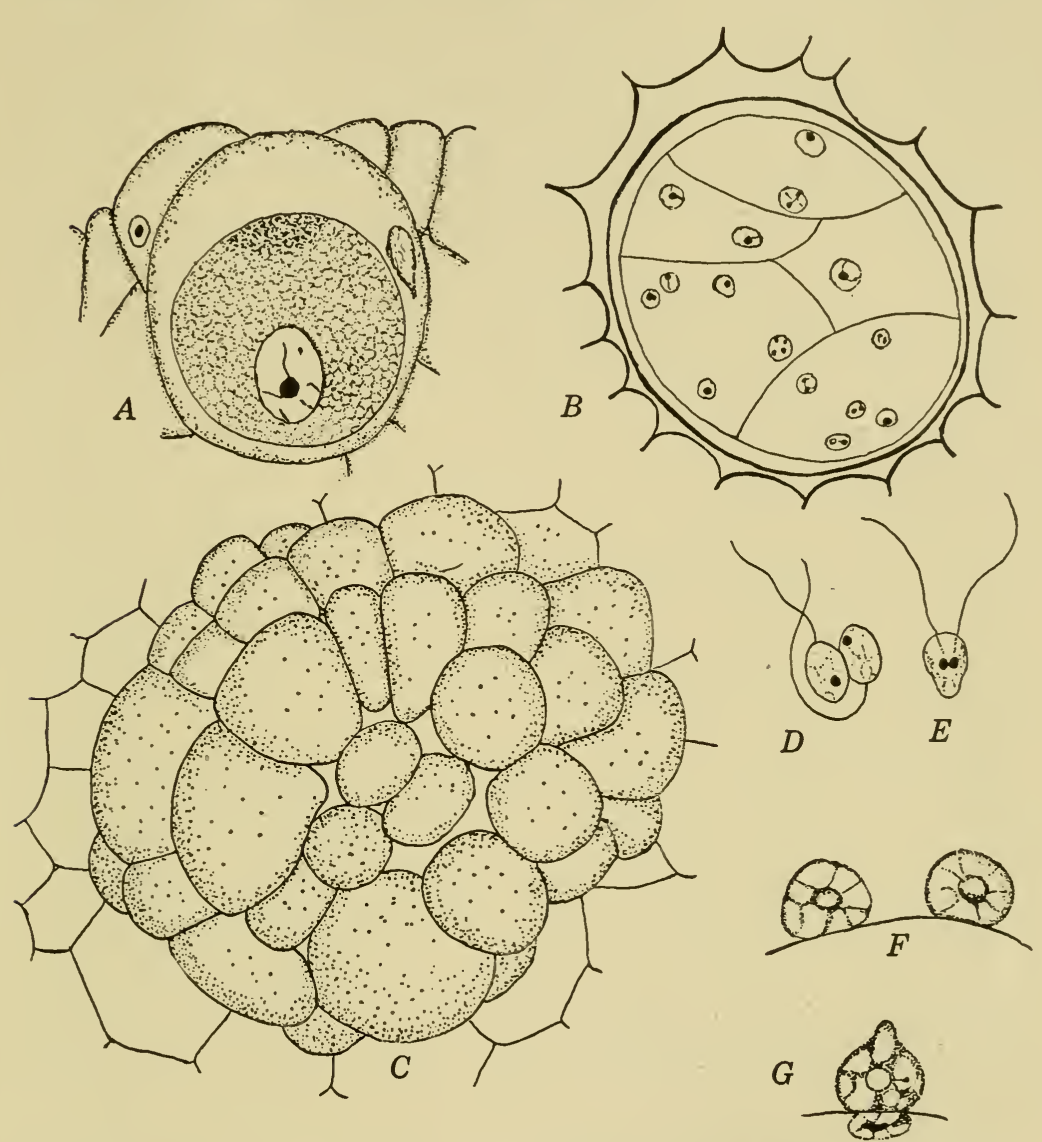

Fig. 20. Synchytrium endobioticum, causing potato wart. $A$. Young uninucleate thallus with characteristic clear zone near periphery. $B$. The thallus has segmented, each segment being multinucleate and each becoming a sporangium. C. Sorus of mature sporangia, each of which has rounded up. D. A pair of zoospores in preparation for fusion. E. Zygote that has not yet settled down. F. Zygotes lodged on surface of potato in preparation for penetration. $G$. Early stage in penetration.

a rhizomycelium, which is typically limited to a single host cell. In Physoderma zeae-maydis, causing brown-spot disease of corn and teosinte, the rhizomycelium becomes segmented and trans- 
formed into resting sporangia. Tisdale (1919) noted that the resting sporangia hibernate within leaves and stalks and that each emits 20 to 30 swarm cells through a circumscissile pore. According to Sparrow (1934), these swarmers produce ectosporangia (temporary sporangia), which are anchored to the host; from them come what may be presumed to be true gametes. These gametes fuse in pairs, the zygote infects the corn, and resting sporangia eventually are again formed.

Urophlyctis alfalfae induces the formation of galls near the ground level on alfalfa and burr clover. The thallus consists of a series of top-shaped, thick-walled cells, each provided with a crown of haustoria. Each cell is a resting sporangium that germinates when conditions are favorable. The zoospores escape through a papilla; each is provided with two flagella, one about $5 \mu$ long and the other about 10 times as long. These zoospores are presumed to conjugate before infections of suitable host tissues. The morphology and pathogenicity of this organism were carefully studied by Wilson (1920) and Jones and Dreschler (1920). Since so few Cladochytriaceae have been studied intensively, the development and sexuality of its members are not well understood.

Hyphochytriaceae. The Hyphochytriaceae include a few species of doubtful relationships. The rhizomycelium is coarse, and the apical portion becomes the zoosporangium. Macrochytrium botrydioides, first found growing on decaying apple, typifies the family. When its sporangia are mature, each opens with a lid, quite as in the resting sporangia of Physoderma and Cladochytrium, and the contents escape in a vesicle or are freed directly. Resting sporangia, however, are unknown in M. botrydioides.

Macrochytrium has somewhat the appearance of the Rhizidiaceae and the Leptomitales and may well be a link between the Chytridiales and Leptomitales.

\section{LITERATURE CITED}

Barrett, J. T., "Development and sexuality of some species of Olpidiopsis (Cornu) Fischer," Ann. Botany, 26: 209-238, 1912.

Butler, J. B., AND A. Humiphries, "On the cultivation in artificial media of Catenaria anguillulae, a Chytridiacean parasite of the ova of the liver fluke, Fasciola bepatica," Sci. Proc. Roy. Dublin Soc., 20:301, 1932. 
Coucr, J. N., "New or little-known Chytridiales," Mycol., 27: 160-175, 1935.

"Technic for collection, isolation, and culture of Chytrids," J. Elisha Mitchell Sci. Soc., 55:208-214, 1939.

Cox, H. T., "A new genus of Rhizidiaceae," J. Elisha Mitchell Sci. Soc., 55: 389-397, 1939.

Curtis, K. M., "The life history and cytology of Synchytrimm endobioticum (Schilb.) Perc., the cause of wart disease of potato," Ploil. Trans. Roy. Soc. London, B, 210: 409-479, 1921.

Dienl, H., "Beiträge zur Biologie ron Olpidiopsis saprolegniae Barrett," Zentr. Bakt. Parasitenk., 92: 229-249, 1935.

Jones, F. R., ANd C. Dreschler, "Crown wart of alfalfa caused by Uroplolyctis alfalfae," J. Agr. Research, 20: 295-325, 1920.

Karling, J. S., "The cytology of the Chytridiales, with special reference to Cladochytrium replicatum," Mem. Torrey Botan. Club, 19:5-92, 1937.

"A further study of Catenaria," Am. J. Botany, 25:328-335, 1938.

Simple bolocarpic biflagellate Plbycomycetes. 123 pp. Published by the author, New York. 1942.

Kusavo, S., "On the life history and cytology of a new Olpidium, with special reference to the copulation of motile isogametes," J. Coll. Agr. Univ. Tokyo, 4:141-199, 1912.

"Cytology of Synchytrinm fulgens Schroet.," J. Coll. Agr. Univ. Tokyo, 10: 347-388, 1930.

McLarty, D. A., "Studies in the Woroninaceae. II. The cytology of Olpidiopsis acblyae, sp. nov.," Bull. Torrey Botan. Club, 68: 75-99, 1941.

Minden, M. von, "Chytridineae," in Kryptogannenflora der Mark Brandenburg, 5: 209-422, 1911.

Percival, J., "Potato-wart disease: the life history and cytology of Synchytrium endobioticum (Schilb.) Perc.," Zentr. Bakt. Parasitenk., II Abt., 25:440-447, 1910.

Scherffel, A., "Zur Sexualität der Chytrideen," Arch. Protistenk., 53:1-58, 1925.

Schilberszky, K., "Ein neuer Schorfparasit der Kartoffelknollen," Ber. deut. botan. Ges., 14:36-37, 1896.

Schroeter, J., "Chytridineae." In Engler and Prantl, Die natürlichen Pflanzenfamilien, Vol. I, pp. 63-92. 1892.

Sparrow, F. K., "Two new chytridiaceous fungi from Cold Spring Harbor," Am. J. Botany, 18:615-623, 1931.

"The occurrence of true sporangia in the Physoderma disease of corn," Science, n.s., 79: 563-564, 1934.

"Recent contributions to our knowledge of the aquatic Phycomycetes," Biol. Rev., 10: 150-186, 1935.

Aquatic Pbycomycetes exclusive of the Saprolegniaceae and Pythizm. $\mathrm{xx}+785 \mathrm{pp}$. The University of Michigan Press. 1943.

Tisdale, IV. H., "Physoderma disease of corn," J. Agr. Research, 16:137154, 1919. 
Whiffen, Alma J., "A new species of Nephrochytrium, Neplorochytrium aurantium," Am. J. Botany, 28:41-44, 1941.

"Cellulose decomposition by the saprophytic chytrids," J. Elisha Mitchell Sci. Soc., 57: 321-329, 1941a.

Wilson, O. T., "Crown gall of alfalfa," Botan. Gaz., 70: 51-68, 1920.

\section{Doubtful Chytrids}

The most interesting organism among those whose relationship with chytrids is doubtful is Rhodochytrium spilanthidis. This organism is abundantly prevalent every season in North Carolina as a parasite on the leaves, stems, and flowers of ragweed, Ambrosia artemisiifolia. It forms bright-red pustules, the color being imparted by the presence of haematochrome. In gross appearance it resembles the members of the Genus Entophlyctis among the Rhizidiaceae. The zoospores, however, are biflagellate and contain starch grains [Griggs (1912)]. The possession of starch largely influenced Griggs to relate it to the Protococcoideae (Algae). Its ability to transform absorbed sugars into starch does not appear to present an unsurmountable obstacle, however, to regarding this organism as a fungus. Because of its biflagellate zoospores it is not a chytrid.

\section{LITERATURE CITED}

Griggs, R. F., "The development and cytology of Rhodochytrium," Botan. Gaz., 53:127-172, 1912.

\section{LAGENIDIALES}

This group of fungi was previously known to mycologists as the Ancylistales. It has long been recognized, however, that the type genus, Ancylistes, which includes three species, differs rather widely from other members of the order. Ancylistes closterii, the most thoroughly studied form, is an intracellular parasite of Closterium. Zoospore formation has never been observed within the numerous hyphae which project from infected host cells. It has recently been found [Berdan (1938)], however, that the extramatrical hyphae of Ancylistes function as conidiophores and produce conidia, which are forcibly discharged. This fact has necessitated the removal of Ancylistes to the Order Entomophthorales. 
With the removal of the type genus there is left a more unified group of 3 genera, Lagenidium, Myzocytium, and Achlyogeton, all of which were originally described by Schenk (1857, $1858,1859)$. Lagenidium is the largest genus, having about 15 species [Cook (1936)]; Achlyogeton is monotypic. The group

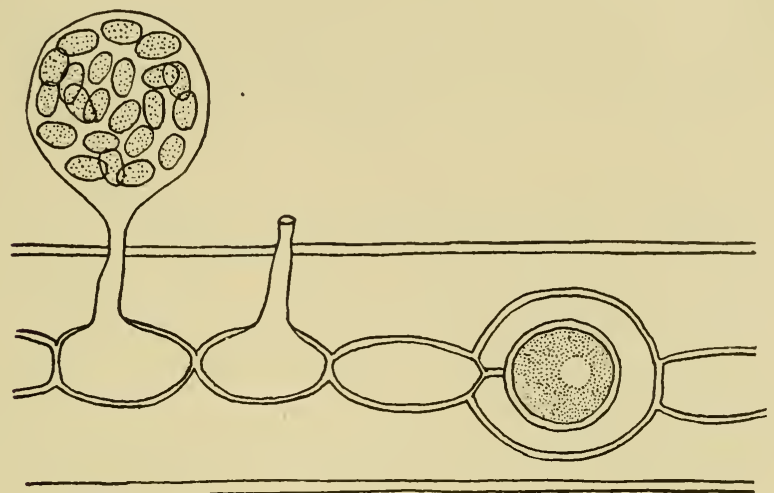

$A$

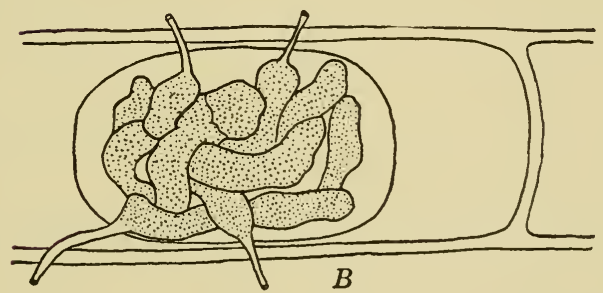

FIG. 21. A. Portion of thallus of Lagenidinm rabenlorstii, showing swarm spores in vesicle, an empty sporangium, and two cells, an antheridium and oogonium. B. Lagenidium americamım. (After Atkinson.)

has been monographed by Schröter (1893) and von Minden (1915), and the Japanese forms have recently been studied by Tokunaga (1934). The species for the most part are obligate parasites of desmids, diatoms, and filamentous green algae. A single representative, Lagenidium giganteum, has been grown in pure culture [Couch (1935)].

The thallus throughout the order is not extensive, being usually confined to a single host cell. A young thallus generally takes the form of a unicellular cylindrical tube, which later becomes di- 
vided by septa into a number of cells. The thallus is unbranched in Achlyogeton and Myzocytium, whereas in Lagenidium it is more or less profusely branched. Each cell of the thallus eventually becomes transformed into a sporangium, an oogonium, or an antheridium. In asexual reproduction an exit tube from the sporangium penetrates the cell wall of the host, and eventually the laterally biciliate zoospores are formed. In Lagenidium and Myzocytium a vesicle may or may not be present; in Achlyogeton the zoospores are fully delimited within the sporangium but encyst at its mouth.

Sexual reproduction is unknown in Achlyogeton. In the remaining genera, the plant body is homothallic, adjacent cells functioning as antheridia and oogonia. The antheridium is usually cylindrical, whereas the oogonium is spherical in shape, but the gametangia are not so well differentiated as in the higher Oomycetes. The contents of the antheridium are discharged into the oogonium through a conjugation tube, and the oogonial contents become transformed into thick-walled oospores. Oospores may occasionally be formed parthenogenetically. The conjugation tube is persistent, remaining attached to the wall of the oospore. Germination of the oospore occurs by the formation either of a germ tube or of zoospores. Sexual reproduction has been studied cytologically in only a single species, Myzocytium iermicolum, by Dangeard (1906), and further work is necessary to clarify all the details.

Probably also to be considered as belonging to this order is Lagena radicicola [Vanterpool and Ledingham (1930)], a parasite of cereal roots, reported from Canada.

The taxonomic account of Sparrow (1943) is most useful as a guide in classification of this order. The possession throughout the order of an oomycetous type of sexual reproduction, together with simplicity in thallus structure, suggests that the order is intermediate between the chytrids and the higher filamentous oomycetes, such as the Saprolegniales [Scherffel (1925), Cook (1936) j.

\section{LITERATURE CITED}

Berdax, H., "Revision of the genus Ancylistes," Mycol., 30: 396-415, 1938. Соок, W. R. I., "The genus Lagenidium Schenk, with special reference to L. Rabenhorstii Zopf and L. entophytum Zopf, Arch. Protistenk., 86: $58-59,1936$. 
Couch, J. N., "A new saprophytic species of Lagenidium, with notes on other forms," Mycol., 27:376-387, 1935.

Dangeard, P. A., "Recherches sur le développement du périthecè chez les Ascomycetes. I. Les ancètres des champignons supérieurs," Botaniste, 9: 207-226, 1906.

Minden, M. vos, "Ancylistineae," in Kryptogamenflora der Mark Brandenburg, 5: 423-461, 1915.

Sснекк, A., "Algologische Mittheilungen," Verband. Pbys.-med. Ges. Würzburg, 9: 12, 1857.

Über das Vorkommen Kontraktiler Zellen im Pflanzenreiche. 20 pp. IVürzburg. 1858.

"Achlyogeton, eine neue Gattung der Mycophyceae," Botan. Ztg., 17: 398-400, 1859.

Scherffel, A., "Endophytische Phycomyceten-parasiten der Bacillariaceen und einige neue Monadinen. Ein Beitrag zur Phylogenie der Oomyceten," Arch. Protistenk., 52: 1-141, 1925.

Schröter, J., "Ancylistineae." In Engler and Prantl, Die natürlichen Pflanzenfamilien, I. Teil, Abteil. 1:88-92, 1893.

Sparrow, F. K., Aquatic Pbycomycetes exclusive of the Saprolegniaceae and Pytbium. $\mathrm{xx}+785 \mathrm{pp}$. The University of Michigan Press. 1943.

Tokuraga, Y., "Notes on the Lagendiaceae in Japan," Trans. Sapporo Nat. Hist. Soc., 13: 227-232, 1934.

Vanterpool, T. C., ANd G. A. Ledingham, "Studies on 'Browning' root rot of cereals. I. The association of Lagena radicicola, n.g., n. sp., with root injury of wheat," Can. J. Research, 2: 171-194, 1930.

\section{BLASTOCLADIALES}

The Order Blastocladiales includes about 15 species belonging to 4 genera. All are filamentous aquatic fungi with a more or less well-developed mycelium. In this group the cell walls do not stain blue with zinc chloroiodide, an indication of the absence of cellulose. Asexual reproduction occurs by means of thinwalled zoosporangia and zoospores, which are characteristically uniciliate, as they are in the Monoblepharidales and certain of the chytrids.

All representatives of the order produce, in addition to the thin-walled sporangia, thick-walled resistant sporangia of a type not known elsewhere among the fungi. From these persistent structures with pitted walls there are produced after a dormant period zoospores similar to those formed in the thin-walled sporangia.

The Genus Blastocladia contains about seren species, of which the best known is $B$. pringsheimii. Species of Blastocladia occur 
saprophytically on submerged plant materials, fruits of rose, Crataegus, and tomato being especially preferred. Methods of collection of these fungi and a taxonomic account of the genus are given by Kanouse $(1925,1927)$. The thallus of Blastocladia consists of a rhizoidal system within the substratum, from which arises a main trunk or axis that branches repeatedly. At the ends of the branches are borne the thin-walled sporangia which produce zoospores. The resistant sporangia are also produced apically. Search for sexual reproduction in connection with the germination of the resistant sporangia has produced only negative results. The resistant sporangia of $B$. pringsheimii have recently been germinated by Blackwell (1940). She states that after a rest period of several months they germinate, producing zoospores which develop into asexual plants, just as do zoospores from ordinary thin-walled sporangia. Thus sexuality is not known in the Genus Blastocladia.

The Genus Allomyces, recently monographed by Emerson (1941), contains five species, all apparently of rather wide distribution in soil. This extensive distribution in soil throughout the world is stressed by Wolf $(1939,1941)$ and Emerson (1941), but the function therein of these species is unknown, and no one appears to have attempted to explain their wide dissemination.

The structure of the thallus of Allomyces is quite similar to that of Blastocladia. From the basal portion or trunk, attached by rhizoids, arise numerous slender branches, which are separated into segments by pseudosepta. On the branches are borne thinwalled zoosporangia and resistant sporangia similar to those of Blastocladia.

Interest attaches to two species of the genus, $A$. arbuscula [Butler (1911)] and $A$. javanicus [Kniep $(1929,1930)$ ], by reason of the nature of their sexual reproduction and life cycle. In both of these species there is a distinct morphological alternation of sexual and asexual phases [Kniep (1930), Hatch (1935)]. On germination of the resistant sporangia, the zoospores develop into thalli bearing paired male and female gametangia. Both male and female gametes are motile, the female being considerably the larger and unpigmented, whereas the smaller gametangium is orange in color. This pigmentation has been shown to be due to the presence of $\gamma$-carotene [Emerson and Fox (1940)]. The 


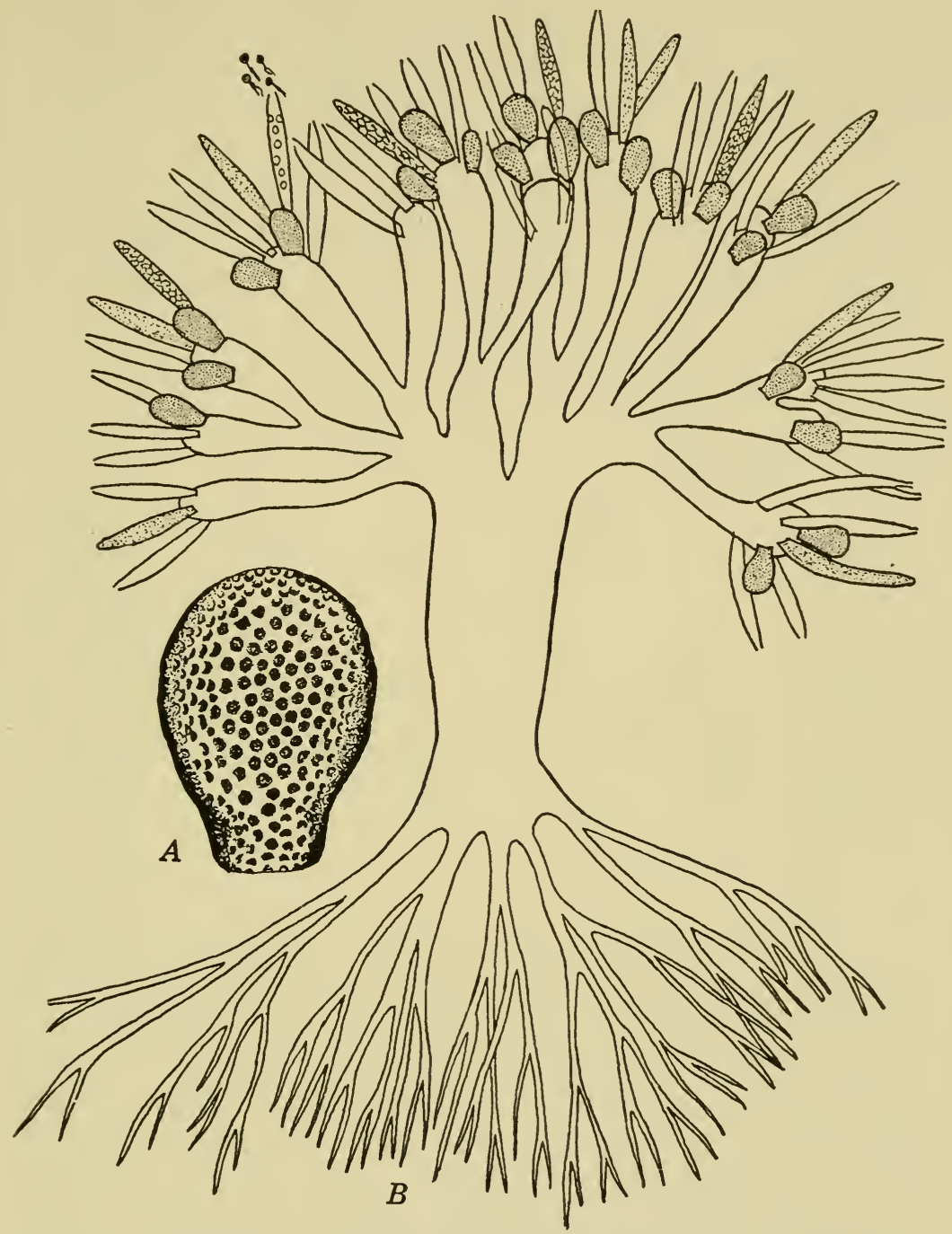

FIG. 22. Blastocladia pringsheimii. A. Resistant sporangium. B. Habit sketch of an entire plant. (Adapted from Blackwell.) 
anisogametes (unequal in size) are liberated and fuse in the water to form a motile, biciliate zygote. The zygote soon comes to rest and develops into a thallus bearing sporangia. On germination these sporangia produce motile spores that develop, in turn, into

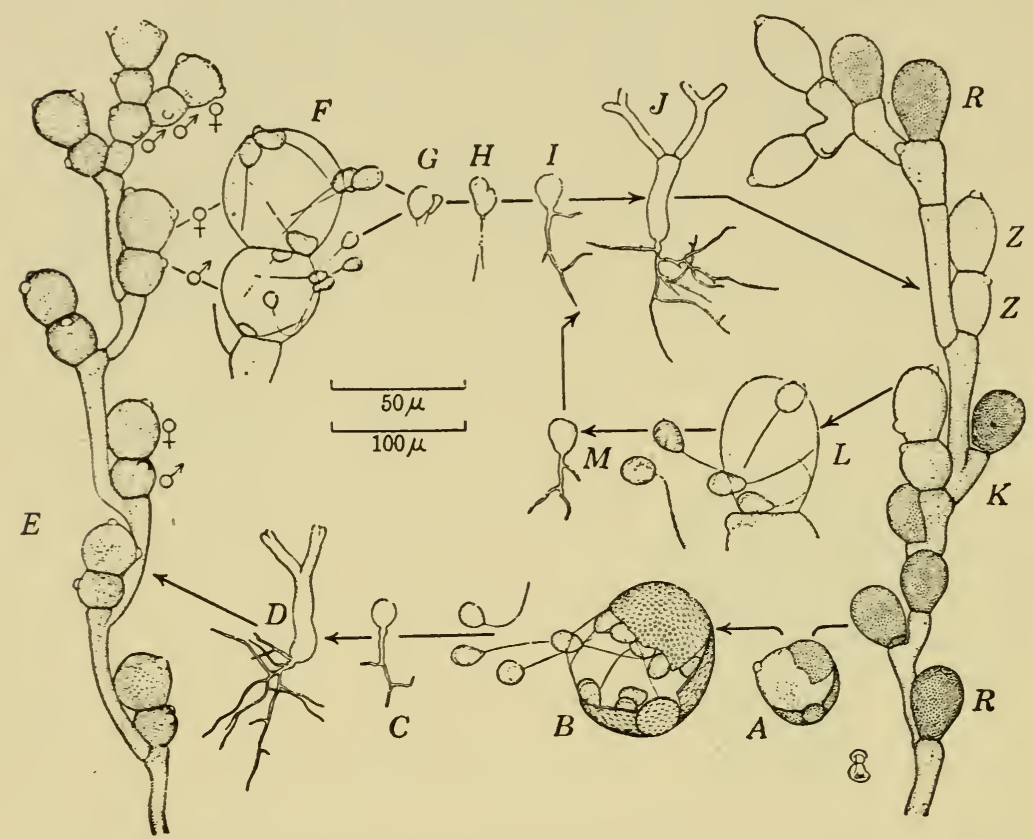

Fig. 23. Life cycle of Allomyces arbuscula. A. Germinating resistant sporangium with outer wall split. $B$. Zoospores emerging from germinating resistant sporangium. C. Germination of one of these zoospores. D. Young plant of gamete-producing phase. E. Hypha bearing male and female gametangia. F. Emergence of male and female gametes. G. Copulation of gametes. H. Motile zygote. I. Germination of zygote. J. Young plant of sporangium-producing phase. K. Mature hypha bearing both thin-walled and thick-walled zoosporangia. L. Emergence of zoospores from zoosporangium. M. Germinating zoospores. $R$. Resistant sporangium. Z. Thin-walled zoosporangium. (Courtesy of Ralph Emerson.)

thalli, each of which bears male and female gametangia, thus continuing the alternation. Some workers regard this sequence of sporogenic and gametogenic phases as an "alternation of sporophyte and gametophyte generations," whereas others interpret 
the phenomenon as sexual and asexual phases of a single generation.

In $A$. cystogemus the resistant sporangium cracks open on germination, and the content becomes a group of encysted cells at the point of discharge [McCranie (1942)]. After a period semiamoeboid gametes, each with a single flagellum, emerge from these cysts. They conjugate in pairs, forming biflagellate, motile zygotes of a size like that of the uniflagellate zoospores from the thin-walled sporangia. Conjugation in this species is therefore isogamous. Presumably, the life cycle of $A$. monilifornis is similar to that of $A$. cystogemus. There is no alternation of sexual and asexual phases as in $A$. javanicus or $A$. arbuscula; instead, the hyphae bear both thin-walled and resistant sporangia, the latter germinating to produce isogamous gametes.

In the remaining species, $A$. anomalus, there is no indication of gamete or cyst formation, the zoospores from resistant sporangia developing directly into plants bearing thin-walled and thickwalled sporangia. Sörgel (1937) has reported this occurrence in $A$. arbuscula as well, so perhaps this life cycle is a mere variant; at any rate three distinct life cycles are known in the genus. A precise evaluation of this situation is at present impossible in the face of such complexities as the occasional presence of resistant sporangia on the gamete-bearing plants [Sörgel (1937), Indoh (1940), Emerson (1941)] and the discrepancies in the various cytological accounts of the life history [Hatch (1938)].

Two additional genera of somewhat greater simplicity in thallus structure have recently been described; they are Blastocladiella [Matthews (1937)] and Sphaerocladia [Stüben (1939)]. In these genera the thallus is much reduced, bearing but a single sporangium, either a zoosporangium or a resistant sporangium. Likewise the male and female gametangia are borne on separate thalli, so that these genera are heterothallic, whereas Allomyces is homothallic. The gametes themselves are isogamous [Harder and Sörgel (1938)].

The simplicity of thallus structure and sexuality in Blastocladiella and Sphaerocladia suggests their relationship with the chytrids. It is therefore possible to postulate an ascending series from the chytrids through these isogamous forms to Allomyces, 
which is anisogamous, culminating in the oogamous Monoblepharis of the next order.

\section{LITERATURE CITED}

Blackwell, E., "A life cycle of Blastocladia pringsheimii Reinsch," Trans. Brit. Mycol. Soc., 24:68-96, 1940.

Butler, E. J., "On Allomyces, a new aquatic fungus," Ann. Botany, 25: $1023-1035,1911$.

Emiersox, Ralph, "An experimental study of the life cycles and taxonomy of Allomyces," Lloydia, 4: 77-144, 1941.

Emerson, Ralph, ANd D. L. Fox, " $\gamma$-Carotene in the sexual phase of the aquatic fungus Allomyces," Proc. Roy. Soc. London, Ser. B., 128:275$293,1940$.

Harder, R., axd Georg Sörgel, "Über einen neuen planoisogamen Phycomyceten mit Generationswechsel und seine phylogenetische Bedeutung," Naclsr. Ges. Wiss. Göttingen, N. F., VI: Biol., 3: 119-127, 1938.

Нatch, IV. R., "Gametogenesis in Allomyces arbuscula," Ann. Botany, 49: 623-650, 1935.

"Conjugation and zygote germination in Allomyces arbuscula," Ann. Botany, N. S., 2:583-614, 1938.

INDoh, H., "Studies on Japanese aquatic fungi. II. The Blastocladiaceae," Science Repts. Tokyo Bunrika Daigaku, Sec. B, 4:237-284, 1940.

Kaxouse, B. B., "On the distribution of the water molds with notes on the occurrence in Michigan of members of the Leptomitaceae and Blastocladiaceae," Papers Mich. Acad. Sci., 5: 105-114, 1925.

"A monographic study of special groups of the water molds. I. Blastocladiaceae," Am. J. Botanzy, 14:287-306, 1927.

Kxiep, H., Allomyces javanicus, n.sp., ein anisogamer Phycomycet mit Planogameten," Ber. deut. botan. Ges., 47: 199-212, 1929.

"Über den Generationswechsel von Allomyces," Z. Botan., 22: 433-441, 1930.

Matthews, V. D., "A new genus of the Blastocladiaceae," J. Elisha Mitchell Sci. Soc., 53: 191-195, 1937.

MicCranie, James, "Sexuality in Allomyces cystogemus," Mycol., 34: 209-213, 1942.

Sörgel, Georg, "Untersuchungen über den Generationswechsel ron Allomyces," Z. Botan., 31:401-446, 1937.

STüBEx, H., Über Entwicklungsgeschichte und Ernährungsphysiologie eines neuen niederen Phycomyceten mit Generationswechsel," Planta, 30: 353-383, 1939.

Wolf, F. T., "A study of some aquatic Phycomycetes isolated from Mexican soils," Mycol., 31:376-387, 1939.

"A contribution to the life history and geographic distribution of the genus Allomyces," Mycol., 33: 158-173, 1941. 


\section{MONOBLEPHARIDALES}

The Order Monoblepharidales includes a small number of aquatic fungi of rather unique characteristics, the outstanding of which is that in sexual reproduction a large non-motile egg is fertilized by a small motile antherozoid. This situation is unknown elsewhere among the filamentous fungi. Asexual reproduction throughout the group is accomplished by means of zoosporangia producing uniciliate zoospores. In this order the cell walls do not turn blue with zinc chloroiodide, an indication of the absence of cellulose.

Monoblepharis, the largest genus and the one most completely known, contains about eight species, the first of which was described by Cornu (1871) in France. The characteristics of Monoblepharis are so different from those of other phycomycetous fungi that some doubt as to the existence of these forms remained in the minds of most mycologists until Thaxter (1895) rediscovered representatives of the group in America. Shortly thereafter, as the result of the studies of Lagerheim (1900) in Sweden and Woronin (1904) in Finland, Monoblepharis became better known. The most recent monograph of the group is that of Sparrow (1933).

Monoblepharis is found most frequently on dead submerged twigs in quiet, clear, fresh-water pools. The genus appears to have been found most often in cool waters, early in spring, in the countries of northern Europe and in the northeastern United States. It is seldom recognized in the field but will derelop readily when the twigs are placed in aquarium jars in the laboratory. In cool waters $\left(8\right.$ to $11^{\circ} \mathrm{C}$ ) only sporangia will develop; higher temperatures $\left(21^{\circ} \mathrm{C}\right)$ are required for the production of sexual organs. The tufts of delicate hyphae protruding from the lenticels of the twigs consist of a rhizoidal system, which anchors the plant to the substratum, and a series of slender branches. The protoplasmic contents of the hyphae include regularly arranged vacuoles and oil globules, which impart a characteristic foamy appearance to the hyphae.

The sporangia are borne terminally, containing a single row of zoospores, and are cylindrical, to spherical, to more or less 
ovate in shape. At maturity a pore is formed at the tip of the sporangium; the zoospores creep through the pore in an amoeboid fashion, adhering to the mouth of the sporangium for a time, and finally swim away. The zoospores are provided with a single slender cilium, posterior in position. Both in its ciliation and internal structure, the zoospores of Monoblepharis are very similar to those of the Blastocladiales. Each germinates by two germ tubes, one of which forms the rhizoidal system and the other the main hyphae.
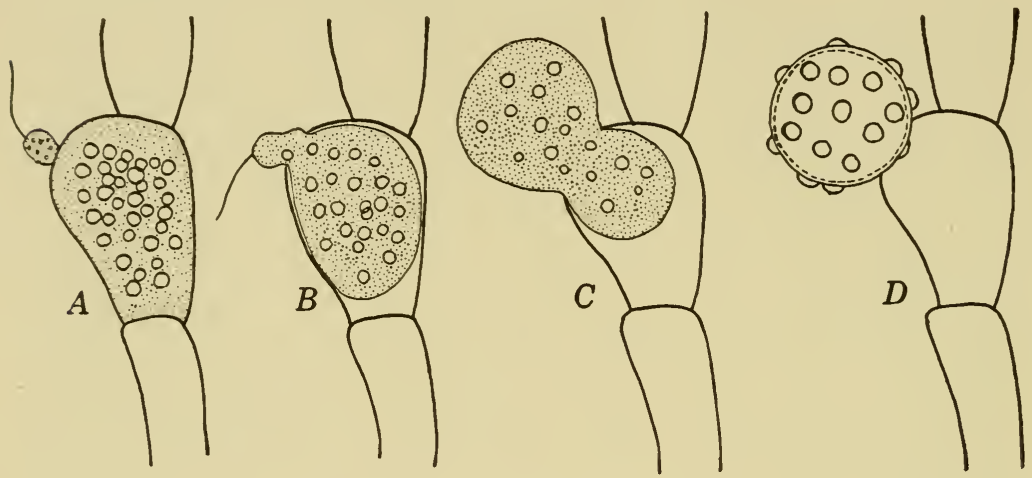

FIg. 24. Fertilization and emergence of the oospore of Monoblepharis polymorpha. $A$. The small uniciliate sperm lodged at the receptive spot on the oogonium. B. Fusion has begun. C. Fusion has been completed. (This process, $A$ to $C$, may require less than 10 minutes.) $D$. Mature thick-walled oospore, such as may be noted after several hours. (Adapted from Barnes and Melville.)

Considerable specific variation occurs in connection with the sexual reproductive structures. In $M$. polymorpha, for example, the antheridia are exserted on the oogonia (epigynous); whereas in 11 . sphaerica and 11 . macrandra the antheridia are hypogynous. The development of the antheridia and the maturation of the antherozoids occur in a manner very similar to those of the zoospores; the antherozoids are smaller than the zoospores and have a more pronounced amoeboid movement but otherwise resemble them very closely.

The content of the oogonium becomes a single egg. When it is mature, a receptive papilla is formed on the wall of the oogonium, providing a point of entrance for the sperm. Immediately after fertilization the egg becomes extruded from the oogonium 
in some species. According to the observations of Barnes and Melville (1932) on $M$. polymorpha, only 8 minutes was required from the time of contact of the sperm with the oogonial wall until fertilization had been completed and the oospore had been completely extruded from the oogonium. In $M$. fasciculata and $M$. insignis the oospores are not extruded but are retained within the oogonium. After fertilization the oospore becomes surrounded with a heavy wall, which may be either smooth or bullate in nature.

The cytological studies of Laibach (1927) have shown that the oogonium is uninucleate from the time of its formation. After the fusion of egg and sperm nuclei, nuclear divisions occur in the oospore during germination, in the course of which meiosis probably occurs.

The generic name Monoblepharopsis was created by Laibach to include two species, $M$. regignens and $M$. ovigera, differing from Monoblepharis in the more slender hyphae, proliferating sporangia, and absence of sexual organs. In view of the relative unimportance of these characters, Sparrow (1933) does not accept the genus as valid and would reunite these species with Monoblepharis.

Monoblepharella [Sparrow $(1939,1940)$ ] consists of two species, M. taylori, which was recently found in soil from Trinidad and other parts of tropical America, and M. mexicana [Shanor (1942)] from Mexico. Asexually it is similar to Monoblepharis; the distinctive characters of the genus lie in the behavior of the egg. When the fertilized egg is extruded from the oogonium, as in certain species of Monoblepharis, it swims away by means of a single cilium derived from the male gamete.

The similarity of the reproductive structures of Monoblepharis and of the green alga Oedogonium has been stressed in connection with the views of those who maintain the algal ancestry of fungi. The discovery of such forms as Monoblepharella has tended to discredit this view in favor of the probability of a close relationship of the Monoblepharidales with the Blastocladiales and Chytridiales, all of which have uniciliate zoospores. It has been maintained that Monoblepharella and Monoblepharis form an ascending series from an anisogamous ancestor, such as Allomyces javanicus. 

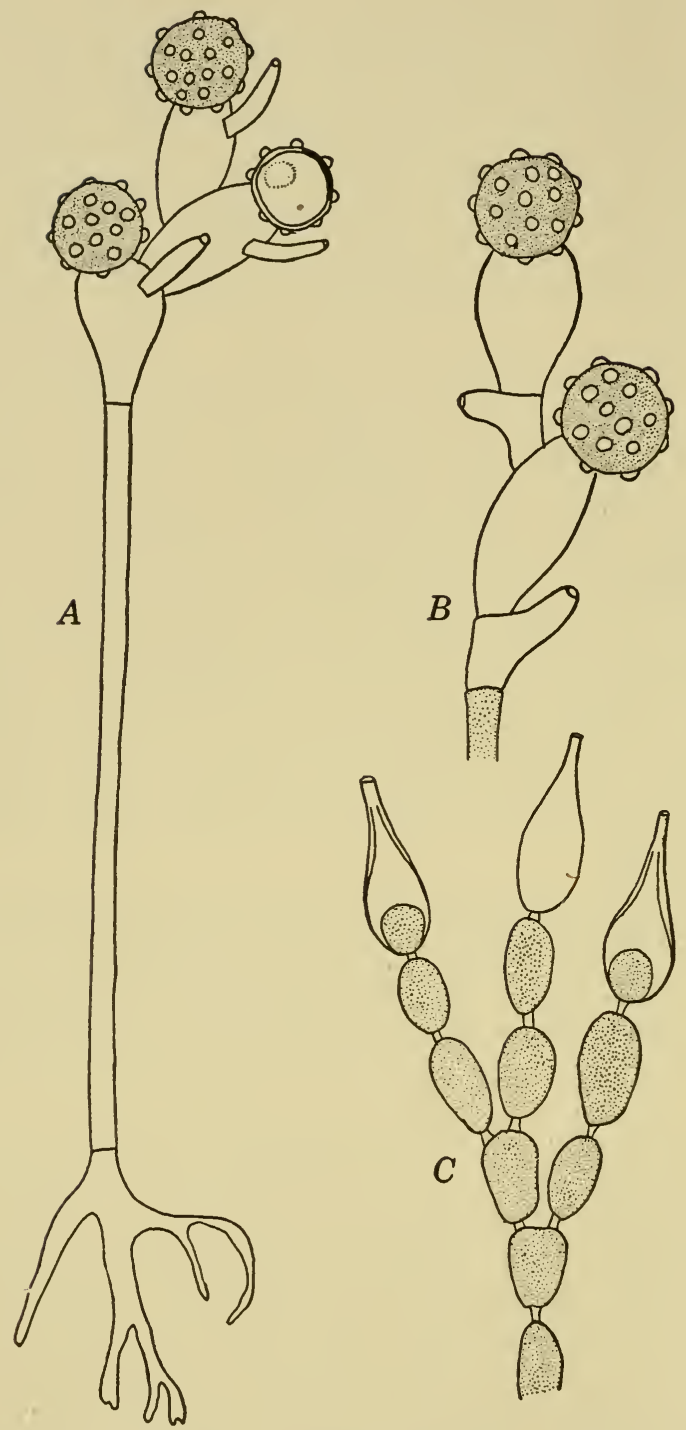

Fig. 25. A. Monoblepharis polymorpha, showing mature oospores with empty dwarf antheridia borne on the empty oogonia. B. M. sphaerica, empty antheridia occurring at the base of the empty oogonia. (Both after Sparrow.) C. A segment of the thallus of Gonopodya siliquaeformis. 
Somewhat different from these genera is Gonapodya, which occurs on submerged fruits of apple, rose, or Crataegus, in association with Blastocladia and various members of the Leptomitales. There are two described species: $G$. prolifera var. siliquaeformis and $G$. polymorpha. The thallus is filamentous, being composed of short segments of hyphae, which are frequently constricted. The constrictions are provided with cellulin plugs, like those in Leptomitus, but Gonapodya has uniciliate zoospores and is thus not related to the Leptomitales. Gonapodya has been placed in the Blastocladiales [Fitzpatrick (1930), Coker and Matthews (1937)], but it lacks the characteristic resistant sporangia of that order. A proper disposition of the genus must await knowledge of its sexual reproduction. It has been strongly suspected, however, that if the proper environmental conditions were provided, the fungus would be found to produce sexual organs similar to those of Monoblepharis. Gonapodya is included in the Monoblepharidales by Sparrow (1933).

The sporangia are terminal and more or less oval but taper at the apices to a blunt tip, thus resembling a lamp mantle. Young sporangia frequently proliferate within older ones. Sporangia of the two species of Gonapodya differ greatly in size. In structure and behavior of zoospores, Gonapodya is similar to Monoblepharis.

This order is rather poorly known to most mycologists. The literature gives no indication that any representative of the group has ever been grown in pure culture. Because of lack of understanding of proper methods of collection and of cultural requirements there is a current notion that these forms are very rare. Sparrow, however, has found practically all the species in a single favorable location, and future work will doubtless show that they are far more widespread than has previously been supposed.

\section{LITERATURE CITED}

Barnes, B., ANd R. Melville, "Notes on British aquatic fungi," Trans. Brit. Mycol. Soc., 17: 82-96, 1932.

Coker, IV. C., axd V. D. Matthews, "Monoblepharidales," North Am. Flora, 2 (1): 1-67, 1937.

Cornu, M., "Note sur deux genres noureaux de la famille des Saprolégniées," Bull. soc. bot. France, 18:58-59, 1871. 
Fitzpatrick, H. M., The lower fungi: Phycomycetes. 331 pp. McGrawHill, New York. 1930.

Lagerhem, G., "Mycologische Studien II. Untersuchungen über die Monoblepharideen," Beibang t. K. Svensk. Vet. Akad. Handl., 25: Afd. III (8): 3-42, 1900.

Laibach, F., "Zytologische Untersuchungen über die Monoblepharideen," Jabrb. wiss. Botan., 66: 596-630, 1927.

Shaxor, L., "A new Monoblepharella from Mexico," Mycol., 34:241-247, 1942.

Sparrow, F. K., Jr., "The Monoblepharidales," Ann. Botany, 47:517-542, 1933.

"Monoblepharis taylori, a remarkable soil fungus from Trinidad," Mycol., 31: 737-738, 1939.

"Aquatic Phycomycetes recovered from soil samples collected by W. R. Taylor on the Allan Hancock 1939 Expedition," Allan Hancock Pacific Exped., 3: 101-113, 1940.

Thaxter, R., "New or peculiar aquatic fungi. I. Monoblepharis," Botan. Gaz., 20:433-440, 1895.

II. "Gonapodya Fischer and Myrioblepharis, nor. gen.," Botan. Gaz., 20: $477-485,1895$.

Woronis, M., "Beitrag zur Kenntnis der Monoblepharideen," Mem. Acad. St. Petersburg (Phys. Math. Cl.), 16: 1-24, 1904.

\section{LEPTOMITALES}

The group Leptomitales is one of the smaller orders of aquatic fungi, including 7 genera and approximately 20 species. Throughout the group the zoospores are biciliate, and the cell walls are invariably composed of cellulose. The group differs from the Saprolegniales chiefly in the constriction of the hyphae to form a chain of segments. Large granules of cellulin, a carbohydrate related to cellulose, occur within the hyphae near the constrictions and may form plugs resembling septa.

There is a great diversity of form among the various genera. Some workers, including Indoh (1939), recognize two distinct groups: (1) a "filamentous" group, including Leptomitus and Apodachlya, and (2) an "arbusculate" group, including Sapromyces, Araiospora, and Rhipidium. The appearance of the arbusculate forms, with their basal cell giving off numerous slender branches above, is reminiscent of the Blastocladiales, with which they are frequently found associated in nature.

The usual method of collection [Kanouse (1925)] is to leave a "bait" of fruit or twigs in the water for some time. The group has been little studied and appears to be of rather infrequent oc- 
currence. The only monographic treatment is that of Kanouse (1927).

Leptomitus, the type genus, contains but a single species, $L$. lacteus. It occurs in sewage effluents in waters containing industrial wastes of various kinds and may occasionally be found growing en masse in clogged drains and similar places. Detailed studies of the nutrition of this species have recently been made by Schade (1940), and Schade and Thimann (19+0).

The thallus of Leptomitus is filamentous and constricted, and sporangia are not differentiated as such. The segments become transformed into sporangia in basipetal succession and liberate the biciliate zoospores either through a pore in the terminal segment or through a number of pores, one in each segment. Sexual reproduction is unknown in the genus.

Apodachlya bears considerable resemblance vegetatively to Leptomitus, but the segmented hyphae bear pyriform sporangia, whose zoospores may either swim away directly or remain encysted for a time at the mouth of the sporangium. Sexual reproduction occurs by means of a terminal oogonium subtended by a hypogynous antheridial cell [Kevorkian (1935)]. The development of the oogonium differs from that of other representatives of the order in that no definite periplasm is formed. It has therefore been suggested that Apodachlya and the allied Leptomitus are more closely related to the Saprolegniales than are the remaining genera of this group.

In the Genus Sapromyces the thallus is of the arbusculate type, consisting of a trunk or basal cell and numerous branches, but there is very little difference in size between trunk and branches. Sporangia, lobate to cylindrical in shape, occur terminally or near the constrictions of the branches and liberate the biciliate zoospores. The genus has two species, S. androgymus, which is homothallic, and $S$. reinschii, which is heterothallic. In both species the oogonia are pyriform and contain a single oospore surrounded by periplasm, according to cytological investigations of Kevorkian (1935). Bishop (1940) has recently demonstrated the occurrence of relative sexuality in S. reinschii and has grown this organism in pure culture.

In Araiospora and Rhipidium, both of which have several species, there is a stout trunk with rather slender, constricted branches. As in Sapromyces, the trunk is attached to the sub- 


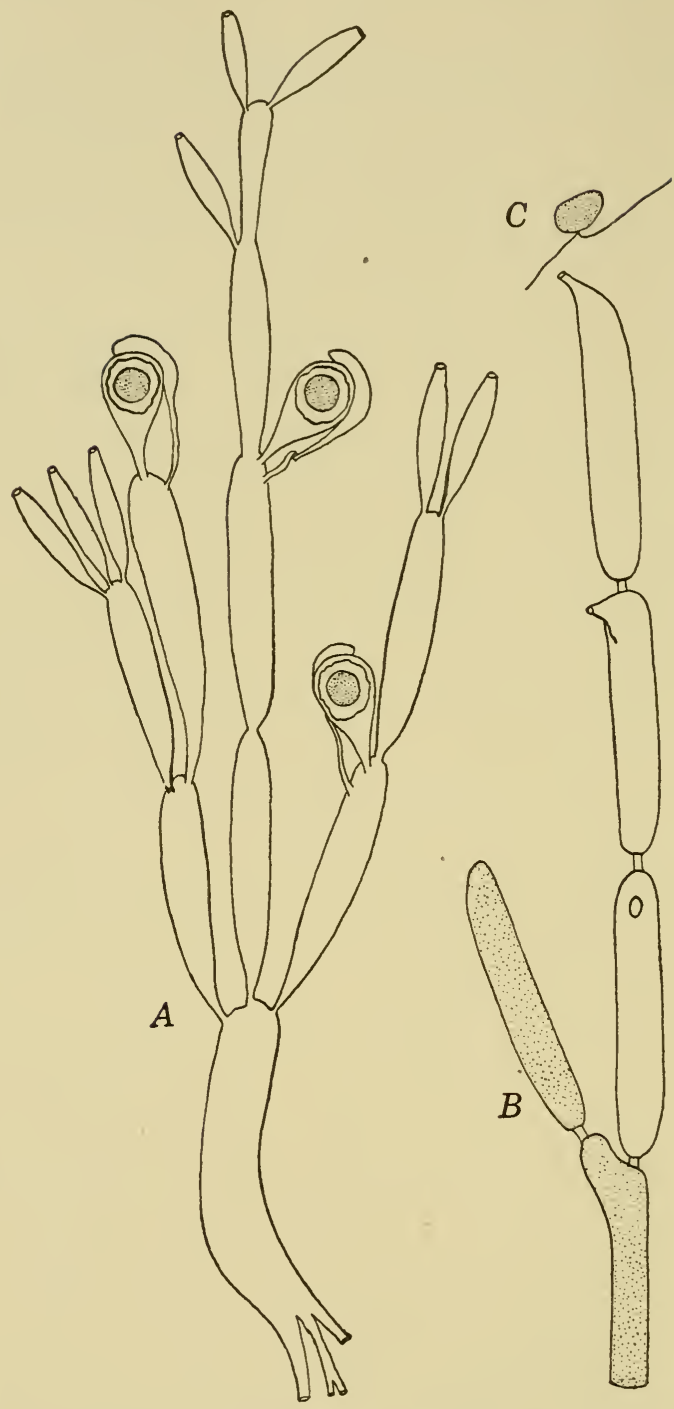

Fig. 26. A. Habit sketch of Sapromyces androgynus, bearing sexual organs and empty swarm sporangia. B. Fragment of Leptomitus lacteus, some of the sporangia being empty. C. Biciliate swarm spore. 
stratum by numerous rhizoids. In Rhipidium the sporangium discharges its zoospores into a vesicle. Sexual reproduction in Rhipidium is not unlike that in Sapromyces. Fertilization in $R$. europaeum has been studied by Behrens (1931), who reports the formation of a definite exospore from the periplasm. In Araiospora there may be indications of a vesicle, but when formed it is ephemeral. In this genus two kinds of sporangia are present, one smooth-walled, the other provided with conspicuous spines. In $A$. pulchra, according to King (1903), the nuclei of the periplasm do not degenerate but become enclosed within cell walls, so that a layer of cells comes to surround the oospore within the oogonium.

Although possessing a superficial resemblance to the Blastocladiales, the arbusculate representatives of the Leptomitales cannot be considered as closely related to that group because of differences in the structure of the zoospores and composition of the cell wall. They perhaps form an ascending series from such a filamentous form as Apodachlya to the Pythiales or Peronosporales, which they resemble closely in the structure of sexual reproductive organs.

\section{LITERATURE CITED}

Behrexs, A., "Zytologische Untersuchungen an Rbipidium europaeum (Cornu) ron Minden," Planta, 13: 745-777, 1931.

Bishop, H., "A study of sexuality in Sapromyces Reinschii," Mycol., 32: 505-529, 1940.

Ixpoh, H., "Studies on the Japanese aquatic fungi. I. On Apodacblyella completa, sp. nov., with revision of the Leptomitaceae," Science Repts. Tokyo Bunrika Daigaku, B, 4:43-50, 1939.

Kaxouse, B. B., "On the distribution of the water molds, with notes on the occurrence in Michigan of members of the Leptomitaceae and Blastocladiaceae," Papers Mich. Acad. Sci. Arts Letters, 5: 105-114, 1925.

"A monographic study of special groups of the water molds. II. Leptomitaceae and Pythiomorphaceae," Am. J. Botany, 14:335-357, 1927.

Ketorkiax, A. G., "Studies in the Leptomitaceae. II. Cytology of Apodacblya bracbynema and Sapromyces Reinscbii," Mycol., 27:274-285, 1935.

Krvg, C., "Observations on the cytology of Araiospora pulchra Thaxter," Proc. Boston Soc. Nat. Hist., 31:211-245, 1903.

Schade, A. L., "The nutrition of Leptomitus," Ann. J. Botany, 27: 376-384, 1940.

Schade, A. L., ANd K. V. Thinasy, "The metabolism of the water mold, Leptomitus lacteus," Am. J. Botany, 27: 659-670, 1940. 


\section{SAPROLEGNIALES}

Members of this order are commonly termed "water molds." The group includes about 15 genera and approximately 120 species, of which a number are of rather common occurrence. All members of the order are characterized by a well-developed mycelium, the hyphae of which have cell walls composed of cellulose. The zoospores, produced in zoosporangia of various types, are invariably biflagellate. Sexual reproduction occurs by means of antheridia and oogonia containing one to several oospores; periplasm is lacking.

The characteristic habitat of the Saprolegniales includes all kinds of fresh water, in which they exist as saprophytes on various kinds of organic materials. Practically all the species may be readily grown in pure culture, either on solid media or in water cultures on hempseed. Because of the great variability displayed by many species, the hempseed medium has been rather extensively used as a basis for taxonomic work. The most workable monographs of the group are those of Coker (1923) and Coker and Matthews (1937).

When Saprolegniales are cultivated in water culture on hempseeds, the hyphae radiate in a white mat that surrounds the seed. Typically hyphal tips are delimited by cross walls, and each such terminal segment becomes a zoosporangium. As observed with low magnification under a microscope, young sporangia are densely filled with protoplasm, whereas the remainder of the hypha seems empty. If the stale water is replaced by fresh water, spore formation and emergence, a fascinating spectacle, may be observed. As the zoospores take shape, the apex of the sporangium softens; at the critical moment it opens, and the zoospores rapidly emerge. Within 10 to 20 seconds they may all have come to the exterior and may be dispersed quickly.

Although most Saprolegniales are aquatic, the discovery by Harvey (1925) that certain of them can readily be isolated from the soil has resulted in the finding of many previously known forms in this habitat and in the description of a number of new genera and species [Coker (1927), Harvey (1928), Cook and Morgan (1934)]. 


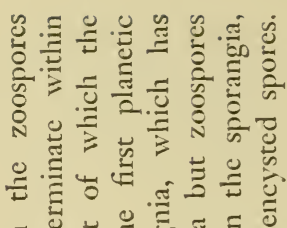

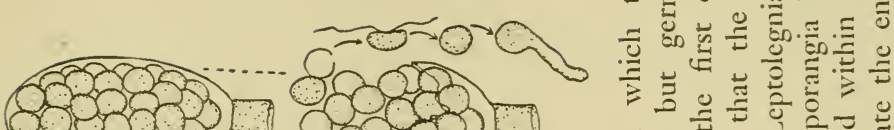

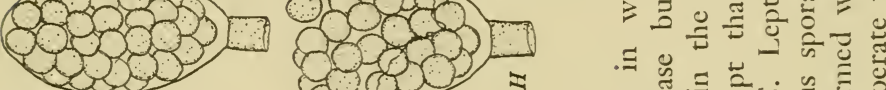
$50 \%$

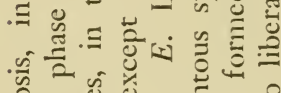

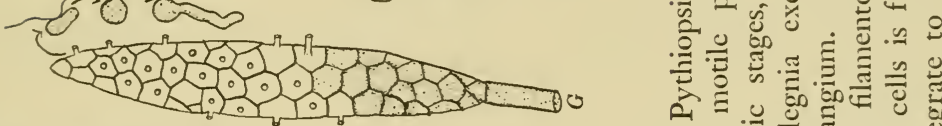

803000

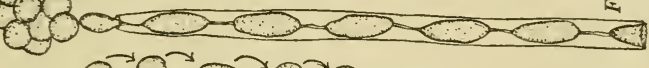

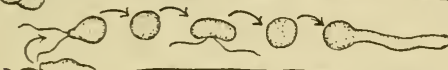

$\omega$

800.50

8838080

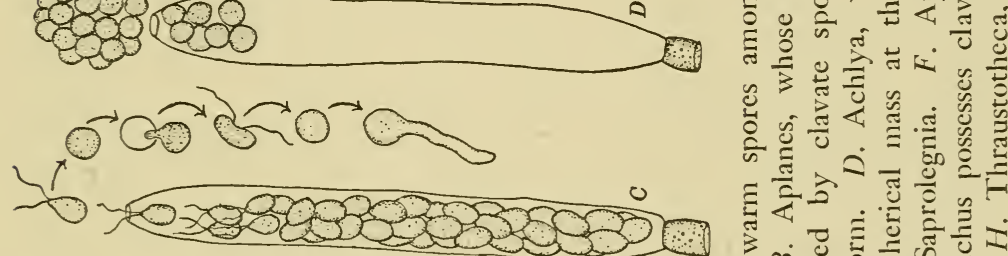

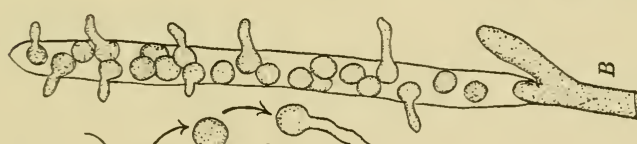

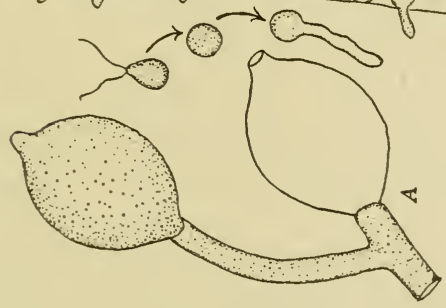

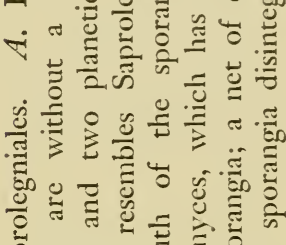

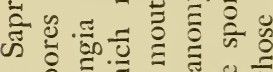

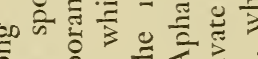

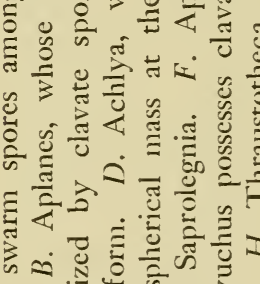
के

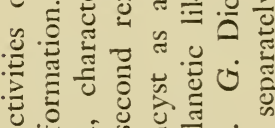

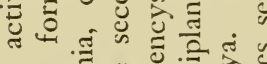

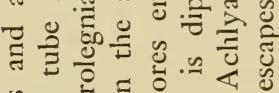

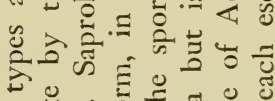

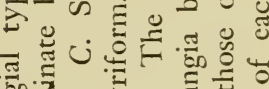
政震

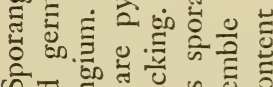
के

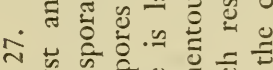

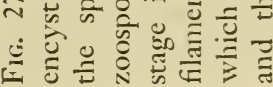


As an important exception to the saprophytic mode of life of these fungi may be mentioned Saprolegnia parasitica, which causes a serious disease of fishes and fish fry [Tiffney (1939)]. Likewise, various species of Aphanomyces are known as parasites on the roots of such higher plants as peas, radish, and beets [Kendrick (1927), Drechsler (1929)] and on Spirogyra and other aquatic fungi.

Asexual Reprodection. A number of species reproduce asexually by means of gemmae of various size and shape, usually formed in terminal chains. After a dormant period the gemma may form a germ tube, produce sporangia, and give rise to oospores.

The regular means of asexual reproduction, howerer, is by sporangia and zoospores. The young sporangium is multinucleate and cut off from its parent hypha by a septum. Cleavage planes, which appear in the protoplasm, gradually branch and divide the sporangial content into a number of uninucleate masses, each of which will eventually form a zoospore. It is principally by means of variations in the structure and behavior of the zoospores that the various genera are delimited. Other characteristics of importance in this connection include the method of renewal of the sporangia, whether by proliferation or by cymose branching from below, the shape of the sporangium, and the number of eggs within the oogonium [Coker and Matthews (1937)].

In the rather uncommon Genus Pythiopsis the sporangia are spherical to pyriform in shape, and the zoospores are monoplanetic; that is, there is but a single period of motility. The zoospore itself is pyriform and has two apical cilia.

All the remaining genera have sporangia which are cylindrical, fusiform, or clavate in shape. In Aplanes sporangia are rarely produced; but when they are developed, the spores germinate in situ within the sporangium, and the germ tubes protrude through the sporangial wall.

In Saprolegnia, Isoachlya, and Leptolegnia the spores are diplanetic, that is, have two motile phases. On discharge from the sporangium the pyriform "primary" zoospores are motile by means of two apical cilia. After a brief motile period they encyst and then give rise to "secondary" zoospores that are reniform and possess two lateral cilia. 
In Achlya, Protoachlya, Sommerstorffia, Aphanomyces, and Plectospira the first swimming stage is almost completely suppressed. The spores, on discharge, come to rest at the mouth of the sporangium and encyst, and the reniform or "secondary" zoospores escape from the cysts.

In Dictyuchus encystment of the zoospores occurs within the sporangium, and each reniform zoospore escapes individually through its own pore in the sporangial wall.

In Thraustotheca, Brevilegnia, and Geolegnia the spores, having encysted within the sporangium, are gradually liberated by a dissolution of the sporangial wall. In some species of Brevilegnia and in the genus Geolegnia zoospores are not formed as such. The spores are non-motile and may even be multinucleate. This phenomenon has been interpreted [Höhnk (1935)] as an adaptation for life in the soil. The occurrence of two distinct types of zoospores in the Saprolegniales is a feature for which no satisfactory explanation has yet been offered.

Sexual reproduction. Sexual reproduction, involving the formation of antheridia and oogonia, generally occurs in water cultures upon the exhaustion of the nutrient supply. Except in occasional instances the sex organs are not readily produced on solid media. When a single hypha gives rise to both oogonia and antheridia, the species is said to be androgynous (homothallic). To other species, in which antheridia and oogonia may be formed on hyphae at some distance from each other, the term diclinous has been applied. In Dictyuchus monosporus [Couch (1926)], Acblya bisexualis [Raper (1936)], and A. ambisexualis [Raper (1940)] true heterothallism has been demonstrated. Working with $A$. ambisexualis, Raper has clearly shown the existence of relative sexuality; that is, a strain which produces antheridia in one cross may produce oogonia instead when crossed with a different isolate.

The young oogonium, which generally appears as a lateral branch of a main hypha, is multinucleate. After nuclear division there occurs a degeneration of many nuclei and a reorganization of the oogonial contents into a number of uninucleate eggs (oospheres). In a number of genera, including Leptolegnia, Aphanomyces, Dictyuchus, Brevilegnia, and Geolegnia, only a single egg is formed within the oogonium. In most of the remaining genera more than one egg is produced, but the number 


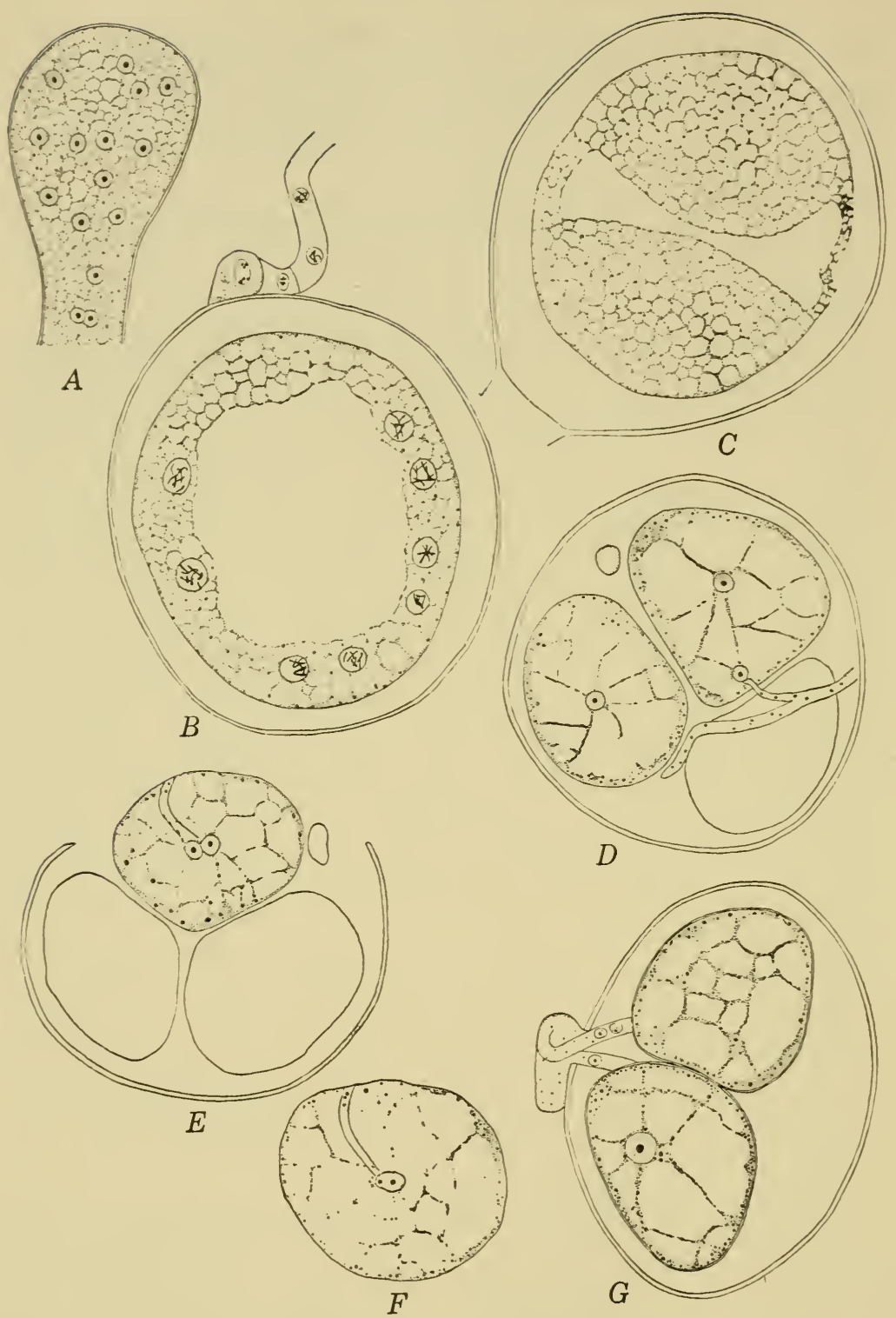

Fig. 28. Gametogenesis and fertilization in Aclolya flagellata. A. Multinucleate oogonial initial. $B$. Oogonium with nuclei in prophase and antheridium with nuclei in anaphase. $C$. Oosphere formation. $D$. Uninucleate oospheres, with nucleus just discharged from fertilization tube. $E$. Oosphere with gamete nuclei in contact. $F$. Fusion of gametic nuclei; two nucleoli visible. G. Two nearly mature oospores, one with large fusion nucleoli 
formed may vary considerably within a single species. As many as thirty eggs may be formed in certain species.

The development of the antheridium, paralleling that of the oogonium, culminates in the formation of fertilization tubes, which penetrate the oogonial wall and enter the eggs. Fertilization has been demonstrated in a considerable number of species of Achlya [Patterson (1927), Wolf (1938)], Saprolegnia [Claussen (1908), Höhnk (1935a)], Aphanomyces [Kasanowsky (1911)], Brevilegnia [Cooper (1929)], Leptolegnia [Couch (1932)], and Thraustotheca [Shanor (1937)], and doubtless it occurs whenever antheridia are present. It has been known since the time of de Bary that antheridia may not be present on all the oogonia produced, and in certain forms oospores may be produced parthenogenetically.

The mature oospore is surrounded by a heavy wall. After a rest period of several months, the oospore eventually germinates by forming a short germ tube bearing a sporangium. It has recently been shown [Schrader (1938)] that meiosis occurs during oospore germination.

\section{LITERATURE CITED}

Claussen, P., "Über Eientwickelung und Befruchtung bei Saprolegnia monoica," Ber. deut. botan. Ges., 26: 144-161, 1908.

CoKer, W. C., The Saprolegniaceae, with notes on other water molds. 201 pp. University of North Carolina Press, Chapel Hill. 1923.

"Other water molds from the soil," J. Elisha Mitchell Sci. Soc., 42:207226, 1927.

Coker, W. C., ANd V. D. Matrhews, "Saprolegniales (Saprolegniaceae, Ectrogellaceae, Leptomitaceae)," Nortb Am. Flora, 2, Part 1: 15-67, 1937.

Соoк, W. R. I., Axid Evid Mlorgan, "Some observations on the Saprolegniaceae of the soils of Wales," J. Botany, 72: 345-349, 1934.

Cooper, G. O., "Cytological studies on the sporange development and gametogenesis in Brevilegnia diclina Harvey," Trans. Wis. Acad. Sci., 24: 309-322, 1929.

Couch, J. N., "Heterothallism in Dictyuchus, a genus of the water molds," Ann. Botany, 40: 849-881, 1926.

"The development of the sexual organs in Leptolegnia caudata," Am. J. Botany, 19: 584-599, 1932.

Drechsler, C., "The beet-water mold and several related root parasites," J. Agr. Research, 38:309-361, 1929.

HaRvey, J. V., "A survey of the water molds occurring in the soils of Wisconsin, as studied during the summer of 1926," Trans. Wis. Acad. Sci., 23: 551-562, 1928. 
"A study of the water molds and Pythiums occurring in the soils of Chapel Hill," J. Elisha Mitchell Sci. Soc., 41: 151-164, 1935.

Нӧнхк, IV., "Saprolegniales und Monoblepharidales aus der Umgebung Bremens, mit besonderer Berucksichtigung der Oekologie der Saprolegniaceae," Ablaandl. Nat. Ver. Bremen, 29: 207-237, 1935.

"Zur Cytologie der Oogon- und Eientwickelung bei Saprolegnia ferax," Abloandl. Nat. Ver. Bremen, 29: 308-323, 1935 a.

Kasaxowsky, V., "Aphanomyces laevis de Bary. I. Entwickelung der Sexualorgane und Befruchtung," Ber. deut. botan. Ges., 29:210-228, 1911.

Kexdrick, James B., "The black-root disease of radish," Indiana Agr. Expt. Sta. Bull., 311.32 pp. 1927.

Patrensox, P. M., "Fertilization and oogenesis in Aclolya colorata," J. Elisha Mitchell Sci. Soc., 43: 108-123, 1927.

Raper, J. R., "Heterothallism and sterility in Achlya and observations on the cytology of Achlya bisexualis," J. Elisha Mitchell Sci. Soc., 52: $274-289,1936$.

"Sexuality in Acblya ambisexualis," Mycol., 32: 710-727, 1940.

Schrader, E., "Die Entwickelung von Thraustotheca clarata," Flora, N. F., 32: $125-150,1938$.

Shayor, Lelaxd, "Observations on the development and cytology of the sexual organs of Thraustotbeca clavata (de Bary) Humph.," J. Elisha Mitchell Sci. Soc., 53:119-135, 1937.

Tiffeney, W. N., "The host range of Saprolegnia parasitica," Mycol., 31: 310-321, 1939.

"The identity of certain species of the Saprolegniaceae parasitic to fish," J. Elisha Mitchell Sci. Soc., 55:134-151, 1939a.

Wolf, F. T., "Cytological observations on gametogenesis and fertilization in Acblya flagellata," Mycol., 30:456-467, 1938.

\section{PYTHIALES}

The Pythiales are characterized by possession of a well-dereloped mycelium that lacks haustoria and that bears sporangia sympodially and in succession at the tips of sporangiophores which are little differentiated from the mycelium. It is a small group, intermediate phylogenetically between the Leptomitales and Peronosporales. A wide diversity of opinion exists among mycologists on generic and specific limits within the order. Some workers maintain that there are only + or 5 genera; others recognize as many as 14. Of these Pythium and Phytophthora, which some students would combine, are the best known, are of most importance, and contain the larger number of species. These two genera include destructive pathogens capable of attacking both herbaceous and woody plants and also of main- 
taining themselves for long periods as saprophytes. Some of the Pythiales attack other fungi, algae, and insects or are said to be the mycorrhizal component in liverworts and ferns. Zoophagus is predaceous. Many species live in the soil.
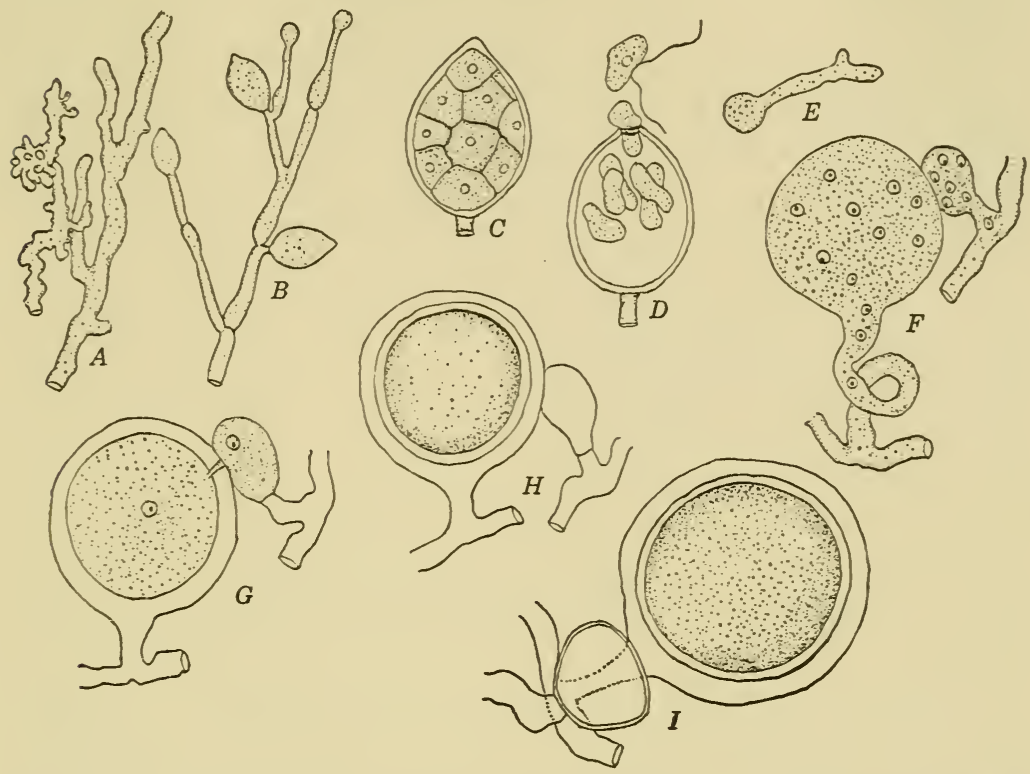

Fig. 29. Structures possessed by Phytophthora. $A$. The mycelium in culture is irregular in diameter and may have many nodular bodies. $B$. Sporangiophores that branch below the last-formed sporangium. C. Sporangium whose content is cleared preparatory to opening at the papilla to permit the zoospores to escape singly. $\dot{D}$. Sporangium that is partly empty with a swarm spore in the orifice. $E$. After coming to rest, the swarm spore germinates by germ-tube formation. $F$. Multinucleate antheridium and oogonium that arise as termini of lateral branches. G. All nuclei except one in each organ disintegrate, and a fertilization tube forms for passage of the antheridial nucleus into the oogonium. $H$. Paragynous antheridium. I. Androgynous antheridium.

The Pythiales, by and large, are essentially aquatic, as their biflagellae zoospores, produced in sporangia, indicate. In some instances, however, the sporangia germinate directly by the formation of a germ tube. Normally the zoospores encyst after a period of swarming, and further development is initiated by the formation of a hypha. 
In some species the sporangia are detachable, whereas in others they remain attached to the mycelium. Sporangial shape is one of the features that has been employed as a basis for generic types, as is indicated by the names Sphaerosporangium and Nematosporangium, more appropriately regarded as names of subgenera.

The development of oogonia and antheridia has been studied repeatedly, and essential features in Pythinm de baryanum were determined long ago by Miyake (1901). The hyphal tips first become inflated, are multinucleate, and are set off by septa. As the oogonium enlarges, the central portion becomes the oosphere; and the peripheral portion, the periplasm. All the nuclei but one migrate into the peripheral layer, where they disintegrate. Meanwhile all but one of the antheridial nuclei disintegrate also, and a wide pore forms at the point of contact of the antheridium with the oogonium. This stage is followed by the migration of the antheridial nucleus and a portion of the cytoplasmic content through the periplasm to contact the centrally located egg nucleus and cytoplasm. These two nuclei then fuse, and a thick wall, a modification of the periplasn, is developed around the zygote.

In respect to position of antheridia with respect to oogonia, there are two general types of Pythiales: paragynous and amphigynous. In the first type the antheridia are applied at the side of the oogonia; in the second they are applied as a doughnutshaped collar around the oogonial stalk.

The Pythiales grow readily on a wide variety of artificial substrata. Many of them can be induced to form both sporangia and sexual spores on agar, whereas others remain sterile or form sporangia only. Emergence of swarm spores often takes place if fresh water is applied or if the sporangia are placed in fresh water. Boiled hempseeds placed in water are very satisfactory in isolating Pythiales from soil samples.

Pythium. The Genus Pythium is extensively treated by Butler (1907), Matthews (1931), and Middleton (1943). As monographed by Matthews (1931), it contains approximately 40 species, whereas Middleton (1943) recognizes 66 species as valid. Perhaps the best known among them is $P$. de baryanum, which causes damping off of seedlings, both herbaceous and woody. It is especially destructive to coniferous seedlings in nurseries and 
to such crop plants as tobacco, cabbage, and tomatoes being grown in seed beds. It is probable that $P$. ultimum, when isolated from diseased seedlings, has been wrongly identified in some instances as $P$. de baryanum. Although $P$. ultimum does not form zoospores, its sporangia germinate directly, that is, by germ tubes, and its antheridia are androgynous.

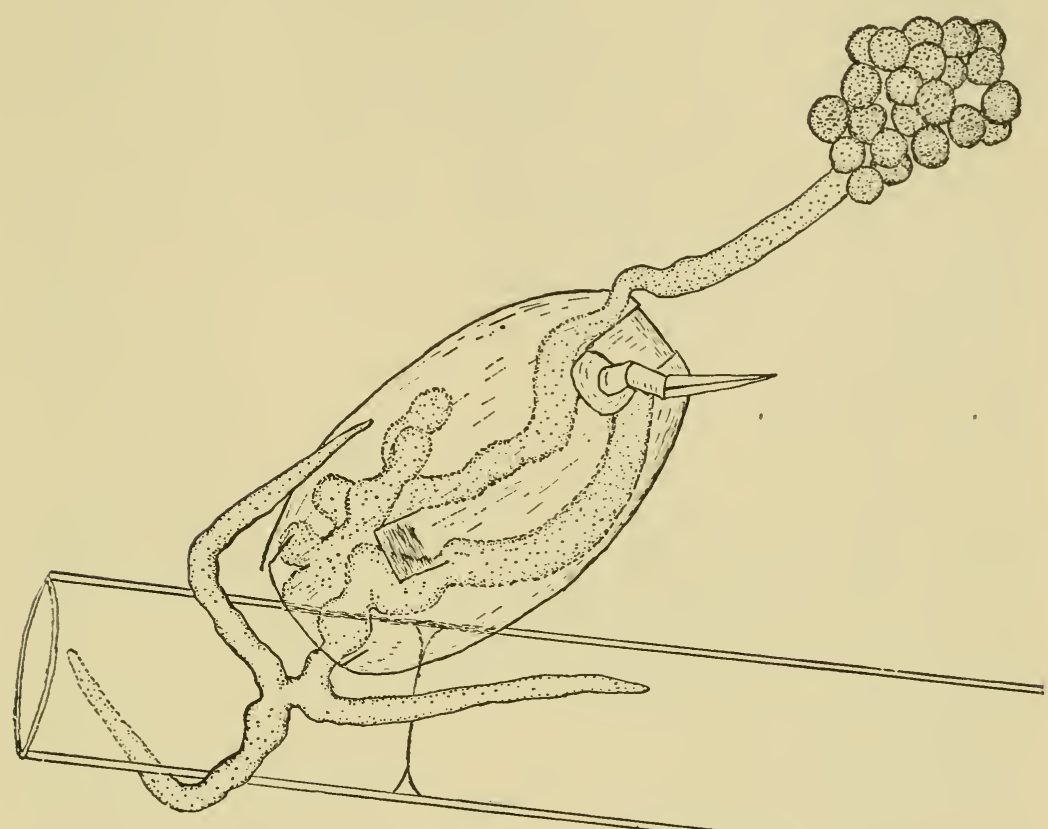

Fig. 30. Sommerstorffia spinosa, parasitizing the rotifer Monostyla attached to a filament of the alga Rhizoclonium. (Adapted from Sparrow.)

Pytbium aphanidermatumn, described by Edson (1915) as Rheosporangium aphanidermatum, is the cause of a seedling- and rootrot disease of sugar beets and radishes. It has been found to attack also the seedlings of various other species. Its cytology and developmental history, as reported by Edson, agree with that known to characterize Pythium. Similarly Zoophagus insidians, described by Sommerstorff (1911) as a predator on rotifers, appears to belong to the Genus Pythium instead.

In Pythium, as usually encountered, the protoplasm passes in an undifferentiated state into a vesicle at the tip of the exit tube, 
which is approximately as long as the diameter of the sporangium. This vesicle is the inner sporangial wall. After 10 to 15 minutes the zoospores become differentiated within the vesicle and move about within it, at first sluggishly and then with increasing rapidity. At length the vesicle ruptures, and the zoospores dart away at high speed. After a few minutes they come to rest, encyst, and then germinate by the formation of a tube.

Phytophthora. The Genus Phytophthora (the name signifies "plant destroyer"), well known to all plant pathologists, includes 17 species and 1 variety, according to the monograph by Tucker (1931). The name was first employed by de Bary in 1876 as a result of his studies of $P$. infestans, which causes late blight and tuber rot of potatoes. This organism was introduced into Europe, where it has produced serious losses year after year. How it hibernates remained a controversial question for years, but the mycelium is now known to survive within the "seed" tubers. Smith (1875) early maintained that it forms, within the potato foliage, oospores by means of which it survires from year to year, but de Bary demonstrated that the oospores observed by Smith were those of Pythium. Jones, Giddings, and Lutman (1912) obtained oogonium-like structures in pure cultures. Antheridia were not observed, however, and Clinton (1911), who secured oogonia and antheridia on oat agar, believed the structures seen by Jones and his associates might as well have been chlamydospores.

Microscopic examination of diseased potato foliage shows that the mycelium of $P$. infestans is intercellular and that haustoria penetrate the host cells. Slender, sparsely branched hyphae in small groups, the sporangiophores, emerge from the stomata. Ovoid to pear-shaped sporangia are formed at the tips of the sporangiophores, after which the hyphae continue to elongate, thus causing the sporangia to appear laterally attached. Sporangia are readily detachable and may be carried by rain-splash or air currents to other leaves to initiate new infections.

The type of germination of sporangia is determined by temperature and moisture. The sporangium may form a germ tube that penetrates the host directly, or else its content becomes divided to form biciliate zoospores. Zoospores escape through an apical pore, and after 2 or 3 hours, have settled, produced a germ tube, and penetrated new host tissue. Entrance occurs 


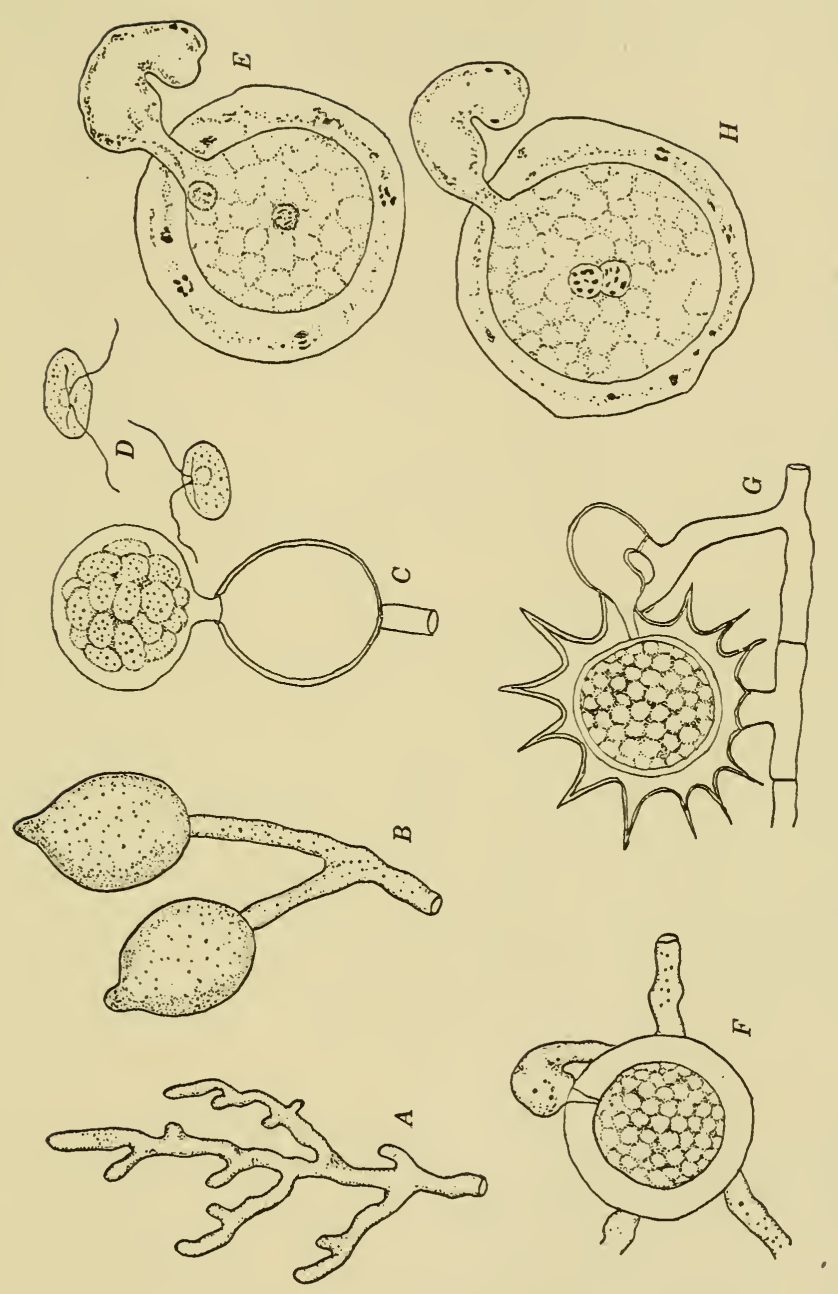

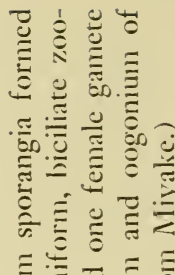

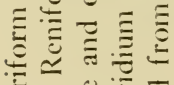

들

$\therefore \dot{\Xi} \cong \bar{\Xi}$

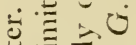

导产

ป

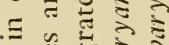

วิ

.

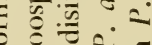

$\Xi$ ㄴ.

ఏ등

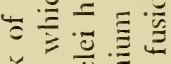

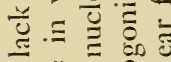

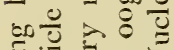

的氙

产

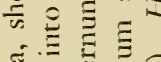

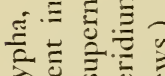

至造 क

Ј

可芯《之

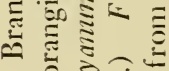

एं ڤे

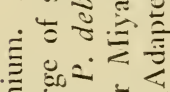

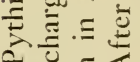

$\sim$ บ

"ั口

记悉

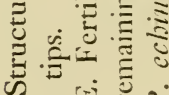

के

- $\frac{\bar{T}}{2} \dot{0}$

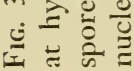


either through the stomata or through unbroken epidermis. Soon lesions are formed, and after 3 to 5 days of favorable weather $P$. infestans will again be sporulating. The short sporangial cycle makes possible the rapid development of potato-foliage blight in epiphytotic proportions. Presumably zoospores are transferred through the soil and gain entrance through the lenticels, and thus tuber decay is initiated.

There are other rery destructive species of Phytophthora. Among the better known are P. palmivora, studied by Seal (1928) in connection with bud rot of coconut and other tropical plants.

Nearly 50 years ago ran Breda de Haan (1896) recorded a disease of tobacco in Sumatra, the cause of which he identified as $P$. nicotianae. The fungus has since spread throughout the tropics, and about 15 years ago it appeared in the flue-cured tobacco district of North Carolina. Tucker (1931) regards it as specifically identical with $P$. parasitica and uses nicotianae as a varietal name. Phytophthora citrophthora, causing brown rot and gummosis of lemons, was first described by Smith and Smith (1906) as Pytbiacystis citrophthora. Petersen's (1910) monotypic Pytbiomorpha gonapodioides, growing on twigs and fruits immersed in water. has been indicated to be a Phytophthora.

The Genus Phytophthora differs from Pythium in that on germination the zoospores are fully formed within the sporangium and escape through an opening at the papilla. In Phytophthora palmizora, however, a resicle may at times be formed; at others the swarm spores escape directly.

The taxonomy of both Phytophthora and Pythium is difficult, since so much devends on cultural characteristics and host relationships.

\section{LITERATURE CITED}

BREDA DE HAAx, J. rax, "De bibitziekte in de Deli tabak reroorzaakt door Phytophthora nicotinnae," Mededeel. s'Lands Plantentuin, 15:107 pp., 1896.

Butter, E. J., "An account of the genus Pythium and some Chytridiaceae," Mem. Dept. Agr. India, Bot. Ser., 1:1-160, 1907.

Curnton, G. P., "Oospores of the potato-blight fungus, Plbytophthora infestans," Rept. Conn1. Agr. Expt. Sta., 1909-1910: 753-774, 1911.

EDsox, H. A., "Rheosporangium aphanidermatum, a new genus and species of fungus parasitic on sugar beets and radishes," J. Agr. Research, 4: 279-291, 1915. 
Jones, L. R., N. J. Giddings, And B. F. Lutuiax, "Investigations of the potato fungus, Phytophthora infestans," U. S. Dept. Agr. Bur. Plant Ind. Bull., 275. 100 pp. 1912.

Matthews, Velia D., Studies on the gemus Pytbium. $136 \mathrm{pp}$. The University of North Carolina Press. 1931.

Middetox, J. T., "The taxonomy, host range, and geographic distribution of the genus Pythium," Memi. Torrey Botan. Club, 20:1-171, 1943.

Mryake, K., "The fertilization of Pytbium de baryamum," Amn. Botany, 15: 653-666, 1901.

Petersen, H. E., "An account of Danish fresh-water Phycomycetes, with biological and svstematic remarks," Ann. Mycol., 8: 494-560, 1910.

Seal, J. L., "Coconut bud rot in Florida," Fla. Agr. Expt. Sta. Bull., 199: 87 pp. 1928.

Smith, R. E. ANd Elizabeth H., "A new fungus of economic importance," Botan Gaz. 42:215-221, 1906.

Smith, Worthingtox G., "The resting spores of the potato fungus," Gard. Cloron., n.s., 4: 68-70, 1875.

Sommerstorf, H., "Eine Tiere fangender Pilz (Zoophagus insidians, nov. gen., nov. sp.)," Oest. Bot. Z., 61:361-373, 1911.

Tucker, C. M., "Taxonomy of the genus Phytophthora de Bary," Mo. Agr. Expt. Sta. Research Bull., 153. 208 pp. 1931.

\section{ALBUGINALES}

The Albuginales, commonly called "white rusts," comprise a single genus, Albugo, having approximately 25 species. All are obligate parasites of flowering plants, and none has been cultivated on artificial media. They are an aberrant group, distinguishable mainly on the basis of their host relations. For example, $A$. candida is limited to various species of crucifers, A. bliti to species of Amaranthus, $A$. ipomoeae-panduranae to morning-glory, sweet potato, and other Convolvulaceae, $A$. tragopogonis to salsify and other Composites, and A. portulacae to Portulaca oleracea. Usually none occurs in epidemic proportions on crop plants, except perhaps $A$. occidentalis, recently reported [Wiant, Ivanoff, and Stevenson (1939)] on spinach. Whether this pathogen occasions real harm is questionable.

Certain of these species comprise rather widely different morphological groups of entities that have been regarded as biological species. By means of biometrical studies Togashi, Sibasaki, and Sugano (1930) were able to show that the sporangia of $A$. candida on Brassica and Raphanus have measurements approximately $25 \%$ greater than those on Arabis, Capsella, and Draba. Their 

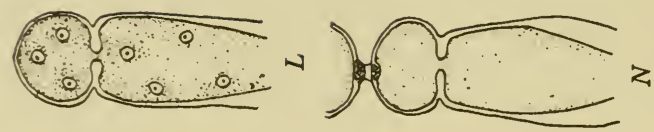

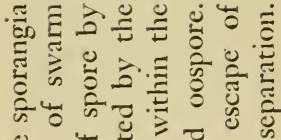
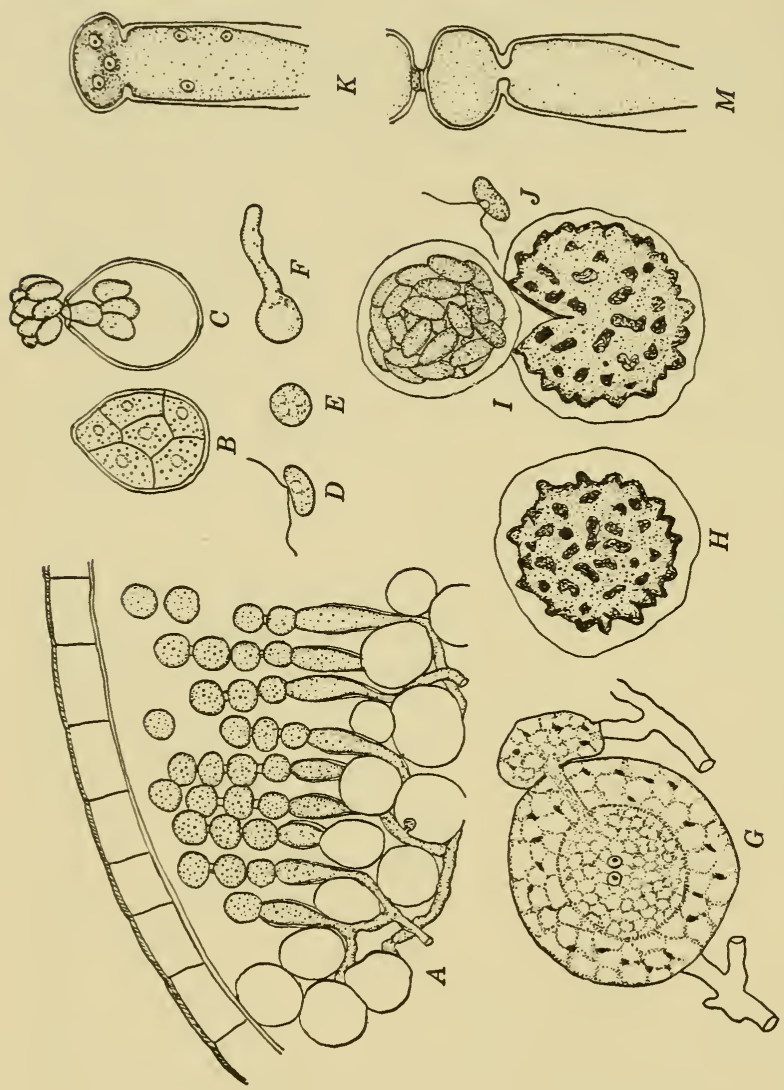

Е

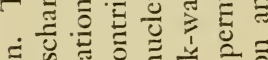

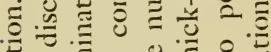

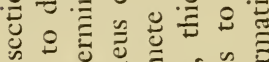

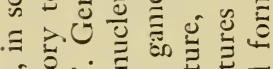

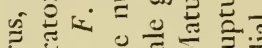

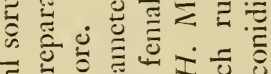

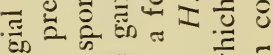

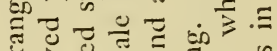

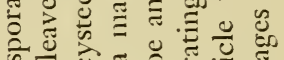
के

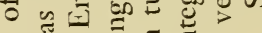

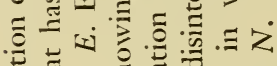
हूँ

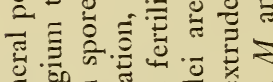

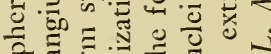

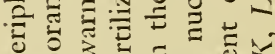
อั ष乎心 ए

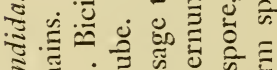

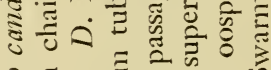

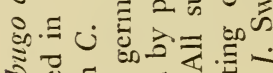
吾

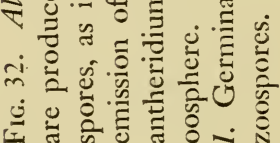


examination of sporangia from 42 cruciferous genera led them to divide $A$. candida into two groups, macrospora and microspora.

A monograph by IVilson (1907, 1908, 1908a) deals with the classification of species known to occur in North America.

Albugo is characterized by the possession of sporangiophores arranged in a palisade-like layer, thus forming pustules beneath the epidermis of the host. The sporangiophores are broadly clavate, and the sporangia are abstricted in basipetal succession and adhere in chains. The sporangia have the appearance of being separated by intercalary cells, but instead the outer sporangial wall partly gelatinizes at the point of contact of adjacent sporangia, forming disks which, when gelatinization is complete, permit the sporangia to fall apart. Pressure exerted on the superimposed epidermis by the accumulation of sporangia finally causes the leaf tissues to rupture and permits the powdery mass of sporangia to be disseminated by the wind.

Germination of the sporangium results in the formation of 12 to 20 zoospores. The zoospores are reniform and biflagellate. After a brief period of swarming, they encyst, and further development consists in the formation of a germ tube which is capable of penetrating a suitable host by way of the stoma.

Melhus (1911) found that direct germination may also occur, governed by temperature. Palm (1932) observed that sporangia of $A$. portulacae, $A$. bliti, and $A$. spimulosa, on germination, may commonly form germ tubes.

Antheridia and oogonia of white rusts begin to appear when the production of sporangia is ceasing. They arise within the host tissues. De Bary first described the sexual organs of Albugo, and Wager (1896) gave a correct account of the details of fertilization. The oogonia are globular, multinucleate cells, and one or more small globular antheridia arise near the oogonium. Gradually the oogonial content becomes differentiated into the egg cell, or ooplasm, and a peripheral layer, the periplasm. The details which accompany these changes are carefully delineated in a series of papers by Stevens $(1899,1901)$. He found that there are essentially three types of fertilization. In the first, represented in $A$. bliti and $A$. portulacae, which he records as the most primitive, there are many functional nuclei, a large receptive papilla and a small coenocentrum. In $A$. tragopogonis, representing the second type, all but one male and one female 
nucleus disintegrate after migration into the periplasm, and this species possesses a small papilla and a large coenocentrum. In $A$. candida, typifying the third type, a pair of functional nuclei fuse after disintegration of all supernumerary nuclei, and the size of both papilla and coenocentrum is intermediate between those of the other two types.

According to Wager (1896), the fusion nucleus soon divides in $A$. candida, and after five simultaneous divisions of the nuclei the oospore becomes dormant. Evidence indicates that the first divisions are reductional. Meanwhile a thickened, variously sculptured, three-layered wall is formed. The oospores of each species appear to have a distinctive pattern of sculpturing, ten of which are illustrated in Wilson's (1907) monograph. After overwintering, more divisions occur, the wall cracks open, the inner wall slips out as a vesicle containing abcut 100 zoospores, the vesicle bursts, and the zoospores swim away.

\section{LITERATURE CITED}

Meluus, I. E., "Experiments on spore germination and infection in certain species of Oomycetes," Wis. Agr. Expt. Sta. Research Bull., 15:25-91, 1911.

PaLM, B. T., "Biological notes on Albugo," Amn. Mycol., 30: 421-426, 1932. Stevens, F. L., "The compound oosphere of Albugo bliti," Botan. Gaz., 28: 149-176, 225-245, 1899.

"Gametogenesis and fertilization in Albugo," Botan. Gaz., 32: 77-98, 157169, 238-261, 1901.

Togashi, K., Y. Sibasaki, and Y. Sugano, "Morphological studies of whiterust fungi in the cruciferous plants," Agr. Hort., 5: 859-882, 1930.

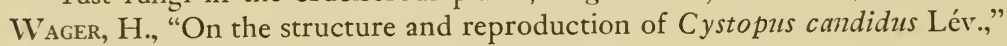
Ann. Botany, 10:295-342, 1896.

Wiant, J. S., S. S. Ivaxoff, AND J. A. Stevexsox, "White rust of spinach," Phytopatbology, 29: 616-623, 1939.

Wilsos, G. WV., "Studies in North American Peronosporales. I. The genus Albugo," Bull. Torrey Botan. Club, 34: 61-84, 1907.

III. "New or noteworthy species," Bull. Torrey Botan. Club, 35:361-365, 1908.

IV. "Host index," Bull. Torrey Botan. Club, 35:543-554, 1908a.

\section{PERONOSPORALES}

Approximately 300 species of fungi, commonly called downy mildews, are included in the Peronosporales. All are obligate 
parasites, and none has been grown on artificial media. Their sporangiophores project from the host, forming en masse a downy, whitish, gray, or violet coating, whence the name, downy mildews. Many of them occur on crop plants and are very destructive. The best known among them are Plasmopara viticola on grapes [Arens (1929, 1929a)], Peronospora destruction on onion [Cook (1932)], Peronoplasmopara cubensis on cucurbits [Clinton (1905)], Peronospora tabacina on tobacco, Bremia lactucae on lettuce, Peronoplasmopara bumuli on hop, and Sclerospora graminicola on cereals [Weston (1924), Weston and Weber (1928), Melhus, van Haltern, and Bliss (1928)].

Mrcelius. The mycelium courses through the intercellular spaces, and haustoria penetrate the host cells. In many species the haustoria are vesicular, but in others they are branched and filamentous. Some few species, among which are Peronospora schachtii on Beta vulgaris, P. alsinearum on Stellaria media, P. effusa on Spinacea oleracea, P. viciae on Vicia sepium, and Plasmopara viticola on Vitis vinifera, are known to perennate as mycelium [Melhus (1915)].

Asexual reproduction. The sporangiophores of downy mildews are distinctive and constitute the most important basis for identification of genera. Those of Basidiophora are clubshaped, and the sporangia are borne in a cluster at the enlarged tip; those of Bremia are branched with saucer-shaped terminal enlargements. Usually 4 to 6 branchlets (sterigmata), bearing sporangia, project from the rim of the saucer. The sporangiophores of Plasmopara are irregularly branched, as are also the blunt-tipped branchlets. The branches of Peronospora terminate dichotomously, and the branchlets are of equal length. Each sporangiophore of Sclerospora simulates a thick-handled, compact brush.

Species, on the other hand, are distinguished largely on the basis of host relationships. Sporangiophores emerge from the stomata singly or in small groups and appear usually on the lower leaf surface. The sporangia are borne singly at the tips of branchlets. Sporangial formation usually occurs at night and, at least in Sclerospora graminicola and Peronospora tabacina, is conditioned by temperature and relative humidity [Weston (1924), Wolf et al. (1934) ]. In S. graminicola the formation of sporangia begins near midnight, if there is a film of moisture on the corn 


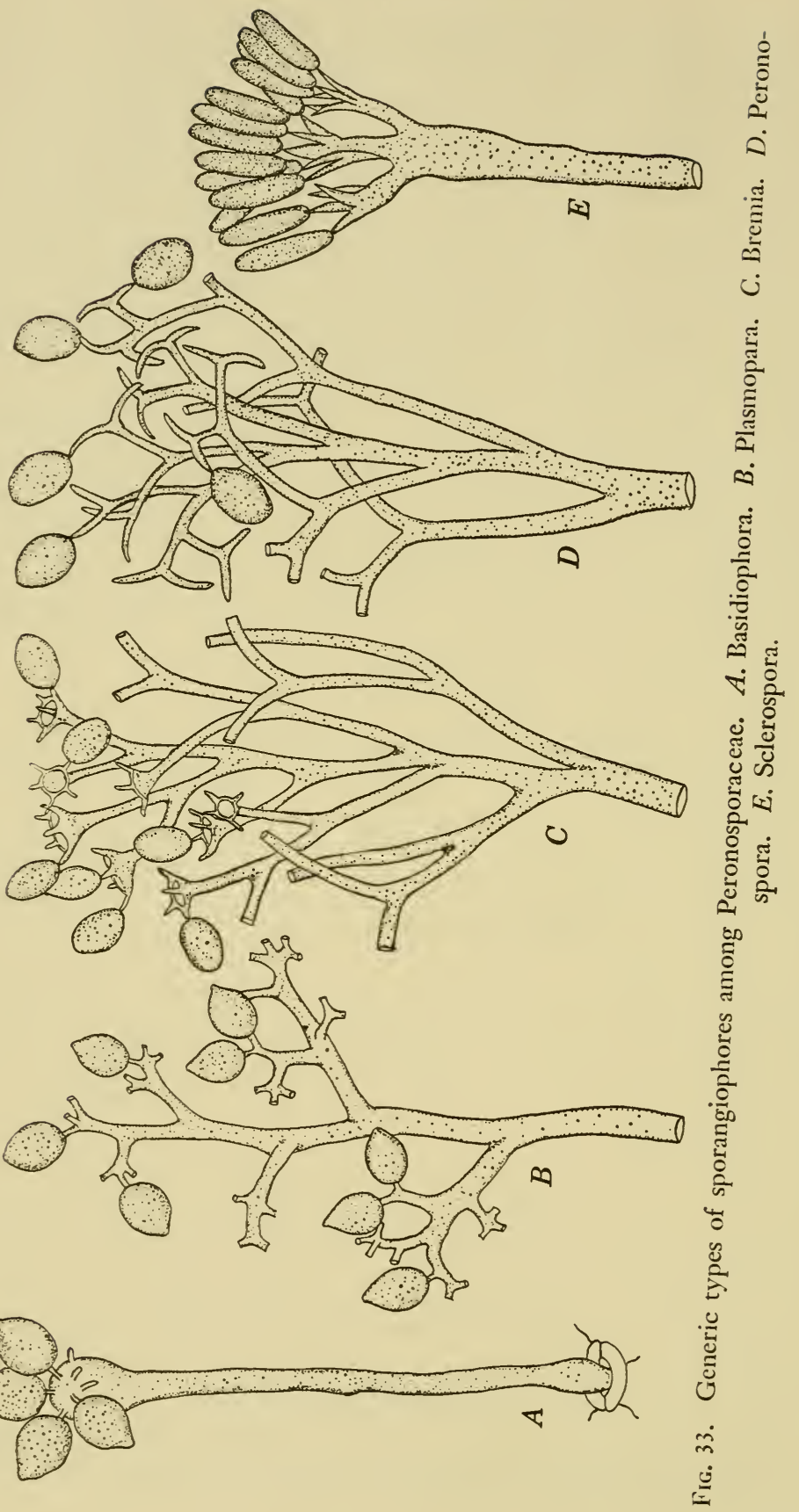


leaves. Within $1 \frac{1}{2}$ hours the sporangia will mature, and they are then dispersed. Several crops of sporangia are produced during the night as the spent sporangiophores collapse and new ones emerge in their places. This process will be repeated night after night, except on dry nights.

In $P$. tabacina, however, a single crop of sporangiophores and sporangia is developed during the period between daybreak and sunrise. The dependence of this organism upon temperature and high relative humidity is indicated by the fact that epidemics are suddenly checked with the advent of hot weather and that it has been possible to induce fructification, under controlled conditions, at any time throughout the year. Indeed, in North Carolina sporangia were caused to be formed on 21 nights during the month of August.

Germination of the sporangia and infection are usually accomplished during the early morning. In all downy mildews, except species of Peronospora, zoospores are normally produced. In Peronospora, however, representing the most advanced terrestrial habit, germ tubes are formed. In Peronoplasmopara, germination of both types occurs, temperature being an important factor in conditioning the type. Usually the zoospores are emitted singly through a papillar opening, swim around for a brief period, encyst, and then germinate by production of germ tubes.

Sexual reproduction. The oogonia and antheridia form within the tissues, arising on closely adjoining hyphal tips. Details of their formation and of fertilization are contained in the accounts of Wager (1900), Krüger (1910), Arens (1929, 1929a), and McDonough (1937). Each organ is multinucleate after segmentation from the supporting mycelium. Gradually the cytoplasm of the oogonium becomes differentiated into a central uninucleate egg and a peripheral periplasm containing the supernumerary nuclei. All disintegrate except the egg nucleus. Meanwhile, within the adjacent antheridium the nucleus of the male gamete becomes differentiated, and the other nuclei, about a dozen, disintegrate. A fertilization tube that pierces the oogonial wall and periplasm is then produced. The male-gamete nucleus passes through the fertilization tube into the ooplasm. Nuclear fusion follows, whereupon a thick, resistant wall is formed around the zygote. 
Opinions differ regarding the time of occurrence of reductional division. Wager (1900) maintains that it takes place just before fertilization, and Krüger (1910) and Arens (1929, 1929a) at the time of the first division of the zygote nucleus. It is probable that Krüger and Arens are correct, but this point requires elucidation.

In most downy mildews the oospores constitute the hibernating stage. They usually form within necrotic tissues near the end of the pathogenic cycle and are liberated by decay of the host tissues. In Plasmopara viticola [Arens (1929, 1929a)], however, they form all summer long. In Peronoplasmopara cubensis they form most abundantly in the youngest host tissues. In Sclerospora graminicola they continue to fall to the ground as the leaf parenchyma disintegrates [Weston and Weber (1928)]. In Peronospora tabacina they form only in tissues that have been dead a week or more. Essentially nothing is known about the influence of environmental factors on oospore formation among any of the downy mildews.

The essentiality of oospores in the hibernation of $P$. tabacina was established by Dixon et al. (1935). By epidemiological methods they determined that this pathogen overwinters as oospores in North Carolina. Primary infections in all areas appeared in seed beds sown on the sites of old beds. These infections antedated by 7 to 19 days those in near-by seed beds located on new sites. Furthermore sporulation occurred in beds located on old sites before the time when sporangia could be entrapped from the air in the same locality.

Oospore germination has been observed in a few species. Gregory (1912) and Arens (1929, 1929a) noted that a short germ tube arises from the oospore of Plasmopara viticola and that a sporangium forms at the end of this tube. Swarm spores emitted from this germ sporangium are capable of inducing primary infection. In Sclerospora graminicola Hiura (1935) observed germtube formation, which may be assumed to cause infection after penetration of the grass host. In respect to the factors which favor oospore germination, temperatures of 20 to $25^{\circ} \mathrm{C}$ have been found to be optimum for both $P$. viticola and $S$. graminicola. Manifestly because of the paucity of observational data the germination of oospores of downy mildews is worthy of extensive investigation. 


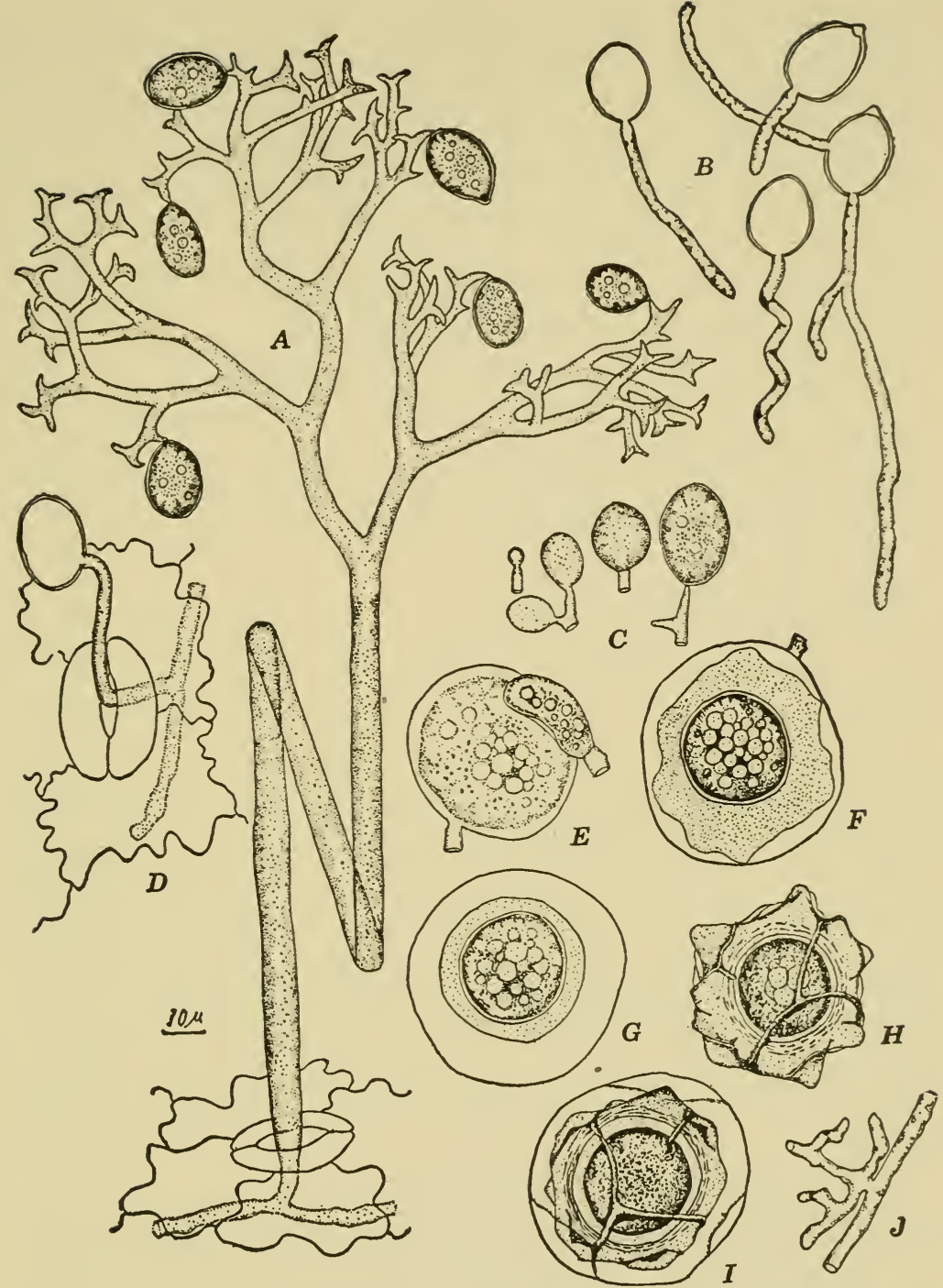

Fig. 34. Structural features of Peronospora tabacina. A. Dendritic sporangiophore at whose dichotomous apices a few sporangia remain. $B$. Germinating sporangia; the germ tubes are spiral when germination occurs in thin films of water. C. Stages in formation of sporangia. D. Entrance of germ tube into stomate. (Penetration may also be direct.) $E, F, G, H$, and $I$. Stages in formation and maturation of oospores, as dissected from the interior of leaves. $J$. Branched haustorium, by means of which the intercellular hyphae absorb nutriment. 
Classification. No recent comprehensive monographic treatments of downy mildews exist. That of Berlese (1903) now has a limited usefulness. Wilson's $(1907,1914)$ accounts deal only with approximately 40 North American species. Gäumann's (1923) monograph of Peronospora treats of 140 species occurring in Switzerland. He divided the genus into two subgenera, Leiotheca and Calotheca, on the basis of whether the oospores have smooth or verrucose walls, respectively. Each subgenus contains 2 groups. In Leiotheca the parasiticae include 36 thickwalled species, and the effusae, 72 thin-walled species. In Calotheca the verrucosae include 5 species with hemispherical warts, and the reticulatae, 28 species with a network of anastomosing ridges. Species are separated largely on the basis of biometrical measurements of sporangia and of the results of cross-inoculation trials.

In identifying downy mildews the mycologist depends almost wholly upon the use of a host index. Such a procedure has little to commend it and indicates the urgent need of a usable monograph.

General considerations. It may be of more than passing interest to point out that all the dozen or more known species of Sclerospora, with one doubtful exception, appear to be confined to grasses. Sclerospora graminicola attacks not only corn and sugar cane but also a large number of other grasses. Several other species are known to attack corn in the tropics. Sclerospora macrospora also attacks a wide variety of grass species, including rice, oats, and wheat. Some species are known only in the conidial stages and appear to lack the ability to form oospores.

Bremia lactucae, common on lettuce, seems to be a monotypic species.

Downy mildews are of rare occurrence on trees and shrubs. Peronoplasmopara celtidis on hackberry (Celtis spp.) and $P$. meliae on chinaberry (Melia azadarrach) are notable exceptions.

The discovery in 1882 of the fungicidal value of Bordeaux mixture by Millardet (1933), marking the beginning of spraying, is a landmark in the history of plant pathology. This discovery may be attributed to two circumstances: (1) the outbreaks of downy mildew in the vineyards of France, and (2) the propensity of boys, on certain occasions, to pilfer fruit.

It is an interesting coincidence that the use of volatile fungi- 
cides to control diseases of plants had its beginning in attempts to control another downy-mildew disease, namely, that induced by Peronospora tabacina. The fundamental principles involved in the use of two volatile materials, benzol and paradichlorobenzene, and related compounds are presented in reports by Wolf et al. (1940), Pinckard et al. (1940), and McLean et al. (19+0).

\section{LITERATURE CITED}

Aress, K., "Untersuchungen über Keimung und Zytologie der Oosporen von Plasmopara viticola (Berl. et de Toni)," Jalbrb. wiss. Botan., 70: 57-92, 1929.

"Physiologische Untersuchungen an Plasmopara riticola, unter besonderer Berucksichtigung der Infektionsbedingungen," Jabrb. wiss. Botan., 70: 93-157, 1929a.

Berlese, A. N., Saggio di una monografia delle Peronosporaceae. 311 pp. 1903.

Cliston, G. P., "Downy mildew or blight of muskmelons and cucumbers," C'onn. Agr. Expt. Sta. Ann. Rept., 1904: 329-362, 1905.

Соoк, H. T., "Studies on the downy mildew of onions and the causal organism, Peronospora destructior (Berk.) Caspary," Cornell Agr. Expt. Sta. Mem., 143. 40 pp. 1932.

Dixon, L. F., Ruth Mclean, and F. A. Wolf, "The initiation of downy mildew in North Carolina in 1934," Plytopathology, 25:628-639, 1935.

Gäumans, E., "Beiträge zu einer Monographie der Gattung Peronospora Corda," Beitr. Kryptogamenfl. der Scbweiz, 5: 1-360, 1923.

Gregory, C. T., "Spore germination and infection with Plasmopara viticola," Phytopatbology, 2: 235-249, 1912.

Hivra, M., "Mycological and pathological studies on the downy mildew of Italian millet," Gifu lmp. Coll. Agr., Research Bull., 35: 121-283, 1935.

KrüGER, F., "Beitrag zur Kenntnis der Kernverhältnisse von Albııo candida und Peronospora ficariae," Zentr. Bakt. Parasitenk., 11 Abt., 27: 186-205, 1910.

McDonough, E. S., "The nuclear history of Sclerospora graminicola," Mycol., 29: 151-173, 1937.

Mclean, Ruth, J. A. Pinckard, F. R. Darkis, F. A. Wolf, and P. II. Gross, "The use of paradichlorobenzene in seedbeds to control tobacco downy mildew," Plbytopathology, 30:495-506, 1940.

Melhus, I. E., "Perennial mycelium in species of Peronosporaceae related to Phytophthora infestans," J. Agr. Research, 5: 59-69, 1915.

Melhus, I. E., F. H. van Haltern, and D. E. Bliss, "A study of Sclerospora graminicola (Sacc.) Schroet. on Setaria viridis (L.) Beauv. and Zea mays (L.)," lowa Agr. Expt. Sta. Res. Bull., 111:297-338, 1928.

Millardet, P. A., "The discovery of Bordeaux mixture." 25 pp. Phytopath. Classics, 3, 1933. (Translated by F. J. Schneiderhan.) 
Pinckard, J. A., Ruth Mclean, F. R. Darkis, P. M. Gross, and F. A. Wolf, "Toxicity of paradichlorobenzene in relation to control of tobacco downy mildew," Phytopathology, 30:485-495, 1940.

Wager, H., "On the fertilization of Peronospora parasitica," Ann. Botany, 14: $263-279,1900$.

Weston, W. H., "Nocturnal production of conidia by Sclerospora graminicola," J. Agr. Research, 27:771-784, 1924.

Weston, IV. H., and G. F. Weber, "Downy mildew (Sclerospora graminicola) on everglade millet in Florida," J. Agr. Research, 36: 935-963, 1928.

Wilson, G. IV., "Studies in North American Peronosporales. II. Phytophthoreae and Rhysotheceae," Bull. Torrey Botan. Club, 34: 387-416, 1907.

VI. "Notes on miscellaneous species," Mycol., 6: 192-210, 1914.

Wolf, F. A., L. F. Dixon, Ruth Miclean, and F. R. Darkis, "Downy mildew of tobacco," Phytopathology, 24:337-363, 1934.

Wolf, F. A., Ruth A. Mclean, J. A. Pinckard, F. R. Darkis, and P. M. Gross, "Volatile fungicides, benzol, and related compounds, and the principles involved in their use," Phytopathology, 30:213-227, 1940.

\section{MUCORALES}

The Mucorales, commonly called "black molds," comprise about 30 genera and 450 species. They are mostly saprophytic on plant or animal tissues. Although a few species are pathogenic, others are of considerable importance in the decay of fruits and vegetables, and several are utilized in industrial processes. Absidia corymbifera is associated with human bronchomycosis, A. cornealis with lesions of the cornea, and Mortierella niveo-velutina with inflamed, intensely prurient, papular skin lesions; Rbizopus migricans produces a destructive decay of sweet potatoes that have not been properly cured before being placed in storage. These mentioned species and a number of other Mucorales are pathogenic to laboratory animals. Choanepbora cucurbitarum is widely parasitic on squash flowers and fruits and also on cowpea. Rhizopus oryzae and Mucor javanicus saccharify starch and can be used in alcoholic fermentation. Several species of Rhizopus are employed in lactic fermentation. Mortierella bainieri, Piptocephalis freseniana, Dispira cormuta, and Parasitella (Mucor) simplex are parasitic on other Mucorales. Their parasitism is generally regarded as restricted to other Mucorales, but Dobbs (1942) reported that a species of Piptocephalis, near P. tiegbemiana, is parasitic on Penicillium notatum, $P$. roqueforti, $P$. glabrum, P. pfefferianum, and Aspergillus niger, as well as Mucor mucedo and $M$. biemalis. Species of Pilobolus are coprophilous, 
MUCORALES

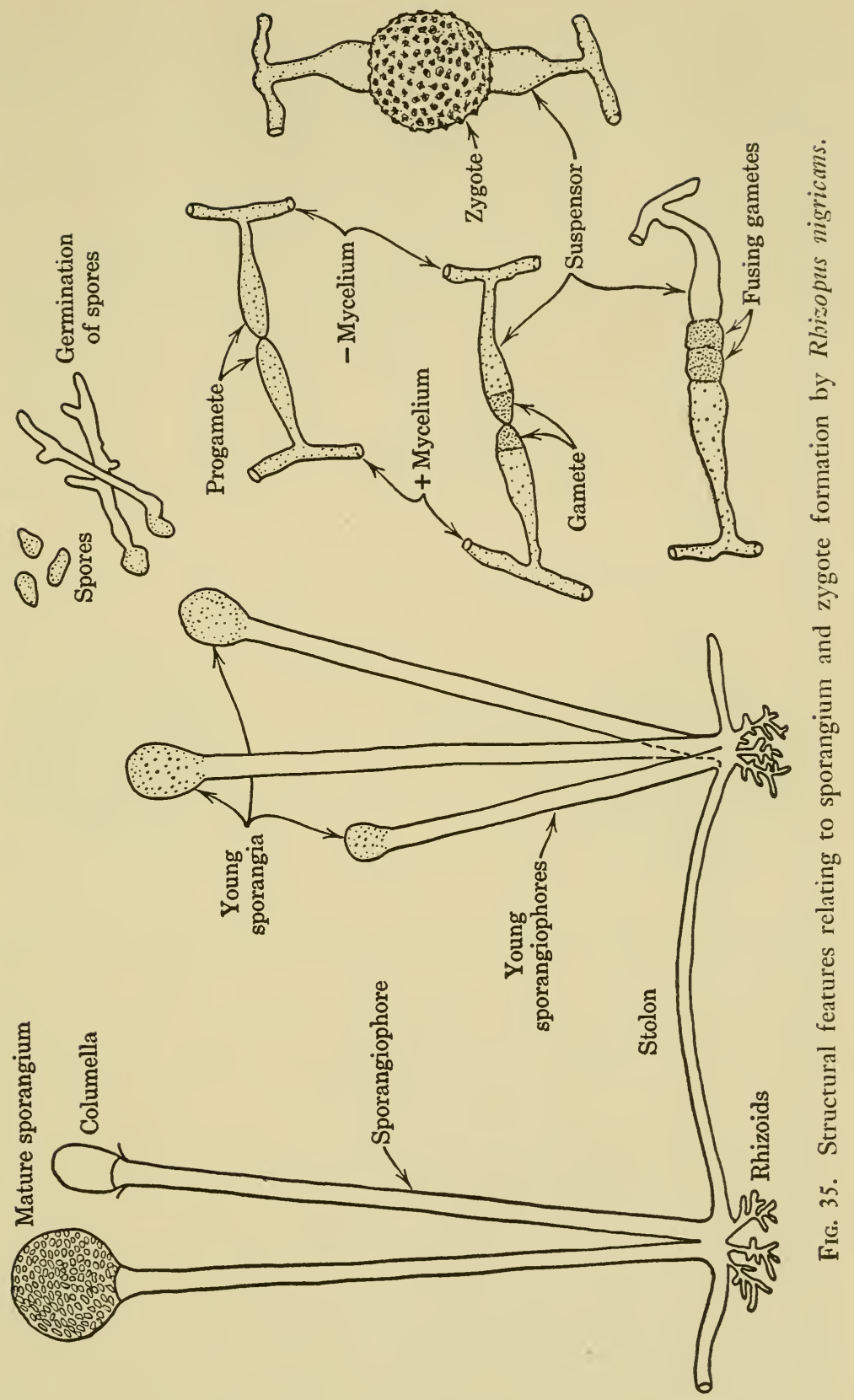


some being restricted to the dung of herbivores, others to that of carnivores. Many species of Mucor have been isolated from soils, but little is known of their function therein. Sporodinia grandis occurs on fleshy species of gill fungi and pore fungi.

Mrcelium. In general the Mucorales possess an extensive, much-branched coenocytic mycelium. They grow readily on ordinary culture media, upon which asexual fructifications are commonly produced. In liquid media they may fail to fructify, and the hyphae may segment and bud in yeast-like fashion. Senescent hyphae or those grown in the presence of high concentrations of sugars may also become segmented. The hyphae of Haplosporangium early become partitioned into multinucleate segments. Special runner-like hyphae, called stolons and attached to the substrate by specialized rhizoids, are produced by Rhizopus and Absidia.

Asexual reproduction. The sporangia of Mucorales are formed on erect sporangiophores that are usually unbranched. In Thammidium elegans the sporangiophore is verticillately branched; in Blakeslea trispora, Choanephora manshurica, and Sporodinia grandis; dichotomously branched; and in Circinella umbellata, circinately corymbose. The formation of sporangia and sporangiospores has been detailed by Harper (1899), Swingle (1903), and Schwarze (1922). The sporangium is initiated by a swelling of the sporangiophore tip or the swelling of the tips of its branches. A septum eventually delimits the sporangium. This septum remains plane in the Mortierellaceae but forms a globular, cylindric, or pyriform dome called a columella in the Mucoraceae.

Spore formation in this order is of three types. One type is illustrated by species of Pilobus. Harper (1899) found in $P$. crystallinus and $P$. oedipus that the sporangial content is usually cleaved into uninucleate portions along the lines of the vacuoles, using up all the protoplasm. These portions round up and after several nuclear divisions become invested with spore membranes. A second type, in which cleavage directly results in the formation of multinucleate masses, is found in Rhizopus nigricans and Pbycomyces nitens [Swingle (1903)], in Sporodina grandis [Harper (1899)], in Circinella conica [Moreau (1913)], and in C. minor [Schwarze (1922)]. These multinucleate portions, without undergoing nuclear division, round up, form a membrane, and 
are the spores. In the third type, illustrated by Cumninghamella echimulata and C. bertbolletiae [Moreau (1913)], the tip of the sporangiophore enlarges into a capitate structure. Short protuberances (sterigmata) then appear over the surface of this

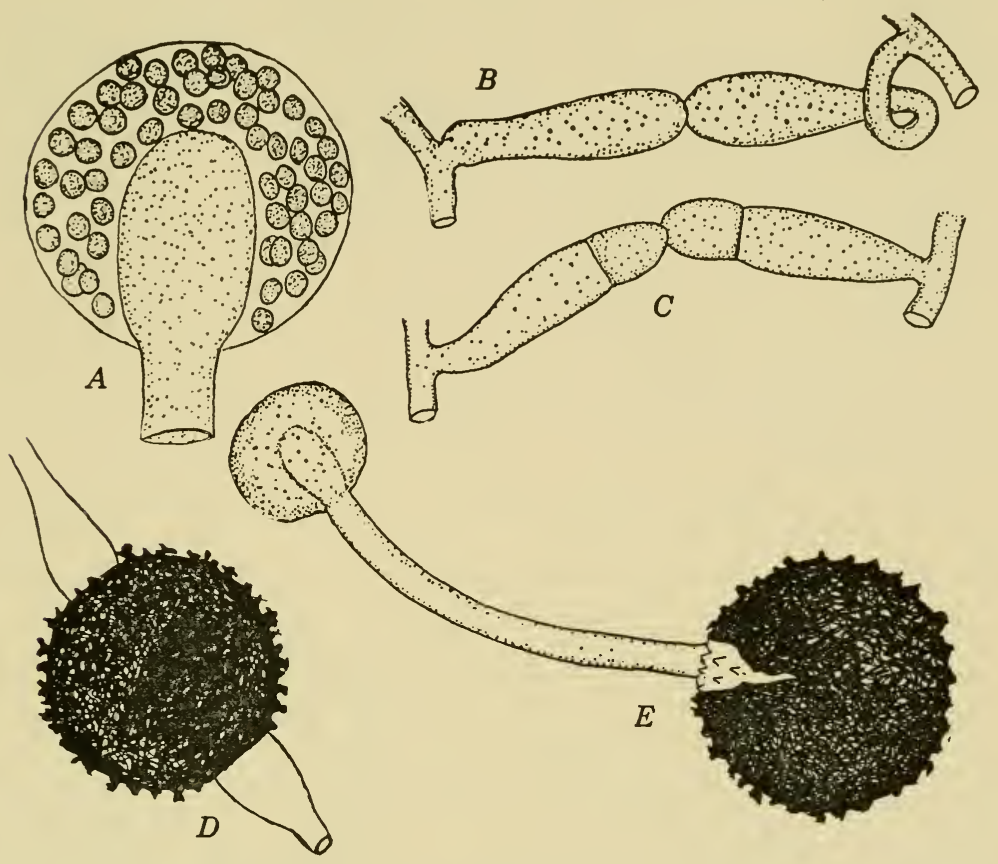

Fig. 36. Mucor mucedo. A. Sporangium in section with oblong columella. $B, C$, and $D$. Stages in formation of zygote. In $B$, the progametes have come into contact; in $C$, the gametes have been delimited and are supported by suspensors; in $D$, the rough, thick-walled zygote has developed. $E$. On germination of zygote a tube is formed that is surmounted by a germ sporangium.

structure, and small globular enlargements develop at the tips of the protuberances. Each enlargement receives a complement of protoplasm and 3 to 8 nuclei and is eventually abjointed to become the spore.

Various modifications of these three types of spore formation are exhibited by certain other of the Mucorales. In Syncephalis and Syncephalastrum long tubes (sporangia) develop at the tips of sterigmata that project in all directions from a globular head- 
like structure. Each sporangium is multinucleate and comes to contain uni- or multinucleate spores arranged in a lineal series in the long axis of the sporangium. In Blakeslea trispora similar development takes place, except that the sterigmate sporangia are elongate spherical, and the content normally cleaves into three spores. In rare cases a single spore is formed in each sporangium. In Chactocladium jonesii and $C$. brefeldii the sporangia are reduced to the extent of containing a single spore. In the several species of Mortierella and Haplosporangium the reduced sporangia (sporangioles) contain 2 to 4 spores, $H$. bisporale containing 2, typically. In Mycotypha microspora [Fenner (1932)] the tip of the sporangiophore swells into a head, having the appearance of the fructification of a diminutive cattail, sterigmata are formed in a spiral arrangement over its surface, and onespored sporangia are abstricted singly from the tips of each of the sterigmata.

The occurrence of many-spored, few-spored, and one-spored sporangia among Mucorales is interpreted by some workers as indicating progressive transformation of a sporangium into a conidium. This interpretation requires that the spore wall in one-spored sporangia either be not formed at all or else be completely fused with the sporangial wall. If the spore develops its own wall and the sporangium wall is separate, even though the two are closely applied, a one-spored sporangium may not properly be regarded as a conidium. Moreover on germination, whether both membranes are extended to become the wall of the germ-tube or the spore membrane alone becomes the wall should be the critical feature. Apparently most mycologists seem inclined to interpret one-celled sporangia as being sporangia and not conidia.

Sexual reproduction. Sexual reproduction in the Mucorales is effected by the conjugation of two morphologically similar gametes. In this process a pair of lateral branches arises from adjoining hyphae. These branches come into contact, swell, and constitute the progametangia. Each progametangium delimits a terminal cell, the gametangium. Then by fusion of the contents of both gametangia the zygote is formed. A thickened, severallayered wall is provided for the zygote by modification of the membranes of the gametangia. 
The basis of present-day knowledge of sexuality in the Mucorales was provided by the classical studies of Blakeslee (1904). He determined that hyphal branches from the mycelium arising from a single sporangiospore of some species interact to form
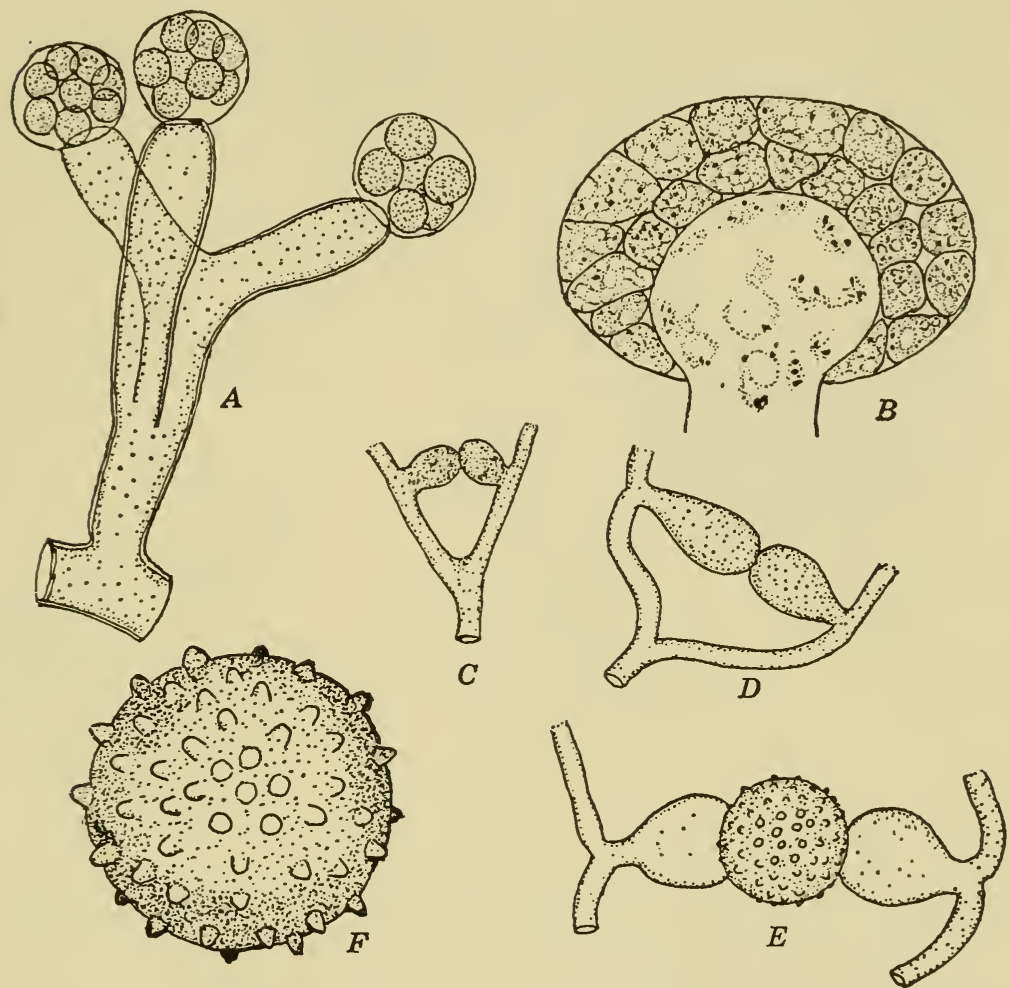

FIG. 37. Sporodinia grandis. A. Sporangiophore bearing sporangia. (Adapted from de Bary.) B. Vertical section of sporangium; spores have been delimited by cleavage. (After Harper.) $C, D$, and $E$. Stages in zygote formation. (Adapted from Bainier.) F. Mature zygote.

zygospores. He termed such species homothallic. In other species zygospores do not mature unless the interacting hyphae arise from two sporangiospores of different potentialities. $\mathrm{He}$ termed these species heterothallic. One of these thalli is functionally female $(+)$, and the other is functionally male $(-)$. Studies have shown that Sporodinia grandis, Absidia spinosa, Dicranophora fulva, Rbi sopus sexualis, Zygorhynchus spp., and some species of Mucor belong to the homothallic group, whereas 
Absidia caerulea, Blakeslea trispora, Choanephora cucurbitarum, Mucor mucedo, Pbycomyces nitens, and Rbizopus nigricans are heterothallic. Under certain environmental conditions unmated gametangia become thick-walled and may be designated azygospores, or chlamydospores.

Cytological features associated with fertilization have been studied in several species of Mucorales. Each gamete is multi-
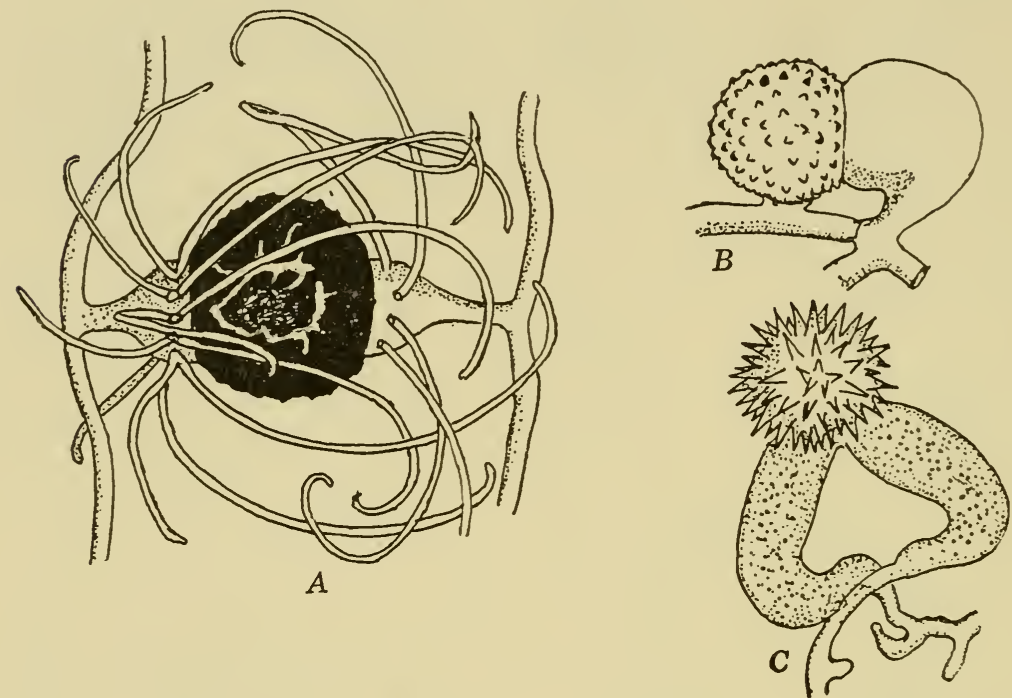

Fig. 38. Zygotes of sereral Mucorales. A. Absidia glauca. (Adapted from Lendner.) B. Zygorbyncbus beterogannus. (Adapted from Blakeslee.) C. Piptocephalis freseniana. (Adapted from Brefeld.)

nucleate in Sporodinia grandis, and multiple fusions of paired + and - nuclei occur soon after the protoplasts intermingle. Unmated nuclei degenerate and disappear. In Phycomyces all except 2 pairs of nuclei degenerate. These 4 nuclei fuse after several months [Burgeff (1915)]. Keene (1919) determined, however, that 6 to 8 pairs of nuclei, rather than 2 pairs, fused. Delayed nuclear fusion has been reported in Zy gorbynchus dangeardi and Rbizopus sexualis [Callen (1940)].

Germination of zygospores. After a rest period zygospores may be induced to germinate by the formation of a short germ tube that is terminated by a germ sporangium. Blakeslee (1906) observed with reference to + and - characters that there are 
three distinct types of germination. (a) All the spores from the germ sporangia of Sporodinia grandis are pure homothallic, that is, are all $(+-)$. (b) All the spores from any single germ sporangium of Mucor mucedo are either all $(+)$ or else all $(-)$;

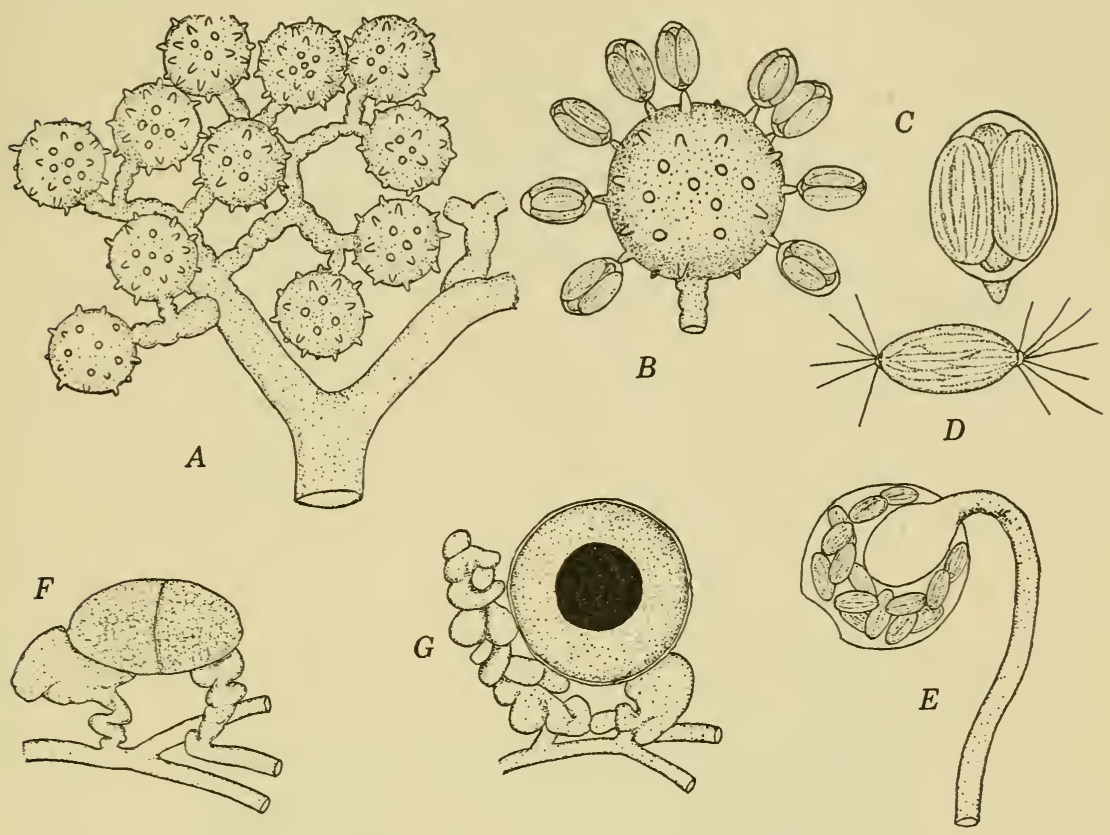

Fig. 39. Blakeslea trispora. A. Portion of sporangiophore from which the sporangia have been remored from the capituli. $B$. Three-spored sporangia borne on sterigma-like processes over the surface of the capitulum. C. Sporangium with sterigma at the base. D. Sporangiospore, provided with tufts of slender hair-like appendages. $F$ and $G$. Stages in zygote formation. E. Sectional view of nodding sporangia that have not been noted to occur except in culture.

that is, each is unisexual. (c) In Phycomyces nitens the spores are $(+),(-)$, and $(+-)$; that is, some are unisexual and others bisexual. Cytological evidence in support of what may logically be assumed to transpire to account for these phenomena has been presented by Cutter (19+2).

The 15 species of Mucorales studied by Cutter represent four patterns of nuclear behavior. In the Mucor type all functional zygospore nuclei fuse in pairs; immediately after, reductional division takes place, and the zygospores then become dormant. In 
the Rhizopus type some of the paired nuclei fuse, the supernumerary nuclei degenerate before dormancy begins, and reductional division is delayed until germination of the zygospores. In the Phycomyces type the paired nuclei remain associated until germination of the zygospore begins, whereupon some of them fuse, but the unfused ones do not degenerate. As the germ sporangium forms, some of the diploid nuclei undergo reduction, but others enter the sporangiospores in the unreduced condition. In the Sporodinia type nuclear fusion does not take place at all.

Various aspects of the numerous later studies on sexuality among Mucorales by Blakeslee and other students of this group are summarized by Blakeslee (1920) and Satina and Blakeslee (1929).

Classification. Among the older taxonomic works that of Lendner (1908) is the most satisfactory. Sporangial characters furnish the most usable bases for readily distinguishing families and genera. To distinguish species, however, is difficult.

\section{KEY TO FAMILIES}

1. Sporangia globular to pyriform, sometimes accompanied or replaced by sporangioles

2. Sporangium having a columella; zygospore not enveloped by interwoven hyphae

3. Sporangia always present, but sporangioles lacking

4. Sporangial wall not cutinized

4. Sporangial wall cutinized

coraceac

3. Sporangioles always present, but sporangia may be lacking 5

5. Sporangioles and sporangia both present on same sporangiophore

Thamnidiaceae

5. Sporangioles and sporangia, when present, on different sporangiophores

6. Sporangia absent; sporangioles on subterminal branches

Chaetocladiaceae

6. Sporangia present or absent; sporangioles on capitate tips

Choanephoraceae

2. Sporangium lacking a columella; zygospores enveloped by interwoven hyphae

Mortierellaceae

1. Sporangia narrowly elongate; spores arranged in a lineal series

Piptocephalidaceae (Cephalidaceae)

REMARKS ON IMPORTANT, BETTER-KNOWN SPECIES. In spite of the wide use of Rbizopus nigricans to demonstrate heterothallism, no one appears to have succeeded in germinating its zygospores. 
This species subsists on a wide variety of media and lends itself well to biochemical experimentations on the nutrition of fungi and to studies on enzymic and respiratory activities.

Sporodinia grandis is commonly and widely found on decaying mushrooms, especially species of Russula and Lactarius.

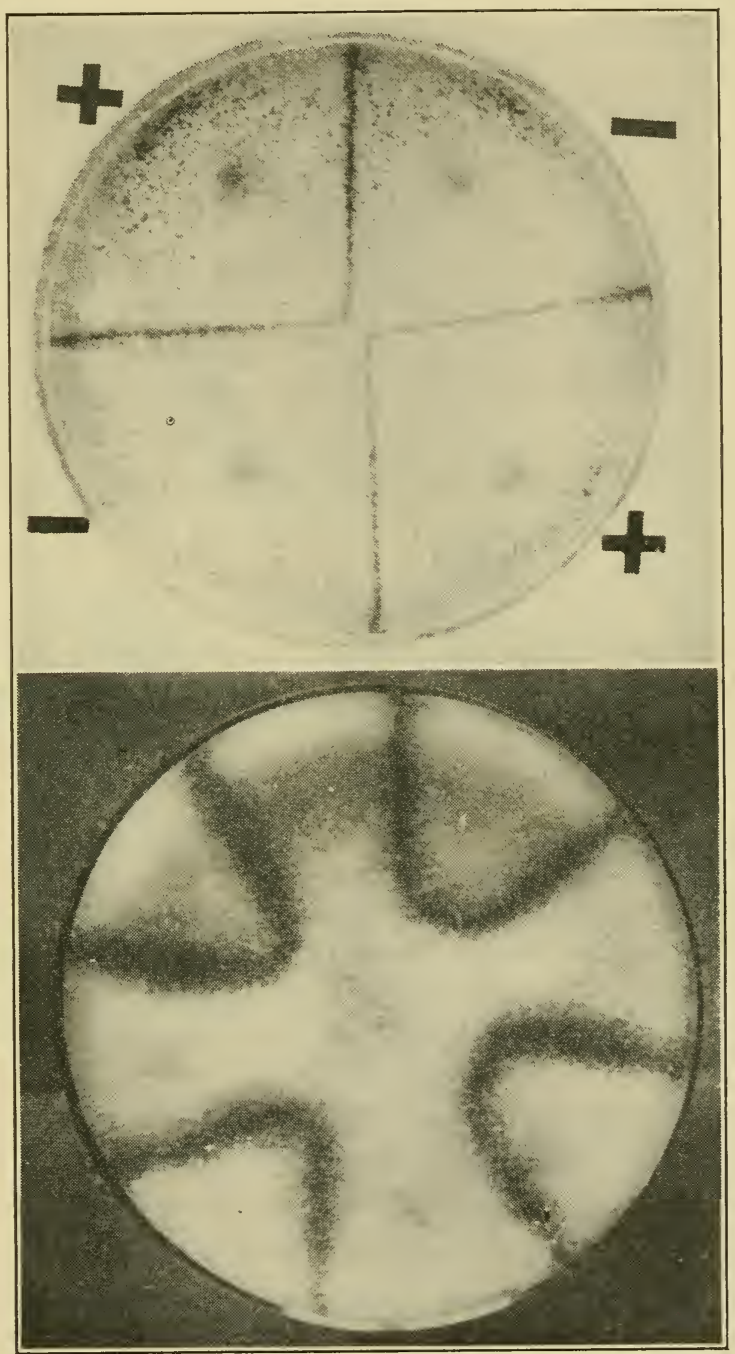

Fig. 40. Matings of + and - strains of Blakeslea trispora. Zygotes form lines at junction of colonies. (From Weber and Wolf.) 
Phycomyces nitens is of interest because of the height of turf formed by the sporangiophores, which rise to a height of 6 to 12 inches or more above the substrate. In nature this turf may form a veritable carpet on the earthen basement floor of cotton-

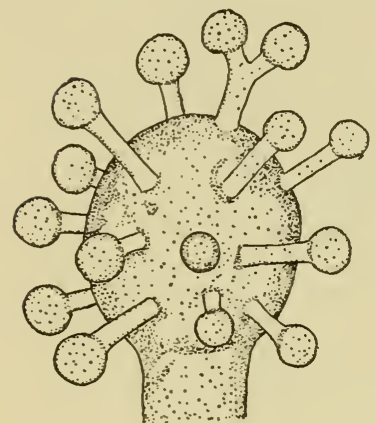

A
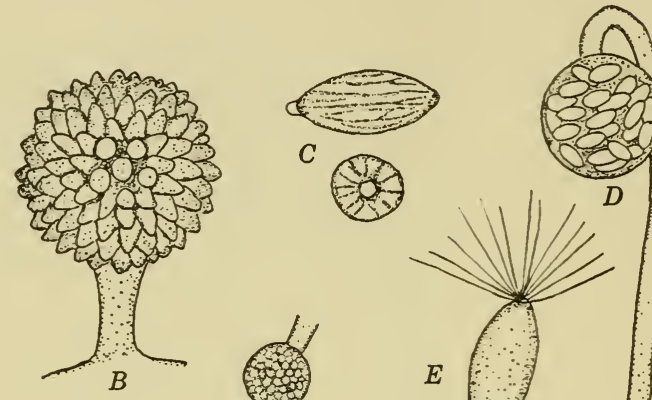

D
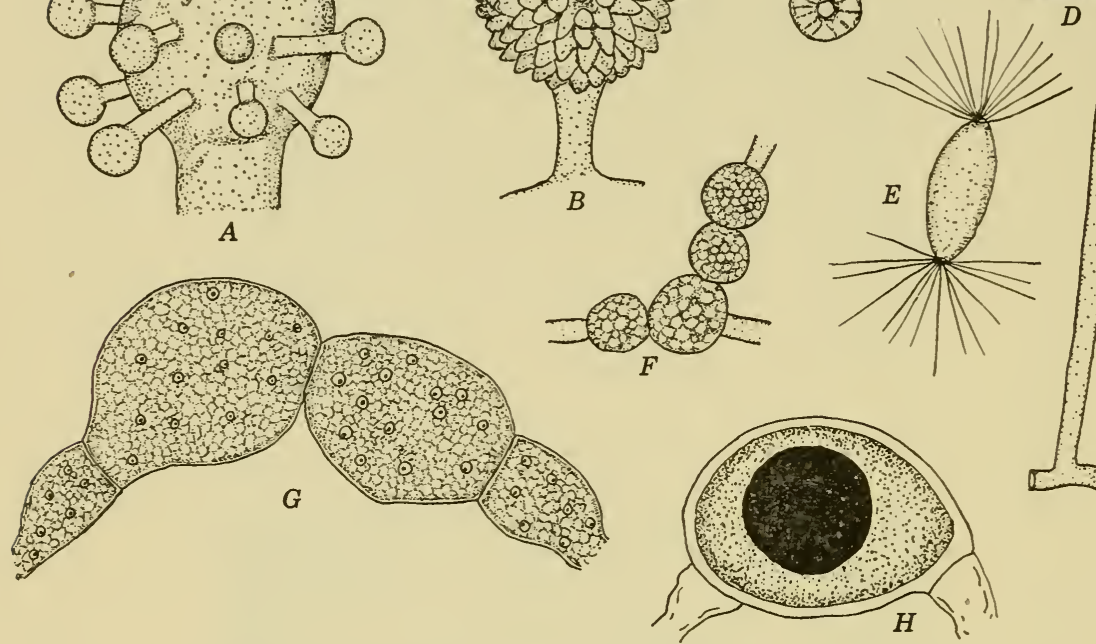

Fig. 41. Choanephora cucurbitarum. A. Apex of sporangiophore with capituli developing on the primary head. $B$. Mature capitulum covered with conidia. C. Side view and end view of conidium. D. Nodding sporangium that contains spores with tufts of hair-like appendages, as in $E$. $F$. Chlamydospores from old cultures. $G$ and $H$. Stages in zygote formation. Each mature zygote contains a large oil droplet.

seed-oil mills or on seed beds fertilized by the use of cottonseed meal. The area immediately beneath the sporangium bends to direct the sporangium toward the source of light. Its phototrophic responses are considered in Chapter 6, Volume II.

Among the species parasitic on other Mucorales, Dispira cormuta is perhaps of most interest. Ayers (1935) found that it has a more extensive host range than any other parasitic species of the Mucorales. In fact, he demonstrated its parasitism on 
members of all families of Mucorales, but it was unable to attack members of any other class of fungi.

The genera Choanephora and Blakeslea are of unusual interest in several respects. In nature both form copious sporangiophores, having the luster of a rifle barrel, on a variety of plant tissues. Actually acres of freshly mowed Sida spinosa in Florida have been observed covered with Blakeslea trispora [Weber and Wolf (1927)]. Both are tropical to subtropical species, although Choanephora cucurbitarum extends farther northward than does B. trispora. Choanephora cucurbitarum is abundant every summer on cotton, cucurbit, and cowpea flowers [Wolf (1917)] throughout the southeastern United States. Blakeslea trispora has been collected only once as far north as Durham, North Carolina.

In nature both genera are known to produce only their sporangial (sporangiole) stage. In culture, however, true nodding sporangia and zygospores are readily developed. The sporangiospores of both are striate and are provided with polar tufts of delicate hairs.

All species of Pilobolus are adapted to a coprophilous habit and react positively to the source of light. The researches on this problem, especially the physical and chemical principles involved in this phototrophic reaction, are summarized in Buller's Researches on Fungi (1934). Brief consideration is given this matter in Chapter 6, Volume II, of the present work.

\section{LITERATURE CITED}

Ayers, T. T., "Parasitism of Dispira cornuta," Mycol., 27: 235-261, 1935.

Blakeslee, A. F., "Sexual reproduction in the Mucorineae," Proc. Am. Acad. Arts Sci., 40:205-319, 1904.

"Zygospore germinations in the Mucorineae," Ann. Mycol., 4: 1-28, 1906.

"Sexuality in mucors," Science, n.s., 51:375-409, 1920.

Buller, A. H. R., Researches on fungi, Vol. 6. 224 pp. Longmans, Green and Co., London. 1934.

Burgeff, H., "Untersuchungen über Variabilität, Sexualität, und Erblichkeit bei Phycomyces nitens Kunze," Flora, 107: 259-316; 108:353-448, 1915.

Callen, E. O., "The morphology, cytology, and sexuality of the homothallic Rbizopus sexualis (Smith) Callen," Amn. Botany, n.s., t: 791-818, 1940. 
Cutter, V. M., "Nuclear behavior in the Mucorales. I. The Mucor pattern," Bull. Torrey Botan. Club, 69: 480-508, 1942.

II. "The Rhizopus, Phycomyces, and Sporodinia patterns," Bull. Torrey Botan. Club, 69: 592-616, 1942a.

Doвbs, C. G., "A mucorine parasite on Penicillia," Nature (London), 150: $319,1942$.

Fenner; E. Aline, "Mycotypha microspora, a new genus of Mucoraceae," Mycol., 24: 187-198, 1932.

Harper, R. A., "Cell division in sporangia and asci," Ann. Botany, 13:467525, 1899.

Keene, Mary L., "Studies of the zygospore formation in Pbycomyces nitens," Trans. Wis. Acad. Sci., 19: 1195-1220, 1919.

Lender, A., "Les Mucorinées de la Suisse," Beitr. Kryptogamenf. Schweiz, 3:1-180, 1908.

Moreau, F., "Recherches sur la reproduction des Mucorinées et de quelques autres Thallophytes," Botaniste, 13:1-136, 1913.

Satina, Sophia, and A. F. Blakeslee, "Criteria of male and female in bread molds (Mucors)," Proc. Nat. Acad. Sci., 15:735-740, 1929.

Schwarze, C. A., "The method of cleavage in the sporangia of certain fungi," Mycol., 14: 143-172, 1922.

Swingle, D. B., "Formation of spores in the sporangia of Rbizopus nigricans and of Ploycomyces nitens," U. S. Dept. Agr., Bur. Plant Ind., Bull. 37: 1-40, 1903.

IVEBER, G. F., AND F. A. Wolf, "Heterothallism in Blakeslea trispora," Mycol., 19: 302-307, 1927.

Wolf, F. A., "A squash disease caused by Choanephora cucurbitarmm," J. Agr. Research, 8:319-328, 1917.

\section{ENTOMOPHTHORALES}

The Entomophthorales, as their name indicates, are insectdevouring fungi. The order is constituted of about 6 genera containing 60 species, mostly parasitic on plant lice, flies, scale insects, and the larvae of butterflies and beetles. They may at times be so destructive to insects as to cause epidemics. Outbreaks of plant lice on clover and on citrus have been suddenly checked by species of Entomophthora. Basidiobolus ranarum occurs on the excreta of lizards and frogs. Several species of Conidiobolus occur on the pilei of Auricularia, Hypochnus, and other Basidiomycetes. Completoria complens is parasitic on fern prothalli. Nearly everyone is acquainted with Entomophthora muscae through having seen dead houseflies sticking to attic windows. Immediately surrounding such flies and covering the pane is a white, mealy patch produced by the pathogen. 
Mycelium. The mrcelium of this assemblage of fungi is much reduced. It arises from a coenocytic spore, which in Entomophthora fumosa, according to Rees (1932), is always four-nucleate. Soon the mycelium becomes plurinucleate, whereupon it segments and falls apart into plurinucleate or even uninucleate elements called hyphal bodies. These, in turn, may increase in number by further segmentation until they replace most of the internal tissues of the host insects.

Asexual reprodection. Shortly after the death of the insect tubular outgrowths, the conidiophores, emerge in tufts, usually at the junctures of the chitinous covering. These processes extend from the hyphal bodies. They gradually become inflated apically, and the entire complement of approximately 20 nuclei moves into the inflated portion. Then a small outgrowth, which becomes globose, forms apically, and into it much of the cytoplasm moves. A septum is next formed to delimit the globose tip, the conidium. The conidia are eventually forcibly projected by opposed swelling of the conidium and the conidiophore. Projection of conidia by Entomophthora sphaerosperma is detailed by Sawyer (1931). According to his account, the swelling results in a sudden circumferential rupture of the attachment of conidium and conidiophore, and the recoil of the basal membrane of the conidium propels it away.

Although the Entomophthorales are among the sporangial fungi, they have true conidia. The outer, so-called "sporangial," membrane is only a gelatinous layer which functions to stick the spore to the surface upon which it lodges. When these conidia germinate, there is, therefore, no sporangial membrane to rupture. Instead the conidial wall stretches and grows to become the hyphae.

Conidia are typically plurinucleate [Olive (1906)], although the hyphal bodies of Basidiobolus and those of Entomophthora sciarae regularly become uninucleate. Goldstein (1929) found the conidia of Massospora cicadina binucleate and the resting spores four-nucleate. On germination the tube may become a secondary conidiophore, bearing a secondary conidium. This production of conidia may be repeated several times until the reserve food has become exhausted.

Thick-walled resting spores, sometimes called chlamydospores, are not uncommon among Entomophthorales. They have many 
times been noted in Entomophtbora muscae and in Massospora cicadina [Speare (1921)]. In M. cicadina the sculpturing of the wall is reminiscent of the design on golf balls.

In $E$. muscae resting spores are formed within the abdominal cavity [Goldstein (1923)] after the death of the fly. They form only after conidial formation is no longer possible, and undoubtedly they function primarily in hibernation.
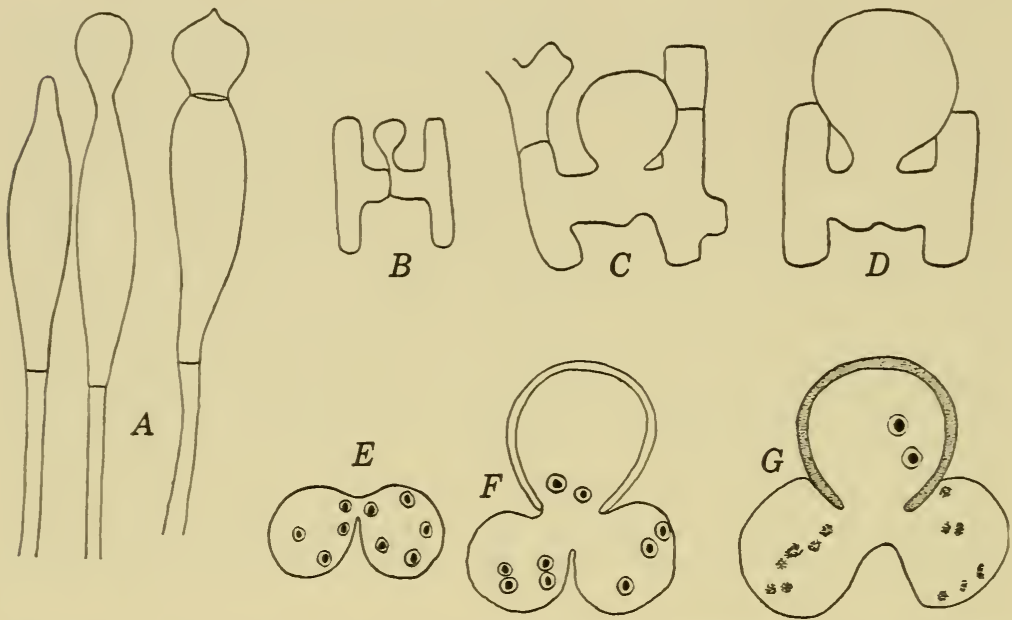

FIG. 42. A. Stages in conidial formation by Entomophthora. $B, C$, and $D$. Stages in zygote formation in Entomophthora. $E, F$, and G. Zygote formation by Empusa fumosa. (After Rees.)

Sexual Reproductiox. Conjugation with the formation of zygospores is known in only a few species. Rees (1932) observed the conjugation of two adjoining hyphal bodies in Entomopbthora muscae. A narrow isthmus appears at the point of contact of hyphal bodies; then a globular body forms as an outgrowth of this isthmus. A nucleus from each hyphal body, together with a quantity of cytoplasm, moves into the outgrowth, the zygote, and a thickened wall is formed around it.

A somewhat different situation prevails with Basidiobolus ranarum. In this species a pair of beak-like protrusions forms on each side of the septum separating adjoining cells. The single nucleus from each parent cell passes into the beak and divides, and one daughter nucleus of each pair passes back into the parent 
cell cavity, the other remaining in the beak and disintegrating. One of the pair of parent cells then enlarges, a pore opens into the adjoining smaller one, the protoplast from the smaller flows over into the cavity of the larger, and the two nuclei finally fuse. Soon a thick wall is formed around the zygote.
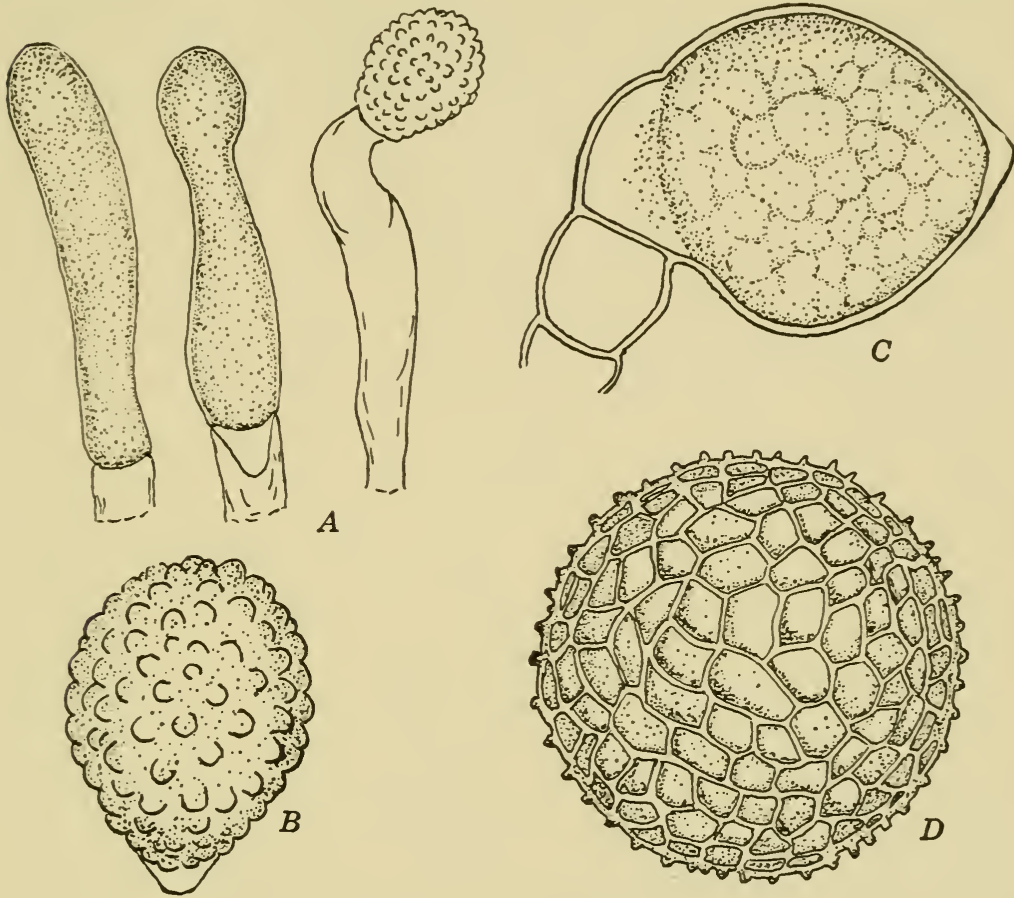

FIg. 43. Massospora cicadina. A. Conidial formation from conidiophores that extend to the exterior of the body of the parasitized cicada. $B$. Conidium. C. Early stage in formation of resting spore within the cicada's body. $\dot{D}$. Nature resting spore. (Adapted from Speare.)

Conidiobolus utriculosus also forms zygotes, but neither their germination nor that of any other of this assemblage of fungi has with certainty been observed.

Kevorkian (1937) regards Conidiobolus villosus, commonly held to be saprophytic, as a parasite on termites in Cuba. He also concluded that its minute conidia, borne at the appendage tips of the resting conidia, are like those which characterize Delacroixia coronata and therefore placed the latter name in synonymy with C. villosus. 
Basidiobolus ranarum grows on the excrement of frogs, lizards, salamanders, and similar animals. The sporangia produced on this substrate are eaten by beetles and other insects, which may in turn be devoured by frogs. During digestion within the frog's stomach the spores are delimited within the sporangia and set free. They are not digested but increased by budding and are voided intact to initiate again the developmental cycle.

Artificial cultivation. The saprophytic members of the Entomophthorales grow rather well and readily on artificial media. Many failures resulted from attempts to cultivate the entomogenous species, however, until Sawyer (1929) determined that media high in proteins are required. He employed media containing eggs, various kinds of fish, clams, beef, and pork and found them suitable for artificial cultivation of Entomophthora spbaerosperma, isolated from Rbopobata racciniana, E. pseudococci from Pseudococcus calceolariae, and an Empusa from Peronea minuta. These organisms are said to ammonify proteins without the liberation of gas and odorous cleavage products. Perhaps this situation may result from (1) either the utilization of ammonia as rapidly as it is formed, or (2) its accumulation in amounts too meager to be detectable.

Classification. No general taxonomic treatise of this group is extant except Thaxter's monograph (1888), which lists 26 species of Entomophthora. Olive (1906) described 5 additional species, and subsequent accounts bring the total number to approximately 40. Completoria complens, a monotypic species, exists on fern prothallia. Six species of Massospora have been described, including Massospora cicadina on cicadas. Basidiobolus ranarum and $B$. lacertae are regarded as identical.

\section{LITERATURE CITED}

Goldstein, Bessie, "Resting spores of Empusa muscae," Bull. Torrey Botan. Club, 50: 317-328, 1923.

"A cytological study of the fungus Massospora cicadina, parasitic on the 17-year cicada, Magicicada septemdecim," Am. J. Botany, 16:394-401, 1929.

Kevorkian, A. G., "Studies in the Entomophthoraceae. I. Observations on the genus Conidiobolus," J. Agr. Puerto Rico, 21: 191-200, 1937.

Otive, E. W., "Cytological studies on the Entomophthoreae," Botan. Gaz., 41: 192-208, 229-261, 1906. 
ReEs, Olive M., "The morphology and development of Entomophtbora fumosa," Am. J. Botany, 19: 205-217, 1932.

SAwYER, WV. H., "Observations on some entomogenous members of the Entomophthoraceae in artificial culture," Am. J. Botany, 16:87-121, 1929.

"Studies on the morphology and development of an insect-destroying fungus, Entomophthora sphaerosperma," Mycol., 23:411-432, 1931.

Speare, A. T., "Massospora cicadina Peck, a fungus parasite of the periodical cicada," Mycol., 13: 72-82, 1921.

Thaxter, R., "Entomophthoreae of the United States," Mem. Boston Soc. Nat. Hist., 4: 133-201, 1888.

\section{DOUBTFUL ZYGOMYCETES}

\section{Endogonaceae}

Among the fungi whose position among the Phycomycetes has not been established with finality are the Endogonaceae, a group of 6 genera containing approximately 30 hypogeous species. They somewhat resemble truffles in gross appearance, ranging from tiny objects up to the size of a hazel nut. According to Bucholtz (1912), the type Endogone pisiformis was described by Link in 1809; he thought it to be among the Gastromycetes. Although Fries did not observe specimens of it, he placed it near Rhizopogon among the Basidiomycetes. Meanwhile other species of Endogone were found, and other early mycologists, among them Berkeley and Tulasne, placed these fungi among the truffles. Schröter, in Engler and Prantl's Die natürlichen Pflanzenfamilien, regarded these fungi as Hemiascomycetes. More recent students of the group [Thaxter (1922), Walker (1923)] place them near the Mortierellaceae.

The assignment of Endogonaceae as a family of Mucorales is indicated as proper mainly because the hyphae are coenocytic, the multinucleate sporangiospores are delimited as in Mucorales, and the clusters of zygospores are invested with a dense mass of hyphae, forming a sclerotium-like structure. The sporangia lack columellae and appear somewhat like those of Mortierella.

Walker (1923) germinated the sporangiospores of Endogone malleola but found no evidence of zygote formation. No one seems to have succeeded, however, in germinating zygospores of any members of the group. The account by Bucholtz (1912) 
contains many facts regarding the derelopment of these fungi, but further investigation of them is required.

\section{LITERATURE CITED}

Bucholtz, F., "Beiträge zur Kenntnis der Gattung Endogone Link," Beitr. Botan. Centrb., Il Abt., 29: 147-225, 1912.

Thaxter, R., "A revision of Endogoneae," Proc. Amer. Acad. Arts Sci., 57: 289-350, 1922.

WALker, Leva B., "Some observations on the development of Endogone malleola Hark.," Mycol., 15:245-257, 1923.

\section{ECCRINALES}

The position of this order among the Phycomycetes is not established. In fact, its members are not included in Saccardo's Sylloge Fungorum, even though some of them were first described nearly 100 years ago. Leidy $(18+9,1849 a, 1849 b)$ first observed a capillary, unbranched organism attached by means of disk-like holdfasts to the intestinal wall near the anal opening of Spirobolus marginatus. To this organism he gave the name Enterobrus elegans, placing it among the Confervaceae. He then added two other species, E. spiralis in Iulus pusillus, and E. attemuatus in Passalus cornutus. In the following year Leidy (1850) created the additional closely related genus Eccrina and changed the name Enterobrus to Enterobryus. Three years later Robin [Léger and Duboscq (1929)] described another species and indicated that Enterobryus was among the Saprolegniales.

Little attention was given these organisms until 1905, when Léger and Duboscq began a series of studies of them. Among recent reports through which the worker may become acquainted with the Eccrinids are those by Poisson (1929) and Léger and Duboscq $(1916,1929,1933)$. Léger and Duboscq (1929) classified them into two orders, Eccrinales and Amoebidiales. The Eccrinales have long filaments and are attached to the intestinal wall of terrestrial, marine, and fresh water Arthropods. They reproduce by endogenously formed microconidia and macroconidia. The Amoebidiales have short filaments or are saccate, are attached to the external cuticle or rectal chitin of Crustacea and insects, and form only one type of endospore. Approximately 10 genera have been described, but it is probable that the 
features used to distinguish genera are of specific, rather than of generic, nature.

Eccrinids are commonly present in crabs and millipeds. In fact, one species grows so copiously within the mud crab, Pano-

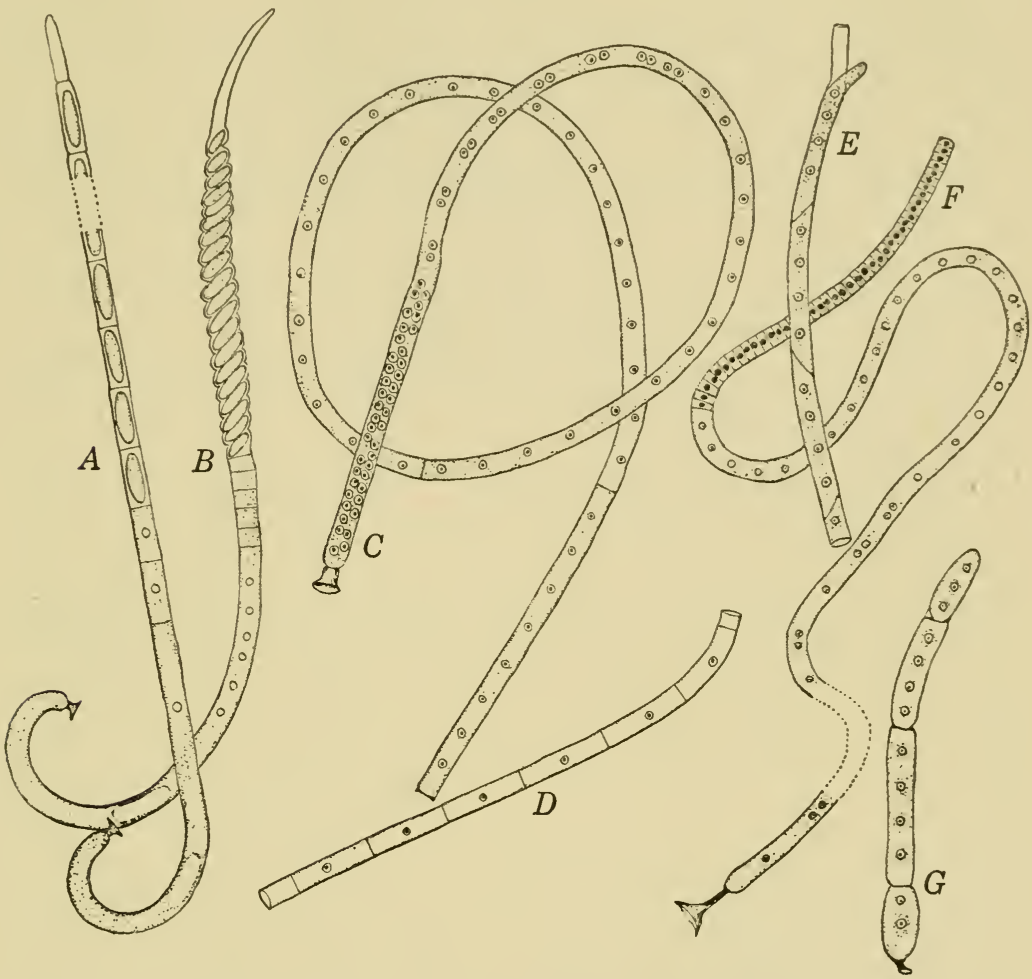

FIG. 44. Various Eccrinids. $A$ and B. Eccrinella gamnnari from intestine of Gammarus locusta. (Adapted from Léger and Duboscq.) $C$ and $D$. Eccrinopsis bydroploilorum from intestine of Hydropbilus piceus and $H$. pistaceus. (Adapted from Léger and Duboscq.) $E$ and $F$. Eccrinoïds benneguyi from Logoglomeris rugifera. (Adapted from Léger and Duboscq.) G. Taeniellopsis flexilis from Orchestia gammarella. (Adapted from Poisson.)

peus berbstii, in the vicinity of Beaufort, North Carolina, that tufts of hyphae, visible to the unaided eye, protrude from the anal opening.

More should be known of the possible parasitism of Eccrinids, their developmental history, relationship, and classification. 


\section{LITERATURE CITED}

Léger, L., and O. Dubosce, "Sur les Eccrinides des Hydrophilides," Arch. zool. exp. gén., 56:21-31, 1916.

"Eccrinoïds benneguyi, n.g. sp., et la systematique des Eccrinides," Arch. anat. micros., 25: 309-324, 1929.

"Eccrinella (Astreptonema?) gammari Lég. et Dub. Eccrinide des Gammares d'eau douce," Arch. zool. exp. gén., 75:283-292, 1933.

Leidy, Joseph, "Enterobrus, a new genus of Confervaceae; Enterobrus eleganns. Cladophytum, a new genus of Entophyta, allied to Mycodermata; Cladopbytum comatum. Anthromitus, a second new genus of Entophyta, allied to the Mycodermata," Proc. Acad. Nat. Sci. Pbila., 4: $225,1849$.

"On the existence of Entophyta in healthy animals as a natural condition," Proc. Acad. Nat. Sci. Phila., 4: 233, 1849a.

"Remarks on several new species of Entophyta, Enterobrus spiralis and E. attemuatus, and a new species of Gregarina," Proc. Acad. Nat. Sci. Plila., 4: 245, $1849 \mathrm{~b}$.

"Descriptions of new Entophyta growing within animals," Proc. Acad. Nat. Sci. Pbila., 5: 35, 1850.

"A flora and fauna within living animals," Pub. Smitbsonian Inst., 5: 2-67, 1853.

Porsson, R., "Recherches sur quelques Eccrinides parasites de Crustacés, Amphipodes, et Isopodes," Arcl. zool. exp. gén., 69: 179-216, 1929. 


\section{Chapter 6}

\section{THE ASCOMYCETES}

The Ascomycetes, or sac fungi, comprise between 25,000 and 35,000 species. They possess a multiplicity and complexity of architectural design and a seemingly infinite variety of patterns of activity that are baffling to all who attempt to catalogue or to orient them. It is an all too common experience of the mycologist, after having studied a group of kindred forms, to encounter one which appears to be related to the others and therefore to anticipate that its behavior will be similar. He may find to his surprise, however, after intimate acquaintance, that the apparently similar species is entirely distinct and that it does not fit into the niche into which he anticipated it would fall. If he then attempts to console himself for this error in judgment, he may arrive at the sage conclusion that no Emily Postian rules of conduct exist for the guidance of Ascomycetes; and, even if they did, all fungi are illiterate and hence unable to determine how they are supposed to behave.

Assimillatory pHase. The thallus of Ascomycetes generally consists of septate hyphae, more or less entangled, each cell of which is usually uninucleate. In some the hyphal cells separate with age, forming oidia, or become thick-walled, forming chlamydospores. In others the hyphae become compactly aggregated into sclerotia or stromata, in which stage the species is able to survive periods of stress or to hibernate. In certain species the hyphae themselves perennate within twigs or buds.

Asexual reproduction. A large number of Ascomycetes have one or more asexual or conidial stages by means of which they propagate and disseminate themselves. Sometimes the conidia are able to survive from one season to the next. The fact that a conidial fungus can hibernate, it may be pointed out, does not constitute evidence that it lacks an ascogenous stage. Many organisms are know only in the conidial stage, especially among pathogenic species. Similarly many fungi are known in the asco- 
mycetous stage, but genetic connection with a conidial stage has not been established.

A structural parallelism between conidia and ascospores has been observed [Orton (1915)] in several of the more common genera, such as Endothia, Pleospora, Coccomyces, Diplocarpon, Gibberella, Venturia, Glomerella, Cucurbitaria, Erysiphe, and Mycosphaerella. It does not occur universally, however, among Ascomycetes.

SExUAl ReProduction. The sac or ascus, normally containing eight ascospores, is the resultant of sexual processes among Ascomycetes. As will be apparent in the accounts that follow, the young asci in all species are binucleate. These two nuclei then fuse to form the nucleus of the primary ascus. There follow three nuclear divisions, after which the ascospores are delimited by a process of free-cell formation, leaving portions of the cytoplasm outside the spores. Great differences, however, exist in observations of the origin of the pair of nuclei and the kinds of structures in which they are produced. The two sex organs, as in Eremascus, may be quite alike, or there may be well-differentiated antheridia and ascogonia, as in Pyronema confuens. Lateral hyphal branches may either be coiled archicarps or bear clusters of spermatia, as in Plenrage anserina. Separate locular stromata may become differentiated into spermogonia, bearing spermatia, and carpogonia, bearing archicarps, as in Mycospbaerella bolleana. One or the other of the sex organs may be abortive, and in consequence parthenogenesis may occur. In any erent one or more ascogenous cells occur within each developing ascocarp. In these ascogenous cells (ascogonia) one or more functional pairs of nuclei occur. Hyphal protrusions that become the ascogenous hyphae arise from the ascogonium. The ascogenous hyphae recurve (crosier formation), and the penultimate cell of each hyphal tip becomes the ascus.

Some workers maintain that apogamy is of wide occurrence among Ascomycetes. In our opinion it seems more probable that it is rare. It must be admitted, though, that spermatization, supplemented by cytologic evidence of fertilization, has been recorded in only a few species. Spermatia and ascogonia are too commonly present, it would appear, to be regarded as vestigial and nonfunctional. Strangely, however, many well-trained mycologists have never seen these structures among Ascomycetes. 
Phylogeny of the Asconiycetes. Two widely divergent hypotheses have been advanced to account for the derivation of the Ascomycetes: the rhodophycean or floridean hypothesis and the phycomycetean hypothesis. The rhodophycean hypothesis, first proposed by Sachs in 1875 , is based on the similarities between the reproductive structures of Ascomycetes and red algae, such as $(a)$ ascocarp and cystocarp, $(b)$ the trichogyne apparatus in each, $(c)$ the non-motile spermatia of each, and $(d)$ the resemblance of ascogenous hyphae and ooblastema filaments. The phycomycetean hypothesis was first proposed by de Bary in 1887, who maintained that primitive Ascomycetes are those in which the asci are directly formed from the zygote, as they are in Dipodascus and Eremascus. Mortierella and Piptocephalis among the Phycomycetes are regarded as in the line of origin. The adherents of this hypothesis regard analogous structures among Ascomycetes and Florideae as being parallel developments and not as being derived one from the other. Both of these hypotheses are elaborated in the accounts by Dodge (1941) and Atkinson (1915). Both hypotheses emphasize morphology as a basis for phylogenetic development and fail to stress physiology.

\section{LITERATURE CITED}

Atkisson, G. F., "Phylogeny and relationship in Ascomycetes," Ann. Botan. Garden, 2: 315-376, 1915.

Dodge, B. O., "The morphological relationships of the Florideae and the Ascomycetes," Bull. Torrey Botan. Club, 41: 157-202, 1914.

Ortos, C. R., "Structural parallelism between spore forms in the Ascomycetes," Mycol., 7: 21-27, 1915.

\section{HEMIASCOMYCETES}

The Ascomycetes are usually considered as composed of 2 subclasses: Hemiascomycetes, in which the asci arise singly or in groups but ascocarps are lacking, and Euascomycetes, in which the asci are aggregated and ascocarps are developed. According to this classification, the Hemiascomycetes comprise two Orders, Endomycetales (Saccharomycetales) and Taphrinales (Exoascales). Dodge (1935), however, includes both orders under the name Endomycetales and divides them into 11 families. In the 
present treatment the 2 orders are retained; and the Endomycetales are considered to consist of 3 families, the Taphrinales of one family.

\section{ENDomycetales}

The Order Endomycetales, accordingly, may for convenience be divided as follows:

1. Spore sacs many-spored; gametangia plurinucleate

1. Spore sacs with 8 or fewer spores; gametangia uninucleate

Ascoideaceae

2. Mycelium well dereloped

2. Mycelium lacking or scantily developed

Endomycetaceae Saccharomycetaceae

Ascoideaceae. The Ascoideaceae are a small family whose main interest to the mycologist centers around the fact that they
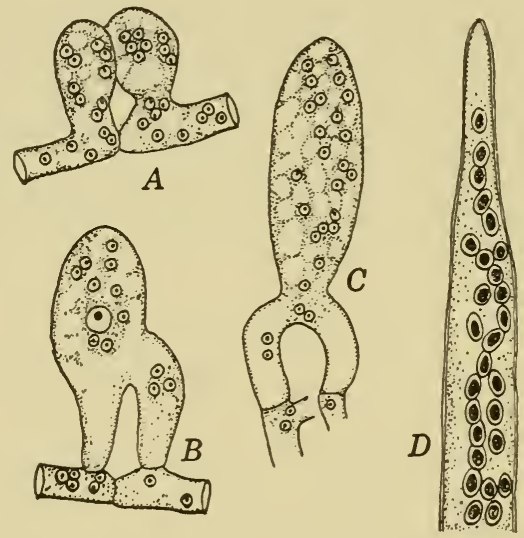

Fig. 45. Dipodascus albidus. A. Two lateral hyphal branches, the one an oogonium, the other an antheridium. Each is multinucleate. $B$. The hyphal branches have fused apically, and the sporangium-like ascus has started to form. C. Later stage in ascus formation. D. Tip of mature sporangium-like ascus. (Adapted from Juel.)

may constitute a link between the Phycomycetes and Euascomycetes. The best-known members are Ascoidea rubescens, Spermophthora gossypii, and Dipodascus albidus. Ascoidea rubescens, originally collected in the slime flux of felled beeches, was first studied comprehensively by Brefeld (1891) and more recently by Walker $(1931,1935)$, who found it in slime flux of elm. Its mycelium is coenocytic but septate and branched. It forms tufts 
of conidia that are multinucleate and, on germination, either bud or give rise to coenocytic hyphae. Hyphal tips give rise apogamously to multispored asci. Uninucleate ascospores are delimited in such a manner as to leave unused a portion of the cytoplasm; that is, by free-cell formation, such as occurs in Euascomycetes. The ascospores are extruded in a long, coiled, gelatinous mass. They are hat-shaped. Before germination ascospores become two- to several-nucleate and either give rise directly to hyphae or else fuse and then form coenocytic hyphae.
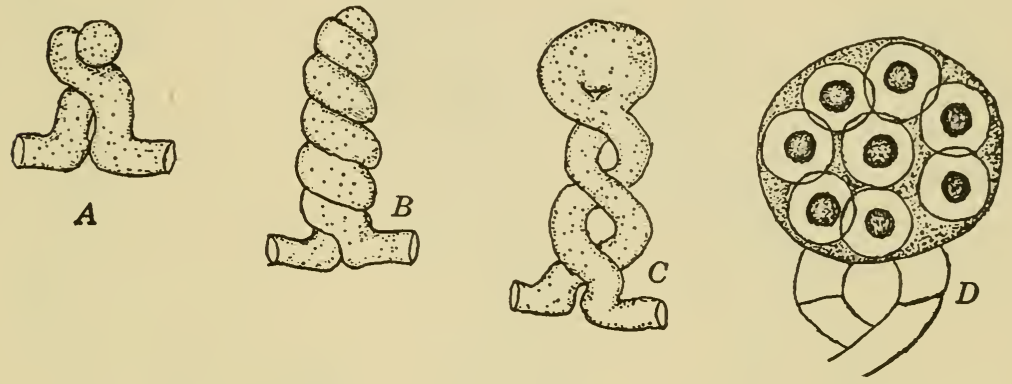

FIg. 46. Eremascus albidus. $A$ to $C$. Stages in fusion of antheridial and oogonial branches to produce the eight-spored ascus, in $D$. (Adapted from Eidam.)

Whether nuclear fusions also occur at the time of hyphal fusions is not established. The asci may proliferate repeatedly, as do sporangia in the Saprolegniales.

The account by Varitchak (1931) differs from that of Walker in showing the fusion of a pair of "privileged" nuclei in the ascus with degeneration of supernumerary nuclei.

Spermophthora gossypii, critically and comprehensively studied by Guilliermond (1928), occurs on cotton flowers in India. He cultivated it on carrots and potatoes or on decoctions of these vegetables. Its mycelium is coenocytic and may produce buds in yeast-like manner. At the time of gametangial formation segments of the mycelium containing 6 to 8 nuclei become swollen, and after 2 or 3 successive nuclear divisions 25 to 40 fusiform gametes are developed. The gametangium then dehisces, and the liberated gametes fuse in pairs. If they do not mate, they develop parthenogenetically. The resulting zygote may germinate immediately by hyphal formation. Each hypha is septate, and 
the cells are uninucleate, each containing a diploid nucleus. This hypha is therefore the homologue of the ascogenous hypha. The asci are borne apically on the ascogenous hyphae, and usually each ascus contains 8 haploid ascospores.

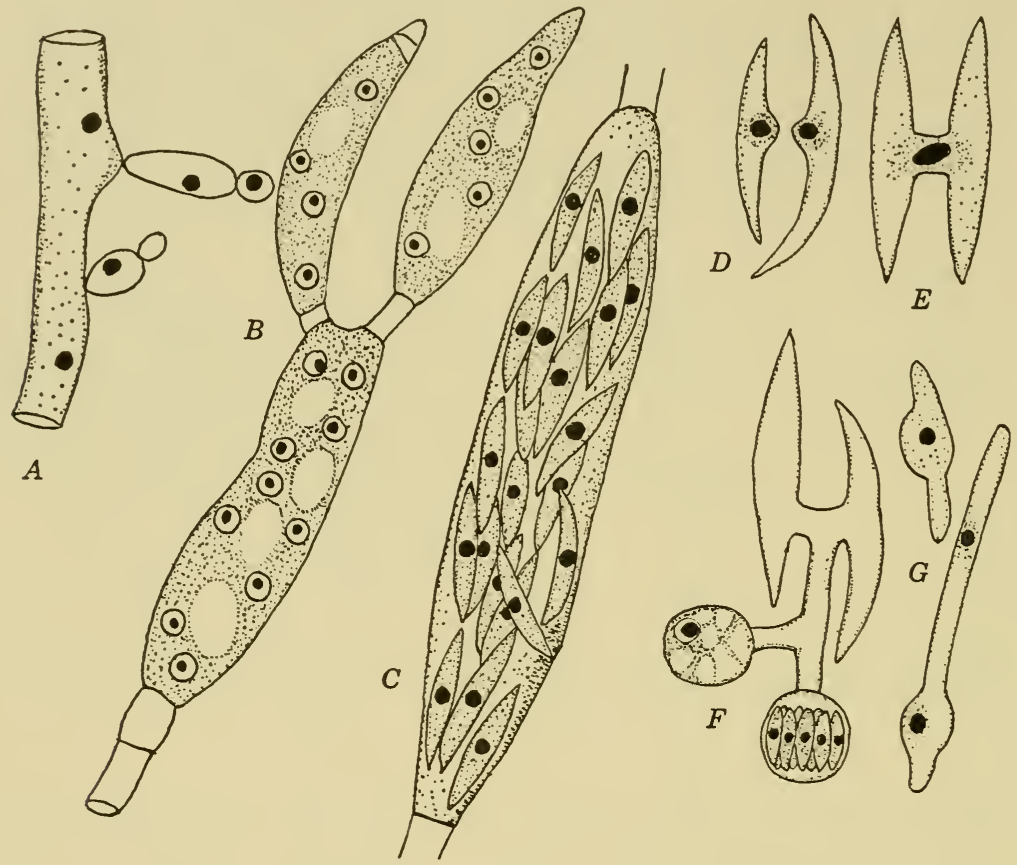

Fig. 47. Spermophthora gossypii. $A$. Yeast-like buds may arise laterally from the hyphae. $B$. The hyphae become segmented; each segment is swollen, contains many nuclei, and is a potential sporangium. C. Sporangium containing fusoid sporangiospores. $D$ and $E$. Fusion of spores through connecting tube. $F$. Germination of zygote with formation of asci at apices of hyphae, each ascus having eight small, fusoid ascospores.

G. Germination of ascospores. (Adapted from Guilliermond.)

Dipodascus albidus is best understood from work by Juel (1902, 1921), whose first studies of it were published in 1905 . He found it in exuding sap from birch, in which it appeared as floccose, branched, septate, multinucleate mycelium. From neighboring hyphal cells of the same or from different hyphae a pair of lateral protrusions arises. Each protrusion contains 10 to 12 nuclei. These protrusions (gametangia) soon come into contact, whereupon a pore is developed, permitting the two protoplasts to 
intermingle. A pair of nuclei, one from each gametangium, fuses, and the supernumerary nuclei remain non-functional and disappear. The female gametangium then elongates into a saccate structure. Meanwhile several successive nuclear divisions take place, and numerous ascospores are formed by free-cell formation. At maturity the ascus tip opens to emit a gelatinous mass of ascospores and cytoplasm, attractive to flies and other insects that serve as vectors. Ascospores are capable of immediate germination to repeat the course of development. There is evidence that the ascospores may at times develop parthenogenetically.

Closely related to these Ascoideaceae, and perhaps within the same family, although placed in the closely related family Coccidioidaceae by Dodge (1935), are several very important human pathogens. Among them are Coccidioides immitis, the cause of "valley fever," Rhinosporidium seeberi, the cause of polypoid growths in the nose, ears, and eyes, and Histoplasma capsulatum, the cause of Darling's disease, a necrotic involvement of the lymph nodes, intestines, liver, and spleen.

Endonicetaceae. The few members that comprise the Endomycetaceae are little known. Eremascus albidus, found years ago by Eidam on malt and apparently not seen since, has pairs of spirally wound gametangia which fuse apically. At the point of contact of 2 gametangia a globular ascus arises, in which 8 ascospores are delimited.

Endomyces decipiens, found on decaying mushrooms, bears pairs of lateral branches. These branches fuse, and Juel (1921) found that, although 3 nuclear divisions occur in the ascus, only 4 ascospores develop. In culture the hyphae of this fungus become segmented into uninucleate oidia, which on growth again become mycelioid.

Endomyces mali causes a decay of ripe apples [Lewis (1910)]. It produces conidia on short conidiophores. These conidia, in turn, produce hyphae. The ascus develops from a single hyphal branch that contains a single nucleus. Four ascospores are developed in this parthenogenetic ascus.

Many important human pathogens are placed by Dodge (1935) within the Eremascaceae Imperfectae, or detached conidial forms of Eremascaceae, a family which some workers would include among Endomycetaceae. These detached fungi belong 
to such genera as Geotrichum, Mycoderma, Candida, Castellania, and Monilia, with all of which the physician is more or less familiar.

Saccharomicetaceae. This family comprises the yeasts, first described by Leeuwenhoek in 1680. Although fermentations
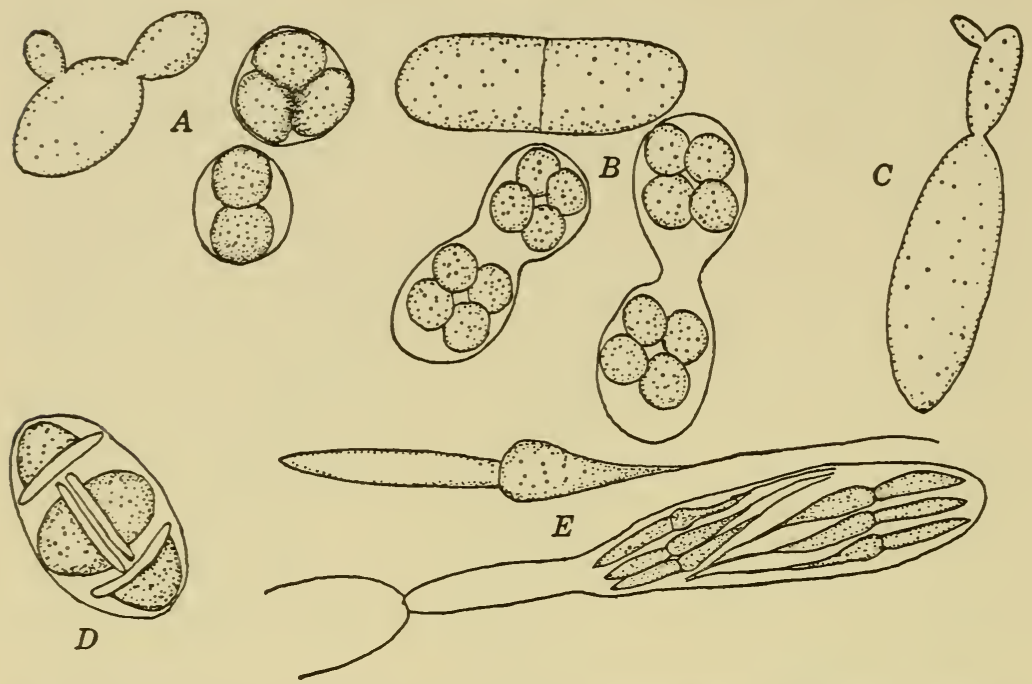

Fig. 48. Tarious genera of yeasts. A. Saccharomyces cerevisiae, showing growth by budding and the formation of ascospores. B. Schizosaccharomyces octosportus, with one cell undergoing fusion and two asci each containing eight spherical ascospores. C. Saccbaromyces ellipsoideus, the wine yeast. D. Ascus of Willia anomala with derby-hat-like ascospores. (From Hansen.) E. Nematospora phaseoli, a single-appendaged ascospore and an eight-spored ascus. (From Wingard.)

were carried out long before this time and scientific observers are known to have speculated on the nature of this process, the role of yeasts was not definitely established until nearly 200 years later as the result of Pasteur's researches. Much of present-day knowledge of their physiology and taxonomy has come from the investigations of Hansen and of Guilliermond (1920). The work of Henrici (1941) should be consulted by all who desire an acquaintance with yeasts.

Guilliermond (1920) recognized 18 genera of yeasts. Yeasts are characterized as fungi which multiply by budding or by fission and also by forming sacs. Each cell may become an 
ascus parthenogenetically, or it may fuse with another similar cell before ascospores are developed.

Mycelium is lacking in nearly all yeasts, but on gelatin Scbizosaccharomyces ludwigii forms hyphae, as does Saccharomyces pombe when grown on beer wort. Hansen observed that S. cerevisiae, the cultivated yeast, formed ascospores on gypsum or clay blocks if good aeration was provided, the temperature and humidity were favorable, suitable food was available, and the cells were young. Other important species of Saccharomyces include S. ellipsoideus, a wine yeast; $S$. piriformis, the ginger-beer yeast that lives symbiotically with Bacterium remifome; and S. sake, which saccharifies rice starch to make sake.

Schizosaccharomyces octosporus, occurring commonly on figs and raisins, conjugates within 10 to 12 hours if cultivated on sterilized carrot or potato or on sucrose agar. Pairs of cells form short tubes that unite. The 2 nuclei fuse within the canal formed by these tubes, and the canal then broadens until the structure is dumbbell- or barrel-shaped. Meantime 3 nuclear divisions hare taken place, and soon 8 ascospores are delimited. Saccharomyces pombe, used in the fermentation of millet to make African beer, and $S$. mellacei, used in the manufacture of Jamaica rum, may reproduce in the same manner as Schizosaccharomyces octosportus, or may form ascospores parthenogenetically. Picbia mandsburicus is used in the fermentation of sorgho, and another species is concerned in the manufacture of pulque from the juice of decapitated maguey (Agave spp.) plants. Willia anomala is one of the beer-wort yeasts.

In Nematospora the ascospores are long and needle-shaped and are formed in 2 groups of $t$, a group in either end of the ascus. Each ascospore is provided with a long whip-like appendage. Three species of some economic importance have been described, $N$. coryli from hazel nuts, $N$. lycopersici from tomato fruits [Schneider (1916)], and N. phaseoli from beans [Wingard (1925)].

\section{LITERATURE CITED}

Brefeld, O., "Die Hemiasci und die Ascomyceten," Untersuch. Gesammit. Mykol., 9: 1-156, 1891.

Doder, C. W., Medical mycology. 900 pp. C. V. Mosby Co., St. Louis. 1935. 
Guilliermond, A., The yeasts. xix + 424 pp. John Wiley and Sons, New York. 1920.

"Recherches sur quelques Ascomycètes inférieurs isolée de la stigmatomycose des grains du cotonnier," Rer. gén. botan., 40:328-342, 397$414,474-485,555-574,606-624,689-704,1928$.

Hexrici, A. T., "The yeasts: genetics, cytology, variation, classification, and identification," Bact. Rev., 5:97-179, 1941.

(Rerised by Skinner, Emmons, and Tsuchiya), Molds, yeasts, and Actinomycetes. John Wiley and Sons, New York. In press.

Juel, H. O., "Über Zellinhalt, Befruchtung, und Sporenbildung bei Dipodascus," Flora, 91: 47-55, 1902.

"Cytologische Pilzstudien. II. Zur Kenntnis einiger Hemiasceen," Nora Acta Regiae Soc. Sci. Upsaliensis, IV, 5: 1-43, 1921.

Lewis, C. E., "A new species of Endomyces from decaying apple," Maine Agr. Exp. Sta. Bull., 178:45-65, 1910.

SchNeider, A., "A parasitic saccharomycete of the tomato," Pbytopatbology, 6:395-399, 1916.

VARITChak, B., "Contribution à l'étude du déreloppement des Ascomycètes," Botaniste, 23: 1-183, 1931.

IVAlker, Leva B., "Studies on Ascoidea rubescens. I. History and development," Mycol., 23: 51-76, 1931.

II. "Cytological observations," Mycol., 27: 102-127, 1935.

Wingard, S. A., "Studies on the pathogenicity, morphology, and cytology of Nematospora plaseoli," Bull. Torrey Botan. Club, 52: 249-290, 1925.

\section{TAPHRINALES}

The Taphrinales comprise about 100 species. They have been variously divided into 2 or 3 families, of which the Taphrinaceae are the most important. All the members of this family are parasitic on seed plants and ferns. They cause hypertrophic malformations of their hosts, producing such diseases as those commonly called leaf curl, blister, and fasciation, which involve buds, leaves, twigs, flowers, and fruits. The best known of these diseases is peach-leaf curl, caused by Taphrina deformans. Other very common and wide-spread Taphrinaceae are $T$. pruni, causing plum pockets, and $T$. coerulescens, causing leaf curl of oaks.

Myceliun. The mycelium is annual in most species, but in Taphrina pruni, T. mirabilis on plum twigs, Taphrinopsis laurencia on Pteris biaurita, $T$. cerasi, causing witches' broom of cherries, and certain other species, it is perennial. In species with perennial mycelia the hyphae extend into the new growth as the buds expand in spring. Moreover, it is intercellular, except in 

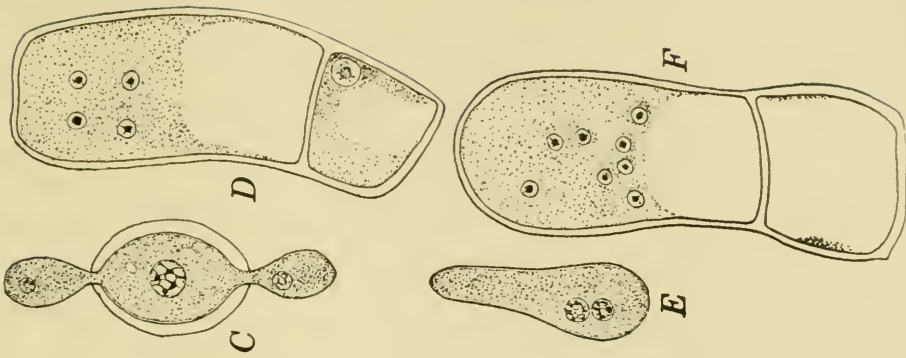

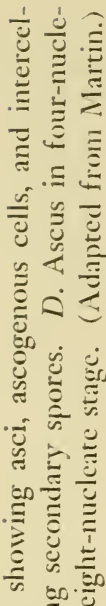

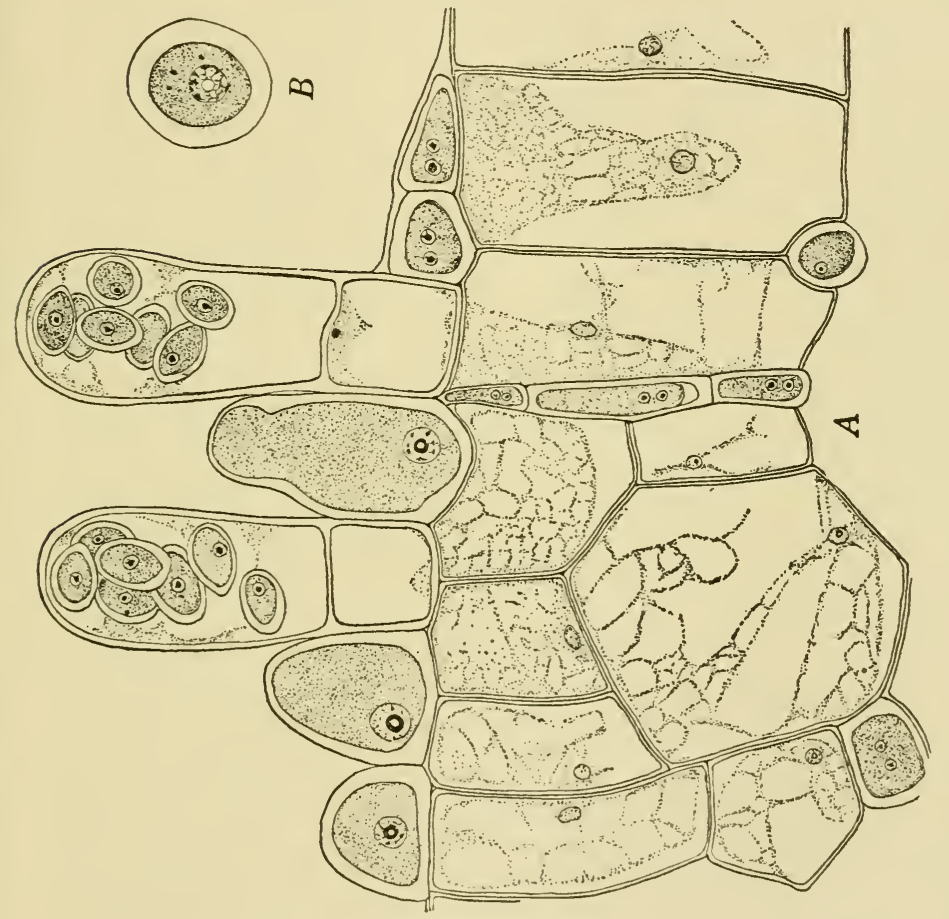

כ.

氖

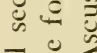

$\bar{\Xi}$

$\because \underline{\Xi}$

$\Xi \frac{0}{\circ}$

Ч छ

$\simeq \stackrel{0}{\simeq}$

บै

टँ के

है को

.

-

○一

¿

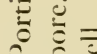

$\sim$ के

षं

¿

롤

巳े

$\frac{0}{2} \approx \equiv$

ङ

ఏ $\Xi$

워

家

$\tau=$

$\triangleq \triangleq$ 
a few species. Haustoria are lacking. Sadebeck (1893) placed in Magnusiella those species having intracellular hyphae.

Reproductios. Reproduction among Taphrinaceae is accomplished by the formation of a palisade-like layer of asci that arise as terminations of the internal mycelium. Before ascus formation a compact mycelial layer, one cell thick, is formed subcuticularly in most species. In Taphrinopsis laurencia the ascus-bearing layer develops within the epidermal cells. All the cells of this layer are binucleate. As they elongate, the nuclei fuse, after which, in most species, a short stalk is cut off at the base of the ascus. In Taphrina carnea stalk cells are not formed [Juel (1921)], but the cell containing the fused nucleus becomes the ascus. Juel (1921) states that the basal cell nucleus migrates into the cell that is to become the ascus before the cross wall is formed. In $T$. coryli [Martin (1924)] the fusion nucleus divides reductionally; as a result, the nucleus of the stalk cell and that of the ascus contain $n$ chromosomes. The nucleus in the stalk cell soon degenerates, but that in the ascus divides and redivides to form eight daughter nuclei. Eight ascospores are then formed. In Taphrina deformans the ascospores on discharge germinate by yeast-like budding [Martin (1925), Mix (1924)], but in certain other species, such as $T$. jobansonii, budding takes place while the spores are still confined within the ascus.

Circumstantial evidence has long indicated that the ascospores of $T$. deformans or the conidia formed by budding lodge between the bud scales and overwinter there. The fact that peachleaf curl can be very successfully eliminated by the application of a dormant spray [Pierce (1900)] constitutes evidence of how this organism hibernates. In fact, the discovery of lime-sulphur sprays was made as the result of drenching peach trees with limesulphur solutions used as sheep dip. The trees adjacent to vats were covered with dip while the solution was being changed in the vats. As a consequence trees that were drenched remained leaf-curl free. More direct evidence of hibernation of spores on peach buds was secured by Mix (1924) as the result of bagging and of inoculation experiments.

In regard to the origin of the binucleate condition of the hyphal cells Martin (1940) states that in T. deformans, when the ascospores, buds, or thick-walled spores from culture germinate 
to form hyphae, two nuclei arise by mitosis and pass into the germ tube, and that all subsequent divisions are conjugate. If the spores bud to form secondary spores, however, the cells remain uninucleate whether the cultures originate from monosporic or polysporic cultures. Wieben (1927) reported that buds conjugate in cultures of $T$. epiphylla and $T$. klebabni, thus resulting in paired nuclei.

Wieben (1927) showed that infection of the host is possible by $T$. epipbylla and T. klebahni only if the penetration tube arises from two spores that have fused. Fitzpatrick (1934), however, found that a single spore of $T$. deformans can cause infection. These divergent results may be interpreted to indicate that some species of Taphrina are homothallic, others heterothallic.

Artificial cultivation. Among the older mycologists to report growth by budding in liquid media are Brefeld and Sadebeck (1893). Pierce (1900) grew T. deformans on malt extract, beer, and various sugar solutions. Klebahn (1923) grew $T$. tosquinetii, $T$. epiphylla, $T$. sadebeckii, and $T$. aurea on agar fortified with salep. Mix (1924) grew $T$. deformans on agar media containing decoctions of potatoes, carrots, corn meal, rice, or beets, and also on those containing the common carbohydrates. Martin (1940) also grew this leaf-curl fungus on a variety of media. On these artificial media the fungus grows in yeast-like fashion, and some of the cells in old cultures become thick-walled (chlamydospores). Mix (1924) kept $T$. deformans in culture for 22 months without loss of its virulence.

Classification. There are no comprehensive recent treatises on the taxonomy and classification of the Taphrinaceae. Sadebeck (1893) placed in Exoascus those species with a subcuticular ascogenous layer and perennial mycelium, and in Taphrina those whose mycelium is annual but which are otherwise like Exoascus. In Magnusiella he placed those whose asci arise from intercellular mycelium without the formation of a subcuticular layer. Giesenhagen (1895) distinguished four types on the basis of the shape of the ascus: (a) filicina type, with slender cylindrical asci; (b) betulae type, with plump cylindrical asci; (c) pruni type, with long clavate asci; and (d) magnusiella type, with large globular, oval, or saccate asci. Since asci in which the spores bud profusely change shape, good morphologic features to distinguish 
genera are lacking. Perhaps all may as well be regarded as Taphrina, with host relationship as the basis for specific separations.

\section{LITERATURE CITED}

Fitzpatrick, R. E., "The life history and parasitism of Tapbrina deformans," Sci. Agr., 14: 305-326, 1934.

Giesenhagen, K., "Die Entwicklungsreihen der parasitischen Exoasceen," Flori, 81:267-361, 1895.

Juel, H. O., "Cytologische Pilzstudien. II. Zur Kenntnis einiger Hemiasceen," Nova Acta Regiae Soc. Sci. Upsaliensis, IV , 5: 1-43, 1921.

Klebahn, H., "Infektionsversuche mit Taplorina tosquinetii," Ber. deut. botan. Ges., 41: 108-113, 1923.

Martin, Ella M., "Studies on the morphology and cytology of Taphrina coryli Nishida," Trinzs. Wis. Acad. Sci., 21:345-356, 1924.

"Cultural and morphological studies of some species of Taphrina," Phytopathology, 15:67-76, 1925.

"The morphology and cytology of Tapbrina deformans," Am. J. Botany, 27: 743-751, 1940.

Mix, A. J., "Biological and cultural studies of Exoascus deformans," Plbytopatbology, 14:217-233, 1924.

Pierce, N. B., "Peach-leaf curl. Its nature and treatment," U. S. Dept. Agr., Div. Veg. Physiol. Path., Bull. 20: 11-204, 1900.

Sadebeck, R., "Die parasitischen Exoasceen, eine Monographie," Jahrb. Hamburg wiss. Anst., 10: 5-110, 1893.

Wieben, Magdalexe, "Die Infektion, die Mycelüberwinterung, und die Kopulation bei Exoasceen," Forsch. Gebiete Pflanzenk. Inmmım. Pflanzenr., 3: 139-176, 1927.

\section{EUASCOMYCETES}

For convenience the Euascomycetes may be arbitrarily subdivided into the Plectomycetes, Pyrenomycetes, and Discomycetes. The Plectomycetes include those in which the asci are irregularly arranged within a closed ascocarp or cleistothecium; the Pyrenomycetes, those with asci regularly arranged within an ostiolate ascocarp or perithecium; and the Discomycetes, those with asci regularly arranged within a widely opened or discoid ascocarp or apothecium. Groups of Ascomycetes occur, to be sure, that are intermediate between these arbitrary groupings or that are in some respects aberrant.

The fact that such groupings are arbitrary becomes all too apparent when an attempt is made to locate in kevs certain of the Perisporiales, some of which are said to be ostiolate; the 

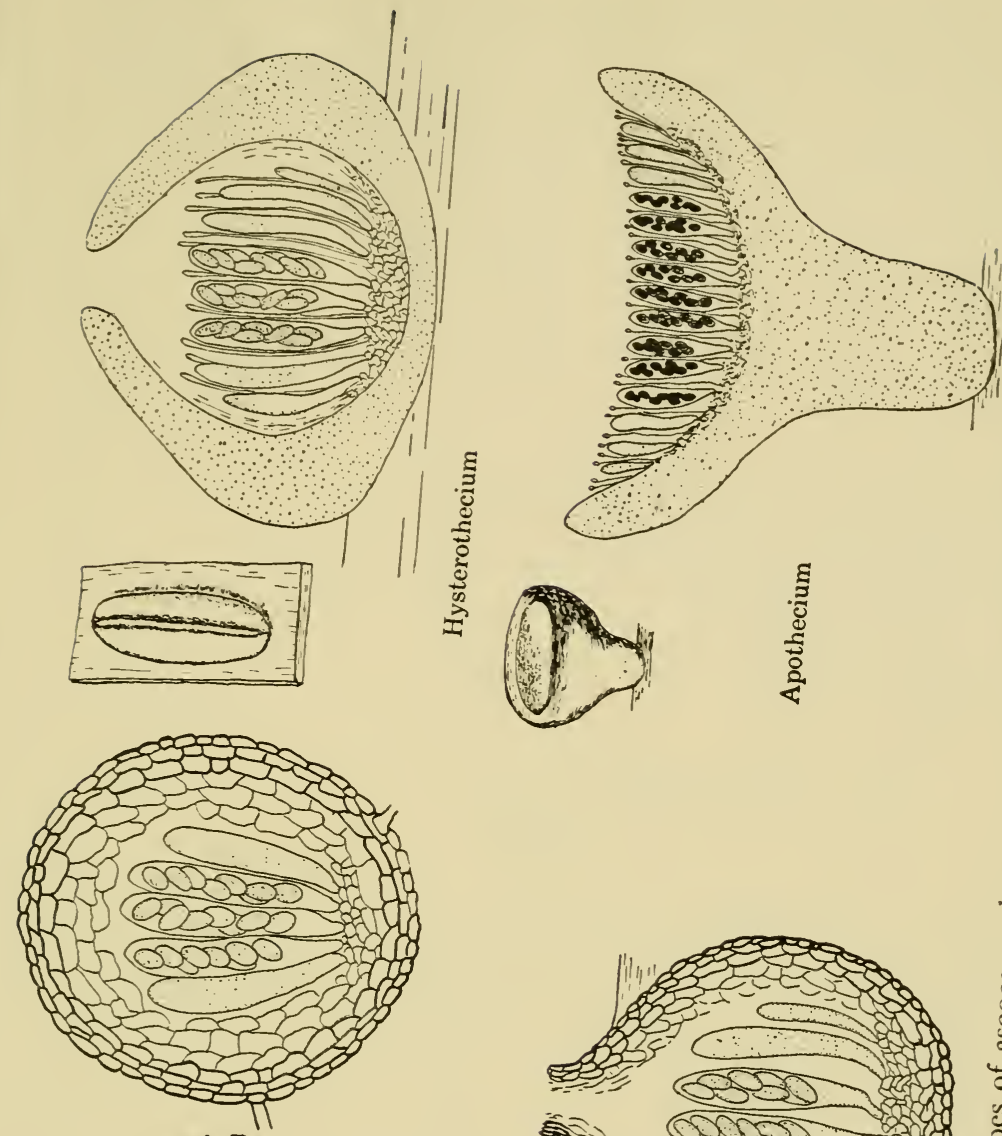

苞

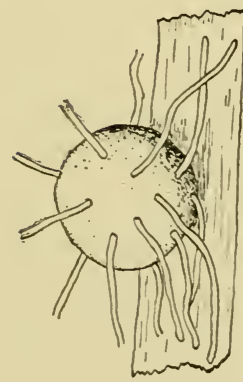

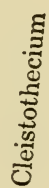

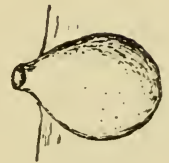

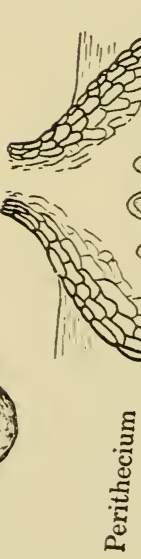


Myriangiales, which are stromatic but some of which have asci borne at different levels, and others asci all borne at the same level; and the Hemisphaeriales, Laboulbeniales, and Tuberales, each of which contains a miscellaneous aggregation. The student eventually comes to recognize whether his unknown species occurs in these orders and meantime becomes further convinced that present-day keys are not necessarily based on natural affinities.

Proper classification of Ascomycetes would seem to require that more detailed research be performed on the origin and developmental anatomy of ascocarps and the origin of stromatic locules, paraphyses, and periphyses. It may well be that more significance should be attached to whether the paraphyses (a) arise from the floor of the locule and remain free above, $(b)$ arise from the ceiling of the locule and remain pendant, or $(c)$ are attached at each end.

\section{Plectonimcetes}

\section{Eurotiales}

This group includes the Order Eurotiales, also called the Aspergillales and Plectascales, an assemblage of approximately 800 species. They are arranged in 5 or more families, including the Gymnoascaceae, Aspergillaceae, Onygenaceae, Elaphomycetaceae, and Terfeziaceae.

\section{Gymmoascaceae}

The Gymnoascaceae are primitive fungi, many of which grow saprophytically on dung, feathers, dead grass, puparia of moths, leather, paper, and garbage. Others are important pathogens of men and animals, if the dermatophytes, or Trichophytoneae, are imperfect forms of Gymnoascaceae, as some mycologists believe. Evidence that Achorion gypseum, causing favus, possesses a Gymnoascus stage was presented by Nannizzi (1927). These findings, however, remain unconfirmed. Eidamella spinosa is associated with skin lesions in dogs. Ctenomyces serratus occurs on decaying chicken feathers. Its spiral hyphae, aleuro- 
spores, and pectinate hyphae very closely resemble those of dermatophytes. Gymmoascus reesii has been collected on badly decomposed twigs.

The developmental cycle of members of this family is typified by that of Amauroascus ierrucosus, occurring on soil and dung,
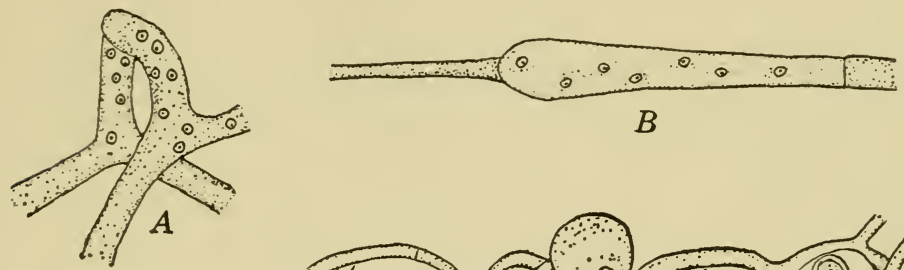

$B$
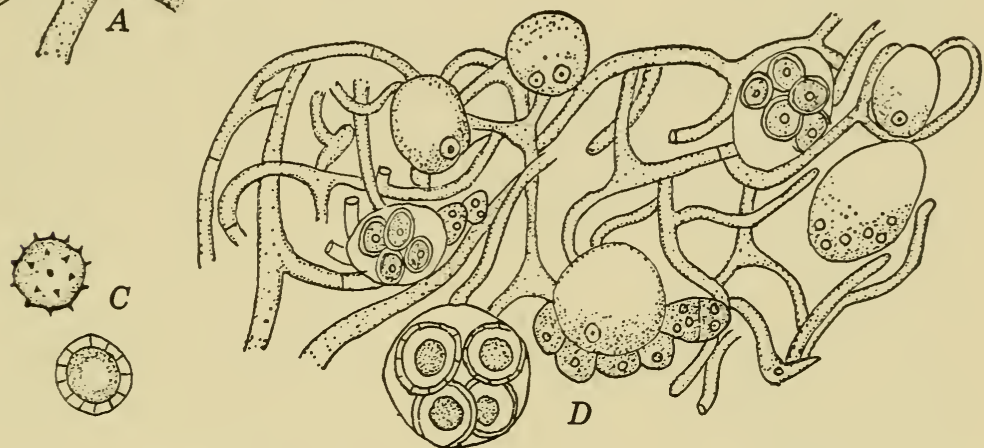

Fig. 51. Amauroascus verrucosus. (After Dangeard.) A. Antheridium and ascogonium by which the binucleate condition is initiated. B. Hyphal segment. C. Ascospore. D. Segment of ascocarp, showing stages of ascus formation. The asci are enreloped within a loose tangle of hyphae.

which forms a profuse arachnoid covering orer the substrate. According to Dangeard (1907), pairs of erect branches coil around each other, one an antheridium, the other an ascogonium. Nuclear fusions have not been observed, but the ascogones continue to grow, become branched, and eventually are segmented into binucleate cells. These cells become enlarged and finally are the eight-spored asci. Meanwhile a loose, hyphal tangle envelops the asci and ascogenous hyphae. This loose envelope constitutes the peridium, the forerunner of the compact-walled rind of higher cleistocarpous forms. A quite similar course of development takes place in Gymmoascus reesii, $G$. setosus, and $G$. candidus, according to Dale (1903). 


\section{Aspergillaceae}

Everyone who has attempted to grow organisms on artificial media has encountered Aspergillus and Penicillium, both of which genera are cosmopolitan. Many members of each are adapted, by virtue of their enzyme-producing ability, to grow on a variety of substrata.

Aspergillus. Aspergillus is usually encountered as a conidial fungus. The conidial apparatus consists of globose or elliptical heads borne singly on erect stalks. The heads are covered with radiately arranged bottle-shaped sterigmata that bear conidia in chains. If the sterigmata are branched, the species are considered by some workers to belong to Sterigmatocystis. In a few species the cleistothecial stage has been observed. This stage was first described as belonging to Eurotium, before the connection with the conidial stage had been established, and de Bary proved that E. herbariorum and Aspergillus glaucus are genetically connected. Aspergillus berbariorum, common on bread, forms its cleistothecia on this substrate. Zikes (1922) secured these structures from $A$. oryzae in gelatin cultures enriched with $1 \%$ asparagine, $0.5 \% \mathrm{~K}_{2} \mathrm{HPO}_{4}, 0.25 \% \mathrm{MgSO}_{4}$, and $7.5 \%$ sucrose. Members of the $A$. nidulans group commonly form cleistothecia.

Sexual reproduction. The essential features of cleistothecial formation were long ago observed by de Bary (1854) and were verified by Fraser and Chambers (1907) and Dale (1909). In Aspergillus repens and $A$. berbariorum the ascogonium develops as a hyphal branch. It becomes septate, the terminal portion being the trichogyne, and each cell is multinucleate. At the same time a multinucleate antheridium, formed on another branch, winds spirally around the ascogonium. The antheridium may fuse with the trichogyne and become paired, with an antheridial and an ascogonial nucleus in each pair. If fusion does not occur, the ascogonial nuclei become paired. In any event ascogenous hyphae grow out from the ascogonium and eventually bear irregular clusters of asci. Dangeard (1907) found no antheridium in $A$. flavus and $A$. fischeri. In these species the cells of the ascogonium become binucleate, and pairs of nuclei migrate into the ascogenous hyphae as they form.

Classification. Classification of species of Aspergillus is diffi- 
cult. Thom and Church (1926) divided them into the following groups: (a) A. glanıcus group, (b) A. nidulans group, (c) A. fumigatus group, (d) A. niger group, (e) A. flavus-oryzae group, (f) A. clavatus group, (g) A. ochraceus group, (b) $A$. wentii group, (i) A. flavipes group, and $(j) A$. versicolor group. Color
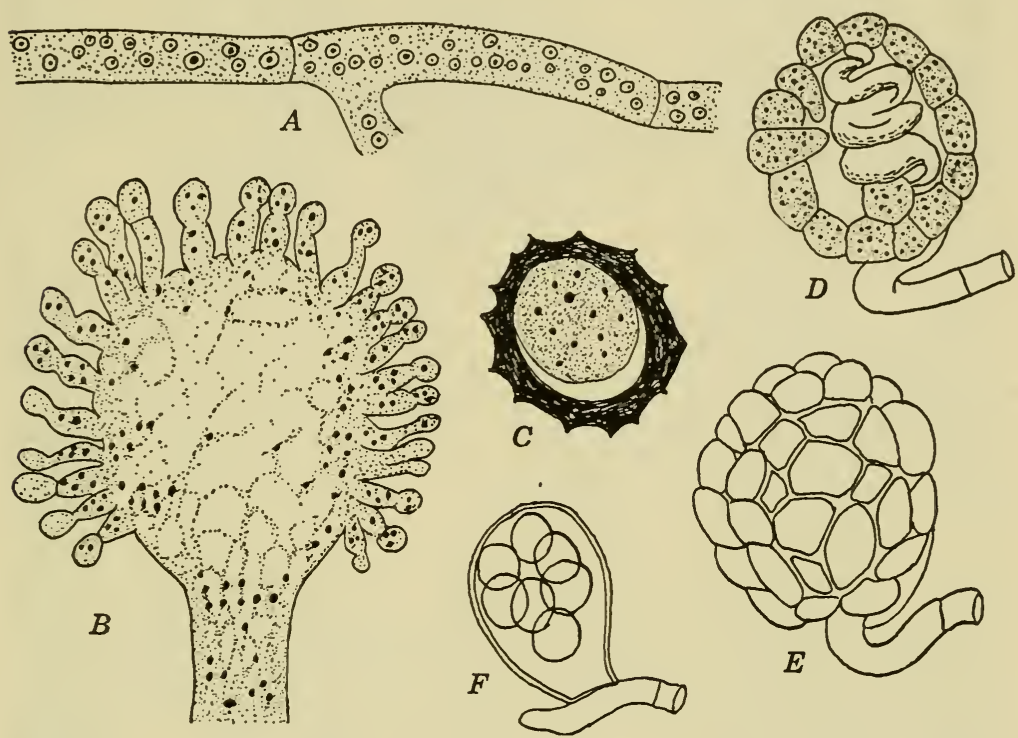

Fig. 52. Aspergillus repens. A. Segment of multinucleate hypha. $B$. Sectional view of conidiophore, which is multinucleate throughout. C. Ascospore in optical section, which is also multinucleate and has thick verrucose wall. D. Section of young sclerotium showing ascogonial coil. $E$. Same section as $D$ in surface view. $F$. Ascus. ( $A$ and $C$ after Dale, $B$ after Fraser and Chambers, others after de Bary.)

of stalks and heads, shape of heads, shape of conidia, smoothness or roughness of stalks, and one or two series of sterigmata constitute the features employed in separating these groups. In a recent account [Thom and Raper (1945)] the genus is divided into 14 groups, and the synonymy of all valid species is recorded.

Important species and their activities. Aspergillus niger is associated with a rot of pomegranates [MacMurran (1912)] and of figs [Hodgson (1918)] and dates. It also causes decay of stored tobaccos and cigars. Aspergillus glaucus, A. flavus, A. oryzae, and $A$. wentii are all associated with the spoilage of walnuts, 


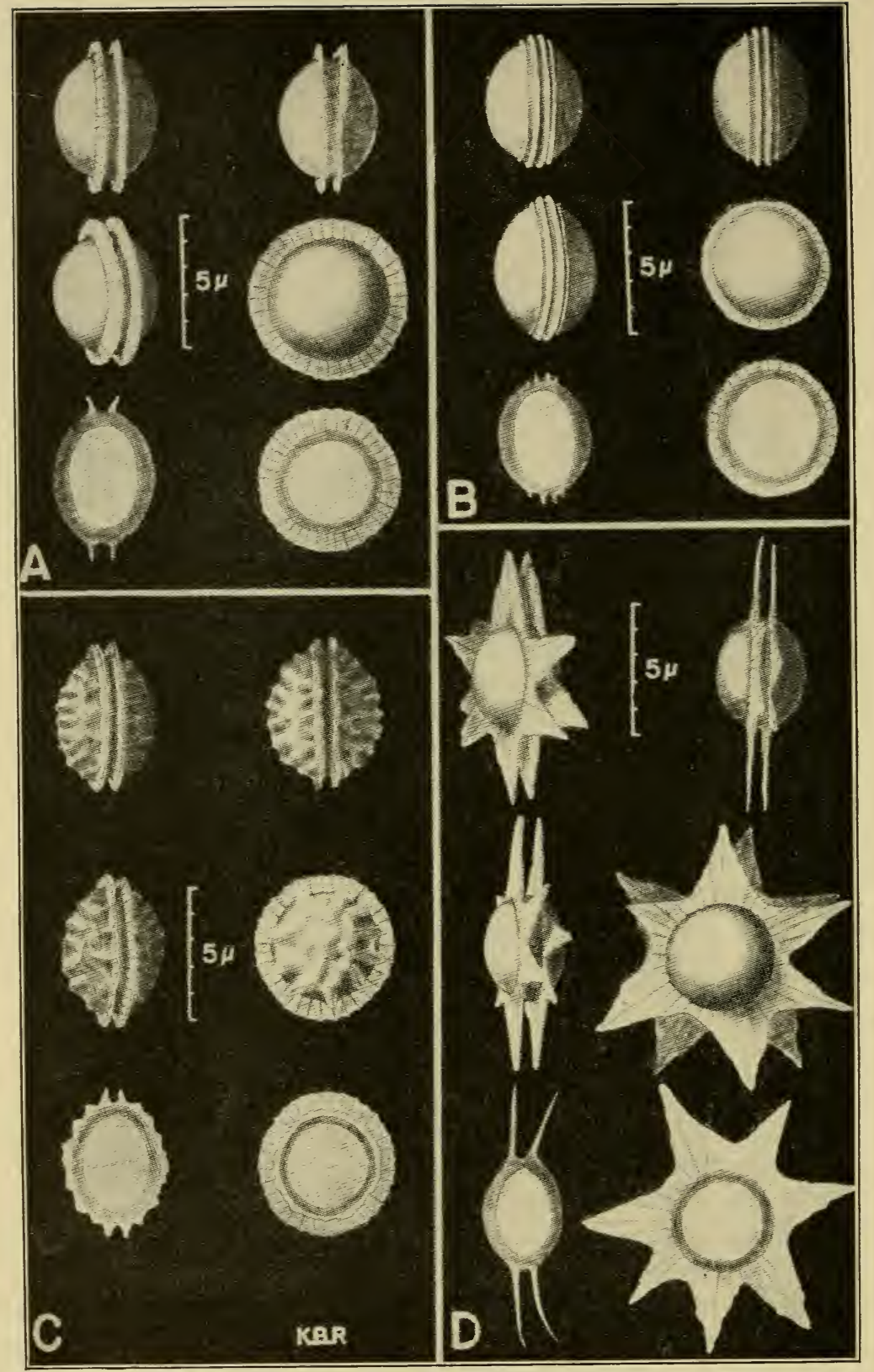

Fig. 53. Ascospores of different species of Aspergillus. $A$. A. nidulans. B. A. quadrilineatus. C. A. rugulosus. D. A. variaecolor. (Courtesy K. B. Raper.) 
pecans, Brazil nuts, and chestnuts. Aspergillus glaucus occurs on stale bread and on gloves, shoes, or soiled clothes that are stored under conditions of high relative humidity. Aspergillus oryzae is utilized in the saccharification of rice starch in making alcohol. It is also used, as is $A$. niger, in commercial production of citric acid and other organic acids. Aspergillus fumigatus, $A$. flavus, $A$. niger, and $A$. nidulans occur within the human ear, causing otomycosis. Aspergillus fumigatus causes involvement of the lungs of persons occupied as hair combers or feather dressers or employed in force-feeding fowls or preparing furs for clothing. The same organism causes pneumonic symptoms in canaries, grouse, and other birds, appearing at times in epidemic proportions.

Penicilliun. There are about 600 named species of Penicillium, many of which are synonymous. Thom (1930) would reduce the number of species to less than 200. These organisms are commonly known as "blue mold" or "green mold" and are universally present on decaying organic matter. The conidiophores have the appearance of tiny brooms, with chains of conidia as the tips of the brooms. The branches of the broom divide and redivide several times and terminate in verticels of sterigmata. The sterigmata, because of their bottle-shape, are termed phialides. The conidia adhere in long chains, sometimes of 100 or more elements.

Sexual reproduction. Brefeld's (1874) account of ascocarpic development in Penicillium, presumably $P$. glaucum, has been verified in essential details by subsequent investigations. Pairs of short hyphae spirally coiled about each other are the antheridia and ascogonia. These are invested by yellowish sclerotia constituted of three or four layers of cells. Three kinds of hyphal elements make up the sclerotial interior: (1) large septate hyphae, the ascogonia; (2) ascogenous hyphae with short lateral branches originating from the ascogonia; and (3) very slender hyphae that Brefeld thought functioned to nourish the asci. Dodge (1933) observed these hyphal types in P. brefeldianum but found that asci may also arise from the tips of the slender hyphae. The cells of the ascogenous hyphae swell to become asci, and for this reason the asci have the appearance of being in monilioid chains. In mounts made by crushing cleistothecia, aggregates of asci may be readily obtained. 
Although cleistothecial formation is not known to occur generally among species of Penicillium, it is of rather common occurrence in certain ones, notably $P$. avellaneum, $P$. spiculisporum, $P$. luteum, $P$. glaucum, $P$. brefeldianum, and $P$. javanicum.

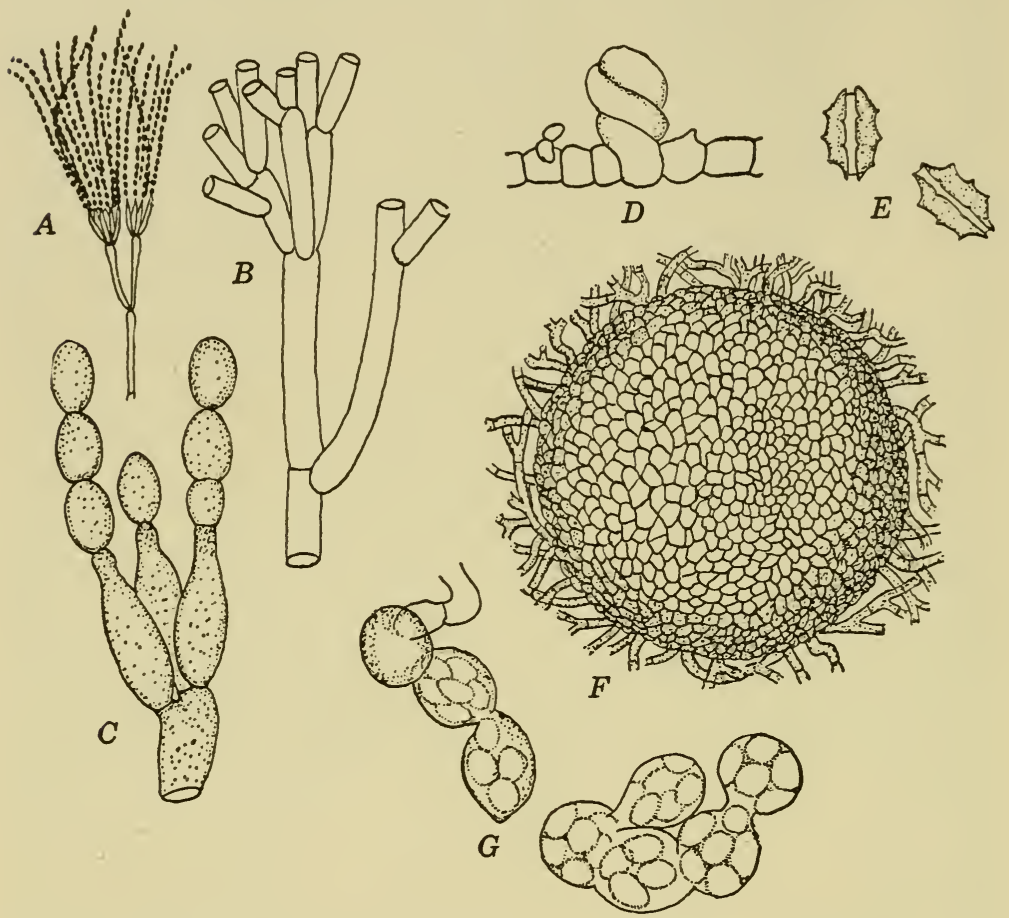

FIg. 54. Development of Penicillium. $A, B$, and $C$. Conidiophores and conidia of $P$. roqueforti. D, E, F, and G. P. crustaceum. (Adapted from Brefeld.) D. Coiled antheridial and ascogonial hyphae. E. Ascospores. $F$. Cleistothecium in surface view. G. Clusters of asci.

Classification. The treatises by Thom (1910, 1930) bring together for the systematist means for identification of this difficult group of species. He treats Penicillium as a form genus, for the reason that so few species are known to possess a perfect stage. The nature of the colonies (whether, for example, they are velvety, compact, or arachnoid), the type of branching of conidiophores, the production of sclerotia, the degree of spreading or compactness of the penicillus, and the color of conidia 
en masse, are among the characteristics employed in separating the assemblage into groups of species.

Important species and their activities. Penicillium expansum is responsible for a great deal of the spoilage of apples, pears, and grapes in storage. Two species of Penicillium, P. italicum, a
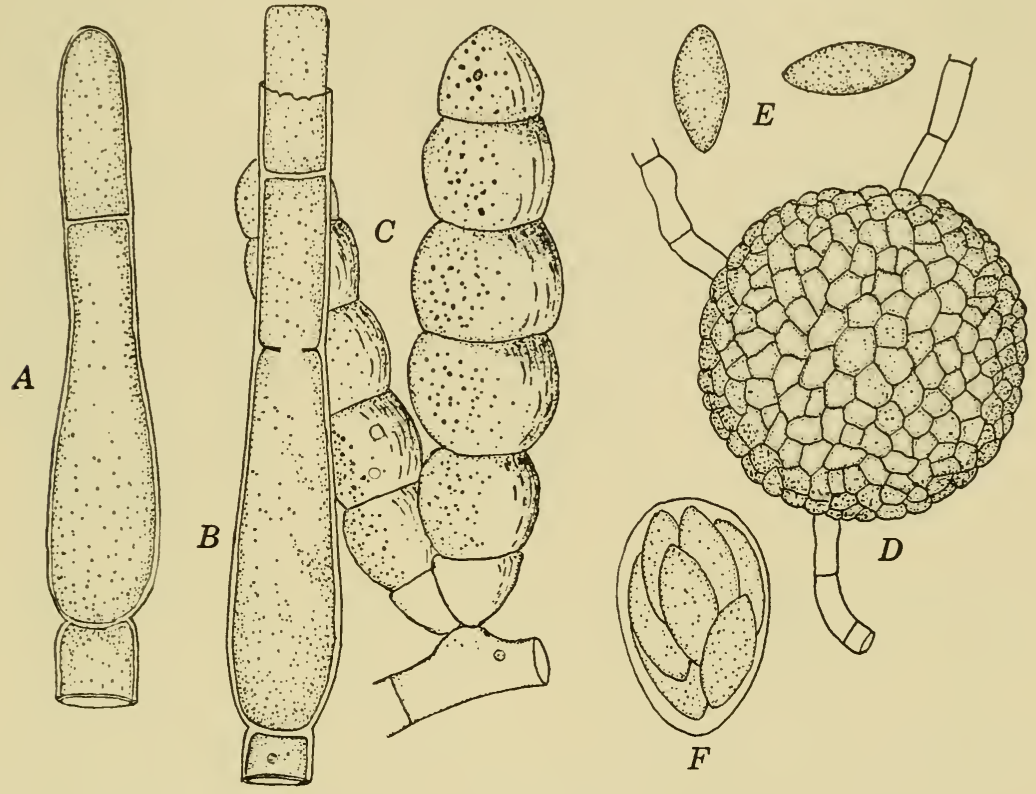

Fig. 55. $A$ and B. Stages in endoconidial formation by Thielaviopsis basicola. C. Chlamydospores of T. basicola. (After Brierley.) D. Cleistothecium of Tbielavia basicola. E. Ascospores. F. Ascus.

blue-green mold, and $P$. digitatum, an olive-green mold, occur on citrus fruits in storage. Penicillium purpurogenum spots print paper, books, and engravings. Textile fibers, paper pulp, and lumber are stained and discolored, and consequently lowered in market value, by species of Penicillium. Frequently P. crustaceum has been isolated in chronic pulmonary disorders in man, but its etiologic role in human disease has not been established. By hydrolyzing the butter fats which produce such volatile acids as caproic, acetic, butyric, and capric, P. roqueforti imparts to cheese a piquant flavor. Penicillium camemberti flavors camembert cheese by means of the products of hydrolysis of casein. 
Penicillium notatum is used in the preparation of the best-known antibiotic, penicillin.

Thielavia. The several species of Thielavia appear to be closely related to Aspergillus and Penicillium. The best-known member is T. basicola, considered by Gilbert (1909) and others the cause of black-root rot of tobacco and various leguminous plants. McCormick (1925) presented evidence, however, that $T$. basicola is not genetically connected with a conidium- and chlamydospore-producing fungus, Thielaviopsis basicola, with which it is associated in nature. This genetic relationship, or lack of it, might well be given further consideration.

The development of ascocarps in Thielavia terricola and $T$. sepedonium was studied by Emmons (1932). Cultures from single spores give rise to ascocarps, which begin as hyphal coils. The distal ends of these hyphae recurve, and cross walls are laid down. The tip or ultimate cell of each is just beyond the one that makes up the crook or crosier. This crosier is therefore penultimate. Each cell of the ascogenous hypha is uninucleate except the penultimate one, which has two nuclei. Such binucleate cells enlarge, and each becomes an ascus. During this process there is first a fusion of the two nuclei, followed by three nuclear divisions, and the cutting out of ascospores.

The production of so-called "endoconidia" was studied by Brierley (1915). He found that the first conidia are formed endogenously, but that the tip of the conidiophore bursts to liberate these conidia. The conidium-producing cell is therefore endogenous and produces chains of conidia.

\section{Onygenaceae}

One genus, Onygena, with 6 species comprises this family. Its habitat is hair, hoofs, fur, feathers, horns, claws, and other animal materials. The ascocarps of 4 species are stalked and capitate. A powdery coating of gemmae may cover the young heads. When they are mature, sterile hairs occur, interspersed with the asci, which disintegrate. The heads open irregularly, so that the ascocarps look like tiny puffballs or else like sporangia of slime molds. Little is known about the developmental history of Onygena beyond the information contributed long ago by Ward (1899). 


\section{Elaphomycetaceae}

Dodge (1929) states that 2 genera containing about 30 species comprise this family. The yellow to brown ascocarps are hypogeal, resembling truffles, although the asci are scattered or clustered in nests rather than in layers, as they are in truffles. The peridium is thick and verrucose, and at maturity a powdery mass of spores fills the interior.

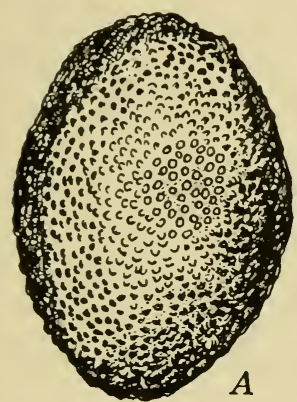

A
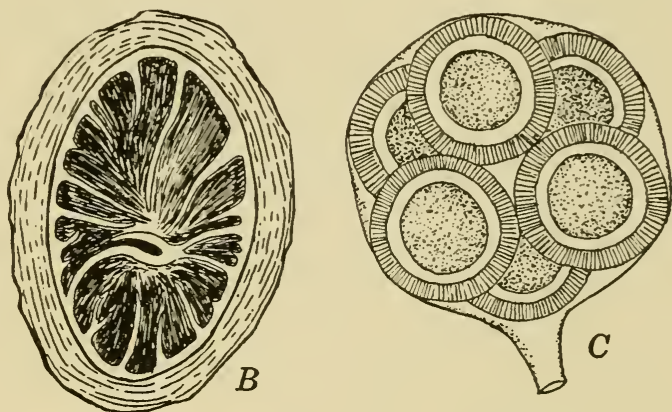

Fig. 56. Elaphomyces cervinus. A. Surface view of ascocarp. B. Ascocarp in section. The veins are corered with asci. C. Spherical ascus with thickwalled ascospores. (After Rees and Fisch.)

Some species of Elaphomyces, notably $E$. cervinus and $E$. granulatus, are known to be mycorrhizal and are associated with the roots of pines, oaks, and beeches. The ascocarps of several are parasitized by species of Cordyceps. In fact, species of Elaphomyces are found only by accident, unless the clavae of the Cordyceps parasitizing them come to the surface of the ground.

\section{Terfeziaceae}

The Terfeziaceae are subterranean fungi, presumably mycorrhizal and apparently limited in range to the Mediterranean region. Their peridium is a thin layer, much narrower than that of the Elaphomycetaceae. The spore mass is not powdery at maturity. According to Lindau, there are eight genera, but many of the species included in them have been found to be truffles and accordingly have been transferred to the Tuberales. 


\section{LITERATURE CITED}

BARY, Anton DE, "Über die Entwickelung und den Zusammenhang ron Aspergillus glaucus und Eurotium," Bot. Zeit., 12:425-434, 465-471, 1854.

Brefeld, O., "Die Entwickelungsgeschichte von Penicillium," Botan. Untersuch. Schimmelpilze, 2: 1-98, 1874.

Brierley, WV. B., "The 'endoconidia' of Tlielaria basicola Zopf," Ann. Botany, 29: 483-493, 1915.

Dale, E., "Observations on the Gymnoascaceae," Ann. Botany, 17: 571-596, 1903.

"On the morphology and cytology of Aspergillus repens de Bary," Ann. Mycol., 7: 215-225, 1909.

Dangeard, P. A., "L'origine du périthecè chez les Ascomycetes," Botaniste, 10: 1-385, 1907.

Dodge, B. O., "The perithecium and ascus of Penicillium," Mycol., 25:90104, 1933.

Dodge, C. W., "The higher Plectascales," Ann. Mycol., 27: 145-184, 1929.

Emmons, C. W., "The development of the ascocarp in two species of Thielavia," Bull. Torrey Botan. Club, 59:415-422, 1932.

Fraser, H. C. I., ANd H. S. Chambers, "The morphology of Aspergillus berbariorum," Ann. Mycol., 5: 419-431, 1907.

Gilbert, W. IV., "The root rot of tobacco caused by Thielaria basicola (B. and Br.) Zopf," U. S. Dept. Agr., Bur. Plant Industry Bull., 158. 55 pp. 1909.

Hodgson, R. W., "A Sterigmatocystis smut of figs," Plbytopatbology, 8: 545-546, 1918.

MacMurran, S. M., “A new internal rot of pomegranate," Phytopatbology, 2: $125-126,1912$.

McCormick, Florence A., "Perithecia of Thielaria basicola Zopf in culture and the stimulation of their production by extracts from other fungi," Conn. Agr. Exp. Sta. Bull., 269: 539-544, 1925.

Naxnizzi, A., "Richerche sull'origine saprofitica dei funghi delle tigne. II. Gymmoascus gypseum, sp. n., forma ascofora del Sabouraudites (Acborion) gypseum (Bodin) Ota et Langeron," Atti accad. fisiocritici Siena, X, 2: 89-97, 1927.

Thom, Charles, "Cultural studies of species of Penicillium," U. S. Dept. Agr., Bur. Animal Ind. Bull., 118. 109 pp. 1910.

The Penicillia. xi +644 pp. Williams and Wilkins Co. 1930.

Thom, Charles, and M. B. Church, The Aspergilli. ix +272 pp. Williams and Wilkins Co. 1926.

Thom, Charles, and K. B. Raper, Mamual of the Aspergilli. 373 pp. Williams and Wilkins Co. 1945.

WARD, H. M., "Onygena equina Willd., a horn-destroying fungus," Plsil. Trans. Roy. Soc. London, B, 191: 269-291, 1899.

Zikes, H., "Über die Perithecienbildung bei Aspergillus oryzae," Zentr. Baki. Il Abt., 56:339-343, 1922. 


\section{Myriangiales}

The Myriangiales are stromatic angiocarpous fungi. The stromata are cushion-shaped in many of them, and the asci are borne irregularly dispersed, either singly or in layers within chambers or locules. Many of these fungi occur on leaves, fruits, and bark, and some are parasitic upon insects, especially in the tropics.

Relatively few species have been thoroughly studied; hence mycologists are not in accord on which species properly belong in the Myriangiales. Speculations concerning relationships to other orders and to phylogeny are believed to be quite futile because of this lack of knowledge. For the present purpose the following families are regarded as comprising the order: Myriangiaceae, Elsinoeaceae, Saccardiaceae, Dothioraceae, and Pseudosphaeriaceae. These may be separated as follows:

1. Asci arising at different levels

2. Stroma massive, of homogeneous texture, without a rind

Myriangiaceae

2. Stroma effuse, interior gelatinous, exterior crustose Elsinoeaceae

1. Asci arising at one lerel

3. Stroma naked

3. Stroma with crustose rind

4. Multiloculate

4. Uniloculate or perithecium-like

Saccardiaceae

4

Dothioraceae Pseudosphaeriaceae

Myriangiaceae. A recent study by Miller (1938) on the morphology and cytology of Myriangium duriaei and $M$. curtisii provides the basis for an understanding of this family. Both of these species occur as parasites on scale insects that attack Nyssa sylvatica, Carya illinoensis, and other broad-leaved trees in the southeastern United States. Both species of Myriangium possess cushion-like stromata, from the upper surface of which extend aggregates of black cupules. The interior of the cupules consists of thin-walled fungus parenchyma, in which asci are dispersed, one ascus in each locule. As the interascal tissues are weathered away, the asci become exposed, and spores are liberated.

Young ascocarps contain multicellular, coiled ascogones that extend to the surface of the stromata. From the archicarps numerous ascogenous hyphae arise and bud off binucleate cells that are to become asci. In Myriangium duriaei there is a single 

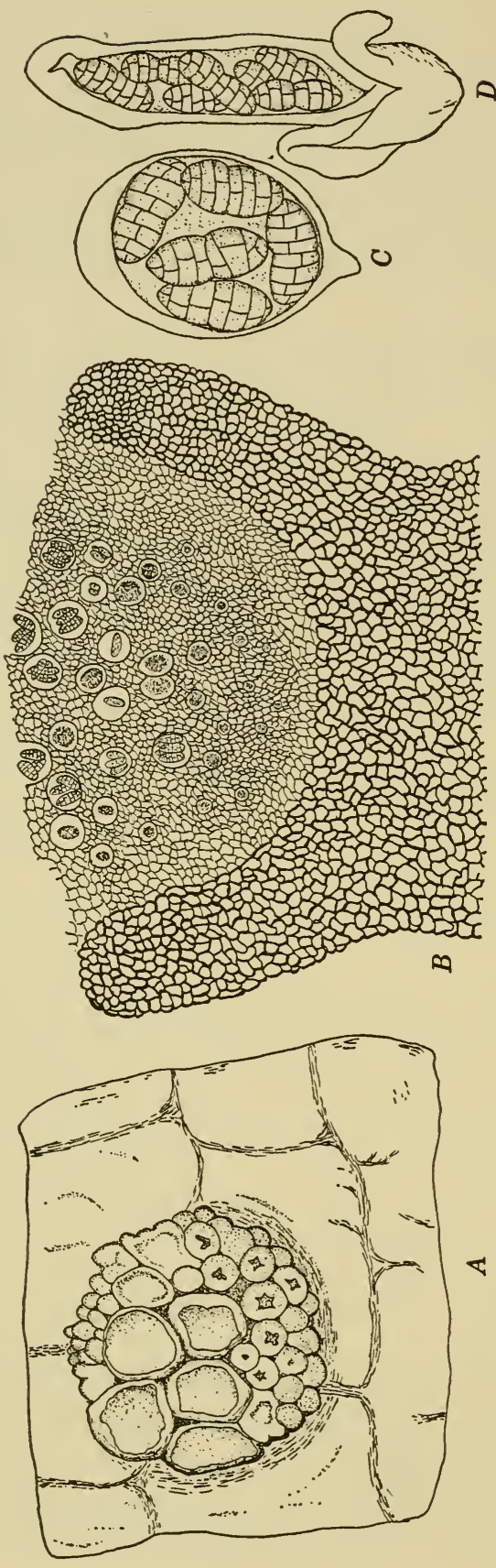

त⿱

क ०

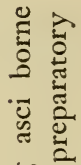

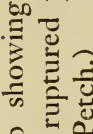

- $=1$

ปू.

$\approx$ 出

흘

$\frac{\pi}{2} 0$

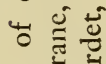

으ㄹㅡㅡ를

¿

ㅍำ

.

히 엄

๑

$\dot{\infty} \approx$

ไู่

ర్ల స

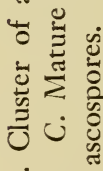

षن்

$\therefore$.

픈

ड

इ

. 犬ู

ปี

ลे क

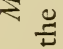

in.

范 
archicarp in each of the thirty to fifty cupules on each stroma, whereas in $M$. curtisii there are many in each archicarp. Miller (1938) is uncertain whether antheridia are associated with the coiled ascogones.

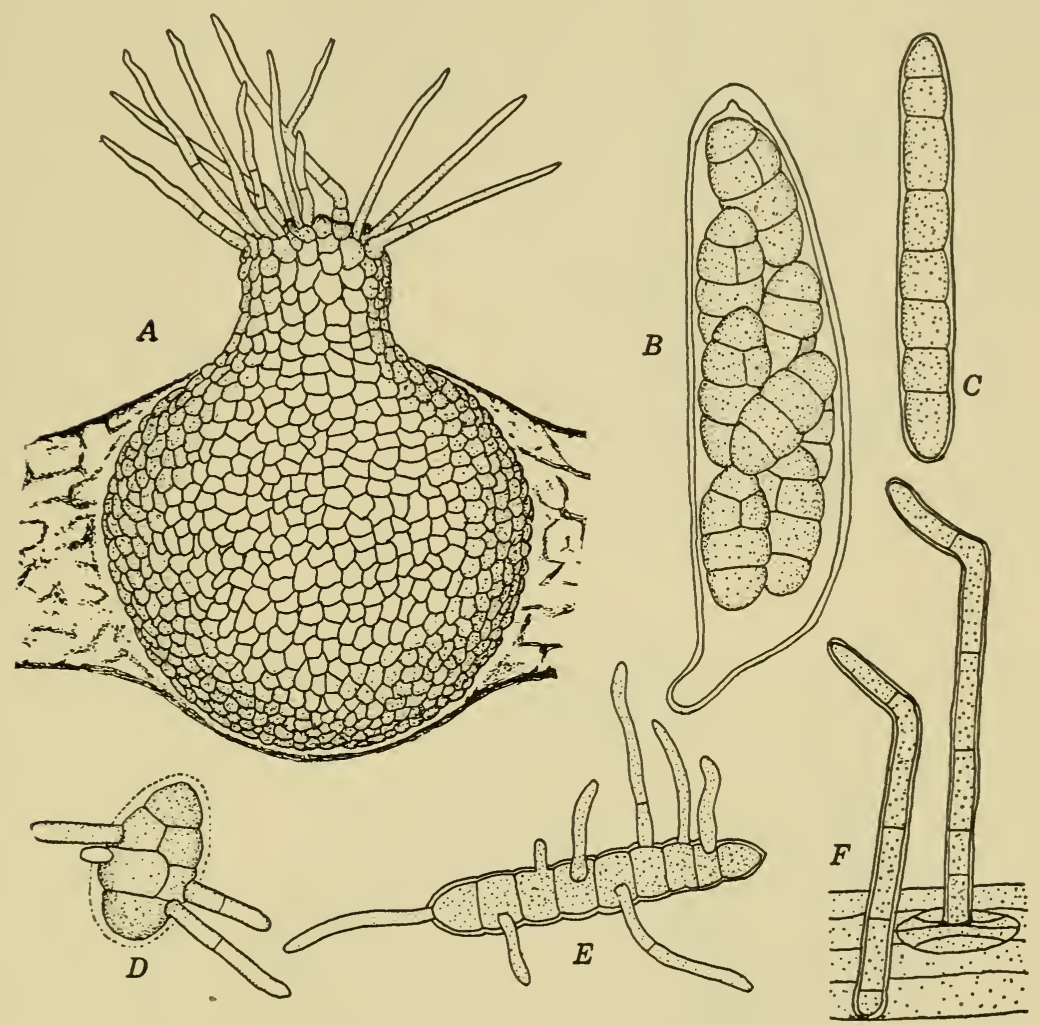

FIG. 58. Pyrenophora tritici-repentis. A. Perithecium in surface view, immersed within tissues of wheat leaf. B. Mature ascus. C. Conidium of the Helminthosporium stage. D. Germinating ascospore. E. Germinating conidium. $F$. Conidiophores extending from the surface of leaf of wheat.

They may emerge through the stomata. (Adapted from Drechsler.)

The morphological characteristics presented by the Myriangiaceae indicate that they should be placed close to the Aspergillales.

Elsinoeaceae. This family, also called Plectodiscellaceae, contains several very important plant pathogens. Woroninchin 


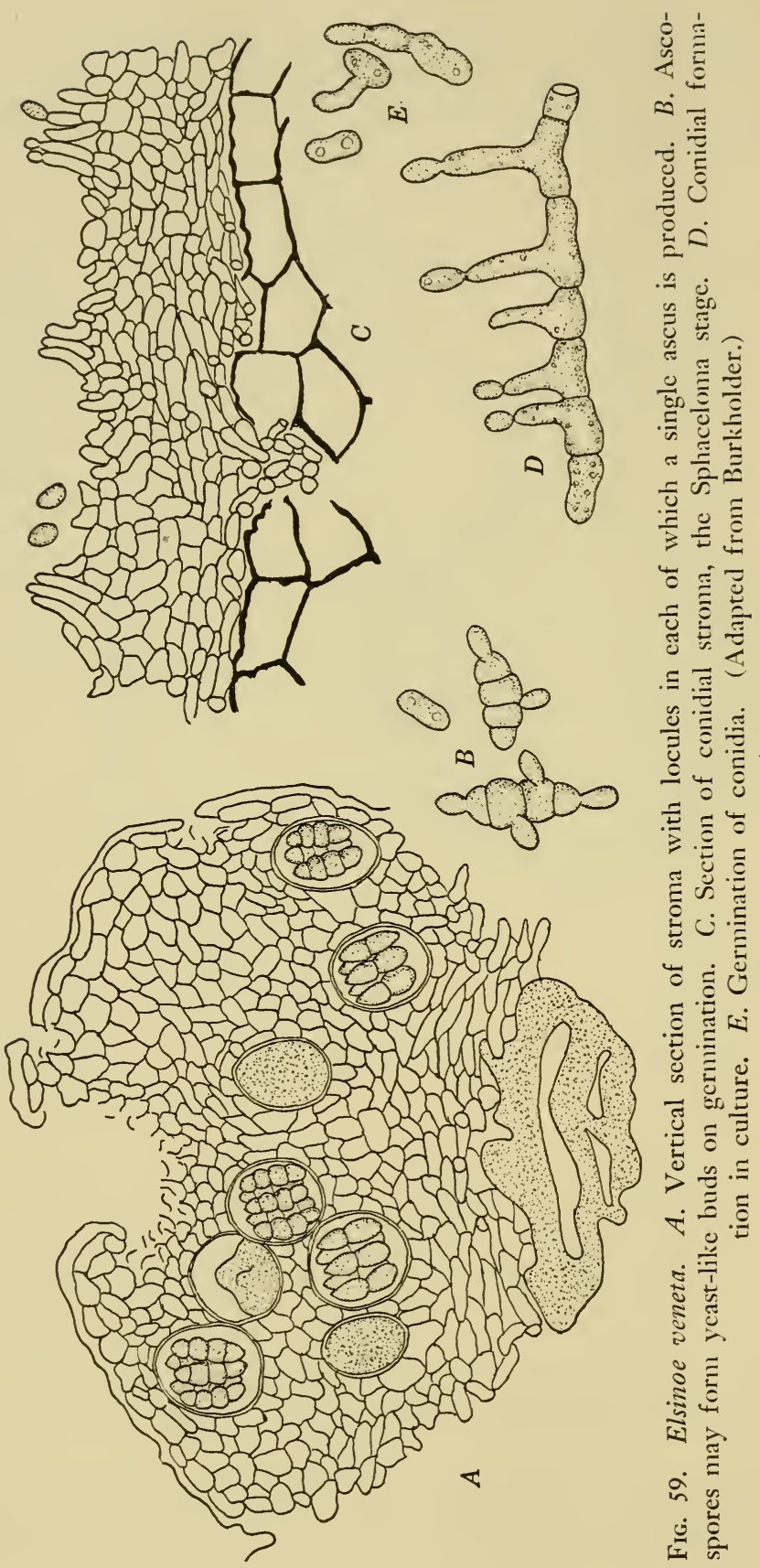


(1914) established the Plectodiscellaceae, using as the type Plectodiscella piri, which causes a leaf spot of apple and pear in the Caucasus. Three years later Burkholder (1917, 1917a) described the ascogenous stage of the raspberry anthracnose pathogen, designating it Plectodiscella veneta, which had previously been known in its conidial aspect as Gloeosporium venetum. Burkholder showed that monascous locules occur in the stromata which form within the decaying tissues. These stromata become erumpent at maturity and the asci are freed by the wearing away of overlying stromatic tissues, which readily become gelatinous.

In 1932 Jenkins (1932) pointed out that the genus Plectodiscella is synonymous with Elsinoe, previously established, and for this reason she changed the name of IVoroninchin's Plectodiscella piri to Elsinoe piri. She also established that the conidial stages of species of Elsinoe belong to Sphaceloma and not to Gloeosporium, Cladosporium, and other form genera to which they had been assigned. As a result of these findings, Jenkins turned to a critical examination of various related species. She found that the "scab" of Phaseolus lunatus from Cuba is caused by Elsinoe canavaliae [Jenkins (1931)] and is identical with an organism attacking species of Canavalia in Java, Ceylon, the Malay Peninsula, and the Philippines. Avocado scab is caused by Sphaceloma perseae [Jenkins (1935)]. The scab disease of lemons, sour oranges, and certain other citrus fruits [Bitancourt and Jenkins (1936)] occurring throughout all citrus-growing regions, is induced by Elsinoe fawcetti (Cladosporium citri), whereas that of sweet orange is caused by E. australis [Bitancourt and Jenkins (1937)].

Although the type of angiocarpous development in the Elsinoeaceae apparently is quite like that in the Myriangiaceae, cytologic details are still lacking, and nothing is known of their sexuality.

Dothioraceae. The structure of members of this family, including Dothiora, Bagnisiella, Bagnisiopsis, and Botryosphaeria, was established by Theissen (1916) largely from a study of Botryosphaeria. He found wide structural variation in this genus. In $B$. inflata the locules are scattered throughout the stromatic tissue. In B. mascarensis they are seated upon the surface of the stroma at maturity. In $B$. ribis the locules are left standing on stipes, and each one is perithecium-like. 

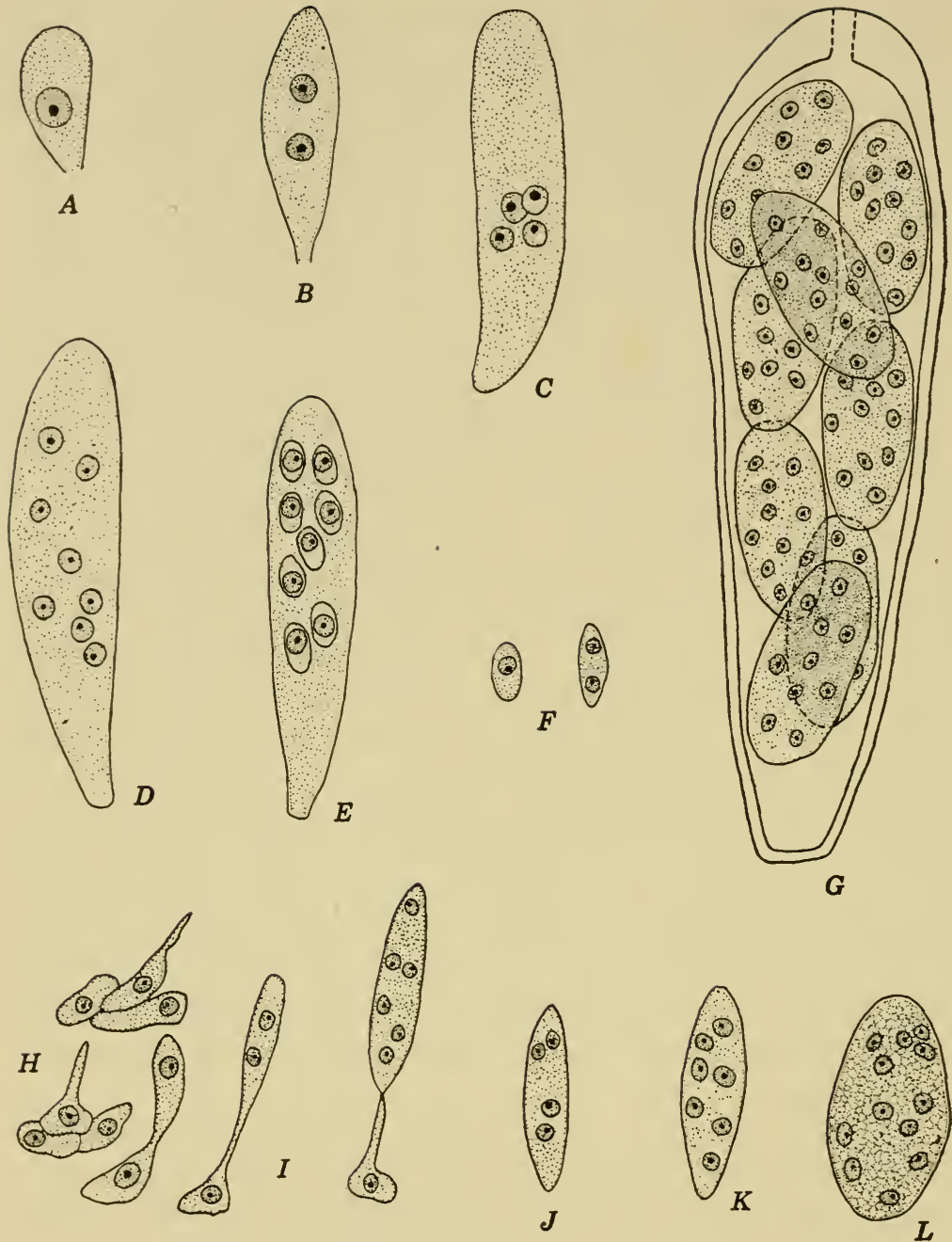

FIG. 60. Botryosphaeria ribis. A. Young ascus containing the primary ascus nucleus. $B$. Binucleate ascus. $C$. Ascus in the four-nucleate stage. $D$. Ascus containing eight free nuclei. $E$. Eight uninucleate ascospores have been delimited. $F$. Uninucleate and binucleate ascospore. $G$. Mature ascus with multinucleate ascospores. $H$ and $I$. The uninucleate cells from the inner pycnidial wall of the Dothiorella stage function as conidiophores. Various stages in the formation and abstriction of multinucleate conidia are shown. $J, K$, and $L$. Stages in multinucleate condition of ascospores. 
Botryospbaeria ribis, first described as the cause of currantcane blight, is now known to parasitize the stems of over 50 species of woody plants. Its pycnidial stage, Macrophoma, appears on recently formed lesions. Accompanying the pycnidia is another stage, Dothiorella, bearing minute spores in stromatic locules. These microconidia are believed to be spermatia [Wolf

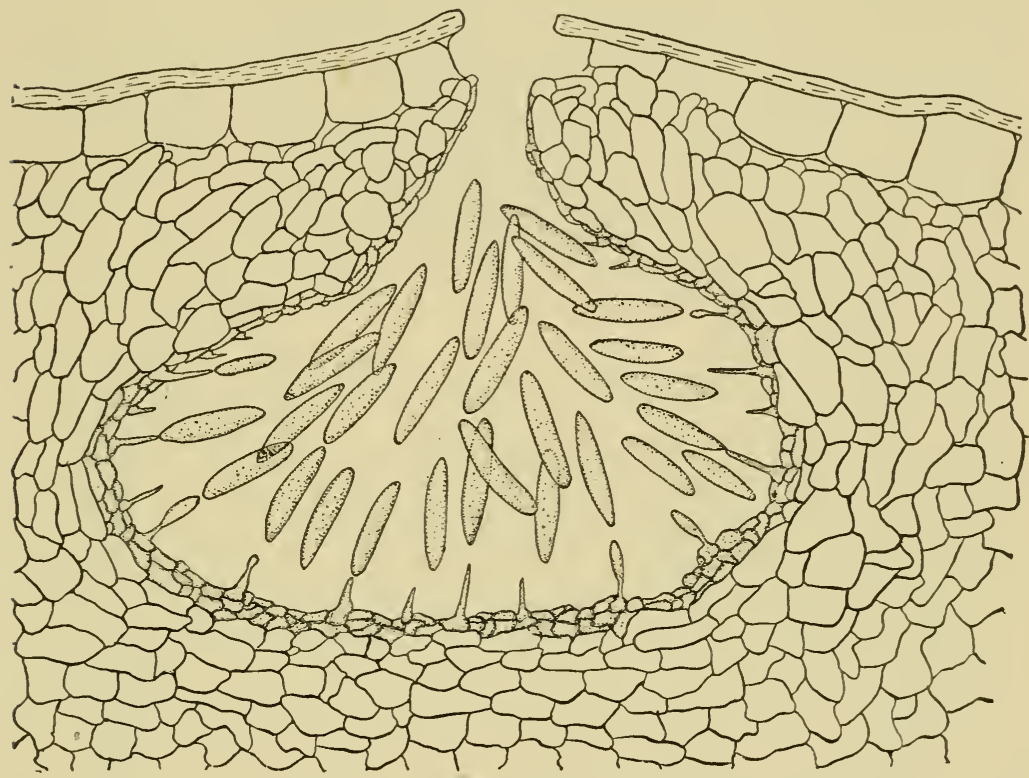

Fig. 61. Stroma in section showing pycnidium of Dothiorella stage of Botryosphaeria ribis with conidiophoral cells and conidia.

and Wolf (1939)]. Perithecial locules are initiated at the same time that spermatia are being produced. This fungus produces multinucleate conidia and multinucleate ascospores [Wolf and Wolf (1939)], a condition like that described years ago for Aspergillus repens by de Bary.

Pseudosphaeriaceae. The Pseudosphaeriaceae comprise organisms that have until recently been regarded as Sphaeriales. Interthecal tissues remain, however, after the asci have matured. These tissues are compressed as the asci enlarge and have been designated pseudoparaphyses. Their stromata are spatially separated, that is, are not fused, and are therefore perithecium-like in appearance. 
Included in the Pseudosphaeriaceae are such genera as Pleospora, having approximately 300 species, Didymella, having over 200 species, Leptosphaeria, having over 500 species, and Pyre-

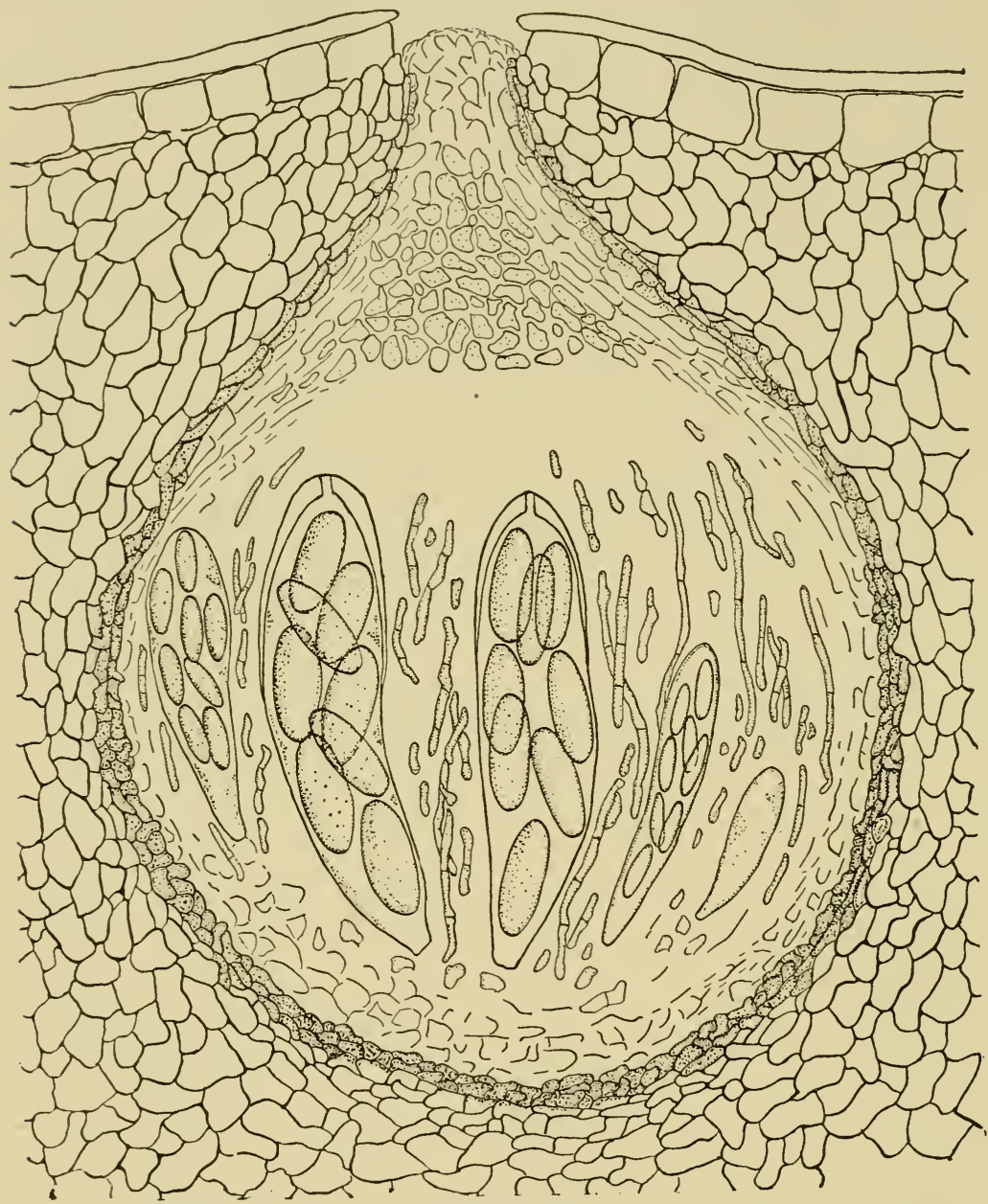

FIg. 62. Section of stroma of Botryosphaeria ribis, showing a perithecial locule with asci and paraphyses.

nophora. Most of them are saprophytic on plants. Some species of Pleospora have been shown to possess conidia belonging to Alternaria and Macrosporium, in both of which imperfect genera are many plant pathogens. Various grasses are parasitized by 
species of Helminthosporium, several of which, as Drechsler (1923) established, are genetically related to Pyrenophora.

\section{LITERATURE CITED}

Bitancourt, A. A., And A. E. Jenkins, "Elsinoe fawcetti, the perfect stage of the citrus-scab fungus," Phytopatbology, 26:393-396, 1936.

"Sweet-orange-fruit scab caused by Elsinoe australis," J. Agr. Research, 57: 1-18, 1937.

Burkholder, W. H., "The anthracnose disease of the raspberry and related plants," Cornell Agr. Expt. Sta. Bull., 395: 157-183, 1917.

"The perfect stage of Gloeosporium venetum," Plsytopatbology, 7: 83-91, 1917a.

Drechsler, C., "Some graminicolous species of Helminthosporium, I," J. Agr. Research, 24: 641-740, 1923.

Jenkins, A. E., "Lima-bean scab caused by Elsinoe," J. Agr. Research, 42: 13-23, 1931.

"Elsinoe on apple and pear," J. Agr. Research, 44: 689-700, 1932.

"Sphaceloma perseae, the cause of avocado scab," J. Agr. Research, 49 : 859-869, 1935.

Miller, J. H., "Studies in the development of two Myriangium species and the systematic position of the Myriangiales," Mycol., 30: 158-181, 1938.

Theissen, F., "Studien über Botryosphaeria," Ann. Mycol., 14: 297-340, 1916. Wolf, F. T., ANd F. A. Wolf, "A study of Botryosplacria ribis on willow," Mycol., 31:217-227, 1939.

Woroninchin, N. N., "Plectodiscella piri, der Vertreter eines neuen Ascomyceten-Gruppe," Mycol. Centrb., 4: 225-233, 1914.

\section{Erysiphales}

Among the Erysiphales, also called the Perisporiales, are two important families: Erysiphaceae, or powdery mildews, and Meliolaceae (Perisporiaceae), or sooty molds. Essentially all are limited in habitat to the surface of green plants, and none appears to have been cultivated on artificial media. Their ascocarps are cleistothecia in which the asci are arranged in an orderly layer, rather than being dispersed as in the Eurotiales.

Erysiphaceae. The powdery mildews, except Erysiphe graminis on various grasses, are limited in host range to dicotyledonous angiosperms. The monograph of Salmon (1900) lists 49 species and 11 varieties, occurring on about 1500 host species. Many of those listed in Saccardo's Sylloge Fungorum have been reduced to synonymy by Salmon. Six genera, Erysiphe, Micro- 
sphaera, Podosphaera, Phyllactinia, Sphaerotheca, and Uncinula, are generally recognized. They are separated on the bases of type of cleistothecial appendages and number of asci within each cleistocarp.
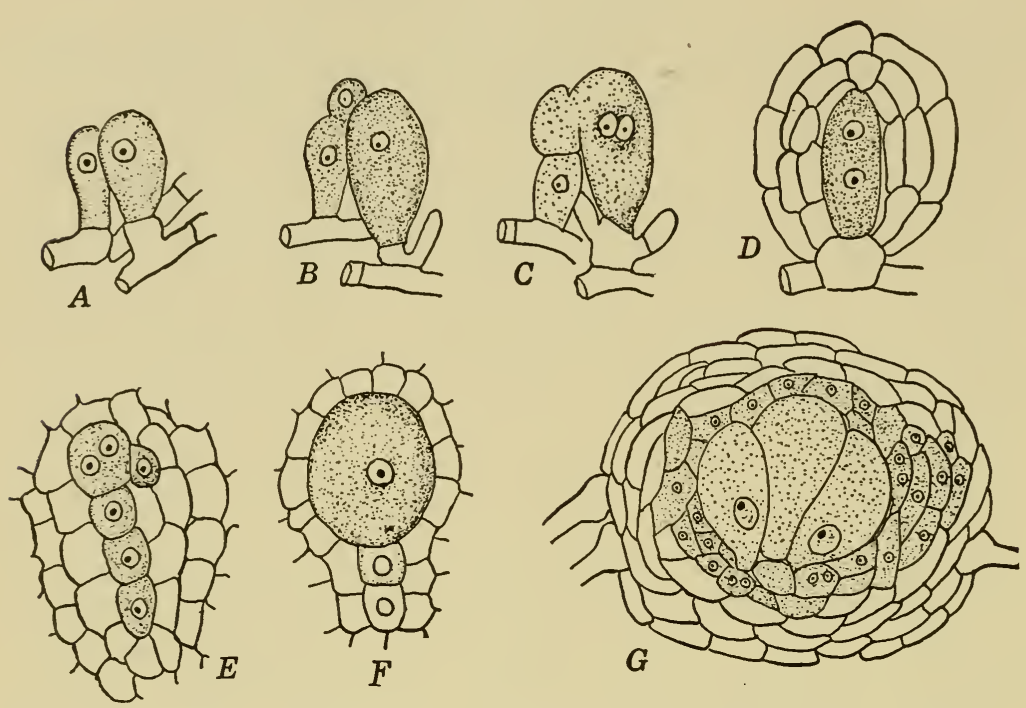

Fig. 63. Stages in the initiation of cleistocarps in Erysiphaceae. $A$ to $F$, Sphaerotheca bumuli. $A$. Antheridial and oogonial branches. $B$. Large oogonium and small antheridium at apex of antheridial branch. C. Migration and association of nuclei of opposite sex; branches at base of oogonium starting to form envelope. D. A later stage in which oogonium is enclosed within wall. $E$. Oogonium has become a series of cells, the penultimate of which is to become an ascus; contains a pair of nuclei that will fuse. $F$. Young ascus containing fusion nucleus. Peripheral cells are nurse tissue. G. Section of young cleistocarp of Erysiphe polygoni. (Adapted from Harper.)

The appendages are flexuous, unbranched hyphae in Erysiphe, Sphaerotheca, and Leveillula; they are unbranched but hooked or coiled at the tip in Uncinula, dichotomously branched at least at the tips in Microsphaera and Podosphaera, and needle-shaped with bulbous bases in Phyllactinia. Each cleistothecium of Podosphaera and Sphaerotheca contains only a single ascus.

Mycelium and conidial stage. The name powdery mildew appropriately describes the white, mealy appearance of affected leaves, stems, flowers, and fruits, the whiteness being imparted 
by the profusion of external mycelium and conidia. The arachnoid mycelium, composed of uninucleate cells, with few exceptions is external to the host tissues. The host cells are penetrated by haustoria, one or more entering each epidermal cell. In Uncimula salicis the penetrating tubes may also pass through the epidermal cells and form haustorial expansions within the cells of the mesophyll [Smith (1900)]. In most species the haustoria are bulbous and uninucleate. In Erysiphe graminis, however, and in certain other species of Erysiphe, notably E. galiopsidis and $E$. cichoracearum, they are ellipsoid, with digitate processes at the ends [Smith (1900)].

Some species of powdery mildews perennate as mycelium. Apple powdery mildews, caused by Podosphaera leucotricha and $P$. oxyacantbae, have been reported to hibernate between the bud scales [Ballard (1914)]. Similarly a series of observations has convinced the writers that the powdery-mildew fungus of crepe myrtle, Lagerstroemia indica, perhaps Uncinula lagerstroemiae, overwinters as mycelium within the buds.

Oidiopsis (Leveillula) taurica is of particular interest because its mycelium is wholly endophytic [Salmon (1906)]. This fungus is endemic to Asia Minor and northern Africa, occurring on many species of plants. This endophytic habit is believed to be an xerophytic adaptation. Its conidiophores emerge through the stomata. In like manner a portion of the mycelium of Phyllactinia corylea occurs between the mesophyll of its numerous hosts.

The conidial stage of most powdery mildews belongs to the form Genus Oidium. Special hyphal branches arise from the leaf surface, and near the tip of each a septum is formed. This apical cell becomes the first conidium in a chain of basipetally abstricted conidia. Each conidium is at first cylindrical, then becomes barrel-shaped, and finally, when ready for dissemination, is elliptical. If moisture is provided, conidia germinate by formation of one or more germ tubes, and within 3 or 4 days new mycelium has grown to the extent of being capable of forming a crop of conidia.

Cleistothecial stage. The origin of cleistocarps of powdery mildews was properly traced and their structure correctly described by de Bary as long ago as 1863 . He employed Sphaerotheca castagnei growing on dandelion and noted that at the 
point of contact of two hyphae a pair of erect branches arises. Each is separated from its parent hypha by a septum. One branch, the oogonium, becomes ellipsoidal; the other remains cylindrical and becomes closely applied to the oogonium, and a cell, the antheridium, is cut off at its apex. The walls at the
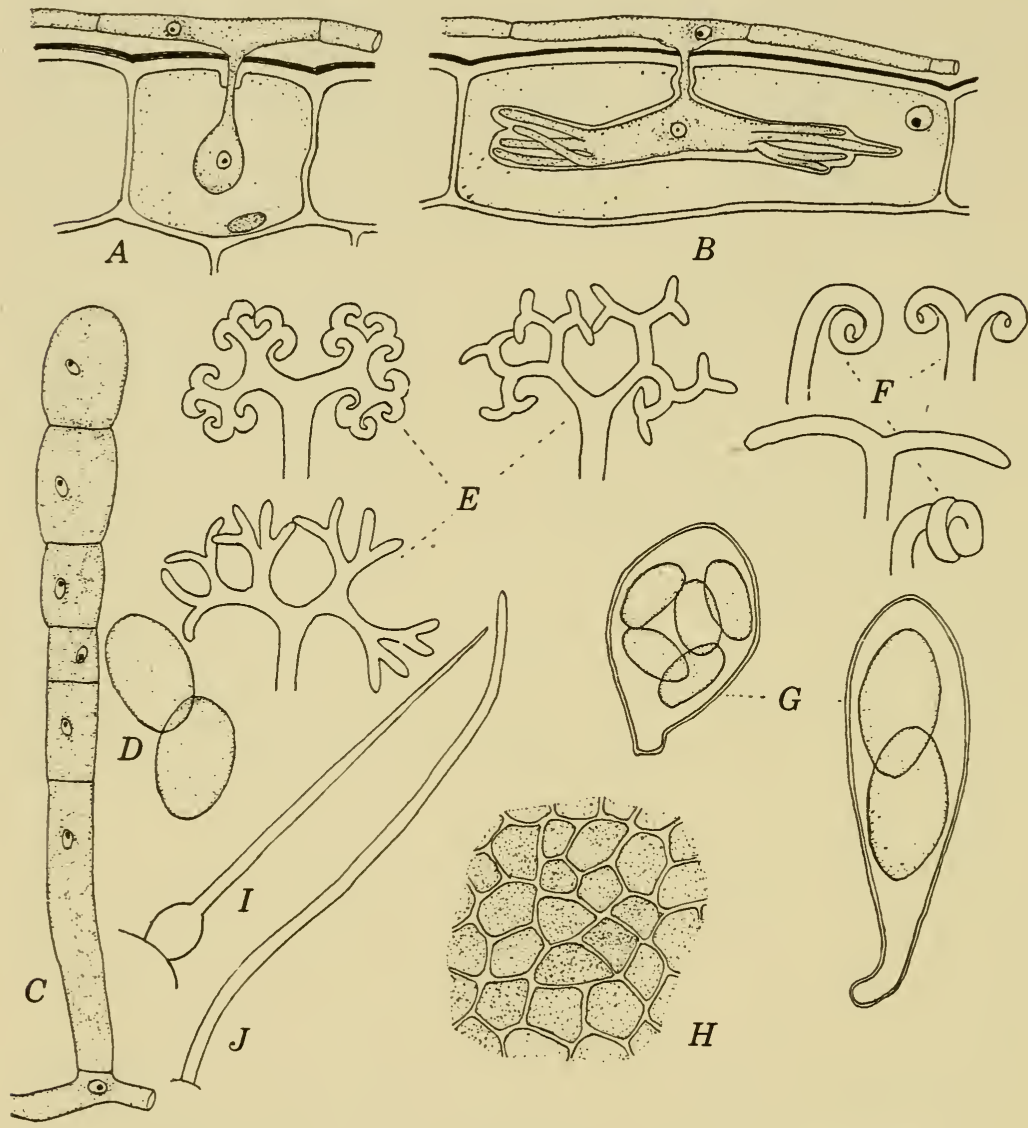

Fig. 64. Structural features of Erysiphaceae. A. Bulbous haustorium, a type common among powdery mildews, in epidermal cell. $B$. Digitately branched haustorium of Erysiphe graminis. $C$ and D. Conidiophore and conidia, the Oidium stage of powdery mildews. E. Types of dichotomously branched tips of appendages. $F$. Types of uncinate or hooked tips of appendages. $G$. Types of asci. $H$. Surface view of cleistocarp wall. I. Appendage with bulbous base as in Phyllactinia corylea. J. Flexuous appendage as among species of Erysiphe. ( $A$ and $B$ adapted from Smith.) 
point of contact of the oogonium and antheridium open by a broad pore, after which the protoplasts intermingle. In Sphaerotheca, bearing a single ascus, there are two cells formed from the oogonial structure, the upper of which becomes the ascus and the lower gives rise to the nurse tissue and wall of the cleistocarp.

Harper $(1895,1905)$ verified these observations of de Bary and contributed many additional cytologic facts in studies based on the same species and on Phyllactinia corylea and species of Erysiphe. He traced the development of antheridia and oogonia, the fusion of nuclei, one from each organ, and the cytologic features that accompany nuclear division within the ascus and delimitation of ascospores. The development in powdery mildew's producing more than a single ascus differs mainly in that the oogonium becomes transformed into a row of cells. Each of these cells becomes an ascus or else gives rise to short branches (ascogenous hyphae), whose penultimate cells become asci.

Certain mycologists, among them Eftimiu (1929), maintain that there is no migration of antheridial protoplast into the oogonium in powdery mildews. In Eftimiu's observations were included Erysiphe galeopsidis, E. tortilis, Uncinula clandestina, and Microsphaera herberidis. . Colson (1938) concluded that the cleistothecia of Pbyllactinia corylea, growing on Corylus avellana, develop apogamously. The antheridial nucleus degenerates within the antheridium. The oogonium becomes four-nucleate by division of its single nucleus. These four nuclei become separated by walls, with two nuclei in the middle cell. After further nuclear divisions the ascogenous hyphae grow out from this middle cell. By septation these hyphae become rows of binucleate cells, the terminals being uninucleate. The asci then arise directly from these binucleate cells, nuclear fusion follows, and eventually several uninucleate ascospores are delimited within each ascus.

Distribution of powdery mildews. Most of this group of fungi are known to occur in the North Temperate Zone, perhaps because more collectors of fungi live in this region. Approximately one-third of all known species is confined to Europe, and one-third is common to both Europe and North America. Thirteen species and 5 varieties of those listed by Salmon (1900) occur in North America. Phyllactinia corylea is essentially 
world-wide in range. Moreover Salmon (1900) lists it as having 140 hosts belonging to 36 families. Other widely dispersed species are Erysiphe polygoni, having 355 hosts belonging to 42 families, and E. cichoracearum, having 280 hosts belonging to 27 families [Reed (1913)]. On the other hand, Podosphaera biuncinata is limited to witch hazel, Hamamelis virginiana; and Uncinula geniculata, to red mulberry, Morus rubra. Uncinula circinata is confined to maples. Infrequently, several species of mildews occur on a single host; on Ribes grossularia, for example, Sphaerotheca mors-uvae is most common, but Microsphaera grossulariae and Phyllactinia corylea may also occur.

Important species and their activities. Since these fungi are all obligate parasites, they can be expected to cause a great deal of damage if they appear on plants of economic importance. Among destructive pathogens are Uncinula necator on grape, known in Europe since 1847 as Oidium tuckeri. Its cleistothecial stage was not found there for over 40 years, hibernation being accomplished by means of special resistant mycelial cells. Cleistothecia are commonly developed, however, in California. Sphaerotbeca mors-uvae is very destructive to gooseberries, $S$. bumuli to hops [Blodgett (1913)], and S. pannosa to roses, especially climbing varieties. Erysiphe graminis is widespread on oats, wheat, barley, rye, and bluegrass; $E$. polygoni is very prevalent on clovers but seldom, if ever, forms cleistothecia in the southeastern United States. Erysiphe cichoracearum seriously attacks cucumbers and squashes, especially those grown in greenhouses. Podosphaera oxyacantbae is very damaging to cherries and may also attack apples and peaches, especially when the trees are grown in nursery rows.

Meliolaceae. The Meliolaceae, or sooty molds, resemble the Erysiphaceae closely in structural features, but, as the common name implies, the mycelium is dark in color instead of being white. The hyphae may be so profuse as to form crusts. They may adhere to the epidermal cells so intimately as to absorb their food, may attach themselves by means of holdfasts, hyphopodia, or may send haustoria into the host tissues. Lasiobotrys is subcuticular. Stomatogene and Piline form foot-like structures within the substomatal cavities.

Sooty molds occur most abundantly in the tropics. Conidia are lacking in most species. Conidia of the Helminthosporium 
type are commonly associated with Meliola, but Stevens (1916) omitted them in his classification of approximately 100 Puerto Rican species of Meliola for the reason that he was uncertain of their genetic connection.

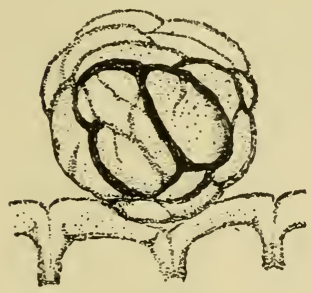

A
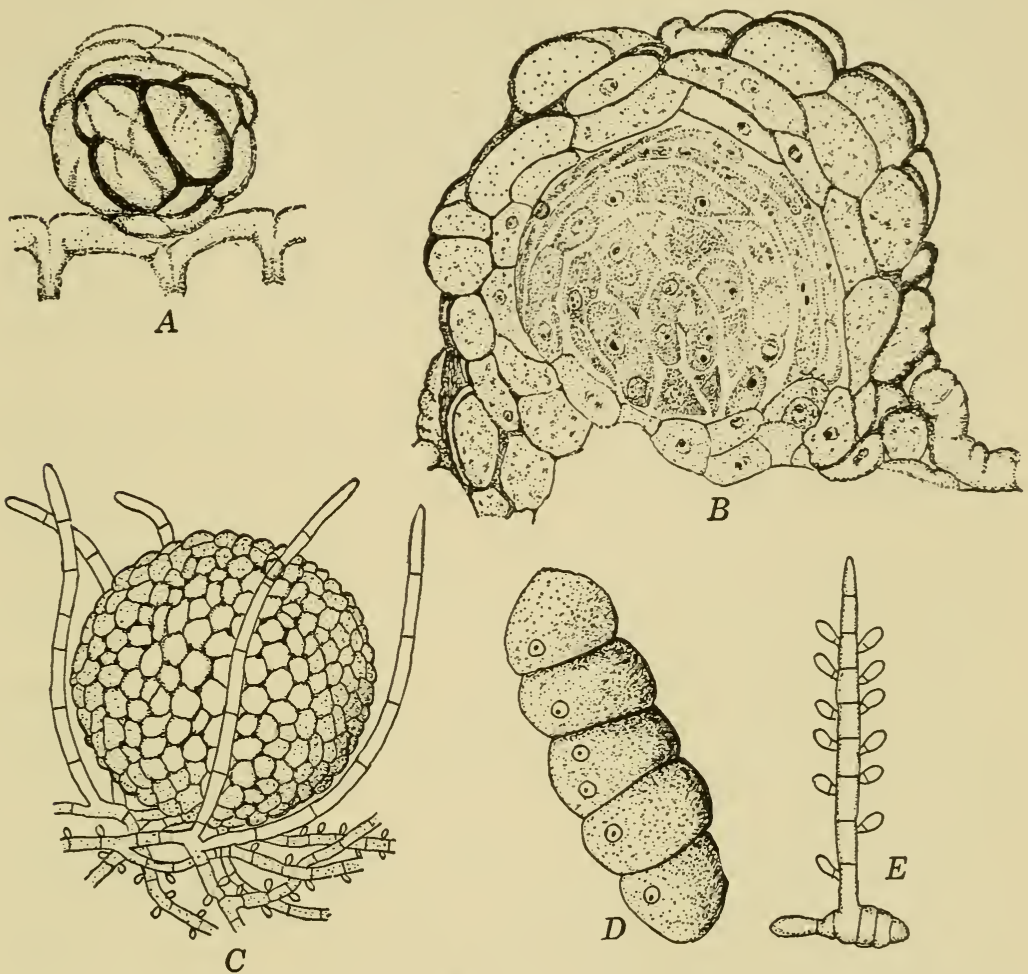

Fig. 65. Structural features of Meliola, a sooty mold. $A$. Young cleistothecium of Meliola circinans at surface of Carex leaf, surface view. $B$. Vertical section of $A$ enlarged, showing ascogenous hyphae filling center of stroma. C. Mature cleistocarp of Meliola corallina with basal hyphae and hyphopodia. D. Mature ascospore of $M$. circinans. E. Germinating ascospore of $M$. corallina with hyphopodia on germ tube. ( $A, B$, and $D$ adapted from Graff, $C$ and $E$ from Gaillard.)

The cleistothecia are unappendaged but may have setae or be partly invested with hyphae. They are usually coal-black. Details of their development are quite unknown. In Meliola circinans, however, Graff (1932) found that essentially the same processes as in the Erysiphaceae lead to cleistocarp formation. Hy- 
phal branches that are in approximate contact bear oval oogonia and slender, somewhat spirally wound antheridia. Each organ is borne on a stalk cell, and each is uninucleate. After the opening of their adjoining tips, the antheridial protoplast passes into the oogonium. The oogonium then elongates and divides into several uninucleate cells, which send out ascogenous hyphae. After crosier formation asci are formed. In each ascus eight nuclei are produced, but only four ascospores are formed.

The group has been rather extensively monographed. The studies of Stevens $(1916,1928)$ deal with Puerto Rican and Hawaiian species, those of Doidge (1920) with South African species, and those of Fraser (1933, 1934, 1935, 1935a) with Australian species. Theissen and Sydow (1917) divide the family into 19 genera.

Other Erysiphales. Two other families, Englerulaceae and Capnodiaceae, are included by Theissen and Sydow (1917) in this order. Both are sooty molds, the Englerulaceae containing about 30 species of parasites on tropical plants and the Capnodiaceae 25 genera and hundreds of species that live mostly on excretions of aphids and scale insects.

Among the best-known species is Capnodium citri, causing sooty mold of citrus. This fungus may be so profuse as to interfere with photosynthesis, and the fruits must be cleansed before being marketed.

Scorias spongiosa occurs on beech twigs, making sponge-like masses several inches in diameter. They are carbonaceous and brittle when dry but pliable when moist, and can absorb and hold water quite like a sponge.

Attention has been called to the occurrence of Adelopus gäumamni on Douglas fir in Switzerland and in the northeastern United States [Boyce (1940)]. This capnodiaceous fungus is associated with a leaf-cast disease that may be so severe as to result in the death of affected trees.

\section{LITERATURE CITED}

Ballard, WV. S., "Apple powdery mildew and its control in the Pajoro Valley," U. S. Dept. Agr., Burr. Plant Ind. Bull., 120. 26 pp. 1914.

Blodgett, F. M., "Hop mildew," Cornell Agr. Exp. Sta. Bull., 328:281-310, 1913. 
Boyce, J. S., "A needle-cast of Douglas fir associated with Adelopus gäumanni," Plbytopatbology, 30:649-659, 1940.

Colson, Barbara, "The cytology and development of Plyyllactina corylea Lév.," Amn. Botany, n.s., 2:381-401, 1938.

Doidge, Ethel M., "South African Perisporiaceae, III," Trans. Roy. Soc. Soutb Africa, 8: 235-282, 1920.

Eftimiu, Paxca, "Contribution à l'etude de l'evolution nucléaire chez certaines Erysiphacées," Bull. bot. soc. France, 76: 10-20, 1929.

Fraser, Lilliax, "An investigation of the sooty moulds of New South IVales, I," Proc. Linnean Soc. N. S. IVales, 58:375-395, 1933; II, 59: 123-142, 1934; III, 60:97-118, 1935; IV , 60: 159-178, 1935a.

GrafF, P. W., "The morphological and cytological development of Meliola circinans," Bull. Torrey Botan. Club, 59:241-266, 1932.

Harper, R. A., "Die Entwickelung des Peritheciums bei Splarerotbeca castagnei," Ber. deutsch. botan. Ges., 13:475-481, 1895.

"Sexual reproduction and the organization of the nucleus in certain mildews," Carnegie Inst. Wash. Pub., 37. 104 pp. 1905.

Reed, G. M., "The powdery mildews-Erysiphaceae," Trans. Am. Micr. Soc., 32: 219-258, 1913.

Salmon, E. S., "A monograph of the Erysiphaceae," Mem. Torrey Botan. Club, 9: 1-292, 1900.

"On Oidiopsis taurica Lév., an endophytic member of the Erysiphaceae," Ann. Botany, 20: 187-200, 1906.

Sinth, Grant, "The haustoria of the Erysipheae," Botan. Gaz, 29:153184, 1900.

Stevens, F. L., "The genus Meliola in Porto Rico, III," Biol. Monogr., 2: 475-554, 1916.

"The Meliolineae, I," Ann. Mycol., 25:405-469, 1923; II, 26: 165-383, 1928.

Theissex, F., And H. Srdow, "Synoptische Tafeln," Ann. Mycol., 15:389 $491,1917$.

\section{Pyrenomicetes}

The Pyrenomycetes include a large assemblage of fungi variously estimated to number between 10,000 and 20,000 species. They possess perithecia the wall of which opens by an ostiolum or pore. The asci are typically arranged in a parallel series over the inner basal wall of the perithecium. This group of Ascomycetes is usually regarded as being comprised of four orders, Dothideales, Hypocreales, Sphaeriales, and Laboulbeniales, the last-named of which is an aberrant assemblage. The orders may be distinguished as follows:

Perithecial wall differentiated from stroma

Stromata, if present, and perithecia bright colored, red, yellow, purple, etc.

Hypocreales 
Stromata, if present, and perithecia carbonaceous Perithecial wall not differentiated from stroma, but perithecia mere locules in the dark-colored stromata Dothideales Minute external parasites of insects; ascocarps borne on a receptacle that may be appendaged

Laboulbeniales

\section{Dotbideales}

As described by Lindau in Die natürlichen Pfanzenfamilien, the Dothideales comprise 24 genera and 400 species, all included in the one family Dothideaceae. In their monographic treatment Theissen and Sydow (1915) set up the order with 4 families having 140 genera and containing a total of about 8000 species, a large proportion of which are tropical. They later reduced the order to two families, Dothideaceae and Phyllachoraceae. In the Dothideaceae the stromata are immersed within the host and become erumpent at maturity; in the Phyllachoraceae they remain covered by host tissues. Members of the two remaining families, as first used by Theissen and Sydow, have been distributed among the Myriangiales, Hemisphaeriales, and Sphaeriales. There has even been some question as to whether the Dothideales constitute a natural order. The foregoing statements convincingly indicate the confused status of the Dothideales, a chaos largely traceable to the fact that the life histories of less than a halfdozen dothideaceous species are known.

As employed in this work, the Dothideales are pyrenomycetous fungi, possessing black stromata within which perithecial cavities, lacking independent perithecial walls, are developed. Whether the stromata remain endogenous (innate) or become exogenous (erumpent) at maturity is the basis for separating the two families, Phyllachoraceae and Dothideaceae.

Dibotryon (Plowrightia) morbosum, the cause of black knot of plums and cherries, is widely known, but its ordinal position is not yet established. It has been placed in older accounts among the Dothideales, but Theissen and Sydow (1915) regard it as nearly related to Botryosphaeria, which some mycologists place among the Myriangiales. Undoubtedly it is not a member of the Phyllachoraceae. To shift it from the Dothideales on the basis of present knowledge would only add to existing confusion.

A study of the life history of $D$. morbosum was early made by Farlow (1876), and similar recent studies include those of Koch 
$(1934,1935)$. Infection takes place in the spring; and, when the host resumes growth the next spring, the invaded tissues rapidly become enlarged, a velvety layer of conidiophores appearing

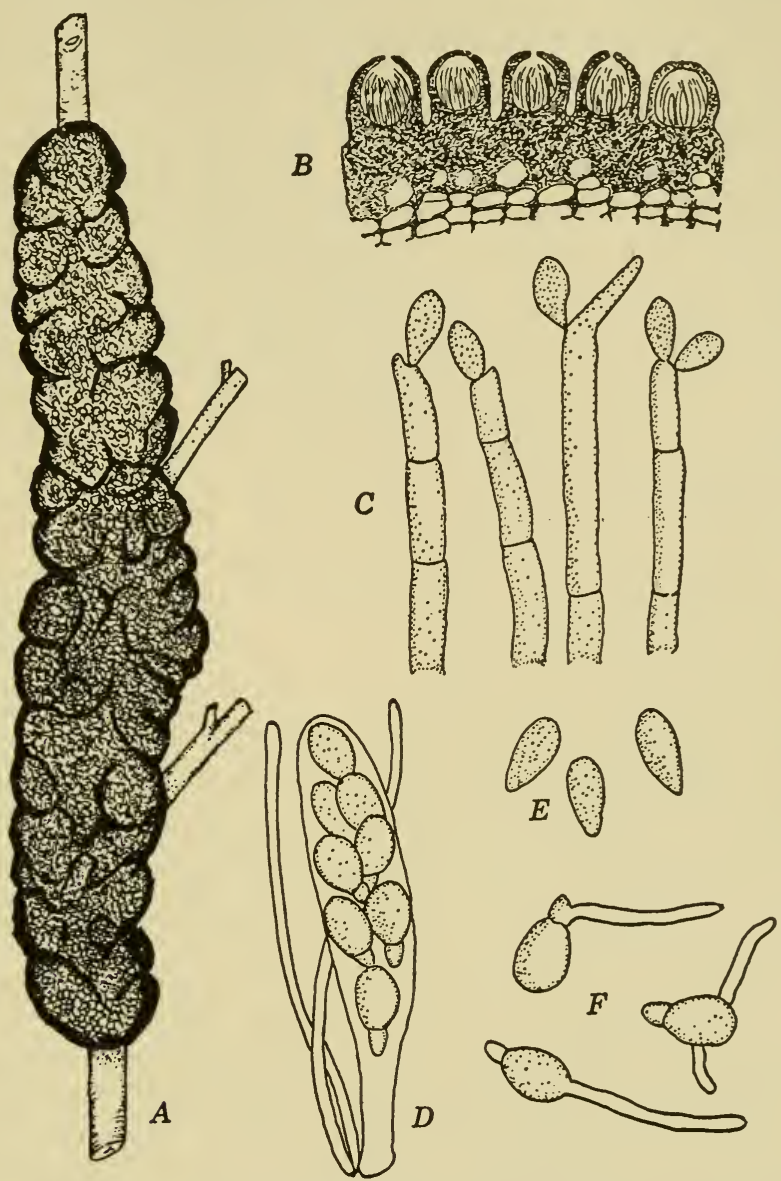

Fig. 66. Dibotryon (Plowrigbtia) morbosum. A. Habit sketch of stroma on branch of cherry. B. Portion of perithecial stroma in vertical section. $C$. Conidiophores and conidia of the Hormodendrum stage. D. Ascus, unequally two-celled ascospores, and paraphyses. E. Conidia. F. Germinating ascospores.

over the surface of the swollen tissues. This conidial stage belongs to the form Genus Hormodendrum. After midsummer, black stromata develop, covering the affected tissues, and by the 
succeeding spring the perithecia are mature. Koch (1935) isolated ascospores in culture and produced from them the Hormodendrum stage. Farlow (1876) and Koch (1934) call attention to an associated Coniothyrium (pycnidial) stage, which Koch states is not genetically connected. Since details of the initiation of ascocarps are lacking, this familiar organism should be reinvestigated.

Phyllachoraceae. Phyllachora graminis and related species on various grasses are the most' commonly encountered representatives of this family. Phyllachora graminis produces its stromata within the leaves of many grasses. It may prove to be a composite of many species, but this hypothesis can be proved only by comparative morphologic studies and by reciprocal crossinoculations. Phyllachora graminis has not been artificially cultivated, does not possess a conidial stage, and has been stated to have perithecial walls like those of the Sphaeriales. For this reason Orton (1924) is of the opinion that all species of Phyllachora and perhaps the entire family Phyllachoraceae should be removed to the Sphaeriales.

Dothideaceat. The several members of the Dothideaceae investigated include Systremma ulmi, parasitic on elm, Cymadothea trifolii, causing sooty blotch of clovers, and Systremma acicola, ${ }^{*}$ the cause of brown-spot needle disease of pines. Killian (1920) found that ascospores of Systremma ulmi initiate the primary infections in the spring. As a result, a subcuticular stroma, from

* The organism was given the name Scirrbia acicola (Dearness) by Siggers in 1939 (Phytopath., 29:1076-1077, 1939), and this name is retained by him in a later report (Tech. Bull. U. S. Dept. Agr., 870, 36 pp., 1944). His photographs in Plate 1 are manifestly those of an immature stroma (Fig. C) and immature ascospores (Fig. D). Mature stromata are exposed and prominently protrude and hence (Fig. D) are not those of the Phyllachoraceae. Discharged ascospores have brown walls as well as brown cell content. The ascospores of the Genus Scirrhia, as delimited and accepted, are colorless. In this connection it may be well to reflect upon the fact that the conidia of the brown-spot fungus are brown-walled, that the stromata (conidial, spermogonial, carpogonial, and perithecial) are composed of brown-walled cells, and that the mycelium in culture is colored and produces smoky to black colonies. What, then, is the likelihood of "uncolored" ascospores? It seems unthinkable that this brown-spot fungus could be properly placed in the Genus Scirrhia. 


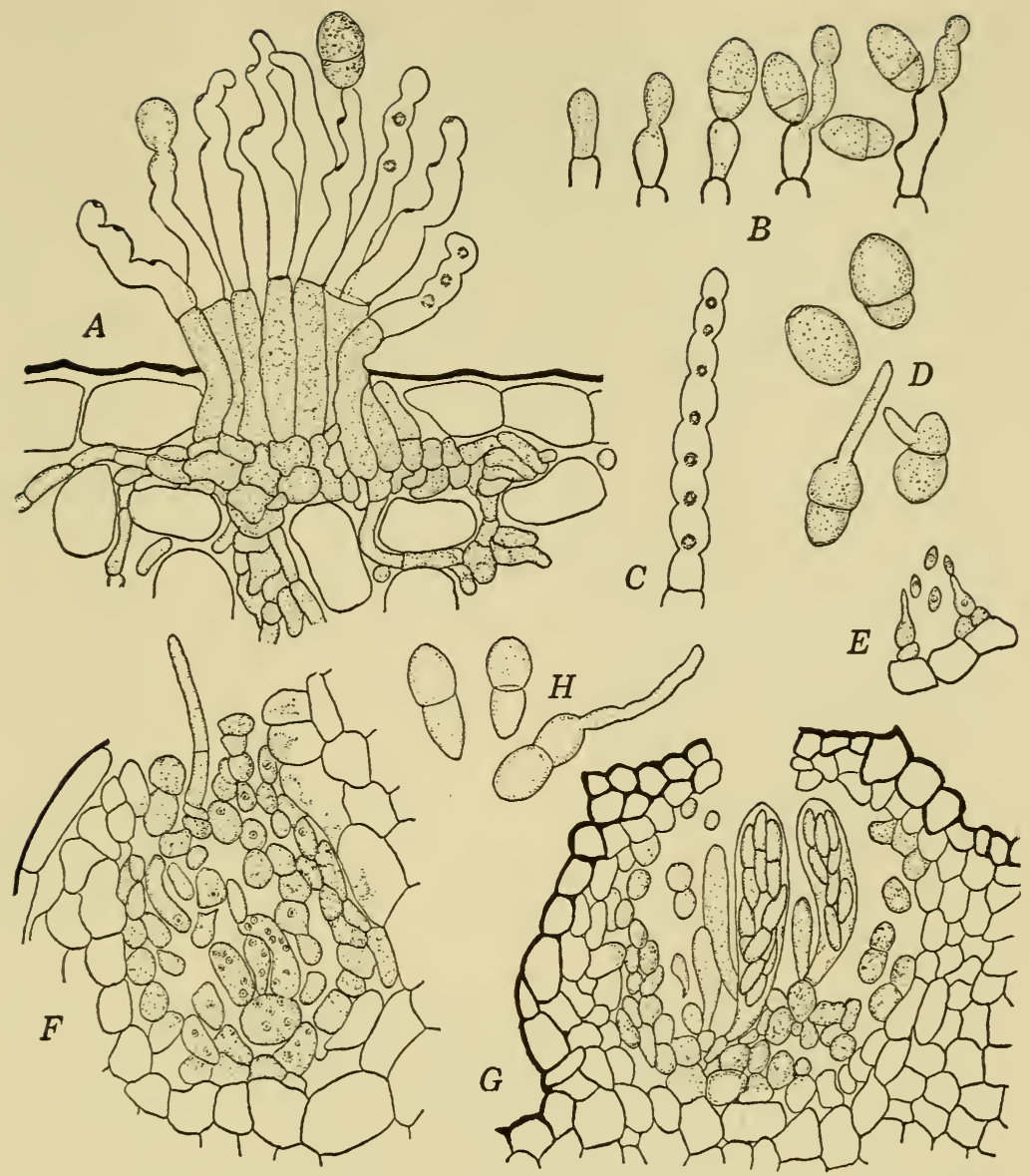

Fig. 67. Cymadothea trifolii. A. Conidial pustule in section of the stage known as Polytbrincium trifolii. The nodose, wavy conidiophores bear scars from which the two-celled conidia are abstricted. $B$. Diagrams showing stages in production of conidia such as might occur on a single conidiophore. The undulate appearance is the result of sympodial branching. $C$. Nodose conidiophore bearing a series of scars from which conidia were abstricted. D. Conidia, some of which are germinating. E. Portion of wall of spermogonial locule, with spermatiophores and spermatia. $F$. Young perithecial locule in section. The trichogyne projects to the surface and the multinucleate cells belong to the basal part of the carpogonium. $G$. Edge of perithecial stroma, showing locule in section with one mature ascus and others all immature. $H$. Ascospores, one germinating. 
which conidia are abstricted, is developed. After conidial production ceases, these conidial stromata disappear, and the deeperseated hyphae develop pads of fungus tissue beneath the epidermis. Within these pads are certain deeply staining cells, each of which abjoint three or four daughter cells that become twoto three-nucleate. Pairs of these cells fuse, and from the fused cells ascogenous hyphae arise.

The type of sexuality in Systremma ulmi is quite unlike that recently described for S. acicola by Wolf and Barbour (1941). This fungus forms coincidentally on dead needles conceptacles of two kinds. In one, small rod-shaped spermatia are produced in profusion from rows of spermatium mother cells. In the other, sevieral ascogonial coils occur, surrounded by loosely packed nurse cells. The trichogynes project well above the surface of the stromata. Presumably the spermatia lodge upon the trichogynes and effect fertilization. About 6 to 8 weeks thereafter the perithecia are mature, having been transformed from the locules containing ascogonial coils.

The conidial stage, Lecanosticta acicola, develops both on green needles and on dry ones. Cultures isolated from conidia produce conidia on artificial media. Furthermore cultures isolated from ascospores produce the conidial stage on artificial media.

The development of perithecia by Cymadothea trifolii [Wolf (1935)] is quite like that described for S. acicola. Both spermatial and ascogonial locules may occur within the same stroma. If moisture is available, the spermatia ooze out and lodge on the several projecting trichogynes during the autumn. By the following spring the perithecia will have matured.

The conidial stage, Polythrincium trifolii, possesses nodose, wavy conidiophores, which were first noted about 125 years ago. This wavy characteristic, a type of sympodial branching, arises as the result of elongation of the conidiophore after each conidium is matured and dislodged in succession.

The mature stromata of Dothideales have been examined by Orton (1924) and Blain (1927). Until more studies of similar nature, involving a goodly number of species and elucidating development of the stromata, have been made, exact knowledge of this order is essentially non-existent. 


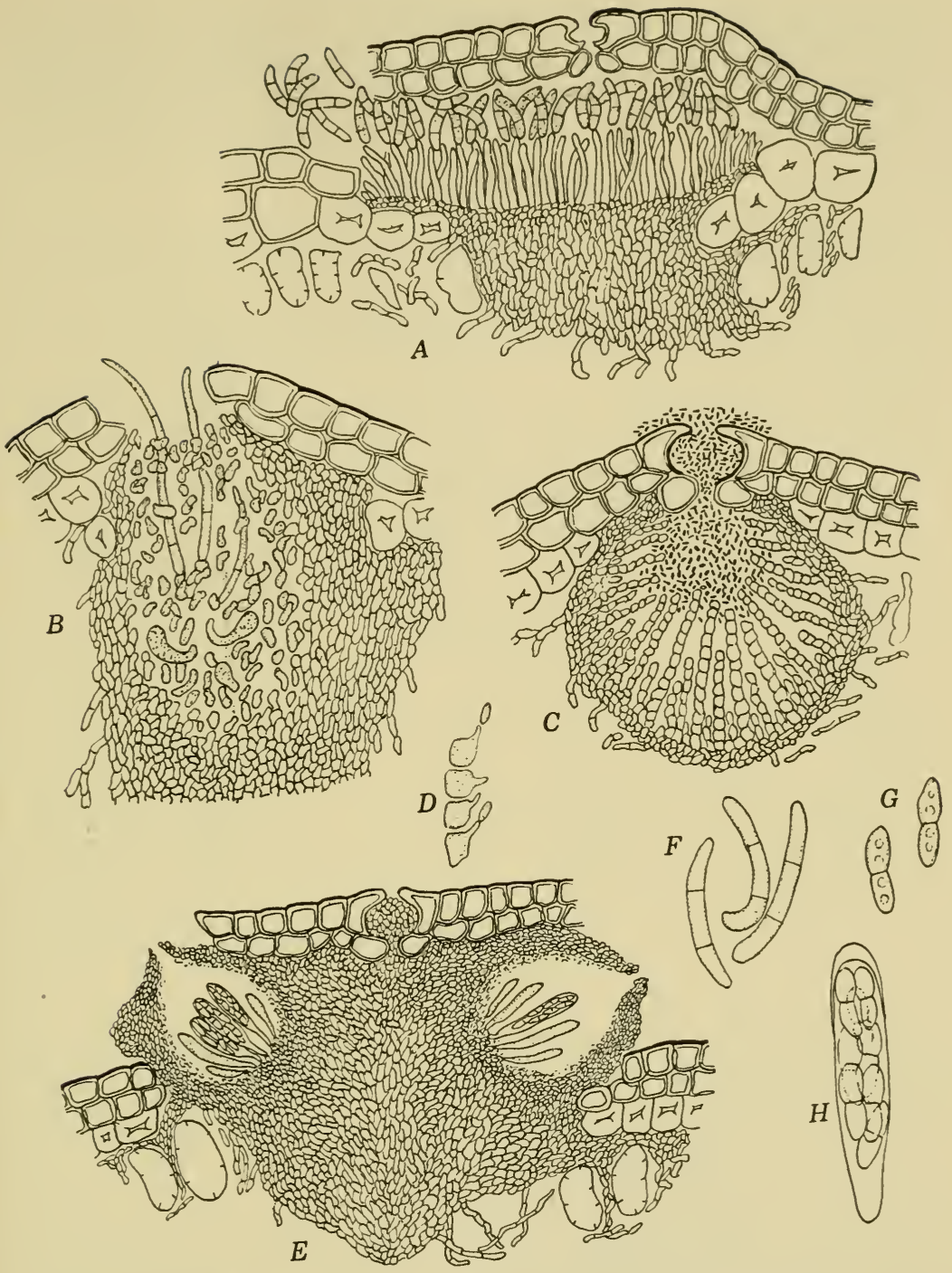

Fig. 68. Systremma acicola. A. Vertical section of stroma showing structure of the conidial stage, Lecanosticta acicola. B. In section, a carpogonial locule formed concurrently with the spermogonial locule. C. Spermogonial locule. D. Chain of spermatiferous cells and spermatia. E. Cross-section of elongate perithecial stroma. F. Conidia. G. Ascospores. H. Mature ascus. 
Classification. The monograph by de Jaczewski (1895) of the Dothideaceae of Switzerland and that by Theissen and Sydow (1915) constitute the most important ones available to presentday students.

\section{LITERATURE CITED}

BLAIN, W. L., "Comparative morphology of Dothideaceous and kindred stromata," Mycol., 19: 1-20, 1927.

Farlow, W. G., "Black knot," Bull. Bussey Inst., 1: 440-453, 1876. Jaczewski, A. DE, "Les Dothidéacées de la Suisse," Bull. soc. mycol. France, 11: $155-195,1895$.

Killiax, C., "Le déreloppement du Dotbidella ulmi (Duv.) Wint.," Reü. gén. botan., 32: 534-551, 1920.

KocH, L. W., "Investigations on black knot of plums and cherries. II. The occurrence and significance of certain fungi found in association with Dibotryon morbosim (Schw.) T. and S.," Sci. Agr., 13: 80-95, 1934.

III. "Symptomatology, life history, and cultural studies of Dibotryon morbosum (Schw.) T. and S.," Sci. Agr., 15:411-423, 1935.

Orton, C. R., "Studies in the morphology of the Ascomycetes. I. The stroma and compound fructification of the Dothideaceae and other groups," Mycol., 16: 49-95, 1924.

Theissen, F., ANd H. Sydow, "Die Dothideales," Ann. Mycol., 13: 149-746, 1915.

Wolf, F. A., "Morphology of Polythrincium, causing sooty blotch of clover," Mycol., 27: 58-73, 1935.

Wolf, F. A., ANd W. J. Barbour, "Brown-spot needle disease of pines," Pbytopatbology, 31:61-74, 1941.

\section{Hypocreales}

The Order Hypocreales comprises those Pyrenomycetes whose perithecia are soft textured and brightly colored. Approximately 1750 species, distributed among over 60 genera, are included in this group. Nearly all of them subsist on plant tissues, either as parasites or saprophytes; certain genera, however, notably Cordyceps and Sphaerostilbe, contain entomogenous species. In Hypomyces are included species that parasitize Hymenomycetes; and in Claviceps, species that transform the ovaries of various grasses into sclerotia that, if consumed, are poisonous to man or domestic animals.

No satisfactory classification of Hypocreales is possible at this time. Some workers regard the group as belonging to 1 family, some to 2 families, and some to 3 families. Seaver (1910) em- 
ployed 2 families: Nectriaceae, having solitary perithecia, and Hypocreaceae, having perithecia seated within a stroma and therefore partially or wholly immersed. In some instances, as in the Genus Nectria, the stroma is so meager as to invest only the basal
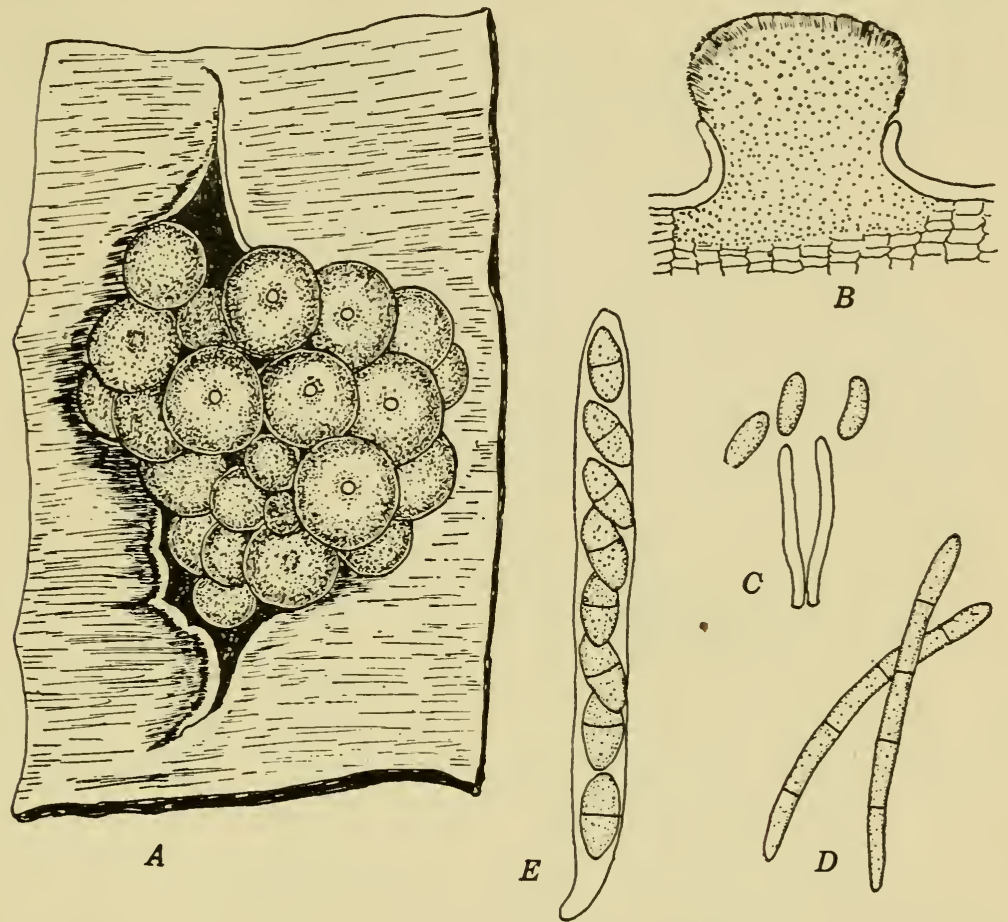

Fig. 69. Nectria and associated conidial stages. A. Nectria coccinea, habit sketch. B. Sporodochium (diagrammatic) of Tubercularia vulgaris, in rertical section. C. Conidiophores and conidia of T. vulgaris. D. Conidia of Cylindrocarpon. E. Ascus and ascospores of Nectria coccinea.

portion of the perithecia, whereas other species have completely discrete perithecia. Septation of ascospores provides a workable, although wholly artificial, basis of generic classification.

Asexual reproduction. Many of the Hypocreales possess conidial or chlamydospore stages. The conidial stage of Nectria cinnabarina on currants, pear, basswood, maple, elm, and oak is Tubercularia vulgaris. Nectria coccinea on beech [Ehrlich (1934)] has a macroconidial stage belonging to the Genus Cylindrocarpon. Other species of Nectria, including N. ipomoeae on 
sweet potatoes, have been connected with Fusarium. Isaria constitutes the conidial stage of Cordyceps, Sphacelia that of Claviceps, Fusarium that of Neocosmospora, and Verticillium that of Hypomyces ocbraceus and H. chrysospermus. Diplocladium minus is connected with Hyponyces lateritins, and Trichotbecinım candidum with $H$. rosellus. Mycogone perniciosa and $M$. rosea parasitize mushrooms and are chlamydosporic stages of Hypomyces. Sepedonium chrysospermum is the chlamydosporic

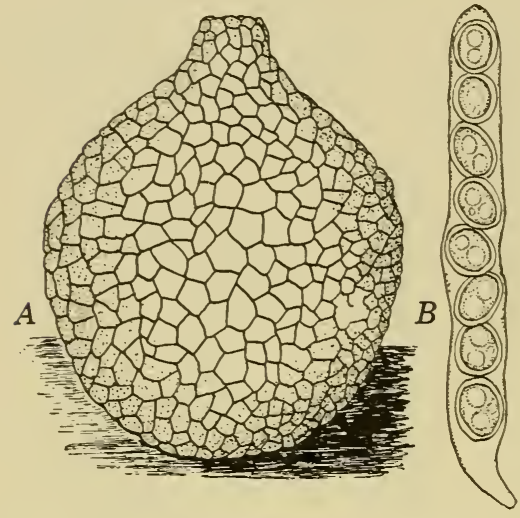

Fig. 70. Neocosmospora vasinfecta. $A$. Surface view of perithecium. $B$. Ascus contains thick-walled ascospores. stage of Hyponyces clrrysospermmus, which attacks Boletus. Gibberella saubinettii ( $G$. zeae) appears late in the season on cereals whose heads (inflorescences) are blighted by the Fusarium stage. Ephelis constitutes the conidial stage of Epichloe, Dothichloe, and Balansia. Verticillium globuligernun is connected with Podocrea alutacea.

RePresentative Foriss. In the accounts that follow brief mention will be made of a few species regarded as representative of this rather large group. In Nectria, containing over 250 species, are some very important plant pathogens. Nectria galligena causes a canker disease of pomaceous trees in Europe and has been reported to attack pears in the Pacific Northwest [Zeller and Owens (1921)]. Cayley (1921) found ascogonial coils in dereloping perithecia but was of the opinion that they do not function to produce ascogenous hyphae. She also observed pycnidia, which may well have been spermogonia. In the eastern United States $\dot{N}$. ditissinna causes "target-spot" cankers on basswood, red maple, birches, walnut, and yellow poplar. In the Maritime Provinces of Canada N.coccinea is associated with the scale insect, Cryptococcus fagi, in the destruction of beech [Ehrlich (1934)].

The Genus Thyronectria, monographed by Seeler (1940), contains species having muriform ascospores. In some species these 
ascospores, while still within the ascus, bud to form myriads of hyaline spores. Conidial stages, so far as is known, belong to Gyrostroma, Dendrochium, and Stilbella. Thyronectria austroamericana causes a wilt disease of Gleditsia japonica and a canker disease of G. triacanthos [Seeler $(1940,1940 a)$ ].

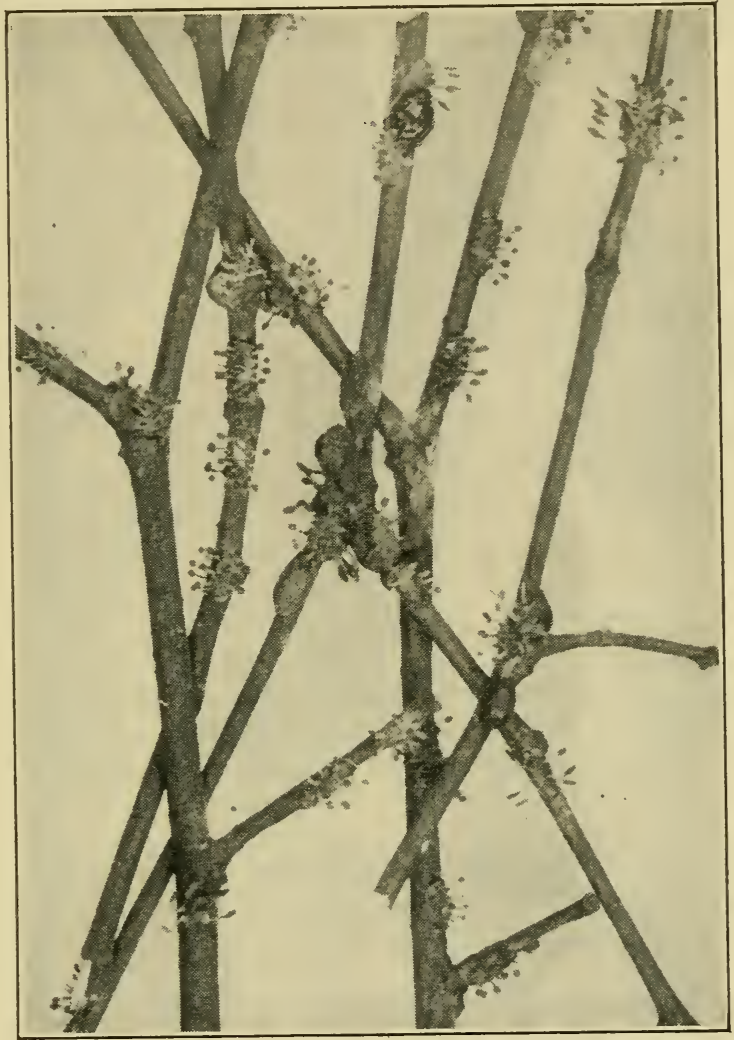

Fig. 71. Cordyceps clavulata on Lecanium sp. on Morus rubra.

Neocosmospora vasinfecta is of common occurrence in the southeastern United States on the roots of cotton, cowpeas, peanuts, and soybeans. This organism was reported to be connected with Fusarium vasinfectum, the cause of cotton wilt. Butler (1910), working in India with this fungus on chickpea, Cicer arietinum, disproved genetic association with a parasitic Fusarium but showed that it is connected with a saprophytic species of Fusarium. 
Species of Hypomyces are of interest because they are parasitic on various agarics and boletes. At times they are serious enemies of mushroom culture, attacking the sporocarps in the button stage and covering them with bright red or orange perithecia. The ascospores are hyaline, two-celled, and fusiform.

Polystigma rubrum causes a red-spot disease of Prunus, especially cherry, in Europe. Its development has been described
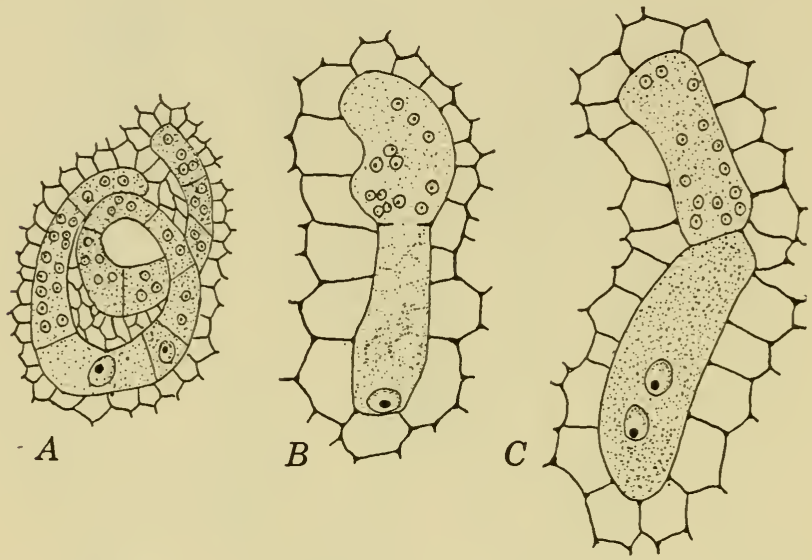

Fig. 72. Polystigma rubrum. A. Basal portion of ascogonial coil, trichogyne not shown. $B$. IVall between two ascogonial cells partly absorbed. C. Complete plasmogamy. (After Nienburg.)

by Blackman and Welsford (1912) and Nienburg (1914). Infections are initiated by ascospores. Five or six weeks later bright-red stromata have formed within the leaves. Within these stromata two types of conceptacles arise. One is flask-shaped and bears slender, hooked spores that have been termed spermatia. The other is filled with a loose tangle of hyphae, in which a coiled, septate ascogonium is embedded. Filaments extend from the ascogonium to the leaf surface. During damp weather in late summer the spermatia ooze out in a slimy mass and adhere to the trichogyne, but they have not been proved to function in fertilization. Nienburg recorded the absorption of the wall between certain cells of the ascogonium, permitting a pair of sister nuclei to be associated and plasmogamy to occur. Ascogenous hyphae arise from this ascogonial cell. 
Epicbloe typhina forms cream-colored sheaths around the stems of Phleum, Poa, Dactylis, and other meadow grasses. Enormous numbers of hyaline, ovate conidia cover the young stromata. The perithecia are eventually seated within these stromata, superseding the conidial or Ephelis stage. The perithecial initials contain three- to five-celled ascogonia, each cell being multinucleate. The protoplasts of a pair of these cells fuse; ascogenous hyphae then form and eventually produce the asci. The ascospores are hyaline and thread-like.

Other closely related genera, occurring on grasses and having similar conidial stages but purplish black stromata, are Balansia and Dothichloe. Each also produces filamentous ascospores that in Dothichloe separate into segments. The fertile stromata of Balansia bypoxylon are cushion-shaped and sclerotium-like, and they are elevated above the stroma that invests the grass stems. Early studies of these genera within the United States were made by Ȧtkinson $(1894,1905)$ and more recent ones by Diehl (1930).

The Genus Cordyceps was early monographed by Massee (1895). It contains about 200 species, nearly all of which parasitize insects, transforming their tissues into sclerotia. The most commonly encountered entomophthorous species are C. capitata on scale insects and C. spbingum and C. militaris on larvae and pupae of various Lepidoptera. The remainder parasitize Elaphomyces, especially E. cervinus and E. gramulatus. The development and cytology of one of this second group, Cordyceps agariciformia, were studied by Jenkins (1934) and found to be quite like those of Epichloe, Claviceps, and Polystigma. The stromata of Cordyceps, or clavae, are stalked, and the perithecia are produced in the capitate tips.

Shanor (1936), using as media living lepidopteran pupae placed on sphagnum in moist chambers, grew Cordyceps militaris to maturity.

Claviceps purpurea and related species parasitize grasses, especially the cereals, transforming the ovaries into sclerotia, commonly called ergot grains. Monographic treatises by Atanasoff (1920) and Barger (1931) summarize the numerous papers dealing with this genus and with ergotism, the disease which results from ingestion of ergot grains or sclerotia. These sclerotia are grayish violet externally and grayish white to white within. Their size, which varies, is dependent upon that of the ovaries 
from which they arise. On rye, they are 1 to $3 \mathrm{~cm}$ long; on Molinia coerulea, 4 to $6 \mathrm{~mm}$; on Poa pratensis, $6 \mathrm{~mm}$; on Elymus canadensis, the same size as on rye.

The sclerotia mature at harvest time and normally fall to the ground, where they hibernate. If they are harvested and stored with the threshed grain, they may be returned to the field with the seed. Tulasne (1853) found that the minimum dormant period is 3 months. Kirchhoff (1929) reported that after several weeks' exposure to cold, followed by a similar period of higher temperature, germination may ensue. He secured 60 to $80 \%$ germination after 4 to 8 weeks' exposure at $15^{\circ} \mathrm{C}$. If the period of exposure was short, germination proceeded tardily. If the sclerotia were stored in the cold, at a temperature near freezing, for 2 months, satisfactory germination ensued after 3 to 4 weeks' exposure at the higher temperatures. Burial in moist sand constituted a favorable substratum for germination.

Zimmerman (1906) noted that sclerotia usually germinate during May of the year following that in which they were formed. They may remain dormant, however, until the second year and then germinate at the normal season. Germination is first evident as bulges in the sclerotial cortex. These bulges burst through the rind and develop into the clavate stromata, which consist of slender stalks surmounted by spherical heads, 1 to $1.5 \mathrm{~mm}$ in diameter. The entire stroma is yellowish white at first but changes to grayish violet. The stromata that arise from a sclerotium may vary in number from a few to more than a score. At maturity the head of each is covered with wart-like projections that mark the position of the innate, pear-shaped, perithecial locules with orifices at the tip.

Details of the formation of perithecia were first elucidated by Killian (1919). He described pairs of branches, one an antheridium, the other an ascogonium, which formed on the top of peculiar voluminous cells and became the primordia of ascogenous hyphae. The antheridia and ascogonia are surrounded by fungous parenchyma that fills the locules. Eventually the parenchyma cells are entirely replaced by asci and paraphyses. Each ascus contains 8 filamentous spores 50 to $75 \mu$ long and 0.6 to $0.7 \mu$ in diameter. Numerous paraphyses are interspersed among the asci. 
According to Falck (1911), the ascospores are violently discharged into the air and then are carried by convection currents to grass flowers. This method of spore dispersal has been verified by several observers by means of the beam-of-light method. Stäger (1903), however, maintains that the spores are slowly exuded from the perithecia to form a slimy layer. Then dispersal is facilitated by insect visitors, especially flies and beetles. Some idea of the profligacy of ascospore production can be gained from Künn's calculation [Atanasoff (1920), p. 29] that a sclerotium with fifteen stromata will produce over a million ascospores.

The exact manner in which the ovary becomes infected is not known. There is reason to believe that germ tubes from ascospores lodged on the glumes cannot penetrate them. If the glumes are open so that the ascospores lodge on the stigmata or in the nectar, they should germinate, and the germ tube should extend into the ovary. Experiments by Stäger (1903) indicate that infection takes place both in pollinated and non-pollinated flowers. When he inoculated the ovaries 3 or 4 days before flowering, he found that infection developed very rapidly. Infection is indicated by the investment of the ovary with a superficial weft of mycelium. The ovarian tissues are penetrated, however, and become completely replaced by a furrowed, porous mass that will eventually be the sclerotium. Meanwhile the surface of the mass is densely covered with elongated cells from whose apices conidia are abstricted. This constitutes the sphacelial stage. The conidia are formed in great numbers and collect in droplets that appear at the edges of the glumes. These droplets are the "honey dew" which is sweet to the taste, and, if examined microscopically, will be found to be teeming with millions of ellipsoidal hyaline conidia. Honey dew is attractive to flies and other insects that incidentally aid in disseminating the conidia to cause secondary infections. Dew and rain also serve to convey conidia to other grass flowers.

Different explanations have been given to account for the origin of honey dew. Some workers believe that it is secreted by the sphacelial hyphae, and others that it is secreted by the nectaries in response to stimulation by the ergot fungus.

The time required for the formation of sclerotia is correlated with the weather. In moist weather sclerotia may first be appar- 


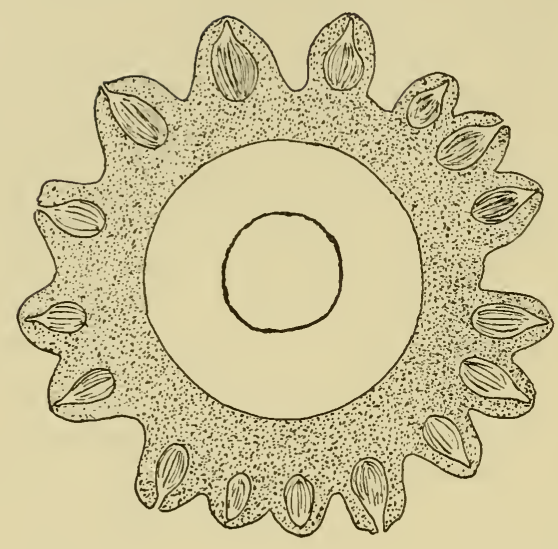

A
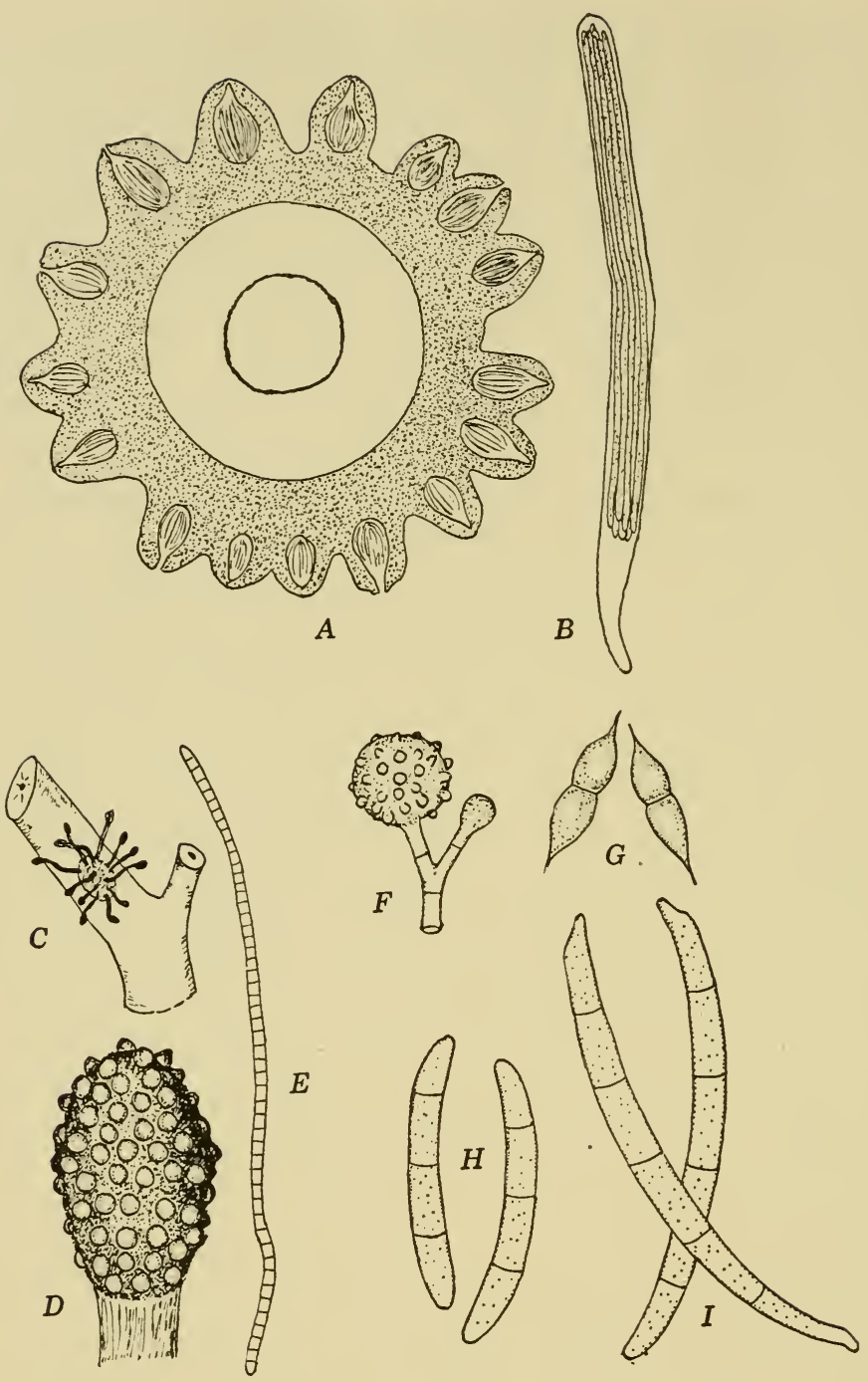

Fig. 73. Various Hypocreales. A. Cross-section of stroma of Epichloe typloina. The stroma invests the leaf sheath and culm, and the pinkish perithecia are seated in the stroma. B. Ascus of $E$. typbina containing eight thread-like ascospores. C. Habit sketch of Cordyceps clavulata on Lecanium on twig of mulberry. D. Tip of clava enlarged, indicating arrangement of perithecia. $E$. Single, segmented, filamentous ascospore. $F$. Sepedonium or chlamydospore stage of Hypomyces. G. Ascospores of Hypomyces, parasitizing Russula. H. Ascospores of Gibberella saubinettii, from wheat. I. Conidia of the Fusarium stage of the wheat-scab pathogen. 
ent 1 week after the first appearance of honey dew, whereas in dry weather 2 weeks may elapse. Sclerotial formation progresses gradually, and the sclerotia normally reach maturity by the time the rye is ready to be harvested.

Ordinarily young ovarian tissues are completely destroyed and are replaced by the sphacelial mycelium. Sometimes, however, the upper portion of the ovary remains. At any rate, a rather densely interwoven mass of hyphae replaces the normal grain, which it exceeds by several times in bulk. These hyphae become densely compacted at the exterior of the mass, forming the sclerotium. These sclerotia are yellowish brown and cartilaginous when they first attain their mature size, but on drying they become grayish violet and are corneous.

Hosts. Claviceps purpurea is world-wide in distribution and occurs on approximately 200 species and varieties of grasses, a list of which appears in the monograph of Barger (1931, pp. 117122). In wet seasons it causes an important disease of rye but is of less consequence on wheat, oats, and barley. Cases are on record in which 20 to $50 \%$ of rye heads have been ergotized. More commonly the losses in yield of rye are less than $1 \%$.

The injury to forage grasses is greater than that to cereals. Single heads of Agropyron occidentale are known to produce 40 ergot grains, 5 or $6 \%$ by weight of the seed being ergot. Rostrup [Atanasoff (1920), p. 5] found 2700 sclerotia in a sample pound of Festuca seed, 5600 in one of Poa, 500 in one of Holcus, and 2500 in one and 2700 in another of two samples of Agrostis alba seed.

Species of Claviceps. Of the 20 named species of Claviceps, 8 are indigenous to Europe, and 12 to America. Those recorded for Australia appear to have been introduced into that continent. Undoubtedly unnamed species occur in Asia and Africa. Species are separated on the bases of shape, size, color and dimensions of stromata, and dimensions of perithecia, asci, ascospores, and conidia. Paraphyses are present in some species but lacking in others.

These morphological characteristics, although useful in specific identification, may not always be sufficient criteria. This appears to be the situation when Claviceps paspali and C. rolfsii must be distinguished, the reported dimensions of the former be- 
ing essentially half those of the latter. For several seasons the writers have collected sclerotia from the inflorescences of Paspalum laeve, $P$. dilatatum, and $P$. floridanum. The sclerotia borne on the heads of each of these grasses differ in average size. Sclerotial size is found to be proportional to the normal size of the ripened ovaries in each of these species of grass. The perithecia, asci, and ascospores, however, are all alike and correspond with measurements for C. paspali.

The complete host range of species of Claviceps can be known only by means of reciprocal inoculations. Stäger (1903) alone conducted such studies during a period of 10 years, but his results should be verified and the experiments extended. He applied dilute suspensions of honey dew by means of an atomizer to flowering grasses grown under controlled conditions. Conidia of Claviceps wilsoni from Glyceria fluitans failed to produce infection upon any other species, although they were applied to seventeen other kinds of grass. Similarly C. sesleriae failed to produce infection except on Sesleria coerulea. Claviceps purpurea itself he found to consist of several biological races. For example, the Claviceps of Antboxantbum odoratum, although morphologically indistinguishable from $C$. purpurea of rye, produces abundant sclerotia if used to inoculate $A$. odoratum. If, on the other hand, Claviceps of rye is used as inoculum for $A$. odoratum, sclerotia are almost never found, and, if they are found, are very abnormal and small.

The Claviceps of Brachypodium silvaticum is also a distinct biological race of C. purpurea. Brachypodium silvaticum comes into flower too late to be infected by ascospores originating from sclerotia borne on this grass during the previous summer. Such ascospores readily infect Milium effusum, however, and abundant honey-dew formation results. Meanwhile B. silvaticum comes into flower and can be readily infected with conidia produced on M. effusum. Numerous sclerotia develop on B. silvaticum but are very seldom formed on $M$. effusum. Apparently under normal conditions this variety of $C$. purpurea requires two hosts, $B$. silvaticum and M. effusum.

Barger's (1931) account deals extensively with ergot poisoning through the eating of bread, especially that made from ergotized rye. Numerous epidemics originating from eating bread made from such rye flour have been reported. The disease results in 
gangrenous loss of extremities, paralysis, and death. Domestic animals are also poisoned from eating cereal grains admixed with ergot grains. Poisoning by species of Claviceps is more fully . considered in Chapter 15, Volume II.

\section{LITERATURE CITED}

Atanasoff, D., "Ergot of grains and grasses," U. S. Dept. Agr., Bur. Plant Ind. (mimeographed). 107 pp. 1920.

Atrinson, G. F., "Steps toward a revision of the linosporous species of North American graminicolous Hypocreaceae," Bull. Torrey Botan. Club , 21:222-225, 1894.

"The genera Balansia and Dothichloe in the United States, with a consideration of their economic importance," J. Mycol., 11: 248-267, 1905.

Barger, G., "Ergot and ergotism, a monograph based on the Dohme lectures delivered in Johns Hopkins University." 279 pp. Gurney and Jackson, London. 1931.

Blackman, V. H., and E. J. Welsford, "The development of the perithecium of Polystigma rubrum," Ann. Botany, 26:761-767, 1912.

Butler, E. J., "The wilt disease of pigeon pea and the parasitism of Neocosmospora vasinfecta Smith," Mem. Dept. Agr. India, Botan. Series, 2: 1-64, 1910.

Cayley, Dorothy M., "Some observations on the life history of Nectria galligena Bres.," Ann. Botany, 35:79-92, 1921.

DieHL, W. W., "Conidial fructifications in Balansia and Dothichloe," $J$. Agr. Research, 41:761-766, 1930.

EhrLich, John, "The beech-bark disease; a Nectria disease of Fagus following Cryptococcus fagi (Baer)," Can. J. Research, 10:593-692, 1934.

FaLCK, K., "Über die Luftinfektion des Mutterkorns (Claviceps purpurea) und die Verbreitung pflanzlicher Infektionskrankheiten durch Temperaturströmungen," Z. Forst.- u. Jagdw., 43: 202-227, 1911.

Jenkins, W. A., "The development of Cordyceps agariciformia," Mycol., 26: 220-243, 1934.

Killian, C., "Sur la sexualité de l'ergot de seigle, le Claviceps purpurea Tulasne," Bull. soc. mycol. France, 35: 182-197, 1919.

Kırchноғf, H., "Beiträge zur Biologie und Physiologie des Mutterkorns," Zentr. Bakt. Parasitenk., II Abt., 77: 310-369, 1929.

Massee, George, "A revision of the genus Cordyceps," Ann. Botany, 9: 1-44, 1895.

Nienburg, W., "Zur Entwicklungsgeschichte von Polystigma rubrum D.C.," Z. Botan., 6: 369-400, 1914.

Seaver, F. J., "Hypocreales," N. Am. Flora, 3: 1-56, 1910.

SeEler, E. V., JR., "A monographic study of the genus Thyronectria," $J$. Arnold Arboretum, 21:429-460, 1940.

"Two diseases of Gleditsia caused by a species of Thyronectria," $J$. Arnold Arboretum, 21:405-426, 1940a. 
SHaxor, L., "The production of mature perithecia of Cordyceps militaris

(L.) Link in laboratory culture," J. Elisha Mitchell Sci. Soc., 52:99104, 1936.

- StÄger, R., "Infektionsversuche mit Gramineen bewohnenden ClavicepsArten," Botan. Z., 61:111-158, 1903.

Tulasne, L. R., "Memoire sur l'ergot des Glumacées," Ann. sci. nat. bot., 3 ser., 20:5-56, 1853.

Zeller, S. M., ANd C. E. Owens, "European canker on the Pacific slope," Phytopathology, 11: 464-468, 1921.

Zinmerman, H., "Ergänzende Versuche zur Festellung der Keimfahigkeit älterer Sclerotien von Claviceps purpurea," Z. Pflanzenk., 16: 129-131, 1906.

\section{Spbaeriales}

The Sphaeriales, the largest order of Pyrenomycetes, is variously estimated to include between 6000 and 10,000 species, mostly saprophytic, but many parasitic, especially on seed plants. Its members are distinguished by their dark membranaceous, corky, or carbonaceous perithecia, which either stand singly and free or are variously aggregated and embedded in the substrata or in stromata. Of this vast assemblage only a relatively small number have been carefully studied; hence adequate bases for classification are lacking, and a purely artificial system must therefore be employed. Lindau, in Engler and Prantl's Die natürlichen Pflanzenfamilien, recognizes 18 families, and Martin (1936) recognizes 12 families, both employing similar characteristics throughout. Shape, septation, and color of spores are employed in distinguishing genera; species, unfortunately, are too commonly separated on the basis of host and substrate relationship.

The families of Sphaeriales considered in this book may be distinguished as follows:

a. Perithecia free or nearly so b

b. IVall membranaceous

c. Upper portion of perithecium having long, straight, or coiled and branched hairs

Chaetomiaceae

c. Ostiolar region lacking hairs, mainly dung inhabiting

Fimetariaceae (Sordariaceae)

b. IVall leathery or carbonaceous

d. Perithecia with papillate ostiole

d. Perithecia with beak-like ostiolar region

Sphaeriaceae

a. Perithecia partly embedded in substratum or in stroma

Ceratostomataceae 
e. Perithecia at maturity completely emergent from stroma

Cucurbitariaceae

e. Basal portions of perithecia persistently immersed in substrate $f$ f. Ostioles circular

Amphisphaeriaceae

f. Ostioles compressed, appearing elongate-elliptical in crosssection

Lophiostomataceae

a. Perithecia embedded in substratum or in stroma, but with ostiolar neck only protruding

g. Immersed in substratum, but well-defined stromata not formed $h$ h. Perithecia papillate, asci not usually thickened apically

h. Perithecia beaked, asci thickened apically

Mycosphaerellaceae

g. Inmersed in stromata

Gnomoniaceae

i. Stromata pulvinate, composed of fungus and host elements j j. Asci short-stalked and ephemeral j. Asci long-stalked, spores allantoid

Diaporthaceae

i. Stromata pulvinate or erect, composed wholly of fungal elements; spores dark

Xylariaceae

Throughout the order the asci within any perithecium are of different ages. In the larger proportion of species the ascospores are forcibly expelled. In certain of them, such as the Ceratostomataceae and Fimetariaceae, however, the asci are evanescent; and the ascospores are extruded in mucoid droplets, or else the asci break away and are forced intact toward the ostiolar neck, where they rupture. The asci are elongate-clavate, quite generally with ascospores arranged biseriately, obliquely, and in a single row, or else lacking special arrangement. The number of ascospores is mostly 8 , but occasional species, such as Neurospora tetrasperma and Pleurage anserina, have 4, or even 2, as in Gnomonia dispora. Pleurage zy gospora bears 16 spores; $P$. caeruleotecta, 128; and some species of Sporormia form 256, 512, or even 1024.

Many genera lack paraphyses; in others they are commonly intermingled with the asci. In many species sterile hyphae, periphyses, occur at the periphery of the hymenial area and may also line the ostiolar orifice.

Conidial production is of common occurrence among the Sphaeriales. Usually the same type of conidia is produced by all species of a given genus, but some genera, as at present delimited, possess as conidial stages a wide variety of conidial types. Quite commonly, too, among plant pathogens the conidial stage occurs during pathogenesis, and the ascogenous stage during saprogenesis. 
Chaetoniaceae. As their name indicates, the members of this family are distinguished by fructifications the exteriors of which are partly or completely beset with hairs. They occur on paper, straw, dung, and decaying plant tissues and are known to be capable of digesting cellulose and therefore of functioning in the formation of humus. Chivers (1915) in his monograph recognizes 114 species and 14 varieties of Chaetomium and 2 species of Ascotricha. Species of Bommerella are regarded as belonging to Chaetomium. Chaetomidium lacks an ostiole and thus shows affinity with the Plectascales.

The ascospores, which are freed by early deliquescence of the asci, are brown to black and typically lemon-shaped.

Conidia are commonly borne on the hairs which adorn the perithecia. Various conidial forms have been observed, most of them belonging to the form Genera Sporotrichum and Verticillium. In Ascotricha chartarum there occur not only a Sporotrichum stage but also a peculiar chlamydospore stage, which was described as Dicyma ampullifera.

Finetariaceae (Sordariaceae). The Fimetariaceae are saprophytic species, most of them occurring on dung. Some are limited rather closely to the dung of certain species of herbivors. Their perithecia are flask-shaped, the perithecial walls being membranaceous. The ascospores are typically unicellular and are provided with a gelatinous sheath or one or two gelatinous appendages. By means of this gelatinous coating the ascospores, which are forcibly discharged, adhere to vegetation. They are ingested by browsing animals and hence disseminated by them. Conidial stages are rarely found.

Among the better-known representative species is Pleurage anserina. This species is normally four-spored, but occasionally five-spored asci are seen. In four-spored asci the spores are binucleate; in five-spored asci the spores differ in size, two of them being small and uninucleate. The binucleate spores, when grown in monosporic culture, are hermaphroditic and self-fertile, as found by Ames (1934), whereas the small spores are of two classes, which Ames called A and B. Monosporic cultures from these small ascospores bear both ascogonia and spermatia but are self-sterile, although, when reciprocally crossed, they are fertile. In regard to this fungus, therefore, it is not proper to speak 
of a plus strain or class and a minus strain or class, for each strain produces both male and female organs and is thus bisexual or hermaphroditic. Obviously the difference between strains must be based on compatibility.
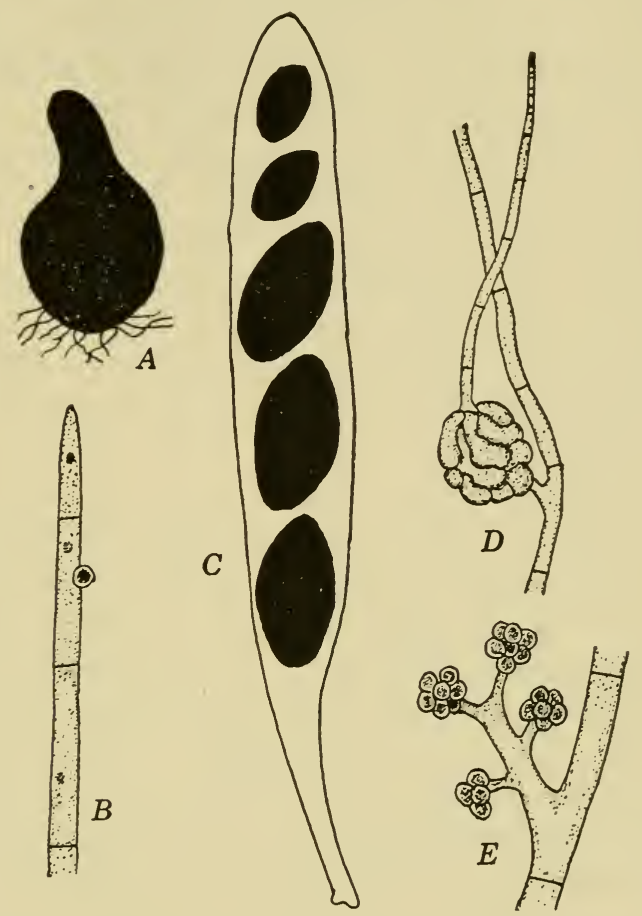

Fig. 74. Pleurage anserina. A. Peritherium in silhouette. $B$. Tip of trichogyne with spermatium attached. C. Mature ascus containing three normal and two dwarf spores. $D$. Ascogonium before fertilization. $E$. Clusters of spermatia. (After Ames.)

In Pleurage zygospora, which has 16 spores, Lewis (1911) found that the typical 8 free nuclei are formed; each then becomes delimited by a membrane. Additional nuclear divisions to form a sporogenous filament follow. A functional spore is cut off from each end of each filament, thus making 16 ascospores. In Philocopra (Sporormia) coeruleotecta [Jolivette-Sax (1918) ], on the other hand, free nuclear divisions occur until 128 nuclei are formed, whereupon the ascospore membranes are developed. 
Another well-known genus, which many mycologists place among the Fimetariaceae, is Neurospora. Its conidial stage is monilioid. The pink bakery mold, N. sitopbila, has 8 spores, whereas $N$. tetrasperma has 4 . Knowledge of sexuality in these species comes from the accounts by Dodge (1927, 1932, 1935), Colson (1934), and Backus (1939). By isolating each of the ascospores from individual asci of $N$. sitophila and mating their mycelia in cultures, Dodge (1927) showed that the species is heterothallic. Similarly, each ascospore of $N$. tetrasperma normally contains two nuclei differing from each other in compatibility. When this species is grown in monosporic cultures, therefore, it is found to be hermaphroditic. Occasionally, however, it forms dwarf ascospores, each having only one nucleus, and these are not totipotent. They are of either class A or class B in their sex reaction, and thalli of both classes must be grown together to produce perithecia.

Both $N$. sitophila and $N$. tetrasperma form coiled ascogonia with branched trichogynal hyphae, although Colson (1934) concluded that they may not be formed in heterothallic races of $N$. tetrasperma. Both also form spermatia. Dodge (1935) applied spermatia from class A cultures of $N$. tetrasperma to cultures of class B and secured perithecia in the loci of application, indicating that spermatia function in fertilization. He also found that monilioid conidia can function in fertilization, or that "young aerial hyphae or even trichogynes or trichogynous hyphae, if they come in contact with trichogynous elements of the opposite sex reaction, are capable of effecting fertilization." This tendency of "substitute sexuality," as denominated by Backus (1939), was verified in Backus's experiments, in which the archicarpic stromata became transformed into perithecia after contact with germinated conidia, germinated ascospores, or mycelial mats of the complementary sexual strain of $N$. sitophila. Moreover, a small group of perithecia was induced to form near the site where a single ungerminated conidium was deposited, just beyond the advancing margin of the mycelium. The performance of sexual functions is therefore regulated by compatibility factors which prevent self-fertilization.

It has been suggested that Acanthorbynchus vaccinii, causing a rot of cranberries, also belongs in this family. This fungus normally produces perithecia in decaying leaves of its host, and 
perithecia develop also in culture. The ascospores are peculiar for the reason that on germination appressoria develop.

The monographic treatment by Griffith (1901), although old, is very useful in any taxonomic study of the Fimetariaceae. That by Seaver (1910) should also be employed.

Sphaerlaceae. The Sphaeriaceae comprise some 20 or more genera. The perithecia stand singly or in small groups, and their bases may be immersed in a felt-like mesh or subiculum. The perithecial walls are firm, and the ostiolar region is papillate. Most of the numerous species are saprophytes on plant tissues, especially wood and bark, but a few are destructive pathogens. Rosellinia deserves mention as typifying the parasitic species. Rosellinia quercina attacks oaks throughout Europe, being especially destructive to seedlings and young trees in nurseries. It forms strands of hyphae, rhizomorphs, characteristic of the form Genus Dematophora. These strands ramify throughout the cortex of the roots and extend through the soil to contact the roots of near-by seedlings. Black sclerotia, by means of which the pathogen hibernates, also develop, both within the root tissues that have been killed and at the exterior. During the summer, conidia and perithecia form at the surface of affected roots or on the soil. Details of perithecial development are wanting, as they are for all other Sphaeriaceae.

Rosellinia clavariae parasitizes Clavaria cinerea and other species, giving to the bases of these coral fungi a blackened appearance. Its conidial stage has been identified as Helmint bosporium clavariorum.

Ceratostonataceae. The distinguishing feature of this family is the presence of long, ostiolar beaks on the perithecia. Otherwise the Ceratostomataceae resemble the Sphaeriaceae. Most species are saprophytic. In the Genus Ceratostomella, however, are several very destructive pathogens, as well as certain others commercially important because they stain lumber or logs that have not yet been made into lumber.

The most notable of the pathogens is Ceratostomella ulmin, the cause of Dutch elm disease. This disease was first recognized in Holland and its causal agent described as Grapbium ulmin, the conidial stage, in 1922. Eight years later it was discovered on elms in Cleveland, Ohio, and in Cincinnati, Ohio. Soon afterwards it was located in the area surrounding New York City, where it 

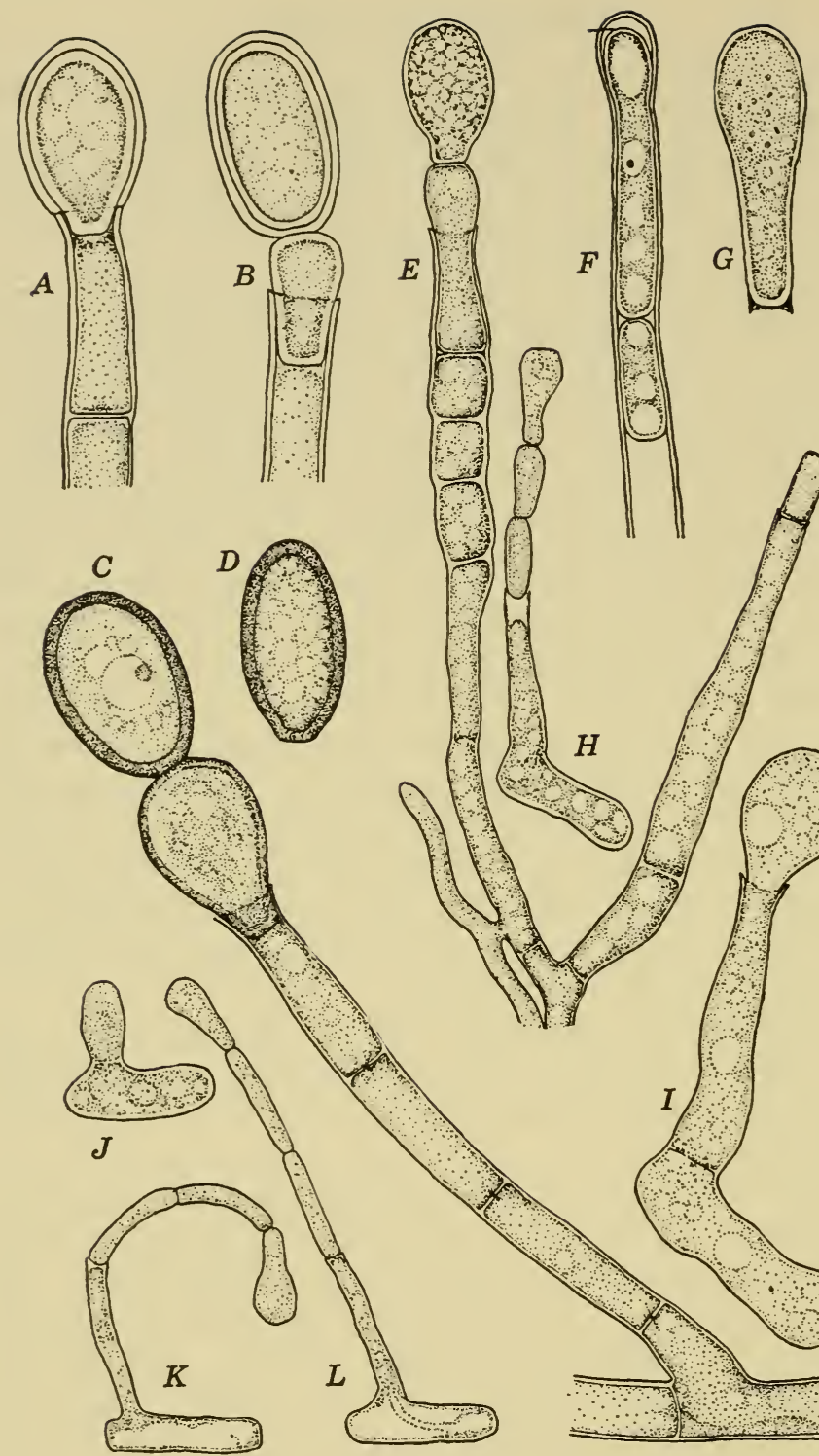
has continued to spread at an alarming rate and threatens to eliminate the American elm. In 1932 Buisman (1932) found, by growing together on sterilized elm twigs certain stains isolated from conidia, that perithecia characteristic of Ceratostomella are produced. She also secured perithecia by inoculating elm branches with paired strains; this evidence in its entirety is interpreted to show that C. zulmi is heterothallic. An account of this disease and the developmental history of its causal fungus, to which the student is referred, is available from the researches of Clinton and McCormick (1936). Ahrens and his associates (1935) have prepared a complete list of references to studies of this disease, especially studies conducted in Europe.

Ceratostomella fimbriata causes black rot of sweet potatoes. Its "asci" are ephemeral; consequently the perithecial stage was long regarded as the conidial fungus, Sphaeronema fimbriata, as Elliott (1925) has shown. The true conidial stage consists of endogenously formed conidia that adhere in chains. An understanding of the details attendant on perithecial formation has come from studies by Elliott (1925) and Andrus and Harter (1933, 1937). Although a pair of closely associated organs is produced to initiate the perithecia, it is not definitely determined that a fusion of antheridium and ascogonium involving nuclear migraton occurs. Apparently by a crosier device a binucleate cell arises from the subterminal cell of the ascogonium. As soon as the hyphae have formed an envelope around the original ascogonium, its walls disintegrate, and the ascogonium appears as a naked protoplast. The initial binucleate cell then proliferates, and soon the interior of the perithecial cavity is filled with naked cells or vesicles. Eventually paired nuclei in these unwalled cells fuse to make the primary nucleus of the ascus. There then follow three successive nuclear divisions. The immature spores are delimited by a layer of cytoplasm, and all appear to have a common base of attachment. They are thus clustered; and, since no well-defined ascus wall ever appears, there is none to be dissolved. The periphery of the ascus is merely a cytoplasmic layer.

Among the organisms responsible for blue stain of wood the world over are several species of Ceratostomella, notably C. pilifera, C. ips, C. pluriannulata, C. minor, C. pseudotsugae, and C. piceaperda. They may penetrate sapwood by way of the rays; 

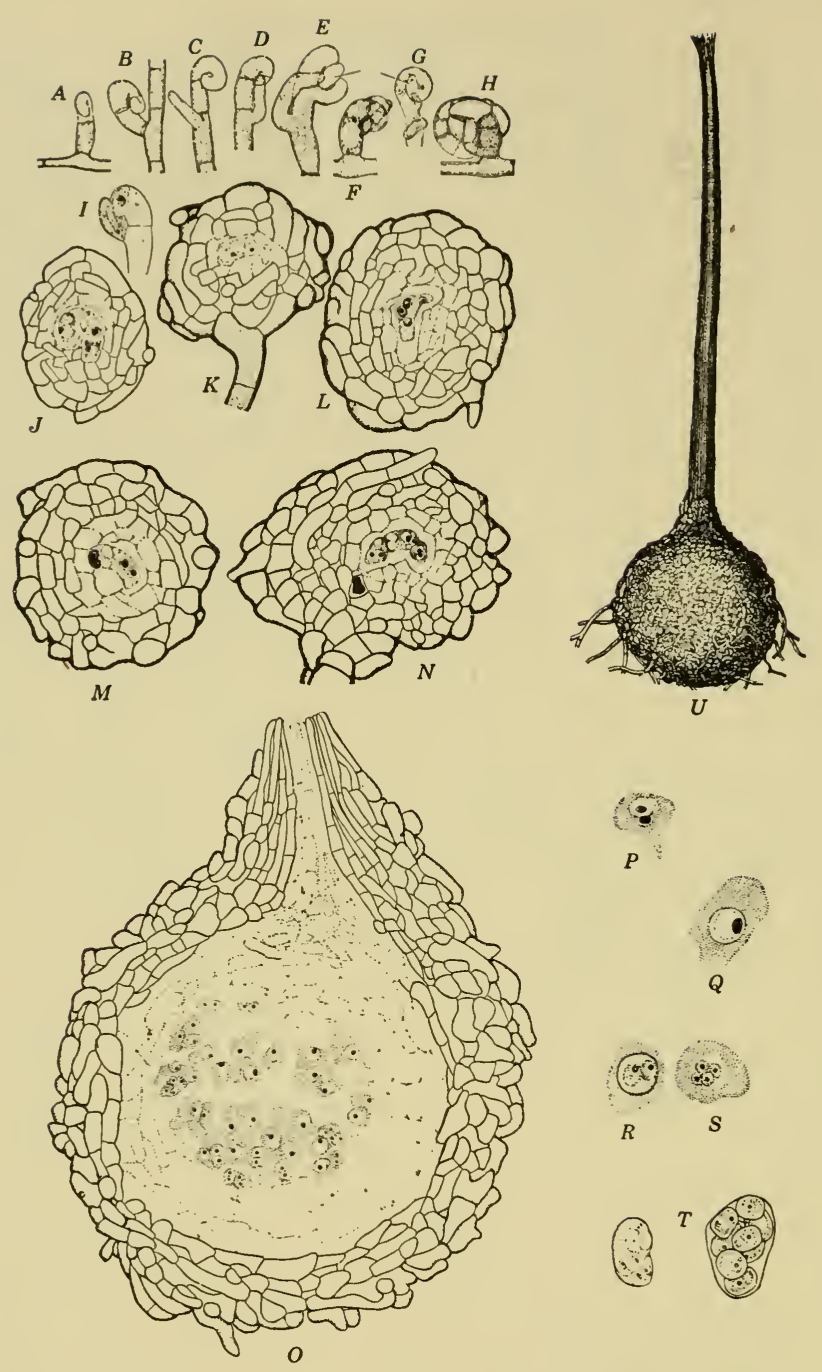

Fig. 76. Formation of perithecia by Ceratostomella fimbriata and C. moniliformis. $A$ to $N$. C. moniliformis. $A$ to $H$. Initiation of perithecia from primordium consisting of an antheridium and an ascogonium. I. Uninucleate protoplasts of antheridium and oogonium before plasmogamy. $J$ to $N$. Binucleate cells or ascogonial cells within young perithecia. $O$ to $U$. C. fimbriata. O. Somewhat later development of perithecium, showing beak formation, and arrangement of ascogenous cells within the perithecial cavity. $P$. Nuclear fusion to make the primary ascus nucleus, $Q$. $R$. Binucleate ascus. S. Quadrinucleate ascus. $T$. Early and late stages in formation of eight ascospores. $U$. Habit sketch of mature perithecium. (Andrus and Harter.) 
and, although there is no evidence that they weaken the wood, they cause enormous losses by degrading the lumber. Conditions favoring the development of these fungi and methods for prerenting losses are fully discussed in a report by Scheffer and Lindgren (1940).

Opbioceras albicedrae is of more than passing interest, for the reason that it is commonly present on Juniperus mexicana, producing conspicuous white patches on the trunk and limbs. [Heald and Wolf (1910)]. These patches are regarded as a specific characteristic to be employed in identifying the tree.

Cucurbitariaceae. The Cucurbitariaceae are characterized by the possession of stromata varying from a thin subiculum to a rather thick pulvinate layer, upon which the perithecia are seated, usually in caespitose aggregates. Most of them are saprophytic, occurring on the stems of woody plants.

The Cucurbitariaceae are quite like the Sphaeriaceae, and Fitzpatrick (1923) has suggested that the two families be merged. This suggestion arises from his critical study of the Subfamily Nitschkieae, in which, within a single species, as among members of the Genus Calyculosphaeria, there may be found an intergrading transition between a well-defined stroma and stromata consisting of a loose, hyphoid subiculum. Furthermore the perithecia of the Nitschkieae are all turbinate to cupulate in shape with a tapering, sterile base. The closely related Genus Fracchiaea is not cupulate but seems to be intermediate between the Cucurbitariaceae, as delimited by Lindau, and the Nitschkieae.

Axiphisphaeriaceae. The perithecia of members of this family are partly sunken in the substratum, with the upper portions free. Among its representatives of world-wide occurrence is Caryospora putaminum, commonly found on old pits of prunes and peaches. This organism, recently studied by Jeffers (1940), has large conical perithecia, and its asci usually contain three large, fusoid, two-celled ascospores. He found that the five nuclei remaining within the young ascus after spore formation disintegrate. Spermogonia containing spermatia developed in cultures on pea-extract agar, but Jeffers did not regard them as essential for sexual reproduction. The problem of how this organism thrives on sclerenchyma tissues is of more than passing interest. 
Another member of special interest is Pleosphaeria citri, occurring on citrus and oleander in the Mediterranean area. It is epiphytic, subsisting on the honey dew of plant lice. Both perithecial and pycnidial stages are embedded in a thin but welldefined, loosely woven stroma.

Lophiostomataceae. As the name of this family indicates, the perithecial ostioles of its members are laterally compressed and

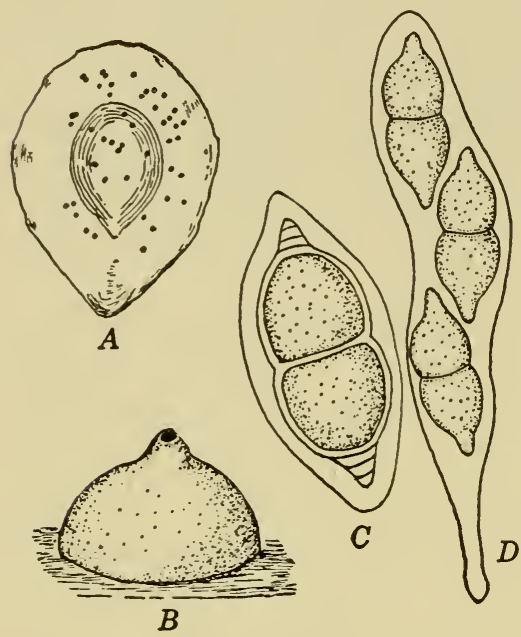

Fig. 77. Caryospora putaminum. A. Half of peach pit, at the surface of which are numerous black perithecia. $B$. Perithecium, in outline, indicating shape and attachment to the pit. C. Mature two-celled ascospore with thick envelope. D. Typical ascus. have slit-like openings. For this reason the Lophiostomataceae are regarded as a link connecting the Sphaeriales with the Hysteriales. All of them seem to be saprophytic on herbaceous or woody stems. No detailed studies of any of them appear to have been made.

Mycosphaerellaceae. This family is beyond all doubt the most unwieldy assemblage of Pyrenomycetes. As employed in this book, it includes the Pleosporaceae, as used by Lindau, excepting those members belonging to the Pseudosphaeriaceae, which were included among the Myriangiales. The Pleosporaceae remaining after this arrangement resemble Mycosphaerellaceae in all features except that they possess paraphyses. Such a characteristic seems scarcely worthy to constitute a basis for familial rank. In the Mycosphaerellaceae the genera Mycosphaerella, Guignardia, Venturia, Physalospora, and Ophiobolus deserve attention, partly for the reason that they contain so many plant pathogens, some of which are very destructive to crop plants.

Mycospbaerella. Mycosphaerella, as at present delimited, contains well over 1000 species. Many of them possess a conidial stage that has been classified as belonging to such form genera as Phyllosticta, Phoma, Ascochyta, Septoria, Phleospora, Ramu- 
laria, Cercospora, Cercosporella, Ovularia, and Marssonia. Manifestly the type of imperfect stage could be employed as a criterion for separating this large group into sections, as was suggested by Klebahn (1918). On this basis he proposed such names as Septoriosphaerella, Cercosphaerella, and Ramularisphaerella. Some species do not possess conidial stages, for example,

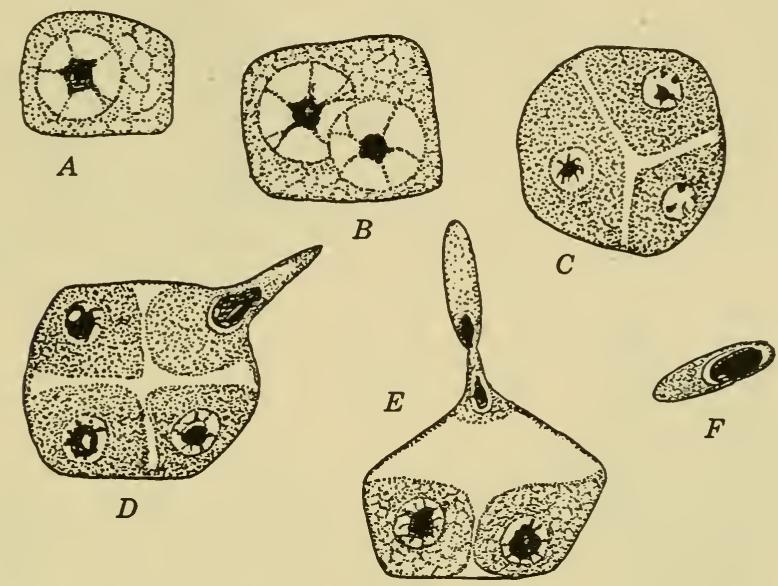

FIg. 78. Formation of spermatia by Mycosphaerella bolleana. A. Uninucleate spermatiferous cell just before first nuclear dirision. $B$. Binucleate spermatiferous cell. C. Quadrinucleate cell, only three of the cells shown. $D$. Sterigma being formed and protoplast from one quadrant migrating into the sterigma and forming a spermatium. E. Spermatium formation nearly completed. F. Spermatium with relatively large nucleus. (After Higgins.)

Mycospbaerella fraxinicola [Wolf (1939)] and M. nyssaecola [Wolf $(1940,1940 a)]$. Mycosphaerella fraxinicola is associated with Phyllosticta viridis and M. nyssaecola with P. nyssae; both of these species of Phyllosticta proved to be not conidial stages but spermogonial stages.

The conidial stage of species of Mycosphaerella generally appears during the pathogenic portion of their developmental cycle, and the perithecial stage is initiated during late summer or fall and becomes mature during the following spring. Two distinct stromatic structures are concerned in perithecial formation, and both are initiated concurrently. One of these is the spermogonium, containing spermatia; the other is the perithecial primordium, containing within it one or more coiled ascogonia. Each 
ascogonium consists of a basal ascogonial cell and a terminal trichogynal portion that projects to the exterior. Whether the spermatia function in fertilization has not been determined, but indirect evidence indicates that they are necessary. For example,
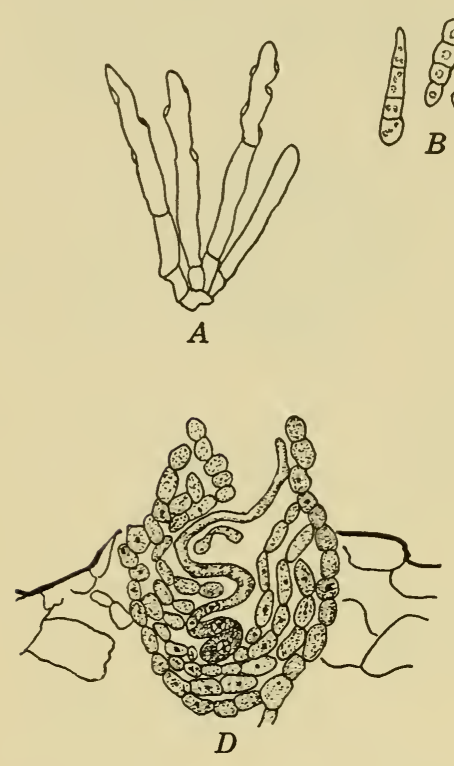
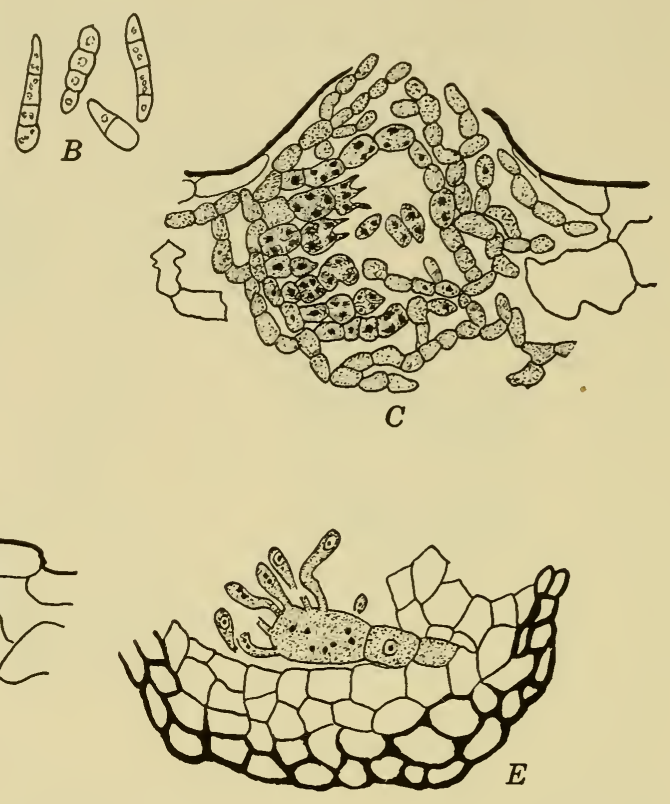

Fig. 79. Development of Mycosphaerella bolleana. A. Conidiophore fascicle of Cercospora bolleana. B. Variation in shape and septation of conidia. C. Young spermogonium just beginning to form spermatia. The stroma is still a loose tangle of hyphae without an outer wall of thickwalled cells. D. Young carpogonial locule with coiled ascogonium developing coincidentally with the spermogonium. Conidia of the Cercospora stage may be formed on both kinds of young stromata. E. Portion of base of mature carpogonial stroma with ascogenous hyphae and asci borne on ascogonium. (After Higgins.)

the spermatia collect in a film or droplet at the spermogonial orifice, and, unless moisture is present to make possible their transfer to the archicarpic locules, perithecia are not produced. Furthermore, if material bearing the conidial stage is collected and kept indoors to dry for a month or more before being placed outdoors to hibernate, in most instances the perithecial stage will not develop, because of the lack of moisture in the form of dew or rain at the critical stage when spermatization should have been 
accomplished. If the leaves are occasionally moistened while they are maintained indoors, however, perithecia will develop.

An ever-increasing body of evidence is available which indicates that spermatia are commonly produced in Mycosphaerella. Some of the species known to possess spermatia are listed in Table 1, and spermatia have been observed in a number of others whose life histories are being elucidated.

TABLE 1

Species of Mycosphaerella Known to Possess Spermatia

Organism

Mycosphaerella nigerristigma

Prunus cerasus, $P$. pennsylvanica

$\begin{array}{ccc}\begin{array}{c}\text { Mycosphaerella } \\ \text { hieracii }\end{array} & \begin{array}{c}\text { Hieracium } \\ \text { boreale }\end{array} & \text { Klebahn (1918) } \\ \begin{array}{c}\text { Mycosphaerella } \\ \text { punctiformis f. } \\ \text { tiliae }\end{array} & \text { Tilia cordata } & \text { Klebahn (1918) } \\ \begin{array}{c}\text { Mycosphaerella } \\ \text { hippocastani }\end{array} & \begin{array}{c}\text { Aesculus hippo- } \\ \text { castanum }\end{array} & \text { Klebahn (1918) }\end{array}$

Mycosphaerella Ficus carica bolleana

Mycosphaerella

Punica grana-

Mycosphaerella Vitis spp. personata

Mycosphaerella Prunuscerasus Jenkins (1930) cerasella
Observer

Higgins (1914) tum

\begin{abstract}
castanum
\end{abstract}
Higgins (1920)

Wolf (1927)

Higgins (1929)
Jenkins $(1930)$
Remarks

Spermogonia pycnidialike and associated in late summer with the Septoria stage, of ten in same pycnidia.

Micropycnidia associated with the Ramularia stage.

Bacteria-like conidia produced in old stromata of the Cercospora stage or in separate pycnidia of Phyllosticta type.

Called microconidia. Occur interspersed with Septoria stages, and also produced in pure culture.

Associated with Cercospora bolleana at close of season. Spermogonia pycnidia-like.

Associated late in season with Cercospora lythracearum.

Associated with Cercospora viticola during autumn. Spermogonia are pycnidia-like.

Spermogonia are pycnidia-like and occur late, associated with the Cercospora stage in bases of conidial stromata. 
TABLE 1 (Continued)

Species of Mrcosphaerella Known to Possess Spermatia

Organism

Mycosphaerella areola

Mycosphaerella Vigna sinensis Latham (1934) cruenta

$\begin{array}{ccc}\begin{array}{c}\text { Mycosphaerella } \\ \text { berkeleyi }\end{array} & \begin{array}{c}\text { Arachishypo- } \\ \text { gaea }\end{array} & \text { Jenkins (1935) }\end{array}$

Mycosphaerella arachidicola

Mycosphaerella confusa

Mycosphaerella arachnoidea

Mycosphaerella persicae

Mycosphaerella Fraxinus spp. fraxinicola

Mycosphaerella cercidicola

Mycosphaerella nyssaecola

Mycosphaerella effigurata

Mycosphaerella polymorpha

Host

Gossypium spp.

Arachis hypo- Jenkins (1935) gaea

Rubus spp.

Morus rubra

Prunus persica

Cercis canadensis

Nyssa spp.

Fraxinus spp. son (1941)

Wolf (1939)

Wolf (1935)

Wolf (1936)

Wolf (1939) dentalis
Ehrlich and Wolf

Wolf and David-

Higgins and Wolf

Wolf $(1940,1940 a)$ Associated with Cercospora cercidicola.

Wolf $(1940,1940 a)$ Spermogonial stage has been called Phyllosticta nyssae.

Associated with Marssonia fraxini. Spermogonial stage identified as Piggotia fraxini. Platanus occi- Smith and Smith
Associated with Stigmina polymorpha.

The details of spermatial formation in this genus were first recorded by Higgins (1920). He found that the uninucleate spermatium mother cells, occurring in chains, become quadrinucleate; the protoplast then separates into four units but without wall formation. These units then migrate one at a time into a sterigma and are abstricted from its tip. After the mother cell is empty, its wall dissolves to become part of the mucoid matrix 

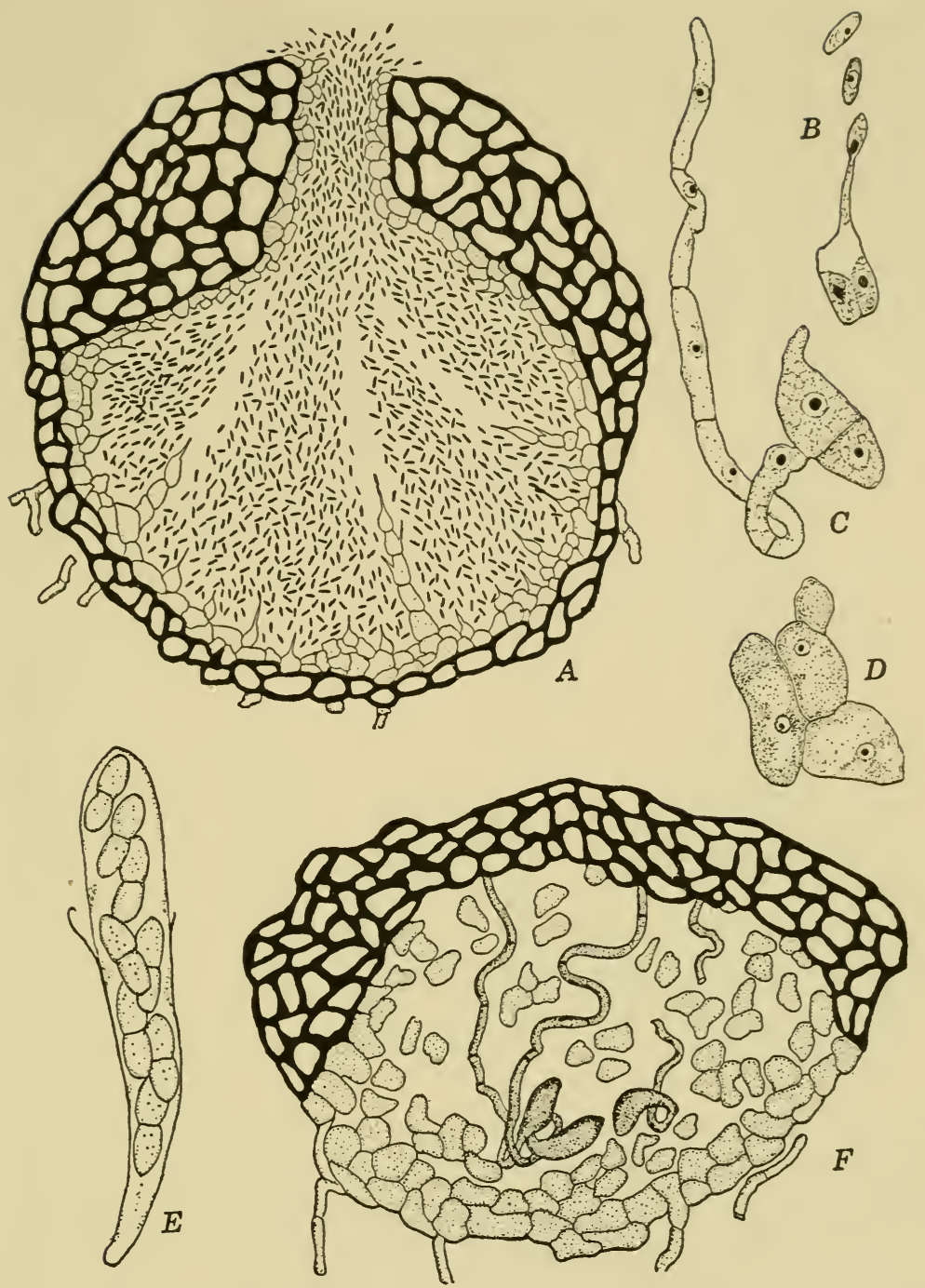

FIG. 80. Mycosphaerella fraxinicola. A. Mature spermogonium, in section, of "multilocular" appearance. This appearance may be accounted for because, in spermatial formation, all chains of spermatiferous cells do not bear spermatia at the same time. $B$. Spermatium mother-cell whose content is quadrinucleate. Spermatia are abstricted as the mother-cell contents migrate into the sterigma seriatim. C. Multicellular ascogonium. D. Uninucleate nurse cells from the interior of the young perithecial locule. $E$. Mature ascus. F. Young perithecial locule containing three ascogonia. Both spermogonial and ascogonial locules develop coincidentally. 
which invests the entire mass of liberated spermatia. This matrix swells in the presence of moisture, and as a result the spermatia are forced to the exterior of the spermogonium. Their germina-

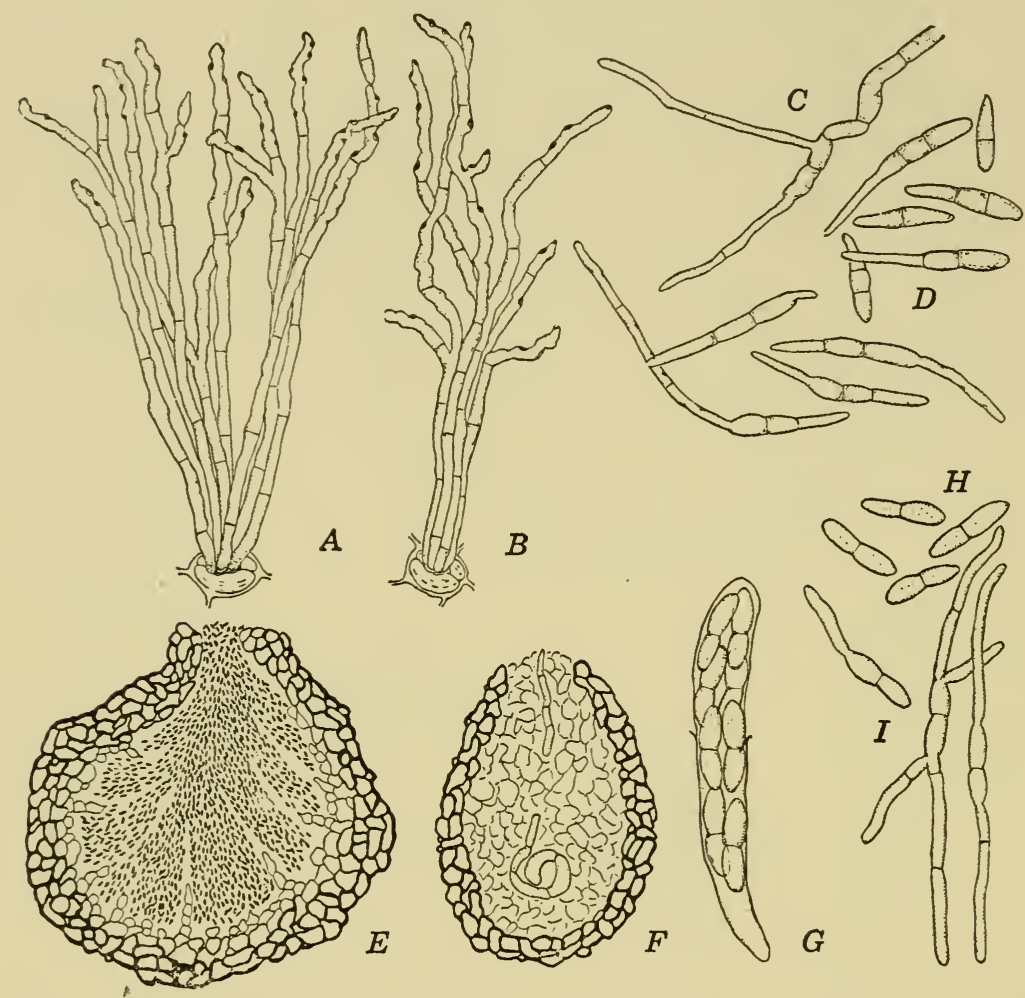

Fig. 81. Mycosplacerella cercidicola. $A$ and B. Fascicles of conidiophores, the conidiophores tending to be coremioid. C. Germinating conidiophore. $D$. Germinating conidia. E. Vertical section of mature spermogonium. $F$. Vertical section of perithecial primordium with single archicarp. G. Ascus after elongation by rupture of outer ascal membrane. $H$. Mature ascospores. I. Germinating ascospores.

tion has not been observed. Each spermatium contains a single nucleus, so large that it practically fills the cell. These characteristics are interpreted to indicate that spermatia are male cells.

Guignardia. The best-known species of Guignardia is G. bidwellii, causing black rot of grapes, endemic to North America and introduced into Europe about 1885. It was first described 
by Ellis in 1880 as Sphaeria bidwellii, and about a dozen other binomials have subsequently been applied to it. The most extensive studies of this fungus are those of Reddick (1911). Its pycnidial stage belongs to Phyllostictina and is characterized by large spherical to ellipsoidal hyaline but granular pycnidiospores. These appear in lesions on leaves, canes, and berries. Reddick noted microconidia, produced in pycnosclerotia, which occurred among the true pycnidia, especially on shrivelled berries. These undoubtedly are spermogonia, and archicarpic sclerotia should be looked for, interspersed among the pycnosclerotia. In the spring, in the leaves and berries that have overwintered on the ground, are mature perithecia. They contain hyaline, unequally twocelled ascospores that become septate at time of maturing.

Guignardia baccae, possessing larger ascospores than those of G. bidwellii, is regarded as the cause of grape black rot in the Caucasus region. Undoubtedly still other species are responsible for diseases of muscadine grapes native to the southeastern United States.

Venturia. Several species of Venturia are concerned with scab diseases of pomaceous fruits. Of these $V$. inaequalis of apples, involving leaves, flowers, fruits, and twigs, is the most widely known. Its conidial stage, Fusicladium dendriticum, forms stromatic cushions beneath the cuticle, and from their surface conidia are abstricted. The pathogen may hibernate in the conidial stage on twigs, but more commonly its survival is accomplished by the perithecial stage, which develops throughout the winter and matures in the spring in decaying leaves.

The initiation of perithecia was described by Killian (1917) and has been confirmed in essential features by several investigators. A coiled hypha arises within a fungus stroma. The cells at the periphery of this stroma are uninucleate, and their walls become thickened, whereas the inner cells remain thin-walled and multinucleate. One of these thin-walled cells produces a chain of cells, the ascogonium, each cell of which is bi- to quadrinucleate. The apical cell becomes clavate and is the trichogyne. Meanwhile, near the developing ascogonium another hyphal tip thickens and becomes lobate, and paired nuclei migrate into its lobes. This structure is the antheridium. Its growth continues until the lobes contact the trichogyne and become closely applied to it. A pore then forms, and the antheridial content empties 

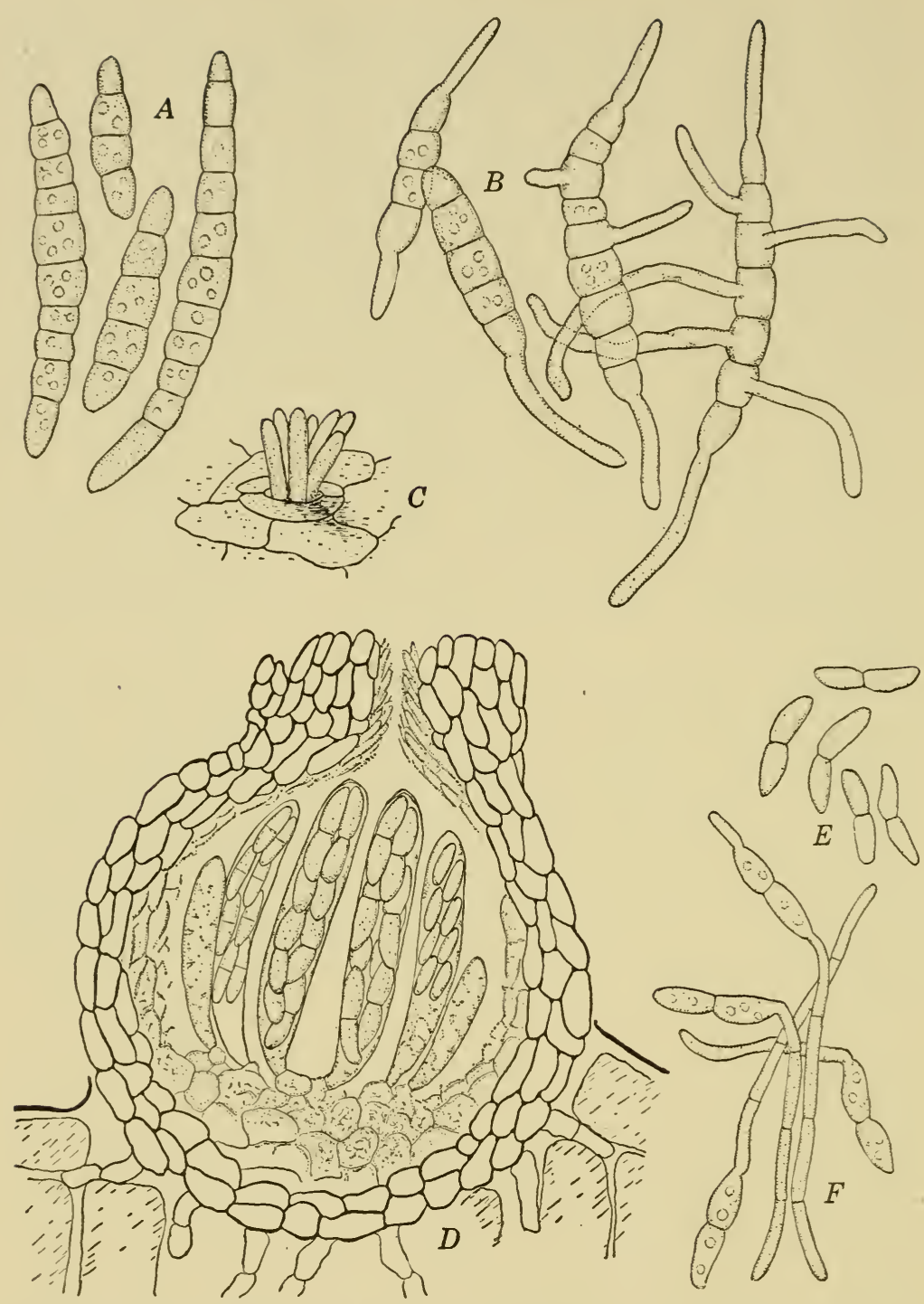

Fig. 82. Mycosphaerella mori. A. Conidia of Cercosporella stage. $B$. Germinating conidia. C. Fascicle of conidiophores. D. Perithecium in vertical section. E. Mature ascospores. $F$. Germinating ascospores. 
into the trichogyne. Septations in the ascogonial chain are then dissolved, whereupon the antheridial nuclei migrate to the ascogonium and become associated in pars with the ascogonial nuclei. After this stage ascogenous hyphae are developed as outgrowths from the ascogonium. Meanwhile the uninucleate perid-
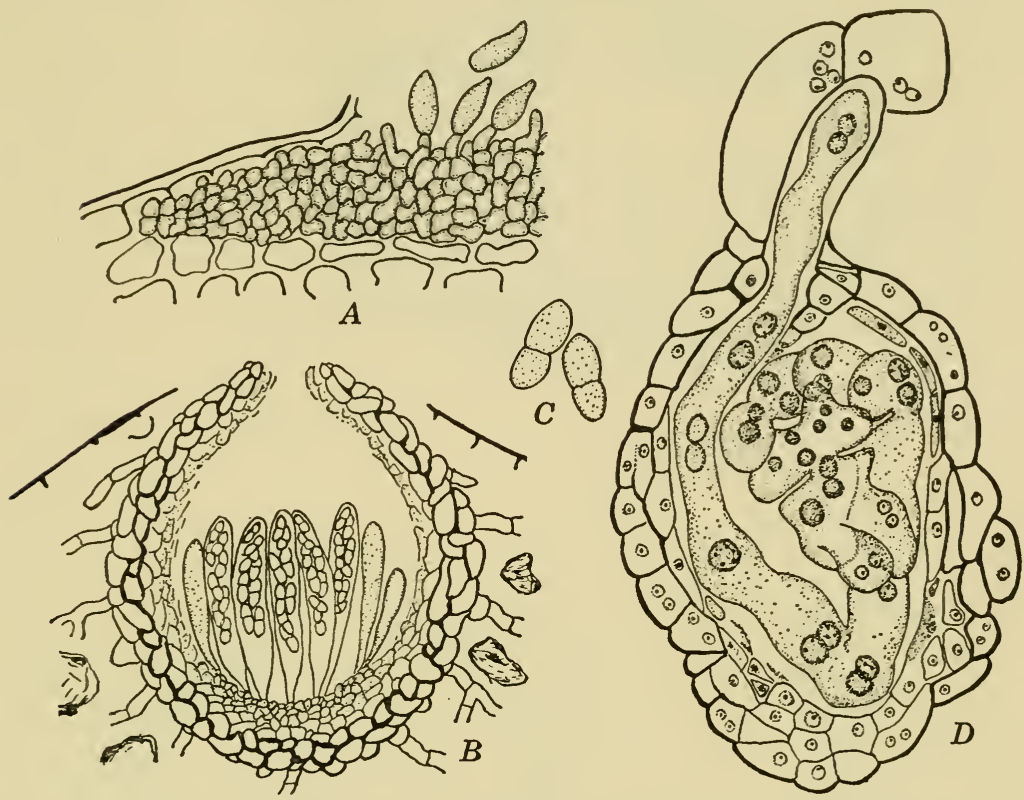

Fig. 83. Venturia inaequalis. A. Edge of conidial stroma in vertical section. The conidial stage is commonly known as Fusicladium dendriticum. B. Section of perithecium innate in tissues of decaying leaves. C. Ascospores. $D$. The fertilized ascogonium (diagrammatic), showing the multinucleate condition after migration of nuclei from the antheridium. The septa of the ascogonium have been dissolved. (After Killian.)

ial cells have multiplied to form the wall of the developing perithecium and the nurse tissue for the developing asci and paraphyses.

Physalospora. Several species of Physalospora are involved in the production of important crop-plant diseases. These include $P$. cydoniae on pomaceous fruits [Hesler (1916)] and P. fusca and $P$. rbodina on citrus [Stevens (1926)]. Physalospora $c y$ doniae, the cause of apple black rot, leaf spot, and canker, was shown by Hesler to possess a wide host range, including other 
pomaceous species and about a score of forest trees and shrubs. Its conidial stage is Sphaeropsis malorum. Physalospora fusca and $P$. rbodina are associated with the imperfect Genus Diplodia.

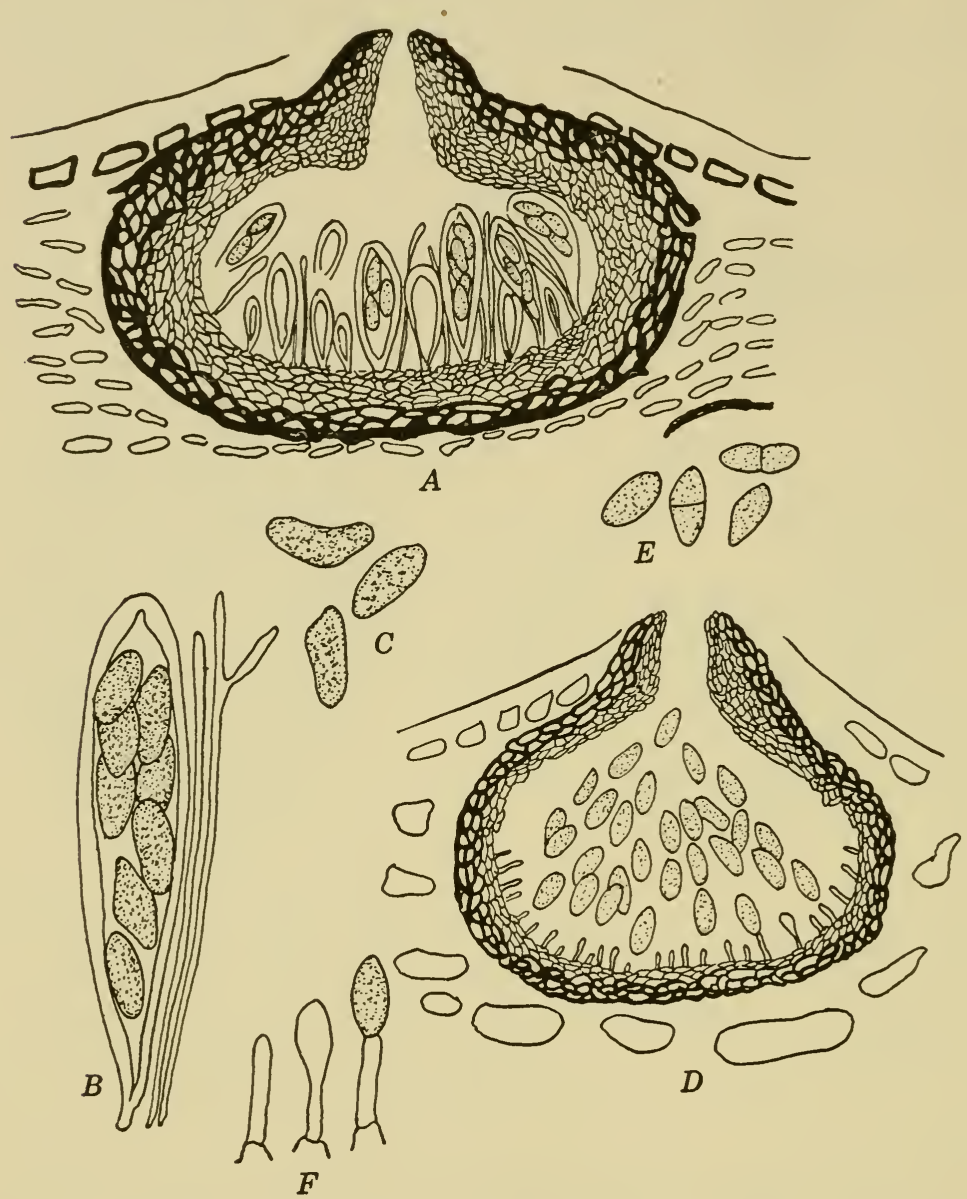

Fig. 84. Pbysalospora cydoniae. A. Perithecium in section. B. Ascus and paraphyses. C. Ascospores. D. Pycnidium, in section, of Sphaeropsis malorum, the conidial stage. E. Conidia. $F$. Stages in conidial formation. (Adapted from Hesler.)

Diplodia natalensis, a cause of stem-end rot of citrus, is the conidial stage of $P$. rhodina. Stevens (1926) regards $P$. gossypina, with its associated Diplodia gossypina, as synonymous with $P$. 
rhodina. Sexuality in species of Physalospora has never been investigated.

Attention may well be directed to the fact that the ascospores of some species of Physalospora have been described as hyaline and those of other species as yellowish. Hesler (1916) states that those of $P$. cydoniae are yellowish. There remains the likelihood that all species having Sphaeropsis, Diplodia, or other conidial stages with dark spores will be found to have pigmented ascospores. Mature ascospores must be examined.

Opbiobolus. The most important member of the Genus Ophiobolus is $O$. cariceti var. graminis, causing take-all disease of cereals and grasses. This disease was first reported in the United States in 1920 but was known long before that date in Australia, Europe, and Africa. Its causal fungus was first described as Sphaeria cariceti from England in 1861. Essential facts regarding the disease are contained in a report by Kirby (1925) and regarding the development of the pathogen in a report by Jones (1926).

Opbiobolus cariceti produces spermatia, which Jones regards as functionless, in association with perithecial primordia containing coiled ascogonia. They too are regarded as abortive, and fertilization is apogamous, involving vegetative cells. From these conjugated vegetative cells the ascogenous hyphae arise. Nuclear fusion is not antecedent to ascus formation, and meiosis occurs with the first division of the primary nucleus of the ascus. Since Gnomonia erytbrostoma has a similar type of development, Jones suggested that $O$. cariceti be placed among the Gnomoniaceae. In the opinion of the present authors both of these organisms should be reinvestigated in regard to the function of spermatia.

Gromoniaceae. The Gnomoniaceae resemble the Mycosphaerellaceae in that their perithecial walls are of similar texture; the perithecia of both are embedded within the substratum, but those of the Gnomoniaceae have ostiolar necks that project much more prominently. The asci of Gnomoniaceae possess thick apices provided with a canal. Gnomonia and Glomerella, both of which contain a considerable number of destructive plant pathogens, have been extensively studied and are worthy of more than passing mention. Their conidial stages, belonging to the imperfect genera Gloeosporium, Colletotrichum, and Marssonia, produce diseases known as anthracnoses. The conidia of anthrac- 
nose fungi usually become uniseptate as an initial step in germination. At the apex of the germ tube, moreover, a thick-walled, dark organ of attachment, called an appressorium, develops. The appressoria anchor the organism during host penetration. Appressoria are developed in culture and on the host in Glomerella but have never been observed in Gnomonia.

A few of the best-known members of this family include Gnomonia erythrostoma on cherry [Brooks (1910)], G. lep-
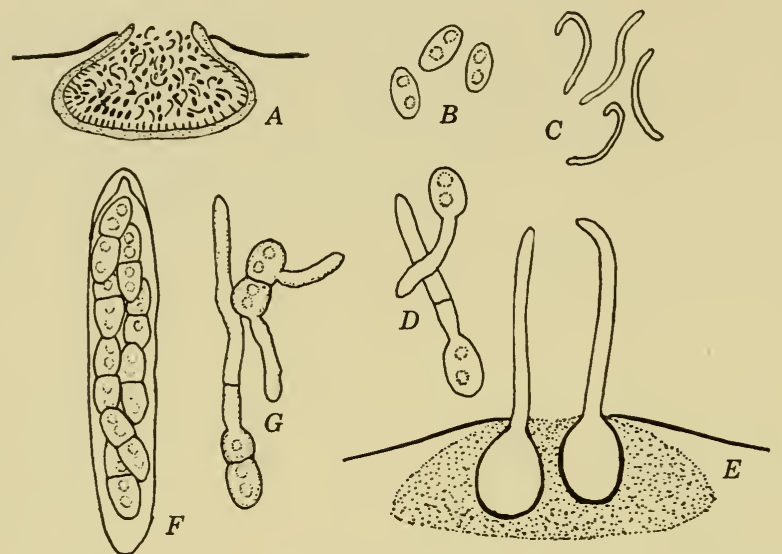

Fig. 85. Diaporthe citri. A. Pycnidial stage (diagrammatic) of Phomopsis citri, in section, bearing two kinds of spores, oval ones that germinate and thread-like ones, stylospores or scolecospores, that have not been found capable of germination. B. Conidia. C. Stylospores. D. Germinating conidia. E. Diagram of perithecial stroma in section bearing long-beaked perithecia. F. Ascus with thickened apex. G. Germinating ascospores.

tostyla on walnut, $G$. veneta on sycamore [Klebahn (1905, 1918), Edgerton (1908)], G. ulmea on elms [Miles (1921), Pomerleau (1938)], Glomerella cingulata on apple [von Schrenck and Spaulding (1903), Shear and Wood (1913)], G. gossypii on cotton, G. lagenaria on melons, $G$. lindemutbiana on beans, and G. glycines on soybeans.

Details of perithecial development among the species just mentioned are best known fòr Gnomonia erytbrostoma. Brooks (1910) observed that this organism possesses filamentous spermatia, borne in pycnidia, which he deemed functionless. Ascogones bearing trichogynes are also formed, but the trichogynes 
do not function in fertilization. Brooks suggested that instead they may serve as respiratory channels. His evidence led him to doubt that the ascogonia give rise to ascogenous hyphae.
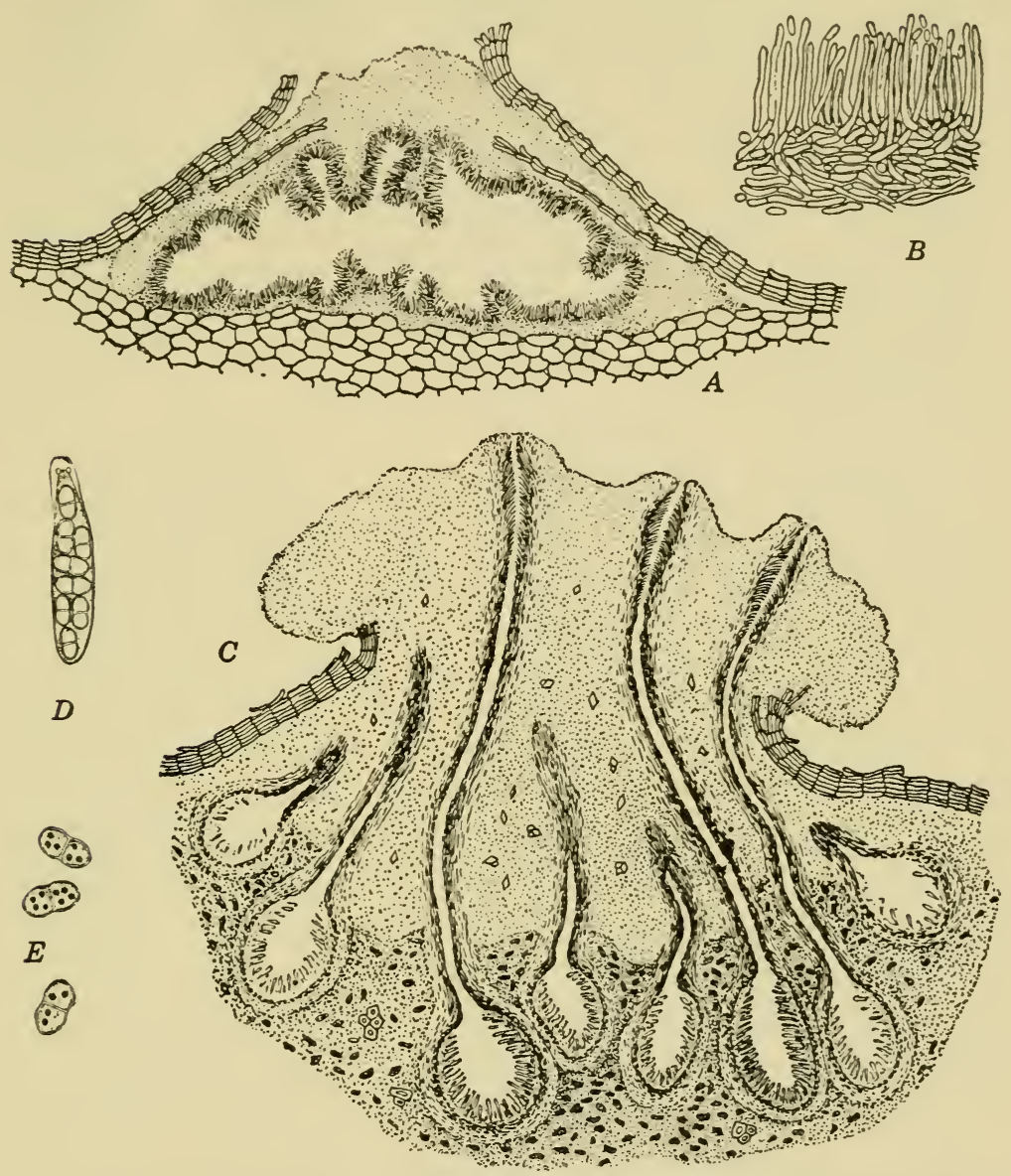

FIG. 86. Endotbia parasitica. A. Diagrammatic section of pycnidial stroma. $B$. Section of the inner wall of pycnidium, showing conidiophores and conidia. C. Perithecial stroma of $E$. parasitica in section. D. Ascus of $E$. parcitica. E. Ascospores. ( $A$ and $C$ from Heald, $B, D$, and $E$ from Anderson and Rankin.)

Ascogonial coils in Gnomonia ulmea were observed by Miles (1921) and Pomerleau (1938), but these workers did not account for the manner in which the ascogonial cells become binucleate. 
Gnomonia leptostyla produces bacillar spermatia in acervuli concurrently with the conidial stage, Marssonia juglandis.

Klebahn (1905) first connected a Gloeosporium with Gnomonia in his study of the sycamore-blight pathogen. The conidial stage, causing the buds to blight and necrotizing strips on either side of the veins of older leaves, is known as Gloeosporium nervisequum. The stage blighting the twigs is known as Myxosporium valsoideum. On fallen leaves cleistocarpous pycnidia are produced and are known as Sporonema platani. This lastnamed stage may prove to be spermogonial. Klebahn listed sixteen names in synonymy of Gnomonia veneta, and Edgerton (1908) added two others. The sycamore-blight pathogen grown on oaks, which Stoneman (1898) and Edgerton (1908) regarded as hosts, has much longer perithecial beaks than when it is grown on sycamore.

Stoneman (1898) determined that Gloeosporium cingulatum occurring on privet has a perithecial stage for which she employed the generic name Gnomoniopsis. Von Schrenck and Spaulding (1903), in connection with studies on apple bitter rot, found that the perithecial stage occurs on limb cankers and on decaying fruits. They found furthermore that the apple pathogen belongs in the Genus Gnomoniopsis, as described by Stoneman, but, because of preoccupation of Gnomoniopsis, they established in its stead the Genus Glomerella. Some regard the organism on privet and that on apple as specifically identical; support for this belief comes from extensive studies by Shear and Wood (1913). They found it on avocado, cinnamon, coffee, cocoa, cranberry, dewberry, ebony, fig, grape, guava, loquat, mango, and tea. Other workers contend that species of Glomerella have greater host specificity than is indicated by Shear and Wood's studies.

Edgerton (1914) secured evidence of heterothallism in strains of Glomerella, isolated from Populus deltoides and Ipomoea purpurea. These isolates appeared indistinguishable from the applebitter-rot fungus. By mating strains he secured rows of perithecia on the boundary line between colonies cultured in Petri dishes.

The perithecial stage of certain species of Glomerella has never been observed except on host tissues. Others, however, such as the bean-anthracnose fungus and the watermelon-anthracnose fungus, appear never to have been observed except in artificial 

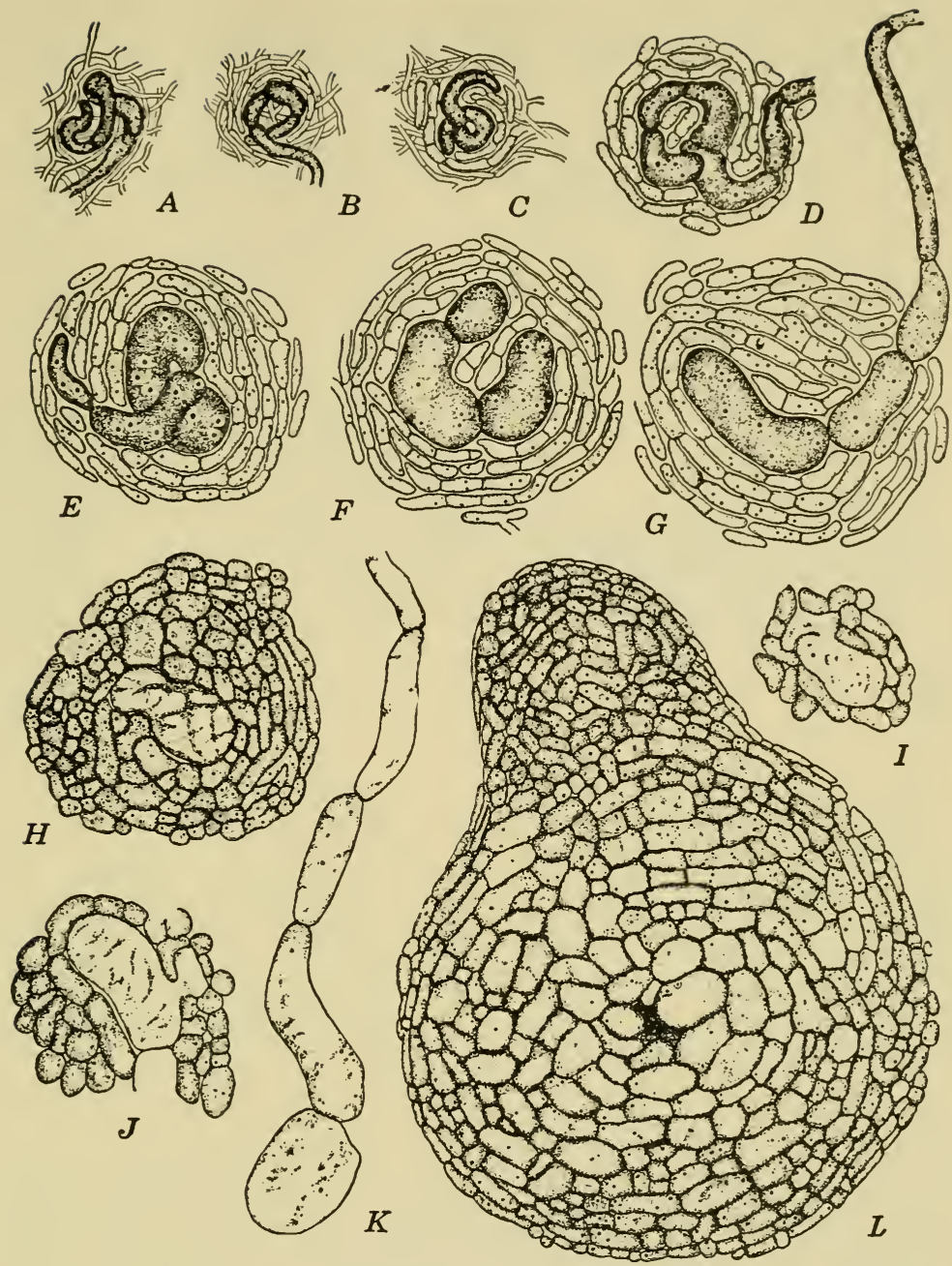

Fig. 87. Initiation of perithecia in Endotbia parasitica. (From Anderson and Rankin.) $A, B$, and $C$. Coiled ascogonia, invested with loosely arranged fungous tissue that makes up the central portion of the primordium. Many primordia occur within each stroma. $D, E$, and $F$. Densely staining multinucleate cells composing the basal portion of the ascogonia. G. Multicellular, multinuclear ascogonium, viewed laterally, the upper portion being a part of the slender trichogyne. $H$. Stroma with ascogonium at center, viewed from above. $I, J$, and $K$. Degeneration of ascogonial base and trichogyne with no evidence of formation of ascogenous hyphae. L. Young perithecium, a complex of fungus cells all quite alike. 
culture. The genus is therefore well adapted to cytologic and genetic studies, matters on which essentially nothing is at present known.

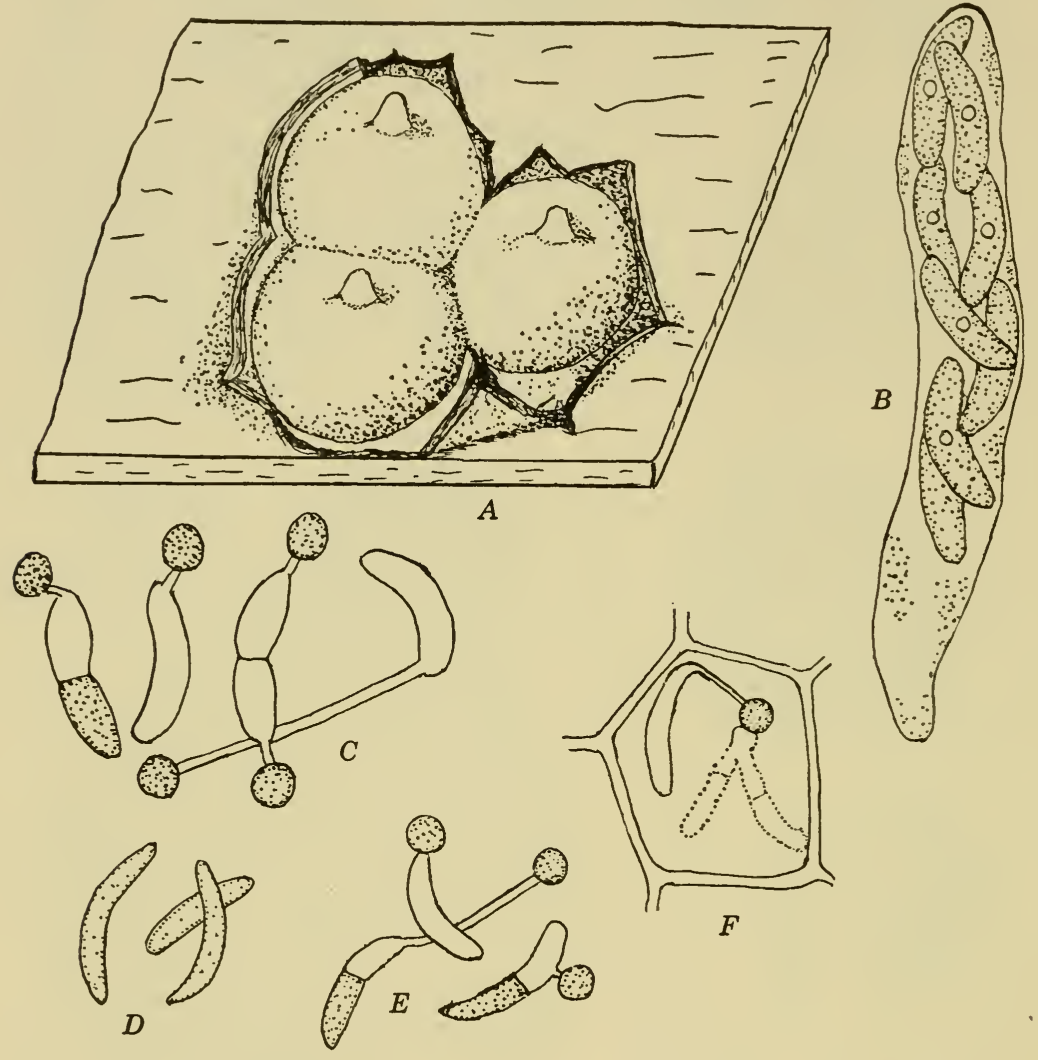

FIG. 88. Structure of Glomerella glycines. A. Diagram of three perithecia borne innately on dead stems of soybean. B. Ascus. C. Germinating ascospores with resultant formation of appressoria. D. Conidia (Colletotrichum glycines) from pustules on living pods and stems. E. Appressoria formed from germinating conidia. $F$. Infection from conidium. The infection hypha penetrates the host cell wall by a narrow tube formed immediately below the appressorium.

Diaporthaceae. The Diaporthaceae comprise a group of over 1000 species of stromatic Sphaeriales. Most of them are saprophytic, but in this family is Endotbia parasitica, which, within a period of about 30 years, spread throughout the entire Appalachian region and practically accomplished the extinction of 
American chestnut. Other important pathogenic species are included in Diaporthe and Valsa. Of these species Diaporthe citri, D. phaseolorum, D. sojae, and Valsa leucostoma are of interest. The conidial stages of species of Diaporthe belong to Phomopsis; of V'alsa, to Cytospora.
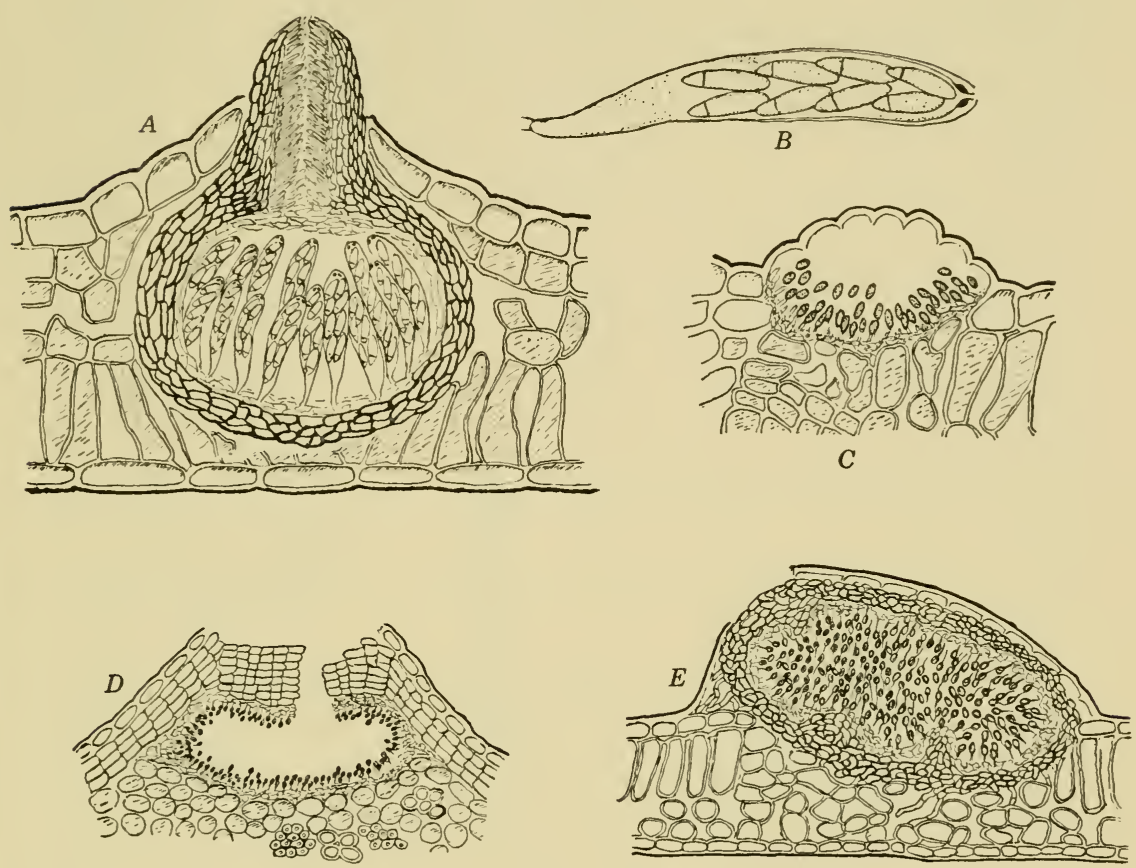

Fig. 89. The sycamore-blight fungus, Gnomonia veneta. $A$. Perithecium in section. $B$. Ascus and ascospores. C. Conidial stage, commonly designated Gloeosporium nerisequum, on young leaves. $D$ and $E$. Secondary spore stages that may prove to be spermogonia. $D$, on rotting leaves, regarded as Myxosporium valsoideum (Discella platani); $E$, on twigs, designated Sporonema platani. ( $A, C, D$, and $E$ adapted from Klebahn.)

Diaporthe citri [Wolf (1926)] causes melanose, dieback, and stem-end rot of citrus. Perithecia have been observed only on twigs lying on the ground. The conidial stage of this species is known as Phomopsis citri.

Diaporthe phaseolornm [Harter (1917)] attacks stems, pods, and leaves of Lima bean. Perithecia mature on old pods in the late summer. The conidial stage has been designated Phoma 
subcincta and Pbyllosticta pbaseolina, but Harter showed that this stage properly belongs with Phomopsis, since both ellipsoidal conidia and stylospores are produced.

Diaporthe sojae was found by Lehman (1923) to be seed-borne and to involve leaves, pods, and stems of soybean. Its ascigerous stage has been developed in pure culture.

Valsa leucostoma produces its stromata within the bark of the trunk and twigs of stone fruits. The stromata protrude at maturity and in coming to the surface cause the host to appear silvery. Rolfs (1910) found that this organism attacks trees weakened by freezing, by drought, and by lack of an adequate supply of minerals.

Although numerous reports of studies of Endotbia parasitica have been published, adequate acquaintance with this organism can be gained by perusal of those by Anderson (1914), Anderson and Rankin (1914), and Shear, Stevens, and Tiller (1917). This organism was described as Diaporthe parasitica by Murrill in 1906, although Merkel reported its presence in New York 2 years earlier. In 1913 the plant explorer Meyer found it in northern China, whence it had probably been imported to the United States.

Endotbia parasitica causes the formation of cankers on twigs, larger branches, and trunk. The mycelium spreads within the cambium of these parts, girdling and killing them. The pycnidia arise from a loose tangle of hyphae, the central branches of which become conidiophores. This hyphal mass becomes stromatic, and pycnidia are produced near the surface. Conidia are extruded in tendrils if moisture is present. The perithecia form from more deeply seated parts of the same stromata. First there is a coiled ascogonium with a functionless trichogyne. Around this ascogonium are enveloping hyphae, whose cells are deeply staining. These enveloping hyphae produce the perithecial loculi, the innermost of which nourish the developing asci. Details regarding fertilization are unknown.

The taxonomic monograph by Wehmeyer (1933) is a basis for study of the Genus Diaporthe; that by Shear, Stevens, and Tiller (1917), for study of Endothia. The closely related genera Melanconis, Pseudovalsa, Prosthecium, and Titania are taxonomically treated by Wehmeyer (1941). 
Allantosphaeriaceae. This family is also stromatic; some of its members are to be found among the Valsaceae and Diatrypaceae, as used in older literature. They occur as saprophytes or weak parasites on woody plants. As the family name indicates,
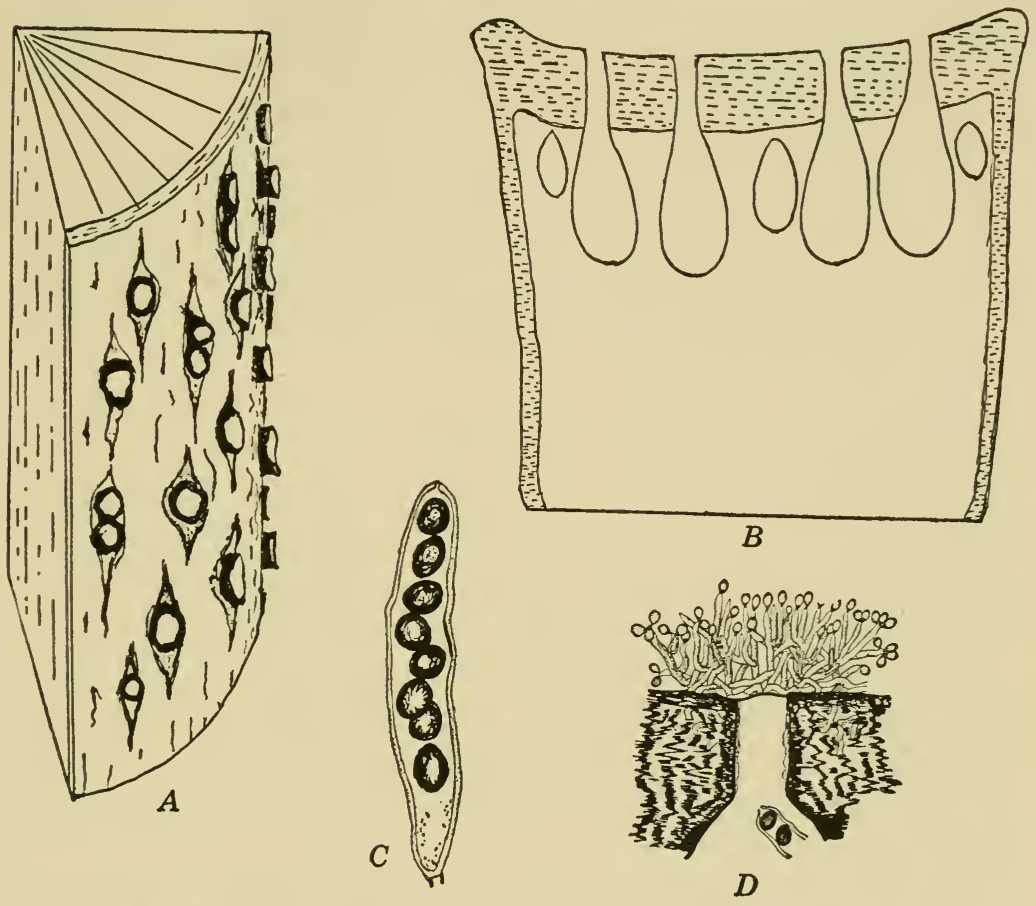

Fig. 90. Nummularia discreta, the apple blister-canker fungus. A. Diagram showing disk-shaped black stromata that protrude through fissures in the bark. $B$. Sectional diagram of perithecial stroma; the outer rind is compact and dark, and a black ring remains in the wood when a stroma is broken off. The flask-shaped perithecia open to the surface by pores. C. Ascus and dark ascospores. D. Layer of conidiophores and conidia at surface near a perithecial pore. (After J. R. Cooper.)

the ascospores are allantoid. The asci are long-stalked. The paraphyses usually jellify at maturity. The family may further be characterized as having ectostroma that is usually deciduous and a persistent entostroma. The ectostroma develops at the surface and within the periderm and consists of fungus elements and remnants of periderm. The entostroma develops within the cortex or woody tissues and contains remnants of these tissues. 
Usually the ectostroma is deciduous and may bear the conidial stage. When it is thrown off, the entostroma is exposed. The perithecia are sunken in the entostroma, the ostiolar necks extending to the surface. The ostioles may be separate or may open collectively into a few passages. The stromata are cushionshaped or even broadly effuse. In some species the substratum is not greatly modified in the formation of the entostroma, and its periphery is indicated by a definite dark line.

Diatrype and Diatrypella are the most commonly encountered representatives of this family. They differ mainly in that Diatrype has eight-spored asci, whereas the asci of Diatrypella are polysporous. Acquaintance with this family and its relationship with the Diaporthaceae may be gained from the work of Wehmeyer (1926, 1933, 1941).

XYlariaceae. The stromata of Xylariaceae are well developed and are entirely fungal in composition. They are nearly always exposed from the beginning and in youth are covered by a conidial layer. The stromata are cushion-shaped or crustose in such representative genera as Hypoxylon and Daldinia but are erect and club-shaped or variously branched in Xylaria.

Nearly all are saprophytic on woody substrata. A few, however, cause important diseases of trees, notably Xylaria mali, which produces a black root-rot disease of apples [Fromme (1928)] and Nummularia discreta, which causes apple-tree canker [Cooper (1917)].

Hypoxylon, with broadly effuse to hemispherical stromata, is the largest genus, containing over 200 species. Daldinia, monographed by Child (1932), has concentrically zonate stromata that may be 3 to $5 \mathrm{~cm}$ in diameter. Nummularia discreta forms stromatic cushions 3 to $6 \mathrm{~mm}$ across, which are seated on the wood but protrude through the bark. When the stromata break away, a black ring remains in the wood. Xylaria polymorpha forms thick, black clubs 6 to $8 \mathrm{~cm}$ tall, and $X$. bypoxylon forms staghorn-shaped stromata 3 to $4 \mathrm{~cm}$ tall.

Little is known about the development of any members of this family, although the grosser features of $X$. polymorpha and $X$. bypoxylon were studied by Fisch as long ago as 1882 [Brown (1913)]. Xylaria tentaculata was found by Brown (1913) to be parthenogenetic. Ascogonial coils form in the young stromata, 


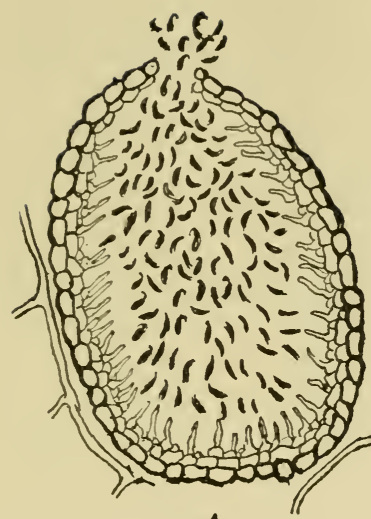

A

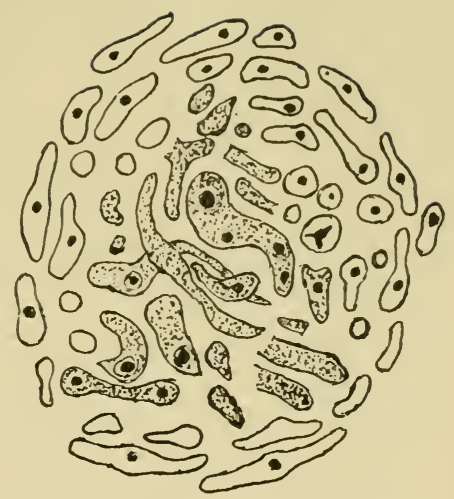

$B$

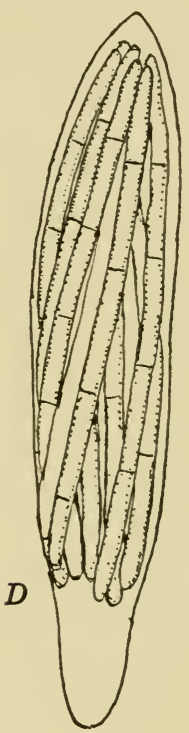

FIG. 91. Opbiobolus cariceti, cause of take-all of wheat. A. Spermogonium in section. Spermatia are pear-shaped and curved. B. Portion of initial of perithecium. The hyphae make a loose aggregate, in the center of which are coiled ascogonia with deeply staining cells. C. Mature perithecium, in diagram, lying obliquely and entirely immersed within the tissues, except for the tip of the beak. D. Mature ascus. The asci are extruded intact during wet periods and collect in a mass at the tip of the beak. ( $A$ and $B$ adapted from Jones.) 
and the ascogonium, uninucleate at first, comes to have twenty or more nuclei. The ascogenous hyphae arise as outgrowths from the ascogonium.

\section{LITERATURE CITED}

Ahrens, IV. E., et al., "A list of references to literature on the Dutch elm disease." 29 pp. (Mimeographed.) U. S. Dept. Agr., Dutch Elm Disease Laboratory. Morristown, N. J. 1935.

Axtes, L. M., "Hermaphroditism involving self-sterility and cross-fertility in the Ascomycete, Pleurage anserina," Mycol., 26: 392-414, 1934.

Axderson, P. J., "The morphology and life history of the chestnut-blight fungus," Commission for the Investigation and Control of the ChestnutTree-Blight Disease in Pennsylvania, Bull. 7. 44 pp. 1914.

Axderson, P. J., ANd IV. H. Rankin, "Endothia canker of chestnut," Cornell Agr. Expt. Sta. Bull., 347: 530-618, 1914.

Andrus, C. F., and L. L. Harter, "Morphology and reproduction in Ceratostomella fimbriata," J. Agr. Research, 46: 1059-1078, 1933.

"Organization of the unwalled ascus in two species of Ceratostomella," J. Agr. Research, 54: 19-46, 1937.

Backus, M. P., "The mechanics of conidial fertilization in Neurospora sitoplila," Bull. Torrey Botan. Club, 66: 63-76, 1939.

Brooks, F. T., "The development of Gnomonia erytbrostoma," Ann. Botany, 24: 585-603, 1910.

Brown, H. B., "Studies in the development of Xylaria," Ann. Mycol., 11: $1-13,1913$.

Buisman, Christine, "Ceratostomella ulmi, de geschlachtelijke vorm van Grapbium ulmi Schwarz," Tijdschr. over Plantenziekten, 38: 1-5, 1932.

Child, Marion, "The genus Daldinia," Ann. Mo. Botan. Garden, 19:429496, 1932.

Chivers, A. H., "A monograph of the genera Chaetomium and Ascotricha," Mem. Torrey Botan. Club, 14: 155-240, 1915.

Clinton, G. P., and Florexce A. McCormick, "Dutch elm disease, Grapbium ulmii," Conn. Agr. Expt. Sta. Bull., 389: 701-752, 1936.

Colson, B., "The cytology and morphology of Neurospora tetrasperma Dodge," Ann. Botany, 48:211-224, 1934.

Cooper, J. R., "Studies of the etiology and control of blister canker on apple trees," Nebr. Agr. Expt. Sta. Bull., 12. 117 pp. 1917.

DodgE, B. O., "Nuclear phenomena associated with heterothallism and homothallism in the ascomycete Neurospora," J. Agr. Research, 35: 289-305, 1927.

"The non-sexual and sexual functions of microconidia of Neurospora," Bull. Torrey Botan. Chub, 59:347-360, 1932.

"The mechanics of sexual reproduction in Neurospora," Mycol., 27:418438, 1935.

Edgerton, C. W., "The physiology and development of some anthracnoses," Botan. Gaz., 45: 367-407, 1908. 
"Plus and minus strains in the genus Glomerella," Am. J. Botanı, 1: 244 $254,1914$.

Ehrlich, John, ANd F. A. Wolf, "Areolate mildew of cotton," Ploytopathology, 22: 229-240, 1932.

Elliott, J. A., "A cytological study of Ceratostomella fimbriata (E. and H.) Elliott," Ploytopathology, 15:417-422, 1925.

FitzPatrick, H. M., "Monograph of the Nitschkieae," Mycol., 15:23-44, $45-67,1923$.

Fromme, F. D., "The black-root-rot disease of apple," Va. Agr. Expt. Sta. Bull., 34: 5-52, 1928.

Griffith, D., "The North American Sordariaceae," Mem. Torrey Botan. Club, 11: 1-134, 1901.

Harter, L. L., "Pod blight of the Lima bean caused by Diaporthe plaseolorum," J. Agr. Research, 11:473-504, 1917.

Heald, F. D., and F. A. Wolf, "The whitening of the mountain cedar, Sabina sabinoides (H.B.K.) Small," Mycol., 2: 205-211, 1910.

Hesler, L. R., "Black rot, leaf spot, and canker of pomaceous fruits," Cornell Agr. Expt. Sta. Bull., 379:51-148, 1916.

Higgins, B. B., "Life history of a new species of Sphaerella," Mycol. Centrb., 4: 187-193, 1914.

"Morphology and life history of some of the Ascomycetes, with special reference to the presence and function of spermatia," Am. J. Botany, 7: 435-444, 1920.

"Morphology and life history of some Ascomycetes, with special reference to the presence and function of spermatia, II," Am. J. Botany, 16: 287-296, 1929.

Higgins, B. B., And F. A. Wolf, "Frosty mildew of peach," Ploytopathology, 27: 690-696, 1937.

JefFers, W. F., "Studies on Caryospora putaninum," Mycol., 32: 550-566, 1940.

Jenkins, W. A., "The cherry-leaf-spot fungus, Mycospbaerella cerasella Aderh., its morphology and life history," Plbytopatbology, 20:329-337, 1930.

"Two fungi causing leaf spot of peanut," J. Agr. Research, 56:317-322, 1935.

Jolivette-SAx, H. D. M., "Spore formation in Pbilocopra coeruleotecta," Am. J. Botany, 5:61-78, 1918.

Jones, S. G., "The development of the perithecium of Ophiobolus graminis Sacc.," Ann. Botany, 40:607-629, 1926.

Killian, C., "Über die Sexualität von Venturia inaequalis," Z. Botanı., 9: 353-398, 1917.

KIRBy, R. S., "The take-all disease of cereals and grasses caused by Oploiobolus cariceti (Berkeley and Broome) Saccardo," Cornell Agr. Expt. Sta. Mem., 88. 44 pp. 1925.

Klebahn, H., "Untersuchungen über einige Fungi Imperfecti und die zugehörigen Ascomycetenformen," Jabrb. wiss. Botan., 41:515-558, 1905. Haupt- und Nebenfruchtformen der Ascomyceten. 395 pp. Gebr. Bornträger, Leipzig. 1918. 
LathaM, D. H., "Life history of a Cercospora leaf-spot fungus on cowpea," Mycol., 26: 516-527, 1934.

Lehinan, S. G., "Pod and stem blight of soybean," Ann. Mo. Botan. Garden, 10:111-178, 1923.

Lewis, I. M., "The development of spores of Plentrage zygospora," Botan. Gaะ., 51:369-373, 1911.

Martin, G. IV., "A key to the families of fungi, exclusive of the lichens," Univ. Iowa Studies, 17:83-115, 1936.

Miles, L. E., "Leaf spots of the elm," Botan. Gaz., 71: 161-196, 1921.

Ponerleau, R., "Recherches sur le Gnomonia ulmea (Schw.) Thüm," Contrib. inst. bot. Univ. Montreal, 31. 139 pp. 1938.

RedDick, D., "The black-rot disease of grapes," Cornell Agr. Expt. Sta. Bull., 293: 289-364, 1911.

Rolfs, F. M., "Winter killing of twigs, cankers, and sun scald of peach," Mo. Fruit Sta. Bull., 17:9-101, 1910.

Scheffer, T. C., ANd R. M. Lindgrex, "Stains of sapwood and sapwood products and their control," U.S. Dept. Agr. Tecl. Bull., 71t. 123 pp. 1940.

Schrexck, H. von, and P. Spaulding, "The bitter rot of apples," U. S. Dept. Agr., Bur. Plant Ind. Bull., 44. 54 pp. 1903.

Seaver, F. J., "Fimetariales," North Am. Flora, 3: 57-88, 1910.

Shear, C. L., N. E. Stevens, ANd Ruby J. Tiller, "Endotbia parasitica and related species," U. S. Dept. Agr. Professional Paper Series, Bull. 380. 82 pp. 1917.

Shear, C. L., ANd ANxa K. ITood, "Studies of fungous parasites belonging to the genus Glomerella," Bur. Plant Ind. Bull., 252. 110 pp. 1913.

Simth, D. J., ANd C. O. Sııтн, "Species of Stigmina and Stigmella occurring on Platanus," Hilgardia, 17: 205-231, 1941.

Stevexs, N. E., "Two species of Physalospora on Citrus and other hosts," Mycol., 18: 206-217, 1926.

Stoneman, Bertha M., "The comparative derelopment of some anthracnoses," Botan. Gaz., 26: 69-120, 1898.

W'eHMeyer, L. E., "A biologic and phylogenetic study of stromatic Sphaeriales," Am. J. Botany, 13:574-645, 1926.

"The genus Diaporthe Nitschke and its segregates," Univ. Mich. Studies, Sci. Ser., 9. 349 pp. University of Michigan Press, Ann Arbor, Mich. 1933.

A revision of Melanconis, Pseudovalsa, Prosthecium, and Titania. viii + 161 pp. University of Michigan Press, Ann Arbor, Mich. 1941.

IVolf, F. A., "The perfect stage of the fungus which causes melanose of citrus," J. Agr. Research, 33: 621-625, 1926.

"Pomegranate blotch," J. Agr. Research, 35:465-469, 1927.

"The perfect stage of Cercospora rubi," Mycol., 27:347-356, 1935.

"False mildews of red mulberry," Mycol., 28:268-277, 1936.

"Leaf spot of ash and Ployllosticta viridis," Mycol., 31:258-266, 1939.

"Cercospora leaf spot of red bud," Mycol., 32: 129-136, 1940.

"A leaf-spot fungus on Nyssa," Mycol., 32: 331-335, 1940a.

Wolf, F. A., axd R. WV. Davidsox, "Life cycle of Piggotia fraxini, causing leaf disease of ash," Mycol., 33:526-539, 1941. 


\section{Laboulbeniales}

The Laboulbeniales comprise a group of peculiar pyrenomycetous fungi that are obligate parasites of insects. Knowledge of the group, in which some 50 genera and 1250 species are known at present, is almost entirely the result of the researches of Thaxter $(1895,1908 ; 1924,1926,1931)$. Although most members of the order are parasitic upon Coleoptera, a few are to be found upon Hymenoptera, Diptera, and other groups of insects.

The Laboulbeniales are characteristically ectoparasites upon the chitinous exoskeleton or integument of their hosts. The various species of fungi are limited not only to definite host genera and species, but also in a few instances to a definite and restricted area upon its host; for example, some species occurring upon the right wing cover of a beetle are not to be found in a corresponding position upon the left elytron. The plant body is attached to the chitinous integument by means of a "foot," which in the vast majority of species does not penetrate within the body cavity of the insect. Hence, unlike most other entomogenous fungi, the Laboulbeniales are not fatal to their hosts, which suffer little injury from infection. The role of the foot in the nutrition of the fungus is a question much in dispute.

The plant body consists essentially of a row of cells, arising from the foot, bearing a female reproductive branch and giving rise laterally to filamentous appendages on which are borne the antheridia.

Reproduction. Sterile appendages similar to those bearing antheridia may occur throughout the order. It is upon the basis of the antheridia that the Laboulbeniales have been classified. Uninucleate spermatia are produced throughout the order. In the primitive Family Ceratomycetaceae the spermatia are borne exogenously on the antheridial branches. In the Laboulbeniaceae the spermatia are formed endogenously within flask-shaped antheridia. In the Peyritschiellaceae the antheridia are compound, and the endogenous spermatia are discharged into a common cavity.

The female reproductive branch, or archicarp, consists of a trichogyne, trichophore cell, and carpogenic cell. The carpogenic cell produces from 1 to 32 ascogenous cells; ascogenous 

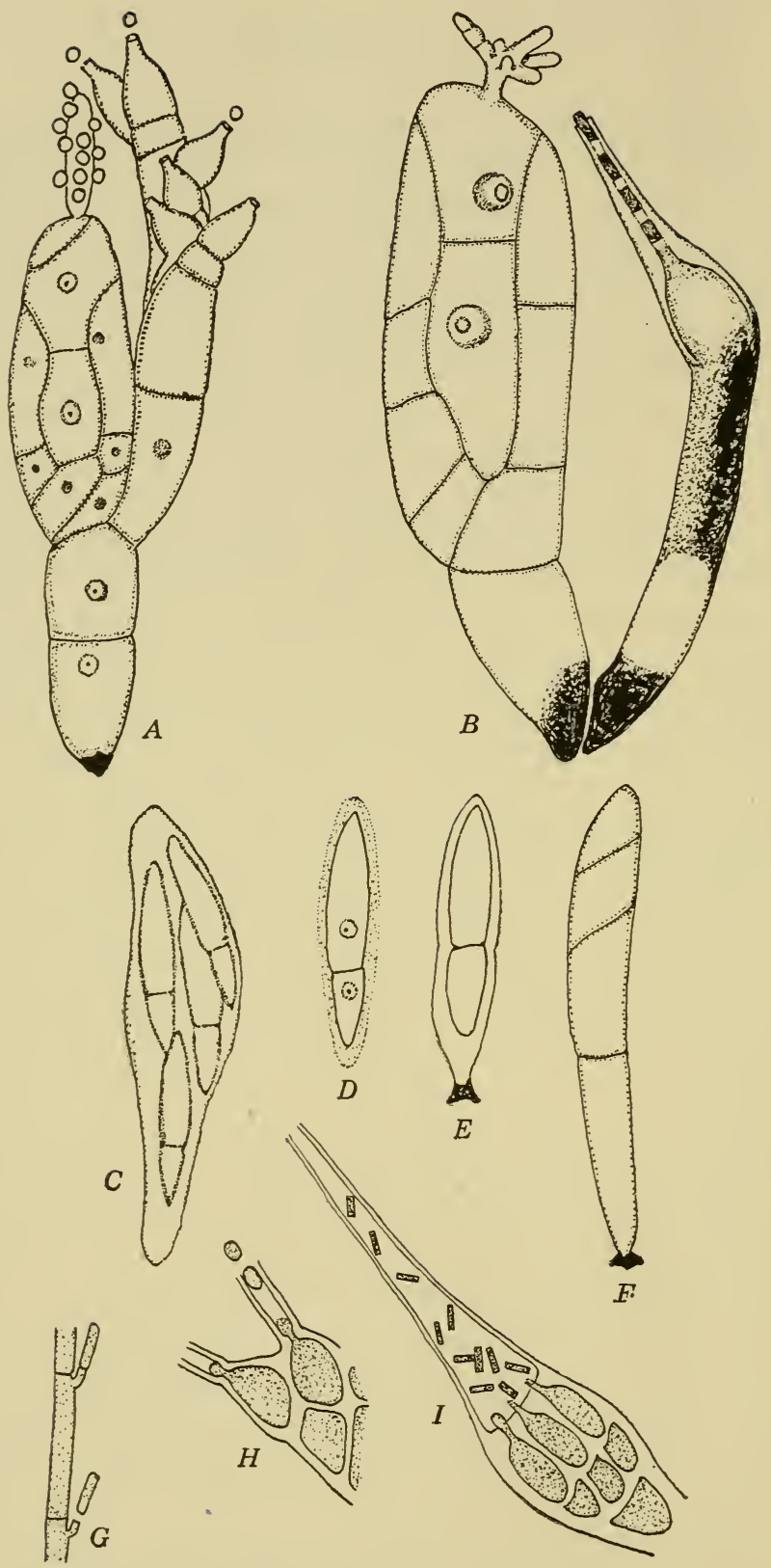
hyphae, as such, are absent. Eventually each ascogenous cell becomes an ascus and forms 4 to 8 ascospores.

Although the attachment of the spermatia to the trichogynes has been observed in many species, the details of fertilization are unknown. The cytological investigations of Faull (1911, 1912) were unfortunately made upon two parthenogenetic species, $L a-$ boulbenia chaetophora and L. gyrinidarum, in which nuclear fusion was observed to occur in the young ascus. Although 3 nuclear divisions give rise to 8 nuclei, 4 of these soon degenerate, and the mature ascus contains 4 ascospores.

The mature ascospore has 2 unequal cells; the larger is covered with a gelatinous material which attaches the spore to its host. No conidia or other spore forms are to be found. A number of genera and species of the group are dioecious; in these forms the ascospores are discharged in pairs and develop into separate male and female plants growing close together on the host.

Relationship. The Laboulbeniales have been prominently mentioned by those who support the red-algal theory of the origin of the Ascomycetes. The presence of spermatia and trichogynes and of sterile cells surrounding the procarp (archicarp) in both groups is certainly a striking instance of parallel development, if nothing more. Furthermore, the protoplasts of adjacent vegetative cells are frequently connected through pores. Yet the difficulty of homologizing the asci with any structure in the Rhodophyceae and the differences in chemical composition of the cell walls in the two groups are strong arguments against the supposed relationship. It is perhaps better to regard the

Fig. 92. Various Laboulbeniales. A. Mature plant of Stigmatomyces baeri, having both antheridial and ascogonial branches. The spermatia are being shed and some are attached to the trichogyne. $B$. Two mature plants of Amorphomyces falagriae, the one at the left ascogonial, at the right antherial. C. Ascus of Stigmatomyces baeri. D. Ascospore of S. baeri, with gelatinous envelope. E. Early development from the ascospore in which foot-like attachment disk has formed. F. Young thallus of S. baeri, with foot, stalk cell (from basal cell of ascospore) and three regetative cells from upper cell of ascospore. G. Amorpbomyces africanus, illustrating spermatial formation among the Ceratomycetaceae. H. Rhynchophoromyces rostratus, illustrating spermatial formation among the Laboulbeniaceae. I. Stignatomyces baeri, illustrating spermatial formation among the Peyritschiellaceae. (Adapted from Thaxter.) 
Laboulbeniales as reduced and specialized forms, differing rather widely from other Ascomycetes.

\section{LITERATURE CITED}

Faull, J. H., "The cytology of the Laboulbeniales," Ann. Botany, 25:649$654,1911$.

"The cytology of Laboulbenia chaetophora and L. Gyrinidarum," Ann. Botany, 26:325-355, 1912.

Thaxter, R., "Contribution toward a monograph of the Laboulbeniaceae," Part 1, Menn. Aml. Acad. Arts Sci., 12:195-429, 1895; Part 2, 13:219469, 1908; Part 3, 14:309-426, 1924; Part 4, 15:427-580, 1926; Part 5, 16: $1-435,1931$.

\section{Hemisphacriales}

The Hemisphaeriales comprise an artificial assemblage of five families which resemble both Pyrenomycetes and Phacidiales and are therefore regarded as intermediate between the pyrenomycetous and discomycetous fungi. Their fructifications are shield-shaped, lack ostiola, and hence rupture irregularly, and their supporting hyphae are for the most part radiately arranged. Certain mycologists have regarded such fructifications as the lower half of inverted perithecia, the morphologic base being attached to the hyphae above and the upper part having atrophied in response to protection afforded by attachment to the host tissues. To such structures, the name thyriothecia has been applied.

The Hemisphaeriales generally are parasitic on leaves of plants. The larger number are tropical, but collectors familiar with the order are finding them not uncommon in the Temperate zones. Relatively few are known to possess conidial stages. In their monographic treatment Theissen and Sydow (1917) recognize over 300 species in 111 genera, arranged in 5 families and distributed as follows: Stigmateaceae, 11 genera; Polystomellaceae, 39; Microthyriaceae, 36; Trichopeltaceae, 6; and Hemisphaeriaceae, 19. In the arrangement of Theissen and Sydow the families are separated on the following bases:

1. Fructification (shield) radially constructed

2. Mycelium thread-like, either not abundant or else wanting 3

3. Ascomata largely internal

4. Ascomata subcuticular

4. Ascomata superficial but hypostromata internal

Stigmateaceae

Polystomellaceae 
3. Ascomata and assimilatory hyphae superficial Microthyriaceae

2. Mycelium membranaceous and radially anastomosed

Trichopeltaceae

1. Fructification (shield) not composed of radially arranged elements

Hemisphaeriaceae

Little regarding the developmental history of Hemisphaeriales is known, and generalizations concerning them will be possible only when a reasonably large number have been adequately studied. Studies of their gross structure, such as those of Arnaud (1918), have been made by using herbarium specimens. Although such studies are very valuable, they are not sufficient to establish relationships within the order or to determine their phylogeny.

Stiganateaceae. The Genus Stigmatea is the best-known representative of this family. Klebahn (1918) studied several species, including S. robertiani, occurring on Geranium robertianum. He noted that this species forms leaf spots during late summer and fall and that the pathogen forms a membranaceous layer beneath the cuticle. During the winter this layer thickens at certain points, these thickened areas (stromata) becoming fructifications that mature in the spring. Killian (1922) described the occurrence within young stromata of a uninucleate antheridial cell and a uninucleate ascogonial cell whose protoplasts fused through a papillar passage. After several divisions of each of the nuclei, fusion in pairs took place; the diploid nuclei then migrated into ascogenous hyphae arising from the ascogonium. Several functional ascogonia may be formed within each stroma. It is probable that this type of sexual apparatus does not occur in all species of Stigmatea, for in $S$. potentillae conceptacles that appear to be spermogonia have been observed.

Microthyriaceae. In this family the radiate nature of the fructifications is best developed. The position of the family has been much in dispute, however, as is indicated by the fact that in Sylloge Fungorum Saccardo placed it first among the Dothideales; then it was shifted among the Erysiphales; and finally Theissen $(1913,1913 a)$ and Theissen and Sydow (1917) included it in their new order, Hemisphaeriales. Doidge (1920) and Ryan (1926) accept this classification among the Hemisphaeriales, but Arnaud (1918) would place it near the Myriangiales.

Ryan (1926) found that the ascocarps of Microthyriaceae may arise either from a mycelial cell, a hyphopodium, a lateral my- 


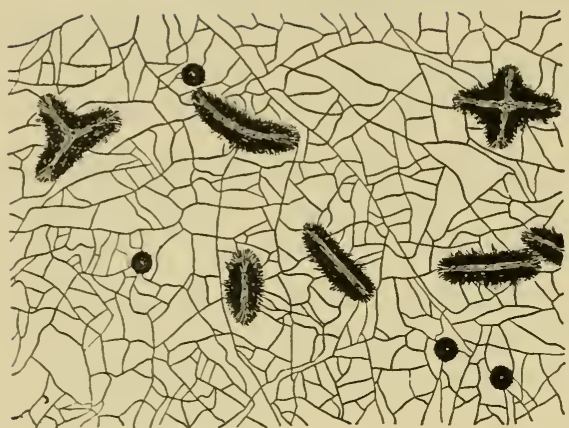

A
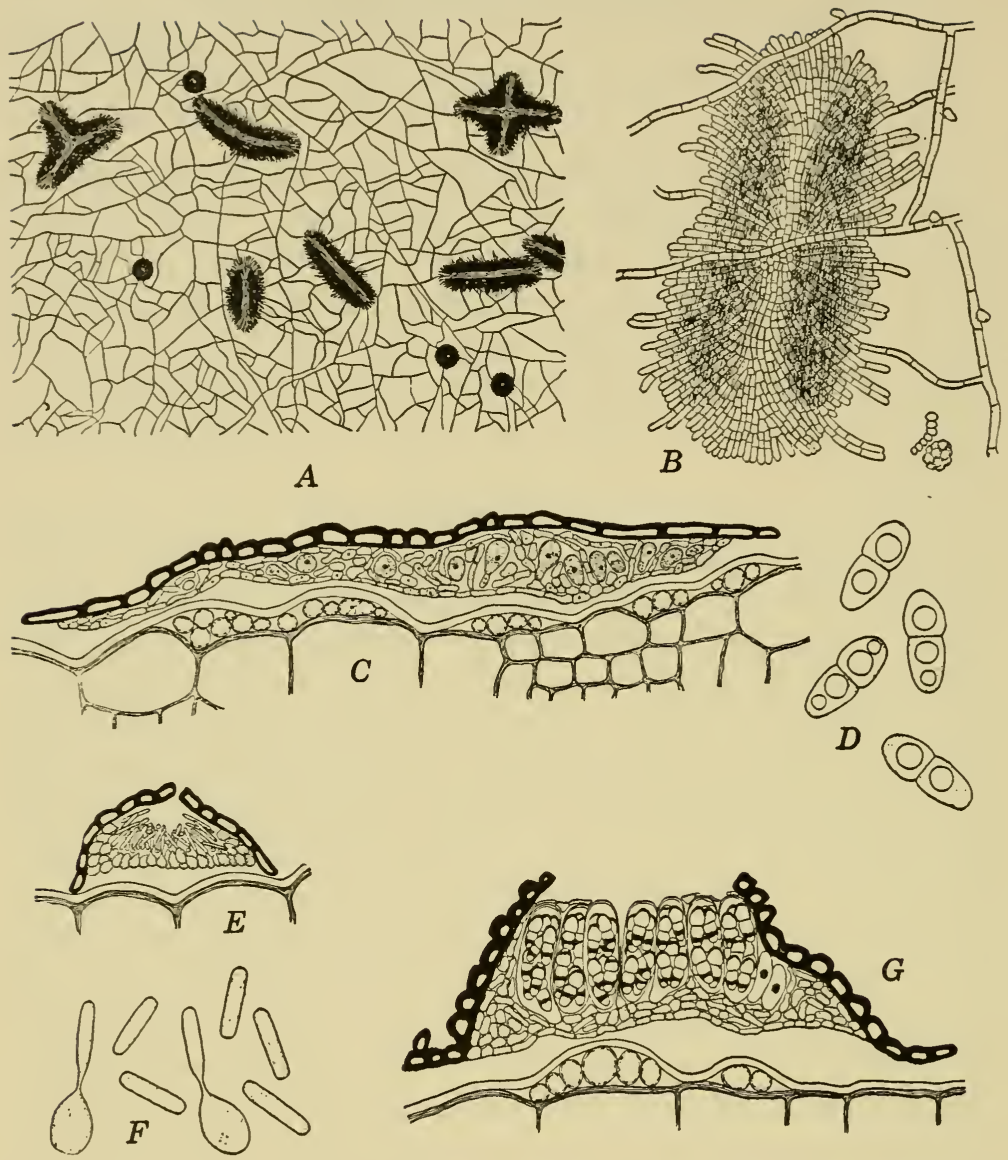

Fig. 93. Morenoella quercina. A. Spermogonia and young ascocarps formed on the mycelium occurring on the upper surface of oak leaves. $B$. A young shield-shaped ascocarp, together with supporting mycelium. C. Cross-section of ascocarp, showing asci forming singly within the superficial stroma. D. Mature two-celled ascospores. $E$. Mature spermogonium bearing rod-shaped spermatia. The spermatiophores form a layer at the base of the spermogonium. $F$. Spermatiophores and spermatia. G. Vertical section of mature ascocarp. Ascocarp superficial, nutritive hyphae subcuticular. (Courtesy of E. S. Luttrell.) 
celial branch, or a nodulate cell. Her data on this point are summarized in Table 2.

TABLE 2

Origin of Ascocarps Among Microthyriaceae

Development from

\begin{tabular}{lcccc}
\cline { 2 - 4 } \multicolumn{1}{c}{ Genus } & Mycelial cell & Hyphopodium & Lateral branch & Nodulate cell \\
Asterina & 35 & 3 & 2 & 2 \\
Asterinella & 6 & 1 & 1 & \\
Amazonia & & 1 & 1 & \\
Aulographum & 1 & & & \\
Caulothyriopeltis & 3 & & & \\
Echidnodes & 3 & & 1 & \\
Echidnodella & 5 & & & \\
Englerulaster & 2 & & 1 & \\
Lembosia & 10 & & & \\
Morenoella & 16 & & &
\end{tabular}

The cells of the fructification are dark brown, being lighter at the periphery, and are laid down in rows. This radiate characteristic persists but may not be discernible in some genera unless the material is cleared by boiling in potassium hydroxide. In other genera the color is so dense as to be carbonaceous, making it impossible, even by use of a clearing reagent, to determine the arrangement of cells. In still other genera the central cells gelatinize.

Morenoella quercina, commonly occurring in the southeastern United States on the foliage of various species of red oaks and black oaks, is the most thoroughly known species of Microthyriaceae. Luttrell (1940) observed that its mycelium is entirely superficial during the early summer and that the hyphae may fragment in a toruloid manner, each element being presumably capable of functioning as a conidium. By late summer subcuticular hyphae are present. By the time the leaves are shed, spermogonia and ascocarp initials are produced coincidentally in separate structures on the same superficial mycelium. Both structures are dimidiate, with a flat cushion of fertile cells formed beneath the shield. The spermogonia are ostiolate and shed spermatia through the pore. Whether the spermatia function is not known, and ascogenous hyphae have not been observed. Each ascus arises individually and creates a loculus within the 

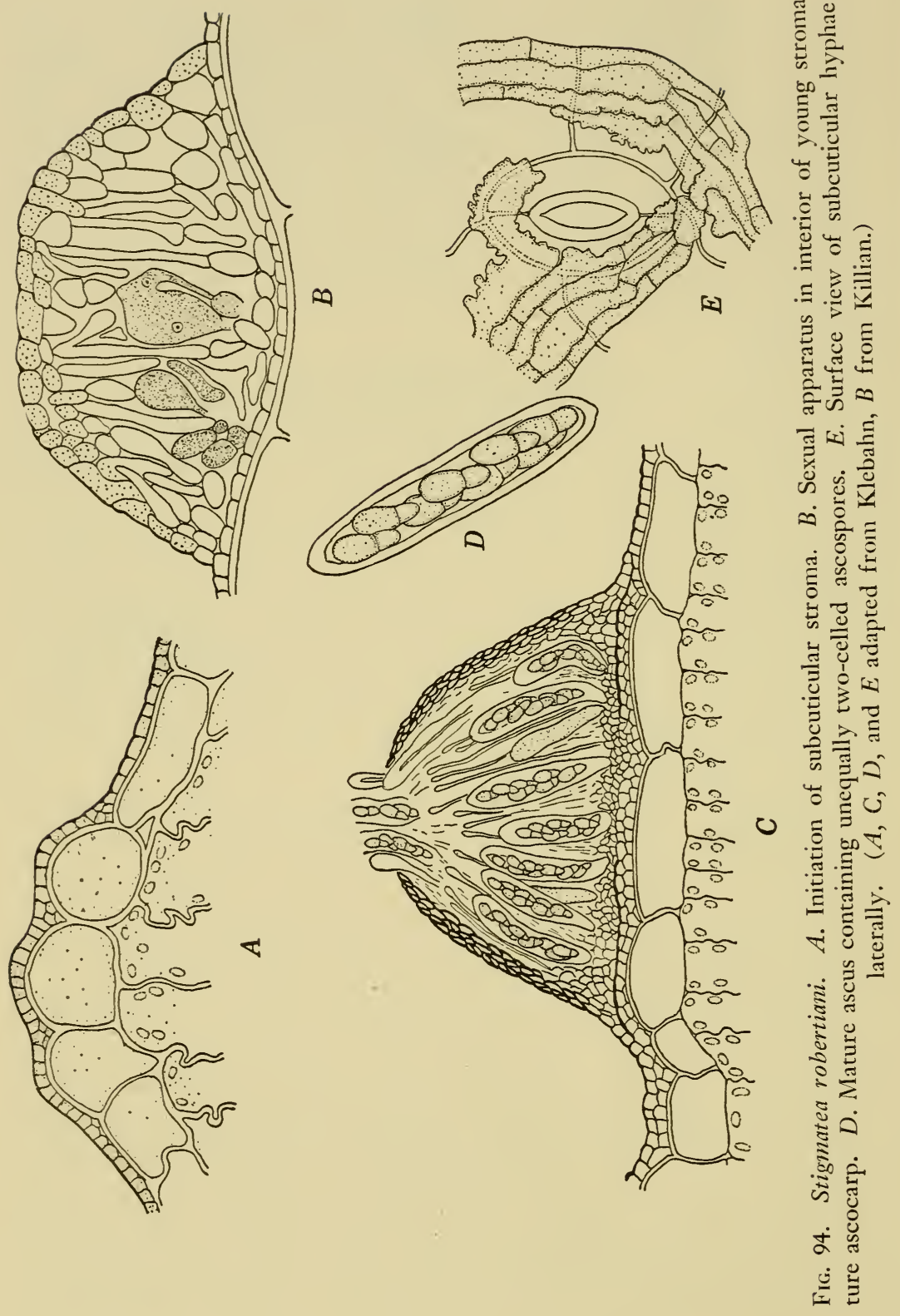
stroma by absorbing or crushing adjacent cells. By spring the asci are mature; then the shield becomes fissured and the asci are thereby exposed.

Morenoella mollenideae is represented by Arnaud (1918) as possessing spermogonia resembling those described by Luttrell (1940). Such spermogonia have been shown to occur also among species of Asterina. More should be learned regarding their possible role in fertilization.

Renianing falinlies. The Polystomellaceae possess ascocarps that expose the asci through a linear aperture, and for this reason the family has been regarded as related to the Hysteriales. Apparently all genera are tropical as are also the Hemisphaeriaceae. Theissen (1913, 1913a) divided the Hemisphaeriaceae into two tribes, using the structure of the shield, whether net-like or knotted, as the basis for separation. In this family the asci are scattered, one in each loculus.

The Trichothyriaceae, monographed by Theissen (1914), are typified by Trichothyrium sarciniferum, described by Spegazzini in 1889. This species grows upon Meliola, one of the genera of sooty molds. Certain other members of the family parasitize stromatic Sphaeriales. Approximately a score of species, all tropical, have been described.

\section{LITERATURE CITED}

Arnaud, G., Les Asterinées. Thèses présentés a la Faculté des Sciences de Paris. 288 pp. 1918.

Doidge, Ethel M., "South African Microthyriaceae," Trans. Roy. Soc. Soutb Africa, 8:235-282, 1920.

Killian, C., "Le déreloppement du Stigmatea robertiani Fries," Rev. gén. botan., 34:577-588, 1922.

Klebahn, H., Haupt- und Nebenfruchtformen der Ascomyceten. 395 pp. Gebr. Bornträger, Leipzig. 1918.

Luttrell, E. S., "Morenoella quercina, cause of leaf spot of oaks," Mycol., 32: 652-666, 1940.

Ryan, Ruth IW., "The development of the perithecia in the Microthyriaceae and a comparison with Meliola," Mycol., 18: 100-110, 1926.

Theissen, F., "Hemisphacriales," Ann. Mycol., 11:468-469, 1913.

"Über Membranstrukturen bei den Microthyriaceen als Grundlage für den Ausbau der Hemisphaeriales," Mycol. Centrb., 3: 273-286, 1913 a.

"Die Trichothyriaceen," Beib. Bot. Centrb., Abt. 2, 32:1-16, 1914.

Theissen, F., ANd H. Sydow, "Synoptische Tafeln," Ann. Mycol., 15:389$491,1917$. 

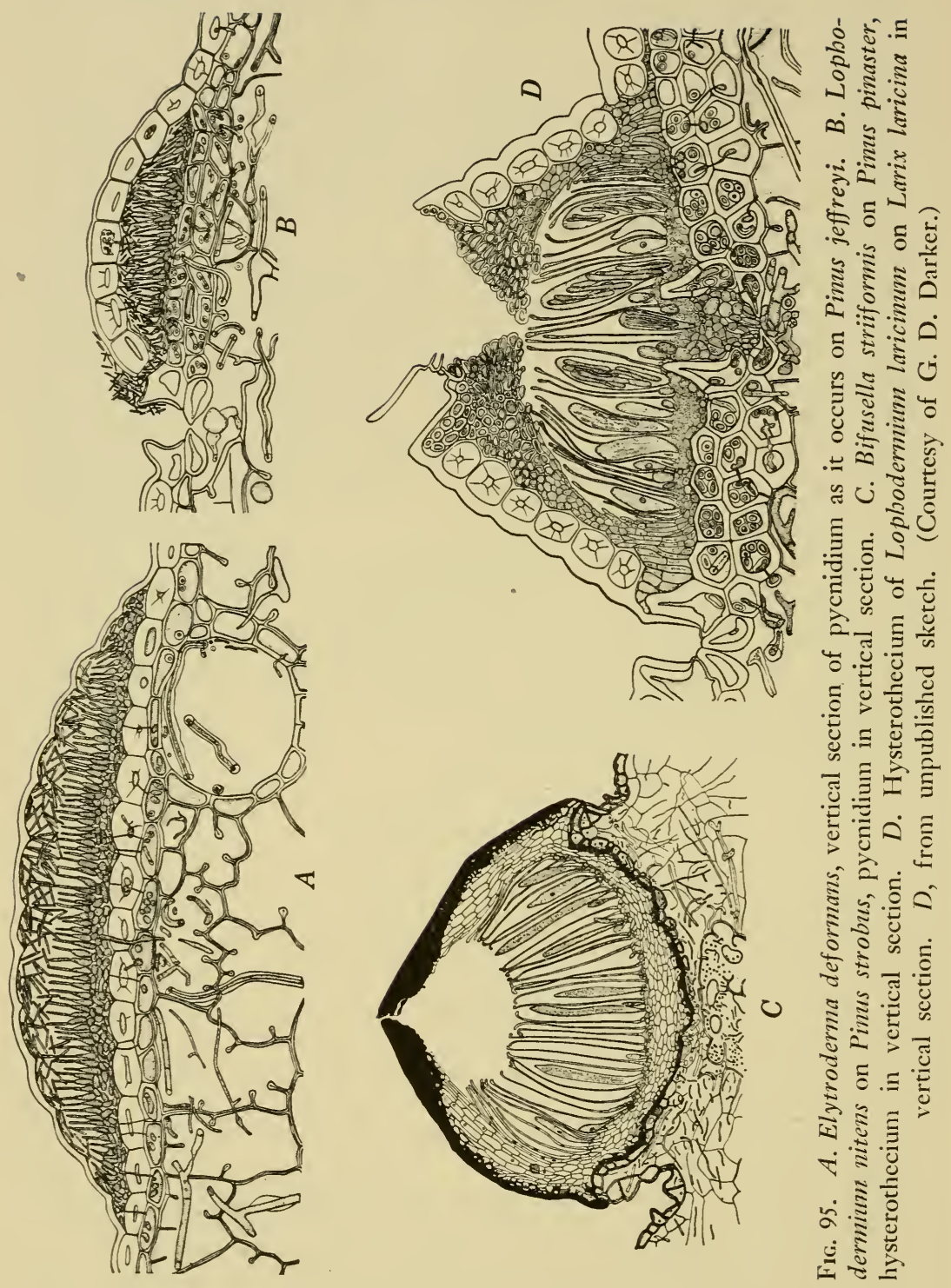


\section{Hysteriales}

The Hysteriales include a group of some 670 species of ascomycetous fungi characterized by the possession of a distinctive type of ascocarp called a hysterothecium. The fruiting body is a small, black, elongate structure of hard or leathery texture, which opens by a single narrow slit at maturity. The hysterothecium has been variously interpreted as an elongated perithecium and as a compressed apothecium. Consequently the Hysteriales have been classified by various systematists with both the Pyrenomycetes and the Discomycetes. According to Bisby (1913), this indicates clearly that they form a transitional group, a fact which was first recognized by Rehm. Höhnel (1918), in a rather radical classification of the group, would emphasize the similarities between the Hysteriales and the family Lophiostomataceae of the Sphaeriales. The similarity of the Hysteriales and the Phacidiales has been pointed out by a number of workers.

The Hysteriales include both parasitic forms and saprophytes that produce the fruiting bodies on dead wood and bark. In the customarily accepted classification [Lindau (1896)], the group is divided into 5 families, of which 2 will be considered here. In the Hypodermataceae, which has been monographed by Darker (1932), the hysterothecia are embedded within the substratum and are overgrown by host tissue to form a clypeus above; in the Hysteriaceae, the carbonaceous hysterothecia are freely exposed.

Elytroderma (Hypoderma) deformans, a typical representative of the Hypodermataceae, is parasitic on the needles and stem tips of Pinus ponderosa in the Pacific Northwest [Weir (1916) ]. Witches' brooms may be formed as the result of involvement of the terminal shoots by this fungus. The needles become browned at the tips and turn yellowish where the black, elongate hysterothecia are produced. A spermogonial stage also is known, but the developmental history of the fungus has not been followed. The asci, intermingled with paraphyses, contain two-celled, fusiform ascospores.

Closely related to Hypoderma is the Genus Lophodermium, which differs only in the filiform nature of its ascospores [Tehon (1935) ]. Lophodermium pinastri is a serious parasite of pines, 
causing a destructive disease called needle cast. The disease is world-wide in its distribution and is especially serious on young trees in the nursery. The characteristic symptom of infection is premature shedding of the needles; in severe attacks all the green needles may fall before May.

Infection of the needles occurs from germinating ascospores by penetration of the stomata. There follows the formation of a

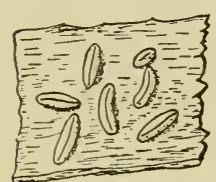

A

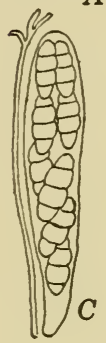

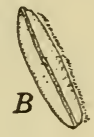
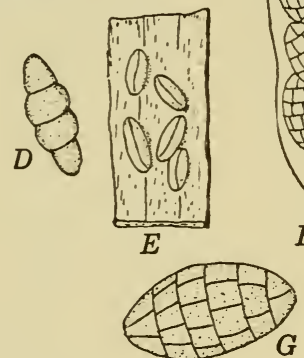
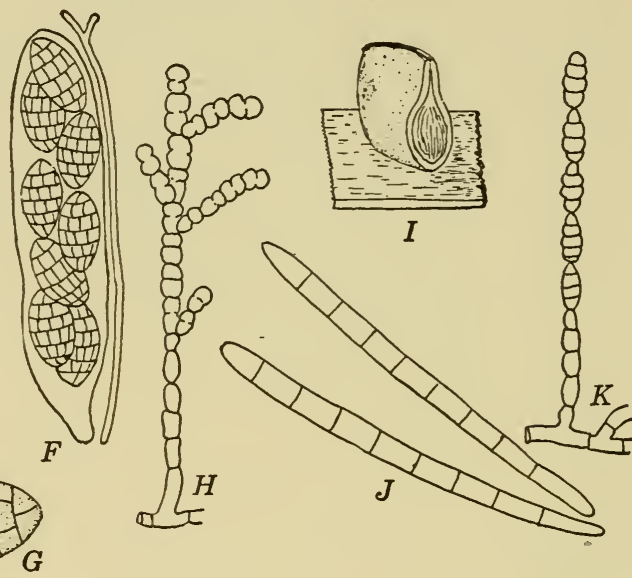

Fig. 96. Various Hysteriales. A. Habit sketch of Hysterium pulicare as it occurs on birch bark. B. Single hysterothecium, surface view. C. Ascus and paraphysis. D. Ascospore. E. Habit sketch of Hysterograpbium fraxini. F. Ascus and paraphysis. G. Ascospore. H. Conidial or Septonema stage. $I, J$, and $K$. Mytilidion scolecosporum. (Adapted from Lohman.) 1 . End view of section of hysterothecium. J. Ascospores. $K$.

Conidial or Septonema stage.

subcuticular or subepidermal stroma; in this are developed spores which have been shown [Jones (1935)] to function as spermatia. Jones describes the initiation of ascogonia as occurring in the summer, whereas the hysterothecia become evident during the winter, and ascospores are discharged the following spring. The most extensive studies of the disease and of the growth of the fungus in pure culture are those of Haack (1911).

In the family Hysteriaceae, which includes saprophytic forms, the fruiting bodies are freely exposed at maturity and are formed singly or are united in a stroma. The hysterothecia throughout the family are black and carbonaceous. The group has been 
studied extensively by Lohman (1933). The genus Glonium [Lohman (1937)], including forms with two-celled, fusiform, and hyaline ascospores, is common on wood of various kinds throughout Europe and North America. Hysterographium, with brown muriform ascospores, is also of rather common occurrence.

Among imperfect stages found associated with members of the group are Septonema, Sporodesmium, and Papulospora. Unfortunately the details of sexual reproduction are almost completely unknown. Spermogonia should be sought, especially among species having pycnidial stages.

\section{LITERATURE CITED}

Bissy, G. R., "The literature on the classification of the Hysteriales," Trans. Brit. Mycol. Soc., 8: 176-189, 1913.

Darker, G. D., "The Hypodermataceae of conifers," Contrib. Arnold Arboretum, 1: 1-131, 1932.

HaACK, G., "Die Schuttepilz der Kiefer," Z. Forst-u. Jagdw., 43: 329-357, 402-423, 481-505, 1911.

Höhnel, F. von, "Mycologische Fragmente 272. Über die Hysteriaceen," Ann. Mycol., 16: 145-154, 1918.

Jones, S. G., "The structure of Lophodermium pinastri (Schrad.) Lév.," Ann. Botany, 49:699-728, 1935.

Lindau, G., "Hysteriineae." In Engler and Prantl, Die natürlichen Pflanzenfamilien, 1: (1) 265-278, 1896.

Lohman, M. L., "Hysteriaceae: Life histories of certain species," Papers Mich. Acad., 17 (1932): 229-288, 1933.

"Studies in the genus Glonium as represented in the southeast," Bull. Torrey Botan. Club, 64: 57-72, 1937.

Tehon, L. R., "A monographic rearrangement of Lophodermium," Ill. Biol. Monogr., 13: 1-151, 1935.

WEIR, J. R., "Hypoderma deformans, an undescribed needle fungus of the western yellow pine," J. Agr. Research, 6:277-288, 1916.

\section{Disconircetes}

The Discomycetes comprise those ascomycetous fungi which have disk-like or cup-like fructifications. The fructifications are given various appellations, such as disks, ascomata, discocarps, and apothecia.

More than 5000 species are included in this major grouping. They may be separated into two sections, the Operculates and 
the Inoperculates. In the first, the asci open by means of a lid or, more rarely, a transverse slit; in the second, no special mechanism for dehiscence of the asci is provided. Seaver $(1928,1942)$ monographed the Operculates and included therein the Pezizales, which embrace the two families, Pezizaceae and Elvellaceae (Helvellaceae). The Pezizaceae contain the cup-shaped or discoid
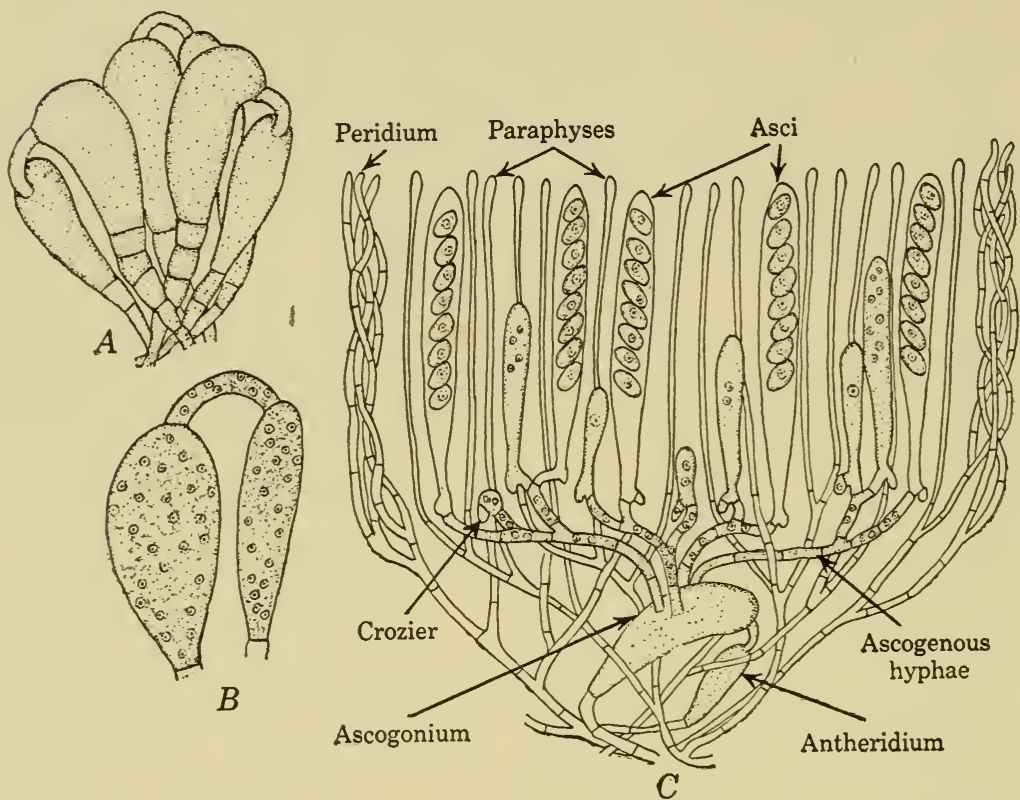

Fig. 97. Pyronema confluens. A. Cluster of paired oogonia and antheridia. $B$. Multinucleate oogonium, antheridium, and trichogyne. C. Diagrammatic representation of parts of ascocarp of $P$. confluens.

forms; and Elvellaceae, the pileate ones. Nannfeldt (1932) monographed the Inoperculates, including two orders, Ostropales and the Helotiales. In Nannfeldt's arrangement the Ostropales contain a single family, Ostropaceae, and the Helotiales contain the Dermateaceae, Phacidiaceae, Orbiliaceae, Hyalocyphaceae, Helotiaceae, and Geoglossaceae.

The tip of the ascus in the Ostropales is thickened and is pierced by a narrow canal. The ascospores are filamentous and readily fall apart into cylindrical elements, whereas those of the Helotiales are never filamentous and do not break up into cylindrical cells. 
An older, more commonly employed system of classification considers the Discomycetes to be comprised of the Pezizales, Helvellales, Helotiales, and Phacidiales. The Phacidiales includes
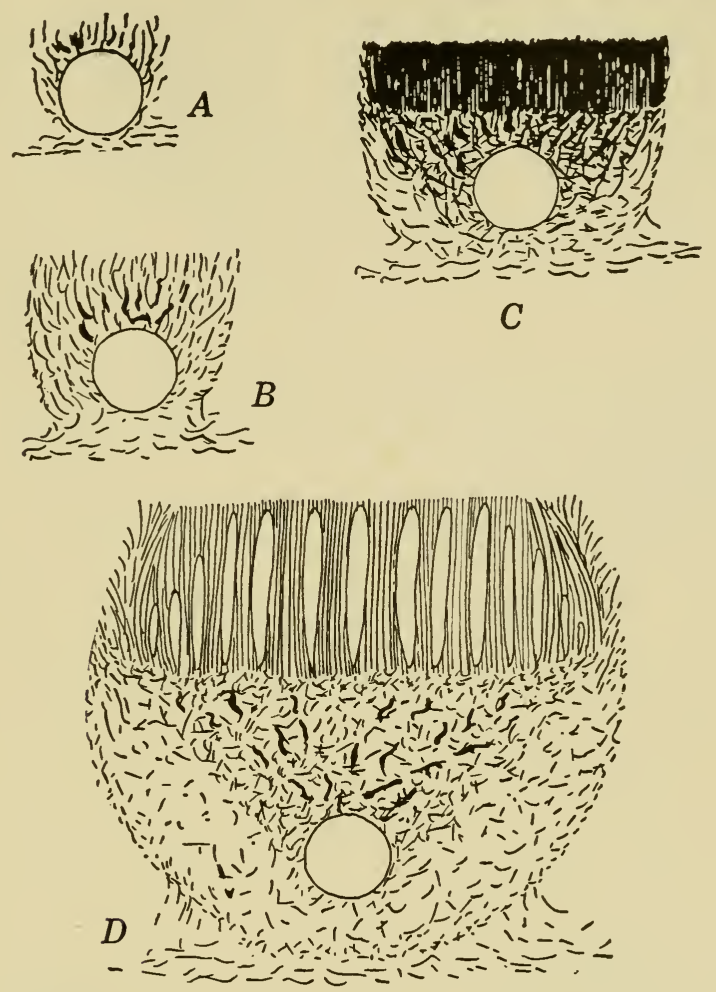

Fig. 98. Diagram of the development of a gymnocarpous apothecium. (After Corner.) The circle indicates the position of the ascogonium within the apothecial initial. $A$. Branched hyphae surround the ascogonium. $B$. Ascogenous hyphae arise from the ascogonium and are separated by sterile hyphae. C. A layer of asci (hymenial layer) forms exposed at the upper surface of the young apothecium. D. A fully formed apothecium with poorly developed rim.

those with leathery and carbonaceous ascomata, whereas the others are fleshy. The operculate genera are included in the Pezizales and the Helvellales. There are approximately 20 genera and 300 species of Helvellales, and 100 genera and 3300 species of Pezizales. Among the larger genera are Helotium with 280 species, Humaria and Dasyscypha with 220 each, Mollisia with 
210, Lachnea with 180, Peziza with 160, Pezizella with 140, Pyrenopeziza with 100, Sclerotinia with 80, Ascobolus, Ascophanus, Geopyxis, and Lachnella with 60 each, and Morchella, Elvella, Sarcoscypha, and Geoglossum, with about 40 each.

Apothecial developinent. The development of apothecia is typified by that in Pyronema confluens, which is among the better-known representatives of cup fungi that may be found in the greenhouse at the surface of pots of sterilized soil or at sites of campfires or of burned brush piles. It may be recognized by the groups of flesh-colored apothecia 1 to $3 \mathrm{~mm}$ broad. The apothecial initials are first recognizable as small hyphal tufts. Within each of these tufts are thickened, erect branches, one of which will become the antheridium and the other the ascogonium. The ascogonial branch is slightly more precocious in development, and the antheridium arises from a stipe cell beneath it. While differentiating, each becomes multinucleate.

At the apex of the antheridium a multinucleate papilla, the trichogyne, is delimited; its tip curves to come in contact with the tip of the ascogonium, and its nuclei gradually degenerate. Then the antheridial nuclei migrate into the trichogyne. The partition between the trichogyne and the ascogonium next dissolves, and the antheridial and ascogonial nuclei pair. Shortly thereafter a score or more of ascogenous hyphae grow out from the ascogonium, and the penultimate cell at each recurved tip (crosier) becomes the ascus. Meanwhile paraphyses arise from cells that are adjacent to the ascogonium.

Among Discomycetes there are two types of apothecial development, gymnocarpic and angiocarpic. Differences in cortical or marginal growth of the primordia during early development account for the two types, as Corner (1929) has shown that both kinds may occur within the Genus Ascobolus. Intermediate between these types is one which Corner designates as hemiangiocarpic. In these genera the marginal hyphae arch over the ascogonium, but their growth is limited, in consequence of which a closed sheath is not produced. Corner lists Cheiymenia stercorea, Antbracobia melaloma, Ascophanus granuliformis, and Peziza aurantia as hemiangiocarpic, and Ciliaria scutellata, Ascophanus carneus, Ascobolus stercorarius, A. citrinus, $A$. magnificus, Pyronema confuens, and Saccobolus violascens as angiocarpic. 

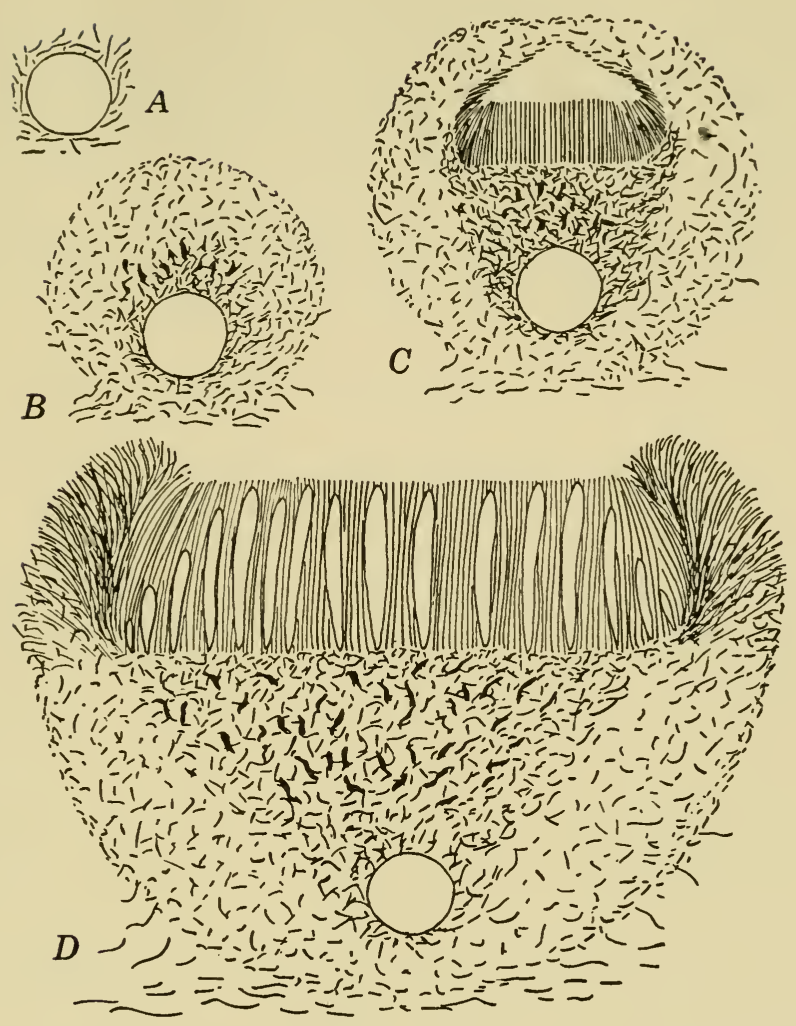

FIG. 99. Diagram of the development of an angiocarpous apothecium. (After Corner.) The circle indicates the position of the ascogonium within the apothecial initial. $A$. Branched hyphae rising from the stalk cells of the archicarp invest the ascogonium. $B$. Tissue differentiation begins within the spherical mass (apothecial initial); cortex is thick-walled, internal tissues thin-walled; ascogenous hyphae appear as protrusions diverging from the ascogonium. C. Mucilage cavity appears in upper portion by dissolution of internal tissues, a palisade of hyphae forms floor of cavity, coming in part from hyphae that ascend with ascogenous hyphae, which together form hymenium. $D$, Pressure from expanding hymenium ruptures cortex above hymenium; as asci enlarge, the disk expands laterally. Asci at center of disk first to mature, and maturation continues centrifugally. 
Corner (1930,1930a) also studied the development of certain stipitate discomycetes, including Mitrula pusilla, Geoglossum difforme, Trichoglossum birsutum, and Microglossum viride, the last of which is angiocarpic, and the others gymnocarpic. The shaft arises a result of greater growth of the medulla than of the cortical region.

Correlation between size of apothecia, rate of development, and duration of the period of ascospore discharge is shown in data by Corner (1930) in Table 3.

\section{TABLE 3}

Size, Age, and Sporing of Certain Discomycetes

$\begin{array}{lccc}\quad \text { Species } & \begin{array}{c}\text { Diameter of Apothecium }(\mathrm{mm}) \\ \text { Dhen sporing } \\ \text { begins }\end{array} & \text { At maturity } & \begin{array}{c}\text { Duration of } \\ \text { sporing (days) }\end{array} \\ \text { Rhizina inflata } & 20 & 80-100 & 40-50 \\ \text { Peziza aurantia } & 12-20 & 40-60 & 40 \\ \text { Galactinia proteana } & 10-15 & 30-40 & 35-46 \\ \text { Galactinia saniosa } & 8-10 & 12-15 & 18-24 \\ \text { Ciliaria asperior } & & 5-6 & 9-13 \\ \text { Pulvinula constellatio } & 1-2 & 4-5 & 12-15 \\ \text { Anthracobia maurilabra } & 0.5-1 & 3-4 & 10-21 \\ \text { Coprobia granulata } & 1.5 & 3 & 9-12\end{array}$

Within the temperature range $14^{\circ} \mathrm{C}$ to $22^{\circ} \mathrm{C}$ these disk fungi shed soores incessantly day and night.

\section{LITERATURE CITED}

Corser, E. J. H., "Studies in the morphology of Discomycetes. II. The structure and derelopment of the ascocarp," Trans. Brit. Mycol. Soc., 14: 275-291, 1929.

III. "The clavulae," Trans. Brit. Mycol. Soc., 15: 107-120, 1930.

IV. "The evolution of the ascocarp," Trans. Brit. Mycol. Soc., 15: 121-134, 1930a.

Nanxfeldt, J. A., "Studien über die Morphologie und Systematik der nichtlichenisierten inoperculaten Discomyceten," Nova Acta Regiae Soc. Sci. Upsalensis, Ser. IV, 8:1-368, 1932.

Seaver, F. J., The Nortb American cup-fungi (Operculates). 284 pp. New York. Published by the author, 1928.

The Nortb American cup-fungi, Supplemented ed. 375 pp. New York. Published by the author, 1942. 


\section{Helotiales (Inoperculates)}

The Helotiales include nearly all the inoperculate Discomycetes, except those that are symbiotically associated in the Lichenes. Nannfeldt (1932), it has been pointed out, divided this order into 6 families, and in the present account brief mention will be made of representative members of 4 of these families, namely, Dermateaceae, Phacidiaceae, Helotiaceae, and Geoglossaceae.

Nannfeldt characterizes the Dermateaceae as having apothecia that are leathery to fleshy and typically dark. They arise either at the surface or within the substratum and are sessile or, at most, have a short stipe. They are paraphysate, and the ascospores are hyaline and filamentous.

The apothecia of the Phacidiaceae arise within a well-developed stroma that is usually dark. They open by an irregular rupture of the stromatic covering. The ascospores are elongate to needle-shaped. The excipulum is poorly developed. The conidial stages of many of the Phacidiaceae belong to the Leptostromataceae.

In the Helotiaceae the apothecia are typically soft, fleshy to corneous, superficial, and stalked. The excipulum is thick. The ascospores are elliptical to elongate. Paraphyses are present. The conidia belong to various form genera.

The apothecia of the Geoglossaceae are club-shaped or stalked, with a capitate hymenial surface. The ascospores are elongate to thread-like, simple or septate, and none is known to possess a conidial stage.

Dernateaceae. This family is divided by Nannfeldt (1932) into 9 tribes. The apothecia of all arise innately and at maturity rupture the overlying tissues. They are corneous to leathery in texture, and the excipulum is thick, being composed of dark, thick-walled cells.

Among the Mollisioideae is the Genus Pyrenopeziza, of which one species, $P$. medicaginis, produces the yellow leaf blotch of alfalfa [Jones (1918)]. Its conidial stage was first described by Desmazieres in 1847 as Sporonema phacidioides. It appears rather to be Phyllosticta. Jones was able to establish the genetic connections of conidial and ascigerous stages, both of which developed in cultures on alfalfa stems and on oatmeal agar. 

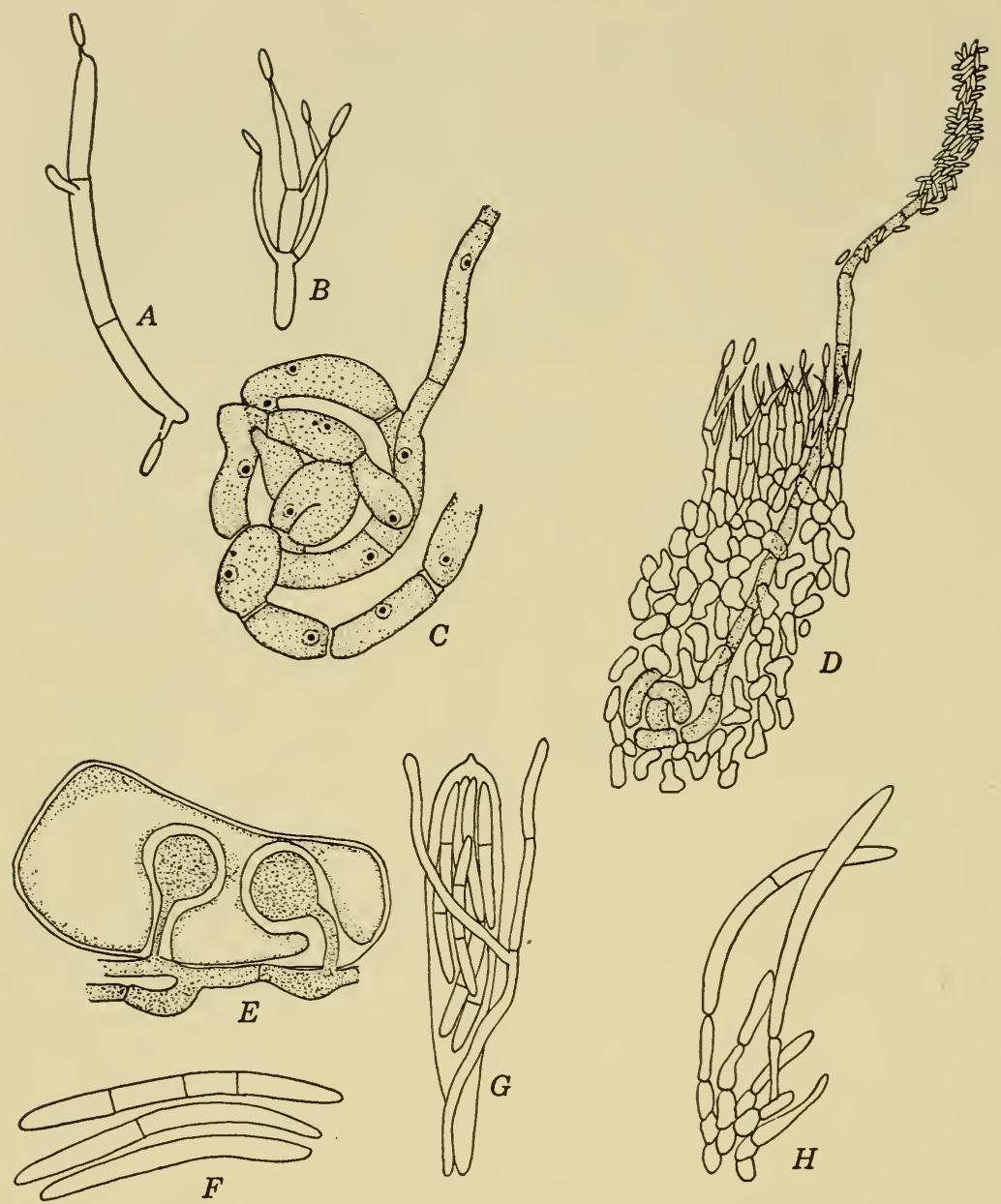

Fig. 100. Coccomyces biemalis, the cause of cherry shot-hole. $A$. Conidium of the Cylindrosporium stage, which on germination formed spermatia. $B$. Branched spermatiophore from conidial acervulus. C. Basal portion of coiled archicarp from interior of stroma, at exterior of which spermatia and conidia are being produced. $D$. Semidiagrammatic representation of a portion of stroma, showing spermatia adhering in great numbers to the trichogyne that protrudes well above the surface of the young apothecial stroma. E. Host cell with intercellular hypha and bulbous haustoria. $F$. Mature ascospores. G. Ascus and branched paraphysis. $H$. Segment of acervulus, showing conidia and conidiophores. At times conidia are borne among the asci within the apothecium. $(A, B, C$, and $D$ adapted from Backus, $E, F, G$, and $H$ adapted from Higgins.) 
Among the Drepanapezizoideae are the several species of Coccomyces that cause shot-hole diseases of Prunus. These include $C$. biemalis on cherries, especially Prumus cerasus, $P$. avium, and $P$. pennsylvanica, $C$. prunophorae on plums, especially $P$. domestica and $P$. americana, and $C$. lutescens on chokecherry, $P$. virginiana, and on black cherry, $P$. serotina. These species were described by Higgins (1914) and were assigned by Nannfeldt (1932) to the new Genus Higginsia. Their conidial stage is Cylindrosporium. Higgins (1914) established that spermatia are formed in late summer within conidial acervuli and among the conidia. At the same time, within the stromata beneath the spermatiferous layer, archicarps are produced, a dozen or more in each stroma. Septate trichogynes project well above the leaf surface. Spermatia adhere in great profusion to the trichogynes. There seems little reason to doubt, both from Higgins' observations and from those of Backus (1934), that the spermatia function in fertilization. By spring, the apothecia have matured on fallen leaves.

Higgins (1914) also made the interesting observation that the shot-hole effect is the result of cleavage of the glucoside amygdalin, by emulsin within invaded cells. In this cleavage of the amygdalin molecule, two molecules of glucose, one of benzaldehyde, and one of prussic acid are formed. The increased osmotic pressure resulting from the presence of glucose causes water to be drawn from cells at the periphery of invaded ones, which swell in consequence, and a line of abscission is developed.

Nannfeldt also placed Diplocarpon in the tribe of Drepanapezizoideae. Among the species included in this genus are D. rosae, causing black spot of roses, $D$. earliana, causing strawberry-leaf scorch, and D. (Entomopeziza) soraueri, causing pear-leaf spot. Diplocarpon rosae is commonly known in its conidial stage as Actinonema rosae. Its morphology, however, is that of the form Genus Marssonia. The ascigerous stage was first described [IVolf (1912)] in 1912 and improperly assigned to the Microthyriaceae. In late summer spermatia are produced in the conidial acervuli [Wolf (1926)]. Coincidentally several ascogones are developed in each apothecial initial. By spring the apothecia have matured within decaying leaves. Occasional apothecia have been noted to bear conidia, as has been recorded also [Backus (1934)] for Higginsia biemalis. A similar course of develop- 

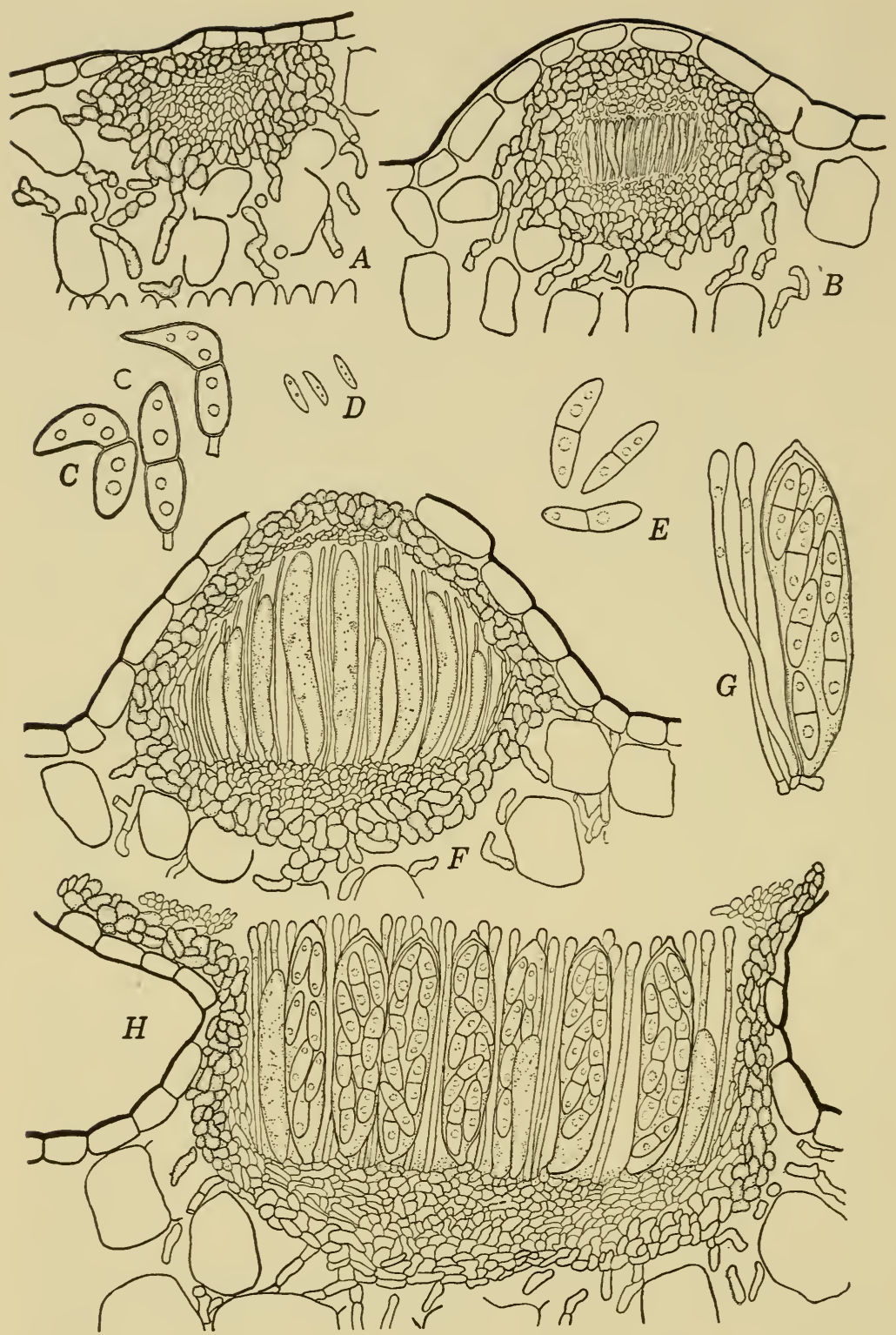

Fig. 101. Diplocarpon earliana causing leaf scorch of strawberry. $A, B$, $F$, and $H$. Stages in progressive development of apothecium, in vertical section. C. Group of conidia of Marssonia stage. D. Spermatia that may be borne in acervulus with conidia. E. Ascospores. G. Ascus and paraphyses. 
ment has been shown to exist in the strawberry-leaf-scorch pathogen [Wolf $(1924,1926)]$. In pure culture each species develops conidia, whether the isolations are from ascospores or from conidia.

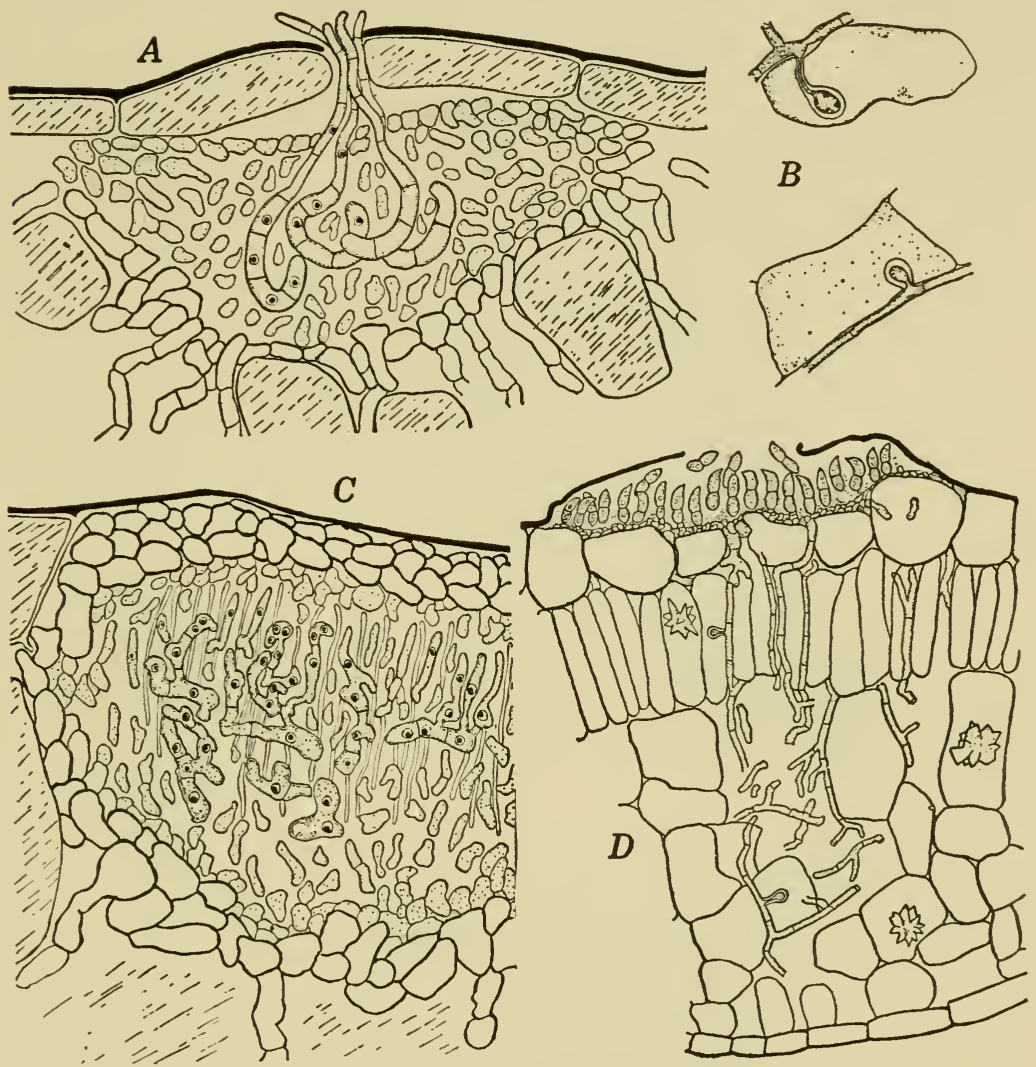

FIG. 102. Other stages in development of Diplocarpon. $A$. Young apothecial stroma of Diplocarpon earliana, in vertical section, showing septate archicarps projecting to the leaf surface. $B$. Bulbous haustoria that arise from intercellular mycelium. C. Intertwining ascogenous hyphae of $D$. rosae that develop similarly in $D$. earliana. D. Vertical section of acervulus of $D$. earliana.

The pear-leaf-spot fungus, whose peculiar conidial stage is known as Entomosporium maculatum, was confirmed by Klebahn (1918) as a discomycetous species. He placed it in Entomopeziza. It had long ago been placed in Stigmatea, among the 


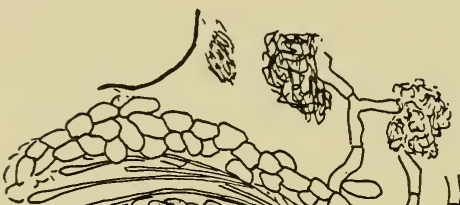

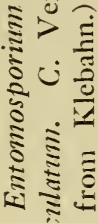

吃

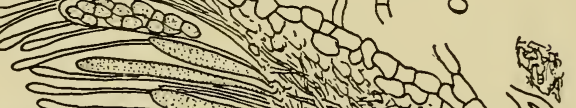

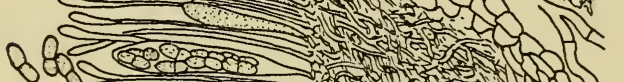

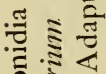

ปิ่

- cererom 2 .

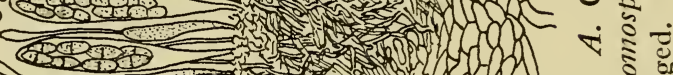
200.
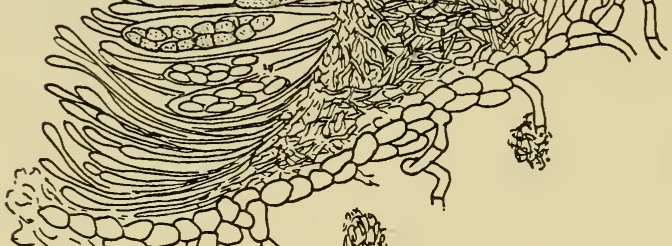

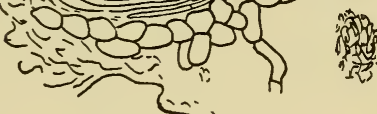

迎焉

पै

苍至

के क्ष

嵌

$\stackrel{\Xi}{\Xi}$

就的

है

ज्ञ<smiles>CCC1CCCC1</smiles>

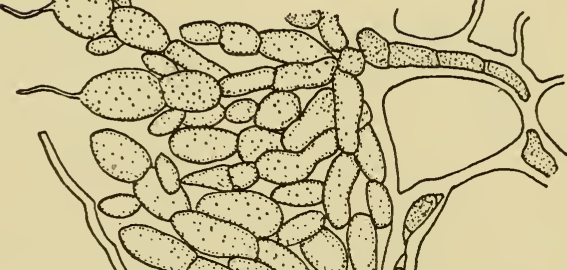

\&

डे

ฮิ

ते है

¿

₹

5.

过是录

:

है.

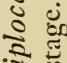

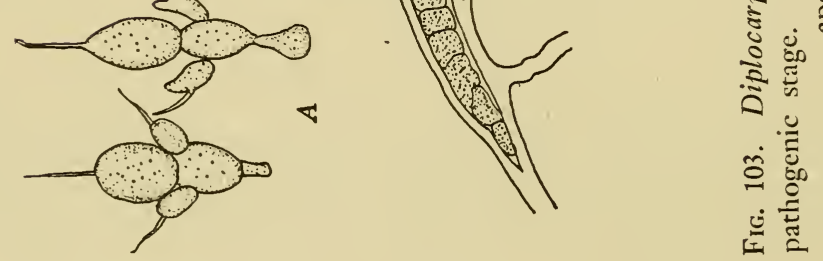


Pyrenomycetes, and Atkinson (1909) was the first to note that it is a disk fungus which, on closing, looks like a perithecial one.

Among the Pseudopezizoideae are Pseudopeziza medicaginis, occurring on alfalfa, and $P$. trifolii, occurring on clovers, each causing leaf-spot diseases. Jones (1919) observed that conidial stages are lacking in both species and that the apothecia may be mature before the leaves are shed. Nothing is known about the events leading to the initiation of apothecia.

Some mycologists include in the Dermateaceae the white-pinecanker fungus, Tympanis pinastri [Hansbrough (1936)]. Its position among the Discomycetes is not given, however, by Nannfeldt (1932). It attacks also red pine, producing cankers on the main stem. The apothecia are most common on cankers several years old. The disks occur in clusters, are dull-black, shortstalked, and about $1 \mathrm{~mm}$ broad. The ascospores are elongate, 3to 9-septate, and hyaline; they bud while still within the ascus. Protruding stromata bear pycnidial loculi having tiny conidia 2 to + by $1 \mu$. V'ery probably this stage will prove to be spermatial, rather than conidial.

Phacidiaceae. Many mycologists regard, the Phacidiaceae as of ordinal rank and as a distinct group intermediate between the Pyrenomycetes and the Pezizales. In this family the genera Rhytisma, Keithia, and Cryptomycina are worthy of mention. The best-known representative of Rhytisma, which includes about 25 species, all causing tar-spot diseases, is $R$. acerinum on maples. The conidial stage of Rhytisma belongs to the form Genus Melasmia, which may well be regarded as a spermatial stage. Jones (1925) found that the black, innate, conidial stromata shed spores during the summer. Deeply seated within these stromata may be ascogonia, each consisting of an ascogonial cell surmounted by several trichogynal cells and supported below by a more slender filament. Adjacent trichogynal cell walls become perforate, and the nuclei become paired in the ascogone. Ascogenous hyphae arise from the ascogone. Crooks may form at the termini of these hyphae, and the penultimate cell either becomes the ascus or else, if it contains more than a single pair of nuclei, proliferates eventually to form asci. Jones (1925) regarded the conidia (spermatia) as functionless.

The five known species of Keithia are restricted to conifers. Keitbia tetraspora occurs on Juniperus communis, and K. jumip- 
eri on J. virginiana. The asci of $K$. tetraspora contain 4 ascospores; those of K. juniperi, 8. Keitbia tsugae on Tsuga canadensis also has asci with 4 spores. The asci of $K$. thujina on Thuja occidentalis and $K$. chamaecyparissi on Chamaecyparis thyoides, however, contain 2 spores. The black apothecia usually occur
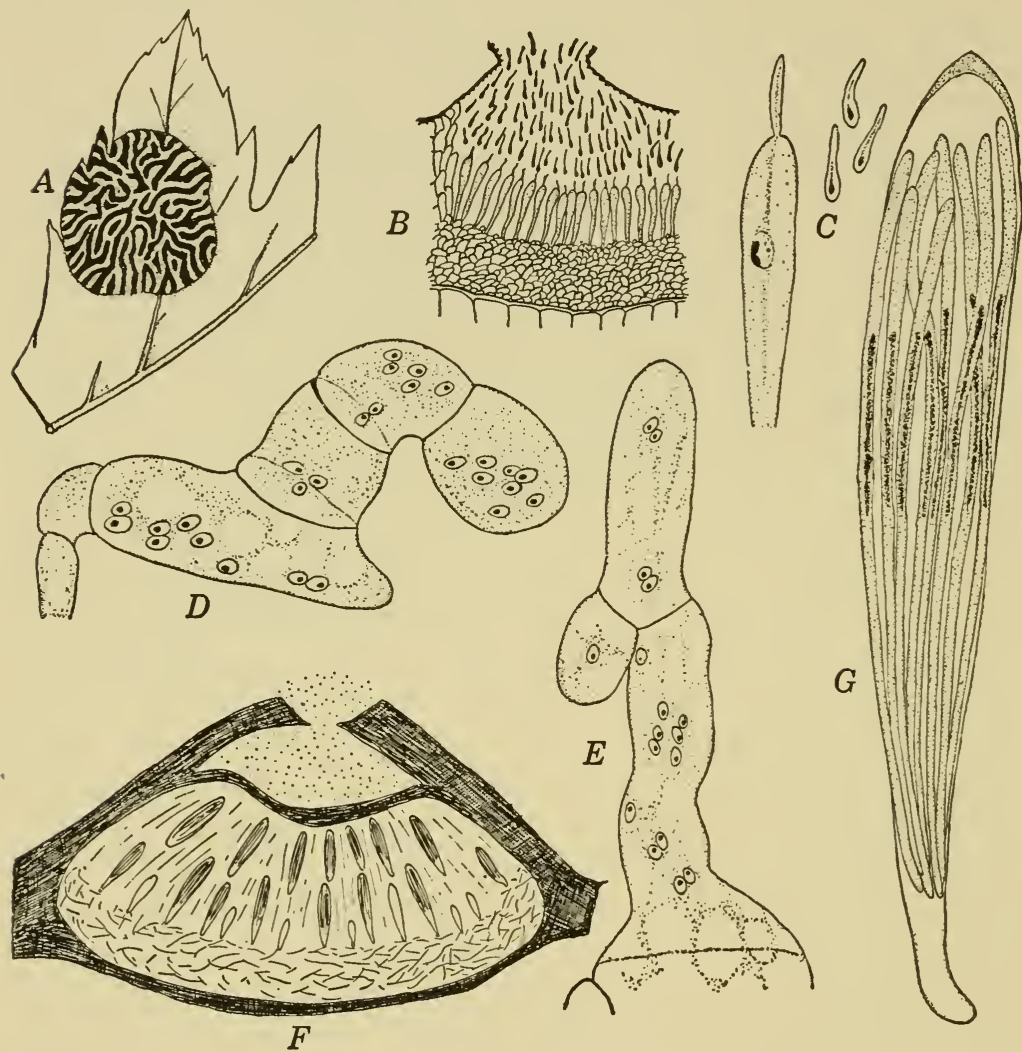

Fig. 104. Rbytisma acerinum, causing tar-spot on maple. A. Apothecial sorus with a variously contoured surface that ruptures irregularly. $B$. Melasmia or conidial stage in vertical section. C. Conidiophore and conidia enlarged. This stage may be spermatiophore and spermatia, instead. $D$. Archicarp with three "trichogyne" cells borne on slender stalk. The ascogonium cell is basal, septa are perforate, and nuclei are migrating into ascogonium cell. E. Ascogenous hypha arising from ascogonium, nuclei paired; penultimate cell has two pairs of nuclei and may again hook and branch. $F$. Vertical section of apothecial stroma in diagram. A mucilaginous cavity at apex aids in rupture and the freeing of ascospores. G. Single ascus enlarged. (Adapted from Jones.) 
singly and may mature on green leaves. Their development has not been studied. None possesses a conidial stage.

Cryptomycina pteridis, widely distributed in Europe and North America, causes leaf roll of bracken fern, Pteridium latiusculum. Recent studies by Bache-Wiig (1940) show that the mycelium perennates in the buds. The conidial stage is of the Cylindrosporium type. Young tissues, even those of prothallia, became infected after artificial inoculation.

Helotiaceae. This family contains numerous parasitic and saprophytic species, arranged by Nannfeldt (1932) into 9 tribes. Their apothecia generally are superficial from the beginning and are fleshy, leathery, or corneous in texture with rather thick excipula.

Among the Trichocyphelloideae is Dasyscypha, called Trichocyphella by Nannfeldt, characterized by apothecia the outer surface of which is densely covered with long white hairs. According to Saccardo's Sylloge Fungorum, this genus contains approximately 150 species. Its best-known member is $D$. willkommii, causing larch canker in Europe. This fungus was introduced into Europe early in the eighteenth century, and the literature on forest pathology contains many controversial articles regarding it. Recently it was introduced into New England but was eradicated by the destruction of all infected larch trees. At the same time a great deal of confusion arose from the finding of a species of Dasyscypha, at first thought to be the larch-canker pathogen, on Douglas fir, Pseudotsuga taxifolia. Hahn and Ayers (1934a), however, determined that the organism on Douglas fir is D. ellisiana, an indigenous species, commonly occurring as a saprophyte on pines. They $(193+\mathrm{b})$ also determined that $D$. pini occurs on species of five-needled pines in the Pacific Northwest. In 1892 this fungus was first described as Lachnella pini from collections on Scots pine in Scandinavia. The details of these studies by Hahn and Ayers are contained in the reports just mentioned $(193+a, 1934 b)$ and those on other species of Dasyscypha in an earlier report (1934).

Sclerotinia. None of the Discomycetes is of greater economic importance than are those usually included in Sclerotinia, belonging in the Tribe Ciborioideae. In Engler and Prantl's Die natiirlichen Pfanzenfamilien, Schroeter divided Sclerotinia into 2 subgenera, Stromatinia and Eusclerotinia. In Stromatinia he placed 
the fungi having pseudosclerotia and conidia of the Monilia type, and in Eusclerotinia those having well-developed sclerotia and conidia of the Botrytis type. Nannfeldt (1932) employed Moni-

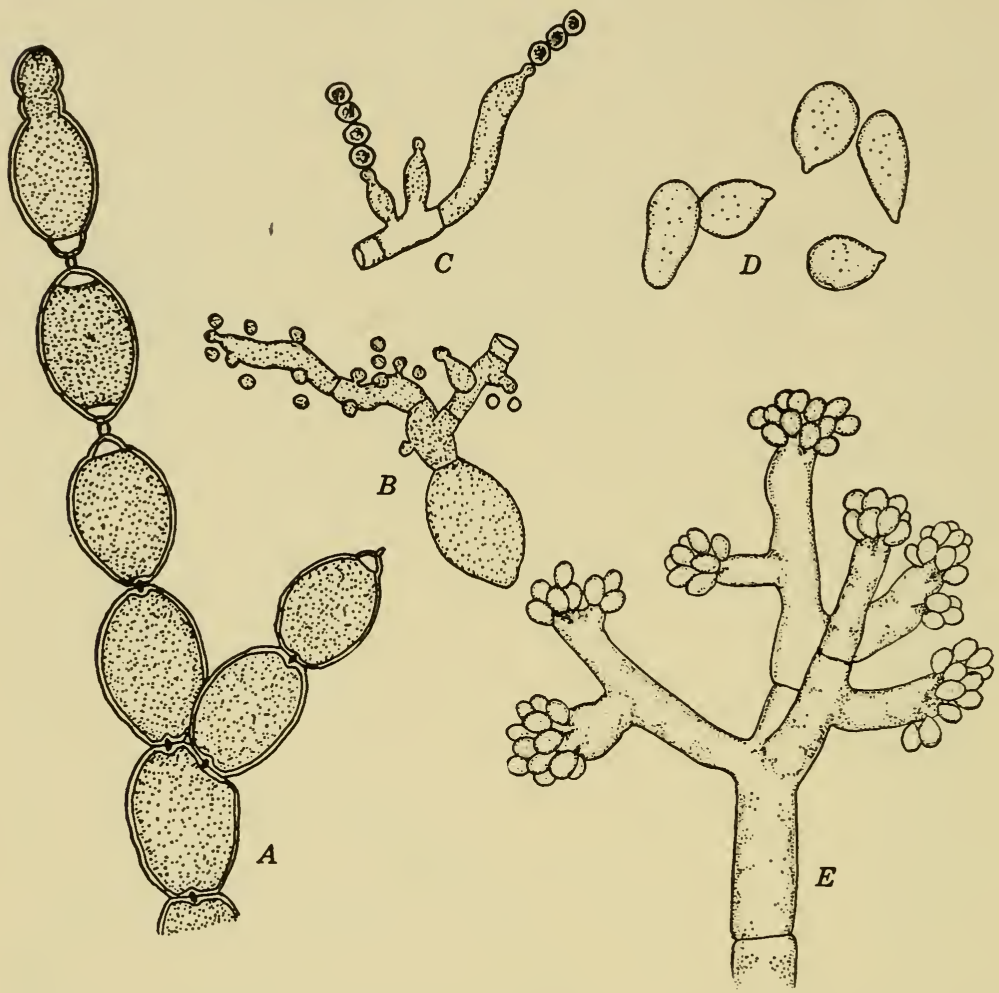

Fig. 105. Conidia and spermatia of Sclerotinia. $A$. Conidial chain from conidial pustule or Monilia stage of Sclerotinia urnula. Each conidium is freed by a disjunctor mechanism. $B$. Germinating conidium from whose hyphae spermatia are being produced. C. Spermatial formation by Sclerotinia trifolionum. D. Conidia of Botrytis cinerea. E. Conidial head of Botrytis cinerea, from diseased tobacco seedlings. ( $A$ and $B$, from Woronin.)

linia, a generic name proposed by Honey, for the fungi Schroeter placed in Stromatinia, and Sclerotinia for those Schroeter placed in Eusclerotinia; he placed in Ciboria those species lacking conidia. Sclerotinia (Ciboria) trifoliorum, causing stem rot of clovers, and Ciboria ficariae on Ranunculus ficaria are representative of this group. In addition account must be taken of the fact 
that conidial stages alone are known in some species, as in Monilia laxa (probably $M$. cinerea of Europe), occurring on cherries in the Pacific Northwest. Similarly detached conidial forms of Botrytis exist, such as B. cinerea, one form of which was recently found by Groves and Drayton (1939) to have a Sclerotinia stage.

Among the better-known species usually placed in Sclerotinia are $S$. fructicola on stone fruits, S. fructigena on pome fruits (not known to occur in North America), S. ricini on castor bean (Ricinus communis), S. urnula on Vaccinium vitis-idaea, S. sclerotiorum on lettuce, cucumber, potato, and various other garden plants, and S. beteroica on Ledum palustre and Vaccinium uliginosum.

Honey (1928) created the name Monilinia for the monilioid species of Sclerotinia, with $S$. fructicola as the type. The taxonomy of this organism has been greatly confused, a subject discussed in detail by Roberts and Dunegan $(1924,1927)$. Its discomycetous stage, which matures on mummified fruits lying partly buried on the ground during the period when the flower buds are opening, was first described as Ciboria in 1883 but was rediscovered in 1902, when it was thought to be identical with $S$. fructigena. Other names applied to it include $S$. cinerea and S. americand.

Sclerotinia (Monilinia) fructicola is most widely known in its conidial or Monilia stage as it occurs on decaying plums and peaches. From the mycelium within the fruits are produced grayish tufts of hyphal branches, which extend through the cuticle. These tufts are conidiophores that form chains of lemonshaped or moniliform conidia. When the end walls between conidia are first formed, they are plane, and the cells are then barrelshaped. Later the septa split into two layers, and a fusiform plug is formed between the two layers. This plug, the disjunctor, serves to detach the conidia from each other. While the disjunctor is forming, the conidia increase in size, become lemonshaped, and are then easily dislodged to inoculate other fruits.

When the fruits have decayed and have fallen to the ground, they become mummified. Within the mummified tissues, apothecial stromata are produced throughout the summer and the succeeding fall and winter. In the spring brownish apothecia, 1 to $1.5 \mathrm{~cm}$ broad, with stipes 1 to $10 \mathrm{~cm}$ long, emerge from the 
surface of the mummified fruits. They are capable of explosively shedding ascospores by the time the flower buds are beginning to open. The flowers become infected thereby and are blighted. Such blighted flowers constitute a means of keeping the fungus alive until the fruits begin to ripen.

The classical studies on Sclerotinia gladioli by Drayton (1934) are fundamental to an understanding of the development of this genus and presumably of related cup-fungi. Drayton grew this fungus in culture. Microconidia (spermatia) were developed in abundance; stromatic masses were also produced. When these stromatic masses were placed on moist sand and kept at a favorable temperature, columnar pilose structures developed. These structures proved to be receptive bodies, for when Drayton placed spermatia on them the columns elongated and eventually were transformed into mature stalked apothecia. On sectioning the columnar structures, Drayton found that each contained a coiled ascogone, larger and more deeply staining than the surrounding filaments.

Drayton furthermore found that monospore cultures yielded isolates that could be divided into two groups on the basis of compatibility. Each produced microconidia that were functional [Drayton (1932)], and also each produced archicarps. Individually the monosporic cultures were sterile. When Drayton crossed a member of one group of isolates with a member of the other, however, apothecia were developed. By crossings he demonstrated that the members of either group were cross-incompatible and intragroup sterile, but intergroup compatible and fertile.

Among the many others who have contributed to an understanding of Sclerotinia are Woronin (1896), Godfrey (1923) and Whetzel (1926, 1929, 1945).

Perhaps the most remarkable Monilinia is one whose pseudosclerotia form on fruits of Ledum palustre, where apothecia are produced. The ascospores initiate infection on the foliage of Vaccinium uliginosum, where conidia form to reinfect the fruits of L. palustre [Woronin and Nawaschin (1896)]. This Monilinia is thus heteroecious, a phenomenon that is otherwise restricted, among fungi, to the Uredinales.

Other Ciborioideae. Other genera of the Ciborioideae of more than passing interest are Ovulinia, Rutstroemia, Septotinia, and 
Lambertella. Ovulinia produces conidia singly on simple conidiophores, but otherwise it closely resembles Sclerotinia [Weiss (1940) ]. Ovulinia azaleae causes flower spot in destructive proportions on cultivated azaleas and rhododendron. Rutstroemia,

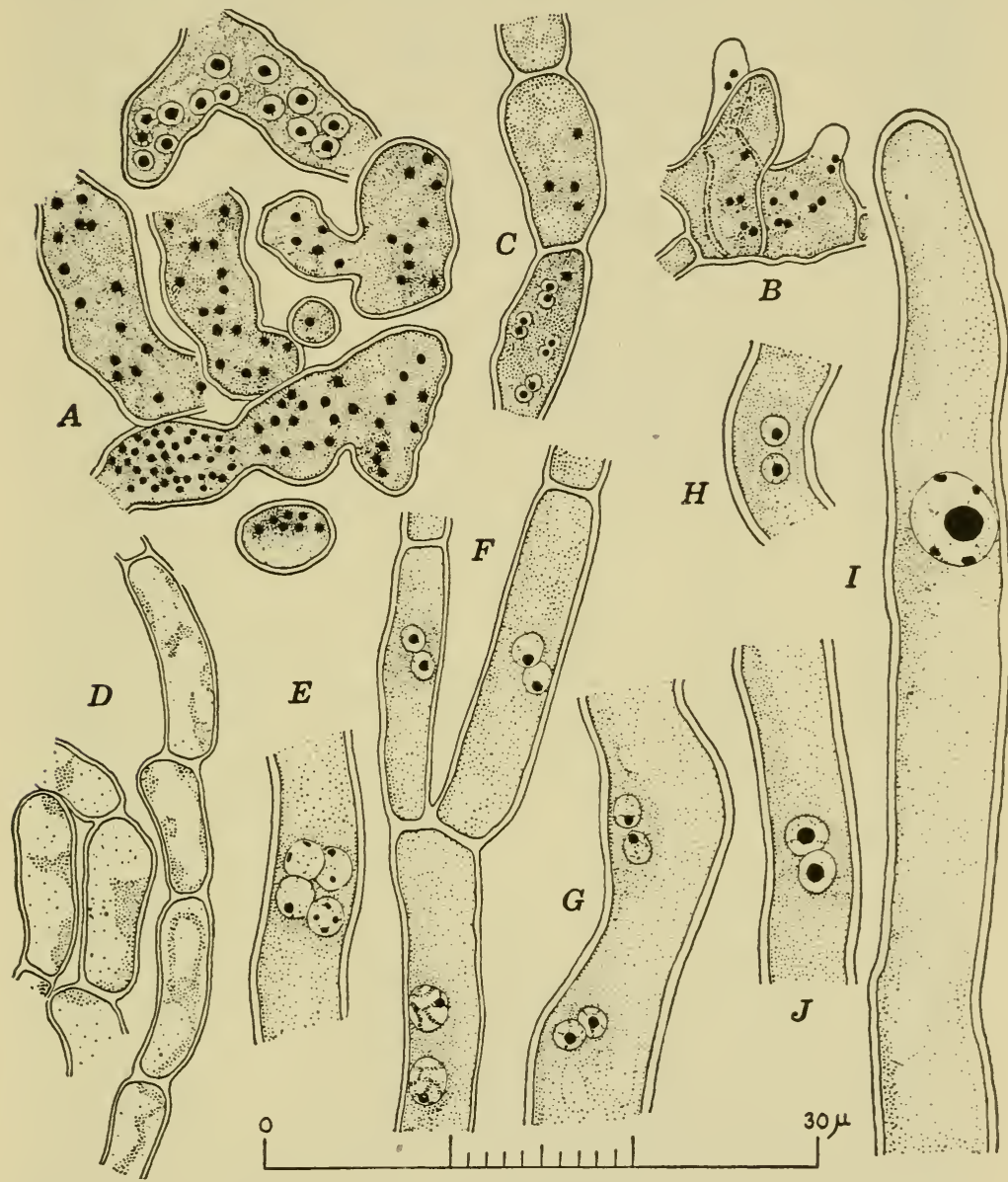

FIg. 106. Sclerotinia gladioli. $A$. Multinucleate cells from vertical section of ascogonial coil that has not been spermatized. $B$. Ascogonial cells, 3 days after spermatization, showing paired nuclei and initiation of ascogenous hyphae. C. Ascogonial cells, 4 days after spermatization. D. Ascogonial hyphae, 6 days after spermatization. $E, F$, and $G$. Stages in conjugate division in ascogenous hyphae. $H$. Conjugate nuclei ready for fusion. I. Fusion of nuclei in young ascus. J. First division of fusion nucleus. (Courtesy of F. L. Drayton.) 


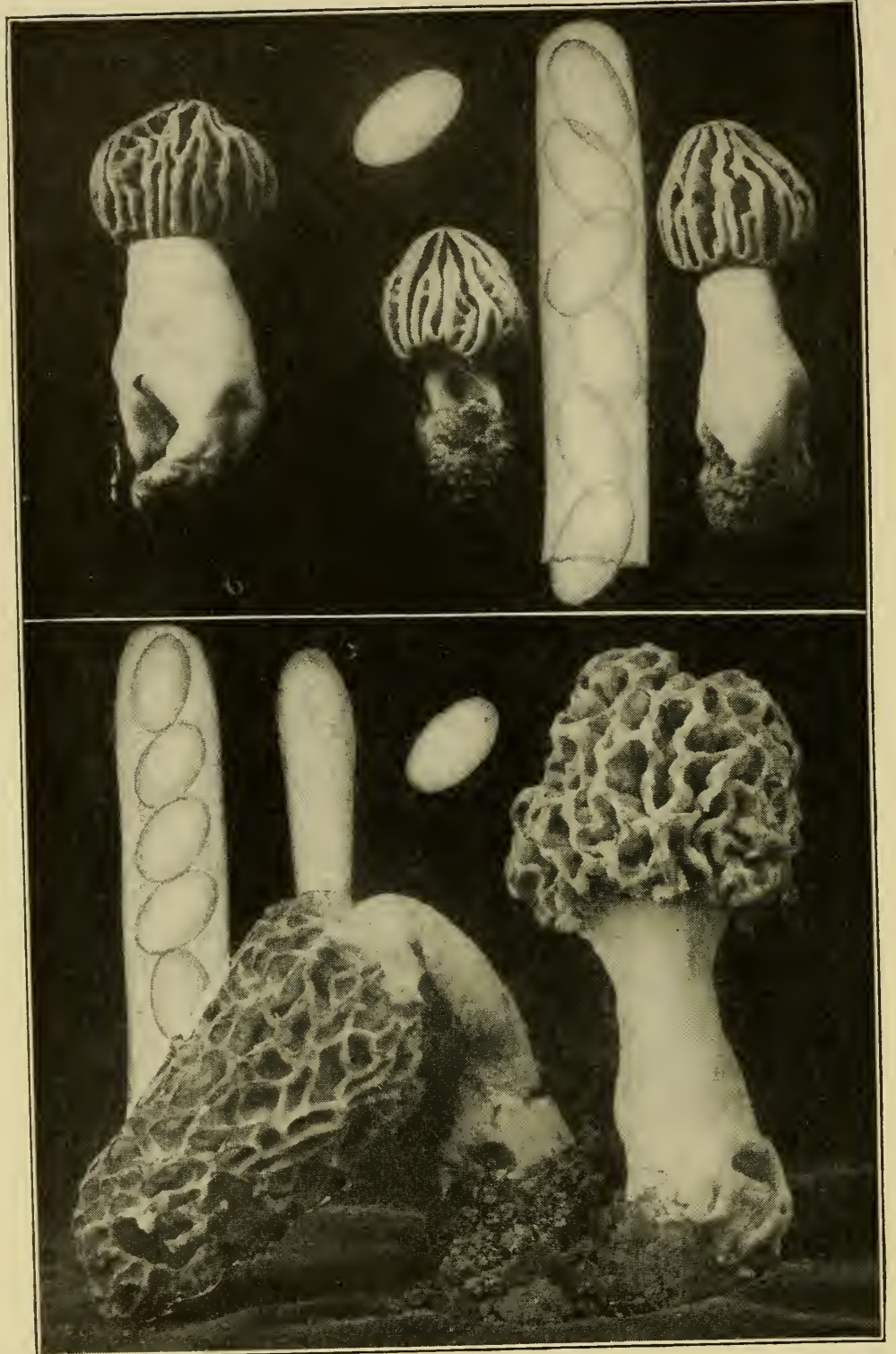

FIG. 107. Morchella bybrida (above), M. esculenta (below), ascocarps, ascal tips, and ascospores. (Courtesy of F. J. Seaver.) 
recently monographed by White (19+1), lacks a conidial stage and has ascospores that are one- to sereral-septate. Septotinia podophyllina, the generic type of Septotinia, possesses elongate, septate conidia borne on sporodochia, but its other structures are like those of Sclerotinia [Whetzel (1937)]. Lambertella, having brown ascospores, but otherwise quite like Rutstroemia, has been monographed by Whetzel (1943).

Certain members of the Ciborioideae (Sclerotiniaceae, according to Whetzel) are known to possess ascospores enclosed by gelatinous envelopes. These envelopes constitute adaptive de-
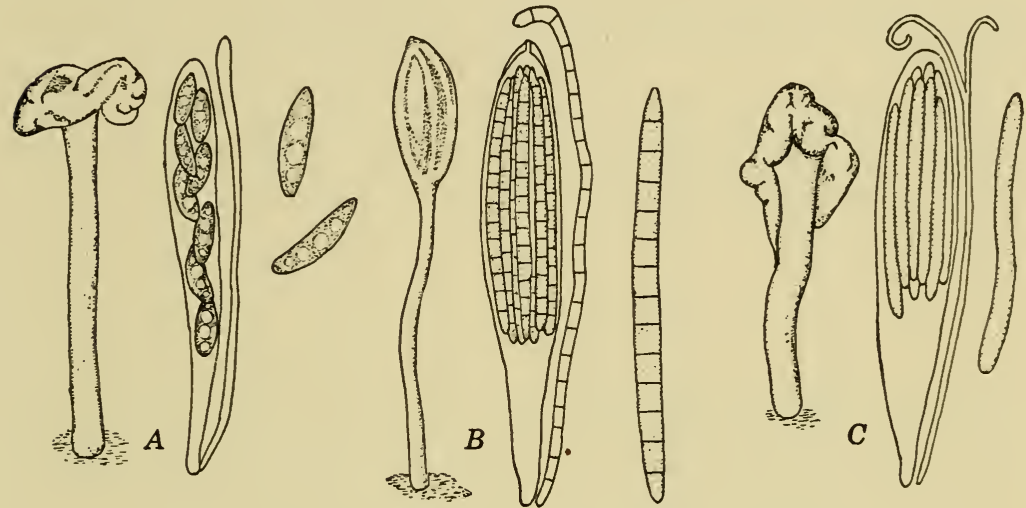

FIG. 108. Some Geoglossaceae showing differences in discocarps, asci, ascospores, and paraphyses in three representative genera. $A$. Leotia. $B$. Geoglossum. C. Spathularia.

vices to cause ascospores to adhere to the suscept and to retain and supply moisture during germination. Attention was recently directed to these structures occurring in Ciboria carunculoides and Monilinia fructicola [Whetzel and Wolf (1945)].

Fungi of other tribes of Helotiaceae. In the Tribe Ombrophiloideae is Cenangium abietis, the cause of dieback of twigs of pines, especially on trees whose vigor has been reduced by drought or other factors. Clusters of brown to black apothecia break through dead bark in the late summer and autumn. The hymenial surface is greenish. The ascospores are hyaline and elliptical. A conidial stage is unknown. In the same tribe occurs Chlorosplenium aeruginosum, which occurs on the decorticated slash of hardwoods and stains the wood a brilliant verdigris green. 
Scleroderis ribis on Ribes and S. abieticola on white firs, members of the Scleroderridoideae, produce inconspicuous, shortstalked, black apothecia on the bark of killed twigs. Their ascospores are several-septate and hyaline.

Geoglossaceae. The Geoglossaceae, or "earth tongues," are saprophytes, occurring in moist locations or in shady woods. Some are restricted to certain kinds of decaying wood, leaves, or mosses, as, for example, Cudonia lutea to beech litter, Mitrula cucullata to coniferous leaves, and Mitrula muscicola to moss litter among living mosses. The family is divided into two tribes on the basis of the form of the stalked ascomata: Geoglosseae, with clavate or spathulate ascomata, and Cudonieae, with pileate ascomata.

The shape and color of ascopores serve as bases for separating genera. Conidial stages are unknown. The monographic treatise by Durand (1908) is indispensable in the identification of North American species.

\section{LITERATURE CITED}

Atrinson, G. F., "The perfect stage of leaf spot of pear and quince," Science, n.s., 30: 452, 1909.

Bache-IVIIG, SARA, "Contributions to the life history of a systemic fungous parasite, Cryptomycina pteridis," Mycol., 32:214-250, 1940.

Backus, M. P., "Initiation of the ascocarp and associated phenomena in Coccomyces biemalis," Contrib. Boyce Thompson Inst., 6:339-379, 1934.

Draytox, F. D., "The sexual function of the microconidia in certain discomycetes," Mycol., 24: 345-348, 1932.

"The sexual mechanism of Sclerotinia gladioli," Mycol., 26: 46-72, 1934. "The perfect stage of Botrytis convoluta," Mycol., 29:305-318, 1937.

Durand, E. J., "A monograph of the Geoglossaceae," Ann. Mycol., 6:387$477,1908$.

Godfrey, G. H., "Gray mold of castor bean," J. Agr. Research, 23:679$716,1923$.

Groves, J. IV., and F. L. Draytox, "The perfect stage of Botrytis cinerea," Mycol., 31: 485-489, 1939.

Hahn, G. G., and T. E. Ayers, "Dasyscyphae on conifers in North America. I. The large-spored white-excipled species," Mycol., 26:73101, 1934.

II. "Dasyscypha ellisiana," Mycol., 26: 167-180, 1934 a.

III. "Dasyscyplaa pini," Mycol., 26: 479-501, 1934b.

Hansbrough, J. R., "The Tympanis canker of red pine," Yale Univ., Sch. Forestry Bull., 43: 1-58, 1936. 
Higgins, B. B., "Contribution to the life history and physiology of Cylindrosporium on stone fruits," Am. J. Botany, 1:145-173, 1914.

Honey, E. E., "The monilioid species of Sclerotinia," Mycol., 20: 127-157, 1928.

Jones, F. R., "Yellow leaf blotch of alfalfa caused by the fungus Pyrenopeziza medicaginis," J. Agr. Research, 13:307-330, 1918.

"The leaf-spot diseases of alfalfa and red clover caused by the fungi Pseudopeziza medicaginis and Pseudopeziza trifolii, respectively," U.S. Dept. Agr. Bull., 759. 38 pp. 1919.

JoNes, S. G., "Life history and cytology of Rlbytisma acerina (Pers.) Fr.," Ann. Botany, 39:41-75, 1925.

Klebahn, H., Haupt- und Nebenfruchtformen der Ascomyceten. 395 pp. Gebr. Bornträger, Leipzig. 1918.

Nannfeldt, J. A., "Studien über die Morphologie und Systematik der nichtlichenisierten operculaten Discomyceten," Nova Acta Regiae Soc. Sci. Upsalensis, Ser. IV, 8: 1-368, 1932.

Roberts, J. IV., ANd J. C. Dunegan, "The fungus causing the common brown rot of fruits in America," J. Agr. Research, 28:955-960, 1924.

"Critical remarks on certain species of Sclerotinia and Monilia associated with diseases of fruits," Mycol., 19: 195-205, 1927.

Weiss, Freeman, "Ovulinia, a new generic segregate from Sclerotinia," Ploytopatbology, 30: 236-244, 1940.

Whetzel, H. H., "North American species of Sclerotinia, I," Mycol., 18: 224-235, 1926; II, 21: 5-32, 1929.

"Septotinia, a new genus of the Ciborioideae," Mycol., 29: 128-146, 1937. "A monograph of Lambertella, a genus of brown-spored inoperculate Discomycetes," Lloydia, 6: 18-52, 1943.

"A synopsis of the genera and species of the Sclerotiniaceae, a family of stromatic inoperculate Discomycetes," Mycol., 37: 648-714, 1945.

Whetzel, H. H., ANd F. A. IVolf, "The cup-fungus, Ciboria carunculoides, pathogenic on mulberry fruits," Mycol., 37:476-491, 1945.

White, W. L., "A monograph of the genus Rutstroemia (Discomycetes)," Lloydia, 4:153-200, 1941.

Wolf, F. A., "The perfect stage of Actinonema rosae," Botan. Gaz., 57: 218234, 1912.

"Strawberry-leaf scorch," J. Elisha Mitchell Sci. Soc., 39: 141-163, 1924. "The leaf-scorch disease of strawberries," N. C. Agr. Expt. Sta. Tech. Bull., 28: 1-16, 1926.

Woronin, M., "Über die Sclerotinia-krankheit der Vaccinieenbeeren," Mém. Acad. Imp. Sci. Petersbourg, 7 ser., 36: 1-49, 1888.

Woronin, M., ANd S. Nawaschin, "Sclerotinia beteroica," Z. Pflanzenkrankl. Gallenkunde, 6: 129-140, 199-207, 1896.

\section{Ostropales}

This order, according to Nannfeldt (1932), contains the single family Ostropaceae. Its ascospores, as has been indicated, are 
thread-like and septate, and the cells separate into cylindrical elements. In this order Nannfeldt assembled Ostropa and Robergea, formerly placed among the Hysteriales, Vibrissea from the Geoglossaceae, Apostemidium, variously placed among the Geoglossaceae, Mollisiaceae, and Helotiaceae, and Stictis and Schizoxylon from the Stictidaceae. Durand (1908) placed Apostemidium among the Geoglossaceae. None of the species are known to possess conidia, with the possible exception of Schizoxylon sepincola and members of Apostemidium.

\section{LITERATURE CITED}

Durand, E. J., "A monograph of the Geoglossaceae," Ann. Mycol., 6:387$477,1908$.

Navifeldt, J. A., "Studien über die Morphologie und Systematik der nichtlichenisierten operculaten Discomyceten," Nova Acta Regiae Soc. Sci. Upsalensis, Ser. IV , 8: 1-368, 1932.

\section{Pesizales (Operculates)}

The Pezizales consist of 2 families, the Pezizaceae and Elvellaceae. Seaver (1942) divided the Pezizaceae into 8 tribes: Sphaerosporeae, Ascoboleae, Aleurieae, Humarieae, Lachneeae, Otideeae, Sarcoscypheae, and Pezizeae. The characteristics used as bases for separation are shape, color, and surface markings of spores and size, consistency, and nature of apothecia-whether stipitate or sessile, and whether hairy or smooth. These 8 tribes contain 39 genera. The Elvellaceae are constituted of 5 genera, distinguished primarily on the shape of the hymenial portion.

The Pezizales are all saprophytic. Their fructifications vary in size from barely visible disks, such as those in Streptotheca, Ryparobius, and Pyronema confluens, to stipitate structures 8 to $10 \mathrm{~cm}$ tall, as in Morchella crassipes, M. esculenta, and Urmula geaster, or even considerably larger, as in Durandiomyces phillipsii. The disks are discrete in nearly all species. In Morchella, however, the hymenial surface is alveolate, being compounded of many disks laterally united, and in Elvella it reposes saddlewise or variously convoluted at the top of the stipe.

The asci typically have 8 spores, but those of species of Streptotheca, Ryparobius, and Theotheca are polysporous, containing 16, 64, or more ascospores. 


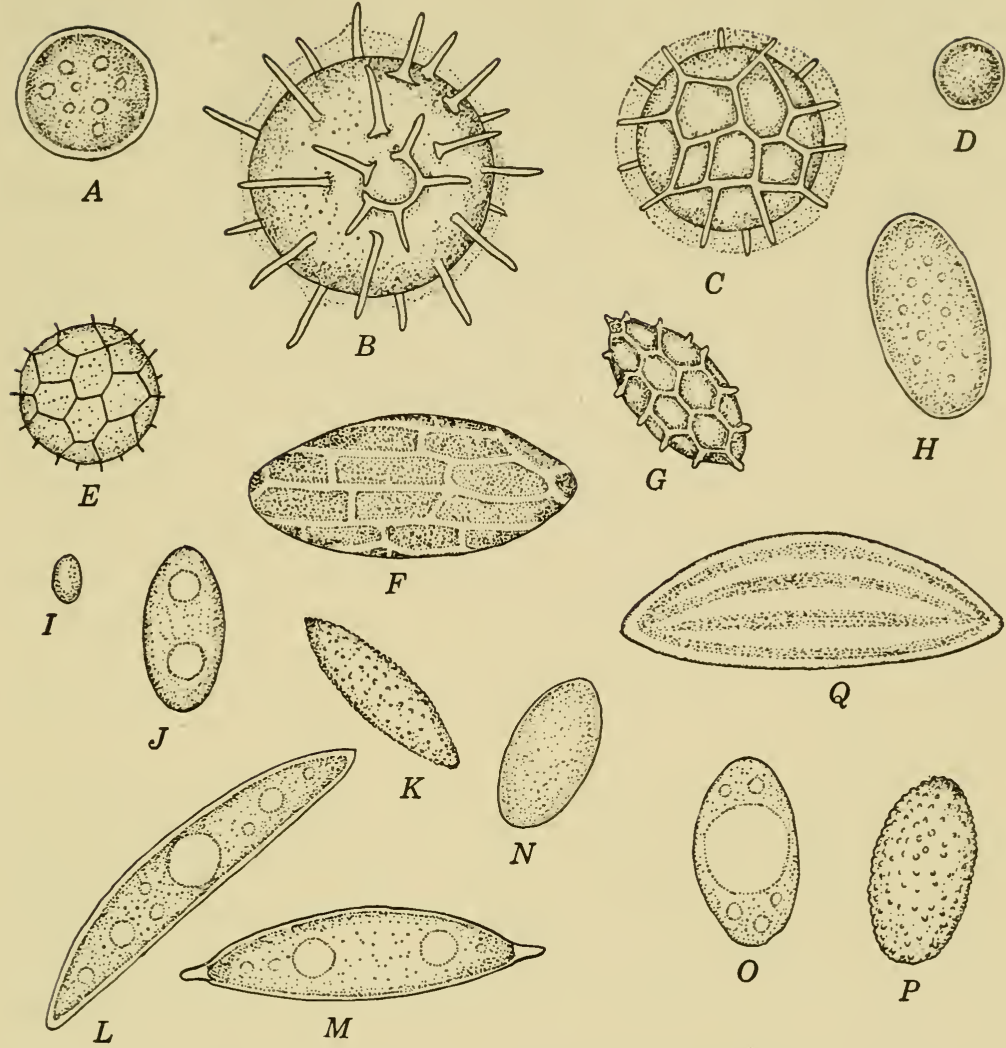

Fig. 109. Ascospores of Pezizales. A. Pseudoplectania nigrella, common on decayed pine wood among mosses. B. Boudieria areolata, on damp soil in swampy situations. C. Lamprospora areolata, on damp soil among moss. $D$. Pitbya cupressi, common on twigs and leaves of recently killed Juniperus and related conifers. E. Ascodesmis microscopica, on excreta of dogs. $F$. Ascobolus viridis. G. Aleuria aurantia, common on damp earth in woods. H. Ascophanus isabellinus, on mud from corrals. I. Streptotheca croumi grows on a variety of dung. The asci are polysporous. J. Patella scutellata, widely prevalent on badly decomposed wood. K. Paxina fusicarpa, on soil in woods. L. Urmula geaster, on decaying wood of Ulmus crassifolia. M. Rbizina inflata, on burned-over ground. N. Peziza vesiculosa, on heavily manured soils. O. Elvella elastica, on soil. P. Underwoodia columinaris, on soil. $Q$. Wynnea americana, on soil in rich woods. 
Conidial stages are uncommon, but Peziza repanda, $P$. vesiculosa, and Patella abundans are reported to possesş conidia. In $P$. abundans the conidia are of the Botrytis type.

The Pezizales generally are not restricted to a particular substrate, most of them occurring on moist soil high in organic content or on decaying wood. Some species, however, are quite restricted in substrate and range. Pyronema confluens is commonly found on burnt ground at the sites of campfires and has been observed to produce a copious pinkish cover upon the surface of pots of soil sterilized by steam. Corner (1930) records having seen millions of apothecia of Anthracobia maurilabra on several acres of burnt ground in England. During rainy weather Pitbya cupressi may densely occupy the recently killed branches of Juniperus and related conifers. Urnula geaster is limited to the vicinity of decaying stumps of Ulmus crassifolia. Some species are coprophilous, and species of Ascobolus, Ascodesmis, Ascophanus, and Ryparobius are limited to the dung of certain animals; Ascodesmis porcina, for example, occurs only on pig dung.

Apothecial development. Sexuality and the development of apothecia among Pezizales have been extensively studied by Harper (1900), Dangeard (1907), Claussen (1912), Dodge (1912), Dowding (1931), Schweitzer (1931), and GwynneVaughan and Williamson (1932). Pyronema confluens and several species of Ascobolus have been employed in these studies. Pyronema confluens has large vesiculate, multinucleate ascogonia. Clavate, multinucleate antheridia arise near the ascogonia, each surmounted by a curved hypha, the trichogyne. The multinucleate protoplast from the antheridium empties, by way of the trichogyne, into the ascogonium. Soon ascogenous hyphae arise from the surface of the ascogonium, from the penultimate cells of whose recurved tips the asci are developed.

Two opposed views are held concerning nuclear activities. Harper (1900) maintained that the nuclei fuse in pairs within the ascogonium and again in the base of the developing ascus, thus making the primary nucleus of the ascus tetraploid. This view is supported by Gwynne-Vaughan and Williamson (1932), who found that the chromosome number in spore nuclei and in the nuclei of sterile tissue is 6 , whereas that in nuclei of the ascogenous hyphae is 12 . Moreover, they found that the number of 
nuclei in the antheridium varies from 100 to 200, with a similar variation in the ascogone. Then, when the ascogenous hyphae start to protrude, the average number in the ascogone is 160 .

The opposing theory was proposed by Claussen (1912), who maintained that the nuclei merely became associated in pairs in the ascogonium and that fusion is delayed until the formation of the primary nucleus of the ascus. This view has a great deal of support, the most striking of which comes from the observations of Schweitzer (1931). He noted that the antheridial nuclei of Ascobolus strobilinus are smaller than the ascogonial nuclei. They do not fuse in the ascogonium but migrate in pairs, a small one and a large one, into the ascogenous hyphae.

Dangeard (1907) found that the antheridium did not open into the trichogyne in Pyronema confluens, and hence he deduced that this species is apogamous, a conclusion that has been supported by several subsequent investigators.

Common species of Pezizaceae and Elvellaceae. Members of both these families are essentially cosmopolitan and are always of interest to the student of fungi. Patella scutellata, occurring on decaying wood, has bright red disks with a fringe of dark hairs. Peziza vesiculosa occurs in clumps in richly manured gardens or on manure piles. Its cups are brown, 2 to 3 in. broad, and are commonly contorted and crimped. Peziza venosa and $P$. badia are common on the ground in deciduous woods. The hymenial surface of $P$. venosa is convoluted. Plectania coccinea grows on partly buried sticks. Its funnel-shaped fruit bodies are about 1 in. broad, and its hymenial surface is scarlet. In the spring the stalked clusters of dark cups of Urmula craterium, 1 to 2 in. broad, are common on partly buried oak branches. The base of the stipes and the mycelium from which they arise are coal black. The gyrosely folded hymenia of Morchella and Elvella give them the appearance of sponges.

\section{LITERATURE CITED}

Claussex, P., "Zur Entwickelungsgeschichte der Ascomyceten, Pyronema confluens," Z. Botan., 4: 1-63, 1912.

Corner, E. J. H., "Studies in the morphology of Discomycetes. IV. The evolution of the ascocarp," Trans. Brit. Hycol. Soc., 15:121-134, 1930.

Dangeard, P. A., "L'origine du perithece chez les Ascomycetes," Botaniste, 10: 1-385, 1907. 
Dodge, B. O., "Nlethods of culture and the morphology of the archicarp in certain species of the Ascobolaceae," Bull. Torrey Botan. Club, 39: 139-197, 1912.

Dowding, E. S., "The sexuality of Ascobolus stercorarius and the transportation of the oidia by mites and flies," Amm. Botan., 45:621-637, 1931.

Gwyne-Vaughan, H. C. I., and H. S. Williamson, "The cytology and development of Ascobolus magnificus," Ann. Botany, 46:653-670, 1932.

Harper, R. A., "Sexual reproduction in Pyronema confluens and the morphology of the ascocarp," Ann. Botany, 14:321-400, 1900.

Schweitzer, G., "Zur Entwickelungsgeschichte von Ascobolus strobilimus, n.s.," Planta, 12: 588-602, 1931.

Seaver, F. J., The North American cup-fungi (Operculates), Supplemented ed. 377 pp. Published by the author, New York, 1942.

\section{Tuberales}

The Tuberales, commonly called truffles, are typically subterranean, although a few species are imperfectly buried or grow quite near the surface among decaying leaves. At least some of them grow only in association with certain species of trees, especially oaks and beeches. It was this constant association with trees, in fact, which led Frank long ago to postulate that truffles may establish the symbiotic relationship which he designated as mycorrhizal. Evidence of this preference for particular tree species is contained in the report of Parks (1920) that in California he unearthed ascocarps of 7 genera, including 11 species, in an area $10 \mathrm{ft}$ square beneath an oak tree, Quercus agrifolia.

The gross appearance of fruit bodies of truffles would lead the observer to suspect them of being Gastromycetes, among which they were, in fact, placed by early investigators. The ascocarps are globular structures varying in size from $0.5 \mathrm{~cm}$ to about $8 \mathrm{~cm}$. They are brownish in color, and their surface may be smooth or warty. The rind or peridium is a compact, resistant layer composed of thick-walled tissue. The interior consists of elaborate folds or chambers lined with a palisade of asci, interspersed with loose fungus tissue.

The Tuberales comprise a relatively small assemblage, having 27 genera and approximately 200 species. Four species were described in Persoon's Synopsis Methodica Fungorum. Thirty years later, with the appearance of Vittadini's classical Monographia Tuberacearum, the known forms increased to 13 genera and 73 species. Massee (1909) lists 11 genera and 32 species as 

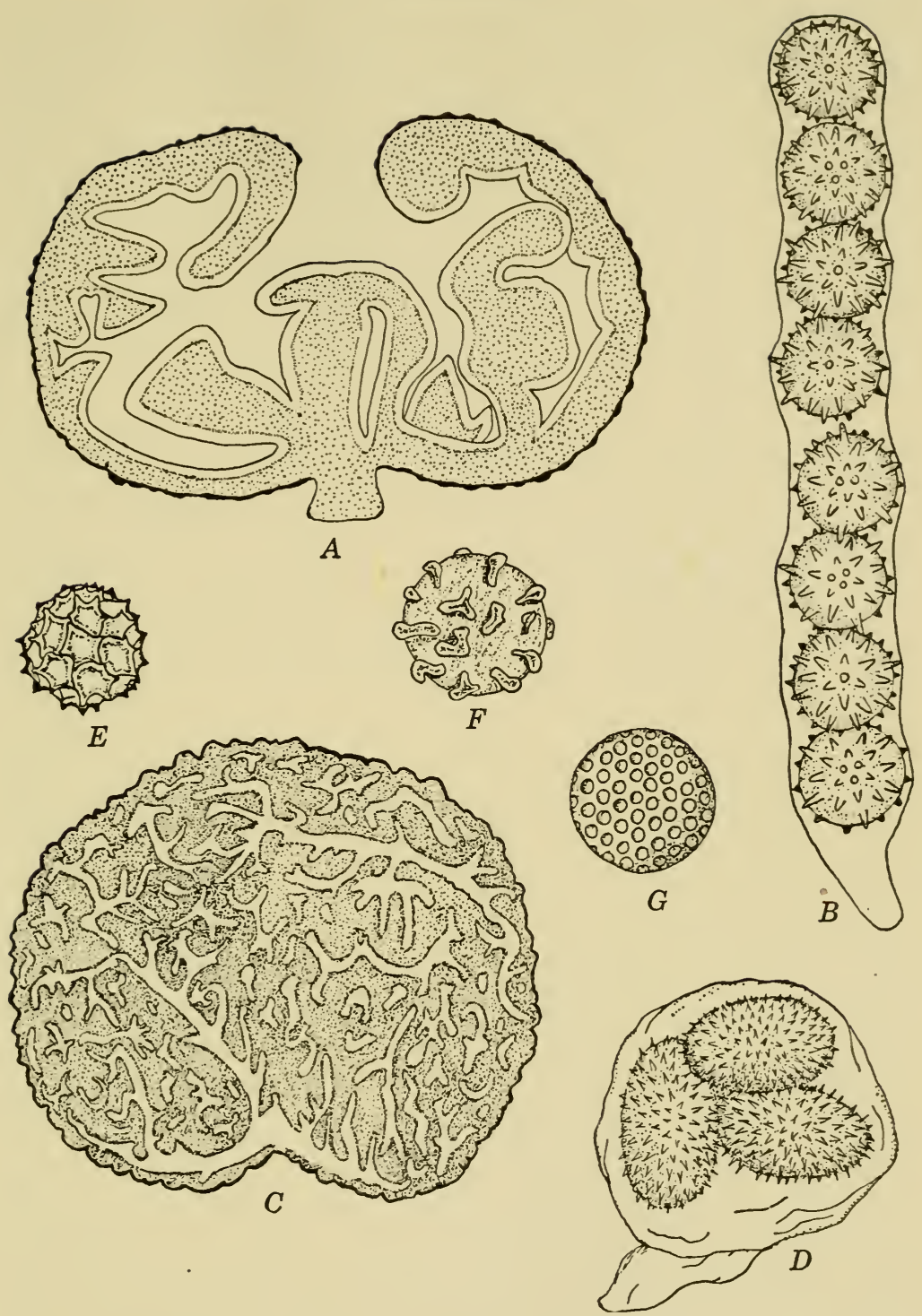

Fig. 110. Truffles. A. Ascocarp of Genea verrucosa, in section. B. Ascus and ascospores of G. ierrucosa. C. Ascocarp of Tuber brumale, in section. D. Ascus and ascospores of T. brumale. (Adapted from Tulasne.) E. Ascospore of Hydnobolites californicus. (Adapted from Gilkey.) F. Ascospore of Hydnotrya tulasnei. (Adapted from Massee.) G. Ascospore of Piersonia alveolata. (Adapted from Gilkey.) 
occurring in England; and Gilkey (1916), 37 species in California. In a later monograph Gilkey (1939) lists and describes 58 species, included in 19 genera, as occurring in North America. All are edible, some species being highly prized as food, especially Tuber aestivum, $T$. brumale, $T$. melanosporum, $T$. magnatum, and $T$. nitidum. Although the number of known species of truffles is not large, edible ones may occur so abundantly as to make their collection commercially profitable. Persons who collect truffles commercially, especially in France and Italy, work with the help of trained dogs or hogs that locate the truffles by scent.

Reproduction. No asexual or conidial stage is known to occur among Tuberales, with the possible exception of one species of Tuber found to form conidia in culture. Their only known reproductive stage is ascospores. Unfortunately the early development of ascocarps, has not been observed; hence little is known about their sexuality. Dangeard (1894) found that crosiers are formed in $T$. brumale and $T$. dryophilum and that the customary number of free nuclei is produced within each ascus. The number of ascospores, howerer, varies from 1 to 8 per ascus, and the wall of the ascospores at maturity is ornamented with spines, warts, or reticulations. Ascospore dispersal is accomplished only after decay of the rind or through the agency of animals, especially rodents, that utilize truffles for food.

Classification and relationship. The truffles are divided into two families: Eutuberaceae, with hymenial chambers that open to the outside, and Balsamiaceae, with closed chambers. It remains questionable whether this basis is adequate for separation. Evidence presented by Bucholtz (1897) shows that Tuber excavatum, typifying the Eutuberaceae, is at first gymnocarpous. In Genea, too, the ascocarps are initially closed, and they open apothecium-like at maturity. These observations incline some mycologists to regard the Tuberales as discomycetous. The findings of Bucholtz $(1903,1910)$ indicate that the convolutions which are to become the hymenium arise as invaginations from the upper surface of the ascocarp. Bucholtz (1910) regards the Balsamiaceae as intermediate between Pezizales and Helvellales.

On further study, as has been indicated, certain of the species formerly placed among the Elaphomycetaceae and Terfeziaceae have been found to belong among the Tuberales. Relationships 
among all these subterranean fungi can be established only after further investigation with access to ascocarps in immature stages.

\section{LITERATURE CITED}

Bucholtz, F., "Zur Entwickelungsgeschichte der Tuberaceen," Ber. deut. botan. Ges., 15: 211-226, 1897.

"Zur Morphologie und Systematik der Fungi hypogaee," Ann. Mycol., 1: 152-174, 1903.

"Zur Entwickelungsgeschichte des Balsamieenfruchtkörpers, nebst Bemerkungen zu Verwandschaft der Tuberineen," Amn. Mycol., 8:121-141, 1910.

DaNgeard, P. A., "La truffe," Botaniste, 4: 63-87, 1894.

Gilkey, Helex M., "A revision of the Tuberales of California," Univ. Calif. Publ. Bot., 6: 275-356, 1916.

"Tuberales of North America," Oregon State Monographs, 1. 63 pp. 1939.

MASSEE, George, "The structure and affinities of the British Tuberaceae," Amn. Botany, 23:243-263, 1909.

Parks, H. E., "California hypogaeous fungi-Tuberaceae," Mycol., 13:301$314,1920$. 


\section{Chapter 7}

\section{THE BASIDIOMYCETES}

The Basidiomycetes, a group of 20,000 to 25,000 species, include the fungi that bear their spores exogenously on basidia. The basidia may occur singly or be variously arranged on hymenia. On the basis of the shape and structure of basidia and of their arrangement, the Basidiomycetes are divided into two groupings, the Heterobasidiomycetes and Homobasidiomycetes. The Heterobasidiomycetes include the fungi commonly known as smuts, rusts, and jelly fungi, and the Homobasidiomycetes all others, including the gill, pore, leathery, and coral fungi, puffballs, stinkhorns, and bird's-nest fungi. Essentially all the Heterobasidiomycetes are gymnocarpous; that is, their basidia arise on the free surface of the fructification. The Homobasidiomycetes are further commonly divided into two subclasses, Hymenomycetes and Gastromycetes. The Gastromycetes include those fungi whose hymenia are formed within the fructification; hence they are spoken of as angiocarpous. Transitional conditions of gymnocarpy and hemiangiocarpy exist among the Hymenomycetes. Among pileate species the sporiferous layer is generally differentiated on the interior of tuberous or "button-like" fundaments, and the hymenium is erentually exposed by expansion and rupture. These fungi are spoken of as hemiangiocarpous. Among leathery fungi and pore fungi generally, the basidia from their beginning comprise a free hymenial layer.

The basidium, the characteristic structural feature of the Basidiomycetes, is typically club-shaped and non-segmented and bears exogenously a complement of four basidiospores. The shape and structure of basidia, as will be pointed out, vary. Initially they are the ends of hyphae composed of dicaryotic (twonucleate) cells. As each terminal cell enlarges, the two nuclei enlarge also. These nuclei soon fuse to form a diploid fusion nucleus, that is, one with $2 x$ number of chromosomes, which 
then undergoes 2 divisions to form 4 daughter nuclei. Each of these nuclei has $x$ number of chromosomes and is therefore haploid. Next, from the apex of the enlarging basidium 4 protrusions (sterigmata) arise. These protrusions expand terminally, and a nucleus passes into each inflated tip. When delimited, the

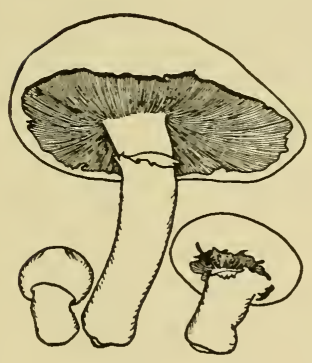

$A$
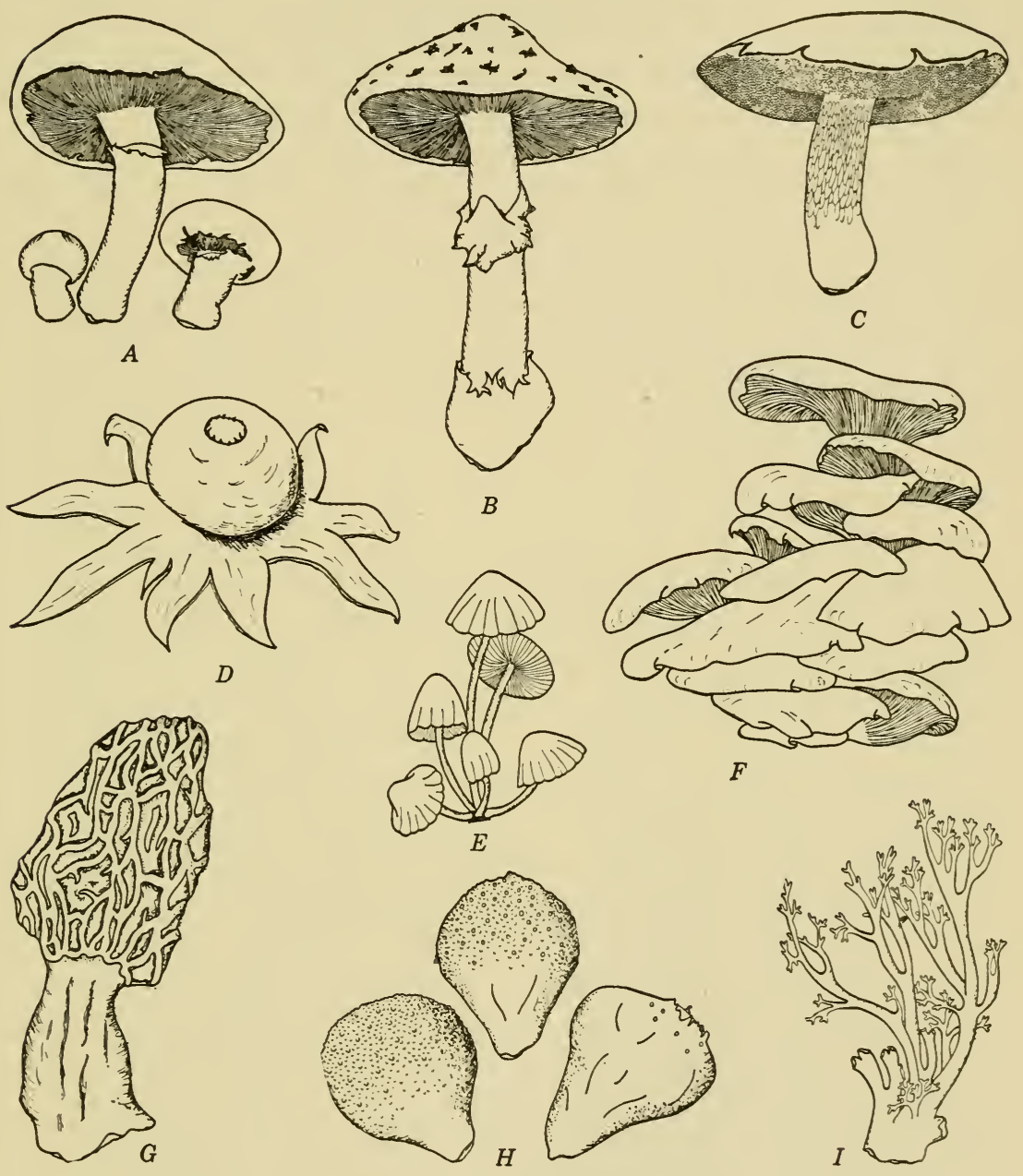

Fig. 111. Common genera of so-called mushrooms, nearly all of which are Basidiomycetes. (Courtesy, General Biological Supply House, Inc., Chicago, Illinois.) A. Agaricus. B. Amanita. C. Boletus. D. Geaster. E. Coprinus. F. Pleurotus. G. Morchella (Discomycete). H. Lycoperdon. 1. Clavaria. 
enlarged tip is the uninucleate basidiospore. Sometimes only 2 sterigmata are produced; then each of the 2 spores may receive 2 nuclei, or 2 nuclei may remain unused within the basidium.

On germination the basidiospores, which are almost universally uninucleate (monocaryotic), give rise to hyphae with uninucleate cells, which constitute the primary mycelium. Soon the primary mycelium gives rise to binucleate (dicaryotic) cells that compose the secondary mycelium. The process of mating in which haploid mycelia become diploid is called diploidization. It is very commonly accomplished by clamp connections. These are buckle-like devices, formed at the septa, that permit a pair of nuclei to be walled off in each cell.

All subsequent nuclear divisions of this pair of nuclei or of their progeny are conjugate; that is, they divide coincidentally. As a result the vegetative mycelium remains dicaryotic throughout. Eventually fruit bodies are produced from fundaments laid down by the dicaryotic mycelium. When the hymenial layer is differentiated in the fruit body, the terminal cells that are to become basidia are dicaryotic. The cycle of development may then be initiated anew by fusion (final stage of diploidization) of the pair of nuclei within each young basidium.

Types of Basidia. Basidia, as has been indicated, vary widely in structure and development. In the Uredinales and Ustilaginales the teliospore, a uninucleate but diploid thick-walled structure, is the probasidium. On germination it gives rise to a tubular basidium, sometimes called a promycelium. Meanwhile meiotic nuclear division has taken place, after which, by transverse septation, the basidium becomes a row of cells, usually 4, each containing a haploid nucleus. Each nucleus then migrates into a laterally or terminally formed bud, which becomes abstricted and is the basidiospore. Among the Ustilaginaceae, the primary haploid nuclei within the basidium may continue to divide, and as a result many basidiospores may be produced.

Quite the same type of basidial structure occurs among all Auriculariales. The cell from which the so-called epibasidium (promycelium) arises is commonly designated the hypobasidium (probasidium). After the first nuclear division in the hypobasidium, a cross wall is formed in the elongating epibasidium; after the next division other cross walls are laid down to form a row of superimposed cells. From each epibasidial cell in 
Auricularia slender sterigmata arise that bear the basidiospores at the same level. In Phleogena (Pilacre) basidiospores are produced in a row down one side of the epibasidium. In Septobasidium the probasidium is thick-walled, quite as in the rusts, and the slender septate epibasidium bears its basidiospores on rather long sterigmata. In this type of basidium with its several minor modifications the nuclear spindles are longitudinally oriented, and such basidia are said to be of the stichobasidial type.

The Tremellales are characterized by another basidial type. The spherical or elongate basidium becomes divided by a vertical septum after division of the primary diploid nucleus. After division of each of these nuclei another vertical septum at right angles to the first is laid down, so that the basidium, as seen from above, is cruciately divided. Each quadrant then bears a slender sterigma on which a single haploid basidiospore is apically produced. The nuclear spindles among Tremellales are oriented transversely to the longitudinal axis of the basidium, such basidia being therefore regarded as of the chiastobasidial type.

Among the Heterobasidiomycetes there exists still another type of basidium. Here the primary diploid nucleus divides twice, the spindles being longitudinally placed. Then a tuningfork-shaped process arises at the apex of the basidium. Two of the nuclei pass into basidiospores, 1 at each tip of the fork, and the other 2 nuclei eventually disintegrate. This type occurs among the Dacryomycetales.

The basidia of the Hymenomycetes and Gastromycetes represent another type. In general they are slender, clavate to broadly clavate in the Hymenomycetes, and nearly globular in the Gastromycetes. The fusion nucleus characteristically undergoes 2 divisions to make 4 haploid nuclei. Sometimes there are 1 or more additional divisions. Usually 4 slender sterigmata arise from the basidial apex, and a uninucleate basidiospore is borne on each sterigma. In Tulostoma the sterigmata may be somewhat lateral. In certain gill fungi, such as Amanita bisporigera, Camaropbyllus virgineus, Cantharellus cornucopioides, Mycena metata, and Psalliota campestris [Bauch (1927), Buhr (1932), Smith (1934), and Colson (1935)], and in the coral fungi, Clavaria cinerea and C. cristata, 2 basidiospores, instead of 4, are regularly produced on each basidium. Bauch (1927) has shown that such basidiospores are rarely binucleate, although they are known 
to possess 2 nuclei in Cantharellus cormucopioides, Coprinus ephemerus, Hydnangium carneum, Mycena murina, and Psalliota campestris. In some species that produce only 2 uninucleate basidiospores, the 2 residual nuclei disintegrate in the basidium. In species that have 4 spores, such as Mycena atkinsoni, M. alcalina, $M$. bemisphaerica, $M$. leptocephala, $M$. sanguineolenta, $M$. stannea, and $M$. viscosa, there may be 4 residual nuclei to disintegrate [Smith (1934)]. Mycena citrinomarginata, M. dissiliens, M. leptocephala, M. polygramma var. albida [Smith (1934) ] and Naucoria lenticeps may produce 2, 3, or 4 spores on different basidia in a single pileus. Galera silignea is said to have monosporous basidia. Smith (1934) also noted that the young basidia of Mycena capillaris, $M$. cholea, $M$. citrinomarginata, $M$. dissiliens, $M$. lasiosperma, $M$. leptocephala, $M$. poly gramma var. albida, M. roseo-pallens, M. rubromarginata var. laricis, and $M$. vitilis have a single nucleus, instead of 2 , in the young basidium. These species are considered parthenogenetic.

Spindle orientation in basidia of Hymenomycetes and Gastromycetes may be transitional between stichobasidial and chiastobasidial, as noted by Levine (1913) in Boletus, or each kind may occur in adjacent basidia in the same hymenium, as in Exobasidium rbododendri [Eftimiu and Kharbush (1927)].

BAsidiospores. The basidiospores of Basidiomycetes generally, except among the Gastromycetes, are inaequilateral, unicellular, uninucleate, thin-walled structures. They may vary in color en masse, being hyaline, pink, yellow, brown, or black, but otherwise are monotonously alike. Their wall is almost universally smooth, echinulations being common in a few genera, such as Lactarius and Russula. In Ganoderma the walls are peculiarly thickened. In Auricularia, Dacryomyces, and related genera the basidiospores may become several times transversely septate. The basidiospores of many Gastromycetes have thick walls that are variously ornamented, and the spore mass may be yellow, brown, purple, or black.

Mrceliun. The conspicuous part of most species of Basidiomycetes is the fructification. The mycelium is usually ensconced within the leaf mold, decaying wood, dung, or other organic matter of the soil or within plant tissues. Here it exists as an interlacing, anastomosing weft of hyphae, as delicate mycelial strands, or as conspicuous rhizomorphs or sclerotia. The 
mycelium of parasitic species is intercellular, entrance to the host cells being accomplished by haustoria in the rusts.

Bensaude (1918) pointed out that the mycelium from a single basidiospore may be incapable of giving rise to fructifications, but that two mycelia of opposite potentialities may be adequate. She regarded such species as heterothallic, in contrast to other species in which a single basidiospore is totipotent and which are therefore homothallic. These fundamental differences have been studied and further elaborated by Mounce (1922), Vandendries (1925), Hanna (1925), Newton (1926), Kniep (1928), and others.

Coprinus lagopus, C. narcoticus, C. niveus, and C. stercorarius are among the species found to be homothallic; Armillaria mucida, Coprinus fimetarius, certain varieties of C. lagopus, C. micaceus, Corticium poly gonium, Fomes roseus, F. subroseus, Lenzites saepiaria, L. trabea, Paneolus campanulatus, Scbizopbyllum commune, and Trametes americana are heterothallic.

Mycelia arising from the germination of basidiospores of different species differ rather fundamentally. Mycelium from most of the rusts and from Corticium varians, Collybia conigena, and Peniopbora sambuci [Kniep $(1915,1917)$ ] consists of uninucleate cells. Mycelium from basidiospores of Peniophora gigantea is also uninucleate, although the basidiospores are themselves binucleate. In this instance one nucleus remains within the spore membrane, and the other migrates into the developing germ tube. The mycelium from basidiospores of Armillaria mucida, Coprimus fimetarius, Hypholoma perplexum, and Pboliota praecox is coenocytic, becoming so by failure of septations to form as the nuclei are undergoing divisions. In Corticium bombycinum ( $\mathrm{Hy}$ pochnus terrestris) and in most Gastromycetes the basidiospores are binucleate, and all divisions are conjugate, resulting in dicaryotic mycelium.

Diploidization. One peculiarity of the mycelium of the majority of Basidiomycetes is the presence of buckle joints or clamp connections, first noted by Hoffman in 1856 and called "Schnallenzellen.". Accord has not been reached on their function and significance. Usually they occur in connection with dicaryotic mycelium only. They are always present at all septa in Daedalea unicolor, Fistulina bepatica, Lenzites abietinus, and Merulius lacrymans and occur at only occasional septa in Coniophora cere- 
bella, Clitocybe expallens, and Lycoperdon pyriforme. A whorl of clamps may be developed in Coniophora cerebella. Clamp connections are commonly present also among the jelly fungi. In Armillaria mellea and Corticium bombycinum, although the cells are dicaryotic, clamps are absent. They occur in the monocaryotic mycelium of Stereum birsutum and in the coenocytic mycelium of Coprinus narcoticus.

The essentials of the process of clamp formation among the higher Basidiomycetes are as follows: A bowed pouch-like protrusion arises from the wall medianly between a pair of nuclei. The nuclei divide conjugately, and one of the daughter nuclei passes into the pouch. A septum is formed near the base of the pouch, producing a uninucleate clamp cell. At the same time another septum is laid down to separate two of the nuclei in the terminal cell from the fourth nucleus in the basal cell. After a time the tip of the clamp cell fuses with the basal cell, and the nucleus of the clamp cell passes out into the basal cell, thus making it binucleate.

Evidently diploidization may be initiated in several ways. Details of the process in Ustilaginales and Uredinales will be considered later in connection with these orders. Among Hymenomycetes it may be initiated by the fusion of monocaryotic hyphae of opposite sexual phases. It may also result by fusion of an oidium borne on a hypha of one sexual phase with the hyphae of the opposite phase [Brodie (1931)], or oidial mycelia of opposite sexual phase may unite [Brodie (1931)]. Some cases of diploidization are not so readily explained and appear to involve factors for compatibility and their disjunction, and the existence of "geographic races." Newton (1926) found among 25 monosporous mycelial cultures of Coprinus rostrupianus that 11 remained haploid, whereas 14 spontaneously became diploid. At any rate mycelial cells once diploid remain diploid throughout the greater period of the developmental cycle, and fusion takes place in the young basidia, whereupon reductional division follows to form haploid basidiospores in the majority of species.

The development of present-day concepts of diploidization and an interpretation of its significance are comprehensively presented in a report by Buller (1941).

Conidia. The production of conidia among Basidiomycetes cannot be regarded as of common occurrence. The basidiospores 
of many smuts bud indefinitely in yeast-like fashion, and these buds, like conidia, may eventually serve to initiate infection. The urediniospores of rusts are like conidia in their origin, and, since they function in dissemination, may in a sense be considered conidia. The basidiospores of many jelly fungi germinate by formation of sprout cells that may eventually develop mycelia.

In Coprinus lagopus [Brodie (1931)] lateral oidiophores arise from the mycelium. These become segmented basipetally into ellipsoidal oidia that cling together in balls at the apices of short branches, the remnants of the oidiophores. These oidia may function as conidia or else in diploidization, as has been mentioned.

Chlamydospores may form as a powdery layer at the upper surface of pilei of certain mushrooms, notably Nyctalis asterophora and $N$. parasitica. These mushrooms parasitize species of Armillaria, Clitocybe, Cantharellus, Lactarius, and Russula.

Gemmae have been noted to arise as propagative devices in several Hymenomycetes. Perhaps the most striking of these is Omphalia flavida [Buller (1934)], whose stalked gemmae are formed on the leaves of coffee and other tropical species. This stage produces leaf spots, and the gemmiferous structures, which are like those in Stilbum, cover the lesions.

True conidia, belonging to the form Genus Oedocephalum, occur in Corticium effuscatum, C. roseo-pallens, Fomes annosus, Peniophora allescheri, Tomentella flava, and T. granulata [Nobles (1935)]. They are uninucleate in $P$. allescheri, according to Nobles, whether they are produced on haploid or diploid mycelia. Conidia from the haploid mycelium are of the same sexual phase as the mycelium from which they are derived, whereas those from the diploid mycelium are of two kinds, some of one sexual phase and the remainder of the other. Pleurotus pinsitus, $P$. corticatus, and Corticium calceum are also said to form conidia.

\section{LITERATURE CITED}

BaUCH, R., "Untersuchungen über zweisporige Hymenomyceten. II. Kerndegeneration bei einigen Clavaria-arten," Arch. Protistenk., 58:285-299, 1927.

Bensaude, M., Recherches sur le cycle évolutif et la sexualité chez les Basidiomycètes. These (Paris). 153 pp. 1918. 
Brodie, H. J., "The oidia of Coprinus lagopus and their relation to insects," Ann. Botany, 45:315-344, 1931.

BuHr, H., "Untersuchungen über zweisporige Hymenomyceten," Arch. Protistenk., 77: 125-131, 1932.

Buller, A. H. R., Researches on Fungi, Vol. 6: 397-443. Longmans, Green and Company, London. 1934.

"The diploid cell and the diploidization process in plants and animals, with special reference to the higher fungi," Botan. Rev., 7:335-431, 1941.

Colson, Barbara, "The cytology of the mushroom Psalliota campestris Quél.," Amn. Botany, 49:1-18, 1935.

Eftimiu, P., ANd S. Kharbush, "Recherches histologiques sur les Exobasidiées," Rer. patl. vegétale entomol. agr. France, 1t: 62-88, 1927.

Hanna, W. F., "The problem of sex in Coprinus lagopus," Ann. Botany, 39: 431-457, 1925.

Kxiep, Haxs, "Beiträge zur Kenntnis der Hymenomyceten. I, II," Z. Botan., 5: 593-637, 1913; III, 7: 369-398, 1915; IV , 8: 353-359, 1916; V, 9:81-118, 1917.

Die Sexualität der niederen Pflanzen. 544 pp. Gustav Fischer, Jena. 1928.

Letixe, M., "Studies in the cytology of the Hymenomycetes, especially the Boleti," Bull. Torrey Botan. Club, 40:137-181, 1913.

Mounce, Irene, "Homothallism and heterothallism in the genus Coprinus," Trans. Brit. Mycol. Soc., 7: 256-269, 1922.

Newton, Dorothy E., "The bisexuality of individual strains of Coprimus rostrupianus," Ann. Botany, 40: 105-128, 1926.

Nobles, Mildred K., "Conidial formation, mutation, and hybridization in Peniophora allescheri," Mycol., 27:286-301, 1935.

Simth, A. H., "Investigations of two-spored forms in the genus Mycena," Mj'col., 26: 305-330, 1934.

VANDENDRIES, R., "Recherches experimentales prouvant la fixité du sexe dans Coprinus radians Desm.," Bull. soc. mycol. France, 41:358-374, 1925.

\section{HETEROBASIDIOMYCETES}

\section{DACRYOMYCETALES}

The Dacryomycetales include a group of jelly fungi, all of which are saprophytes occurring on decaying wood. The fruiting bodies are small, waxy or gelatinous in consistency, and typically yellow to orange in color. Although the Dacryomycetales bear a superficial resemblance to the Tremellales and Auriculariales, they have been classified as a separate order because of the unique basidium, which is a Y-shaped, non-septate structure bearing 2 basidiospores, rather than the 4 spores characteristic of Basidiomycetes in general. 
There is a single family, the Dacryomycetaceae, which includes 7 genera and some 75 to 100 species. Considerable variation occurs among the various genera in the gross structure of the fruiting body, which may be resupinate in Ceracea, pulvinate in Dacryomyces, or stipitate in Guepinia. The basidiocarps of the most complex genus, Calocera, resemble a Clavaria in miniature. Throughout the group the fructifications are able to survive considerable desiccation, becoming shrunken and inconspicuous during dry weather. In periods of rain, however, they imbibe water, swell enormously, and become brilliantly colored.

In the common species Dacryomyces deliquescens young fruiting bodies are orange colored and produce only conidia. The conidia are binucleate but divide before germination to form 2 uninucleate conidia, each of which is capable of developing into a mycelium composed of uninucleate cells [Dangeard (1895)]. Conidial fructifications like those of $D$. deliquescens are unknown in most other members of the order.

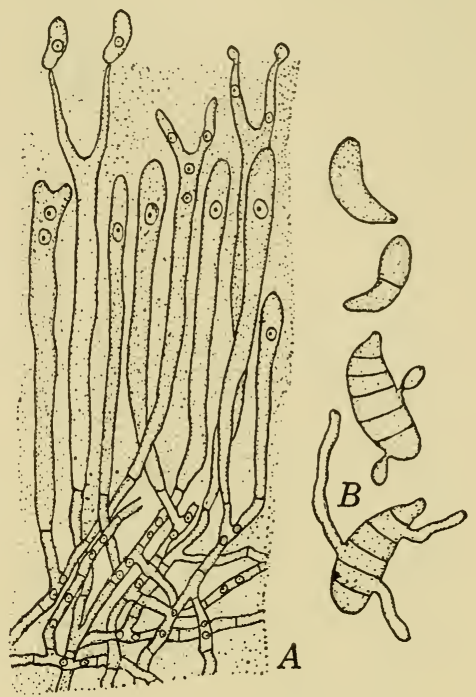

FIG. 112. Dacryomyces deliquescens. $A$. Section of hymenium. The sterigmata project to the surface of the jelly-like envelope. $B$. Septation and growth of basidiospores.

The surface of older fruiting bodies of $D$. deliquescens is covered by a hymenium consisting of narrow, closely compacted basidia. Although it is known that the cells directly beneath the hymenial layer are binucleate, the origin of the dicaryotic condition has never been satisfactorily explained. Clamp connections have been observed in certain members of the order but appear to be lacking in others. Gilbert (1921) states that anastomoses between the cells of the developing fruiting body and division of the single nucleus without accompanying cell division probably explain the origin of binucleate cells.

The developmental history of the basidium has been in dis- 
pute. After the fusion of the 2 nuclei of the young hypobasidium, 2 projections, which become the epibasidia, appear from its apex. Dangeard (1895) reported that only 1 nuclear division occurs in the hypobasidium. Shortly thereafter another nuclear division occurs, resulting in the existence of 4 nuclei within the hypobasidium, as was noted by Istvanffi (1895), Juel (1898), and Maire (1902). Eventually 2 of these nuclei form the 2 uninucleate spores; the 2 remaining nuclei degenerate within the hypobasidium, according to the account of Gilbert (1921). An essentially similar course of development has recently been described for Guepinia spathularia by Bodman (1938); in this species, however, the 2 nuclei pass into the epibasidium before degeneration occurs.

Buller (1922) has presented an account of the development and discharge of basidiospores in living material of Dacryomyces deliquescens. The development of a spore upon the sterigma requires about 50 minutes; the basidiospore is then shot off forcibly for a distance of approximately $0.5 \mathrm{~mm}$. The basidiospore is unicellular and uninucleate upon discharge but shortly thereafter becomes multicellular. The number of cells is commonly 4 and occasionally as many as 8 ; it may vary considerably even within a single species.

The basidiospores of Dacryomyces, like those of certain members of the Auriculariales and Tremellales, have the characteristic of germinating by repetition. Each cell of the mature basidiospore may give rise to 1 or several uninucleate conidia, which develop into a monocaryotic mycelium.

The Dacryomycetales, by virtue of similarities in habit of the fruiting bodies and method of basidiospore germination, appear to be closely related to the other orders of Heterobasidiomycetes. A possible derivation from the Auriculariales, involving reduction in the number of functional nuclei within the basidium from 4 to 2 , and loss of the septate nature of the basidium, has been suggested by Juel (1898) and other authorities.

\section{LITERATURE CITED}

Bodmax, M. C., "Morphology and cytology of Guepinia spatbularia," Mycol., 30: 635-652, 1938.

Buller, A. H. R., Researches on fungi, Vol. II. Longmans, Green and Company, London. 1922. 
Dangeard, P. A., "Mémoire sur la réproduction sexuelle des Basidiomycètes," Botaniste, 4: 119-181, 1895.

Gilbert, E. M., "Cytological studies of the lower Basidiomycetes. I. Dacrymyces," Trans. Wis. Acad. Sci., 20:387-397, 1921.

Istvanffi, G., "Über die Rolle der Zellkerne bei der Entwicklung der Pilze," Ber. deut. botan. Ges., 13: 452-467, 1895.

Juel, H. O., "Die Kerntheilungen in den Basidien und die Phylogenie der Basidiomyceten," Jabrb. wiss. Botan., 32: 361-388, 1898.

MaIRe, R., "Récherches cytologiques et taxonomiques sur les Basidiomycètes," Bull. soc. mycol. France, 18: 1-209, 1902.

\section{Tremellales}

The Tremellales include heterobasidiomycetous jelly fungi in which the basidium is of the so-called cruciate type. The basal portion of the basidium [the hypobasidium of Neuhoff (1924)] is longitudinally septate and is composed of 4 cells, from each of which arises a prolongation (the epibasidium) bearing the spore. About 100 species that have been distributed among 20 genera are included in the order. They are dispersed among 3 or possibly 4 families. The vast majority of the species are wood. inhabiting saprophytes; a few, among which is Tremella myce. topbila on the gills of various agarics, are parasitic. At least 1 species, T. fuciformis, is considered edible. Like other Heterobasidiomycetes, the Tremellales are primarily tropical in their distribution.

Of the 3 families accepted by most authorities, the Tremellaceae, with the vast majority of the species, includes all forms in which the basidia are borne singly and freely exposed. In the Hyaloriaceae the fruiting bodies are angiocarpous, the basidia being enclosed within sterile tissue. The Sirobasidiaceae include the species in which the basidia are produced successively in chains.

The various genera of the Tremellaceae display great diversity in the gross structure of their fruiting bodies. In texture, also, the reproductive structures may vary from gelatinous to waxy or cartilaginous. In one of the simpler genera, Sebacina, the fruiting body is resupinate. In Exidia and Tremella the fructifications may be simple pulvinate masses, or they may be variously lobed, branched, or cerebriform and in some cases appear very similar to those in Auricularia. The genera Clavariopsis and Tremellodendron resemble Clavaria somewhat, and the toothed hymenia of Protohydnum and Tremellodon are strikingly similar in ap- 
pearance to the hymenium of Hydnum. In Gyrocephalus the infundibuliform fruiting body suggests that of Craterellus; in Protomerulius the convolutions and folds of the honeycomb-like hymenium resemble those of the dry-rot organism Merulius. In certain genera the hymenia include various sorts of sterile structures (cystidia, paraphyses).

Asexual reproduction occurs in Tremella and Sebacina but is not known in most of the remaining genera. In some cases conidia are formed on branched conidiophores; or the terminal portions of the hyphae may fragment to form oidia, which may be either uninucleate or binucleate [Dangeard (1895)].

Although mycelium derived from a germinating basidiospore is composed of uninucleate cells, the cells of hyphae composing the fruiting bodies are invariably binucleate. Since the recent genetical studies of Barnett (1937) have disclosed that several species of Exidia are heterothallic, presumably the dicaryotic condition originates shortly after germination of the basidiospore. The exact manner of origin of the dicaryon has not been satisfactorily explained. Clamp connections are present in a considerable number of species but are lacking in others. Hyphal fusions are also of frequent occurrence.

Development of the basidia and basidiospores has been studied cytologically in a considerable number of genera and species [Juel (1898), Neuhoff (1924), Kühner (1926), Whelden (1934, 1935, 1935a, 1937)]. The investigations of Whelden on Tremella, Exidia, Sebacina, Protodontia, and Tremellodendron have disclosed a surprising uniformity in details of basidial development. The young hypobasidium contains 2 nuclei, which unite. The fusion nucleus, which is very large, sometimes appearing to occupy more than half the volume of the hypobasidium, divides in a plane transverse to the longer axis of the hypobasidium, and a longitudinal septum then is formed, separating the 2 hemispherical cells. A second nuclear and cell division, in a plane at right angles to the first, results in a 4-celled, cruciate, longitudinally septate hypobasidium. Meanwhile the 4 epibasidia elongate and project to the surface of the gel layer. The nuclei migrate through the epibasidia and become incorporated into the spores which are formed at the epibasidial apices.

Germination of the basidiospores may occur by repetition and formation of secondary spores. In Tremella the secondary spores 
are very much like the primary basidiospores except for their slightly smaller size; in Exidia the secondary basidiospores are sickle-shaped and may be multicellular.

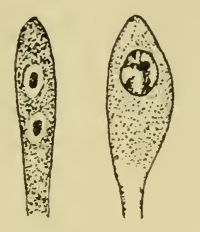

$A$
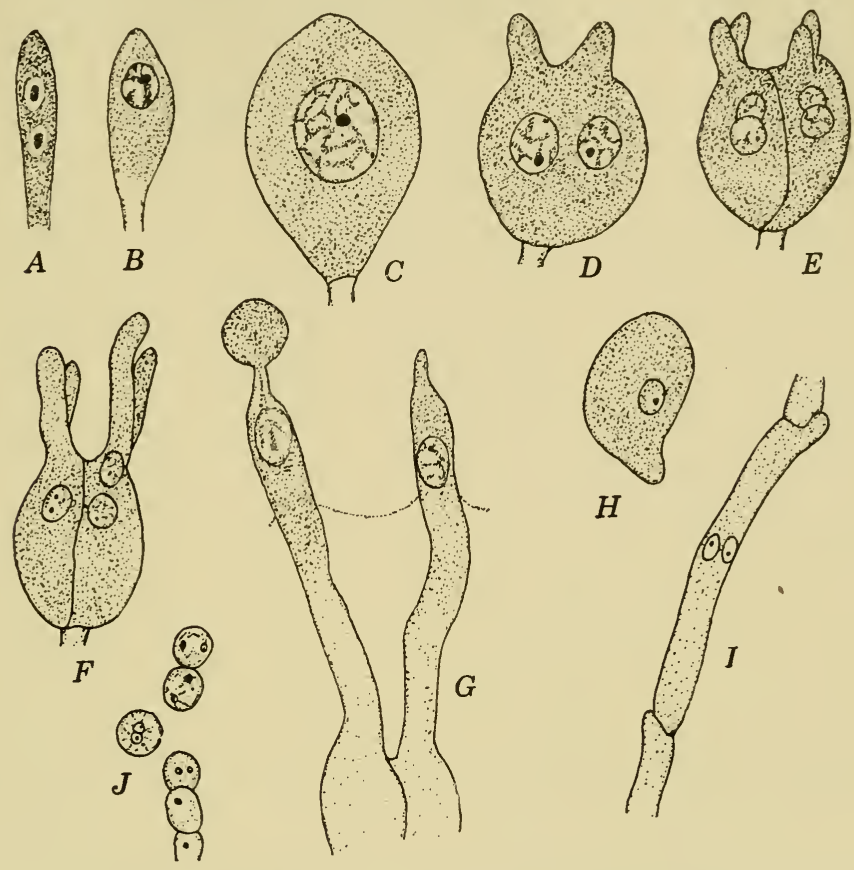

Fig. 113. Tremella mesenterica. A. Hypobasidium initial, showing binucleate condition. $B$. Hypobasidium in which fusion of nuclei has occurred. $C$. Large hypobasidium containing mature fusion nucleus. $D$. Two daughter nuclei resulting from first nuclear division. E. Four-nucleate hypobasidium with four epibasidia in process of formation; the hypobasidium has become cruciately four-celled. $F$. Further development of epibasidia with nuclei beginning to migrate into epibasidia. G. Migration of nuclei into spores formed at apex of sterigma; the epibasidia project above the surface of the jelly-like tissue. $H$. Mature secondary spore. I. Binucleate hyphal segment. J. Hyphal tip bearing conidia. (Adapted from Whelden.)

The family Hyaloriaceae contains a single genus, Hyaloria, of which the best-known species is $H$. pilacre, described from Brazil by Möller (1895). The fruiting body is small and glassy in appearance and consists of a stalk bearing a head, thus resembling an unopened mushroom or the discomycetous Leotia. The basidia are angiocarpous, being borne internally in a dome- 
shaped hymenium within the head. The family therefore has been considered as the tremellaceous counterpart of the Phleogenaceae among the Auriculariales. The cytology of the basidia in Hyaloria has been studied by Martin (1937), who finds that their development is completely in accord with that of the Tremellaceae.

The family Sirobasidiaceae includes tremellaceous forms in which the basidia are produced in chains. There is a single genus, Sirobasidium, with two known species occurring on wood in Brazil and Ecuador [Lagerheim and Patouillard (1892), Möller $(1895)]$. Both are gelatinous forms resembling Tremella in general appearance, but with chains of basidia produced in basipetal succession. In one species the basidium is similar to that of Tremella; in the other, the basidium is divided by a diagonal septum into 2 cells and forms 2 basidiospores. Whether the 2 species under consideration are actually cogeneric is doubtful.

The Sirobasidiaceae, as exemplified by forms with obliquely septate basidia, may easily have been derived from the Tremellaceae. In Tremella lutescens [Coker (1920)], for example, the septations are never longitudinal, as is characteristic of the order, but may come to occupy oblique positions. Furthermore, the proliferation of the basidia in the Sirobasidiaceae appears to be foreshadowed by the condition in Clavariopsis prolifera and Sebacina prolifera [Rogers (1936)]. In the latter species clusters of basidia are formed, each new basidium originating from a clamp connection at the base of an earlier-formed basidium.

Less certainly related to the Tremellales is a group of organisms comprising the family Tulasnellaceae. There are two genera, Tulasnella with 11 species, and Gleotulasnella with 9 [Rogers (1933)]. According to Rogers' (1932) account of basidial development in several species of Tulasnella, the hypobasidium is a non-septate structure. After nuclear fusion and the usual 2 divisions, there appear 4 swollen epibasidia, into which the nuclei migrate. Each epibasidium thereupon becomes separated from the hypobasidium by a wall across its base. A third mitosis occurs within the epibasidia, each of which ultimately bears a binucleate spore. Rogers regards the Tremellales as having been derived from the Tulasnellaceae through the formation of septa within the basidium at an earlier stage in its development. By many authorities, however, the "epibasidia" of Rogers 
are interpreted as spores which germinate in situ, and Tulasnella is placed in the Thelephoraceae near Corticium.

According to Martin (1945), who has devoted extensive consideration to the Tremellales, members of this order "afford a satisfactory transition to the rusts, on the one hand, and to the Homobasidiomycetes, on the other."

\section{LITERATURE CITED}

BARNETt, H. L., "Studies in the sexuality of the Heterobasidiae," Mycol., 29: 626-649, 1937.

Coner, IV. C., "Notes on the lower Basidiomycetes of North Carolina," J. Elisba Mitchell Sci. Soc., 35:113-182, 1920.

Dangeard, P. A., "Mémoire sur la réproduction sexuelle des Basidiomycètes," Botaniste, 4: 119-181, 1895.

Juel, H. O., "Die Kernteilungen in den Basidien und die Phylogenie der Basidiomyceten," Jabrb. wissen. Botan., 32: 361-388, 1898.

KüHNER, R., "Contribution à l'étude des Hyménomycètes et specialement des Agaricacées," Botaniste, 17: 1-215, 1926.

Lagerheim, G. de, aNd N. Patouillard, "Sirobasidium, nouveau genre d'Hymenomycetes Heterobasidies," J. Botanique, 6: 465-469, 1892.

Martin, G. WV., "New or noteworthy fungi from Panama and Colombia," Mycol., 29: 618-625, 1937.

"The classification of the Tremellales," Mycol., 37:527-542, 1945.

Möller, A., "Protobasidiomyceten," Botan. Mitt. Tropen (Scbimper), 8: 1$179,1895$.

Neunoff, W., "Zytologie und systematische Stellung der Auriculariaceen und Tremellaceen," Botan. Arch., 8:250-297, 1924.

Rogers, D. P., "A cytological study of Tulasnella," Botan. Gaz., 94: 86-105, 1932.

"A taxonomic review of the Tulasnellaceae," Ann. Mycol., 31: 181-203, 1933.

"Basidial proliferation through clamp formation in a new Sebacina," Mycol., 28: 347-362, 1936.

Whelden, R. M., "Cytological studies in the Tremellaceae. I. Tremella," Mycol., 26: 415-435, 1934.

II. "Exidia," Mycol., 27: 41-57, 1935.

III. "Sebacina," Mycol., 27: 503-520, 1935 a.

IV. "Protodontia and Tremellodendron," Mycol., 29:100-115, 1937.

\section{Auriculariales}

Included among the Auriculariales are many gelatinous fungi in which the basidium is transversely septate and is divided into 4 cells, each of which forms a basidiospore. In some fungi the 
basidium is differentiated into a swollen hypobasidium (probasidium) and a transversely septate epibasidium; in other forms a hypobasidium is lacking, and the basidium itself is transversely septate. It will be recalled that basidia of the transversely septate type are also found among the Uredinales, from which the Auriculariales have probably been derived. In the Auriculariales, however, many species are saprophytic, although a few are obligate parasites, and they do not possess numerous spore forms characteristic of the rusts.

The Auriculariales, including some 15 genera and approximately 250 species, are customarily divided into 3 families. The Auriculariaceae include both parasitic and saprophytic forms in which the development is gymnocarpous. Certain gymnocarpous members of the order are placed in the family Phleogenaceae, however, and the Septobasidiaceae comprise a number of species characterized in nature by a peculiar biological association with scale insects (coccids).

Auriculariaceae. The Auriculariaceae, with the majority of the genera, include only gymnocarpous forms, some of which have basidia borne directly on the mycelium and others of which have large and complex fruiting bodies.

The imperfect fungus Rbizoctonia crocorum is an economically important parasite of clover and potatoes. Its purplish mycelium bears binucleate conidia both in the soil and on the host plant. It has recently been found [Buddin and Wakefield (1927), Ware (1929)] that $R$. crocorum has an auriculariaceous perfect stage known as Helicobasidium purpureum. The mycelium adjacent to the fructifications is binucleate, and the terminal cells become hypobasidia. The hypobasidium gives rise to a curved 4-celled epibasidium bearing 4 basidiospores. Boedijn and Steinmann (1931), in spite of the presence of a helical epibasidium in some species of Septobasidium as well as in Helicobasidium, and because of the presence of a more expansive and complex fruiting body containing scale insects in Septobasidium, have separated these 2 genera. No such insect relationship is found in Helicobasidium.

The closely related Genus Cystobasidium [Lagerheim (1898)] is parasitic upon fruiting bodies of the coprophilous discomycetous Lasiobolus. In Cystobasidium the hypobasidia become thick-walled, persistent structures, to which the name sclero- 
basidia has been applied. The epibasidia are 4-celled and bear 4 basidiospores.

Platygloea includes several saprophytic, gelatinous, resupinate species in which there is little evidence of a hypobasidium except for a slight swelling at the base of the basidium [Coker (1920), Neuhoff (1924)]. The sterigmata are elongate, extending to the
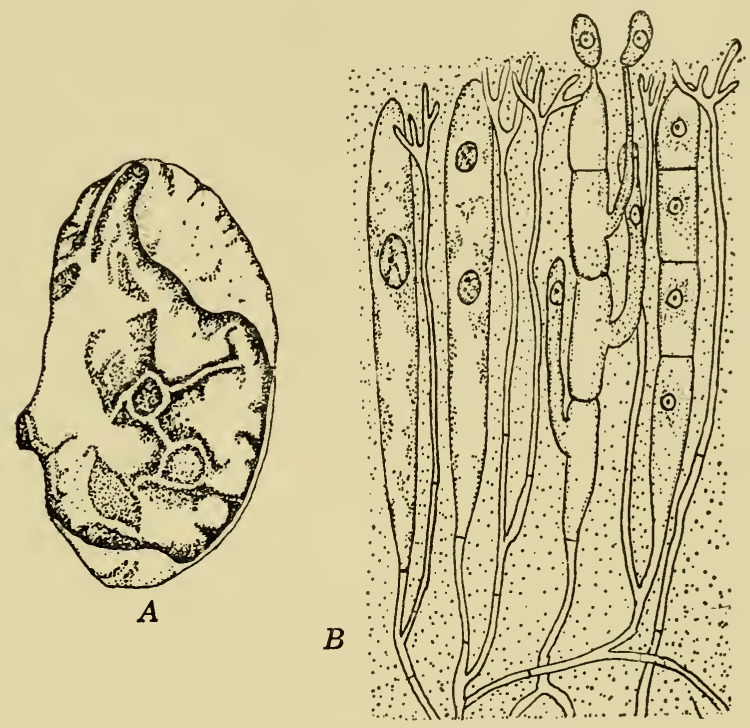

Fig. 114. Auricularia auricula-judae. A. Habit sketch of ear-shaped basidiocarp. $B$. Diagrammatic section of hymenial surface to indicate nuclear activity, promycelial development, sterigmata, and basidiospores.

surface of the gel layer before the basidiospores are formed. The basidiospores have been germinated in nutrient solutions, secondary spores being produced under these conditions.

The slightly more complex fruiting bodies of Saccoblastia are resupinate to pulvinate and are waxy or gelatinous in texture. Several species grow saprophytically on bark [Coker (1920), Linder (1929)]. In the best-known species, S. intermedia, the peculiar hypobasidium originates as a sac-like or pyriform lateral outgrowth from a cell of a dicaryon hypha, and may become pendulous because of its weight. The hypobasidium gives rise to a rather elongate, slender promycelium terminating in a fourcelled basidium bearing uninucleate basidiospores. 
The genera Eocronartium and Iola are parasites of mosses. Eocronartium muscicola [Fitzpatrick (1918, 1918a)] is obligately parasitic upon the moss gametophyte and sometimes inhibits the production of sporophytes. The perennial mycelium within the leafy shoot is composed of binucleate cells and is intracellular. Haustoria and clamp connections are absent. From the upper portion of the moss gametophore, hyphae emerge to form a clavate gelatinous fruiting body. The recent work of Stanley (1940) has shown that a definite hypobasidium is present, although this structure was not reported by Fitzpatrick (1918a). The hypobasidium gives rise to a transversely septate epibasidium bearing 4 spores that are capable of germinating by repetition.

The gelatinous fruiting bodies of Iola are parasitic upon the sporophytes of various mosses. There are 2 species: $I$. bookeriarum, described from Brazil by Möller (1895), and I. javensis, known from Java by the work of Gäumann (1922). In I. javensis the binucleate mycelium grows through the moss capsule and forms a pulvinate mass upon its top. The swollen hypobasidia are borne in clusters, each hypobasidium except the first being derived by proliferation of the subterminal cell of the hypha. Four-celled epibasidia project above the gel layer and bear basidiospores that germinate by formation of secondary spores.

Herpobasidium filicinum, parasitic on ferns in Sweden and Canada, has definite haustoria which penetrate the host cells. A hypobasidium is not present, and the basidia are peculiar in being only two-celled. According to the cytological study of Jackson (1935), each cell of the basidium is binucleate, and both nuclei become incorporated into the basidiospores.

The culmination of the Family Auriculariaceae, in so far as the complexity of the fruiting body is concerned, is reached in some species of the Genus Auricularia (Hirneola). The various species are all saprophytes, growing on wood. The common form, $A$. auricula-judae, has gelatinous, ear-shaped fruiting bodies as large as 4 in. in diameter. Clamp connections are present, and the hyphae composing the fruiting body are binucleate. The basidia are grouped to form a hymenial layer on the ventral surface of the fruiting body. There is no differentiation of basidia into hypobasidial and epibasidial portions. The basidium is 4celled, is transversely septate, and bears 4 spores on long sterigmata which project to the surface of the gel layer. Buller (1922) 
made observations on spore discharge in living material of $A$. auricula-judae and $A$. mesenterica. . He found that, just as in the Hymenomycetes, a droplet of water is exuded at the base of the spore just before discharge, and that discharge itself is a violent process whereby the spore is thrown through a horizontal distance of 0.4 to $0.5 \mathrm{~mm}$.

Septobasidiaceae. The Septobasidiaceae includes a number of species possessing transversely septate basidia characteristic of the Auriculariales and having a peculiar biological relationship with scale insects. There are two genera, Uredinella and Septobasidium.

Uredinella coccidophaga [Couch (1937)] forms small dark patches on the bark of a number of trees in the southeastern United States. Beneath the stroma of the fungus colony is found a single scale insect (Aspidiotus) the body of which contains fungus haustoria. Over the surface of the mycelium are borne numerous thick-walled hypobasidia, each of which may give rise to a 4-celled epibasidium bearing 4 basidiospores. A second species, U. spinulosa [Couch (1941)], occurring in association with scale insects on Psychotria leaves in Ceylon, has a similar developmental history.

Couch has studied the cytology of basidial development in Uredinella and refers to the hypobasidium as a teleutospore (teliospore). Thus Uredinella shows a remarkable relationship to the rusts, which is further borne out by the fact that other bodies, superficially resembling the teliospores and formed on the same mycelium, germinate to give rise to elongate, binucleate spores which are perhaps homologous with rust urediniospores. Couch has suggested that Septobasidium and Uredinella are derived from certain of the rusts, such as Goplana.

The Genus Septobasidium contains approximately 180 species, occurring in large black or brownish patches on the bark of many kinds of living trees in the tropics and subtropics [Couch (1938)]. Whereas Uredinella occurs in association with but a single scale insect, a hundred or more insects may be found within one Septobasidium colony. The insects derive their nourishment from the host plant after piercing its bark by means of their sucking mouth parts. The fungus-insect relationship worked out by Couch provides an interesting study in general biological principles. The scale insects become parasitized only 
by spores of the fungus, apparently never by means of the fungal hyphae. Haustoria of the fungus penetrate the bodies of the insects and develop practically entirely within their circulatory
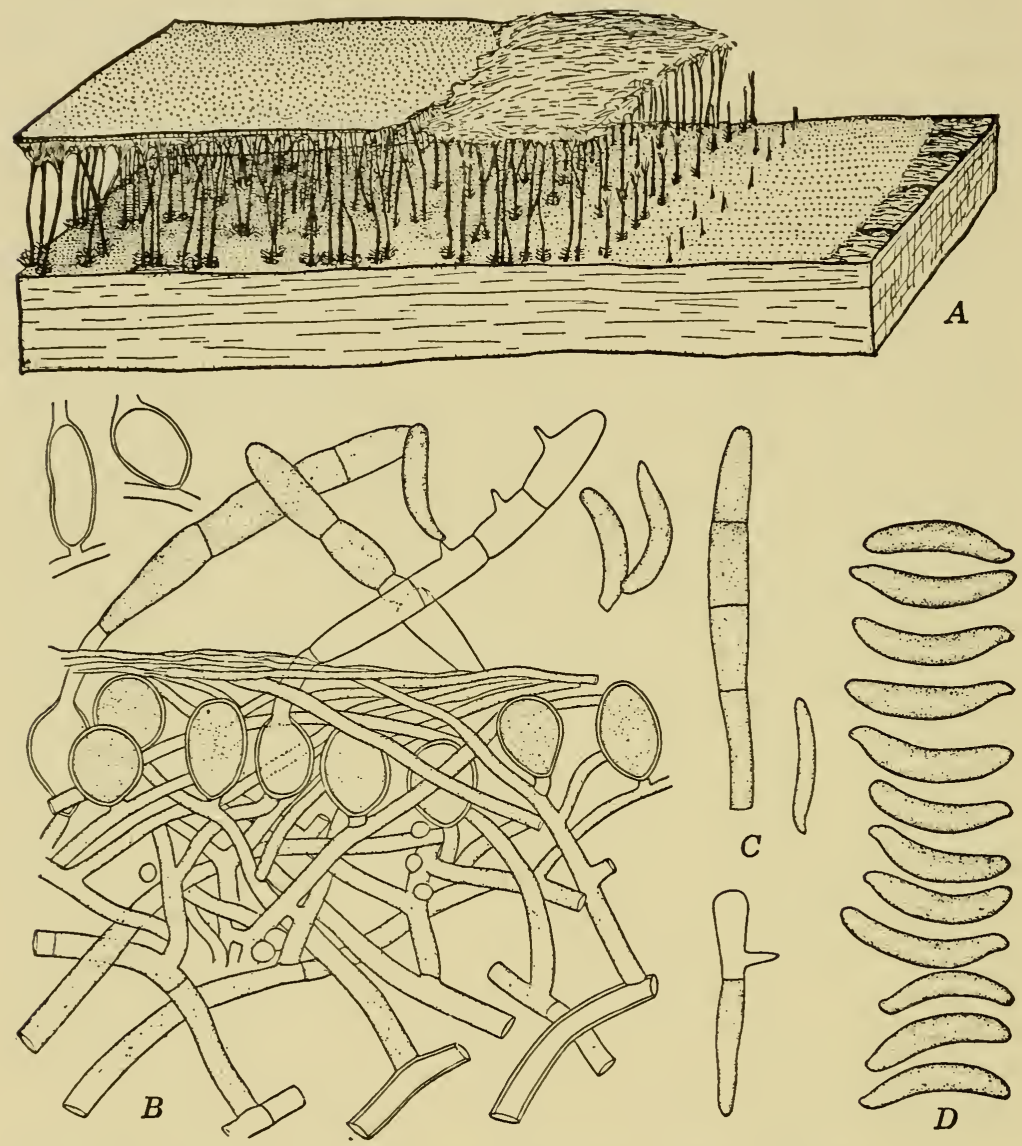

Fig. 115. A. Habit sketch of Septobasidium pseudopedicellatum occurring on Fraxinus sp., showing pillars arising from subiculum and heavy outer corer. B. Section through hymenial layer. Stages of germination, showing probasidia, basidia and paraphyses. Basidiospores are being shed from one mature basidium. C. Variation in basidia. D. Variation in basidiospores. (Courtesy of J. N. Couch.)

systems. The insects apparently suffer little harm as the result of parasitism; they live as long as non-parasitized individuals and are free to move about, although they do not reproduce. During 
the winter comparatively few of the insects within a colony are parasitized, most of them being entirely free of infection. In the summer, however, as the fungus forms spores, a majority of the insects become parasitized. Newly born insects are invariably free of infection.

The advantages of this relationship to the fungus include the food which it obtains from the insect and the spread of the fungus through the agency of parasitized insects. The insects also profit from the association, in spite of the fact that some are parasitized, since the fungus mat offers protection, during reproduction and the rearing of their young, from such natural enemies as birds and parasitic Hymenoptera. Intricate insect houses are formed by some species of Septobasidium. Couch concludes, therefore, that the relationship is one of symbiosis. That the relationship is not entirely an obligate one, however, is shown by the fact that the fungus can be grown apart from the insects in pure culture, although under these conditions it will not form spores.

Some species of Septobasidium have well-developed hypobasidia, whereas others lack these structures entirely. The basidium shows considerable variation in structure between species. It may be 1-, 2-, 3-, or 4-celled and may be straight or, as in Helicobasidium, curved. These characteristics, together with specificity of the host, are used in distinguishing the various species of Septobasidium.

Phleogenaceae. The Family Phleogenaceae includes a number of auriculariaceous fungi in which the fruiting body consists of a stalk bearing a head. The lower members of the family are gymnocarpous, but the group culminates in angiocarpous forms. An interesting feature of the family is the fact that sterigmata are not present, the globose basidiospores being formed directly on the basidium. No differentiation of hypobasidium and epibasidium, as occurs in the other families of the Auriculariales, is found in the Phleogenaceae.

Stilbum vulgare was considered to belong among the Fungi Imperfecti before the study of its development by Juel (1898). Its gymnocarpous fructifications resemble coremia, and the hyphae composing the fruiting body are held together within a gelatinous matrix. The basidia, borne in the bottom of the cup-shaped head, 
are 2-celled, and each cell contains 2 nuclei, 1 of which enters the basidiospore and the other degenerates.

In Hoebneliomyces delectans [Möller (1895)], occurring in Brazil on fallen leaves, the interlacing hyphae of the cup-shaped head overarch the developing basidia, so that the fructification is at least partially angiocarpous. The transversely septate basidia are + -celled and form + basidiospores, which are capable of germinating by repetition.

In the highest member of the series, Pbleogena (Pilacre) faginea, occurring on beech logs, the fructifications are entirely angiocarpous [Shear and Dodge (1925)]. The 4-celled transversely septate basidia are borne within a peridium-like tangle of interlacing hyphae. Phleogena also produces conidia of the Rhinotrichum type. In spite of the heterobasidiomycetous nature of the basidium in Phleogena, Shear and Dodge are inclined to regard this genus as a Gastromycete because of its angiocarpous development.

\section{LITERATURE CITED}

Boedijs, K. B., Axd A. Sternaraxs, "Les espèces des genres Helicobasidium et Septobasidium des Indes Néerlandaises," Bull. jard. bot. Buitenzorg, Ser. III, 11: 165-219, 1931.

Buddis, W., ANd E. M. Wakefield, "Studies on Rbizoctonia crocorum (Pers.) D.C. and Helicobasidium purpureum (Tul.) Pat.," Trans. Brit. Mycol. Soc., 12: 116-140, 1927.

Buller, A. H. R., Researches on fungi, Vol. II, pp. 156-171. Longmans, Green and Company, London. 1922.

Coker, IV. C., "Notes on the lower Basidiomycetes of North Carolina," J. Elisha Mitchell Sci. Soc., 35: 113-182, 1920.

Cotch, J. N., "A new fungus intermediate between the rusts and Septobasidium," Mycol., 29:665-673, 1937.

The genus Septobasidium. 480 pp. University of North Carolina Press, Chapel Hill. 1938.

"A new Uredinella from Ceylon," Mycol., 33: 405-410, 1941.

Fitzpatrick, H. M., "The life history and parasitism of Eocronartium muscicola," Ploytopatbology, 8: 197-218, 1918.

"The cytology of Eocronartium muscicola," Am. J. Botany, 5:397-419, 1918a.

Gäunasx, E., "Über die Entwicklungsgeschichte von Iola javensis," Ann. Mycol., 20: 272-289, 1922.

Jacksox, H. S., "The nuclear cycle in Herpobasidium filicinum, with a discussion of the significance of homothallism in the Basidiomycetes," Mycol., 27: 553-572, 1935. 
JuEL, H. O., "Stilbum vulgare Tode. Ein bisher verkannter Basidiomycet," Bib. Svenska Vet. Akad. Handl., Afd. III, 24: 1-15, 1898.

Lagerheim, G., "Mykologische Studien I. Bih. Svenska Vet. Akad. Handl., Afd. III, 24: 1-22, 1898.

LiNder, D. H., "The life history and cytology of Saccoblastia intermedia, n.sp.," Ann. Mo. Botan. Gäd., 16: 487-498, 1929.

Möller, A., "Protobasidiomyceten," Botan. Mitt. Tropen (Scbimper), 8: $1-179,1895$.

Neunoff, W., "Zytologie und systematische Stellung der Auriculariaceen und Tremellaceen," Botan. Arch., 8:250-297, 1924.

Shear, C. L., ANd B. O. Dodge, "The life history of Pilacre faginea (Fr.) B. and Br.," J. Agr. Research, 30:407-417, 1925.

Stanley, I. N., "Development of the basidium of Eocronartium muscicola," Trans. Am. Micr. Soc., 59:407-413, 1940.

Ware, W. M., "Note on Rbizoctonia crocorum," Trans. Brit. Mycol. Soc., 14: 94-95, 1929.

\section{UstilagiNALES}

The Ustilaginales, or smuts, also called brand fungi and bunts, are a group of approximately 600 species of pathogenic fungi that parasitize flowering plants. They are characterized by the possession of thick-walled spores (chlamydospores) that are typically brown to black. Even though they are parasitic and occur as destructive pathogens, especially upon cereals, many of them have a saprophytic phase, and they can be grown in culture on artificial media. Several workers have reported the completion of the life cycle in culture, although most commonly growth in cultures consists of abortive hyphae and of buds that sprout in yeast-like fashion. Sartoris (1924) obtained chlamydospores in cultures, using Ustilago bordei, $U$. tritici, and $U$. becifleri.

The mycelium is intercellular in most species, as in the cereal and other grass smuts. In $U$. zeae, however, the hyphae grow intracellularly. In a few others, such as Entyloma nymphaeae, Lutman (19i0) demonstrated that appressorial swellings are produced on the intercellular mycelia from which haustoria arise.

IMPORTANCE of SMUTS. The smuts constitute a group of organisms that are of interest not only because of the enormous losses among cereals which they produce but also because basic knowledge regarding fungi and the control of plant-pathogenic species has come from studies of smuts. When Prévost published his memoir on bunt of wheat in 1807, plant diseases were regarded as of autogenous origin. All microscopic life was then 
believed to arise by spontaneous generation. The work of Prérost appears to constitute the first adequate experimental demonstration that fungi may cause disease of plants. He described the bunt fungus as an internal parasitic plant and traced its developmental cycle from the "globules" or "seeds" lodged on the grains to their reappearance within the inflorescence. His field trials with appropriate controls also demonstrated that the disease may be successfully treated by steeping seed wheat in a solution of copper sulphate. Evidently smut diseases had earlier been controlled, but only by empirical procedures. The Moors and Fellahs had long practiced casting seed grain through fire, presumably because fire was regarded, from religious rites, as a means of purification. In 1660 the efficacy of brining in disinfecting seed wheat had also been discovered accidentally.

Trpes of host intolvenient. Smuts may attack any part of the plant above ground, but involvement is generally limited to one organ. In Cinctractia caricis and Tuburcinia trientalis the perennial mycelium may occupy both shoots and rhizomes.

In Ustilago zeae sori may form on all parts of the plant. They are commonly present on ears, tassels, leaves, and stalks and may also appear on the roots. In $U$. avenae, $U$. levis, $U$. bordei, and Tilletia tritici the mycelium occurs in the stem apex and advances into inflorescences as they form.

The mycelium usually causes little, if any, distortion of the host. Oats and wheat attacked by Ustilago avenae and U. tritici, respectively, may be somewhat dwarfed. Ustilago zeae on corn may cause considerable hypertrophy. Ustilago treubii, on stems of Polygonum chinense in Java, stimulates the formation of elaborate galls that resemble fructifications of Cantharellus. In eastern Asia U. esculenta deforms the shoots of Zizania latifolia, and natives eat the deformed stems as a salad [Hori (1907)]. Ustilago violacea induces the staminal rudiments of carpellate flowers of Lychnis dioica to develop apparently normal stamens, but on dehiscence pollen is found to have been replaced by smut spores.

SPORES ANd THEIR DEVELOPNENT. The structure which characterizes all smuts is the smut spore, or chlamydospore, with a thickened wall that is smooth or variously sculptured and usually brown, black, or violet in color. Lutman (1910) studied spore formation in a number of genera. He and all others who have deroted their attention to the origin of smut spores agree that 
they arise from special hyphal branches that constitute a dense, tangled mass within the host tissues. Each cell of this mass is binucleate (dicaryotic), as was first pointed out by Dangeard in 1894. Those cells, destined to become chlamydospores, enlarge, their contents become densely granular, and their walls become gelatinized. New walls that persist are laid down within the gelatinized walls, and as a result of disappearance of the gelat-
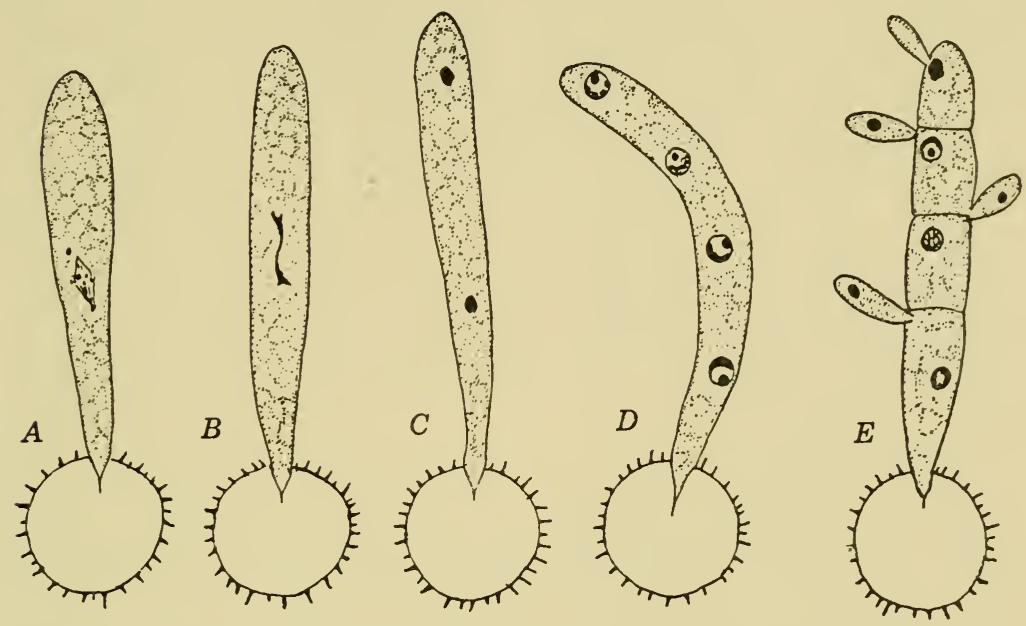

FIG. 116. Ustilago scabiosae. A to E. Stages in germination of chlamydospores, basidium formation, and production of sporidia, typifying that in Ustilaginiaceae. (Adapted from Harper.)

inous outer layer the spores are separated from each other. By the time the spores have reached mature size the two nuclei unite; the new walls then thicken, and the characteristic uninucleate (monocaryotic) smut spore has come into being.

De Bary regarded smut spores as resting spores, since they fail to germinate immediately upon maturity. Plowright termed them teleutospores (teliospores), a term earlier applied to the spore that forms last in the annual cycle of rusts. On the basis of the period of their formation and method of germination he regarded the smut spore as the homologue of the rust teliospore. Brefeld early observed their method of formation and concluded that they are chlamydospores.

In certain genera, such as Ustilago, Tilletia, Sphacelotheca, Cinctractia, and Entyloma, the spores form singly and are freed 
by gelatinization of intercalary cells or of contiguous cell membranes. The spores are joined in spore balls among species of Tolyposporium, Testicularia, Thecophora, Tuburcinia, Doassansia, and Urocystis. In Urocystis the outer cells are sterile, in Testicularia the inner ones are sterile, and in Doassansia sterile cells may occur both at the periphery and at the core of the spore balls.

Germination of spores. The spores of smuts may germinate only after a period of dormancy or immediately after maturity. In any event there are among them two types of germination, which are the bases for separation into families. Among the Ustilaginaceae the spores give rise to a septate basidium (promycelium), from each cell of which a series of sporidia or basidiospores may be produced laterally. Among the Tilletiaceae the smut spore usually gives rise to a non-septate basidium bearing a cluster of elongated primary sporidia at its tip. Buller regards these primary sporidia as specialized sterigmata that in turn give rise to true sporidia.

Within these two types there are various modifications. For example, laterally borne sporidia in Ustilago zeae or $U$. avenae may repeatedly sprout in yeast-like fashion, and eventually the buds, when brought in contact with host tissues, form an infection hypha. In $U$. bromivora on brome grasses, sporidia produced on the basidium do not sprout but form new germ tubes, which in turn produce sporidia. In $U$. olivaceae on Carex, a primary sporidium is formed in place of a basidium, and this sporidium buds indefinitely. Thecophora deformans on various legumes does not form a true basidium. In Ustilago muda on barley and $U$. tritici on wheat the basidium is replaced by a muchbranched hypha, and sporidia are not formed.

Modes of Infection AMONg SMUTs. From the classical researches of Brefeld $(1883,1895)$ has come much of fundamental importance on modes of infection. In these studies the following types are distinguished: (1) Infection of seedlings, in which conditions favor coincidental germination of the seed and the smut, and seedlings are penetrated before they emerge from the soil. This kind is typified by Tilletia tritici, causing bunt of wheat, and Ustilago avenae, causing oat smut. (2) Infection of any embryonic tissues, resulting in local lesions in various organs, such as 
occurs in $U$. zeae on corn. (3) Infection through stigmas, in which the smut spores lodge on the stigmas, penetrate them, and remain within the ovary as a dormant mycelium. When such infected seed germinate, infection becomes systemic and sporulation again occurs when the host flowers. Infection of this kind is exhibited by $U$. tritici, the cause of loose smut of wheat, and by $U$. muda, causing naked smut of barley. (4) Infection through tiller shoots, such as may occur in Urocystis occulta, causing hidden smut of rye.

Sexuality of smuts. Among those who have studied the sexuality of smuts are Harper (1898), Lutman (1910), Rawitscher (1912, 1922), Kniep (1919), Bauch (1925), Stakman and Christiansen (1927), Rodenheiser (1929), Hanna (1929), Sleumer (1931), and Holton (1932). In regard to the fusion of a pair of nuclei in the maturing chlamydospore all are in accord, but in the manner in which the binucleate condition arises there appears to be considerable di-
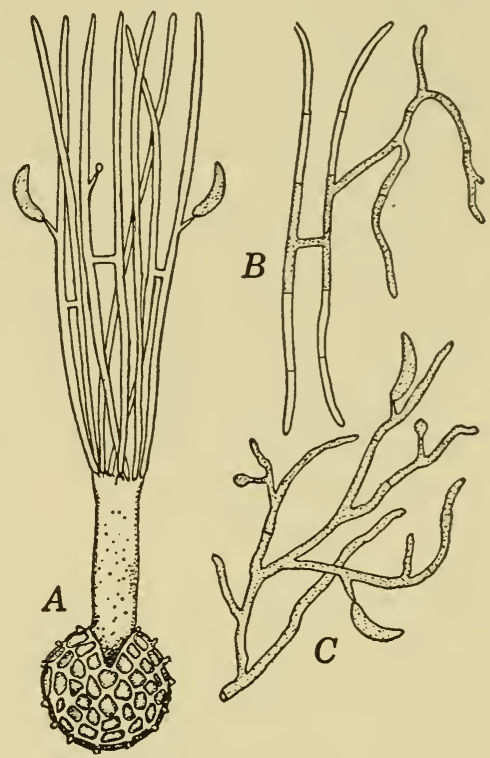

Fig. 117. Tilletia tritici. A. Germination of chlamydospore, production of primary filamentous sporidia from which secondary sporidia arise. B. Fusion of primary sporidia with hyphal formation. C. Portion of branched hypha bearing secondary sporidia. versity among various species. The observations of Harper (1898) on Ustilago scabiosae show that on germination the diploid nucleus migrates into the promycelium at a time when it has attained approximately one-third of its final length. By the time that the promycelium is fully grown, the diploid nucleus has divided meiotically, and $t$ haploid nuclei have formed. Septations then appear, resulting in 4 uninucleate cells that give rise to lateral buds, the sporidia. Each bud is uninucleate, and each promycelial cell may produce similar sporidia indefinitely. Moreover each sporidium may sprout 
indefinitely in a yeast-like manner. Then the original sporidia or the sprout cells may copulate directly or through copulation tubes, with the result that the cells become binucleate. These binucleate cells may sprout, each bud containing a conjugately formed pair of nuclei.

Kniep (1919), Bauch (1925), and Stakman and Christiansen (1927) have shown that sporidia and sprout conidia arising from the same promycelial cell do not copulate with each other. Instead the 4 promycelial nuclei are sexually differentiated in pairs; hence their descendants are also sexually differentiated in pairs. The fusion of 2 strains of opposite sex is known to be prerequisite to the formation of chlamydospores, at least among certain species, such as Ustilago violacea, $U$. levis, and $U$. zeae, and may reasonably be presumed to be necessary for all species. Moreover, Stakman and Christiansen (1927) have shown that smut galls are not formed on corn when this plant is inoculated with 1 sexual strain of $U$. zeae.

In some species of smuts the binucleate condition does not arise by copulation of sporidia or of their progency. Rawitscher (1912) observed that the hyphae of $U$. zeae within the host consist of uninucleate cells and that plasmogamy takes place within the sorus. In Cinctractia montagnei and Ustilago bromivora [Bauch (1925)] copulation involves pairs of neighboring cells of the promycelium, and either the wall of contiguous cells is resorbed or else copulation tubes are formed between the cell pairs. In Ustilago muda, $U$. bordei, and $U$. tritici the promycelium may form sprout mycelia, and conjugation may involve hyphal cells of either a single promycelium or of different promycelia [Rawitscher (1922)].

Although the 4-celled promycelium is normal among Ustilaginaceae, it is by no means constant. In Ustilago panici-frumentacei the promycelium is 2-celled; in $U$. longissima and Thecophora deformans a true promycelium is lacking, and in its stead a muchbranched hypha. is formed that bears 3-celled sprout conidia. Fusion then involves either different sprouts or a pair of sexually different cells of the same sprout.

The studies by Hanna (1929) show that sexual behavior in Ustilago zeae is controlled by 2 allelomorphic pairs of genes located on separate pairs of chromosomes. If both pairs of chromo- 
somes undergo reduction at the same division of the nucleus, 2 of the promycelial cells will contain nuclei of 1 sexual phase and the other 2 of the opposite phase. If, on the other hand, 1 chromosome pair undergoes disjunction at the first nuclear division and the other at the second, then the resultant 4 promycelial nuclei possess 4 different combinations of the sexual factors.

Among Tilletiaceae also the dicaryotic condition arises variously. In Tilletia tritici Rawitscher (1922) found that 8 to 16 nuclei are developed within the short 1-celled promycelium. At the apex of the promycelium a number of filamentous cells are produced, each of which contains a single nucleus. While they are still attached or after they have been dislodged, tubes are formed, connecting them in pairs. Plasmogamy follows, and slender mycelia form, each cell of which is binucleate. These mycelia delimit binucleate, falcate sporidia until the available nutrient is exhausted. These sporidia in turn can produce infection of the appropriate host, and eventually chlamydospores are dereloped.

In Doassansia sagittariae the cells formed on the promycelium do not conjugate in pairs [Rawitscher (1922)]. They fall away and germinate to form uninucleate mycelia, and the dicaryons arise from hyphal fusions within the host tissues.

Classification. The smuts, as has been stated, include the two families Ustilaginaceae and Tilletiaceae. Most mycologists also include a third family, the Graphiolaceae, typified by Grapbiola phoenicis, occurring on the foliage of date palm, Phoenix dactylifera, and of other palms. The structure and classification of this species were made possible by the work of Killian (1924), who established that its spores arise as chlamydospores and that the nuclear activities during spore formation and germination are like those of Ustilaginales. Stylina and Shropshiria are also included among the Graphiolaceae.

In the monograph by Clinton (1906) the Ustilaginaceae include 11 genera, and the Tilletiaceae 8 genera. From the work of others the Ustilaginaceae now have 12 genera, and the Tilletiaceae 13. Various monographic studies for different areas, such as that of McAlpine (1910) of the smuts of Australia, that of Setchell (1892) on species of Doassansia, or that of Zundel (1930) of the smuts on Andropogon in all parts of the world, have been 
prepared and are invaluable in the solution of taxonomic problems. In Zundel's account 1 species of Cinctractia, 28 of Sorosporium, 39 of Sphacelotheca, 3 of Tolyposporella, and 5 of Ustilago are treated.
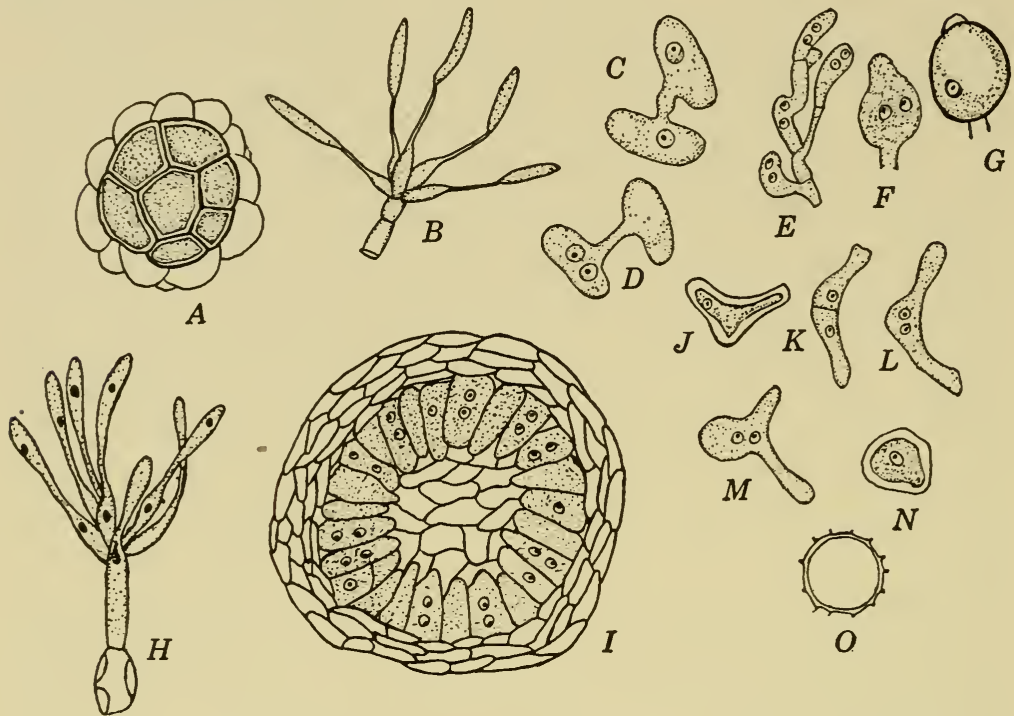

Fig. 118. A. Chlamydospore of Urocystis occulta. B. Tip of hypha (basidium) surmounted by a fascicle of sterigmata bearing sporidia. $C$ and $D$. Copulation of sprout cells of Ustilago violacea, as a result of which the cells are binucleate. (After Harper.) $E, F$, and $G$. Stages in chlamydospore formation in Entyloma nymplaeae. The binucleate cells enlarge, the nuclei fuse, the walls of contiguous cells separate, and the chlamydospores become thick-walled. (After Lutman.) $H$. Germination of fertile cell from spore ball of Doassansia martianoffiana, with ampulliform sterigmata bearing elongate sporidia. 1 . Spore ball of D. martianoffiana, in section, showing sterile periphery and sterile medullary region. (After Setchell and Lutman.) $J, K, L, M, N$, and $O$. Successive stages in formation of chlamydospores in Ustilago zeae. Uninucleate hyphal cells fuse, giving rise to binucleate condition, whereupon the nuclei fuse and the cell walls thicken. (After Rawitscher.)

Generic separations are based largely upon (a) the arrangement of spores, whether occurring singly, in pairs, or in balls; (b) the nature of the smut sori, whether dusty or agglutinated; (c) the presence or absence of sterile tissue in spore balls; and (d) the color of the spores. 
SPECIES OF IMPORTANCE OR SPECIAL INTEREST. In studies of smuts primary consideration has always been given to those involving cereals. These include Ustilago zeae on corn, $U$. avenae and $U$. levis on oats, $U$. tritici, Tilletia tritici, and $T$. levis on wheat, Ustilago muda and U. bordei on barley, Sphacelotheca sorgbi and S. reiliana on sorghum, Urocystis occulta on rye, and Tilletia borrida on rice.

The bunts of wheat caused by Tilletia tritici and $T$. levis, comprehensively treated by Holton and Heald (1941), are believed to occasion greater losses than those caused by any other smuts. They not only transform the smutted kernel into a foetid mass of spores, but also the spores are liberated in threshing operations and may lodge on normal grains. In consequence of the pungency of triethylamine, to which the odor is due, the entire mass of threshed grain may be malodorous. In years when bunt reaches epidemic proportions, it has been known to cause explosions and disastrous fires. Cardiff et al. (1914) noted that static electricity, generated by moving parts of the separator that are not grounded, may ignite the inflammable smut spores to initiate the explosions.

Tilletia borrida on rice is another of the species that completely destroys the ovaries. It appears to have been imported into the United States about 1898 on seed rice and was at first thought by Anderson (1899) to be identical with $T$. corona, attacking various species of Leersia. Apparently in the course of his studies of rice smut Anderson found that rice and wheat can be puffed in much the same manner as popcorn.

It still remains doubtful whether the so-called T. spbagni is a smut fungus, although Nawaschin (1890) concluded that the microspores interspersed in capsules with the spores of Sphagnum were those of this smut.

The chlamydospores of Entyloma ellisii on spinach germinate within the host tissues, and the promycelia emerge in tufts through the stomata. They may be formed in such profusion as to make whitish patches. It is readily understandable that the sporidia may be mistaken for conidia of some imperfect fungus, such as a species of Cylindrosporium, Gloeosporium, or Fusidium. 


\section{LITERATURE CITED}

Axderson, A. P., "A new Tilletia parasitic on Oryza sativa," Botan. Gaz., 27: 467-472, 1899.

BAчCH, R., "Untersuchungen über die Entwickelungsgeschichte und sexualphysiologie der Ustilago bromivora und Ustilago grandis," Z. Botan., 17: 129-177, 1925.

Brefeld, Oscar, "Untersuchungen aus dem Gesammtegebiete der Mykologie," Hefte 5: 67-75, 1883; Hefte 11: 52-92, 1895.

CARdifF, I. D., et al., "Report on fires occurring in threshing separators in eastern Washington in 1914," Wash. Agr. Expt. Sta. Bull., 117. 22 pp. 1914.

Clinton, G. P., "Ustilaginales," Nortb Am. Flora, 7: 1-82, 1906.

HAxid, IV. F., "Studies in the physiology and cytology of Ustilago zeae and Sorosporium reiliamum," Plbytopatbology, 19:415-442, 1929.

Harper, R. A., "Nuclear phenomena in certain stages in the development of the smuts," Trans. Wis. Acad. Sci., 12:475-498, 1898.

Holtox, C. S., "Studies in the genetics and cytology of Ustilago arenae and Ustilago levis," Minn. Agr. Expt. Sta. Tech. Bull., 87: 1-34, 1932.

Holtox, C. S., ANd F. D. HeAld, Bunt or stinking smut of wheat (a world problem). 211 pp. Burgess Publishing Co., Minneapolis. 1941.

Hori, S., "On Ustilago esculenta P. Henn.," Ann. Mycol., 5: 150-154, 1907. Killiax, C., "Le développement du Grapbiola pboenicis Poit. et ses affinites," Rev. gén. botın., 36: 385-394, 451-460, 1924.

Kxiep, H., "Untersuchungen über den Antherbrand (Ustilago violacea Pers.). Ein Beitrag zum Sexualitätsproblem," Z. Botan., 11:257-284, 1919.

Lutmas, B. F., "Some contributions to the life history and cytology of the smuts," Trans. Wis. Acad. Sci., 16: 1191-1244, 1910.

McAlpine, D., The smmets of Australia. vii +288 pp. Melbourne, 1910.

NAwaschin, S., "V'as sind eigentlich die sogenannten Mikrosporen der Torfmoose?" Botan. Centr., 43: 289-290, 1890.

Prévost, B., "Memoir on the immediate cause of bunt or smut of wheat, and of several other diseases of plants, and on preventives of bunt," Ploytopath. Classics, 6. 95 pp. 1939. (Translated by G. IV. Keitt.)

Rawitscher, F., "Beiträge zur Kenntnis der Ustilagineen," Z. Botan., 7: 678-706, 1912.

"Beiträge zur Kenntnis der Ustilagineen," Z. Botan., 14: 273-296, 1922.

Rodenheiser, H. A., "Physiologic specialization in some cereal smuts," Phytopathology, 18: 955-1003, 1929.

Strtoris, G. B., "Studies in the life history and physiology of certain smuts," Am. J. Botany, 11:617-647, 1924.

Setchell, WV. A., "An examination of the species of the genus Doassansia Cornu," Ann. Botany, 6: 1-48, 1892.

Sleumer, H. O., "Über Sexualität und Zytologie von Ustilago zeae (Beckm.) Unger," Z. Botan., 25: 209-263, 1931. 
Stakman, E. C., and J. J. Christiansen, "Heterothallism in Ustilago zeae," Phytopathology, 17:827-834, 1927.

ZuxpeL, G. L., "Monographic studies on the Ustilaginales attacking Andropogon," Mycol., 22: 125-158, 1930.

\section{UREDINALES}

The Uredinales, or rust fungi, are a group of approximately 100 genera containing 5000 to 6000 species of obligate parasites. They attack ferns and seed plants, producing pustules of rusty appearance. Parasitism and specialization are highly developed among rusts, and thus far all attempts to grow them on artificial media have failed. All so-called cultures of rusts consist of inoculated host plants grown under artificial or controlled conditions.

Developaiextal cycle of Puccinia graminis. Because the developmental cycle of rusts is so complicated and the terminology so confusing, an account of the cereal rust, Puccinia graminis, is given at this point. Toward the end of the growing season elongated black streaks may be noted, especially on the cereal (wheat) stems. These streaks are telia (black-rust pustules), compact aggregations of dark, stalked, 2-celled teliospores that are formed within the stem tissues. The teliospores reach the surface by rupture of the overlying tissues. They remain dormant in situ over the winter, and in the spring each cell is capable of germination. From a thin spot in the teliospore wall (germ pore), a short, curved hypha (basidium) emerges. This basidium normally becomes 4-celled, each cell having 1 nucleus. Each basidial cell gives rise to an ellipsoid spore (sporidium, basidiospore) that is attached by a short sterigma. Usually the entire content of a promycelial cell passes into the single sporidium. Sporidia are forcibly dislodged, then caught up by air currents, and may settle on young leaves of barberry. Here each forms a slender germ tube, which penetrates the cuticle and cell wall between the epidermal cells. The actual pore of entry is very small, smaller than the hypha on either side. Then the hypha elongates, branches, and forms an extensive intercellular, uninucleate (monocaryotic) mycelium. The appearance of yellowish leaf spots constitutes external evidence of the loci of infected tissues. At this stage small, dark, globular bodies (pycnia), formed within the tissues, appear at the upper leaf surface. Numerous tiny, spherical, uninucleate spores (pycniospores) are 


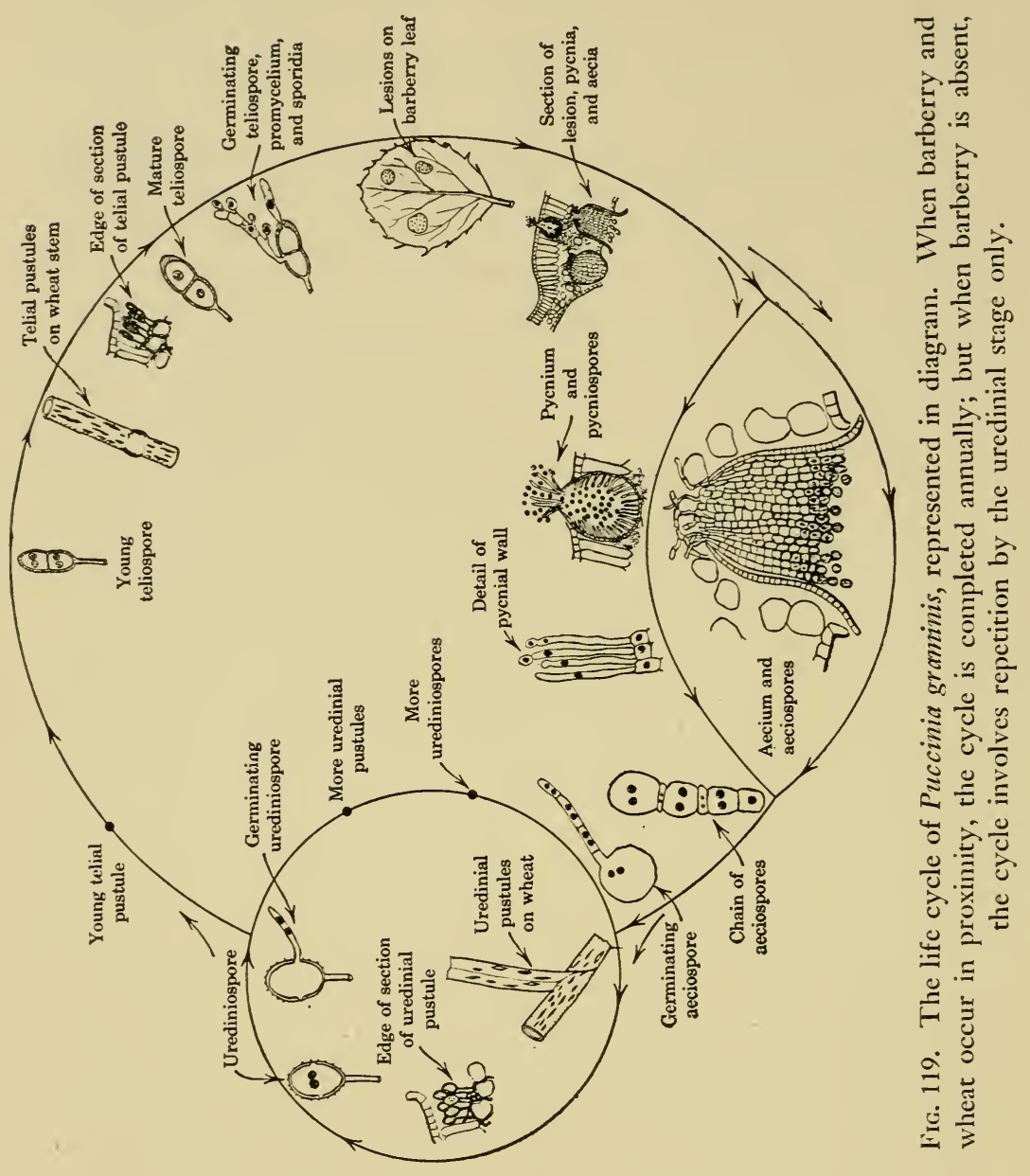


produced on the interior of pycnia and are extruded to the leaf surface.

While the pycnia are forming, other hyphal aggregates, the initials of the aecia (cluster-cups), are being formed at points more deeply embedded within the leaf tissues. Special hyphae that protrude in tufts from the orifices of the pycnia are connected with the young aecia beneath. These protruding hyphae function as trichogynes. Evidence for such functioning rests in part upon the fact that all the cells composing the aecia are uninucleate, except the basal cells that initiate aeciospores (clustercup spores). The aeciospore initials or aeciospore mother cells, however, are binucleate (dicaryotic). By successive divisions of the aeciospore mother cells chains of aeciospores are produced. Pressure exerted on overlying leaf tissues by the developing aeciospores causes the aecia to open, whereupon they have the appearance of cups. The aeciospores, thus liberated, are distributed by winds. Those that lodge on a suitable host (wheat) may germinate, and the germ tube enters the host tissues through a stoma. An intercellular mycelium of dicaryotic cells will give rise within a few weeks thereafter to uredinia (red-rust-stage pustules), containing stalked, rust-colored, ellipsoidal, 1-celled but binucleate urediniospores. Urediniospores are air-borne, are capable of immediate germination on wheat, and thus serve to spread and increase the red-rust stage. The mycelium arising from the germination of urediniospores is dicaryotic throughout.

The same mycelium that gave rise to urediniospores eventually produces 2-celled teliospores. Each young teliospore cell is binucleate, but before germination, during the succeeding spring, the 2 nuclei fuse; thus the fusion nucleus becomes diploid. By 2 successive nuclear divisions that occur during the formation of the probasidium, 4 haploid nuclei are again formed. These haploid nuclei migrate singly into the sporidia, and the sporidia are thus ready to start again the developmental cycle.

The outstanding features of rusts are (1) their polymorphism, as expressed by the production of 5 spore forms in the complete life cycle; and (2) the necessity, for many species, of 2 unrelated hosts for the completion of their developmental cycle. In the complete cycle of rusts there are teliospores, basidiospores or sporidia, pycniospores (spermatia), aeciospores, and urediniospores, formed in sequence. In some species 1 or more stages 
are regularly omitted in the developmental cycle. In others, such as Puccinia vexans, and certain other grass and sedge rusts from arid or semiarid regions [Arthur (1905)] an additional spore form, known as an amphiospore, is produced. In reality such spores are urediniospores with thickened walls and hence are capable of hibernating. As might be anticipated, much confusion on taxonomic problems of rusts arose before their polymorphic nature was understood, and for that matter it still exists. Confusion is also causally related to the fact that some rusts are heteroecious; that is, certain spore forms are produced on 1 host species, and the other spore forms on a wholly unrelated species.

The teliospores (teleutospores), as indicated by their name, constitute the ultimate or last stage in the cycle. They are characteristically thick-walled, germinate after a dormant period in all except a few genera, and are formed in pustules or sori (telia), sometimes associated in the same sorus with urediniospores. On germination, teliospores produce a germinal tube (promycelium or basidium) that is generally transversely 4-celled, and each cell bears on a lateral sterigma a sporidium or basidiospore. Sporidia are capable of immediate germination by germtube formation. These germ tubes enter the host and produce mycelia that bear: (1) aeciospores, urediniospores, and teliospores in sequence. If the rust is heteroecious, the urediniospores and teliospores or the teliospores only are borne on a different host from that on which the aeciospores are produced. Pycniospores may precede or accompany the aeciospores; (2) urediniospores and subsequently teliospores; or (3) teliospores only.

Even within the same genus rusts are so variable in their developmental cycle that generalizations are made with difficulty, and exceptions are known to practically all such generalizations.

General aspect of RUST-AFFECTED plants. Rusts, as has been indicated, cause the formation of pustular rust-colored outgrowths on any or all of the plant parts above ground. The invaded tissues may be discolored, usually paler green than normal, or necrotic lesions may surround the sori. Quite generally rust-affected plants are stunted, but in some instances the invaded tissues are hypertrophic. Gymmosporangium juniperi-virginianae may modify the scale leaves of Jumiperus virginiana to the extent that galls 2 to $4 \mathrm{~cm}$ in diameter are formed. Uromycladium notabile and $U$. tepperianum form galls 6 to $9 \mathrm{~cm}$ across on Aca- 
cia in Australia. The woody galls on various pines produced by Cronartium quercuum may be 2 or 3 times the diameter of the stems on which they are formed. Some rusts cause the branch axes to be foreshortened, resulting in the formation of witches' brooms. Among such rusts are Gymmosporangium nidus-avis on Juniperus, Ravenelia pygmea on tropical species of Euphorbia, $R$. volkesnii on species of Acacia in Africa, Puccinia caricis on Urtica parviflora in central Asia, and Calyptospora goeppertiana on Vaccinium.

Mrcelium. The mycelium of rusts consists of branched hyphae that with a few notable exceptions are intercellular. Intimate contact with invaded tissues is made by means of haustoria. They are usually bulbous but sometimes variously branched and knotted. The opinion that the haustoria may not penetrate the protoplast was expressed by Colley (1918) from observations on Cronartium ribicola and by Rice (1934), who studied Uromyces caladii. In these species, and presumably in rusts generally, the haustoria are invaginations, and the ratio of their surface area to host-cell volume establishes a nutritional balance that does not result in the death of the invaded cells. Pady (1935) has shown that the mycelium of the short-cycled form of Gymnoconia interstitialis on Rubus is intracellular. Goplana mirabilis on the foliage of Michelia velutina in Java is said to have a superficial mycelium.

The mycelium may be short-lived or perennial. Klebahn (1904) lists 44 species in which the mycelium perennates. Among fungi with perennating mycelium are such well-known species as Cronartium ribicola, C. quercunm, C. coleosporoides, attacking conifers, Gymmosporangium clavipes and $G$. nidus-avis on Juniperus, Phragmidium subcorticinum on roses, Uromyces trifolii on clovers, Kunkelia nitens on Rubus spp., Melampsora pinitorqua, Cbrysomyxa abietis, and Endophyllum euphorbiae-sylvatici.

Rust mycelia consists of two well-marked phases that alternate, a monocaryotic phase and a dicaryotic phase. All too commonly this alternation has been erroneously interpreted as alternation of generations. Mature teliospores, promycelial cells, sporidia, the mycelium arising from the germination of sporidia, and pycniospores are monocaryotic. Aeciospore mother cells, aeciospores, the mycelial cells resultant from germination of aeciospores, ure- 
diniospores, the mycelial cells resultant from germination of urediniospores, and young teliospores are dicaryotic. The monocaryotic phase is usually of short duration among species attacking herbaceous plants but may persist for several years among parasites on woody plants.

Developmental Cycles and types. For the reason that the names applied to sori and spore forms of rusts are somewhat long and cumbersome, Karsten in 1879 first suggested that the aecial stage be designated by I, the uredinial by II, the telial by III. Subsequently $\mathrm{O}$ was used to designate the pycnial stage, and IV the sporidial. Arthur and many students of rusts have adopted these symbols. As has been indicated, rusts may have the complete cycle, that is, O, I, II, III, and IV stages in sequence; such rusts are called $E u$ forms. If $I$ is omitted from the cycle, the rusts are bracby forms; if II is omitted, they are opsis forms; if $\mathrm{O}$ and I are omitted, they are bemi forms; if only III is produced, they are either micro or lepto forms. Micro and lepto forms are distinguished on the basis of whether the teliospores germinate only after a period of rest (micro forms) or immediately after maturity (lepto forms).

The I stage is rarely absent among rusts. If $\mathrm{O}$ and I occur on the same host as III, the rust is autoecious; if they occur on a totally different species, it is heteroecious. In arctic and alpine regions the micro and lepto forms predominate. The developmental cycles of many species have not yet been determined; hence they are known in the aecial stage alone or in the uredinial stage alone. Many others are known in the uredinial and telial stages but have not been connected with an aecial stage.

Klebahn (1904) grouped heteroecious rusts into six developmental types as follows:

1. Teliospores that form near the close of the growing season hibernate, and aecia are formed in the spring that give rise to urediniospores which act as a propagative stage. Most species of Uromyces, Puccinia, Melampsora, and Pucciniastrum are included in this group. Example: Puccinia graminis.

2. Telial mycelium hibernates and forms teliospores in the spring. Sporidia are therefore distributed in the spring, whereupon aecia soon develop. Examples: Chrysomyxa rbododendri and C. ledi. 
3. Mycelium perennates and produces teliospores in the spring in Gymnosporangium spp. Such teliospores germinate immediately in situ, and the sporidia are dispersed to infect the alternate host.

4. Aecial mycelium hibernates, that of Coleosporium for 1 year, of Cronartium for several years. Aecia appear in the spring, and aeciospores infect the telial host. Teliospores are formed during the summer that infect the aecial host immediately, and aecial mycelium again hibernates.

5. Both aecial and telial mycelia perennate. In spring aecia arise from mycelium, and the aeciospores infect the telial host. From telial mycelium teliospores also form in the spring, which germinate immediately, and the sporidia initiate infection of the aecial host. Urediniospores arise in the summer from the same mycelium as bore teliospores. Example: Melampsorella caryophyllacearum.

6. Both urediniospores and teliospores form in the late summer. The teliospores germinate immediately and infect Anchusa, upon which pycnia and aecia form. The aeciospores can infect rye during the autumn, but it is not known whether the urediniospores can survive the winter. Example: Puccinia dispersa.

\section{Sori and Spore Forms}

PyCNia OR SPERMOgonia. In the usual course of events, pycnia are the first structures formed as the result of infections initiated by basidiospores. Moreover they usually precede the aecia but may be formed simultaneously with them. Arthur (1904) regards them as of importance in foretelling the length of the developmental cycle. Pycnia do not repeat themselves but occur only once in the life cycle. If pycnia and urediniospores arise from the same mycelium, aecia are absent from the cycle. If pycnia and teliospores are associated, neither aecia nor uredinia exist in the cycle. Occasional species exist, such as Uromycladium maritimum, $U$. notabile, and $U$. robinsoni, in which the pycnia are associated with both uredinia and telia. If the teliospores germinate immediately upon becoming mature and pycnia are associated with them, other spore forms are absent. In Puccinia malvacearum on various mallows, Melampsora farlowii on Tsuga canadensis, Gallowaya pinicola on Pinus virginiana, 
Chrysomyxa abietis on Picea sp., and Puccinia vivipari on Polygomum viviparum, pycnia are unknown. In Cronartium ribicola the pycnia are usually produced a year before the formation of the aecial stage.
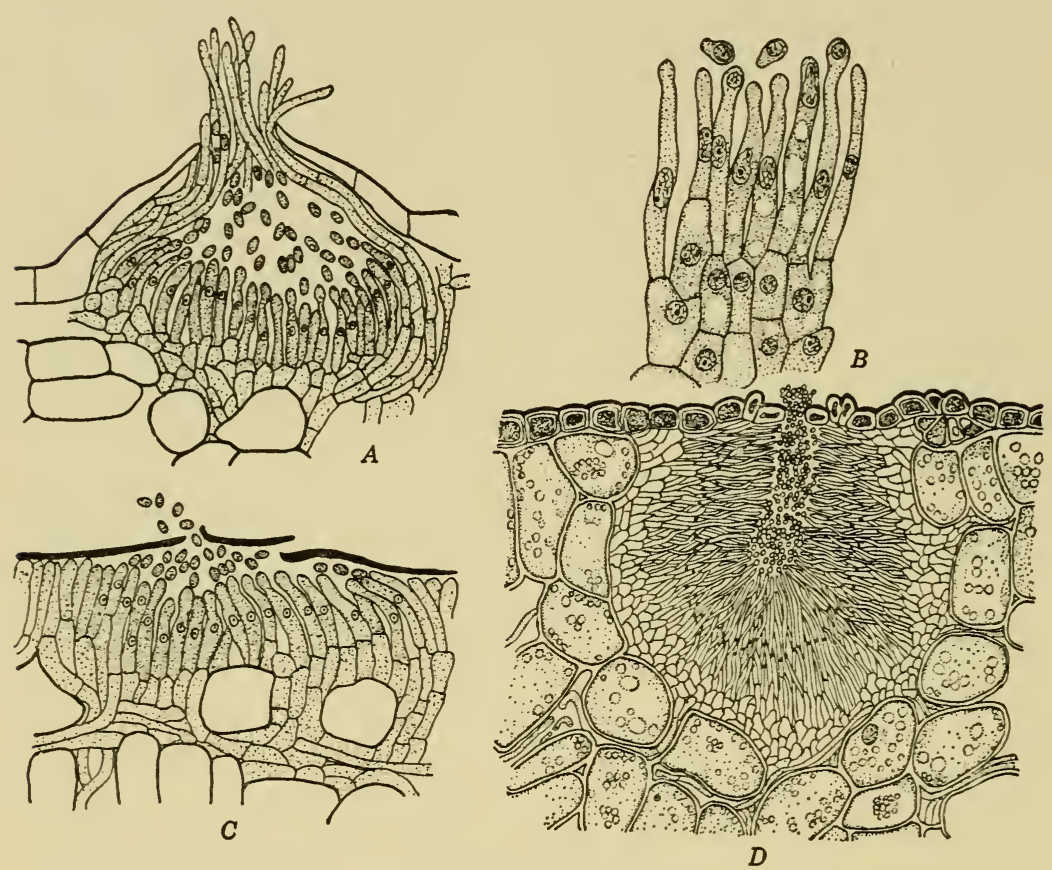

Fig. 120. Acervular and pycnidial types of pycnia. A. Pycnium of Gymnosporangium clavariaeforme, in section, beneath epidermis on leaf of Crataegus. B. Subcuticular pycnium of Pbragmidinnn violaceunn on leaf of Rubus. C. Portion of vertical section of pycnium of Cronartium ribicola on white-pine twig. $D$. Subepidermal pycnium of Milesia marginalis on needle of Abies balsamea. ( $A$ and $B$ adapted from Blackman, $C$ from Colley, and $D$ from Hunter.)

The position, size, color, and form of pycnia are worth noting. In most species they appear on the surface opposite that on which the other stage or stages occur. Occasionally, as in Gymmoconia interstitialis, they are produced on both leaf surfaces.

Pycnia vary in form from hemispherical or acervular to globular or pycnidial. Subcuticular or subepidermal forms are usually acervular, whereas pycnidial forms are more deeply seated. Rusts 
attacking Rosaceae and Ranunculaceae have acervular or hemispherical pycnia.

All pycnia consist of a palisade of slender sporophores that arise from a pseudoparenchymatous tissue. Toward the upper part or the periphery sterile sporophores or paraphyses form a column that extends beyond the surface of the host. In species of Milesia, however, paraphyses are wanting. Spherical to oval spores (spermatia) are abstricted in series from the apices of the sporophores. The mass of spermatia accumulates to the extent of rupturing the overlying host tissues or of effecting an ostiole, through which the spermatia ooze. The ooze is sugary and sometimes gives off a fragrant odor. Various insects are in consequence attracted to the exudate and serve as vectors in the dispersion of the spermatia.

The spermatia are uninucleate, the nucleus being proportionally large. They may germinate by forming a germ tube or by budding, as was observed by Cornu as long ago as 1876.

Opinions concerning the function of spermatia have been in conflict since 1833, when Unger placed all rust spermogonia under one genus and species, Aecidiolum exantbematum. In 1841 Meyen regarded them as male structures but maintained that there is no sexuality among rusts. Later, as the result of cytological studies involving the formation of aeciospore mother cells, a subject given more attention at another point in the discussion, the opinion became established that spermogonia are vestigial and non-functional. In 1927, however, Craigie (1927) observed that spermogonia and aecial primordia develop from infection by a single basidiospore, but that aeciospores never develop in such primordia unless spermatia from one lesion are transferred from one sorus to another. In these studies Craigie employed Puccinia graminis on barberry and $P$. belianthi on sunflower. Later (1931) he demonstrated that the 4 basidiospores arising from any basidium of these rusts are of 2 sexual phases, and that the spermatia arising from 1 phase will fertilize the sorus of the opposite sexual phase, and vice versa. He noticed a similar situation in Puccinia coronata, P. pringsheimiana, and a species of Gymnosporangium; therefore in some rusts, presumably all which form spermogonia, the spermatia are functional.

Attention has also been called by several workers [Andrus (1931), Pierson (1933)] to the presence of receptive hyphae 
(trichogynes) among rusts. Furthermore they are produced from the same haploid mycelium as bears spermatia. Self-fertilization does not occur, but, as would be anticipated, the thalli are cross-fertile and cross-compatible. Heterothallism is now definitely known in Puccinia granninis, $P$. beliantbi, $P$. triticina, $P$. coronata, $P$. sorghi, $P$. pringsheimiana, Melampsora lini, Cronartium ribicola, Uromyces appendiculatus, $U$. fabae, U. trifoliibybridi, $U$. vignae, and Gymmoconia interstitialis. It must by no means be inferred that all rusts are heterothallic. Brown (1939) offers evidence that a single sporidium of Puccinia coronata-elaeagqui, $P$. grindeliae, and $P$. xantbi gives rise spontaneously to binucleate mycelium that is homothallic.

The receptive hyphae are composed of uninucleate cells, according to Andrus (1931), Pierson (1933), and Allen (1934a), and they extend out from uninucleate basal cells of the aecial primordium. Craigie (1931), using Puccinia beliantbi, Allen (1934a), using P. sorghi, and Buller (1938), using P. graminis, have shown that receptive hyphae extend from the ostiole of the spermogonium. The spermatium has been shown to fuse with the receptive hypha (paraphysis or trichogyne) and to pass down through the hypha to the basal cell (egg cell). There the two nuclei associate in what is regarded as the aeciospore mother cell. Here they divide conjugately and repeatedly, and the mother cell gives rise to a series of dicaryotic aeciospores. Allen (1932) has shown in Puccinia triticina that hyphae other than those near the spermogonial orifice may serve as receptors. Instead receptive hyphae may emerge from stomatal openings or may even penetrate to the surface between epidermal cells.

Diploidization may be accomplished otherwise, as is indicated by Brown (1935), who found evidence that hyphal fusions may occur in $P$. helianthi when two haploid pustules of opposite sex phases coalesce. In this case the spermatia did not function, but there is reason to believe that the dicaryotic condition in rusts is quite generally achieved through the agency of spermatia.

AEcia. The aecia are of four form types: aecidium, caeoma, roestelia, and peridermium. These terms are sometimes used as generic names to designate the aecial stages. If the chains of aeciospores are formed compactly within a membrane or peridium that, on opening, is cup-like, the structure is spoken of as an aecidium. If the peridium is lacking and the chains of aecio- 
spores are loosely compacted, the structure is called a caeoma. If the peridium is strongly developed and extends prominently above the chains of aeciospores, the structure is spoken of as a roestelium or a peridermium. In general, the term roestelia is limited to the aecial stage of species of Gymnosporangium, whereas peridermium applies to the aecial stage of Coleosporium, Cronartium, Melampsora, and various other genera having nonpedicellate teliospores.

Another very peculiar type of aecium occurs in Dasyspora faveolata. A much-branched hyphal mass protrudes from the host stomata. Each branch bears at its apex a verrucose aeciospore that is abstricted by a narrow stalk cell.

The aeciospores, it has been pointed out, arise in series from a binucleate mother cell. First the mother cell elongates, and conjugate division occurs; then by a transverse septum a terminal cell containing a pair of nuclei is cut off. This terminal cell again divides transversely. Usually the upper cell so formed is the larger and becomes the aeciospore; the smaller cell is a buffer or intercalary cell. Sometimes the first cell formed by the mother cell becomes a peridial cell. At any rate the basal mother cell repeats the process of conjugate nuclear division and delimitation of the upper portion, and eventually chains of aeciospores and intercalary cells are formed. The intercalary cells serve as disjunctors and may early become disorganized.

The aeciospores are always unicellular, and their wall is hyaline and two-layered. Sometimes the outer membrane is echinulate. Mutual pressure causes the aeciospores to be polygonal. Their content is orange-colored. The germ tubes usually emerge through one or the other of the thin places in the spore wall.

Fromme (1914) studied the development of the aecia of Puccinia claytoniata. He observed that the primordium is at first a tangled globular mass of hyphae. Near the basal portion a layer of mother cells is differentiated. Sporulation begins first with the mother cells near the center of the hymenium and extends outward in a centrifugal manner. The first cells abstricted adhere laterally and constitute the upper and lateral walls of the peridium. In some instances the young peridial cells divide to form intercalary cells, but such a procedure is exceptional. Since the mother cells near the center of the hymenium sporulate first, 


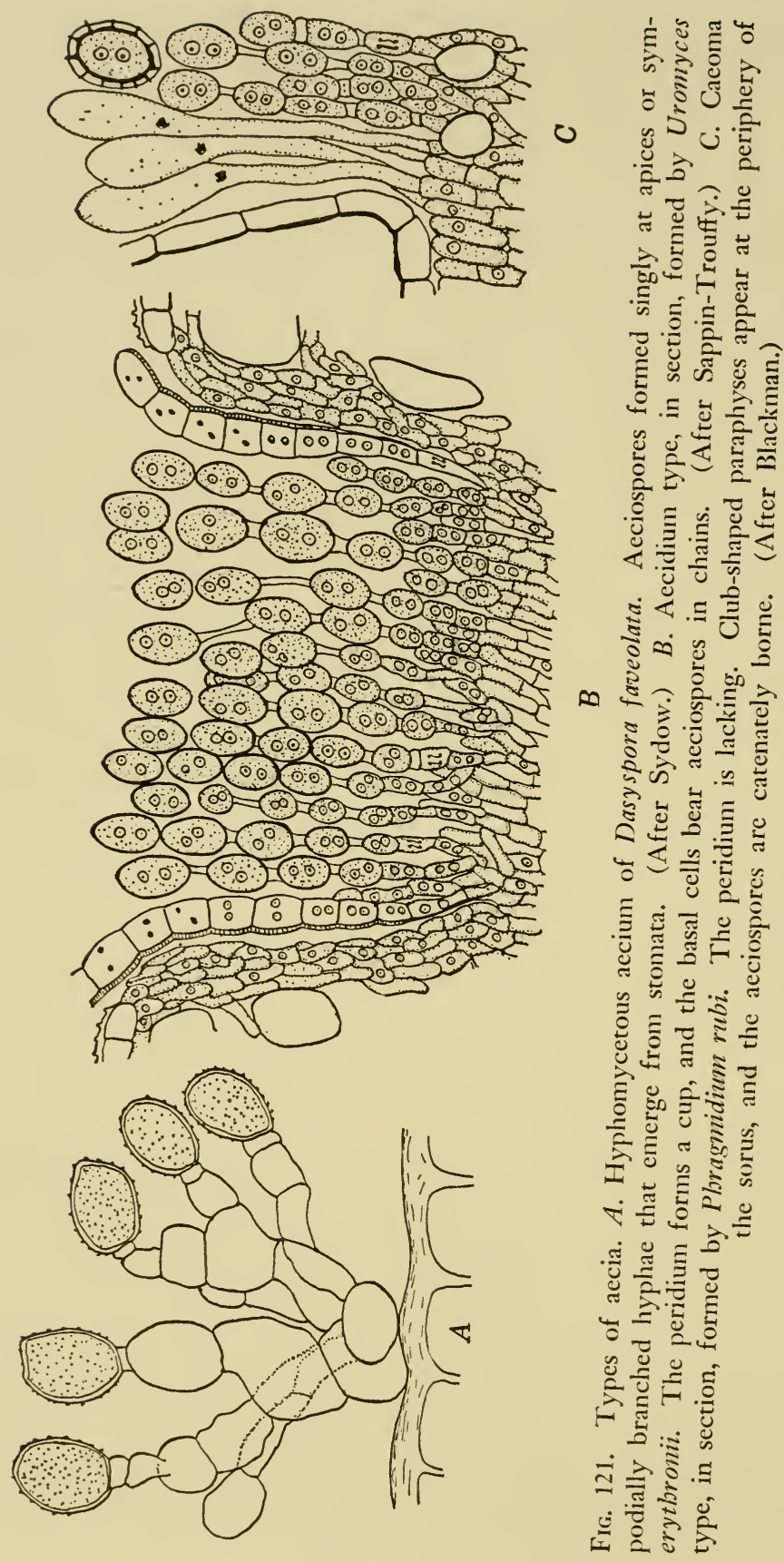


the aecial sorus becomes dome-shaped. As the pressure increases from repeated delimitation of the aeciospores in chains, the peridium is ruptured, thus liberating the aeciospores.

The surface markings or sculpturing of the walls of the peridial cells in species of Roestelia (Gymnosporangium) has been employed to distinguish species. Kern (1910) used this criterion in a study involving 16 species of Roestelia. Hedgcock (1928) separated the needle-inhabiting peridermiums on pines, which be-

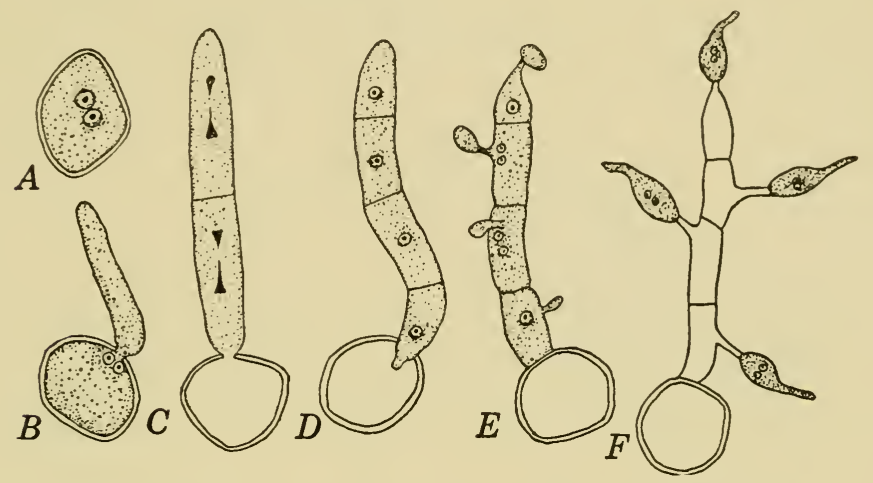

Fig. 122. Germination of apogamous aeciospores of Endophyllum euphorbiaesylvaticae. (Adapted from Moreau.)

long to the Genus Coleosporium, by using structural features and color.

Infection resulting from germinating aeciospores produces mycelia on which urediniospores or teliospores or both are formed. In a few species repeated aecium formation has been observed. Secondary aeciospores have been noted, for example, in Puccinia senecionis and in Uromyces cumninghamianus, the latter occurring on Jasminum grandiflorum in India and appearing to constitute the first known case of repeating aecia [Barclay (1891)].

UREDINiA. The urediniospores are borne on the same host as aeciospores in autoecious rusts but on a different species in heteroecious rusts. Urediniospores originate from mycelium, arising from: (1) germination of aeciospores, (2) germination of sporidia, or (3) germination of other urediniospores. Urediniospores normally constitute the repeating spore forms, and many successive crops may be produced during a season. They are unicellular and ovate to elliptical; the wall is echinulate, and, except for 

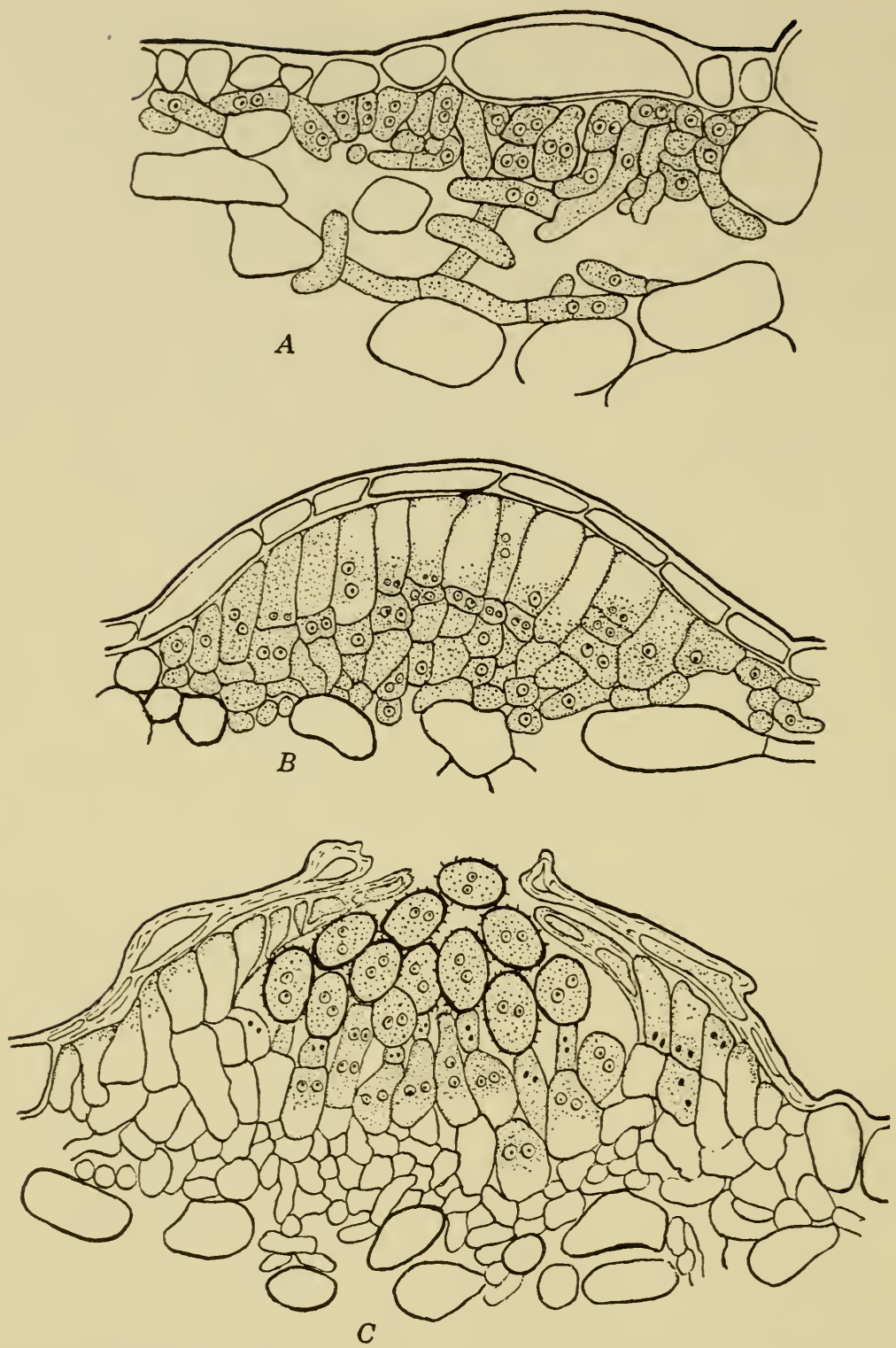

FIG. 123. Stages in derelopment of the uredinium of Cronartiunn ribicola. (Adapted from Colley.) $A$. Subepidermal primordium composed of binucleate cells. B. Layer of cells, destined to become urediniospores, formed on outer surface of primordium. C. Urediniospores liberated by rupture of overlying host tissue. 
Puccinia monopora, they possess more than one germ pore. They are commonly borne singly on stalks. Their color varies from orange to brown, and the pigment may occur in the protoplast or in the wall.

The development of uredinia and urediniospores has been studied by Moss (1926). Since the cells from which the sorus arises are dicaryotic, the soral cells are also dicaryotic. Urediniospores are delimited from basal cells of the sorus in quite the same way as aeciospores are produced. Buffer cells form in some species. In some, the urediniospores are catenulate, especially in Coleosporium and Chrysomyxa, and in others pedicellate. In Hemileia vastatrix the sori arise beneath the stomata of the coffee leaves, and the urediniospores form singly at the apices of the fascicle of stalk cells. They also protrude from the stomata in Olivea capituliformis, Aplospora nyssae, Prospodium plagiopus, and $P$. bahamiense, in which species a circle of incurved paraphyses surrounds the uredinial pustules. Paraphyses accompany urediniospores in a number of other rusts, such as Tranzschelia prunispinosae, Puccinia poarum, P. perplexans, Uromyces dactylidis, and Phragmidium subcorticinum, and they may not form a peripheral ring but instead occur interspersed, as in Melampsora lini. In this last-named species the paraphyses are metamorphosed stalked urediniospores.

Among the genera Hyalospora, Milesia, and Uredinopsis, all of which are fern rusts, and among Cronartium, Melampsorella, Melampsoridium, and Puccinastrum, the uredinia possess peridia.

Urediniospores may be dimorphic, as in the genera Uredinopsis, Hyalospora, and Milesia, and in Tripbragmium ulmariae, occurring on Spiraea. The primary uredinia in T. ulmariae, formed on petioles and veins, are large and abundant, and the secondary ones are quite small and sparsely dispersed on the laminar tissues.

Although urediniospores and aeciospores are generally quite different, they are known to resemble each other very closely in certain species, as in Puccinia fraxinata, having aecia on ash and uredinia on Spartina spp., in P. seymouriana, having aecia on Cephalanthus and uredinia on Spartina spp., and in P. verbenicola, having aecia on Verbena spp. and uredinia on Sporobolus spp.

In some portions of the world, species that are normally heteroecious are perpetuated year after year in the uredinial stage. Such is the situation with Puccinia graminis in Australia, where 
barberry is absent, and with $P$. coronata in Andean regions of South America, where Rhamnus is absent. Such rusts may survive the winter by migration in the autumn from colder to warmer portions of the country, multiplying there during winter, and again migrating to colder regions in the spring. Stakman and his associates have amassed abundant evidence to show that

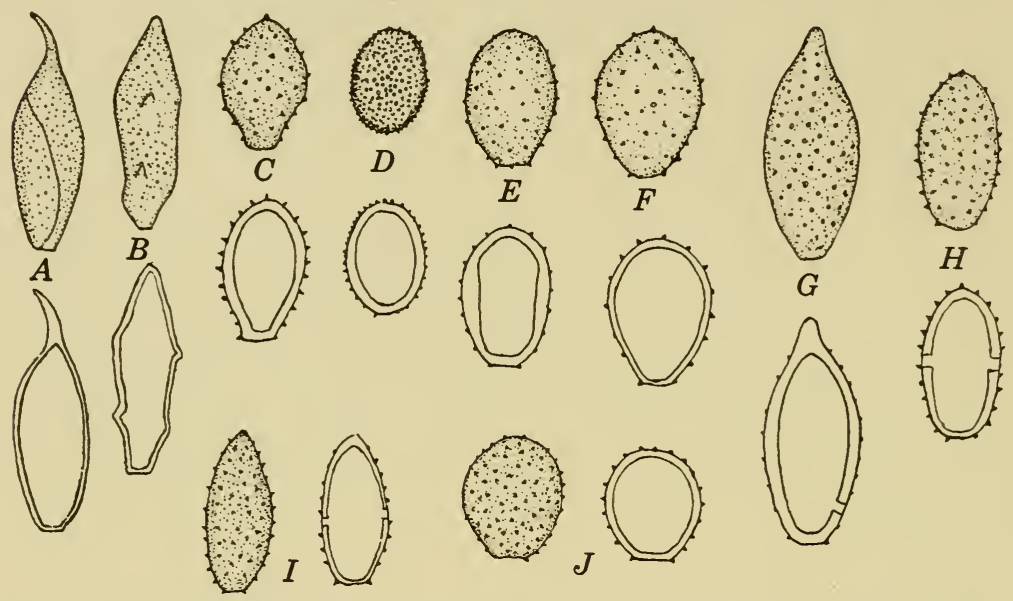

FIG. 124. Urediniospores of various rusts, in surface view and in optical section. (Adapted from Arthur.) A. Uredinopsis mirabilis. B. Milesia polypodoplille. C. Cronartium ribicola. D. Coleosporiun solidaginis. E. Melampsora abietis-canadensis. F. Physopella fici. G. Pileolaria toxicodendri. H. Puccinia granninis. I. Tranzschelia pruni-spinosae. J. Kuebneola uredinis.

there is a seasonal migration of $P$. graminis of this kind in the Great Plains area of the United States. There is also abundant evidence that this rust and other grain rusts cannot survive the winter as urediniospores in the Northern United States or in northern Europe. In Australia viable urediniospores of $P$. graminis, $P$. triticina, and $P$. chrysanthemi have been taken from sori at various times during the winter by McAlpine.

Certain autoecious species also persist and perpetuate themselves in the uredinial stage. Such is reported to be the situation with Uromyces fabae in Ecuador, whereas this same species in Europe produces aecia and also telia. Plasticity among rusts may find expression in other ways, such as the occurrence of shortcycled forms like Kunkelia nitens and Puccinia podophylli. 
Telia. Teliospores arise from mycelium, originating (1) from aeciospores, (2) from urediniospores, or (3) from sporidia. They
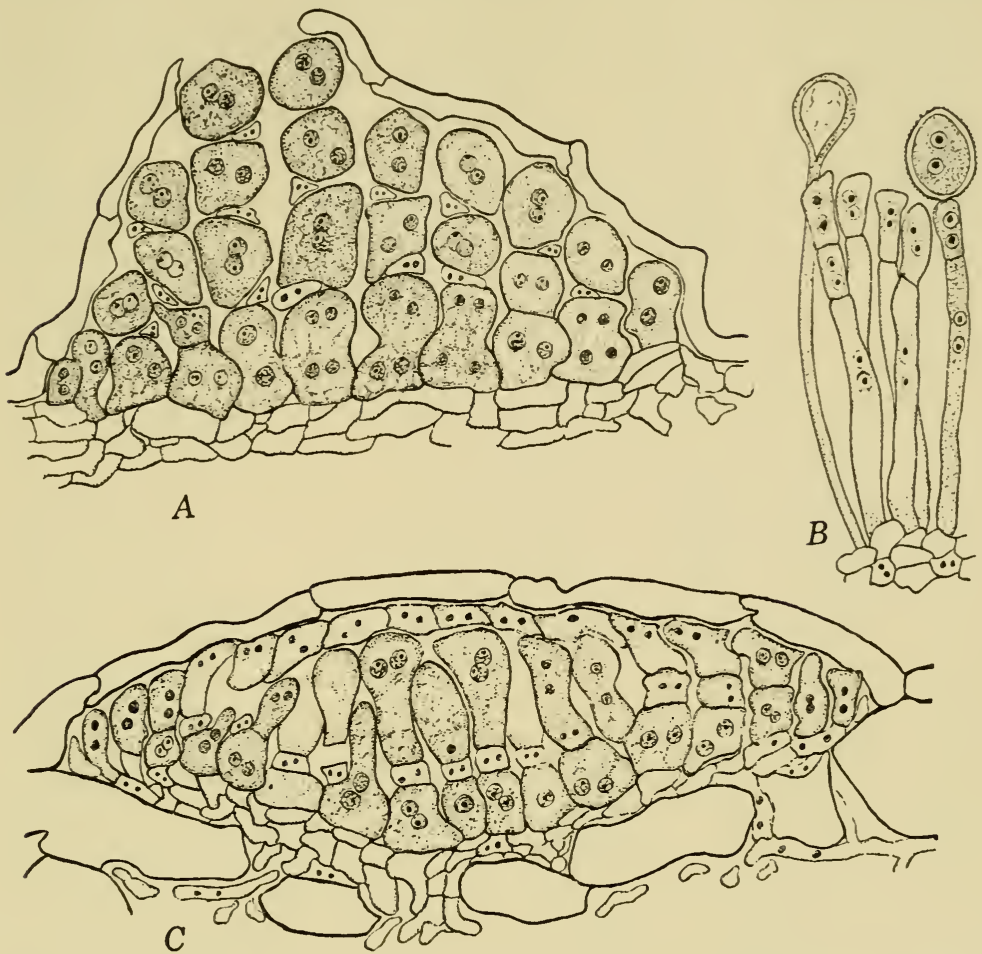

Fig. 125. A. Vertical section of uredinial pustule of Coleosporinm solidaginis. The "buffer" peridial cells are lacking. Intercalary cells separate the urediniospores that are produced in chains. The basal cells give rise in acropetal succession to urediniospores and buffer cells alternately. (Adapted from Moss.) B. Portion of mature uredinium of Melampsora lini. The capitate structure at the left is a paraphysis. The urediniospore at the right is long-stalked. The remaining stalks exhibit stages in urediniospore delimitation. (Adapted from Fromme.) C. Section of young uredinial pustule of Melampsorella elatina. Buffer cells constitute a layer immediately beneath the epidermis. Beneath them are immature urediniospores. Clear binucleate cells beneath the urediniospores separate them from the basal urediniospore-mother cells. (Adapted from Moss.)

are typically thick-walled resting spores that normally have a period of dormancy, but in lepto forms teliospores are capable of germination as soon as they reach maturity. The arrangement 
of teliospores, their shape, and their septation are among the characters used in generic separations. In the Pucciniaceae the teliospores are borne on a stalk or pedicel, whereas in the Melampsoraceae they are sessile and arranged in layers or in columns.

The feature that most strikingly separates teliospores from other types of rust spores is their method of germination. Among many pedicellate species each cell of the teliospore has a single germ pore, through which a short germ tube emerges. This germ tube has a limited growth and is called a promycelium or basidium. It usually becomes 4-celled by transverse septa. It never functions as an infection hypha. From each basidial cell a sterigma arises, supporting a sporidium or basidiospore that is discharged at maturity and is air-borne.

Among certain melampsoraceous species germination of teliospores follows a somewhat different plan. In Coleosporium, Ochrospora, Trichospora, and Chrysopsora, for example, mature teliospores are single-celled but on germination become 4 superimposed cells, each of which bears a long sterigma that abstricts a sporidium. In certain other genera, such as Melampsora, Chrysomyxa, and Cronartium, each superimposed cell forms a 4-celled promycelium and 4 sporidia. This same type of germination occurs in Phragmidium, which has pedicellate spores. The basidia of Ravenelia may bear only a single sporidium. Another unusual kind of germination occurs in Barclayella deformans on Picea morinda in the Himalayas; in this species each cell of the teliospores forms a promycelium, each segment of which rounds up and is the sporidium.

Other noteworthy teliospore types occur in certain shortcycled rusts. In species of Endophyllum the teliospores are borne in cupulate structures in aecioid chains and are morphologically like aeciospores. In fact, they were regarded as aeciospores by early workers. On germination, however, the Moreaus (1919) have shown, promycelia and sporidia are produced. Sappin-Trouffy (1896) showed that E. sempervivi and E. euphorbiae-sylvaticae have binucleate teliospores and that their nuclei divide conjugately. This condition may not occur invariably, and other species of Endophyllum may behave differently [Ashworth (1934)]. Kunkelia nitens produces caeomoid telia. Kunkel $(1913,1914)$ and Dodge and Gaiser (1926) have given considera- 
tion to the phenomena of germination and nuclear activities. Other aecioid telial rusts are Puccinia grindeliae, Uromyces scutellatus, and U. levis [Arthur et al. (1929)], but these species are aecioid only in the sense that the aecial sori and telial sori look quite alike.
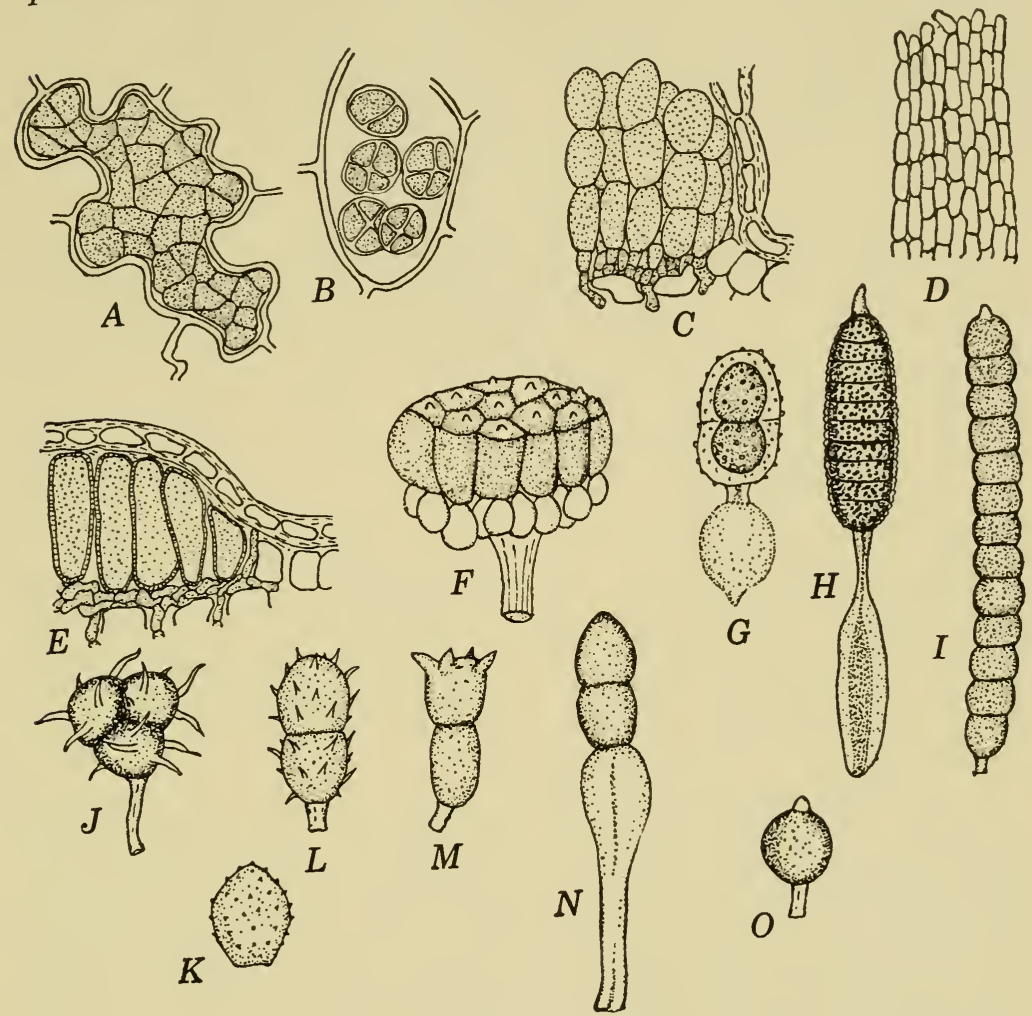

D

FIG. 126. Teliospores of various rusts. $A$. Surface view of epidermal cell of Polypodium virginianum that is occupied by teliospores of Milesia polypodopbila. B. Uredinopsis osmundae in epidermal cell of Osmunda cinnamiomea. C. Chrysomyxa arctostaphyli, margin of sorus. D. Portion of telial column of Cronartium ribicola. E. Portion of telial sorus of Melampsora medusae on Populus. F. Ravenelia cassiaecola from Cassia chamaecrista. G. Uropyxis amorphae from Amorpha. H. Phragmidium americanum from Rosa. I. Xenodocbus carbonarius from Sanguisorba microcepbala. J. Nyssopsora echinata from Oenanthe californica. K. Endophyllum sempervivi from Sempervivum. L. Puccinia podophylli from Podophyllum peltatum. M. Puccinia coronata from Avena sativa. N. Gymnosporangium clavipes from Juniperus virginiana. O. Uromyces caryophyllinus from Diantbus caryophyllus. ( $A, C, E, G, l$, adapted from Arthur.) 
Kursanov [Arthur et al. (1929)] has studied the development of telia among several genera, and his accounts indicate that the developmental features resemble those of aecia and uredinia generally. Occasional genera are exceptional, such as Cystopsora, in which the sori protrude from stomata and the teliospores appear to be superficial, and Goplana mirabilis, occurring on Michelia velutina in Java, the teliospores of which are borne on a superficial mycelium.

\section{Heteroecism}

It is easily understandable that the early students of rusts should regard the different spore forms as distinct genera, although in 1807 de Candolle expressed the opinion that Uredo linearis and Puccinia graminis on wheat were one and the same but that they changed aspect with age. Persoon also suspected that the two were stages of the same species. The Tulasnes (Ann. Sci. Nat. Bot., ser. 4, 2:77-196) in 1854 decided that Uredo and Puccinia were one and the same. They had noted several years earlier, in connection with rose rust, the curious fact that Uredo rosae and Phragmidium incrassatum occur in the same sorus. Corda (Icones Fungorum Hucusque Cognitorum 419, 1840) and Fries (Summa Veg. Scand. 507, 1849) regarded the Phragmidium stage as parasitic upon the Uredo stage.

That the existence of a relationship between cereal rusts and the presence of barberry had become thoroughly established in the minds of farmers long before de Bary's classical demonstration (1865) is shown by the fact that a law was enacted in France in 1660 for the eradication of barberry, and that similar laws were passed in several New England States between 1726 and 1766. Moreover in 1818 Schoeler in Denmark [Arthur et al. (1929) ] transplanted barberry bushes in rye fields and found that rust became abundant, especially on those plants on the leeward side of the barberry bushes. He also applied aeciospores to rye leaves; after 5 days infections were evident, whereas his control plants were rust-free. Nevertheless botanists were not convinced of the genetic connections and continued to regard the aecial stage as a different genus.

In 1863 de Bary (1863) sowed sporidia of Uromyces appendiculatus on beans grown in the laboratory. Lesions appeared on inoculated plants after 5 or 6 days, and spermogonia were ma- 
ture 3 days later. After an additional period of 8 to 12 days aeciospores were produced, and a month later urediniospores and teliospores. By sowing aeciospores on other beans, he se-

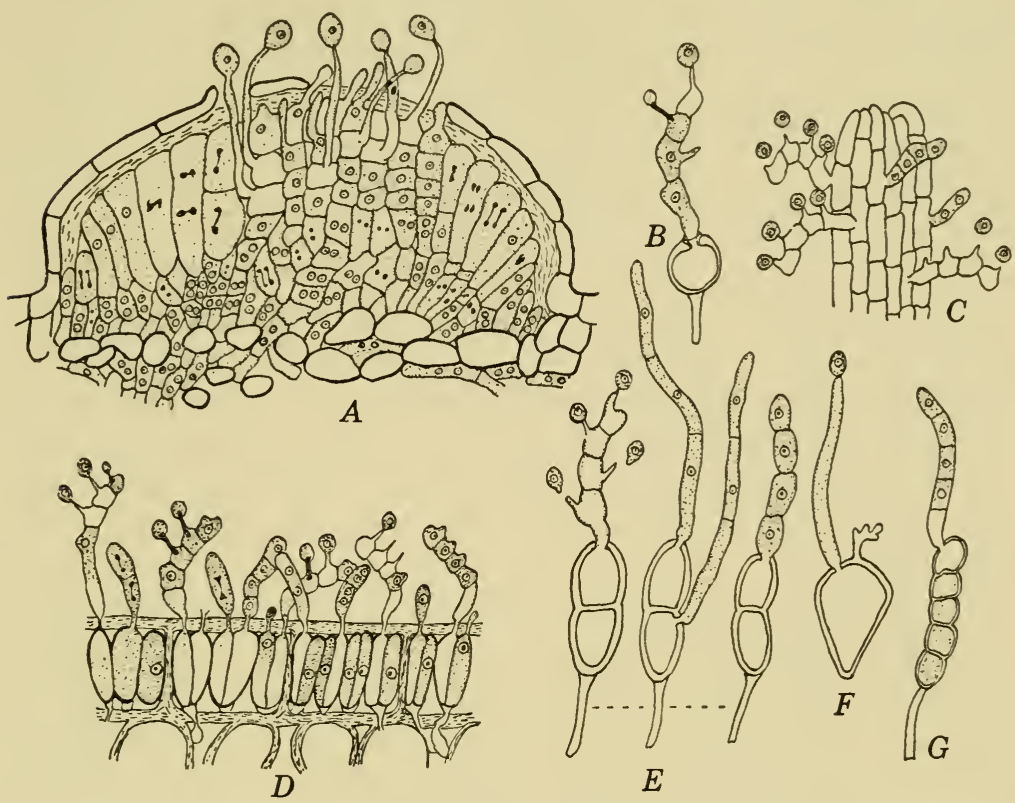

Fig. 127. Germination of teliospores. A. Section of sorus of Coleosporium sonchi-arvensis. The one-celled teliospores, in situ, become transformed into four superimposed cells (the promycelium or basidium), each of which bears a sterigma at whose tip the basidiospore is produced. $B$. Typical germination of teliospore of Uromyces appendiculatus. C. Germination of one-celled teliospores in telial column of Cronartium quercuntm. $D$. Section of telial sorus of Thekopsora areolata. Stages in germination of teliospores. The promycelium extends to the exterior of the host. (After Sappin-Trouffy.) E. Puccinia malvacearum; at left, normal germination, in middle, when teliospores are submerged, and at right, when pressure of $\mathrm{O}_{2}$ is reduced. (After Sappin-Trouffy.) F. Ravenelia sp. G. Barclayella sp.

cured uredinia, followed by telia. Having thus established that the bean-rust fungus is polymorphic, de Bary devoted himself to similar sowings of spores from rust pustules on barberry and on wheat. Again he found that one polymorphic species was involved on both hosts, that the different spore forms appeared in sequence, that the aecial and pycnial stages occurred on barberry 
and the uredinial and telial ones on wheat, that the stages on barberry could infect wheat but could not infect barberry and vice versa, and, as a consequence, that both hosts were required for the polymorphic rust to complete its cycle of development. In spite of these experimentally established results, the heteroecism of rusts was not immediately accepted among mycologists, at least not without temerity. Ørsted [Arthur et al. (1929)] during the summer of 1865 showed the connection of Gymmosporangium sabinae with Roestelia cancellata. By 1880 it had been established that 16 rusts are heteroecious, and during the next 10-year period the list was extended to include about 100 species. Klebahn (1904) lists 153 species, distributed among the genera as follows: Chrysomyxa 2, Coleosporium 14, Cronartium 3, Gymnosporangium 13, Melampsora 21, Melampsorella 1, Melampsoridum 1, Puccinia 85, Pucciniastrum 3, and Uromyces 10. The list compiled by Dietel (1918) contains 264 species, and since 1918 many additional ones have been demonstrated to be heteroecious.

The origin of the heteroecious habit among rusts has long been a fertile field for speculation, and, as on all such topics, accord is lacking. Acquaintance with this problem, with the views of those who have contributed to its solution, and with the difficulties involved can be gained from the accounts by Olive (1911), Grove (1913), Orton (1927), and Jackson (1931). In general two diametrically opposed views are held: (1) that the ancestral forms were autoecious but able to live plurivorously; that is, they were at least able to pass their entire developmental cycle on either of two hosts; or (2) that ancestral rusts were heteroecious, as well as heterothallic and polymorphic. Fischer is among those who assume that heteroecious species once lived on either host autoeciously, and that host specialization is a recent development. Such a species as Puccinia graminella, with both aecia and telia on Stipa, might be regarded as evidence of this point of view. This species is not plurivorous, however, and there is no evidence that it ever was. Other evidence for this point of view is that the host for the monocaryotic phase is the more primitive and that the stimulus imparted by the dicaryotic condition results in invigoration. It would therefore follow that aeciospores possess greater vigor, and hence greater capacity for infecting, than do other spore forms. The fact that aeciospores of some species 
act as a bridge supports this argument. For example, the aeciospores of Cronartium asclepiadium, formed on Pinus sylvestris, infect and produce telia on members of 4 families of flowering plants: Asclepiadaceae, Verbenaceae, Scrophulariaceae, and Ranunculaceae. Again, the aeciospores of Melampsorella caryophyllacearum initiate infection on species among distinct genera of Caryophyllaceae. On the other hand, quite the opposite condition may result, as it does with 7 species of heteroecious Puccinia that bear aeciospores on members of 3 or 4 families of monocots but that all produce teliospores on Pbalaris arundinacea.

The opinion of Jackson (1931) and nearly all present-day students of rusts is not only that the autoecious species have been developed from heteroecious species but also that all species with a reduced cycle typify present-day trends among rusts. These short-cycled species are therefore derived from autoecious species. Olive (1911) and a group of other workers, such as Klebahn, Magnus, and Dietel, regarded lepto and micro forms as the ancestors of heteroecious rusts. They would argue that Puccinia mesneriana, one of the crown rusts, whose telia are produced on Rhamnus, is the progenitor of Puccinia coronata, which requires Rhamnus as its aecial host and Avena as its uredinial and telial host. Autoecism is therefore primitive, according to this group of students, and heteroecism has arisen as an adaptation.

Evidence that the long-cycled forms are ancestral and that they may give rise to forms with simpler cycles is derived from studies of Puccinia podopbylli. This species hibernates as teliospores, and the sporidia may initiate infections that early give rise to teliospores on the bud scales and stems. Shortly thereafter aecia appear on the leaf blades, and they too arise from the same primary source [Whetzel, Jackson, and Mains (1925)]. Pycnia accompany these aecia but are usually absent from the early crop of teliospores. In late summer teliospores are produced on mycelium from infection by aeciospores. Puccinia podophylli is therefore not fixed but plastic in its cycle of development.

It would appear more than a coincidence that species of Uredinopsis, Milesia, and Hyalospora have their uredinial and telial stages on ferns and their other stages on firs, that nearly all species of Gymnosporangium bear their telia on Juniperus or closely 
related Cupressineae and their aecial stage on the Maleae, and that such a large proportion of the species of Puccinia and Uromyces, having teliospores on grasses and sedges, produce aecia on the Compositae or Ranunculaceae. Facts like these stimulate interest in the whole problem of heteroecism, and the conclusion seems inevitable that there is as yet no known reason why rusts are limited and grouped in their aecial and telial host relationships.

\section{Sexuality of the Uredinales}

Many students of fungi have concerned themselves with the sexuality of rusts. Some of the results of their work have already been given in this report, especially if they deal with the relationship of pycniospores to the origin of the dicaryotic condition in aeciospore mother cells [Craigie $(1927,1931)]$.

Presumably the pycniospores in many species of rusts function as male cells, fusing with trichogynes that project to the surface from basal cells in the developing aecia. It must be remembered, however, that some rusts are not known to possess pycnia and that the pairing of nuclei must therefore be accomplished by some other mechanism. This subject cannot be seen in proper perspective, however, unless a few of the other important reports on the sexuality of rusts are given attention. Apparently the work of Poirault and Raciborski (1895) in 1895 constitutes the first real cytological contribution to knowledge of rusts. They described conjugate nuclear division but were in error concerning the chromosome number. The next year the extensive study of Sappin-Trouffy (1896) appeared, describing and amply illustrating soral development in 10 genera and 36 species of rusts. $\mathrm{He}$ also determined that the paired nuclei fuse during maturation of the teliospore and that reduction-division occurs early in the course of promycelial formation.

Interest in the sexuality of rusts was keenly stimulated soon thereafter by Blackman (1904). From examination of the aecia of Phragmidium violaceum he described the migration of a small nucleus from an ordinary vegetative cell into a larger special cell (female cell) containing a larger nucleus. This process was regarded as the initiation of the sexual act, and it was held that actual fusion was delayed until maturation of the teliospore. $\mathrm{He}$ viewed the buffer cells above the chains of aeciospores as degener- 
ate trichogynes and regarded the spermatia as functionally vestigial.

Christman (1905) employed Gymmoconia interstitialis, Uromyces caladii, and Pbragmidium speciosum to study their nuclear activities. He interpreted the basal cells in aecia that gave rise to binucleated aeciospores as isogametes and the aeciospore mother cells as non-resting zygotes.

In the meantime Blackman and Fraser (1906) continued their studies, using Uromyces poae, $U$. ficariae, Puccinia poarum, $P$. malvacearum, $P$. adoxae, and Melampsora rostrupii, and concluded that Blackman's earlier interpretation was correct for certain rusts but that Christman's was for others. A second paper by Christman (1907), using Phragmidium potentillae-canadensis, found the author upholding the conclusions of his earlier report. In 1908 Olive (1908), from studies with Triphragmium ulmariae and Puccinia deformans, sought to harmonize the conflicting interpretations of Blackman and Christman. In this paper Olive indicated that, if one of the pair of cells was tardily pushed upward between larger cells, the fusion would appear to arise from a vegetative cell, thus agreeing with the interpretation of Blackman. If, on the other hand, the cells arose side by side, there was fusion of equal gametes, as stated by Christman. Results of studies of like nature on approximately 40 other species by nearly a score of workers are tabulated by Arthur et al. (1929, pp. 120-121).

\section{The Mycoplasm Hypothesis}

Many investigations have centered about attempts to learn how the cereal rusts hibernate. Perhaps none has directly or indirectly stimulated more study of rust hibernation than the mycoplasm hypothesis announced by Eriksson in 1894. He maintained that during the winter there is an intimate mixture of the protoplasm of the rust with that of the host, so that the two cannot be distinguished. In the spring, when conditions favorable for growth return, the fungus plasma becomes organized into definite elongated, curved bodies (Körperchen), which grow out into the intercellular spaces and become mycelial. Ward (1902, 1903 ) early pointed out that the Körperchen were in reality haustoria, and violent discussion ensued. Other papers by Eriksson (1897, 1903, 1922), which indicate maintenance of his firm be- 
lief in the mycoplasm hypothesis, followed. When he grew cereals in the greenhouse, the plants became infected. It seems highly probable, however, that Eriksson made use of diseased seed grain and that insufficient care was exercised to prevent infection in his greenhouse experiments.

\section{Specialization}

Specialization of parasitism among rusts constitutes one of the most interesting and important problems in uredinology. A basic concept in this field requires that a species be regarded as a collection of morphologically similar organisms or strains that differ in ability to produce infection in different hosts. Although this matter is more fully discussed in Chapter 11, Volume II, it should be indicated at this point that experiments by Eriksson, Klebahn, Stakman, and many others have amply demonstrated the existence of specialized strains, races, and forms among cereal rusts. For example, Puccinia graminis consists of:

(a) P. graminis tritici on Triticum vulgare.

(b) P. graminis secalis on Secale cereale and other hosts.

(c) P. graminis avenae on Avena sativa and other hosts.

(d) P. graminis airae on Aira caespitosa.

(e) P. graminis poae on Poa compressa and other species.

(f) P. graminis agrostidis on Agrostis caninis and other species.

In experiments extending over a long period, Stakman et al. (1934) have shown that barberry is essential for the production and perpetuation of varieties and forms of Puccinia graminis. Of 675 aecial collections $34.2 \%$ were of the tritici variety, $63.7 \%$ of the secalis variety, and $2.1 \%$ of the avenae variety. Their evidence led them to conclude that the origin and persistence of the secalis, poae, and agrostidis varieties are dependent upon the presence of barberries. They found the physiologic forms of $P$. graminis tritici to belong within 26 distinct form groups. In 8000 collections of urediniospores a new form was encountered about once in 100 collections, whereas in 71 collections made near rusted barberries 19 belonged among the 26 recognized forms, and 1 had never before been encountered within the United States. 
Physiologic forms have been demonstrated to exist among other varieties of $P$. graminis and among other cereal rusts. Knowledge of these matters requires perusal of the reports of the extensive researches by Stakman and his associates.

\section{Classification of Uredinales}

There are two outstanding extensive monographic treatises dealing with classification of the rusts: that by Arthur (19071931), published in The North American Flora; and Monograpbia Uredinarum, a four-volume series by the Sydows (1904-1924). The Sydows' first volume is devoted to Puccinia, the second to Uromyces, the third to all other genera, and the fourth to imperfect, cycled species. Other less comprehensive but very useful taxonomic works include those by Arthur (1934), Cunningham (1931), Eriksson and Hennings (1896), Faull (1932, 1934, 1938), Grove (1913), Kamei (1940), Kern (1911), Klebahn (1904), Long (1903), and McAlpine (1906).

The Sydows (1904-1924) separate the rusts into 3 families as follows:

1. Promycelium external

2. Teliospores free, loosely fascicled, fused into a compound head, or in chains, but never compacted laterally into crusts; usually pedicellate

Pucciniaceae

2. Teliospores fused laterally to form a crust, or in columns, rarely occurring singly in the host tissue; not stalked

Melampsoraceae

1. Promycelium internal, teliospores fused laterally, forming waxy closely adherent crusts

Coleosporiaceae

Arthur (1907-1931) employed essentially the same characteristics in his familial separations, but in his Manual of the Rusts in the United States and Canada only 2 families, the Melampsoraceae and the Pucciniaceae, are recognized. The Melampsoraceae are divided into + tribes, Puccinastreae, Cronartieae, Melampsoreae, and Phakosporeae; and the Pucciniaceae into 3 tribes, Ravenelieae, Phragmidieae, and Aecidieae.

\section{Important Species of Rusts}

The rusts are of great economic importance because of the losses that they cause from their attacks, especially on cereals but 
also on fruits and vegetables, on fiber and forage crops, on ornamentals, and on forest and shade trees. Among all these, Puccinia graminis, with its varieties tritici, avenae, and secalis, is undoubtedly the most destructive, and is world-wide in distribution. Puccinia glumarum causes stripe or yellow rust of wheat, rye, and barley throughout the Old World, and was introduced into the Western Hemisphere about 25 years ago. Puccinia triticina, causing leaf rust and producing aecia on Thalictrum, is another important rust of wheat. Puccinia coronata, the crown rust, attacks oats and bears its aecia on Rhamnus. The common leaf rust of rye, $P$. rubigo-vera ( $P$. dispersa), is coextensive in range with its host and bears aecia on Anchusa. Oxalis stricta serves as the aecial host for corn rust, $P$. sorghi. This rust is widely distributed in North America but normally does not cause serious losses.

Among fruit rusts no other produces losses comparable in magnitude to those caused by Gymnosporangium. The monograph of Kern (1911) lists 40 species, all heteroecious except $G$. bermudianumin. None has a uredinial stage except G. nootkatense, occurring on Chamaecyparis nootkatensis. Crataegus serves as aecial host for 11 species, Amelanchier for 12, Pyrus for 7, Malus for 6, Sorbus for 6, Aronia for 4, Cydonia for 5, Cotoneaster for 2, Pourthiaea 2, and Peraphyllum, Fendlera, Porteranthus, Philadelphus, 1 each. Two species, G. juniperi-virginianne and G. globosum, commonly attack apples in North America, and one, G. yammadae, attacks this fruit in the Orient. In the United States, G. claripes is the most serious of the pear and quince rusts; in Europe, G. sabinae. The foliage and also twigs of stone fruits, especially peaches, cherries, and plums, are subject to attack by Tranzschelia pruni-spinosae, whose aecial stage is produced on Anemone, Hepatica, and Thalictrum.

Cronartium ribicola, the cause of blister rust in five-needle pines, is among the best known and most destructive of tree rusts. Its pycnial and aecial stages appear on the trunks and branches of white pines, and the uredinial and telial stages occur on the foliage of currant (Ribes) and gooseberry (Grossularia). The pycnial stage first appears several years after inoculation; the aecial stage (peridermium) may not appear until the following year. The mycelium within pines is perennial and forms annual 
crops of aeciospores throughout the life of the infected branch or tree.

Throughout the southeastern United States Cronartium quercuum and C. cerebrum incite the production of stem galls on pines. This stage (peridermium) on young trees causes dwarfing and crippling. The uredinial and telial stages occur on the lower leaf surface of various oaks.

Cronartium coleosporioides (C. barknessii) causes the formation of stem galls on ponderosa pine and other pines of the western United States. The uredinial and telial stages of this rust occur on certain Scrophulariaceae, especially species of Castilleja and Pedicularis.

Nearly a score of rusts having aecial stages on the needles of various pines occur throughout North America. The aecial stages of all are pink tubular protrusions, and all appear quite alike. The uredinial and telial stages of each are restricted to certain genera of composites, such as goldenrod or sunflowers, or to species of Senecio, Parthenium, Coreopsis, Euthamia, Sonchus, or Elephantopus.

A group of widely spread rusts belonging to Uredinopsis and Milesia attacks various species of firs. Ferns constitute their alternate hosts. Uredinopsis macrosperma on Pteridium aquilinium can persist from year to year in the complete absence of firs. Several species of Melampsora attack larch foliage. One of them, M. medusae, bears pycnia and aecia on species of Populus, and another, M. bigelowii, on species of Salix. Melampsora lini is widely prevalent wherever flax is grown. It is full-cycled but autoecious. Melampsora farlowii, common on hemlock leaves, twigs, and cones, has telia only.

Throughout all tropical countries Cerotelinm fici is the common fig rust.

Hemileia wastatrix, with peculiar urediniospores that are echinulate only on the exposed upper surface, has long been known to cause a serious disease of coffee in the tropics of the Old World. Although it has greatly restricted coffee production there, as yet it has not become established in the Western Hemisphere.

The most important rusts on vegetable crops include Puccinia asparagi on asparagus, Uromyces appendiculatus on beans, Uromyces fabae on peas, and Puccinia subnitens on beets. All are 
autoecious except $P$. subnitens, the telial host of which is salt marsh grass. Disticlalis spicata.

Florists and gardeners have widely encountered Uromyces caryophyllinus on carnations. Puccinia clarysanthemi on chrysanthemums, $P$. malvaceanm on hollyhocks, $P$. antirrbini on snapdragons, and various species of Phragmidium on roses.

\section{LITER.ATURE CITED}

Allex, R. F., "A cytological study of heterothallism in Puccinia triticina," J. Agr. Research, 44:734-754, 1932.

"A crtological study of heterothallism in Puccinia coronata," J. Agr. Resextcl. 45: 513-541, $1932 \mathrm{a}$.

"A cytological study of heterothallism in flax rust," J. Agr. Research, 49: -65-791. 1934.

"A crtological study of heterothallism in Puccinia sorghi," J. Agr. Rese.sicle, 49: 1047-1068, 1934a.

ANDrts. C. F." "The mechanism of sex in Uromyces appendiculatus and U. :ignae," J. AgT. Research, 42:559-587, 1931.

ARTHLR. J. C.. "Taxonomic importance of the spermogonium," Bull. Torrey Bot.zn. Club, 31:125-159. 1904.

"Amphispores of the grass and sedge rusts," Bull. Torrey Botan. Club, 32: 35-41. 190 5.

"'Uredinales," North. Ant. Flord, 7: 83-969, 1907-1931.

Mamual of the rusts in United States and Canada. 438 pp. Lafayette, Ind. 1934.

Arthir, J. C., et al., The plant rusts (Uredinales). $4+6$ pp. John Wiley and Sons. New York. 1929.

Ashrorth, Dorothr, "An experimental and cytological study of the life history of Endoplyllum semperizi," Trans. Brit. Mycol. Soc., 19: $240-258,1934$.

Barclar, A., "On the life history of a remarkable uredine on Jasminum grandiflorum L. (Uromyces cunninghamiamus, n. sp.)," Trans. Linn. Soc. London, 3: 141, 1891.

BARI. ANTOx DE, "Recherches sur le déreloppement de quelques champignons parasites," Ann. sci. nat. Bot.an., ser. 4, 20:5-148, 1863. (Vide pp. 68-101.)

*Neue Untersuchungen über die Uredineen, insbesondere die Entwickelung der Puccinia graminis und den Zusammenhang derselben mit Aecidium berberidis," Monatsber. K. Preuss. Acad. Wiss. Berlin, 1865: $15-49,1865$.

Blackinax, V. H., "On the fertilization, alternation of generations, and general cytology of the Uredineae," Amn. Botany, 18:323-373, 1904.

Blackilax, V. H., ANd Helex C. I. Fraser, "Further studies on the sexuality of the Uredineae." Amn. Botany, 20:35-48, 1906. 
Brows, A. M., "A study of coalescing haploid pustuies in Puccinia helianthi," Phytopatbology, 25:1085-1090, 1935.

"The sexual behavior of several plant rusts," Can. J. Research, 18: 18-25, 1939.

Btzler, A. H. R., "Fusions between flexuous hyphae and pycnidiospores in Puccinia graminis," Nature, 141:33-34. 1938.

Christmax, A. H., "Sexual reproduction in the rusts," Bot.m. Guz., 39:26:$275,1905$.

"The alternation of generations and the morphology" of the spore forms in the rusts," Botan. Giz., 44:81-101, 1907.

Colley, R. H., "Parasitism, morphology, and cytology of Cronartizm ribicola," J. Agr. Research, 15:619-660, 1918.

Craigie, J. H., "Discovery of the function of the pronia of the rust fungi." Nature, 120: 765-767, 1927.

"An experimental investigation of sex in the rust fungi," Phytopatloology, 21: 1001-1040, 1931.

Cexischis, G. H., The rust fungi of New Zealand, together with the biology, cytology, and therapentics of the Uredinales. $\mathrm{xx}+261 \mathrm{pp}$. 1931.

Dietel, P., "Über die wirtwechselnden Rostpilze," Zentr. Bakt., Parasitenk., II Abt., 48: 470-500, 1918.

Dodge, B. O., ANd L. O. Gaiser, "The question of nuclear fusions in the blackberry rust, Caeoma nitens," J. Agr. Research, 32: 1003-1024, 1926.

ERIKsso:, J., "Über die Specialisierung des Parasitismus bei den Getreiderostpilzen," Ber. deut. botan. Ges., 12: 292-331, 1894.

"Die heutige Stand der Getreiderostfrage," Ber. deut. botan. Ges., 15: 183$194,1897$.

"The researches of Professor H. Marshall Ward on the brown rust of the bromes and the mycoplasm hypothesis." Arch. Botm., 1: 139-145. 1903.

"The mrcoplasm theory: Its scientific importance and practical signinicance," Bull. Agr. Internat. Inst., Monthly Bull. Agr. Intel. Plant Dis., 13:269-280, 1922.

ERIKssox, J.. ANd E. Hexings, Die Getreideroste, ihre Geschichte. und -Natur, sowie Massregeln gegen dieselben. 463 pp. Stockholm. 1896.

Fatll, J. H., "Taxonomy and geographical distribution of the genus Milesia," Contrib. Arnold Arboretum, 2:1-1;8, 1932.

"The biology of Milesian rusts," J. Amold Arboretım, 15:50-85. 1934. "The biology of rusts of the genus Uredinopsis," J. Arnold Arborettrn, 19: $402-436,1938$.

Fromine, F. D., "The morphology and cytology" of the aecidium cup." Botan. Guz., 58:1-35. 1914.

Grore, IV. B., "The evolution of the higher Uredineae." New Plytologist, 12: 89-106, 1913.

The British rust fungi (Uredinales), their biology and classification. 412 pp. Cambridge. $1913 \mathrm{a}$.

Hedgcock, G. G., "A key to the known aecial forms of Coleosporium oc- 
curring in the United States and a list of the host species," Mycol., 20: 97-100, 1928.

JAcksox, H. S., "Present erolutionary tendencies and the origin of life cycles in the Uredinales," Ment. Torrey Botan. Club, 18: 1-108, 1931. KAMIEI, S., "Studies on the cultural experiments of the fern rusts in Japan," J. Faculty Agr., Hokkaido lmp. Univ., 77. 191 pp. 1940.

KERN, F. D., "The morphology of the peridial cells in the Roesteliae," Botan. Gaz., 49:445-452, 1910.

"A biologic and taxonomic study of the genus Gymnosporangium," Bull.

N. Y. Botan. Garden, 7: 391-483, 1911.

Klebahx, H., Die W'irtwecloselnden Rostpilze. 447 pp. Berlin. 1904.

Kuxkel, L. O., "The production of a promycelium by the aecidiospores of Caeoma nitens Burrill," Bull. Torrey Botan. Chab, 40:361-366, 1913. "Nuclear behavior in the promycelia of Caeoma nitens Burrill and Puccinia peckiana Howe," Am. J. Botany, 1:37-46, 1914.

Loxi, M. H., "The Ravenelias of the United States and Mexico," Botan. Gaz., 35: 111-133, 1903.

McAlpine, D., The rusts of Australiat. vii +349 pp. Melbourne, 1906. Moreau, F., Axd Mine. F., "Les Uredinées du groupe Endophỵllum," Bull. soc. botan. France, 66:14-44, 1919.

Moss, E. H., "The uredo stage of the Pucciniaceae," Amn. Botany, 40:813847, 1926.

Olive, E. WV., "Sexual cell fusions and vegetative nuclear divisions in the rusts," Amn. Botany, 22: 331-360, 1908.

"Origin of heteroecism in the rusts," Ploytopatbology, 1: 139-149, 1911.

Ortox, C. R., "A working hypothesis on the origin of rusts, with special reference to the phenomenon of heteroecism," Botan. Gaz., 84: 113-138, 1927.

PADY, S. M., "The role of intracellular mycelium in systemic infections of Rubus with the orange rust," Mycol., 27:618-637, 1935.

Piersox, R. K., "Fusion of pycniospores with filamentous hyphae in the prcnium of the white-pine blister rust," Nature, 131:728-729, 1933.

Poirault, G., axd M. Raciborski, "Sur les noyeaux des Uredinées," J. Bot., 9: 318-332, 381-388, 1895.

Rice, Mabel A., "The relation of Uromyces caladii and other rusts to their hosts," Bull. Torrey Botan. Club, 61: 155-162, 1934.

SAPPIN-Trouffr, P., "Recherches histologiques sur la famille des Uredinées," Botaniste, 5: 59-244, 1896.

Stakiax, E. C., M. N. Levine, R. U. Cotter, axd Lee Hixes, "Relation of barberry to the origin and persistence of physiologic forms of Puccinia graminis," J. Agr. Research, 48:953-969, 1934.

SrDow, P. AND H., Monograplsia Uredinarum, seu speciemun omminm ad bunc usque diem descriptio et adumbratio systematica. Leipzig. 1:972 pp., 1904; 2:396 pp., 1910; 3:728 pp., 1915; 4:670 pp., 1924.

IVARD, H. Marshall, "On the relations between host and parasite in the bromes and their brome rust, Puccinia dispersa Erik.," Ann. Botany, 16: $233-315,1902$. 
"On the histology of Uredo dispersa Erik., and the mycoplasm hypothesis," Plil. Trans. Roy. Soc. London, B, 196:29-46, 1903.

Whetzel, H. H., H. S. Jackson, axd E. B. Mains, "The composite life history of Puccinia podoplsylli Schw.," J. Agr. Research, 30:65-79, 1925.

\section{HOMOBASIDIOMYCETES}

\section{Hraienomiretes (Agaricales)}

As considered in this book, the Agaricales include 6 families of fungi. Some mycologists regard certain of these families as of ordinal rank and the tribal groupings as of familial rank. These 6 families are separated as follows:

1. Basidiocarps lacking; parasitic on vascular plants Exobasidiaceae

1. Basidiocarps present; saprobic or parasitic

2. Basidiocarps arachnoid, membranaceous, leathery or woody, effused, shelving or erect; hymenium plane

Thelephoraceae

2. Basidiocarps fleshy to cartilaginous; clavate to coralloid; hymenium amphigenous

Clavariaceae

2. Basidiocarps fleshy gelatinous, cartilaginous, or leathery, variable in form; hymenium typically of spines or tubercules Hydnaceae

2. Basidiocarps fleshy, leathery, or woody, resupinate, shelving, or pileate; hymenium pitted, poroid, daedaloid, or lamellate

Polyporaceae

2. Basidiocarps usually fleshy, mostly stipitate and pileate, a few shelving; hymenium lamellate

Agaricaceae

\section{Exobasidiaceae}

The fungi included in the Exobasidiaceae, approximately 30 species, are parasitic on leaves, stems, flowers, and fruits. Exobasidium typifies the family. Its species produce marked hypertrophy and hyperplasia, especially on Ericaceae. Exobasidium vaccinii deforms the shoots and leaves of cranberry, Oxycoccus macrocarpon, and related species of Vaccinium. Exobasidiunn rbododendri incites the formation of large vesicular galls, especially on the leaves of Rhododendron catawbiense and $R$. maximum. Exobasidium symploci causes galls to form on Symplocus tinctoria. On Azalea E. discoideum may induce the formation of hypertrophies 3 to $5 \mathrm{~cm}$ tall, which resemble somewhat the basidiocarps of Cantharellus.

Long ago Woronin studied Exobasidium, and more recently it was subjected to detailed study by Eftimiu and Kharbush 
(1927). The mycelium is abundantly intercellular, branched haustoria occurring within the host cells. The clavate basidia extend above the surface between the epidermal cells, much as do the asci in Taphrina. Each basidium bears from 2 to 8 basidiospores. In culture the basidiospores of most species of Exoba-

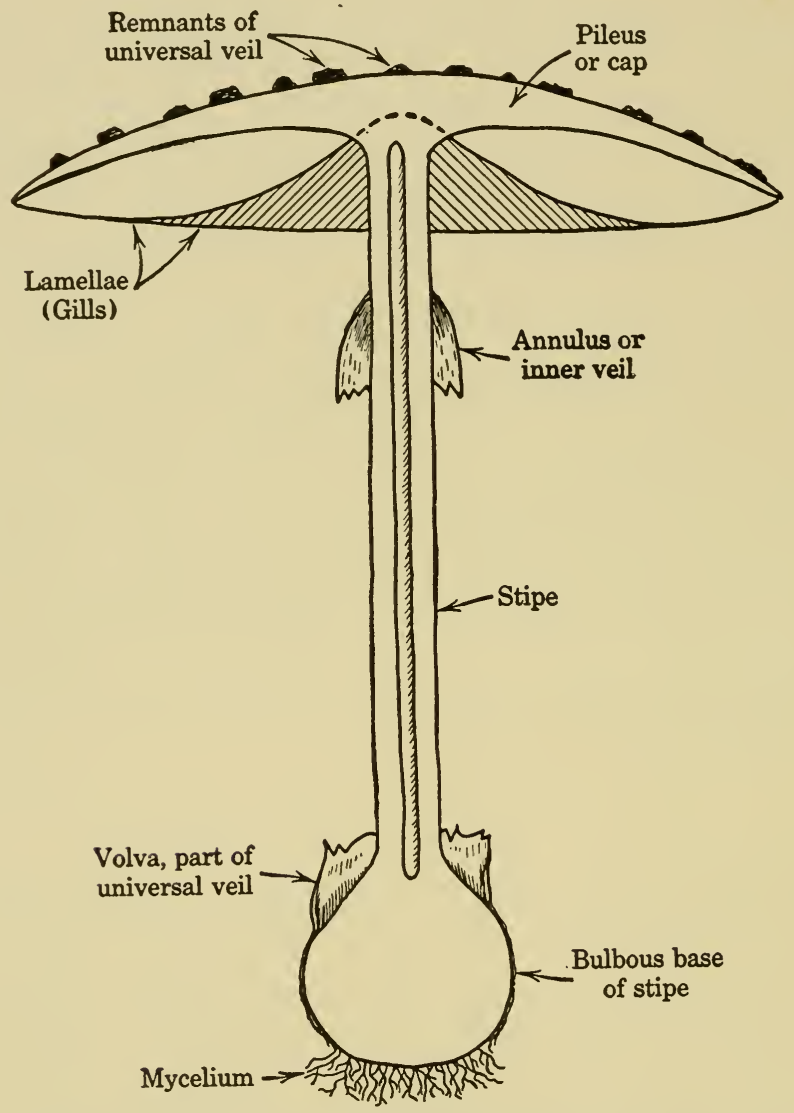

FIG. 128. Structural features of a mature fruit body of Amanita, in diagram.

sidium germinate in the manner of yeasts; E. rhododendri, which forms germ tubes, is a notable exception.

Host differences have been largely employed in distinguishing species of Exobasidium, but it appears that the validity of such specific distinctions can be established only by reciprocal infection experiments. Such experiments remain to be performed. 
Kordyana, causing necrotic spots on tropical species of Commelinaceae, forms fascicles of basidia and sterile hyphae that emerge from the stomata. The basidia are variable in form and are 2-spored. From illustrations of $K$. polliae in the study by Gäumann (1922), this genus may well be judged to be related to Microstroma, which appears to be established among the Fungi Imperfecti [Wolf (1929)].

\section{Thelephoraceae}

This family contains approximately 20 genera and 1000 species of membranaceous to leathery fungi in which the hymenial surface is smooth or only slightly contoured. Under the title "The Thelephoraceae of North America" Burt (1914-1926) published a series of taxonomic papers, the most comprehensive treatise
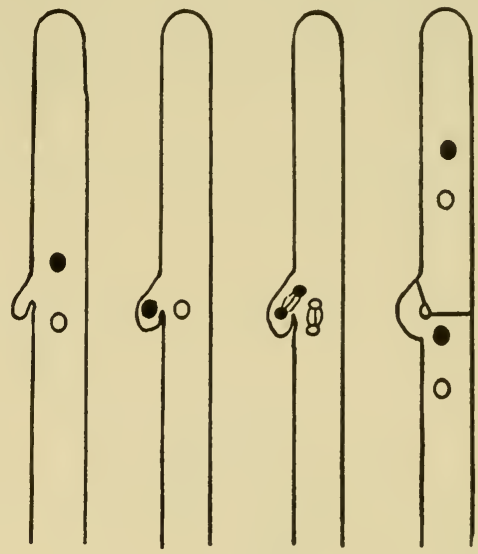

FIG. 129. Stages in formation of a clamp connection. The dicaryotic cell is a hyphal tip, and nuclear division is conjugate. extant on the family. Many Thelephoraceae are important causes of decay in woody plants.

The sporocarps vary in shape from crustose or resupinate to bracket-shaped or funnel-shaped structures with the hymenium on one surface only. Sterile elements occur interspersed with basidia in a few genera, such as Aleurodiscus; in Peniophora and Hymenochaete they are sharp-pointed, whereas in Asterostroma they are stellate. These sterile elements are given different names based on shape and consistency. If they are hair-like, they are cystidia; if thickened and awl-like, they are setae; and corneous or gelatinous gloeocystidia. The nature of the sterile elements is taken into consideration in the separation of genera and of species.

Little consideration has been given the developmental morphology of Thelephoraceae except in a few species. Corticium vagum, widely known as a stem and root parasite of many kinds of economic plants, forms its oval basidia sparsely on an arach- 
noid or loosely compacted subiculum. Its Rbizoctonia solani stage may form compact brown sclerotia capable of withstanding long periods of unfavorable weather. Corticium koleroga is equally widely distributed in tropical and subtropical regions and produces thread blight of leaves, fruits, and twigs of many species of trees and shrubs. Its mycelial stage also belongs to Rhizoctonia, and sclerotial formation is in part determined by whether
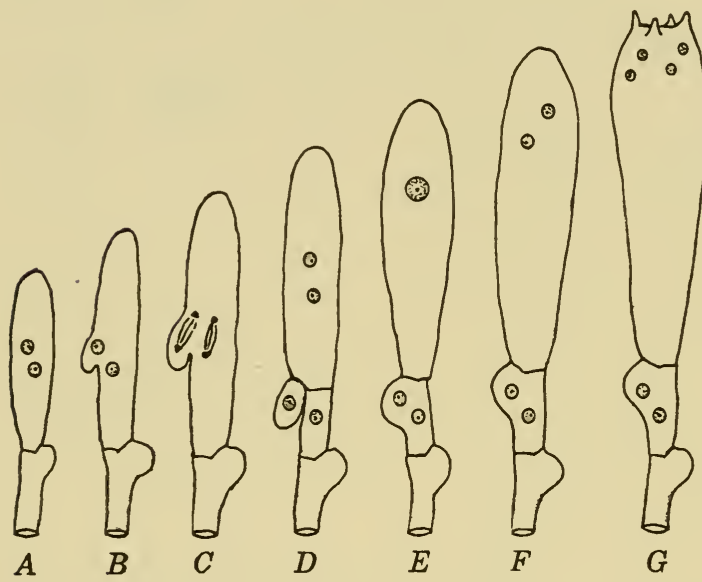

E

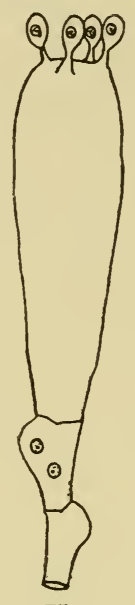

H

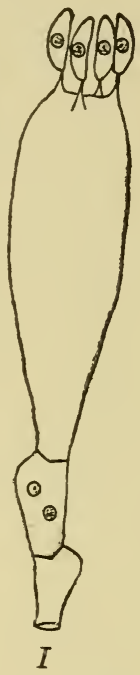

Fig. 130. Diagrammatic representations of stages in transformation of a dicaryotic hyphal tip into a basidium.

the host tissues have a roughened surface. Most species of Corticium have a papery to leathery hymenophore and lack the Rhizoctonia stage. Peniophora is quite like these kinds of Corticium, but awl-shaped cystidia are interspersed among the basidia. In the southeastern United States $P$. gigantea is one of the important fungi involved in the decay of pine pulpwood stacked in yards. Coniophora cerebella also causes dry rot of coniferous wood throughout North America.

Thelepbora fimbriata and $T$. terrestris grow up from the soil of nursery beds and smother or strangle tree seedlings. They seem unable to penetrate living host tissues but are able at times to cause serious losses in forest-tree nurseries.

Stereum is among the larger genera. Burt (1920) lists 80 
species as occurring in North America. In the account of Overholts (1939) 27 species are recognized in Pennsylvania. Certain of them, notably Sterenm gausapatum, cause decay of oak-sprout growth, especially if the sprouts arise high on the stumps. On oaks and other hardwoods S. frustulosum produces a wide-spread white pocket rot.

\section{Clavariaceae}

The Clavariaceae, or coral fungi, comprise 8 or more genera and approximately 500 species. Nearly all are saprophilous, oc-

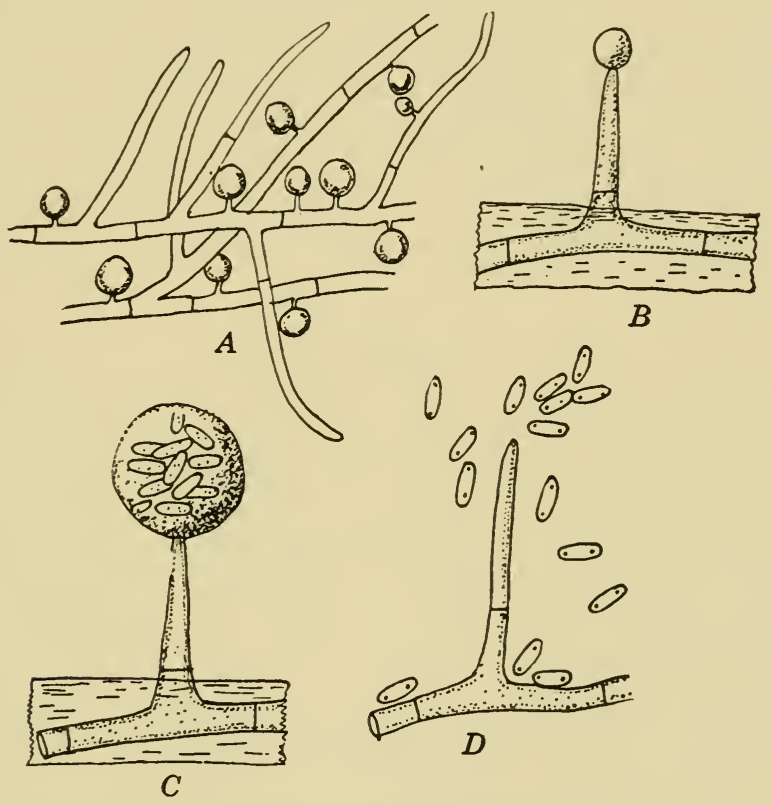

FIG. 131. Oidial production by Coprinus lagopus. A. Diagram showing 48-hour-old haploid mycelium on the surface of dung agar, with short lateral oidial fructifications. $B$. Single oidiophore with an excreted drop of liquid at its apex. C. Oidia held together at apex of oidiophore in a drop of liquid. D. When oidiophore is immersed in film of water, the oidia are dispersed. (Adapted from Brodie.)

curring on the leaf mold of the forest floor, some few are quite surely mycorrhizal, and a few are pathogenic. Their fructifications are fleshy, cartilaginous, gelatinous, or, rarely, leathery; they range from clavate to much-branched and coralloid. Some 
are tiny, being about $1 \mathrm{~cm}$ tall, whereas others, such as Sparassis crispa, may attain a diameter of nearly 0.5 meter. Clavariaceae undoubtedly possess among the most beautiful of fungus fructifications. Many species are edible.

The monograph by Coker (1923), dealing with species of Clavaria occurring in Canada and the United States, is most serviceable for identification of species in these countries. That by Cotton and Wakefield (1918) serves for identification of British species.

Of most importance, perhaps, is Sparassis radicata, reported by Weir (1917) to kill and decay the roots and the sapwood of basal portions of trunks of fir (Pseudotsuga taxifolia), pine (Pinus monticola), and spruce (Picea engelmannii). The fructifications have a long, very compact, root-like base, into which soil particles may be incorporated, and which extends down to the deeper lateral tree roots. This root-like base terminates in rhizomorphs that penetrate the host; eventually the host roots succumb.

\section{Hydnaceae}

The Hydnaceae are characterized by possession of spiny or toothed hymenial surfaces. The fructifications may be resupinate, pileate, or stalked, varying in consistency from fleshy to leathery or woody. The Hydnaceae comprise 10 to 15 genera and approximately 600 species. Nearly all are saprophytic on wood, but a few cause heartwood rots of trees. Others occur on the forest floor.

Taxonomic studies of this family have been conducted by Banker (1906), Miller (1933, 1933a, 1934, 1934a), and Miller and Boyle (1943), and their reports are invaluable in the identification of species.

Hydnum coralloides (also given the generic names Manina and Hericium) may form large fructifications on decaying logs. Hydnum erinaceus (Manina cordiformis) forms white conchoid fructifications, 13 to $15 \mathrm{~cm}$ across, with long-pointed, pendant teeth. The fructifications extend from branch scars on Nyssa, Quercus, Liquidambar, Platanus, and other hardwoods. Echinodontium tinctorium forms large corky to woody fructifications on Tsuga in the Pacific Northwest and is an important cause of 
decay of standing timber. Hydnum septentrionale induces heartwood rot of maples.

\section{Polyporaceae}

The Polyporaceae, or pore fungi, as treated in this book, comprise about 20 genera and perhaps 2000 species. They are of enormous importance as the cause of disease of standing timber

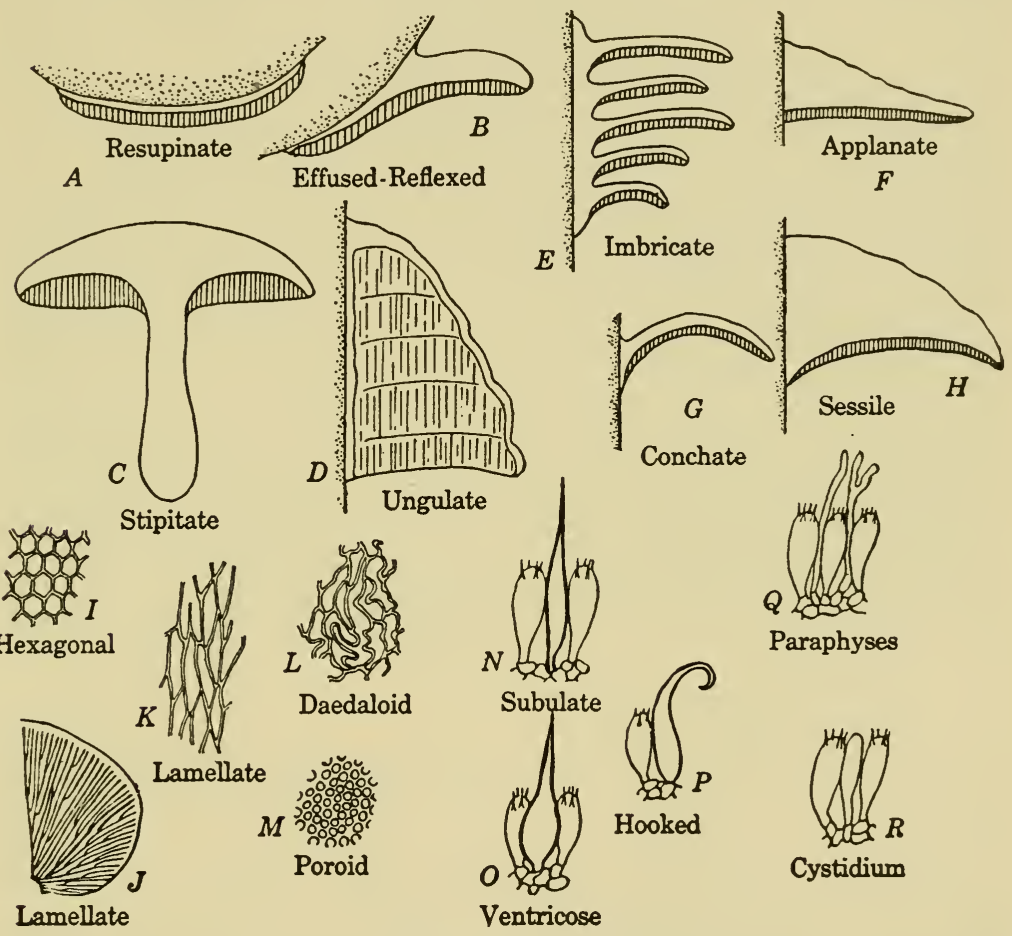

Fig. 132. Structural characters employed in identification of polypores, including: $A$ to $H$, types of fruiting bodies, $I$ to $M$, pore surfaces, $N$ to $P$, setae, $Q$, paraphyses, $R$, cystidium.

and decay of logs and lumber. Many American students have devoted themselves to problems of the taxonomy and classification of the polypores; among them are Murrill (1907-1908, 1910), Ames (1913), Overholts (1914, 1915), Burt (1917), Baxter (1927, 1929, 1932, 1933, 1934), Shope (1931), Humphrey and Leus (1931), and Lowe (1934). Similarly many mycologists in other 
parts of the world have given these fungi critical study. Accord has not been reached on generic and specific limits, as is evident from the fact that Murrill (1907-1908) recognizes 78 genera of North American polypores, whereas others reduce this number to less than 20. Among the structural features which appear to constitute rational bases for generic distinction are: (1) consistency of the fructification, whether fleshy, gelatinous, leathery, corky, or woody; (2) shape of the fructification, whether resupinate, effuse-reflexed, bracket-like, applanate, ungulate, or stipitate; (3) shape of the pores, whether circular, angular, labyrinthiform, daedalioid, or lamelliform; (4) nature of the pore layer, whether the pores are separable from the context (tissue of the pileus), whether the tissue of the pileus extends between the pores, whether the pores are shallow corrugations or well-defined pores, whether the pores are separate peg-like tubes, or whether their contiguous walls are united.

The Polyporaceae may rather conveniently be divided into the following 4 tribes, according to Hennings:

a. Basidiocarp effuse, at first plane but having fold-like elevations which anastomose to make shallow and irregular pits

Meruleae

a. Basidiocarp having tubes, alveolar areas, labyrinthiform passages, or radiating lamellae

b. Substance of the hymenium continuous with dissepiments of the tubes; tubes not readily separable from the context (hymenophore)

c. Tubes closely contiguous

c. Tubes standing singly

Polyporeae

Fistulineae

b. Substance of hymenium easily separable from the hymenophore

Boleteae

Meruleae. Merulius lacrymans, which typifies the genus, causes dry rot of woodwork in buildings. Extension of the fungus is accomplished by fibrous rhizomorphs. It forms widespreading gelatinous to cartilaginous fructifications that are reticulately folded or corrugated. Burt (1917) found that the basidia are mature while the hymenial surface is still plane and that, by subsequent growth, folds appear; thus the basidia clothe the edges of the folds as well as the sides and bottom. In other Polyporaceae the pores are formed in advance of the maturation of basidia; hence some workers would exclude Merulius from this family. 
Poly poreae. In Poria are placed all fleshy, leathery, or woody strictly resupinate forms having true pores. In a sense it is a form genus, since normally shelving species may at times be resupinate. The hymenium continues to develop centrifugally, new pores being formed in the zone near the margin. Baxter $(1927,1929,1932,1933,1934)$ has devoted himself to the difficult problem of classification of this genus. All species may

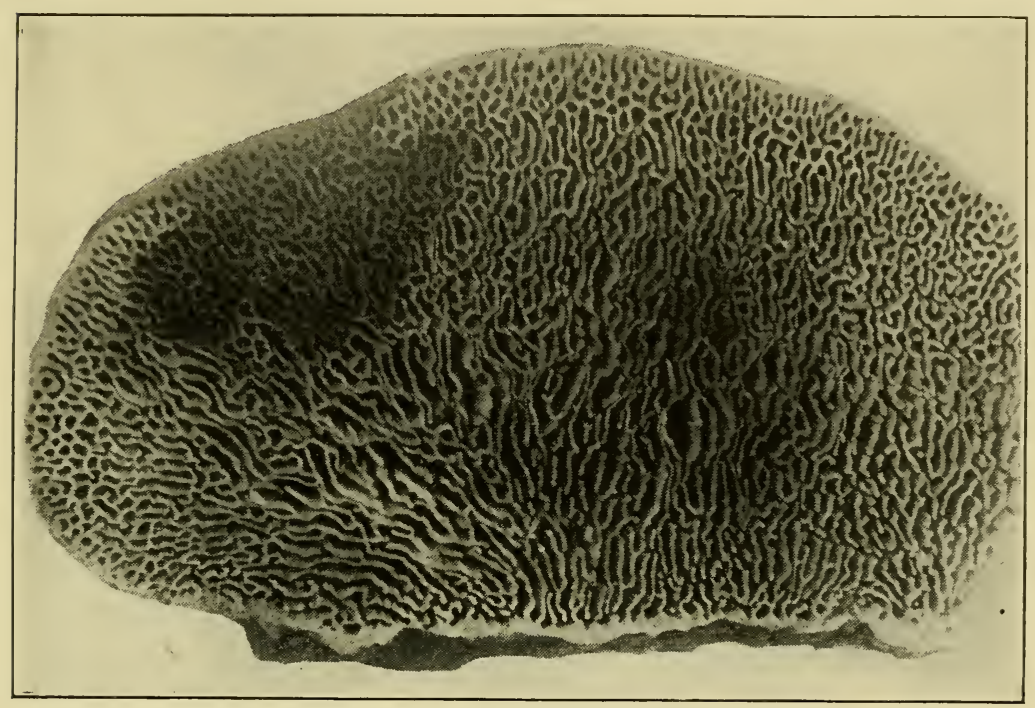

FIG. 133. Daedalea quercina, lower surface of fructification.

cause decay of timber, some being especially destructive to beams, floors, mine props, and lumber piled in yards. Notable among these fungi are $P$. vaporaria and $P$. incrassata [Humphrey (1923)].

Polyporus includes a large number of species of pore fungi having shelving or stalked fructifications that may be fleshy when young but become hardened, leathery, or corky at maturity. The pore layer is usually quite different in texture and color from the remainder of the pileus. As thus delimited, Polyporus may well include several generic types.

Polyporus versicolor and $P$. pargamenus are perhaps the most commonly encountered members of this genus. They cause decay of many species of deciduous woody plants, just as $P$. abietimus does of coniferous species. Polyporus sulphureus, occurring 
at the base of deciduous trees, especially oaks, produces large, fused, imbricated shelves that are conspicuous because of their bright sulphur-yellow to orange color. Polyporus cinnabarinus has bright, cinnabar-colored brackets, especially on decaying oak branches. Polyporus schweinitzii is a common cause of butt rot of overmature coniferous trees.

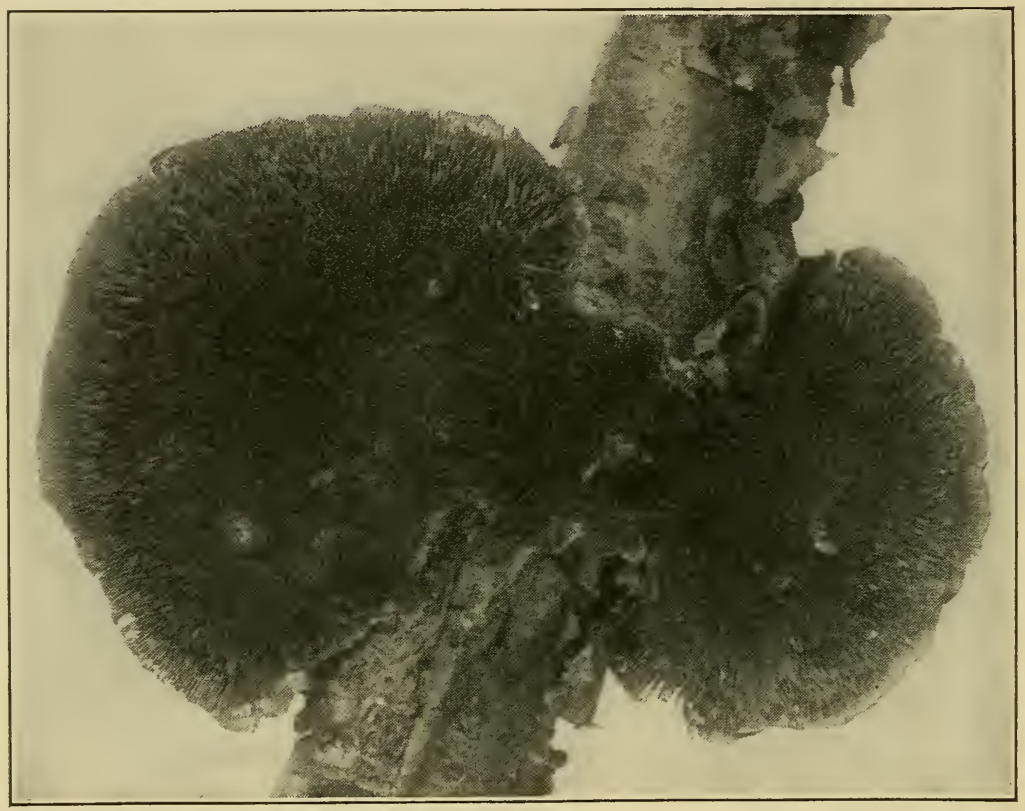

FIG. 134. Daedalea confragosa on birch.

Considerable interest has always centered around the polypores that produce giant sclerotia. The best known among them are $P$. sapurema from Brazil and $P$. mylittiae from Australia. The Australian species may attain a weight of 30 to 40 or more $\mathrm{lb}$. On the roots of various trees, especially pines, in the southeastern United States occur sclerotia that may attain a weight of over $20 \mathrm{lb}$. The polypore responsible, according to Wolf (1922) and Weber (1929), is Poria cocos.

The Genus Fomes includes perennial punky to woody polypores. A new layer of pores is formed each year over that of the preceding year. Among the smaller species is $F$. obioense, with ungulate conchs about $1 \mathrm{~cm}$ in diameter; $F$. applanatus may 
have brackets nearly 1 meter in their largest dimension. Fomes igniarius, $F$. pini, and $F$. robustus, causing heartrot of standing timber, have large hoof-shaped fructifications with as many as 40 to 80 layers of pores. Fomes annosus causes root rot and basalstem rot of conifers in Europe. Its fructifications form near the surface of the soil and may have incorporated in them twigs, leaves, and stones. In culture this fungus bears conidia belong-

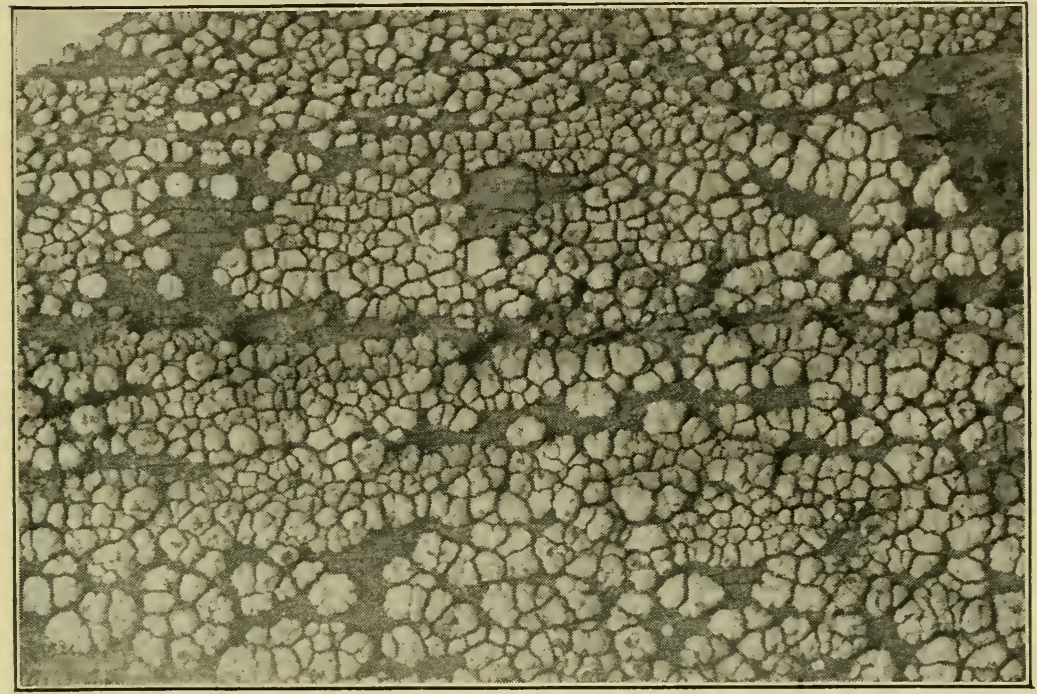

Fig. 135. Stereum frustulosum on oak.

ing to Oedocephalum globuliferum. Studies [Miller (1942)] show that the incidence of root rot and butt rot on Juniperus virginiana caused by $F$. annosus in the southeastern United States is correlated with the degree of competition between cedars and the hardwoods that overtop them.

Fistulineae. Fistulina bepatica, called the beef-steak fungus, grows widely on deciduous trees, especially oaks. Its large, fleshy, fan-shaped fructifications, brown-red on the outside and blood-red within, are attached by thick stipes. The hymenium is beset with closely crowded, but separate, tubes that are closed when young but open at maturity.

Boleteae. The fructifications of this tribe are fleshy, pileate, and mostly centrally stipitate. The pileus is thick and convex, 
and the stipe is stout. Boleteae grow on the forest floor, and many of them are mycorrhizal and always associated with a certain species of tree. The development of boletes has been studied by Zeller (1914), Yates (1916), and Kühner (1926). Boletus (Ceriomyces) zelleri and B. parasiticus, the second of which grows on the pilei of other boletes, are gymnocarpous. In Bo-

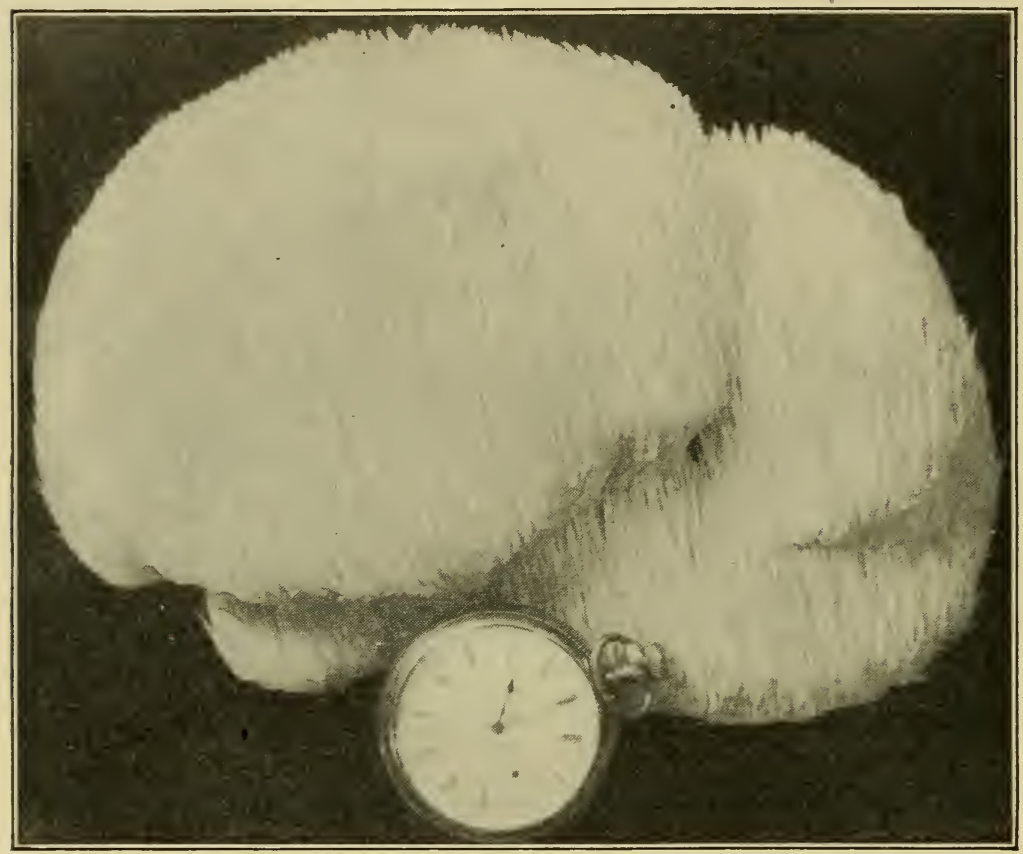

Fig. 136. Fructification of Manina cordifornis (Hydnum erinaceus).

letimus cassipes and Strobilomyces strobilaceus, however, an endogenous annular furrow appears, and a partial veil covers the young pore surface. As the pileus expands, the remnants of the veil remain as a ring surrounding the stipe or as a cortina on the margin of the pileus. Volvoboletus appears to possess a universal veil. The members of the other tribes of Polyporaceae are all gymnocarpous except Cryptoportus volvatus. The course of development among the Boleteae inclines some mycologists [Yates (1916)] to regard them not as polypores but as agarics. The taxonomic studies by Murrill (1910), Snell (1936), and Coker and Beers (1943) should be used in identification of this tribe. 


\section{Agaricaceae}

The Agaricaceae constitute approximately 100 genera and 10,000 species. Nearly all are fleshy, centrally stipitate, pileate forms. A few, notably Pleurotus, Claudopus, and Crepidotus,

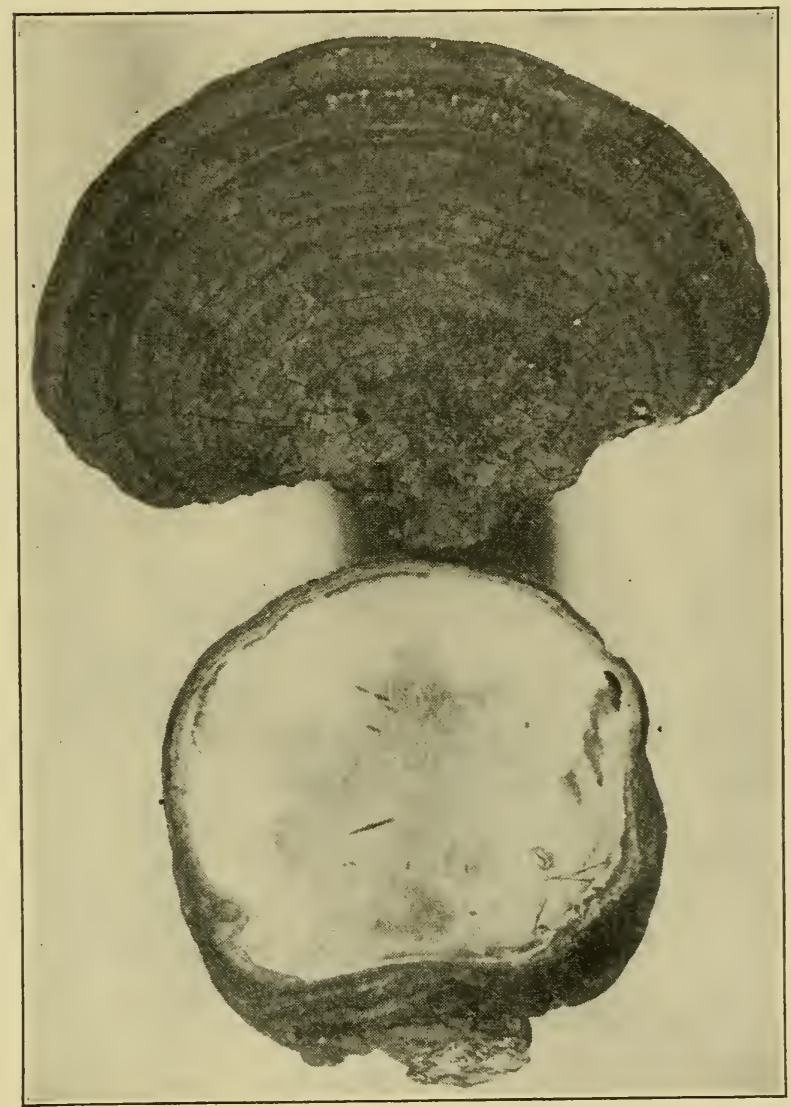

Fig. 137. Conchs of Fomes applanatus, as seen from above and from the pore surface.

are laterally attached and conch-shaped. The feature which characterizes the family is the hymenial surface of radiating gills or lamellae.

This family is of importance mainly because its members accomplish the decomposition of dead plant tissues in the soil and 
because they form mycorrhizae, mainly on forsst trees. A few are pathogenic; Armillaria mellea on orchard and forest trees [Thomas (1934)] and Marasmius sacchari on the roots of sugar cane are the best-known parasitic species. Nyctalis asterophora and $N$. parasitica parasitize other agarics.

Marasmius saramentosus causes "horse-hair blight" of cacao in the tropics, and other species of this genus also are known to

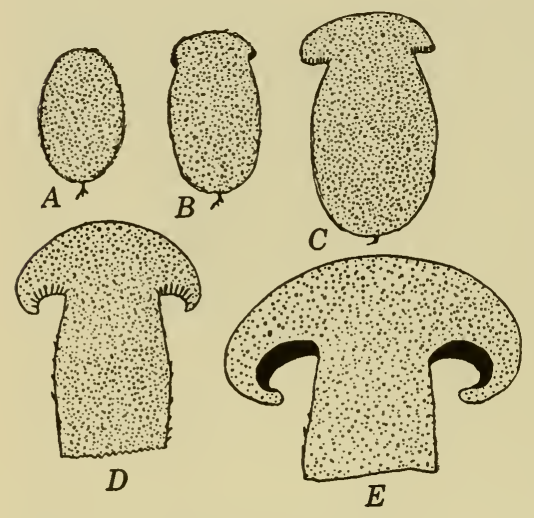

FIG. 138. Diagrammatic sections of developing basidiocarps of Mycena subalkalina, of gymnocarpous type. $A$. Undifferentiated "button." $B$. Initiation of pileus at apex of stipe. C. Hymenial surface becoming apparent at lower edge of young pileus. $D$. Lamellar development has progressed, and margins of pileus are rolled inward toward the stipe. $E$. Development of lamellae is well advanced. (Adapted from Douglas.) cause thread blights of forest trees. Marasmius crinis-equi is not uncommon on oaks in the Gulf Coast states.

The fructifications vary greatly in size and durability. Those of some species of Mycena may have pilei a few millimeters in diameter that are very ephemeral. Schizopbyllum commune, which is quite leathery, can be dried repeatedly but revives on being moistened. In fact, it is remarkably adapted to xerophytism. Agaricus arvensis may have pilei $40 \mathrm{~cm}$ in diameter. The fructifications of Amanita solitaria attain a height of $30 \mathrm{~cm}$ with pilei 20 $\mathrm{cm}$ in diameter. The shaggymane mushroom, Coprinus comatus, has been recorded to have fructifications $36 \mathrm{~cm}$ tall and pilei $25 \mathrm{~cm}$ in circumference.

Development of BASIDIOCARPS AMIONg Agarics. The development of basidiocarps among gill fungi is none too well understood, mainly for the reason that relatively few species have been studied. The status of this subject can best be appreciated from examination of reports by Atkinson (1906, 1914, 1914a, 1914b, 1916), Douglas (1916, 1918, 1920), Sawyer (1917, 1917a), Moss (1923), and Hein (1930).

The fruit bodies of gill fungi are commonly called mushrooms 

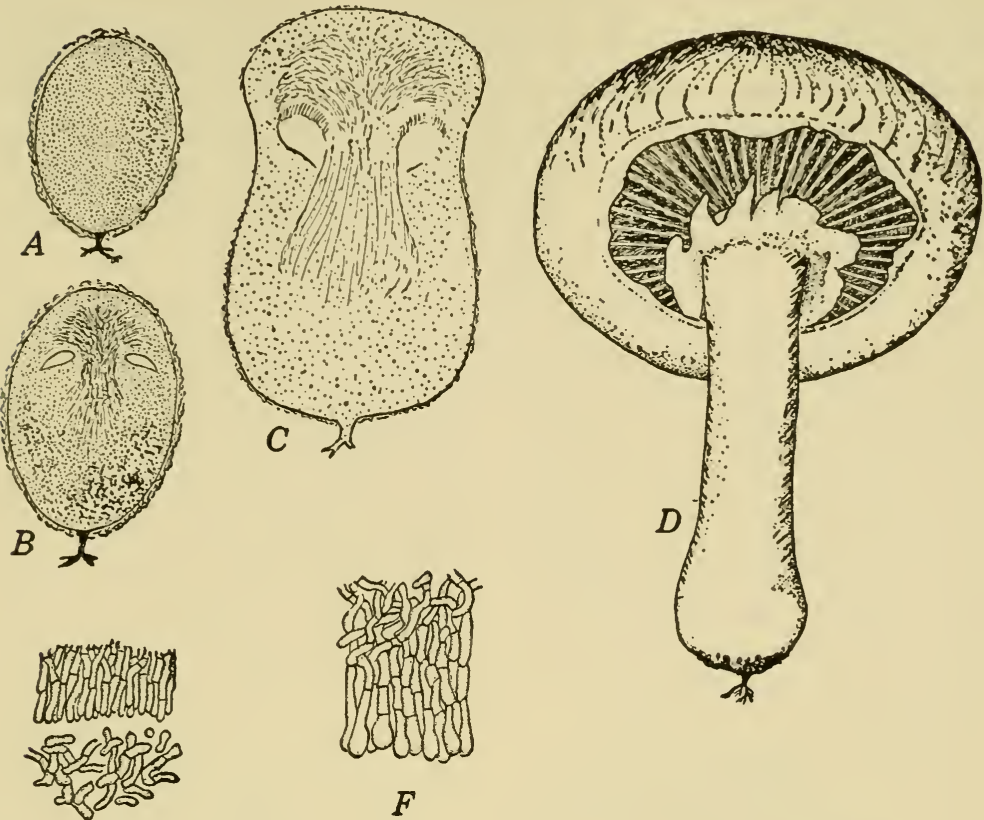

F

E
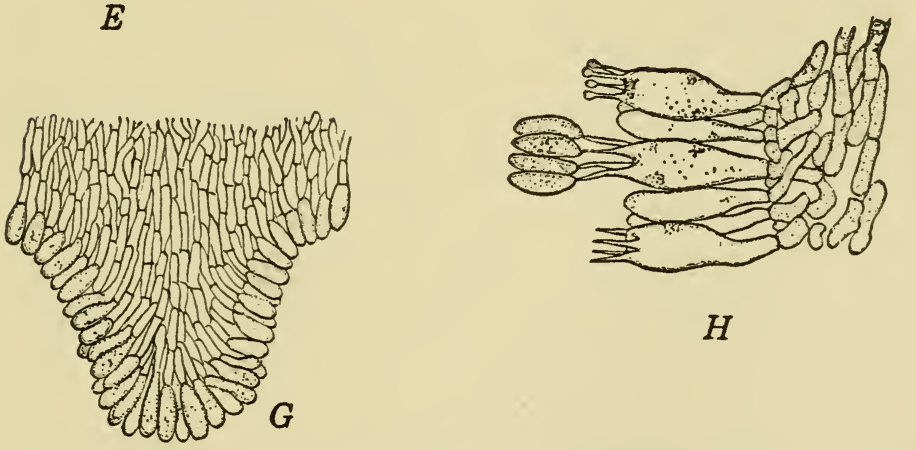

FIG. 139. Diagrammatic sections of developing basidiocarp of Psalliota campestris. A. Undifferentiated egg. B. An annular cavity has formed, marking the site of developing lamellae. $C$. Pileus and stipe have developed to the extent of being evident. D. Expanding pileus with inner veil ruptured to expose the lamellae. $E$. Detail of cavity, as in $B$, with downwardcoursing hyphae at the ceiling. $F$. Detail of these same hyphae, as in C. G. Later stage in growth of gill that extends into the cavity. $H$. Bit of mature hymenium and subhymenium. 
or toadstools. The vegetative portion of a typical one, Amanita, exists in decaying leaf mold as white threads or strands. Small, compact white spherical bodies (buttons) that may be found along these strands constitute the initials of fruit bodies. If they are properly cut in half, it may be observed that a membrane, the universal veil, invests the entire button and that the central axis is occupied by the developing stipe with the pileus or cap at the top. The edges of the cap curve downward. A circular chamber soon appears, surrounding the stipe toward the upper end. This chamber enlarges as development proceeds, and lamellae or gills, radiately arranged, grow into it. The edges of the gills approach the stipe but are separated from it by a thin tissue, the veil, which connects the gill edges and surrounds the stipe. At the approach of maturity the stipe elongates, and the gills open in an umbrellalike fashion. As they do, the universal veil is ruptured but persists as a cup (volva) at the base of the stipe and as scales on the upper surface of the pileus. The veil covers the gills below and eventually ruptures to leave a ring (annulus) around the stipe. As the cap expands, the gills, arranged like spokes in a wheel, hang with their edges directed downward. The surface of the gills is the hymenium (fruiting layer), which consists of a palisade of club-shaped basidia. Each basidium bears four basidiospores that are discharged forcibly into the space between gills. Air currents disseminate the basidiospores.

The student soon learns to distinguish certain of the more common genera of mushrooms. Amanita, Amanitopsis, and Lepiota are white-spored with gills free from the stipe and can be recognized because Amanita possesses a volva and an annulus, Amanitopsis a volva only, and Lepiota an annulus only. Russula and Lactarius, also white-spored, have firm, thick caps and short, thick stipes that are spongy-stuffed within. They differ in that Lactarius possesses "milk" that exudes when the pileus is injured and may rather quickly become yellow, blue, orange, pink, greenish, or gray. Clitocybe and Tricholoma are white-spored, do not possess an annulus or a volva, and have fleshy, fibrous stipes with a cartilaginous rind. The gills of Clitocybe are decurrent or broadly adnate; of Tricholoma, sinuate. Cantharellus has thick, decurrent gills that are forked. Cortinarius is ochre-spored and possesses a cobweb-like veil. Pleurotus and Claudopus have 
eccentric stipes, those of Pleurotus being white-spored and those of Claudopus pink-spored. Psalliota is purple-brown-spored and has an annulus, and its gills are free from the stipe. Coprinus is black-spored, and its gills deliquesce.

Several developmental types exist among gill fungi. In Hygrophorus, Cantharellus, and Clitocybe the gills are gymnocarpous,

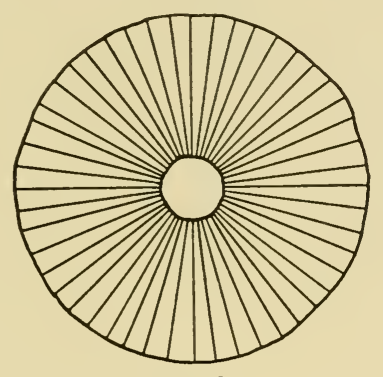

Equal

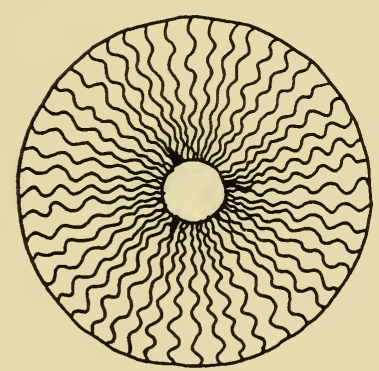

Flexuous

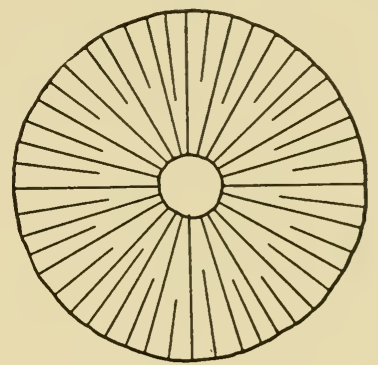

Unequal

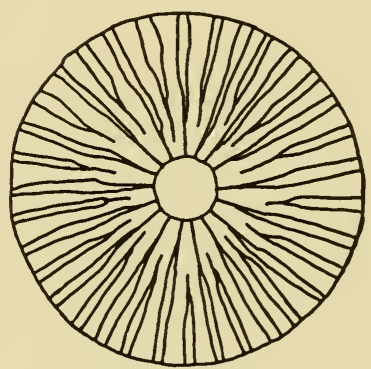

Dichotomous

Fig. 140. Diagrams of gill characters, as shown by the lower surface of the pileus.

arising around the lower edge of a dome-shaped portion that is to be the pileus. The lower margin of the pileus arches downward toward the stipe primordium, and the hyphae from each may intertwine below the developing gills. In Armillaria, Coprinus, Lepiota, Lactarius, Marasmius, Russula, and other genera a schizogenously formed furrow encircles the stipe primordium, marking the beginning of the differentiation of pileus and stipe. This furrow arises endogenously, and hyphae from the ceiling of the furrow grow downward to form the gills. The thin layer of fundament tissue beneath the furrow and extending from the 
margin of the pileus to the stipe is the inner veil or partial veil. Since it may not increase by the addition or formation of new hyphal elements, it may escape detection when the pileus expands to the extent of exposing the gills to the exterior. On the other hand, the partial veil may be reinforced to such an extent that, when the pileus expands, it will remain as an annulus, movable or not, surrounding the stipe, or as a frayed cortina hanging from the edge of the pileus, or both annulus and cortina may exist. The annulus becomes well developed in Amanita, Armillaria, Coprinus, Lepiota and Psalliota, and in Cortinarius arachnoid cortinae exist at the lower edge of freshly expanded pilei.

Quite a distinct additional structure occurs in Amanita and Amanitopsis. Surrounding the entire outer surface of the young button, like an egg shell, is a membranaceous layer, the universal veil. As the pileus expands, this shell ruptures circumscissilely, and its remnants may then be seen as scales at the upper surface of the pileus and as a cup-like sheath or volva around the base of the bulbous stipe. The partial veil in Amanita is also strongly developed and may grow as the pileus expands, eventually tearing at the rim of the pileus; it then hangs skirt-like around the stipe.

The universal veil has been demonstrated as an external layer around the primordia of Agaricus arveneis, $A$. campestris, $A$. comtulus, and Amanitopsis raginata [Atkinson (1914)].

Classificatrox. In classifying agarics it is essential first of all to divide them into wholly artificial tribes, the groupings being based upon color of the spores, as follows: (1) Leucosporae, spores hyaline; (2) Rhodosporae, spores pink to red; (3) Ochrosporae, spores yellow to ochre; (4) Melanosporae, spores dark brown, purple, or black. Manifestly the use of spore color as a primary basis of division results in separating similar genera into different tribes. If spore color cannot be determined by direct examination, a spore print should be made.

The characters next employed in distinguishing genera include: (1) shape of the pileus; (2) consistency and character of the stipe and its attachment to the pileus; (3) shape, arrangement, and attachment of the gills; (4) presence or absence of annulus, cortina, and volva; (5) nature of the pilear surface and stipe and their markings. With experience genera soon come to be satisfactorily recognized, but specific distinctions are much more difficult. Size and color of the fructifications, size and markings 
of the spores, presence of cystidia, presence of latex and its change of color on exposure, and change of color of basidiocarps on being bruised and their taste are among the features that must be

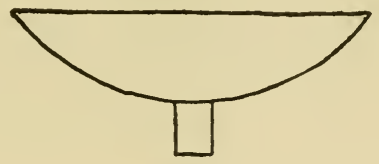

Plane

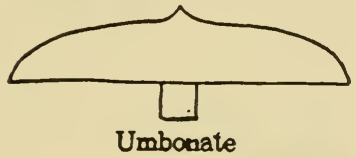

Umbonate

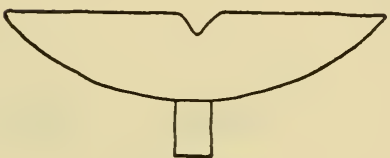

Umbilicate

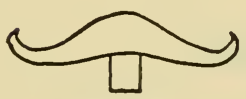

Reflexed

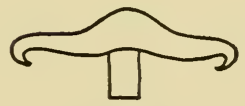

Involute

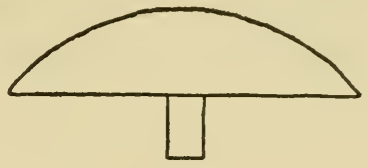

Convex

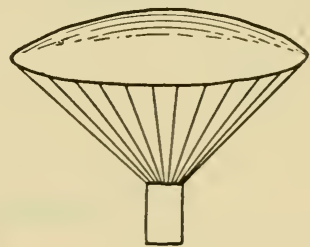

Infundibuliform
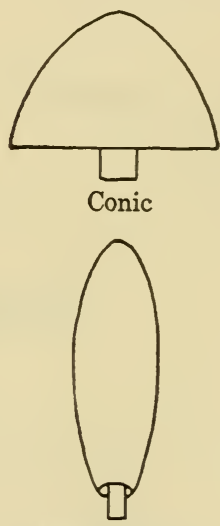

Campanulate

FIG. 141. Characteristic shapes of pilei, in diagram, used in distinguishing genera of mushrooms.

taken into account in distinguishing species. Experienced mycologists admit that species are separated on minor differences and that among the larger genera the species are monotonously similar.

The bibliography on the taxonomy of Agaricaceae is very extensive, a fact which can be appreciated by consultation of the references in North American Flora, Volume 9. Many of the 
treatises are comprehensive, for example, those of Gibson (1895), Atkinson (1900), Kauffman (1918), Murrill (1910-1916, 19141932), Rea (1922), Güssow and Odell (1927), Lange (1934), and Krieger (1936). Many other very useful papers are monographs of individual genera, such as those by Burlingham (1908) on Lactarius, by Coker (1917) on Amanita and Amanitopsis and

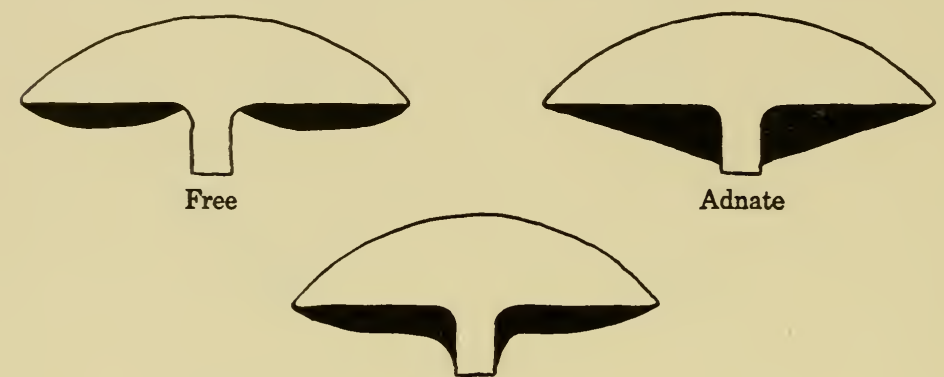

Decurrent

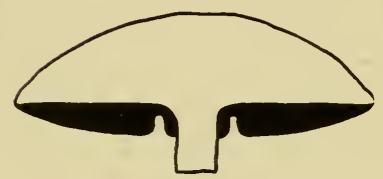

Sinuate

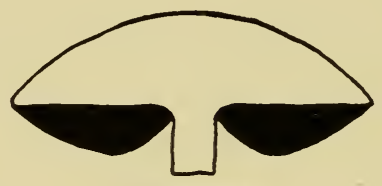

Ventricose

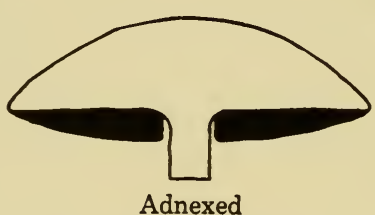

FIG. 142. Diagrams representing the manner in which gills of mushrooms may be attached to the stipe.

(1922) on Laccaria and Clitocybe, by Beardslee (1918) on Russula, by Coker and Beardslee (1921) on Collybia, and by Overholts (1927) on Pholiota.

Among the agarics none has greater interest to mycologists than Coprinus, pilei of which deliquesce during discharge of spores. The pilei, especially of the larger species, are campanulate. Buller (1910) demonstrated that the gills undergo autodigestion upward from the lower rim of the pileus. The gills are propped apart by cystidia. The basidiospores mature progressively upward from the lower pilear margin and are discharged, falling free in the interlamellar spaces. The gills and 
cystidia undergo digestion progressively in the zone immediately behind that from which spores have been discharged.

FAIRY RINGS. From time to time over a period of more than 100 years certain Basidiomycetes have been observed to produce fructifications in rings, called "fairy rings." Such rings arise by initiation of growth at some point, followed by centrifugal spread of mycelium through the soil. The diameter of the ring increases from year to year. As the mycelium advances, the organic matter is decomposed and exhausted, so that recession is impossible. Shantz and Piemeisel (1917) made an extensive study of fairy-ring formation by Agaricus tabularis in grasslands of Colorado. They also noted from previous records that more than 50 species of agarics, boletes, and puffballs, which they list, are known to produce fairy rings.

\section{LITERATURE CITED}

Ames, Adeline, "A consideration of structure in relation to genera of the Polyporaceae," Ann. Mycol., 11:211-253, 1913.

Atrinson, G. F., Studies of American fungi. 275 pp. Andrus and Church, Ithaca, N. Y., 1900.

"The development of Agaricus campestris," Botan. Gaz., 42: 241-264, 1906. "Homology of the "universal veil' in Agaricus," Mycolog. Centr., 5: 1319, 1914.

"The development of Lepiota clypeolaria," Ann. Mycol., 12:346-356, 1914a.

"The development of Amanitopsis raginata," Ann. Mycol., 12:369-392, 1914b.

"Origin and development of the lamellae in Coprinus," Botan. Gaz, 61: 89-130, 1916.

Banker, H. J., "A contribution to a revision of the North American Hydnaceae," Mem. Torrey Botan. Club, 12: 99-144, 1906.

Baxter, D. V., "Some Porias from the region of the Lake States," Mich. Acad. Sci., 6: 67-76, 1927; 9:39-46, 1929.

"Some resupinate polypores from the region of the Great Lakes," Mich. Acad. Sci., 15: 191-228, 1932; 17: 421-439, 1933; 19:305-332, 1934.

Beardslee, H. C., "The Russulas of North Carolina," J. Elisha Mitchell Sci. Soc., 33: 147-199, 1918.

Buller, A. H. R., "The function and fate of the cystidia of Coprinus atramentarius, together with some general remarks upon Coprinus fruit bodies," Ann. Botany, 24: 613-628, 1910.

Burlingham, G. S., "A study of the Lactariae of the United States," Mem. Torrey Botan. Club, 14: 1-109, 1908.

Burt, E. A., "The Thelephoraceae of North America. I. Thelephora," Ann. Mo. Botan. Garden, 1:185-228, 1914. 
II. "Craterellus," 1:327-350, 1914a.

III. "Craterellus borealis and Cyphella," 1:357-382, 1914b.

IV. "Exobasidium," 2:627-658, 1915.

V. "Tremellodendron, Eichleriella, and Sebacina," 2:731-770, 1914c.

VI. "Hypochonus," 3: 203-241, 1916.

VII. "Septobasidium," 3: 319-343, 1916a.

VIII. "Coniophora," t:237-269, 1917.

IX. "Aleurodiscus," 5: 301-372, 1918.

XI. "Tulasnella, Veluticeps, Mycobonia, Epithele, and Lachnocladium," 6: $253-380,1919$.

XII. "Stereum," 7: \$1-248, 1920.

XIII. "Cladoderris, Hypolyssus, Cỵmatella, Skepperia, Cytidia, Solenia, Matrouchotia, Microstroma, Protocoronospora, and Asterostroma," 11: $1-36,1924$.

XIV. "Peniophora," 12: 213-257, 1925.

XT. "Corticium, and supplement to the whole series," 13: 173-354, 1926.

"Merulius in North America," Amm. Mo. Botant. Garden, 4:305-362, 1917 a.

COKER, IV. C., "Amanitas of the eastern United States," J. Elisha Mitchell Sci. Soc., 33: 1-88, 1917.

"The Laccarias and Clitocybes of North Carolina," J. Elisha Mitchell Sci. Soc., 38: 98-126, 1922.

The Clazarias of the United States and Candad. 209 pp. Unirersity of

North Carolina Press, Chapel Hill. 1923.

Coker, WV. C., ANd H. C. Beardslee, "The Collybias of North Carolina," J. Elisha . Mitchell Sci. Soc., 37: 83-107, 1921.

Coker, W. C., ANd Alina H. Beers, The Boletaceae of Nortl Carolina. vii +95 pp. University of North Carolina Press. 1943.

Colsox, Barbara, "The cytology" of the mushroom Psalliota campestris Quél.," Ann. Botany, 49:1-18, 1935.

Cotron, A. D., ANd E. M. Wakefield, "A review of the British Clavariae," Trans. Brit. Mycol. Soc., 6:16t-198, 1918.

Dougl.as, G. E., "A study of development in the genus Cortinarius," Am. J. Botany, 3:319-335, 1916.

"The derelopment of some exogenous species of agarics," Am. J. Botany, 5: 36-54, 1918.

"Early development of Inocybe," Botan. Gaz, 70:211-220, 1920.

EFThire, P., ANd S. KHarbesh, "Recherches histologiques sur les Exobasidiées," Rev. path. végétale entomol. agr. France, 14:62-88, 1927.

Gïtravi, E., "Über die Gattung Kordyana," Ann. Mycol., 20:257-271, 1922.

Gibsos, IV. H., Our edible toadstools and mushrooms and bow to distinguish them. $\mathrm{x}+337$ pp. Harper and Bros., New York. 1895.

Güssow, H. T., AND W. S. Odell, Musbrooms and toadstools. An account of the more common edible and poisonous fungi of Canada. $274 \mathrm{pp}$. F. A. Achland, Ottawa. 1927.

Heir, Illo, "Studies on morphogenesis in Agariculs (Psalliota) campestris," Am. J. Botany, 17: 882-915, 1930. 
Humphrey, C. J., "Decay of lumber and building materials due to Porix incrassata (B. and C.) Burt.," Mycol., 15:258-277, 1923.

Humphrey, C. J., ANd S. Leus, "A partial revision of the Ganoderma applanatum group with special reference to oriental variants," Plilipp. J. Sci., 45:483-589. 1931.

Katffarax, C. H., "The Agaricaceae of Michigan," Mich. Geol. Biol. Survey, Publ. 26, Biol. ser. 5, 1:1-924, 1918; 2: 1-101, 1918.

Krieger, L. C. C., The mushroom handbook. 538 pp. The Macmillan Co., New York. 1936.

KüHNER, R., "Contribution à l'étude des Hỵmenomycetes et specialement des Agaricacés," Botaniste, 17:1-224, 1926.

Lavge, Jаков E., Flora Agaricina Danica. 5 rols. Copenhagen, Denmark. 1934.

Lowe, J. L., "The Polyporaceae of New York State," N. Y. State Coll. Forestry Tech. Publ., 41: 1-142, 1934.

Miller, J. K., "Fomes annosus and red cedar," J. Forestry, 41:37-40, 1943.

Miller, L. W., "The genera of the Hydnaceae," Mycol., 25: 286-302, 1933.

"The Hydnaceae of Iowa. I. The genera Grandinia and Oxy-dontia," Mycol., 25:336-368, 1933 a.

II. "The genus Odontia," 26:13-32, 1934.

III. "The genera Radulum, Mucronella, Caldesiella, and Gloiodon," 26: 212-219, 193 ta.

Miller, L. W., Axd J. S. Boyle, "The Hydnaceae of Iowa," Uniz. Iowa Studies Nat. Hist., 18. 92 pp. 1943.

Moss, E. H., "Derelopmental studies in the genus Collybia," Trans. Roy. Can. Inst., 14: 321-335. 1923.

MItrrill, IT. A., "Polỵporaceae," North Am. Flora, 9:1-131, 1907-1908.

"Boletaceae," North Am. Flora, 9: 133-161, 1910.

"Agaricaceae," Nortb Am. Flora, 9: 162-426, 1910-1916; 10:1-328, 1914 1932.

Orerholts, L. O., "The Polyporaceae of Ohio," Ann. Mo. Botan. Garden, 1: 81-155, 1914.

"Comparative studies in the Polyporaceae," Ann. Mo. Botan. Garden, 2: 667-730, 1915.

"A monograph of the genus Pholiota in the United States," Ann. Mo. Botan. Garden, 14: 87-210, 1927.

"The genus Stereum in Pennsylvania," Bull. Torrey Botan. Club, 66: 515-537, 1939.

REA, C. British Basidionycetae, a landbook to the larger British fungi. $\mathrm{xi}+799$ pp. Cambridge University Press. 1922.

Sawyer, W. H., "The derelopment of Cortinarius pbolideus," Am. J. Botany, 4: 520-532, 1917.

"Derelopment of some species of Pholiota," Botan. Gaz., 64: 202-229, 1917a. 
Shaxtz, H. L., Axd R. L. Piemeisel, "Fungus fairy rings in eastern Colorado and their effect on regetation," J. Agr. Research, 11:191-245, 1917.

Shope, P. F., "The Polyporaceae of Colorado," Ann. Mo. Botan. Garden, 18: $287-456,1931$.

Sxell, IV. H., "Tentative keys to the Boletaceae of the United States and Canada," Rbode Island Botan. Club Publ., 1. 25 pp. 1936.

Thomas, H. E., "Studies on Armillaria mellea (Vahl.) Quél., infection, parasitism, and host resistance," J. Agr. Research, 48:187-218, 1934.

IVeber, G. F., "The occurrence of tuckahoes and Poria cocos in Florida," Mycol., 21: 113-130, 1929.

WEIr, J. R., "Sparassis radicata, an undescribed fungus on the roots of conifers," Plbytopatbology, 7: 166-177, 1917.

Wolf, F. A., "The fruiting stage of the tuckahoe, Pacbyma cocos," J. Elisha Mitchell Sci. Soc., 38: 127-137, 1922.

"The relationship of Microstroma juglandis (Bereng.) Sacc.," J. Elisha Mitchell Sci. Soc., 45: 130-135, 1929.

YAtes, H. S., "The comparative histology of certain California Boletaceae," Univ. Calif. Publ. Bot., 6: 221-274, 1916.

Zeller, S. M., "The development of the carpophores of Ceriomyces zelleri," Mycol., 6:235-239, 1914.

\section{Gastroniycetes}

The Gastromycetes (Gasteromycetes) include those basidial fungi having spores that are produced within closed basidiocarps. Some have subterranean fructifications that emerge as they approach maturity; others remain underground; a third type develops entirely aboveground. In some the basidiospores can escape only after disintegration of the outer or peridial tissues, and in others special means of dehiscence are provided. Some are stalked, others sessile. The Gastromycetes include approximately 120 genera and 1200 species.

The name Gastromycetes suggests the term puffballs, which is popularly applied to the fruit bodies of such typical ones as species of Lycoperdon, Bovista, Geaster, Scleroderma, and Pisolithus. In general, the puffball or fruit body of members of this order has the following course of development: Along the rhizomorphs (strands of compact, mycelial threads), which occur in decaying stumps and logs or in leaf mold, small, white spherical masses appear. As these enlarge, several regions become differentiated. The outer portion is a peridium consisting of one or more layers. At maturity the peridium of Lycoperdon and Bovista is soft and papery, whereas in Scleroderma it is firm and 
hard. Within the peridium is the gleba (spore-bearing tissue) with sterile tissue interspersed. Usually the gleba is chambered, and basidia are produced in a layer lining the chambers. Sub-

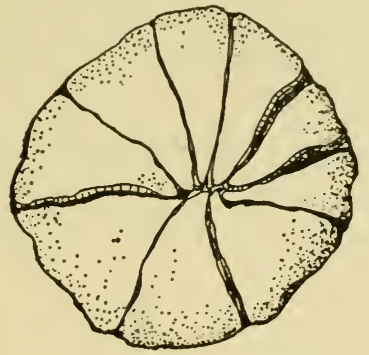

$A$

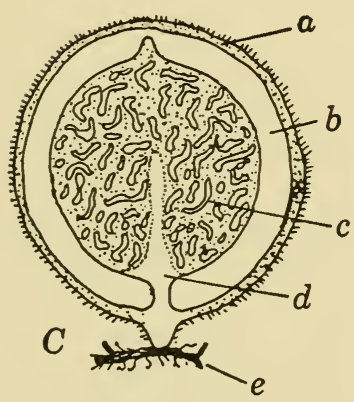

Fig. 143. Structural features of Geaster. $A$. The outer peridium splits into pie-shaped segments that remain folded inward during moist weather. $B$. The outer peridium turns outward on drying, thus exposing the globular inner portion of the fruit body. C. Diagram of structure of fruit body: $a$, outer layer; $b$, outer peridium; $c$, chambered glebal tissue; $d$, columella; $e$, rhizomorph. $D$. Hymenial fragments showing basidia that line the chamber wall. E. Basidia and basidiospores.

jacent to the basidia may be a network of "veins" (interglebal tissue) that serve for support and for food conduction. There may also develop a columella (sterile axial tissue), which is the stipe in Lycoperdon and other genera.

The basidiospores are not forcibly discharged, as they are among the Hymenomycetes. WVind is the agent of dispersal for most species. In many genera the hymenial tissues (gleba) 
undergo autodigestion, and only the powdery spore mass remains, at times interspersed with stiff, thick-walled threads, the capillitium, which functions in spore dissemination. In the Phallales the spore mass becomes slimy. In Sphaerobolus the entire gleba is discharged intact by a special mechanism. In the Nidulariales the masses of glebal tissues (peridioles) serve as disseminules.

The peridium is variable in structure. In Gautieria it is ephemeral and disappears early in the development of fructifications. As the opposite extreme, it is thick and firm in Sclero-

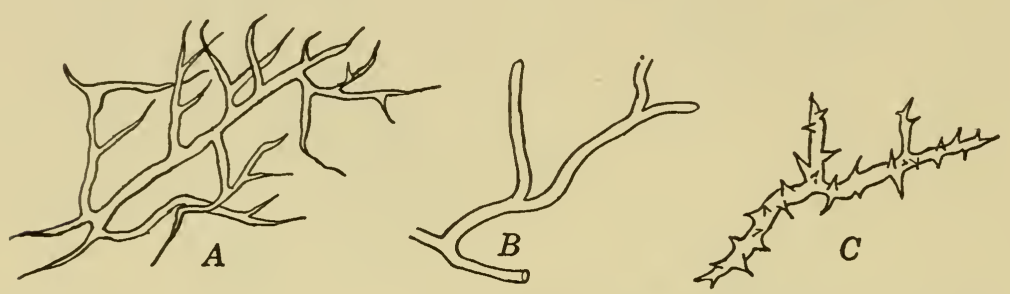

Fig. 144. Types of capillitium among puff balls. A. Capillitium of Bovista. $B$. Capillitium of Lycoperdon. C. Capillitium of Mycenastrum.

derma, rupturing irregularly and tardily in $S$. geaster to permit escape of the spores. The peridium is differentiated into layers in Geaster, the exoperidium everting to become a stalk, and the endoperidium becoming perforate by a special mouth for the escape of the powdery spores. The inner peridial layers in Sphaerobolus evert to project the glebal mass forcibly while it is still partly enclosed by the outer peridial layers.

Little success has attended efforts to grow Gastromycetes in artificial culture. The basidiospores are refractory to germination. Conidia have been reported for a few species only. All are saprophilic, although some species have been found to associate themselves with trees in a mycorrhizal relationship.

For the present purpose the Gastromycetes are divided into 6 orders, following the arrangement of Fischer (1933): Hymenogastrales, Podaxales, Sclerodermatales, Lycoperdales, Phallales, and Nidulariales. The general treatises of Massee (1901), Hollos (1904), and Coker and Couch (1928) should be consulted for the taxonomy of the Gastromycetes as a whole. For special genera the studies of Zeller and Dodge (1918, 1918a, 1919, 1924, 
1929), Lloyd (1898-1905), and Cunningham (1925, 1926, 1927, 1931, 1932) may be utilized.

Consideration will be given to the morphology and development of representative genera of each order as they are encountered in the brief accounts that follow. Special phylogenetic interest, however, centers on Gasterella lutophila, whose fructifications range from 200 to $700 \mu$ in diameter [Zeller and Walker (1935)]. Its basidiocarps are uniloculate, indicating that it is a primitive form.

\section{LITERATURE CITED}

CokeR, W. C., ANd J. N. Couch, The Gasteromycetes of the eastern United States and Canada. 201 pp. University of North Carolina Press, Chapel Hill. 1928.

Cunvingham, G. H., "The Gasteromycetes of Australia," Proc. Linnean Soc. N. S. Wales, 50: 245-258, 367-373, 1925; 51: 72-93, 363-368, 627-642, 1926; 52: 235-257, 1927; 56:1-15, 182-200, 277-291, 1931; 57:27-39, 313$322,1932$.

Fischer, E., "Gastromyceteae." In Engler and Prantl, Die natürlichen Pflanzenfamilien, 7a. 122 pp. Wilhelm Engelmann, Leipzig. 1933.

Hollos, G., Die Gasteromyceten Ungarns. 278 pp. Leipzig. 1904.

Lloyd, C. G., "The genera of the Gasteromycetes," Mycol. Writings, 1: $1-24,1902$.

Massee, George, "A monograph of British Gasteromycetes, Ann. Botany, 4: 1-103, 1901.

Zeller, S. M., and C. IV. Dodge, "Rhizopogon in North America," Ann. Mo. Botan. Garden, 5: 1-36, 1918.

"Gautieria in North America," Ann. Mo. Botan. Garden, 5:133-142, 1918a.

"Arcangeliella, Gymnomyces, and Macowanites in North America," Ann. Mo. Botan. Garden, 6: 49-59, 1919.

"Leucogaster and Leucophebs in North America," Ann. Mo. Botan. Garden, 11:389-410, 1924.

"Hysterangium in North America," Ann. Mo. Botan. Garden, 16: 83-228, 1929.

Zeller, S. M., and Leva B. IValker, "Gasterella, a new uniloculate Gasteromycete," Mycol., 27:573-579, 1935.

\section{Hymenogastrales}

This order includes perhaps 20 genera and more than 80 species of fungi having fructifications that develop in leaf mold or more deeply submerged in the soil. Some remain subter- 
ranean, whereas others emerge at maturity. The group is regarded generally as the most primitive of the Gastromycetes. As delimited in this book, it contains 3 families, separated as follows:

1. Basidiocarps minute, containing a single indehiscent, glebal locule Protogastraceae

1. Basidiocarps several centimeters in diameter, gleba of several locules, indehiscent

2. Tramal folds radiating from the base, not closely connected with the peridium

Hysterangiaceae

2. Tramal folds arising from the peridium

Hymenogastraceae

The fructifications usually originate as enlargements at the ends of rhizomorphs and are at first wholly undifferentiated. In the Protogastraceae, represented by Protogaster rbizophilus [Zeller (1934)] and Gasterella lutopbila [Zeller and Walker (1935)], the basal part of the basidiocarp remains sterile and develops upward as a conical peg into the single glebal locule.

Among the Hysterangiaceae the development of Phallogaster saccatus, Hysterangium stoloniferum var. americanum, and Gautieria graveolens was given consideration by Fitzpatrick (1913). In Phallogaster the columella is a continuation of the medulla of the rhizomorph. The chambered gleba has interposed sterile avenues that arise from the columella. These avenues eventually unite peripherally to form a gelatinous layer that separates the peridium from the glebal chambers. In Hysterangium the fertile tissues and peridium are not separated by a gelatinous layer. In Gautieria the peridium is present in the young basidiocarp, but it early dissolves and disappears.

In the Hymenogastraceae, represented by Hymenogaster, the development of columella is variable, but the gleba is filled with labyrinthiform cavities. In Hymenogaster luteus [Fischer (1927)] no columella is formed; in $H$. bebrii there remains a hemispherical, sterile basal portion. Fischer (1927) noted that glebal cavities arise in a dome-shaped area apically and just beneath the peridium, and subsequently others form basipetally.

Hydnangium carneum, studied by van Bambeke (1904), is of interest because the entire complement of 4 basidial nuclei may migrate into a single spore.

Problems of taxonomy and classification in this order are dealt with by Coker and Couch (1928) and Zeller and Dodge (1918, 
1918a, 1919, 1924, 1929). Among the more important genera Coker and Couch recognize 5 species of Hymenogaster, 10 species and 2 varieties of Hysterangium, 16 species of Rhizopogon, 2 species each of Phallogaster and Gautieria, and 6 species of Leucogaster. Zeller and Dodge recognize 16 North American species of Hysterangium and 12 that occur in other parts of the world. Their monographs list 15 species of North American Rhizopogon, 5 each of Gautieria and Leucogaster, 2 each of Leucophebs and Macowanites, and 3 each of Arcangeliella and Gymnomyces.

\section{LITERATURE CITED}

Bambeke, C. van, "Sur l'evolution nucléaire et la sporulation chez Hydnangium carneum Wallr.," Mem. acad. roy. sci. Belgique, 54:1-44, 1904.

Coker, W. C., ANd J. N. Couch, The Gasteromycetes of the eastern United States and Canada. 201 pp. University of North Carolina Press, Chapel Hill. 1928.

Fischer, E., "Mycologische Beiträge 32. Zur Entwickelungsgeschichte der Fruchtkörper von Hymenogaster," Mitt. naturf. Ges. Bern., 1926: 99108, 1927.

Fitzpatrick, H. M., "A comparative study of the development of the fruit body in Phallogaster, Hysterangium, and Gautieria," Ann. Mycol., 11: 119-149, 1913.

Zeller, S. M., "Protogaster, representing a new order of the Gasteromycetes," Ann. Mo. Botan. Garden, 21:231-239, 1934.

Zeller, S. M., and C. WV. Dodge, "Rhizopogon in North America," Ann. Mo. Botan. Garden, 5: 1-36, 1918.

"Gautieria in North America," Ann. Mo. Botan. Garden, 5:133-142, 1918a.

"Arcangeliella, Gymnomyces, and Macowanites in North America," Ann. Mo. Botan. Garden, 6:49-59, 1919.

"Leucogaster and Leucophebs in North America," Ann. Mo. Botan. Garden, 11: 389-410, 1924.

"Hysterangium in North America," Ann. Mo. Botan. Garden, 16:83228, 1929.

Zeller, S. M., aNd Leva B. Walker, "Gasterella, a new uniloculate Gasteromycete," Mycol., 27: 573-579, 1935.

\section{Podaxales}

This group of Gastromycetes includes forms in which the gleba is borne on the under or inner side of a centrally stipitate fructification resembling an ordinary mushroom. The order contains both gymnocarpous and angiocarpous representatives, 
since at maturity the peridium may surround the gleba completely or may merely surmount it to form a pileate structure on the lower surface of which the gleba is exposed. The gleba invariably is borne around a central columella, which is in reality a prolongation of the stalk of the fruiting body. Approximately 70 species of this order are classified in 2 families: the Secotiaceae, in which the gleba does not break up at maturity into a dry powdery mass, and the Podaxaceae, in which the gleba disintegrates when ripe.

The Family Secotiaceae is typified by Secotium, which is world-wide in distribution and has approximately 25 species. The genus is most common in Australia and New Zealand [Cunningham (1924)], but one representative, S. (Endoptychum) agaricoides, is found in the eastern United States. The development of $S$. agaricoides has been studied by Conard (1915) and Lohwag (1924), and two other species of Secotium have been investigated by Cunningham (1925). The fructification is completely angiocarpous, the thick peridium surrounding the gleba being fused with the stalk below. The gleba becomes divided into irregular masses by tramal plates, which may originate either from the inner surface of the peridium or from the columella and may become lamellate. The development of the four-spored basidia is characteristic of basidiomycetes in general. The spores, which may be either smooth-walled or warted, are liberated by a break in the peridium arising from elongation of the stalk and columella. According to Cunningham (1925), the spores become binucleate upon germination and thus give rise directly to a dicaryotic mycelium.

In the closely related Family Podaxaceae, Podaxis (Podaxon) is chiefly African in its distribution but may also be found in the western United States. The genus has been studied taxonomically by Massee (1890) and Patouillard (1890). In general appearance Podaxis is larger and more slender than Secotium. The friable outer surface of the peridium is shaggy or scaly and is confluent with the stalk both above and below the gleba. The glebal chamber is at times traversed by slender capillitial threads. Within the gleba are masses of basidia, each of which bears four sessile spores. Liberation of the spores begins, as in Secotium, by rupture of the peridium below the gleba as a consequence of elongation of the columella; the gleba, however, matures pro- 


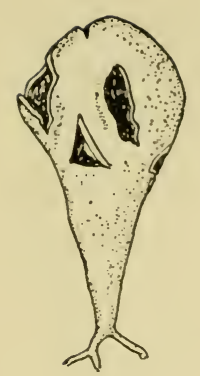

A

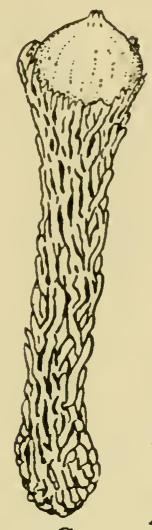

G

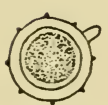

$R$

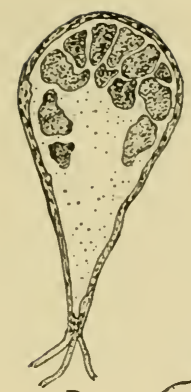

$B$
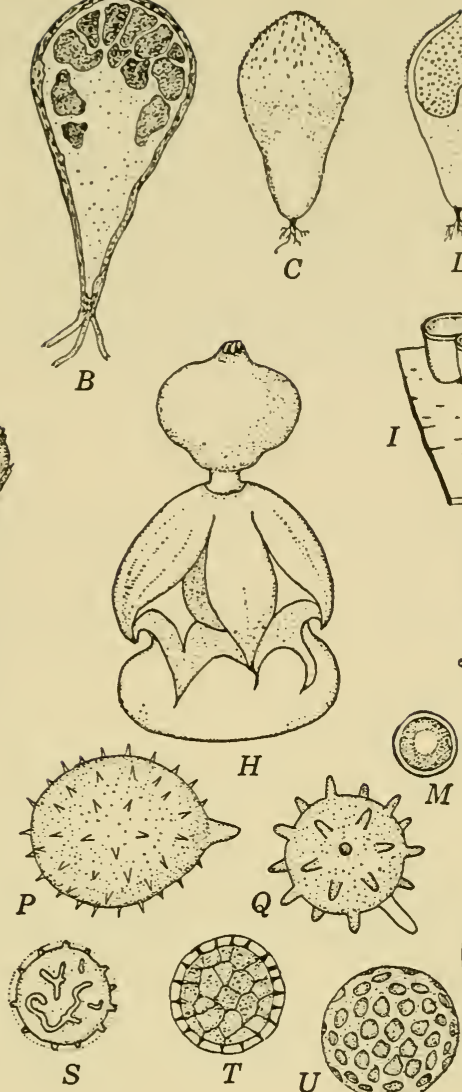
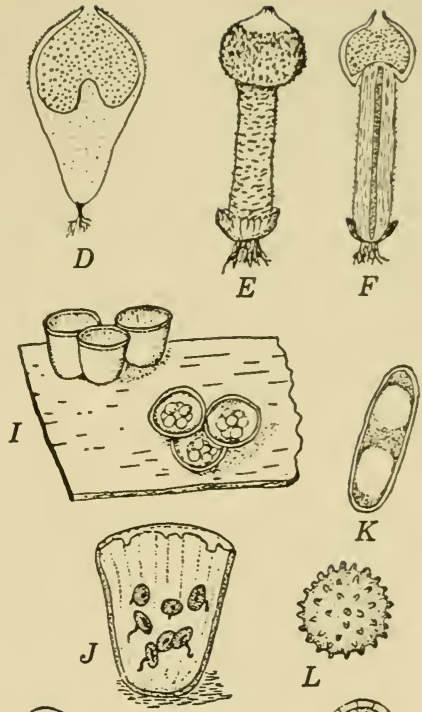

$L$

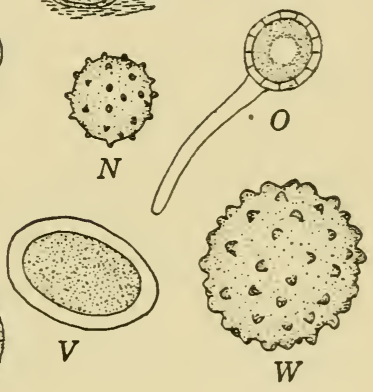

FIG. 145. $A$ and B. Pballogaster saccatus, in surface riew and in section, to show glebal tissue. (Adapted from Thaxter.) $C$ and D. Lycoperdon pyriforme in surface view and in section. The gleba occupies the upper portion that opens to the exterior by rupture of the peridium. $E$ and $F . T y l o-$ stoma mammosum, external view and sectioned view. The basal part of the fruiting body is sterile, and the upper part is fertile. (Adapted from Vittadini.) G. Calostoma lutescens, habit sketch, with glebal portion at the apex. (Adapted from Burnap.) H. Geaster bygrometricus, habit sketch. I and J. Crucibulum vulgare, surface and sectional views. The peridioles are attached to the wall of the cups. $K, L, M, N, O, P, Q, R, S$, $T, U, V$, and $W$. Spores of various Gastromycetes. (From Coker and Couch.) K. Rbizopogon nigrescens. L. Octavinia ravenelii. M. Calvatia cyatbiformis. $N$. Lycoperdon pyriforme. O. Bovistella ecbinulata. P. Geaster fornicatus. Q. Bovista candida. R. Discedera pedicellata. S. Tylostoma campestre. T. Scleroderma geaster. U. Pisolithus tinctorius. V. Cyathus stercoreus. W. Calostona lutescens. 
gressively from the bottom toward the top, and this tissue disintegrates completely as the powdery spore masses mature.

Although Fischer (1933) regarded the Podaxineae (Podaxales) as a separate suborder of the Gastromycetes, Conard (1915) and Gäumann (1926), because of the gill-like nature of the tramal plates in Secotium, have suggested that these fungi are perhaps to be considered aberrant representatives of the Agaricales. Cunningham (1925) regards Secotium as undoubtedly gastromycetous and suggests that it has been derived from a form similar to Hymenogaster.

\section{LITERATURE CITED}

Conard, H. S., "The structure and development of Secotium agaricoides," Mycol., 7:94-103, 1915.

Cunningham, G. H., "A critical revision of the Australian and New Zealand species of the genus Secotium," Proc. Linnean Soc. N. S. Wales, 49: 97-119, 1924.

"The development of two New Zealand species of Secotium," Trans. Brit. Mycol. Soc., 10: 216-224, 1925.

Fischer, E., "Gastromyceteae." In Engler and Prantl, Die natürlichen Pflanzenfamilien. Zweite Auflage, 7a. 122 pp. Wilhelm Engelmann, Leipzig. 1933.

Gäumaxx, E., Vergleichende Morphologie der Pilze. 626 pp. Jena. 1926. Lohwag, H., "Entwicklungsgeschichte und systematische Stellung von Secotium agaricoides (Czern.) Holl.," Osterr. Botan. Z., 73:61-174, 1924. Massee, G., "A monograph of the genus Podaxis Desv.," J. Botany, 28:33, 69, 1890.

Patouillard, N., "Le genre Podaxon," Bull. soc. mycol. France, 6: 159-167, 1890.

\section{Sclerodermatales}

The members of this order possess a thick peridium consisting of a single layer. The gleba is divided into numerous fertile areas separated by intertwined hyphae. Rabinowitsch (1894) studied the development of Scleroderma bovista, finding that knots of deeply staining hyphae appear in the otherwise uniform fundaments. These knots consist of hyphae whose terminal cells, directed toward the center of the knots, enlarge to become the basidia. Masses of spores eventually replace these knots, and the interposed sterile tissues also disintegrate, except for a few simple hyphae that become the capillitia. Finally the peridium ruptures irregularly, permitting spore dissemination. 
The fructifications of Tulostomataceae originate beneath the surface of the soil but become exposed by the elongation of the stalks. The family contains approximately to species and was monographed by White (1901). Tylostoma has slender stalks $5 \mathrm{~cm}$ or more long and 2 to $4 \mathrm{~mm}$ in diameter. An apical pore appears in the peridium; the spores are interspersed with capillitia and puff out, as they do in Lycoperdon. Battarea has stout stalks 10 to $20 \mathrm{~cm}$ tall. Its spores are freed by splitting of the outer peridium, followed by circumferential splitting of the inner peridium. Queletia also is stout-stalked, but its spores are liberated by fragmentation of the inner peridium in irregular pieces.

Calostoma, whose 10 species were treated monographically by Massee (1888), has a very peculiar fibrous, spongy stalk surmounted by a papery spore case. The spore case opens by a puckered, lobed mouth. In the "egg stage," the outer layer of the basidiocarp is covered with a coating of transparent jelly, which falls away as the stalk elongates.

In Scleroderma geaster, having compact, heavy fructifications that usually develop in clay soils, the coarse peridium may rupture stellately. The fructifications of Pisolitbus tinctorius may be 10 to $18 \mathrm{~cm}$ in diameter and are startlingly heary. The maturing spores are deep purple, becoming brown when powdery. Their pigments have been employed as dyes for cloth.

The most interesting members of the Sclerodermatales belong to Sphaerobolus, placed by some taxonomists among the Nidulariales, although Fischer (1933) regards this genus as one of the Sclerodermatales. Its gleba is discharged as a unit by a mechanism involving the several-layered peridium. The developmental studies of Sphaerobolus stellatus and S. iowensis by Walker (1927) may be interpreted as confirming the classification of Fischer.

The Sclerodermatales may be divided into 5 families, as follows:

1. Fructifications sessile

2. Peridium a single thick layer, that is, without a distinct exoperidium

Sclerodermataceae

2. Peridium consisting of an outer layer, which splits stellately at maturity, and a persistent inner layer

Astraeaceae

2. Peridium multiple-layered, gleba discharged intact by eversion of inner layers

Sphaerobolaceae 
1. Fructifications stalked

3. Stalk firm and fibrous, peridium membranaceous

Tulostomataceae

3. Stalk and outer part of peridium gelatinous

Calostomataceae

\section{LITERATURE CITED}

Fischer, E., "Gastromyceteae." In Engler and Prantl, Die natürlichen Pflamzenfanilien. 7a. 122 pp. Wilhelm Engelmann, Leipzig. 1933. Lloyd, C. G., "The Tylostomeae," Mycol. Writings, 2 (1905-1908): 1-28, 1906.

Massee, George, "A monograph of the genus Calostoma Desv. (Mitremyces Nees)," Ann. Botany, 25:45, 1888.

Rabinowitsch, L., "Beiträge zur Entwickelungsgeschichte der Fruchtkörper einiger Gastromyceten," Flora, 79: 385-418, 1894.

IVALKer, Leva B., "Development and mechanism of discharge in Spbaerobolus iowensis, n. sp., and S. stellatus Tode," J. Elisha Mitchell Sci. Soc., 42: 151-178, 1927.

White, V. S., "The Tylostomaceae of North America," Bull. Torrey Botan. Club, 28: 421-444, 1901.

\section{Lycoperdales}

The Lycoperdales are usually regarded as including the Lycoperdaceae (puffballs) and Geastraceae (earthstars). The closely related family, Arachniaceae, is included in this order by some mycologists. These three families may be distinguished as follows:

1. Peridium persistent; glebal chambers becoming transformed into a powdery mass

2. Peridium of 2 layers, the outer opening variously, the inner remaining intact

Lycoperdaceae

2. Peridium of 4 layers, the outermost separating and remaining in the soil as a cup or else remaining united with the 2 middle layers, which split stellately and evert to raise the spore case enclosed by the inner layer

Geastraceae

1. Peridium disintegrating after maturity; glebal chambers falling apart like grains of sand

Arachniaceae

The fructifications of the Lycoperdaceae form in the surface of the soil, in leaf litter, or in decaying logs or stumps. Rehsteiner (1892) early studied the development of Bovista nigrescens. Lander (1933) studied the development of Lycoperdon gemmatum; and Swartz $(1932,1935)$, that of Bovista plumbea, Calvatia craniiformis, C. saccata, Lycoperdon pulcherrimum, $L$. 
pyriforme, and L. wrightii. All are quite similar in differentiation. The fruit-body initial arises on rhizomorphs. It is at first homogeneous throughout. The peridium is early distinguished as loose, radially oriented hyphae which become pseudoparenchymatous. The hyphae of the central region are at first all thin-walled and intricately intertwined. As the fruit body in-

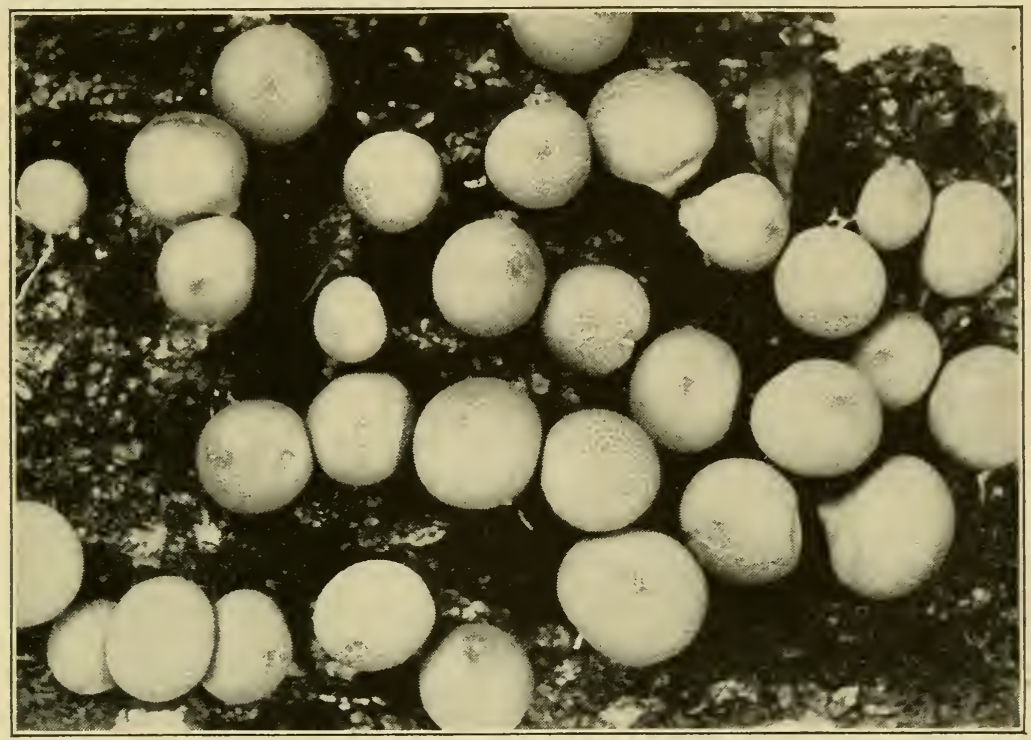

FIG. 146. Cluster of fructifications of Lycoperdon gemmatum.

creases in size, cavities bounded by parallel hyphae appear. The cavities arise by mechanical splitting. As the cavities become larger, the termini of these hyphae become clavate, forming a palisade that surrounds each cavity. These clavate tips eventually become the basidia. The capillitial threads arise from thickwalled, intercavity hyphae which resist disintegration.

In Lycoperdon there is a sterile base that may project as a columella into the glebal area. The outer peridial layer in many of the species is spiny or verrucose and may early become weathered away. An apical pore through which the spores escape develops in the endoperidium. The sterile base of Calvatia is broad, and the peridium, composed of a single layer, breaks off in large pieces. Bovista lacks a sterile base, but the endoperidium 
opens with a pore. In Catostoma circumiscissum the exoperidium splits equatorially, the gleba adhering to the upper half, and breaks away from the sterile base. Then a pore forms in the endoperidium in the region that was morphologically the base of the gleba.

Species of Geaster, commonly called earthstars, never fail to interest collectors of fungi. Cunningham (1927) studied the development of fructifications by Geaster velutimus. A dense layer of coarse hyphae is first differentiated around the homogeneous fundament. Next the fibrillose and fleshy layers of the exoperidium, the gleba, the central sterile area, and the columella are differentiated. The fleshy layer gradually becomes pseudoparenchymatous. The gleba is first evident as cavities arising by splitting apart of hyphae. These cavities become compactly bordered with hyphae that develop into basidia. Meanwhile the outer ground tissue becomes an intricately woven, partly gelatinized endoperidium. Also capillitial threads grow out from the columella. Finally the exoperidium splits into several lobes and everts, and the spore case opens apically with a specialized mouth.

Arachnion, typifying the Arachniaceae, has a simple, very thin peridium that crumbles at maturity; capillitial threads are lacking. The glebal chambers become peridioles, which fall apart as granular particles.

Lander (1934) studied the development of Arachnion album. In young stages the fructifications have a peridium of two zones. In the outer one the hyphae are radially arranged, whereas in the inner zone they are closely and intricately interwoven. The outer zone sloughs off as development proceeds; the inner one becomes pseudoparenchymatous. The glebal cavities arise by mechanical splitting, and gradually the basidial primordia line the cavities.

\section{LITERATURE CITED}

Cunningham, G. H., "The development of Geaster velutinus," Trans. Brit. Mycol. Soc., 12: 12-20, 1927.

Lander, Caroline A., "The morphology of the fruiting body of Lycoperdon gemmatum," Am. J. Botany, 20:204-215, 1933.

"The development of the fruiting body of Aracbnion album," J. Elisha Mitchell Sci. Soc., 50:275-281, 1934.

Lloyd, C. G., "The Geasters," Mycol. Writings, 1 (1898-1905): 1-44, 1902.

"The genus Bovistella," Mycol. Writings, 2 (1905-1908); Mycol. Notes, 23: 277-287, 1905. 
"The genus Mitremyces," Mycol. Writings, 2 (1905-1908); Mycol. Notes, 30: 238-243, 1905a.

ReHsteiver, H., "Beiträge zur Entwickelungsgeschichte der Fruchtkörper einiger Gastromyceten," Botan. Z., 30:761-771, 777-792, 801-814, 823839, 843-863, 865-878, 1892.

Swartz, Delbert, "Some developmental characters of species of Lycoperdaceae," Am. J. Botany, 20:440-465, 1932.

"The development of Calvatia craniiformis," Mycol., 27: 439-448, 1935.

\section{Phallales}

The phalloids or stinkhorns include fewer than 100 species of predominantly tropical fungi, of which about a dozen have been found in the United States [Burt (1896), Coker and Couch (1928)]. The young fructifications or "eggs" are semisubterranean spherical to ovoid masses, surrounded by a tough peridium. The eggs contain the fertile tissue or gleba and a specialized structure called the receptaculum. At maturity the receptaculum elongates, rupturing the peridium, and elevates the gleba above ground.

Two families are generally recognized, the Phallaceae and Clathraceae. In the Phallaceae the receptaculum assumes the form of a stalk, which is surmounted at maturity by the spore mass. In the Clathraceae the receptaculum is generally latticelike or net-like in appearance, and the gleba is borne on its inner side. The group has been most thoroughly studied by Fischer; taxonomic accounts have been written by Burt (1896), Petch (1908), Lloyd (1909), Cunningham (1931), Boedijn (1932), and Fischer (1933).

The Phallaceae include perhaps 10 genera, of which the best known are Mutinus, Phallus, and Dictyophora. The mature fructifications of Mutimus canimus arise from rhizomorph-like strands and consist of a basal egg-shaped peridium, from which protrudes the spongy, stalk-like receptaculum; at the apex of the receptaculum the reddish gleba is borne. The developmental history of M. canimus has been studied by Fischer (1895), Burt (1896a), and Lohwag (1930). The gleba is closely adherent to the receptaculum and at maturity is a viscid, odoriferous mass. Insects, attracted by the carrion-like odor, aid in dissemination of the spores.

In Phallus (Ithyphallus) the distal surface of the receptaculum 
expands into a pileate structure, so that the glebal surface is more extensive than in Mutinus. The culmination of development is reached in Dictyophora, which is similar to Phallus but has in addition a net-like veil or indusium, originating between the pileus and the stalk and encircling the stalk [Atkinson (1911)]. There is great variation among the different species in the de-
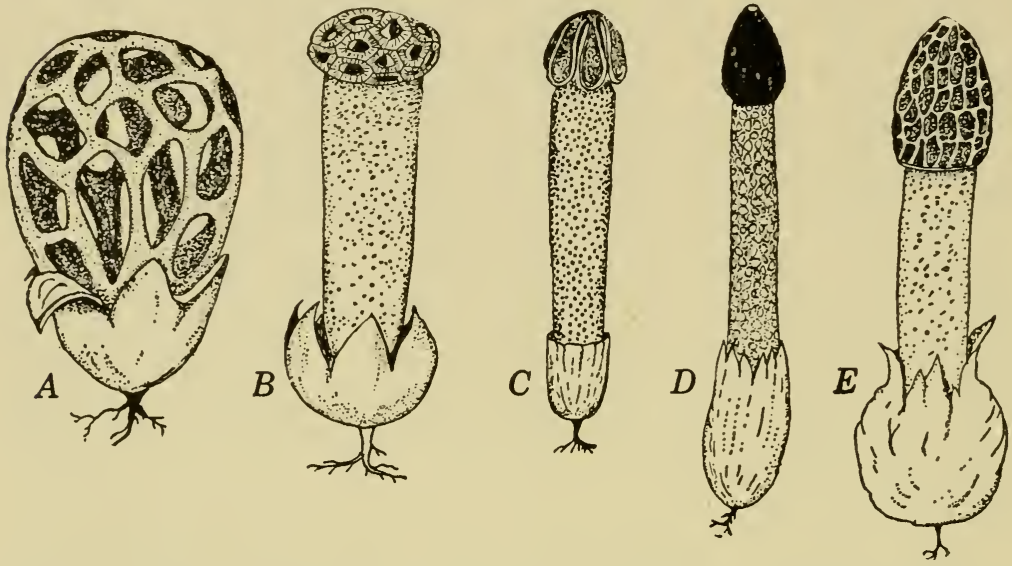

Fig. 147. Various Phallales. A. Clatbrus cancellatus. B. Simblum spbaerocephalum. C. Anthurus borealis. D. Mutinus caninus. E. Itbypballus impudicus.

gree of development of the veil and the nature of the pileate portion of the receptaculum. It has been found [Burt (1897)] that the rapid elongation of the receptaculum, which may shoot up to its mature length overnight, results from quick growth (cellular enlargement) and absorption of water, and the process is accompanied by a depletion of glycogen.

The Clathraceae represent another developmental series, in which the gleba occupies an internal position in relation to the receptaculum. In Clathrus the receptaculum is an ovoid, hollow, lattice-like structure, seated on the fragments of the ruptured peridium. The gleba occupies the entire interior surface of the interlacing arms. In Simblum [Conard (1913)] the basal portion of the receptaculum constitutes a long stalk, whose apex is clathrate, so that the whole fruiting body resembles a miniature Clathrus on a stem. 
In Colus there is a short stalk, and in Anthurus a long one, the upper portion of which divides to form several ascending arms coalescing at the extreme tip of the fruiting body. In Aseroë the hollow stalk-like portion of the receptaculum gives rise to a number of horizontal, radiating, tentacle-like arms. Thus the gleba comes to be formed along the upper (originally the inner) side of the arms. Kalchbrennera is more or less similar to Aseroë, although the arms are thicker and are not pointed at the tips, being instead blunt and swollen. The various genera of this family are thus distinguished by the form of the receptaculum.

The 2 families included within the Phallales have in common the development of the fruiting bodies from an egg, with the extension of a variously shaped receptaculum, on which are borne the spore masses with their carrion-like odor. Anyone who has ever collected mature specimens of these fungi will agree that the common name stinkhorns is apt, if not aesthetic.

\section{LITERATURE CITED}

Atrinson, G. F., "The origin and taxonomic value of the veil in Dictyophora and Ithyphallus," Botan. Gaz., 51: 1-20, 1911.

Boedijs, K. B., "The Phallineae of the Netherlands East Indies," Bull. Gard. Botan. Buitenzorg, Ser. III, 12: 71-103, 1932.

Burt, E. A., "The Phalloideae of the United States. II. Systematic account," Botan. Gaz., 22:379-391, 1896.

"The development of Mutinus caninus (Huds.) Fr.," Ann. Botany, 10: 343-372, 1896a.

"The Phalloideae of the United States. III. On the physiology of elongation of the receptaculum," Botan. Gaz., 24: 73-92, 1897.

CoKer, W. C., AND J. N. Couch, The Gasteromycetes of the eastern United States and Canada. 201 pp. University of North Carolina Press, Chapel Hill. 1928.

Conard, H. S., "The structure of Simblum spbaerocephalum," Mycol. 5: 264-273, 1913.

Cunningham, G. H., "The Gasteromycetes of Australasia. X-XI. The Phallales," Proc. Linn. Soc. N. S. IVales, 56: 1-15, 182-200, 1931.

Fischer, E., "Die Entwicklung der Fruchtkörper von Mutinus canimus (Huds.) Fr.," Ber. deut. botan. Ges., 13: 128-137, 1895.

In Engler and Prantl, Die natïrlichen Pflanzenfamilien, 2nd ed., 7a. 122 pp. 1933.

Lloyd, C. G., "Synopsis of the known Phalloids," Mycol. Writings, 3: 1-96, 1909.

Lohwag, H., "Mykologische Studien. IV. Zur Entwickelungsgeschichte von Mutinus caninus (Huds.) Fr.," Arch. Protistenk., 72:214-246, 1930. 
Petch, T., "The Phalloideae of Ceylon," Ann. Roy. Botan. Gard. Peradeniya, 4: 139-184, 1908.

\section{Nidulariales}

The Nidulariales include some 80 species of "bird's-nest fungi," so-called because the gleba is broken up into a number of eggs or peridioles, which, surrounded by the cup-shaped peridium, resemble a clutch of eggs in a nest. The tendency toward a division of the gleba into a number of elements has already been noted in Pisolithus of the Sclerodermataceae, which is regarded by some workers as an ancestral form of the Nidulariales. A somewhat similar condition is found in Arachnion, sometimes included in the Nidulariales, although the investigations of Long (1941) seem to relate this genus definitely to the Lycoperdales. Similarly, Sphaerobolus [Walker (1927)] has been considered a bird's-nest fungus in which the number of peridioles has been reduced to one; perhaps, however, this genus is better placed in the Sclerodermatales.

As thus delimited, the Nidulariales comprise but a single family with 4 genera: Nidula, Nidularia, Cyathus, and Crucibulum. Perhaps the most thorough taxonomic treatments of North American species are those of White (1902) and Lloyd (1906); Cunningham (1924) has studied the species occurring in New Zealand.

Crucibulum has but a single species, C. vulgare, which is practically cosmopolitan. It has been studied morphologically by Sachs (1855), Molliard (1909), and others, notably Walker (1920), and has been grown in pure culture on artificial media. The epigaeous fruiting bodies arise from mycelial strands and become differentiated into an outer peridium and numerous inner peridioles. Each peridiole, which represents a segment of the gleba, becomes separated from its neighbors by hyphal gelatinization but remains attached to the peridium by a long stalk, the funiculus. The external portion of the peridiole becomes differentiated as a thick wall or tunica enclosing the basidia. Each basidium has a clamp connection at its base and bears 4 spores [Martin (1927)]. The mass of peridioles is completely enclosed by the peridium and a thin membranaceous layer, the epiphragm, which extends over the top of the angiocarpous fruiting body. 
At maturity the epiphragm breaks, and the peridioles become exposed.

Cyathus is a large genus with some 60 described species. In general, it is similar to Crucibulum in having an epiphragm and numerous peridioles, each attached by a funiculus. Within the wall of the peridium, however, there is a central layer of pseudoparenchymatous tissue, so that the wall is composed of 3 layers rather than 1. The basidiospores are sessile, although in Crucibulum they are borne on long sterigmata. Frequently in $\mathrm{Cy}$ athus there are more than 4 spores on each basidium [Martin (1927)]. Within the peridioles the spores are interspersed with numerous sterile threads.

The epiphragm is present also in Nidula, but the peridioles are not provided with a funiculus. In Nidularia, with numerous species, the funiculus and epiphragm are both lacking. The fruiting bodies are rounded at the top, rather than flattened, and at maturity open by irregular slits in the peridial wall instead of by the mechanism of an epiphragm. The development of the peridioles, basidia, and spores of Nidularia has been investigated by Fries $(1910,1911)$, who finds the basidiospores are typically binucleate.

The dissemination of spores in the bird's-nest fungi was not understood for many years. Apparently Martin (1927) was the first to suggest that falling raindrops can spatter the peridioles out of the cup-shaped peridia and thus eventually effect the dissemination of spores. Diehl (1941) showed that a supposedly imperfect fungus, occurring on camellia leaves and formerly known as Leptostroma camelliae, is in reality Cyathus stercoreus, the peridioles of which have adhered to the leaves. Dodge (1941) reported the presence of peridioles on the upper surfaces of leaves 10 to $15 \mathrm{ft}$ above the ground and concluded that the peridioles must be discharged with considerable violence. The spores, eventually freed by decay of the peridiole wall, germinate to form a dicaryotic mycelium.

\section{LITERATURE CITED}

Cunningham, G. H., "A revision of the New Zealand Nidulariales or 'bird's-nest fungi,"” Trans. Proc. New Zealand Inst., 55: 59-66, 1924.

DieHL, IV. W., "The taxonomy of Zenker's Leptostroma camelliae," Mycol., 33: 215-219, 1941. 
Dodie, B. O., "Discharge of the sporangioles of bird's-nest fungi," Mycol., 33: 650-654, 1941.

Fries, R. E., "Om utvecklingen of fructkroppen och peridiolerna hos Nidularia," Svensk Botan. Tid., 4: 126-138, 1910.

"Über die cytologischen Verhaltnisse bei der Sporenbildung von Nidularia," Z. Botan., 3: 145-165, 1911.

Lloyd, C. G., "The Nidulariaceae," Mycol. Writings, 2: 1-32, 1906.

Long, W. H., "Studies in the Gasteromycetes. III. The family Arachniaceae," Mycol., 33: 350-355, 1941.

Martin, G. W., "Basidia and spores of the Nidulariaceae," Mycol, 19: 239$247,1927$.

Moluiard, M., "Le cycle de développement du Crucibulum vulgare Tulasne et de quelques champignons supérieurs obtenus en cultures pures," Bull. soc. bot. France, 56: 91-96, 1909.

Sachs, J., "Morphologie des Crucibulum vulgare Tulasne," Botan. Z., 13: 833-845, 1855.

Walker, Leva B., "Development of Cyatlous fascicularis, C. striatus, and Crucibulum vulgare," Botan. Gaz., 70: 1-24, 1920.

"Development and mechanism of discharge in Spbaerobolus iowensis, n. sp., and S. stellatus Tode," J. Elisha Mitchell Sci. Soc., 62:151-178, 1927.

White, V. S., "The Nidulariaceae of North America," Bull. Torrey Botan. Club, 29:251-280, 1902. 


\section{Chapter 8}

\section{THE DEUTEROMYCETES (FUNGI IMPERFECTI)}

The Deuteromycetes are in reality the trash pile or the leftovers, containing the conidial- or imperfect-stage remnants of the classes already discussed. In many ways they are of the greatest interest among all the classes of fungi and certainly are of timeconsuming concern to the mycologist in his taxonomic problems. They are not given extended treatment in texts mainly for the reason that the groupings are wholly artificial and hence are completely without phylogenetic significance.

To date between 15,000 and 20,000 Fungi Imperfecti have been described. According to Bender (1931), this vast miscellaneous assemblage represents 1331 form genera. They comprise (1) the mycelial, sclerotial, and conidial stages of species having perfect stages, that is, zygospores, oospores, asci, basidia, and teliospores, and therefore properly belong in the classes already discussed, and (2) those species of fungi whose perfect stages are not known. Even though the zygospores or oosporic stages of certain Phycomycetes have never been observed, these species are commonly placed among the Phycomycetes rather than among the Deuteromycetes because of the coenocytic nature of their assimilatory structures. Furthermore, many rusts are known only in the aecial or uredinial stage but are properly placed in the Uredinales among the imperfect form genera Aecidium, Peridermium, Caeoma, Roestelia, and Uredo. Since the hyphae of many Basidiomycetes possess clamp connections, this criterion is of value, in the absence of a basidial stage, in relating so-called imperfect fungi to the Basidiomycetes. It seems probable therefore that the great majority of species treated as Fungi Imperfecti really are Ascomycetes whose connection with an ascogenous stage has not been established. Some may never have possessed a perfect stage or, if they did, may have lost it. 
Many imperfect fungi are pathogenic to plants and sporulate on the plant organs only while these organs are still alive. After the death of the tissues, conditions may be favorable for the production of the perfect stage, which such species may be found to require for hibernation. Other species, however, produce co-

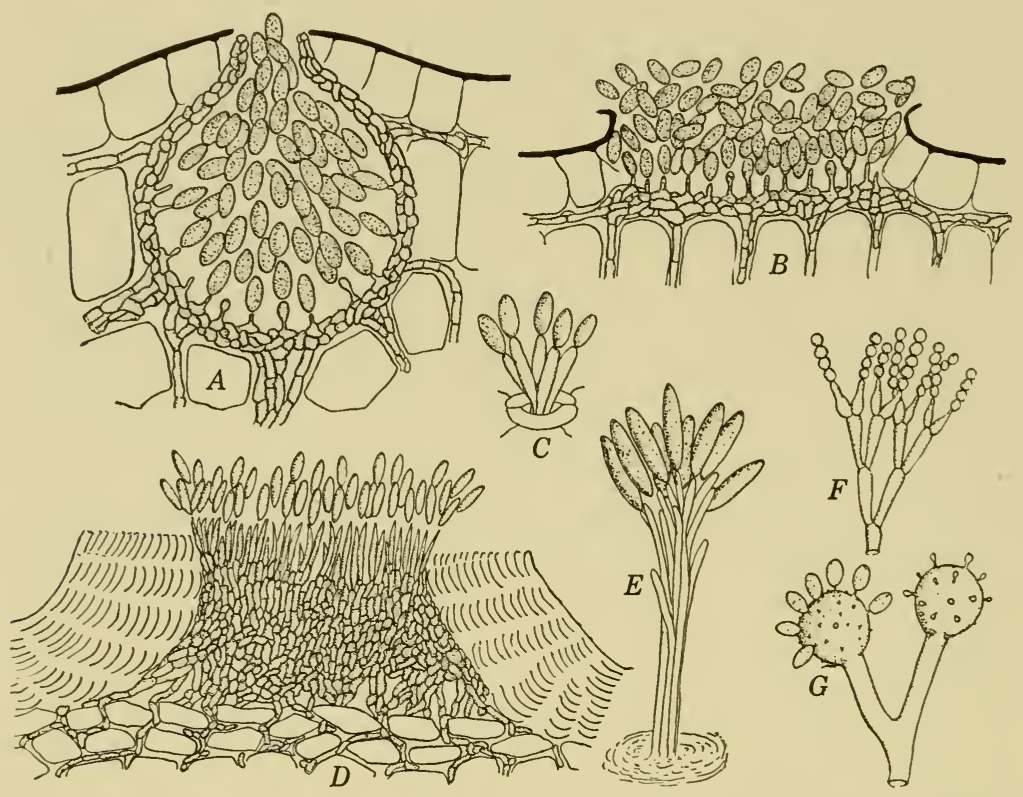

F1G. 148. Types of fructifications among Fungi Imperfecti. A. Pycnidium. $B$. Acervulus. C. Conidiophores protruding separately from stoma. D. Sporodochium. E. Synnema. F. Penicillate conidiophore. G. Capitate conidiophore.

nidia as readily on decaying plant organs as on living ones. Such species may be able to survive from one season to the next without the presence of a perfect stage. It must be remembered, however, that survival of the conidial stage throughout the winter in no way determines, so far as is now known, the production of the perfect stage.

Many imperfect species, although placed in the same form genus, are totally unrelated, as becomes evident when their perfect stages are taken into consideration. On the other hand, a structural parallelism between the conidial stage and ascomycetous stage is known to exist [Orton (1915)]. Evidence in sup- 
port of both these apparently contradictory statements is offered by the imperfect form Genus Gloeosporium. Some species of the pyrenomycetous genera Glomerella and Gnomonia have conidial stages belonging to Gloeosporium. The conidial stage of certain species of the discomycetous Pseudopeziza has also been regarded as Gloeosporium. Again, Marssonia (Marssonina) juglandis is the conidial stage of Gnomonia leptostyla, a pyrenomycete, whereas Marssonia rosae and M. fragariae are conidial stages of Diplocarpon rosae and D. earliana, respectively, both of which are discomycetous. But life-history studies have revealed that the correlated parallelism between form of conidia and form of ascospores is a very useful feature in classification. Species of Guignardia, for example, have Phyllostictina as their conidial stage, species of Rhytisma have Melasmia, species of Cordyceps have Isaria, species of Gibberella have Fusarium, species of Pleospora have Alternaria or Macrosporium, species of Elsinoe have Sphaceloma, species of Venturia have Fusicladium, species of Coccomyces (Higginsia) have Cylindrosporium, and species of Sclerotinia (sensu lato) have Monilia and Botrytis. Parallelism in form of conidia and ascospores, however, may not exist, as is shown by species of Diaporthe that possess conidial stages belonging to Phomopsis and by species of Mycosphaerella that have conidial stages among a variety of genera, including Phyllosticta, Ascochyta, Ramularia, Cercospora, Cercosporella, and Septoria, and by species of Nectria whose conidial stages are classified as Tubercularia, Fusarium, or Cylindrocarpon. Some genera, such as Balansia, Epichloe, and Dothichloe, on the other hand, possess conidial stages belonging to one and the same form genus. In these genera the conidial stages are included in Ephelis.

The conidial stage and the perfect or ascigerous stage are rarely found in nature at the same season. Many species, especially those attacking annual host plants or the foliage and fruit of deciduous trees and shrubs, produce their ascigerous stage in the spring. It is apparent, therefore, that the perfect stage is less conspicuous than the conidial stage and hence is less frequently collected. These facts may account for the widely prevalent but erroneous opinion that the ascigerous stage of such fungi is of infrequent or rare occurrence.

By means of pure-culture techniques it has been possible to secure evidence of genetic connection between the conidial stage 
and the ascigerous stage of a goodly number of fungi. Quite commonly cultures isolated from conidia give rise to conidia in culture, and cultures isolated from ascospores also give rise to conidia. The production of ascocarps in cultures originating either from conidia or from ascospores is of very much less common occurrence. The reasons for this situation are still largely unknown.

The structure of the conidial fructification in culture may be quite different from that which characterizes the species when it is grown on its natural substrate. Cultures of Septoria, a pycnidial fungus, for example, may be hyphomycetous in that the conidia are abstricted in succession from the apex of short, lateral hyphal branches standing singly. Similarly, Cercospora in culture may form conidia by successive acrogenous delimitation of conidia from hyphal branches that stand singly, whereas in nature the conidia are abstricted acropleurogenously from fasciculate conidiophores.

Classification. Several systems of classification of the Fungi Imperfecti have been proposed. The oldest one, used by Saccardo in Sylloge Fungorum, is serviceable and does not appear to have been materially improved by the several modifications proposed. In Saccardo's classification there are 4 orders, which may be distinguished as follows:

1. Conidia present

2. Conidia in globoid, cupulate, or shield-shaped pycnidia

Phomales (Sphaeropsidales, Phyllostictales)

2. Conidia not in pycnidia

3. Conidiophores short and aggregated at the surface of a thin parenchymoid stroma (an acervulus)

Melanconiales

3. Conidiophores varying in length but not on an acervulus, formed singly in fascicles or on sporodochia (cushion-shaped structures)

1. Conidia lacking

Moniliales (Hyphomycetes)

Mycelia Sterila

The Phomales comprise 4 families, separated as follows:

1. Pycnidia globoid

2. Pycnidia brown or black, membranaceous or carbonaceous

Phomaceae (Sphaeropsidaceae)

2. Pycnidia hyaline or bright-colored, soft, fleshy, or waxy

Zythiaceae (Nectrioidaceae)

1. Pycnidia shield-shaped, sometimes radiately constructed 
1. Pycnidia discoid, cupulate, or hysteroid, sometimes opening irregularly

Discellaceae (Excipulaceae)

The Moniliales are constituted of 4 families, distinguished as follows:

1. Hyphae, conidiophores, and conidia hyaline or cottony

Moniliaceae (Mucedinaceae)

1. Hyphae, conidiophores, and conidia typically brown or dark

Dematiaceae

1. Conidiophores aggregated into a cylindric fascicle or synnema

Stilbaceae

1. Conidiophores compacted, forming a globose, cushion-shaped, or cylindric structure, a sporodochium, bearing conidia at the upper surface.

Tuberculariaceae

The single family Melanconiaceae of the Order Melanconiales includes all imperfect fungi having acervular fruiting bodies, and the Mycelia Sterila are not subdivided.

Within each family further groupings are made by employing color, shape, and septation of conidia as the bases for these groupings, as follows:

Amerosporeae: conidia 1-celled, spherical, ovoid, elongated, or allantoid.

Hyalosporeae: conidia hyaline.

Phaeosporeae: conidia colored.

Didymosporeae: conidia 2-celled.

Hyalodidymae: conidia hyaline.

Phaeodidymae: conidia colored.

Phragmosporeae: conidia transversely 3- or more-celled.

Hyalophragmiae: conidia hyaline.

Phaeophragmiae: conidia colored.

Dictyosporeae: conidia divided by transverse and longitudinal septa.

Hyalodictyae: conidia hyaline.

Phaeodictyae: conidia colored.

Scolecosporeae: conidia filamentous, thread-like, 1- to several-celled.

Helicosporaeae: conidia coiled, 1- to several-celled.

Staurosporeae: conidia radiately lobed or star-shaped, non-septate or septate.

Development of pycxidia And acervuli. Few studies have been devoted primarily to the origin and development of pycnidia and acervuli. Incidental observations by a number of workers, however, in connection with a particular species have revealed that all species conform to one or the other of two essential types. These types de Bary long ago designated "meristogenous" and "symphogenous." If the primordium of the fruiting 
body arises by proliferation of a single hyphal cell or of a group of adjacent cells of a single hypha, the species is regarded as
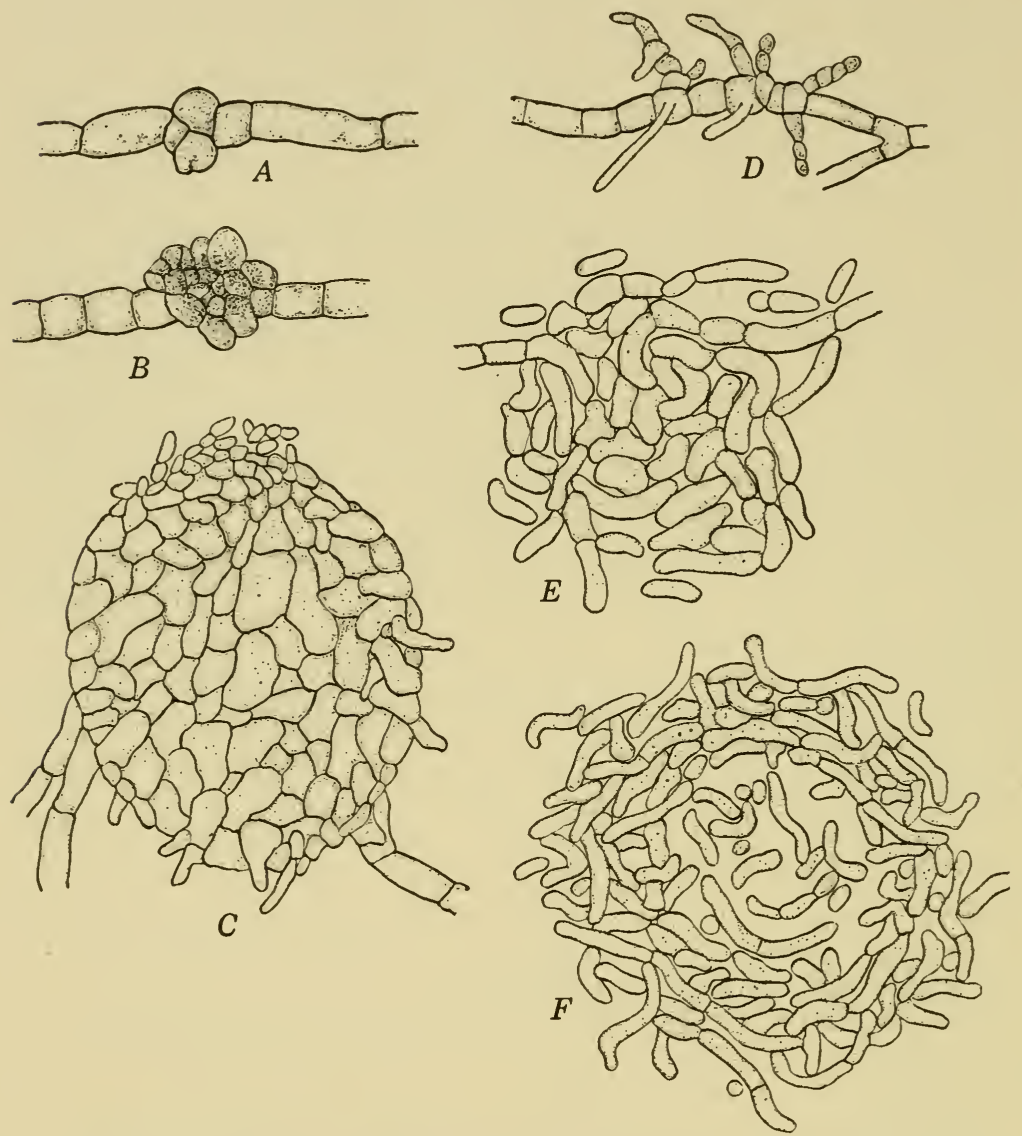

FIG. 149. Simple meristogenous origin of pycnidium, $A$ to $C$, in Phoma berbarum. (Adapted from Kempton.) Symphogenous origin of pycnidium, $D$ to $F$, of Endotbia parasitica. (Adapted from Anderson and Rankin.)

meristogenous in origin. If the primordium of the fruiting body, on the other hand, arises from the interlacing and anastomosing of hyphal branches from several mycelial threads, which then proliferate to form a stroma, the species is regarded as symphogenous. The study by Mercer (1913) of pycnidial morphogenesis in Phoma richardiae showed that its primordia are of both types. Similarly, the pycnidia of other species, such as Septoria 
polygonorum and Macrophoma citrulli, and the acervuli of Volutella (Colletotrichum) circinans and Colletotrichum lagenarium arise according to either of these methods.

Kempton (1919) studied the development of approximately a score of imperfect fungi, most of which were found to be meristogenous. He divided the meristogenous type into two kinds, simple and compound. In the simple type the fruiting body develops from a single hypha, as has been indicated, and in the compound type, from two or more contiguous hyphae. He concluded that simple meristogenous development occurs more often among Sphaeropsidales, whereas compound meristogenous and symphogenous types are more usual among Melanconiales.

TABLE 4

Type of Development of Pycnidia and Acervuli

Organism

Phoma herbarum

Phoma destructiva

Phoma pyrina

Phoma cichorial

Phoma richardiae

Diplodia manilliana

Sphaeropsis malorum

Sphaeropsis citricola

Coniothyrium pyrina

Septoria polygonorum

Septoria scrophulariae

Septoria helianthi

Sphaerella nigerristigma

(Septoria stage)

Cicinnobolus cesatii

Sphaeronemella fragariae

Meliola camelliae (pycnidial stage)

Macrophoma citrulli

Hendersonia opuntiae

Endothia parasitica (pycnidial stage)

Gloeosporium rufomaculans

Gloeosporium musarum

Colletotrichum lagenarium

Pestalozzia palmarum

Pestalozzia guepini

Patellina fragariae

Volutella fructi

Volutella circinans
Simple Compound

Meristogenous Meristogenous. Symphogenous

\begin{tabular}{|c|c|c|}
\hline+ & - & - \\
\hline+ & + & - \\
\hline+ & - & - \\
\hline+ & + & - \\
\hline+ & - & + \\
\hline- & - & + \\
\hline- & + & - \\
\hline+ & + & - \\
\hline+ & + & - \\
\hline+ & + & + \\
\hline+ & + & - \\
\hline+ & - & - \\
\hline- & - & + \\
\hline- & - & + \\
\hline+ & - & - \\
\hline+ & - & - \\
\hline+ & + & + \\
\hline- & + & - \\
\hline- & - & + \\
\hline- & - & + \\
\hline- & - & + \\
\hline+ & + & + \\
\hline+ & + & - \\
\hline- & - & + \\
\hline+ & + & - \\
\hline+ & - & + \\
\hline+ & - & + \\
\hline
\end{tabular}


An appreciation of the origin and modes of development of fruiting bodies among imperfect fungi may be gained from the compilation in Table 4, taken largely from Kempton.

\section{SPHAEROPSIDALES}

According to Bender (1931), this large order of the Fungi Imperfecti contains 568 genera, 359 of which are in the Sphaeropsidaceae, 62 in the Zythiaceae, 88 in the Leptostromataceae, and 59 in the Excipulaceae. Extensive monographs of this order are not available. The treatise on Phyllosticta by Seaver (1922) is helpful, as are others that deal with special genera, such as Phomopsis, Septoria, and Cytospora.

Sphaeropsidaceae. Members of Phyllosticta and Phoma are commonly parasitic on seed plants. These two genera are separated largely upon the basis of the organ attacked, Phyllosticta causing infections on the leaves and Phoma, on the stems and fruits. Distinction of species has been based principally upon the host. Phyllostictina, Macrophoma, and Dendrophoma are structurally quite like Phyllosticta and Phoma; all produce discrete pycnidia that arise innately. Some species of Phyllostictina are genetically connected with Guignardia, whereas certain species of Phyllosticta and Phoma have Mycosphaerella as their perfect stage.

Phyllosticta solitaria, pathogenic to foliage, twigs, and fruits of apple [Guba (1925)], and Phoma lingam, attacking the stems of cabbage [Henderson (1918)], are not known to possess a perfect stage.

Coniothyrium is similar in structure to Phyllosticta and Phoma but has colored conidia. The pycnidia of Cytospora and Ceuthospora are immersed in a stroma, and their conidia are hyaline. Ascochyta has hyaline 2-celled conidia, whereas those of Diplodia are colored and 2-celled. Diplodia zeae, producing a stem and ear rot of corn [Durrell (1923)], is wide-spread and is not known to have an ascigerous stage. Dariuca filum, with 2-celled hyaline conidia, is of unusual interest because it is a hyperparasite on rusts.

Species with hyaline, filamentous, several-septate conidia are placed in Septoria, which contains over 1000 species. Among them are such economically important ones as Septoria lycoper- 
sici on tomato, $S$. apii on celery, $S$. avenae on oats, $S$. tritici and $S$. nodorum on wheat, $S$. secalis on rye, and $S$. rubi on brambles. Weber (1923) connected $S$. avenae with Leptosphaeria avenaria, and Roark (1921), S. rubi with Mycospbaerella rubi.

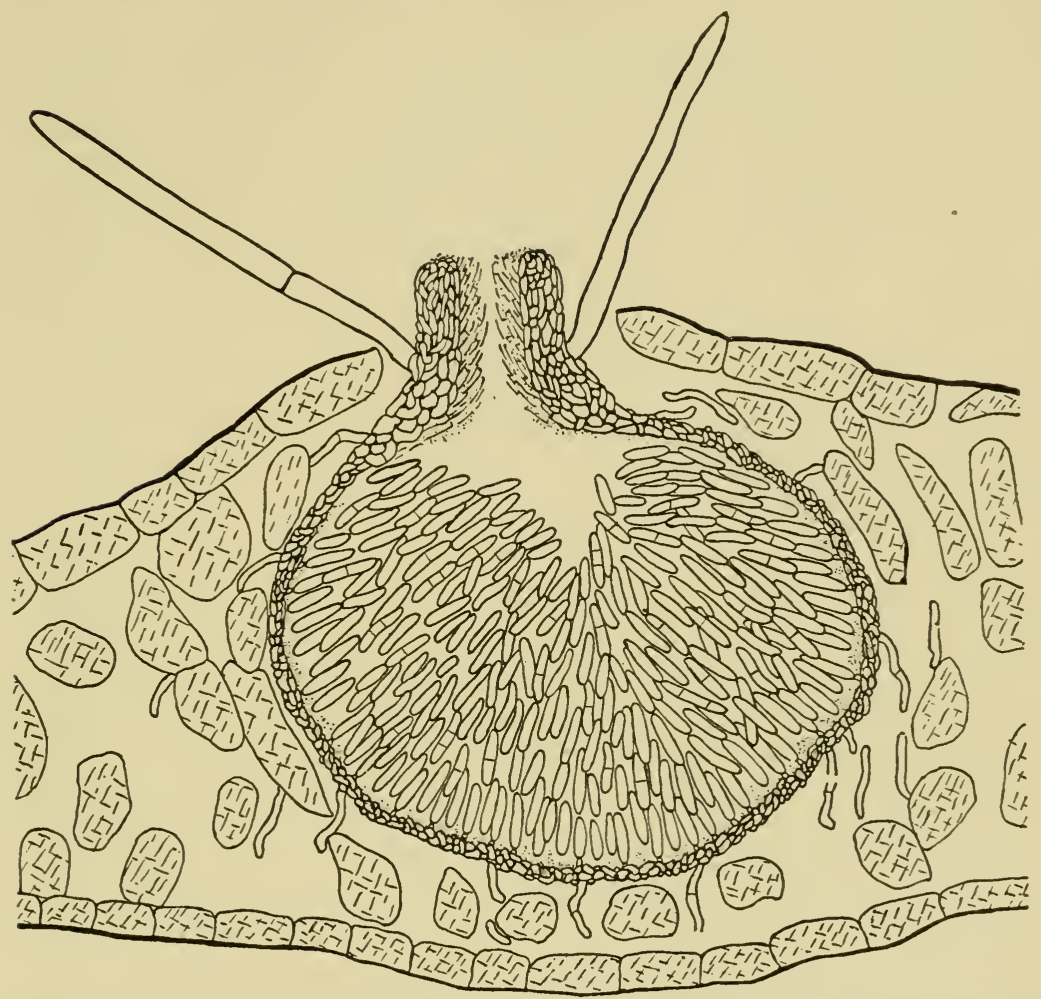

Fig. 150. Pycnidium of Amerosporium oeconomicum, in vertical section of leaf of Vigna sinensis.

Wojnoricia graminis is wide-spread in Australia, northwestern Europe, and the Great Plains area of North America as a weak parasite on fall-sown cereal crops and certain other grasses [Sprague (1935)].

In Europe, Japan, and parts of the United States where snow lies deeply over grain fields and melts late in the spring, the young plants may be covered with a moldy growth. The tissues of injured plants contain small dark sclerotia, identified as species of Sclerotium. In reality these sclerotia are stages of Typhula, 
notably $T$. gramineum, T. itoana, and T. idaboensis [Remberg $(19+0)]$.

ZithiaceaE. The most noteworthy members of this family are entomogenous, especially certain species of Aschersonia as $A$. aleyrodis, $A$. goldiana, $\dot{A}$. coffeae, and $A$. marginata. They attack scale insects and some of them have Hypocrella (among the Hypocreales) as the perfect stage.

Leptostronataceae. Flattened fruiting bodies are possessed by the members of this family. Many are conidial stages of Hypodermataceae and Phacidiaceae. Among the most familiar ones are species of Melasmia, certain of which have been genetically connected with Rhytisma. Leptotbyrium pomi, the "fly-speck" fungus of apples, is another well-known representative. Colby (1920) created the generic name Gloeodes for this organism. Discosia, containing both saprophytic and parasitic species and having a seta at each end of the septate conidium, is also commonly encountered.

Excipulaceae. The pycnidia of species assigned to this family open rather widely. Such genera as Amerosporium, Ephelis, and Lecanosticta contain pathogens of economic importance. Amerosporium oeconomicum, with dark setae around the ostiole, forms on the foliage of cowpeas lesions that are brown at first but become grayish with age. It appears to be coextensive in range with its host. Species of Ephelis which have filamentous conidia constitute the conidial stages of Balansia, Epichloe, and Dothichloe, all of which are parasitic on grasses and have thread-like ascospores. The best-known species of Lecanosticta is genetically connected with Systremma acicola, which causes brownspot needle disease of pines, especially longleaf pine. This fungus seriously menaces the growth of longleaf-pine seedlings, including nursery-grown trees, and natural reproduction.

\section{MELANCONIALES}

This order consists of the single family Melanconiaceae, having 92 genera and more than 600 North American species [Bender (1931) ]. Included in it are such well-known genera as Colletotrichum, Gloeosporium, Myxosporium, Vermicularia, Melanconium, Protocoronospora (Kabatiella), Marssonia, Coryneum, Pestalozzia, and Cylindrosporium. 
Diseases of many kinds of crop plants of the type called anthracnoses are produced by species of Gloeosporium and Colletotrichum. When these fungi involve woody stems, the acervuli produced correspond to those characteristic of Myxosporium.
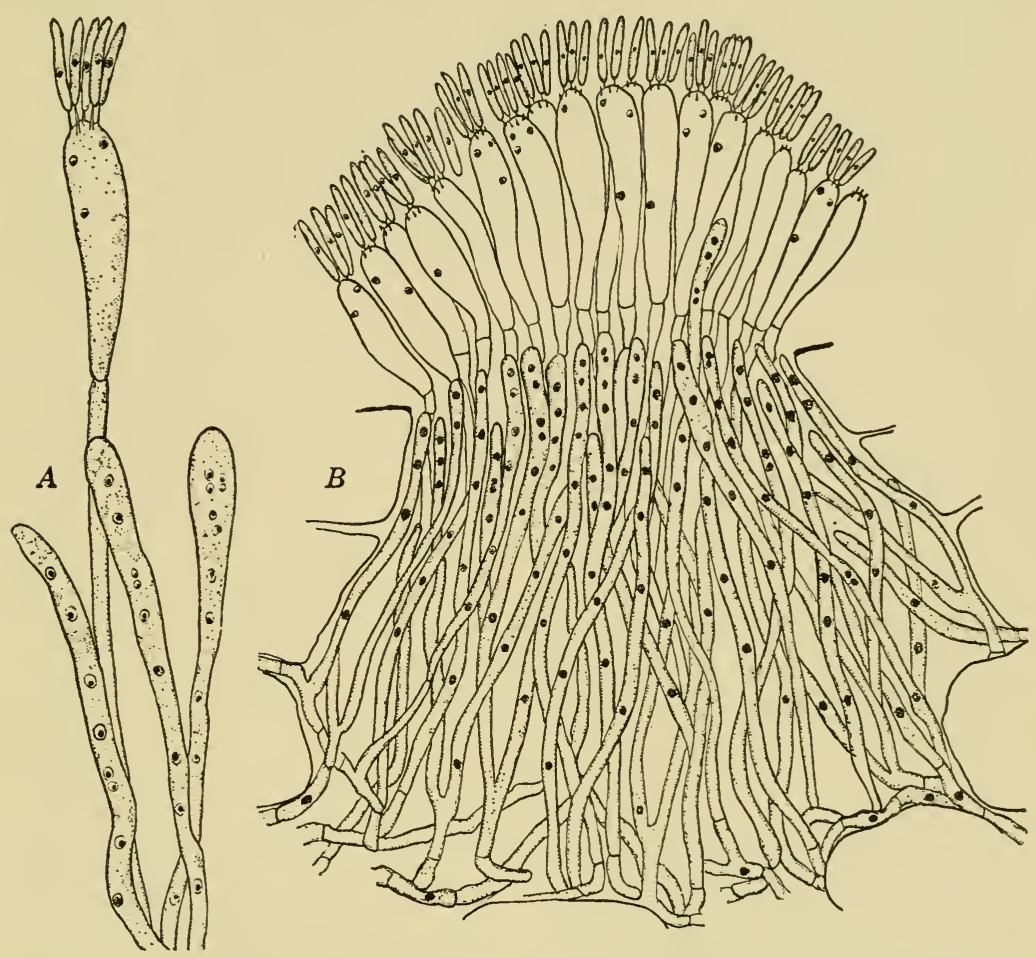

Fig. 151. Microstroma juglandis. A. Portion of pustule showing clavate conidiophore, conidia borne on sterigmata, nuclei remaining in conidiophore, and immature multinucleate conidiophores. $B$. Vertical section of pustule of Microstroma juglandis, occurring on hickory.

Duke (1928) regards Vermicularia and Colletotrichum as of the same generic type. Melanconium, represented by $M$. fuligemum, which causes "bird's-eye rot" of grape berries, has dark conidia.

Certain species of vetch, notably Vicia sativa, are widely attacked by a fungus first described as Protocoronospora nigricans, which was placed near Corticium. It seems instead to be related to the anthracnose-producing fungi [Wolf (1920)], but attendant problems of nomenclature have never been satisfac- 
torily solved. Sampson (1928) properly employed Kabatiella caulivora for the red-clover pathogen previously designated Gloeosporium caulivorum. Its conidiophores and conidia and their germination and type of growth in culture are entirely like those of the so-called Protocoronospora nigricans on vetch. The vetch pathogen, therefore, appears properly to belong in Kabatiella.

The conidial stages of the black-spot fungus on roses and the leaf-scorch fungus on strawberries belong in the form Genus Marssonia. The closely related Marssonina panattoniana, causing "shot hole" on lettuce grown under glass, is not known, however, to possess an ascigerous stage.

The twigs of peach throughout Europe and North America may be parasitized by Coryneum beijerinckii. Acquaintance with Pestalotia (Pestalozzia), characterized by septate conidia that bear three or more hyaline setae, may be gained from the monograph by Guba (1929, 1932).

Three species of Higginsia (Coccomyces), a discomycetous genus occurring on Prunus, namely, $H$. biemalis, $H$. prunophorae, and $H$. lutescens, have hyaline, thread-like conidia that belong in Cylindrosporium. The ascigerous stage of all other species of Cylindrosporium remains unknown.

\section{MONILIALES}

The Moniliales comprise 651 genera and more than 10,000 species, according to Bender (1931), and are divided into 4 families. In the Moniliaceae there are 204 genera, in the Dematiaceae 206, in the Stilbaceae 89, and in the Tuberculariaceae 152.

Moniliaceae. Certain members of this family, notably Aspergillus and Penicillium, are encountered by mycologists, bacteriologists, and plant pathologists everywhere for the reason that they are ubiquitous in distribution and essentially omnivorous in food habits. A few species of both genera are known to develop a perfect stage of the plectomycetous type and were formerly placed in the Genus Eurotium. Most of them, however, are detached conidial stages. The erect conidiophore in Aspergillus is apically enlarged, and from the surface of this enlargement short bottle-shaped branches (sterigmata) arise. From each branch a chain of conidia is produced; instead the branch may 
give rise first to a secondary branch. In Penicillium the erect conidiophore becomes digitately branched, the branches tending to be parallel to the main axis and to attain equal heights. Chains of conidia are borne from the apices of these ultimate branches.

Aspergillus and Penicillium are of enormous importance. Penicillium glaucum causes decay of apples and pears in storage; $P$. italicum and $P$. digitatum produce decay of citrus fruits. Aspergillus niger is used industrially in the production of certain organic acids, such as citric, gallic, and gluconic. Aspergillus oryzae is employed in the preparation of Taka-diastase. Aspergillus fumigatus causes otomycosis, pulmonary disorders, especially among workers who polish metals or handle furs and feathers, and pneumonic symptoms in grouse, quail, canaries, and other kinds of birds. Penicillium roqueforti and P. camemberti impart desirable flavors and odors to cheese. Members of both genera are involved in the production of mold on shoes, gloves, and other leather products, the spoilage of bread, preserves, and jellies, and the mildewing of clothing, awnings, tents, and other articles made of cloth.

The monographic treatises on Aspergillus by Thom and Church (1926) and on Penicillium by Thom (1930) are invaluable in any study involving these genera.

Botrytis contains numerous species and is another of the frequently encountered genera. The genus is characterized by much-branched conidiophores that bear clusters of spherical or ellipsoidal conidia, the entire structure having the aspect of a bunch of grapes. Members of the B. cinerea group cause the decay of many kinds of bulbs, fruits, and regetables. They also parasitize young plants and blight the buds and flowers of many cultivated ornamental species. Some species of Botrytis have been genetically connected with Sclerotinia. Some hibernate by means of sclerotia.

Ramularia and Cercosporella, containing many leaf-spot-producing fungi, are quite alike, as is indicated by the fact that both generic names have been frequently used for one and the same species. As the genera are at present delimited, there are two distinct types of fructifications. In one the short conidiophores emerge in fascicles from the stomata and produce the septate conidia acrogenously. Mature conidiophores have several scars near their tips, the scars marking the sites of attachment of 


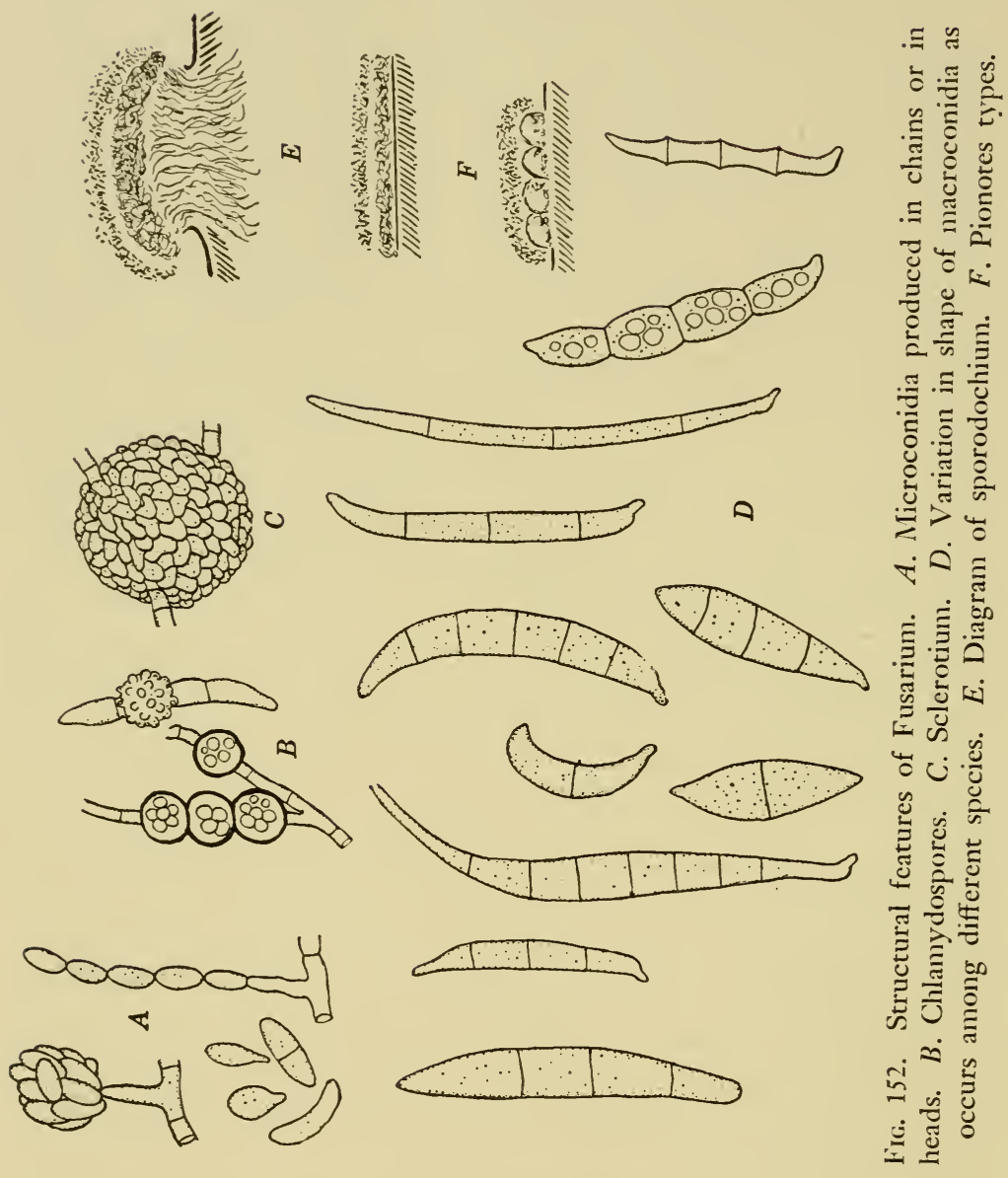


conidia. In the other type the reproductive hyphae form an arachnoid weft at the surface of the lesion, and the conidia are abstricted from short laterally formed conidiophores that stand singly. In the first group is Hycosphaerella mori (Cercosporella maculans), occurring on mulberry. In the second group are Ramularia areola on cotton and Cercosporella persicae on peach, which produce diseases commonly called frosty mildew. The perfect stage of each has been determined to be Mycosphaerella. In Piricularia are species having simple or branched conidiophores bearing ovoid to pear-shaped, septate conidia. Piricularia ory $\approx$ ae is wide-spread on the foliage of rice. Piricularia grisea is common on pasture and hay grasses.

Deniatiaceae. Cladosporium is encountered by all workers who attempt to isolate fungi in culture. Its branched conidiophores bear chains of acrogenously produced conidia, singlecelled or two- or three-septate. The genus contains many saprophytic species that aid in the decomposition of all sorts of plant tissues and also several that produce disease in plants and animals. Perfect stage connections are unknown. Cladosporiumn fulvum blights the foliage of greenhouse-grown tomatoes. Peach scab, caused by $C$. carpopbilum, involves both the fruit and twigs [Keitt (1917)] and is especially destructive to late-maturing varieties. It hibernates in twig lesions. Cladosporium cucumerimum causes scab on the fruit of cucumber. Several other important plant pathogens have been placed in Cladosporium, for example, C. citri, but they properly belong in Sphaceloma, which has been established to be genetically connected with Elsinoe, a hemisphaeriaceous fungus.

Chromoblastomycosis in man is caused by an extremely pleomorphic species, for which a number of generic names, including Hormodendrum, Phialophora, Acrotheca, and Fonsecaea, have been proposed, but it may well be eventually placed in Cladosporium.

Serious diseases of cereal crops and wild grasses, called stripe diseases because of the shape of the lesions, are induced by Helminthosporium. This genus includes fungi with stout, unbranched, septate conidiophores, and with colored, septate, thickwalled, boat-shaped conidia. A few species, such as $H$. ravenelii, completely envelope the inflorescences and are of such widespread occurrence that the hosts are called smut grass. 
The closely related Genus Heterosporium was recently studied by Jacques (1941). The well-known H. iridis on Iris is genetically connected with Didymellina macrospora. Jacques secured the perithecial stage in culture on sterile iris leaves. He found that $H$. ornithogali is the conidial stage of Didymellina ornithogali. The developmental cycle of other important pathogens, including $H$. pblei on Pbleum pratense, H. echinulatum on Dianthus caryophyllus, and H. variable on Spinacea oleracea, should be given consideration.

The two genera Alternaria and Macrosporium, which are regarded as synonymous by some and which are at least closely related to each other, have bottle-shaped conidia that are both transversely and longitudinally septate. The basal end is the larger. The conidiophores are stout, short, lateral hyphal branches. In Macrosporium the conidia are produced singly; in Alternaria they form chains, the basal conidium being the oldest. The features possessed by these genera that are of taxonomic value are given consideration by Elliott (1917).

A few species of Alternaria have been demonstrated to have Pleospora as their perfect stage. Among the better-known species parasitic on plants are Alternaria solani, causing early blight of potatoes, $A$. temuis and $A$. longipes, pathogenic to tobacco, $A$. citri, occurring on citrus, $A$. panax, found on ginseng, and $A$. brassicae var. nigrescens, which seriously blights the foliage of cantaloupes.

Cercospora is undoubtedly the largest genus of the Dematiaceae, and its species are very destructive to cultivated plants. One or more species of Cercospora have been recorded as parasites on practically every crop species and on many kinds of wild plants as well. The studies by Lieneman (1929) and Solheim (1929) give especial attention to taxonomic problems involving this genus. Its conidiophores are typically fasciculate and emerge from the stomata. The upper portions are covered with numerous scars left after the falling of the slender, clavate, septate conidia. Several species of Cercospora, such as $C$. personata on peanuts, C. bolleana on figs, C. musae on banana, and C. lytbracearum on pomegranates, have been demonstrated to be imperfect stages of Mycosphaerella. Cercospora beticola, especially destructive to sugar beets, and C. micotianae, producing frog-eye 


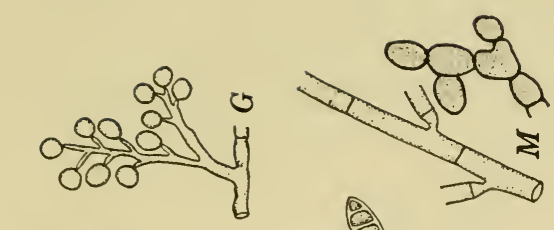

व.
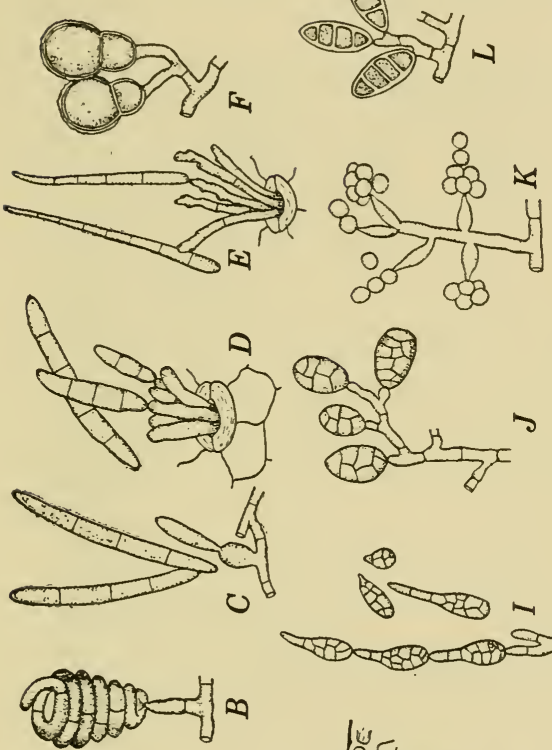

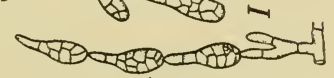
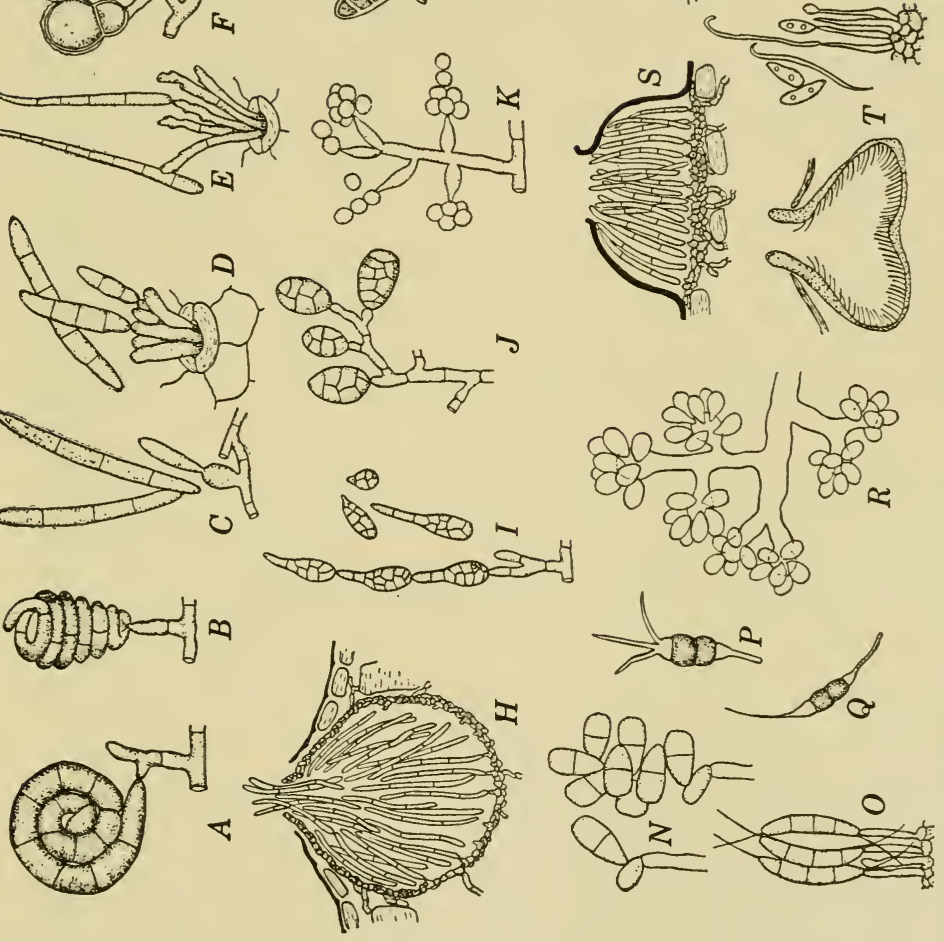

a. $\bar{x}:-3$
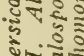

\&-1

ㄷำ

क.

บ.

ن造

ต.ะ.

इ.

牙

๘ँ $:=$

क्ष

हर्ट

ธิ

농ำ:

का

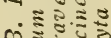

का.

$\therefore \frac{2}{2} \div$

क००

हैं

¿ç

ำ.

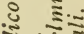

원든

म.

मे है

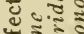

पे

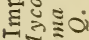

-

छิ

|

पूर्त

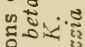

ขึำ

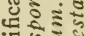

ơ

ज行

काष्य $\approx$ 8

ด.

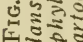


spot of tobacco, are among the species of economic importance not known to possess a perfect stage.

There are approximately 12 genera and 75 species of fungi having peculiar helical conidia. Some are entirely or partly hyaline, and the others have yellow, brown, or dark fructifications. This group has been monographed by Linder (1929). Many of them occur on decaying wood and bark, imparting to it an effuse, dark coating. Helicoma, Helicosporium, and Xenosporella are among the most common representatives. Helicoma curtisii is related to Lasiosphaeria pezizula, but connection with perfect stages has not been definitely established in any others of this group.

Stilbaceae. The fungi that comprise the Stilbaceae are little known even to the experienced mycologist. Possibly the most familiar genera are Isaria and Graphium. Isaria is entomogenous. It is constituted of species having hyaline synnemata with hyaline, one-celled conidia that form over most of the surface of the synnema. Some species have Cordyceps as their perfect stage, whereas the perfect stage of others has not been observed. Isaria farinosa was long regarded as the conidial stage of Cordyceps militaris. Petch (1936), however, found that the two are not connected, Cephalosporium being the conidial stage of C. militaris.

Graphium has dark-colored synnemata with dark, one-celled conidia formed apically. This genus is best known through $G$. ulmi, the cause of Graphium disease of elms (so-called Dutch elm disease). This fungus has Ceratostomella ulmi as its perfect stage. A number of other species are associated with other species of Ceratostemella, which cause "blue stain" of logs and lumber.

Tuberculariaceae. In this family the Genus Fusarium is of outstanding interest. Its members are known to mycologists and plant pathologists the world over, because they cause destructive blights, wilts, and root rots of cereals, fiber plants, truck crops, ornamentals, and woody plants. Its species are extremely difficult to identify, and consequently taxonomic problems have been given a generous share of attention. These matters are extensively considered in the treatise by Reinking and Wollenweber (1935). A somewhat different point of view is maintained by Snyder and Hansen $(1940,1941)$. They studied the progeny of 
cultures isolated from single spores of many so-called species of the Sections Elegans and Martiella. As a result they place 10 species, 18 varieties, and 12 forms belonging, according to Reinking and Wollenweber, to Elegans in one species, Fusarium oxysporum. From Martiella 5 parasites were placed as forms in $F$. solani, and 2 species, 3 varieties, and 1 form were placed in Нypomyces solani, a perithecial fungus. Gibberella saubinettii constitutes the perithecial stage of $F$. gramineum, which causes scab on heads of barley, wheat, and other grains.

\section{MYCELIA STERILA}

A score of genera and approximately 400 species have at one time or another been included in this non-sporiferous group. Some of them were removed from the group as their fertile stages were discovered. Many of them form sclerotia, which are compact structures of definite form, usually light-colored internally but having a dark, hard rind.

In Sclerotium is included S. rolfsii, which is especially destructive to a wide variety of wild and cultivated species in the southeastern United States. It attacks stems near the soil level. Its basidial stage is Corticium (Hypochnus). Sclerotium oryzae on rice and $S$. delpbinii on larkspur produce similar types of disease.

Sclerotium bataticola occurs in warm regions the world over, attacking the roots of a wide variety of cultivated and wild species. Its sclerotia, which are 15 to $30 \mu$ in diameter, form in abundance within the woody tissues. This organism possesses a conidial stage, designated Macropboniniza phaseoli by Ashby (1927).

The wide-spread Rbizoctonia solani causes damping-off of seedlings and stem rot of more mature plants. It has Corticium vagum as its perfect stage but appears as an arachnoid weft on the basal portion of diseased stems or over the soil surface. This fungus has characteristic coarse, septate hyphae whose lateral branches are constricted at their point of origin; a septum occurs just beyond the constriction in each lateral. Its brown sclerotia form in abundance on potato tubers.

The Rhizoctonia stage and the sclerotial stage of Corticium koleroga, causing thread blights of many species of trees. 
especially in tropical and subtropical regions, are of equal interest. Wolf and Bach (1927) regard this species as identical with $C$. stevensii on the basis of similarities in morphologic and cultural characteristics and on ability to produce reciprocal infections. Others, including Matsumoto and Yamamoto (1935), maintain that there are two separate species, mainly because of differences in sclerotial production. It does not seem reasonable, however, in view of the fact that sclerotia form sparsely on smooth surfaces and abundantly on rough surfaces, as on the fruit of Stayman apples and russet apples, respectively, and that strain differences within many single species of fungi are known, to regard C. koleroga and C. stevensii as distinct.

Ozonium possesses loose, bright yellowish masses of mycelium that may unite into strands. Its best-known species is $O$. omnivorum, commonly called the Texas root-rot fungus; its known host range includes approximately 500 species of herbaceous and woody plants, the most important of which is cotton. Sclerotia form in abundance in the soil. Sometimes a conidial stage, known as Pbymatotrichum ommivorum, is produced in large buff-colored patches over the soil surface in areas where cotton has been killed by this root-rot fungus.

Pachyma includes fungi having enormous subterranean sclerotia that have been used for food. Several have been connected with polypores. Pachyma cocos, having sclerotia that may weigh more than $20 \mathrm{lb}$, but more commonly weigh 1 to $8 \mathrm{lb}$, was shown by Wolf (1922) and Weber (1929) to be the sclerotial stage of Poria cocos. Tai and Wei (1933) reported the occurrence of this species in China, where it is known as fuhling or Chinese root and is used medicinally. It is cultivated on buried pine poles, the annual crop being more than 1000 tons. Related species include "black-fellow's bread," Polyporus mylittae of Australia, P. sapurema of southern Brazil, whose sclerotia may attain a weight of $40 \mathrm{lb}, P$. tuberaster of Italy, and the more recently described P. tuckaboe of Canada [Güssow (1919)].

In summary, the Fungi Imperfecti are of unusual interest to the student of problems involving pleomorphism and complicated developmental cycles. Even after several hundred more years of study by many mycologists it is probable that not all these problems will have been solved. 


\section{LITERATURE CITED}

Ashby, S. F., Macrophomina phaseoli (Maubl.) comb. nov., the pycnidial stage of Rbizoctonia bataticola (Taub.) Butler," Trans. Brit. Mycol. Soc., 12: 141-147, 1927.

BeNder, H. B., The genera of Fungi Imperfecti: Nortb American species and bosts, with particular reference to Connecticut. Thesis, Yale University. $2000 \mathrm{pp}$. 1931. (Unpublished.)

The Fungi Imperfecti: Order Sphaeropsidales. With keys and references for genera. 52 pp. 1934.

Colby, A. S., "Sooty blotch of pomaceous fruits," Ill. Sta. Acad. Sci. Trans., 13: 139-174, 1920.

Duke, Maud M., "The genera Vermicularia Fr. and Colletotrichium Cda.," Trans. Brit. Mycol. Soc., 13: 156-184, 1928.

Durrell, L. W., "Dry rot of corn," Iowa Agr. Expt. Sta. Research Bull., 77: 346-376, 1923.

Elliotr, J. A., "Taxonomic characters of the genera Alternaria and Macrosporium," Am. J. Botany, 4: 439-476, 1917.

Grove, W. B., British stem and leaf fungi (Coelomycetes). A contribution to our knowledge of the Fungi Imperfecti belonging to the Sphaeropsidales and the Melanconiales, Vol. I. $\mathrm{xx}+488 \mathrm{pp}$. Cambridge University Press, 1934. Vol. II. ix +406 pp. Cambridge University Press, 1937.

Guba, E. F., "Phyllosticta leaf spot, fruit blotch, and canker of the apple; its etiology and control." Ill. Agr. Expt. Sta. Bull., 256: 481-551, 1925.

"Monograph of the genus Pestalotia de Notaris. Pt. I," Pbytopatbology, 19: 191-232, 1929; Pt. II, Mycol., 24:355-397, 1932.

Güssow, H. T., "The Canadian tuckahoe," Mycol., 11: 104-110, 1919.

Henderson, M. P., "The black-leg disease of cabbage caused by Pboma lingam (Tode) Desm.," Ploytopathology, 8: 379-431, 1918.

JacQues, J. E., "Studies in the genus Heterosporium," Contrb. Inst. Botan. Univ. Montreal, 39:7-46, 1941.

Keitr, G. WV., "Peach scab and its control," U. S. Dept. Agr. Bull., 395: 166, 1917.

Kempton, F. E., "Origin and development of the pycnidium," Botan. Gaz., 68:233-254, 1919.

Lieneman, Catherine, "A host index to the North American species of the genus Cercospora," Ann. Mo. Botan. Garden, 16: 1-52, 1929.

Linder, D. H., "A monograph of the helicosporous Fungi Imperfecti," Ann. Mo. Botan. Garden, 16:227-388, 1929.

Matsumoto, T., and IV. Yanianoto, "Hypochnus sasakii Shirai in comparison with Corticinnn stevensii Burt and Corticium koleroga (Cooke) von Höhn.," Transs. Nat. Hist. Soc. Formosa, 25: 161-175, 1935.

Mercer, W. B., "On the morphology and development of Phoma richardiae, n. sp.", Mycolog. Centr., 2: 244-253, 1913.

Orton, C. R., "Structural parallelism between spore forms in the Ascomycetes," Mycol., 7:21-27, 1915. 
PETch, T., "Cordyceps militaris and Isaria farinosa," Trans. Brit. Mycol. Soc., 20:216-224, 1936.

Reinking, O. A., ANd H. W. Wollexweber, Die Fusarien, ibre Bescbreibung, Schadwirkung, and Bekampfung. viii +355 pp. P. Parey, Berlin. 1935 .

Remberg, Ruth E., "The snow molds of grains and grasses caused by Typbula itoana and Typhula idaboensis," Phytopatbology, 30:178-180, 1940.

Roark, E. W., "The Septoria leaf spot of Rubus," Plyytopatbology, 11: $327-333,1921$.

Sampson, Kathleen, "Comparative studies of Kabatiella caulivora (Kirchn.) Karak. and Colletotricloum trifolii Bain and Essary, two fungi which cause red-clover anthracnose," Trans. Brit. Mycol. Soc., 13:103-142, 1928.

Seaver, F. J., "Phyllostictales," Nortb Am. Flora, 6: 1-84, 1922.

Snyder, WV. C., And H. N. Hansen, "The species concept in Fusarium," Amr. J. Botany, 27: 64-67, 1940.

"The species concept in Fusarium, with reference to section Martiella," Ann. J. Botany, 28: 738-742, 1941.

Solhem, IV. G., "Morphological studies of the genus Cercospora," Ill. Biol. Monog., 12: 1-84, 1929.

SPRAgue, R., "Wojnowicia graminis as a very weak, secondary parasite of winter cereal crops," Plbytopathology, 25:405-419, 1935.

TAI, F. L., ANd C. T. W WI, "Notes on Chinese fungi. III." Sinensia, Contr. Metrop. Mus. Nat. Hist. Acad. Sinica, 4: 83-128, 1933.

Thом, Charles, The Penicillia. xiii $+644 \mathrm{pp}$. Williams and Wilkins Co., Baltimore. 1930.

Thom, Charles, and M. B. Church, The Aspergilli. xi +272 pp. Williams and Wilkins Co., Baltimore. 1926.

IVEBeR, G. F., "Septoria diseases of cereals," Ploytopathology, 12: 448-470, $537-585,1922 ; 13: 1-23,1923$.

"The occurrence of tuckahoes and Poria cocos in Florida," Mycol., 21: $113-130,1929$.

Wolf, F. A., "A little-known vetch disease," J. Elisha Mitchell Sci. Soc., 36: 72-85, 1920.

"The fruiting stage of the tuckahoe, Pachyma cocos," J. Elisha Mitchell Sci. Soc., 38: 127-137, 1922.

"The relationship of Microstroma juglandis (Bereng.) Sacc.," J. Elisha Mitchell Sci. Soc., 45: 130-136, 1929.

Wolf, F. A., ANd IV. J. Bach, "The thread-blight disease caused by Corticium koleroga (Cooke) von Höhn., on citrus and pomaceous plants," Pbytopathology, 17: 689-710, 1927. 


\section{AUTHOR INDEX}

Ahrens, IV. E., 205, 230

Ainsworth, G. C., 32, 39

Allen, R. F., 318, 338

Ames, Adeline, 347, 361

Ames, L. M., 11, 200, 230

Anderson, A. P., 307, 308

Anderson, P. J., 226, 230

Andrus, C. F., 205, 230, 317, 318, 338

Arens, K., 109, 111, 112, 115

Arnaud, G., 237, 241

Arthur, J. C., 312, 314, 315, 327, 328, $330,333,335,338$

Ashby, S. F., 401, 403

Ashworth, Dorothy, 326, 338

Atanasoff, D., 191, 193, 195, 197

Atkinson, G. F., 6, ${ }^{*}$ 62, 139, 191, 197, $257,266,354,358,360,361,378,379$

Ayers, T. E., 259, 266

Ayers, T. T., 126, 127

Bach, IV. J., 20, 27, 402, 404

Bache-IViig, Sara, 259, 266

Backus, M. P., 202, 230, 253, 266

Badcock, E. C., 23, 27

Ballard, IV. S., 173, 178

Bambeke, C. van, 368, 369

Banker, H. J., 346, 361

Barber, M. A., 17, 18, 27

Barbour, W. J., 184, 186

Barclay, A., 321, 338

Barger, G., 191, 195, 196, 197

Barnes, B., 85, 87

Barnett, H. L., 288, 291

Barrett, J. T., 69, 72

Bary, Anton de, 8, 9, 10, 12, 40, 41, $47,53,97,102,107,139,154,162$, $169,173,301,328,329,338,387$

Bauch, R., 279, 283, 303, 304, 308

Bauhin, Gaspard, 4, 12

Baxter, D. V., 347, 349, 361

Beardslee, H. C., 360, 361, 362

Beers, Alma H., 352, 362

Behrens, A., 91

Bender, H. B., 383, 390, 392, 394, 403
Bensaude, MI., 11, 281, 283

Berdan, Helen B., 19, 27, 74, 76

Berkeley, M. J., 8, 12, 133

Berlese, A. N., 114, 115

Bessey, C. E., 62

Berzelius, J. J., 2

Bisby, G. R., 32, 39, 52, 53, 243, 245

Bishop, H., 89, 91

Bitancourt, A. A., 167, 171

Blackman, V. H., 190, 197, 332, 333. 338

Blackwell, E., 78, 82

Blain, IV. L., 184, 186

Blakeslee, A. F., 11, 121, 122, 124, 127,128

Bliss, D. E., 109, 115

Blodgett, F. M., 176, 178

Blomfield, J. E., 45, 53

Bodman, M. C., 286

Boedijn, K. B., 292, 298, 377, 379

Boyce, J. S., 178, 179

Boyle, J. S., 346, 363

Breda de Haan, J. van, 104

Brefeld, Oscar, 8, 12, 140, 145, 149, $157,162,301,302,308$

Bresadola, J., 7, 12

Brierley, IV. B., 160, 162

Brodie, H. J., 282, 283, 284

Brooks, F. T., 220, 221, 230

Brown, A. M., 318, 339

Brown, H. B., 230, 288

Brown, IV., 17, 18, 28

Bucholtz, F., 133, 134, 274, 275

Buddin, W., 292, 298

Buhr, H., 279, 284

Buisman, Christine, 205, 230

Buller, A. H. R., 11, 127, 282, 283. 284, 286, 294, 298, 302, 318, 339. 360,361

Bulliard, P., 5, 9, 12

Burgeff, H., 122, 127

Burk, Mvrle, 45, 55

Burkholder, WV. H., 167, 171

Burlingham, G. S., 360, 361

* An italic numeral indicates that the page contains an illustration. 
Burt, E. A., 343, 344, 347, 348, 361, $362,377,378,379$

Butler, E. J., 78, 82, 100, 104, 189, 197

Butler, J. B., 64, 72

Callen, E. O., 122, 127

Camp, W. G., 46, 50, 53

Candolle, A. de, 328

Cardiff, I. D., 307, 308

Cayley, Dorothy, 188, 197

Chambers, H. S., 154, 162

Child, Marion, 228, 230

Chivers, A. H., 200, 230

Christiansen, J. J., 303, 304, 309

Christman, A. H., 333, 339

Chrzaszcz, T., 11

Chupp, Charles, 44, 53

Church, M. B., 155, 162, 395, 404

Cienkowski, L., 41, 43, 53, 54

Claussen, P., 97, 270, 271

Clements, F. E., 34, 39

Clinton, G. P., 24, 28, 102, 104, 109, $115,205,230,305,308$

Cohen, A. L., 42, 54

Coker, W. C., 87, 92, 94, 97, 290, $291,293,298,346,352,360,362$, $366,367,368,369,377,379$

Colby, A. S., 392, 403

Colley, R. H., 313, 339

Colson, Barbara, 175, 179, 202, 230, 279, 284, 362

Conard, H. S., 370, 372, 378, 379

Cook, H. T., 109, 115

Cook, W. R. I., 44, 45, 54, 75, 76, 92, 97

Cooke, M. C., 7, 12

Cooper, G. O., 97

Cooper, J. R., 228, 230

Corda, A. C. I., 6, 12, 328

Corner, E. J. H., 248, 250, 270, 271

Cornu, M., 83, 87, 317

Cotter, R. U., 334, 340

Cotton, A. D., 346, 362

Couch, J. N., 19, 28, 61, 62, 64, 66, $69,73,75,77,95,97,295,297,298$, $366,367,368,369,377,379$

Cox, H. T., 66, 73

Craigie, J. H., 11, 317, 318, 332, 339

Cunningham, G. H., 335, 339, 367, $370,372,376,377,379,380,381$

Currie, M. E., 50, 54
Curtis, K. M., 66, 68, 73

Cutter, V. M., 123, 128

Dale, E., 153, 154, 162

Dangeard, P. A., 43, 54, 76, 77, 153, $154,162,270,271,274,275,285$, 286, 287, 288, 291, 301

Darker, G. D., 243, 245

Darkis, F. R., 109, 115, 116

Davidson, R. IV., 212, 232

Diehl, H., 69, 73

Diehl, W. W., 191, 197, 381

Dietel, P., 330, 331, 339

Dixon, L. F., 109, 112, 115

Dobbs, C. G., 116, 128

Dodge, B. O., 11, 52, 54, 139, 157, $162,202,230,270,272,298,299$, $326,339,381,382$

Dodge, C. W., 139, 143, 145, 161, $162,366,367,368,369$

Doidge, Ethel M., 178, 179, 237, 241

Douglas, G. E., 354, 362

Dowding, E. S., 270, 272

Drayton, F. D., 11, 261, 262, 266

Drechsler, C., 72, 73, 94, 97, 171

Duboscq, O., 134, 136

Duke, Maud M., 393, 403

Dunegan, J. C., 261, 267

Dunn, M. S., 17, 18, 28

Durand, E. J., 266, 268

Durrell, L. W., 390, 403

Edgerton, C. IV., 17, 18, 28, 220, 222, 230, 231

Edson, H. A., 101, 104

Eftimiu, Panca, 175, 179, 280, 284, 341,362

Ehrlich, John, 187, 188, 197, 212, 231

Eidam, E., 143

Elliott, J. A., 205, 231, 398, 403

Emerson, Ralph, 78, 81, 82

Emmons, C. IV., 160, 162

Engler, A., 7, 12, 133, 198, 259

Eriksson, J., 11, 333, 334, 335, 339

Etter, Bessie E., 23, 28

Ezekiel, W. N., 17, 18, 28

Falck, K., 193, 197

Farlow, W. G., 8, 180, 182, 186

Faull, J. H., 235, 236, 335, 339

Fenner, E. Aline, 120, 128

Fischer, E., 330, 366, 367, 368, 369, $372,373,374,377,379$ 
Fitzpatrick, H. M., 87, 88, 207, 231, 294, 298, 368, 369

Fitzpatrick, R. E., 149, 150

Fleming, Alexander, 11

Fontana, Felice, 7, 12

Fox, D. L., 78, 82

Frank, B., 10

Fraser, H. C. I., 154, 162, 333, 338

Fraser, Lillian, 178, 179

Fries, Elias, 5, 12, 30, 31, 32, 39, 40, $46,133,328$

Fries, R. E., 381, 382

Fromme, F. D., 228, 231, 319, 339

Gaiser, L. O., 326, 339

Gäumann, E., 114, 115, 294, 298, 343, 362,372

Gibson, IV. H., 360, 362

Giddings, N. J., 102, 105

Giesenhagen, K., 149, 150

Gilbert, E. M., 285, 286, 287

Gilbert, F. A., 48, 50, 54

Gilbert, H. C., 48, 54

Gilbert, W. W., 160, 162

Gilkey, Helen M., 274, 275

Godfrey, G. H., 262, 266

Goldstein, Bessie, 129, 130, 132

Graff, P. IV., 177, 179

Gregory, C. T., 112, 115

Griffiths, D., 203, 231

Griggs, R. F., 74

Gross, P. M., 115, 116

Grove, IV. B., 330, 335, 339, 403

Groves, J. IV., 261, 266

Guba, E. F., 390, 394, 403

Guilliermond, A., 141, 144, 146

Güssow, H. T., 360, 362, 402, 403

Gwynne-Vaughan, H. C. I., 270, 272

Haack, G., 244, 245

Hahn, G. G., 259, 266

Haltern, F. H. van, 109, 115

Hanna, IV. F., 17, 18, 28, 281, 284, 303, 304, 308

Hansbrough, J. R., 257, 266

Hansen, E. K., 9, 144, 145

Hansen, H. N., 400, 404

Harder, R., 81, 82

Harper, R. A., 10, 11, 52, 54, 118, $128,175,179,270,272,303,308$

Harsch, R. M., 23, 28

Harter, L. L., 205, 225, 226, 230, 231

Hartig, Robert, 8, 12
Harvey, J. V., 92, 97, 98

Hetch, W. R., 78, 81, 82

Heald, F. D., 207, 231, 307, 308

Hedgcock, G. G., 321, 339, 340

Hein, Illo, 354, 362

Henderson, M. P., 390, 403

Hennings, E., 335, 339, 348

Henrici, A. T., 144, 146

Hesler, L. R., 217, 219, 231

Higgins, B. B., 211, 212, 231, 253, 267

Hildebrand, E. M., 17, 28

Hines, Lee, 334, 340

Hiura, M., 23, 24, 28, 112, 115

Hodgson, R. WV., 155, 162

Höhnel, F. von, 243, 245

Höhnk, IV., 95, 97, 98

Hollos, G., 366, 367

Holton, C. S., 303, 307, 308

Honey, E. E., 260, 261, 267

Hooke, Robert, 4, 12

Hori, S., 300, 308

Howard, F. L., 49, 50, 54

Humphrey, C. J., 347, 349, 363

Humphries, A., 64, 72

Indoh, H., 81, 82, 88, 91

Istvanffi, G., 286, 287

Ivanoff, S. S., 105, 108

Iwanoff, N. N., 11

Jackson, H. S., 294, 298, 330, 331, 340,341

Jacques, J. E., 398, 403

Jaczewski, A. de, 186

Jahn, E., 47, 48, 53, 54

Janssen, Zacharias, 2

Jeffers, W. F., 207, 231

Jenkins, A. E., 167, 171

Jenkins, IV. A., 191, 197, 211, 212, 231

Jolivette-Sax, H. D. M., 201, 231

Jones, F. R., 72, 73, 251, 257, 267

Jones, L. R., 102, 105

Jones, S. G., 219, 231, 244, 245, 257, 267

Juel, H. O., 142, 143, 146, 148, 150, 286, 287, 288, 291, 297, 299

Kamei, S., 335, 340

Kanouse, B. B., 78, 82, 88, 89, 91

Karling, J. S., 44, 45, 54, 66, 69, 73

Karsten, G., 314

Kasanowsky, V., 97, 98 
Kauffman, C. H., 360, 363

Keene, Mary L., 122, 128

Keitt, G. IV., 17, 18, 28, 397, 403

Kempton, F. E., 389, 390, 403

Kendrick, J. B., 94, 98

Kern, F. D., 321, 335, 336, 340

Kevorkian, A. G., 89, 91, 131, 132

Kharbush, S., 280, 284, 341, 362

Killian, C., 182, 186, 192, 197, 215, $231,237,241,305,308$

King, C., 91

Kirby, R. S., 219, 231

Kirchhoff, H., 192, 197

Klebahn, H., 149, 150, 209, 211, 220, $222,231,237,241,255,267,313$, $314,330,331,334,335,340$

Kniep, H., 11, 78, 82, 281, 284, 303, 304, 308

Koch, L. W., 180, 182, 186

Krieger, L. C. C., 360, 363

Krüger, F., 111, 112, 115

Kühn, Julius, 8, 12

Kühner, R., 288, 291, 352, 363

Kunkel, L. O., 45, 55, 326, 340

Kusano, S., 66, 67, 73

Lafar, Franz, 9, 12

Lagerheim, G. de, 83, 88, 290, 291, 292, 299

Laibach, F., 85, 88

Lander, Caroline A., 374, 376

Lange, J. E., 360, 363

LaRue, C. D., 17, 18, 28

Latham, D. H., 212, 232

Ledingham, G. A., 44, 55, 76, 77

Leeuwenhoek, Anthony van, 2, 144

Léger, L., 134, 136

Lehman, S. G., 226, 232

Leidy, Joseph, 134, 136

Lendner, A., 124, 128

Leus, S., 347,363

Levine, M., 280, 284

Levine, M. N., 334, 340

Lewis, C. E., 143, 146

Lewis, I. M., 201, 232

Liebig, Justus von, 2

Lieneman, Catherine, 398, 403

Lindau, G., 161, 180, 198, 208, 243, 245

Lindegren, C., 11

Linder, D. H., 293, 299, 400, 403

Lindgren, R. M., 207, 232

Linnaeus, Carl, 5, 12, 30, 32, 39
Lister, A., 41, 53, 55

Lloyd, C. G., 367, 374, 376, 377, 379, 380,382

Lohman, M. L., 245

Lohwag, H., 370, 372, 377, 379

Long, W. H., 23, 28, 335, 340, 380, 382

Lowe, J. L., 347, 363

Lutman, B. F., 44, 45, 55, 102, 105, 299, 300, 303, 308

Luttrell, E. S., 239, 241

Macbride, T. H., 41, 53, 55

MacMurran, S. M., 155, 162

Magnus, P., 331

Mains, E. B., 331, 341

Maire, R., 44, 45, 55, 286, 287

Martin, Ella M., 148, 149, 150

Martin, G. IV., 33, 34, 39, 41, 53, 55, 198, 232, 290, 291, 380, 381, 382

Massee, George, 7, 12, 41, 55, 191, $197,272,275,366,367,370,372$, 373,374

Matsumoto, T., 402, 403

Matthews, Velma D., 81, 82, 87, 92, $94,97,100,105$

McAlpine, D., 305, 308, 324, 335, 340

McCormick, F. A., 24, 28, 160, 162, 205, 230

McCranie, James, 81,82

McDonough, E. S., 111, 115

McLarty, D. A., 66, 69, 73

McLean, Ruth M., 60, 62, 109, 112, 115,116

Melhus, I. E., 107, 108, 109, 115

Melville, R., 85, 87

Mercer, W. B., 388, 403

Micheli, P. A., 4, 12, 40

Middleton, J. T., 100, 105

Miles, L. E., 220, 221, 232

Millardet, P. A., 114, 115

Miller, J. H., 163, 165, 171

Miller, J. K., 346, 363

Miller, L. W., 351, 363

Minden, $M$. von, 64, 73, 75, 77

Mix, A. J., 148, 149, 150

Miyake, K., 100, 105

Möller, A., 289, 290, 291, 294, 298, 299

Molliard, M., 380, 382

Moreau, F., 118, 119, 128, 326, 340

Moreau, Mme. F., 340

Morgan, Enid, 92, 97 
Moss, E. H., 323, 340, 354, 363

Mounce, Irene, 281, 284

Murrell, W. A., 347, 348, 352, 360, 363

Nannfeldt, J. A., 246, 250, 251, 253, $257,259,260,267,268$

Nannizzi, A., 152, 162

Nawaschin, S., 262, 267, 307, 308

Neuhoff, W., 287, 288, 291, 293, 299

Newton, Dorothy E., 281, 282, 284

Nienburg, W., 190, 197

Nobles, Mildred K., 283, 284

Odell, IV. S., 360, 362

Olive, E. IV., 42, 55, 129, 132, 330, $331,333,340$

Orton, C. R., 138, 139, 182, 184, 186, $330,340,384,403$

Osborn, T. G. B., 45, 55

Oudemans, C. A. J. A., 7, 12

Overholts, L. O., 345, 347, 360, 363

Owens, C. E., 188, 198

Pady, S. M., 313, 340

Palm, B. T., 45, 55, 107, 108

Parks, H. E., 272, 275

Pasteur, Louis, 2, 7, 144

Patouillard, N., 7, 13, 290, 291, 370, 372

Patterson, P. M., 97, 98

Percival, J., 68, 73

Persoon, C. H., 5, 13, 30, 31, 32, 39, 272, 328

Petch, T., 377, 380, 400, 404

Petersen, H. E., 104, 105

Piemeisel, R. L., 361, 364

Pierce, N. B., 148, 149, 150

Pierson, R. K., 317, 318, 340

Pinckard, J. A., 115, 116

Pinoy, Ernest, 42, 55

Poirault, G., 332, 340

Poisson, R., 134, 136

Pomerleau, R., 220, 221, 232

Prantl, K., 7, 12, 133, 198, 259

Prévost, B., 7, 13, 299, 300, 308

Quélet, Lucien, 7, 13

Rabenhorst, L., 7, 13

Rabinowitsch, L., 372, 374

Raciborski, M., 332, 340
Raistrick, H., 11

Rankin, IV. H., 226, 230

Raper, J. R., 17, 28, 95, 98

Raper, K. B., 41, 42, 43, 55, 155, 162

Rawitscher, F., 303, 304, 305, 308

Rawlins, T. E., 22, 28

Rea, Carleton, 360, 363

Reddick, D., 215, 232

Redi, F., 2

Reed, G. M., 176, 179

Rees, Olive M., 129, 130, 133

Rehsteiner, H., 374, 377

Reinking, O. A., 400, 401, 404

Remsberg, Ruth E., 392, 404

Renn, C. E., 43, 55

Rice, Mabel A., 313, 340

Riker, A. J., 22, 28

Riker, R. S., 22, 28

Roark, E. IV., 391, 404

Roberts, J. W., 261, 267

Robin, C., 134

Rodenheiser, H. A., 303, 308

Rogers, D. P., 290, 291

Rolfs, F. M., 226, 232

Rostafinski, J. T., 41, 55

Ryan, Ruth WW., 237, 241

Sabouraud, R., 11

Saccardo, P. A., 7, 13, 32, 34, 39, 134, $171,237,259,386$

Sachs, Julius, 139, 380, 382

Sadebeck, R., 148, 149, 150

Salmon, E. S., 171, 173, 175, 176, 179

Sampson, Kathleen, 394, 404

Sappin-Trouffy, P., 326, 332, 340

Sartoris, G. B., 299, 308

Satina, Sophia, 124, 128

Sawyer, W. H., 129, 132, 133, 354, 363

Schade, A. L., 89, 91

Scheffer, T. C., 207, 232

Schenk, A., 75, 77

Scherffel, A., 64, 73, 76, 77

Schilberszky, K., 67, 73

Schneider, A., 145, 146

Schrader, E., 97, 98

Schrenck, H. von, 220, 222, 232

Schroeter, J., 64, 73, 75, 77, 133, 259, 260

Schwartz, E. J., 44, 45, 54, 55

Schwartz, E. T., 45, 53

Schwarze, C. A., 118, 128 
Schweinitz, L. D. de, 5, 13

Schweitzer, G., 270, 271, 272

Seal, J. L., 104, 105

Seaver, F. J., 186, 197, 203, 232, 246, 250, 268, 272, 390, 404

Seeler, E. V., Jr., 188, 189, 197

Setchell, W. A., 305, 308

Seymour, A. B., 7, 13

Shanor, L., 85, 88, 97, 98, 191, 198

Shantz, H. L., 361, 364

Shear, C. L., 34, 39, 220, 222, 226, 232, 298, 299

Shope, P. F., 347, 364

Shunk, I. V., 22, 28

Sibasaki, Y., 105, 108

Siggers, P. V., 182

Skupienski, F. X., 42, 48, 50, 55

Sleumer, H. O., 303, 308

Smart, R. F., 48, 55

Smith, A. H., 279, 280, 284

Smith, C. O., 212, 232

Smith, D. J., 212, 232

Smith, E. C., 48, 56

Smith, Elizabeth H., 104, 105

Smith, Grant, 173, 179

Smith, R. E., 104, 105

Smith, Worthington G., 102, 105

Snell, W. H., 352, 364

Snyder, W. C., 400, 404

Solheim, WV. G., 398, 404

Sommerstorff, H., 101, 105

Sörgel, Georg, 81, 82

Spallanzani, L., 2

Sparrow, F. K., Jr., 61, 62, 64, 69, $72,73,76,77,83,85,87,88$

Spaulding, P., 220, 222, 232

Speare, A. T., 130, 133

Spegazzini, Carlos, 3, 241

Sprague, R., 391, 404

Stäger, R., 193, 196, 198

Stakman, E. C., 11, 303, 304, 309, $324,334,335,340$

Stanley, I. N., 294, 299

Steinmann, A., 292, 298

Stevens, F. L., 107, 108, 177, 178, 179

Stevens, N. E., 217, 218, 226, 232

Stevenson, J. A., 105, 108

Stoneman, Bertha M., 222, 232

Stüben, H., 81, 82

Sugano, Y., 105, 108

Swartz, Delbert, 374, 377

Swingle, D. B., 118, 128
Sydow, H., 7, 13, 178, 179, 180, 186, $236,237,241,335,340$

Sydow, P., 7, 13, 335, 340

Tai, F. L., 402, 404

Tehon, L. R., 243, 245

Thaxter, R., 83, 88, 132, 133, 134, 233,236

Theissen, F., 167, 171, 178, 179, 180, $186,236,237,241$

Thimann, K. V., 89, 91

Thom, Charles, 42, 55, 155, 157, 162, 395,404

Thomas, H. E., 354, 364

Tiffney, IV. N., 94, 98

Tiller, Ruby J., 226, 232

Tisdale, WV. H., 72, 73

Tison, A., 44, 45, 55

Togashi, K., 105, 108

Tokunaga, Y., 75, 77

Tournefort, J. P. de, 4, 13

Tucker, C. M., 102, 104, 105

Tulasne, C., 6, 9, 13, 133, 328

Tulasne, L. R., 6, 9, 13, 133, 192, 198, 328

Unger, Franz, 7, 13, 317

Vandendries, R., 281, 284

Vanterpool, T. C., 76, 77

Varitchak, B., 141, 146

Vittadini, C., 272

Wager, H., 107, 108, 111, 112, 116

Wakefield, E. M., 292, 298, 346, 362

Walker, Leva B., 133, 134, 140, 1+6,

$367,368,369,373,374,380,382$

Ward, H. M., 160, 162, 333, 340, 341

IVare, IV. M., 292, 299

Weber, G. F., 109, 112, 116, 127, 128 ,

$350,364,391,402,404$

Wehmer, C., 11

Wehmeyer, L. E., 226, 228, 232

Wei, C. T., 402, 404

IVeir, J. R., 243, 245, 346, 364

IVeiss, Freeman, 263, 267

IVelsford, E. J., 190, 197

Wernham, C. C., 45, 56

IVeston, WV. H., 109, 112, 116

Whelden, R. M., 288, 291

Whetzel, H. H., 9, 13, 262, 265, 267, 331,341 
Whiffen, Alma J., 64, 66, 74

White, V. S., 373, 374, 380, 382

White, W. L., 265, 267

Wiant, J. S., 105, 108

Wieben, Magdalene, 149, 150

Wildiers, E., 10

Williamson, H. S., 270, 272

Wilson, G. W., 107, 108, 114, 116

IVilson, O. T., 72, 74

Wingard, S. A., 145, 146

Wolf, F. A., 20, 22, 27, 28, 60, 62, $109,112,115,116,127,128,169$, $171,184,186,207,209,211,212$, $225,231,232,253,255,265,267$, $343,350,364,393,402,404$

Wolf, F. T., 78, 82, 97, 98, 169, 171
Wollenweber, H. IV., 400, 401, 404

Wood, Anna K., 220, 222, 232

Woronin, M. S., 8, 13, 44, 56, 83, 88, $262,267,341$

Woroninchin, N. N., 165, 167, 171

Yamamoto, W., 402, 403

Yates, H. S., 352, 364

Young, E. L., 43, 56

Zeller, S. M., 188, 198, 352, 364, 366, $367,368,369$

Zikes, H., 154, 162

Zimmerman, H., 192, 198

Zopf, W., 43

Zundel, G. L., 305, 306, 309 


\section{SUBJECT INDEX}

Absidia, 118

caerulea, 22

cornealis, 116

corymbifera, 116

glauca, 122 *

spinosa, 121

Acacia, 312, 313

Acantborbynchus vaccinii, 202

Acervulus, 384, 387-390

Acblya, 58, 65, 69, 93, 95, 97 annbisexualis, 95, 98

bisexualis, 95, 98

colorata, 98

flagellata, 96, 98

racemosa, 60

Achlyogeton, 75, 76

Achlyogetonaceae, 64

Achorion gypseum, 152, 162

Acrasiaceae, 42

Acrasiales, 35, 41-43

Acrotheca, 397

Actinonema rosae, 253, 267

Adelopus gäumanni, 178, 179

Aecia, 318-321

Aecidieae, 335

Aecidiolum exanthennatum, 317

Aecidium, 318, 320, 383

berberidis, 338

Aesculus bippocastannm, 211

Aethalium, 40, 49

Agaricaceae, 4, 33, 50, 341, 352, 353364

Agaricales, 38, 50, 341-364, 372

Exobasidiaceae, 341-343

Thelephoraceae, 343-345

Clavariaceae, 345-346

Hydnaceae, 346-347

Polyporaceae, 347-352

Agaricaceae, 353-364

Agaricus, 4, 32, 277

arvensis, 354,358

campestris, 358, 361, 362

conttulus, 358

tabularis, 361
Agave, 145

Agropyron occidentale, 195

Agrostis

alba, 195

caninis, 334

Aira caespitosa, 334

Albuginaceae, 58, 105-108

Albuginales, 62, 105-108

Albugo, 59, 61, 105

bliti, 105, 107, 108

candida, 105, 106, 107, 108, 115

ipomoeae-panduranae, 105

occidentalis, 105

portulacae, 105, 107

spinulosa, 107

tragopogonis, 105, 107

Aleuria anrantia, 269

Aleurieae, 268

Aleurodiscus, 343

Alfalfa, 71, 72, 251, 257

Algae, 62, 63, 64, 69, 71, 73, 75, 99

desmids, 69,75

diatoms, 69, 75

red, 235

Allantosphaeriaceae, 199, 227-228

Allomyces, 57, 69, 78

anonarlus, 81

arbuscula, $60,78,80,81,82$

cystogenus, 81,82

javanicus, 60, 78, 81, 82, 85

moniliformis, 81

Alternaria, 170, 385, 398

brassicae var. nigrescens, 398

citri, 398

longipes, 398

panax, 398

solani, 398

tenuis, 398, 399

Amanita, 277, 342, 356, 358, 360

bisporigera, 279

muscaria, 50

solitaria, 354

Amanitopsis, 356, 358, 360

vaginata, 358, 361

* An italic numeral indicates that the page contains an illustration. 
Amaranthus, 105

Amauroascus verrucosus, 153

Amazonia, 239

Ambrosia artemisiifolia, 73

Amelanchier, 336

Amerosporeae, 387

Amerosporium oeconomicum, 391, 392

Amoebidiales, 134

Amorplomyces

africanus, 234, 235

falagriae, 234, 235

Amphisphaeriaceae, 199, 207-208

Anchusa, 315, 336

Ancylistales, 74

Ancylistes closterii, 74

Andropogon, 305

Anemone, 336

Annulus, 356

Anthoxanthum odoratum, 196

Anthracnoses, 167, 219, 220, 222, 393

Antbracobia

maurilabra, 250, 270

melaloma, 248

Antlourus, 379

borealis, 378

Aphanomyces, 63, 93, 94, 95, 97

laeris, 98

Aplanes, 93, 94

Aplospora nyssae, 323

Apodachlya, 88, 89

bracbynema, 91

Apodachlyella completa, 91

Apostemidium, 268

Apothecium, 150, 151, 245, 247, 249

Apples, 143, 173, 176, 215, 217, 220, $228,336,390,392,395$

Arabis, 105

Arachis bypogaea, 212

Arachniaceae, 374, 376

Aracbnion, 380

albumn, 376

Araispora, 88, 89, 91 pulchra, 91

Arcangeliella, 369

Archimycetes, 35

Arcyria, 52

denudata, 48, 50

incarnata, 50

Armillaria, 283, 357, 358

mellea, 282, 354, 363

mucida, 281
Aronia, 336

Arthropods, 134

crabs, 135

millipeds, 135

Aschersonia

aleyrodis, 392

coffeae, 392

goldiana, 392

marginata, 392

Asclepiadaceae, 331

Ascoboleae, 268

Ascobolus, 248, 270

citrinus, 248

magnificus, 248, 272

stercorarius, 248, 272

strobilinus, 271, 272

viridis, 269

Ascochyta, 208, 385, 390

pisi, 399

Ascodesmis, 270

microscopica, 269

porcina, 270

Ascoidea rubescens, 140, 146

Ascoideaceae, 140-143

Ascomycetes, 32, 33, 35, 37, 38, 137$275,383,384$

asexual reproduction, 137-138

assimilatory phase, 137

phylogeny, 139

sexual reproduction, 138

Hemiascomycetes, 139-150

Endomycetales, 140-146

Taphrinales, 146-150

Euascomycetes, 150-275

Plectomycetes, 152-179

Eurotiales, 152-162

Myriangiales, 163-171

Erysiphales, 171-179

Pyrenomycetes, 179-245

Dothideales, 180-186

Hypocreales, 186-198

Sphaeriales, 198-232

Laboulbeniales, 232-236

Hemisphaeriales, 236-241

Hysteriales, 243-245

Discomycetes, 245-275

Inoperculates, 251-268

Helotiales, 251-267

Ostropales, 267-268

Operculates, 268-275

Pezizales, 268-272

Tuberales, 272-275 
Ascopbanus, 248, 270 carneus, 248 granuliformis, 248 isabellinus, 269

Ascospores, explosive discharge of, $19,24,193,200,262$

Ascotricha, 200 chartarum, 200

Aseroë, 379

Ash, 323

Asparagus, 337

Aspergillaceae, 152, 154-160

Aspergillales, 37, 152, 165

Aspergillus, 25, 50, 154, 160, 394 clavatus, 155

fischeri, 154

flavipes, 155

flavus, 154, 155, 157

fumigatus, 155, 157, 395

glaucus, 154, 155, 157, 162

herbariorum, 154, 162

nidulans, 154, 155, 156, 157

niger, 110, 155, 157, 395

ocbraceus, 155

oryzae, 154, 155, 157, 162

quadrilineatus, 156

repens, 154, 155, 162, 169

rugulosus, 156

variaecolor, 156

versicolor, 155

wentii, 155,157

Aspidiotus, 295

Asterina, 239, 241

Asterinella, 239

Asterostroma, 343

Astraeaceae, 373

Aulographum, 239

Auricularia, 4, 128, 279, 280, 287 auricula-judae, 293, 294, 295 mesenterica, 295

Auriculariaceae, 4, 292-295

Auriculariales, 38, 278, 284, 286, 290, 291-299

Avena, 331

sativa, 334

Avocado, 167, 222

Azalea, 263, 341

Bacterium vermiforme, 145

Badbamia, 52

lilacina, 48,50

magna, 48, 50

utricularis, 50
Bagnisiella, 167

Bagnisiopsis, 167

Balansia, 188, 191, 385, 392 bypoxylon, 191

Balsamiaceae, 274

Banana, 398

Barberry, 309, 317, 324, 328, 329, 330, 334

Barclayella, 329 deformans, 326

Barley, 195, 302, 303，307，336， 401

Basidiobolus, 57, 129 lacertae, 132 ranarum, 128, 130, 131, 132

Basidiomycetes, 32, 33, 35, 38, 39, 276-382, 383

basidiospores, 280

conidia, 282-283

diploidization, 281-282

mycelium, 280-281

types of basidia, 278-280

Heterobasidiomycetes, 284-341

Dacryomycetales, 284-287

Tremellales, 287-291

Auriculariales, 291-299

Ustilaginales, 299-309

Uredinales, 309-341

Homobasidiomycetes, 341-381

Agaricales, 341-364

Gastromycetes, 364-382

Basidiophora, 109, 110

Basidium, 344

Basswood, 187, 188

Battarea, 373

Beans, 145, 220, 222, 328, 329, 337

Lima, 225

Beech, 140, 178, 187, 188, 266, 272, 298

Beets, 71, 94, 101, 337

Benzol, 115

Beta vulgaris, 109

Bifusella striiformis, 242

Binomial system, 5, 30

"Bios," 10

Birch, 142, 188

Birds, 395

Bird's-nest fungi, 276, 380-382

Bitter rot, 222

"Black molds," 116

"Black-fellow's bread," 402

Blakeslea, 59, 127

trispora, 118, 120, 122, 123, 125, 127,128 
Blastocladia, 77,78 pringsheinnii, 77, 78, 79, 82

Blastocladiales, 36, 62, 77-82, 84, 85, 87,88

Blastocladiella, 81

Blue stain, 400

Boletaceae, 4, 361

Boleteae, 348, 351-352

Boletimus cassipes, 352

Boletus, 4, 32, 188, 190, 277, 280 parasiticus, 352 zelleri, 352

Bommerella, 200

Bordeaux mixture, 114

Botryosphaeria, 180

inflata, 167

mascarensis, 167 ribis, 167, 168, 169, 170, 171

Botrytis, 4, 260, 270, 385 cinerea, 260, 261, 266, 395, 399 conioluta, 266

Boudieria areolata, 269

Bovista, 364, 366, 375

candida, 371

nigrescens, 374

plumbea, 374

Bovistella echinulata, 371

Brachypodium silvaticum, 196

Brassica, 105

Bremia, 109, 110 lactucae, 109, 114

Brerilegnia, 95, 97 diclina, 97

Bunt, 302, 307

Cabbage, 44, 66, 101, 390

Cacao, 354

Caeonna, 318, 319, 320, 383 nitens, 339, 340

Calocera, 285

Calostoma, 373 lutescens, 371

Calostomataceae, 374

Calotheca, 114

Calvatia, 375

craniiformis, 374, 377

cyathiformis, 371

saccata, 374

Calyculosphaeria, 207

Calyptospora goeppertiana, 313

Camarophyllus virgineus, 279

Camellia, 381

Canavalia, 167
Candida, 144

Cantaloupes, 398

Cantbarellus, 283, 300, 341, 356, 357 cormucopioides, 279, 280

Capillitium, 40, 51-53

Capnodiaceae, 178

Capnodium citri, 178

Capsella, 105

Carex, 302

Carnations, 338

Carotene, 78

Carya illinoensis, 163

Caryophyllaceae, 331

Caryospora putaminum, 207, 208, 231

Castellania, 144

Castilleja, 337

Castor bean, 261

Catenaria anguillulae, 64, 72

sploaerocarpa, 66

Catostoma circunniscissum 376

Caulothyriopeltis, 239

Celery, 391

Cellulin, 88

Cellulose, 64, 77, 83, 88, 200

Celtis, 114

Cenangium abietis, 265

Cephalanthus, 323

Cepbalosporium roseum, 399, 400

Cephalidaceae, 124

Ceracea, 285

Ceratiomyxa, 48 fructiculosa, 47

Ceratomycetaceae, 233

Ceratostomataceae, 198, 199, 203-207

Ceratostomella

finnbriata, 204, 205, 206, 230, 231

ips, 205

minor, 205

moniliformis, 206

piceaperda, 205

pluriannulata, 205

pseudotsugae, 205

ulmi, 203, 230

Cercis canadensis, 212

Cercosphaerella, 209

Cercospora, 209, 211, 385, 386, 398 arachnoidea, 212

betae, 399

beticola, 398

bolleana, 209, 211, 398

cercidicola, 212

cruenta, 212 


\section{Cercospora}

lytbracearum, 211, 398

musae, 398

nicotianae, 398

persica, 212

personata, 398

rubi, 212, 232

viticola, 211

Cercosporella, 209, 385, 395

maculans, 397, 399

persicae, 397, 399

Cereals, 109, 176, 188, 219, 299, 307, $335,391,397,400$

Ceriomyces zelleri, 352, 364

Cerotelium fici, 337

Ceuthospora, 390

Chaetocladiaceae, 124

Chaetocladium

brefeldii, 120

jonesii, 120

Chaetomiaceae, 198, 200

Chaetomium, 200

Chamaecyparis

nootkatensis, 336

thyoides, 258

Cheese, camembert, 159

Roquefort, 159

Cheiymenia stercorea, 248

Cherries, 146, 176, 180, 190, 220, 253, 261, 336

Chestnut, 225

Chlorosplenium aeruginosum, 265

Choanephora, 58, 127

cucurbitarum, 116, 122, 126, 127, 128

manshurica, 118

Choanephoraceae, 124

Chokecherry, 253

Chromoblastomycosis, 397

Chrysanthemum, 338

Chrysomyxa, 326, 330

abietis, $313,316,323$

arctostaphyli, 327

ledi, 314

rbododendri, 314

Chrysopblyctis endobiotica 67

Chrysopsora, 326

Chytridiaceae, 64

Chytridiales, 19, 36, 45, 62, 63-74, 85 occurrence and cultivation, 64,66 reproduction, 66

Olpidiaceae, 66-67

Synchytriaceae, 67-68

Woroninaceae, 69
Chytridiales, Rhizidiaceae, 69

Cladochytriaceae, 71-72

Hyphochytriaceae, 72

doubtful chytrids, 73

Ciboria, 260, 261

carunculoides, 265, 267

ficariae, 260

trifoliorum, 260

Ciborioideae, 259, 262, 265

Cicada, 132

Cicer arietinum, 189

Cicinnobolus cesatii, 389

Cilia, 61

Ciliaria

asperior, 250

scutellata, 248

Cinnamon, 222

Cintractia, 301, 306

caricis, 300

montagnei, 304

Circinella

conica, 118

minor, 118

umbellata, 118

Citric acid, 157, 395

Citrus, 128, 159, 167, 178, 208, 217, $218,225,395,398$

Cladochytriaceae, 58, 64, 171-172

Cladocbytrium, 72

byalinum, 19, 27

nowakowskii, 63

replicatum, 66, 73

Cladophora, 43

Cladosporium, 167, 397

carpophilum, 397

citri, 167

cucumerinum, 397

fulvum, 397

Clamp connections, 281, 343

Classification of fungi, by Bauhin, 4

by Fries, 5

by Linnaeus, 5

by Micheli, 4

by Persoon, 5

by Saccardo, 7

by Tournefort, 4

Clathraceae, 377, 378

Clatbrus, 4, 32 cancellatus, 378

Claudopus, 353, 356, 357

Clavaria, 4, 32, 277, 285, 287

cinerea, 203, 279

cristata, 279 
Clavariaceae, 4, 341, 345-346

Clavariopsis, 287 prolifera, 290

Claviceps, 186, 187, 191, 197 paspali, 195, 196 purpurea, 191, 195, 196, 197, 198 rolfsii, 195

sesleriae, 196

wilsoni, 196

Clazochytrium stomopbilum, 65, 66

Cleistothecium, 150, 151

Clitocybe, 283, 356, 357, 360 expallens, 282

Closterium, 74

Clover, 128, 176, 182, 257, 260, 292, 313,394

Coccidioidaceae, 143

Coccidioides immitis, 143

Coccomyces, 138,385

biemalis, 252, 253, 266

lutescens, 253

prunoploorae, 253

Cocoa, 222

Coffee, 222, 283, 323, 337

Coleoptera, 233

Coleosporiaceae, 335

Coleosporium, 315, 319, 321, 323, 326, 330

solidaginis, 324, 325

sonchi-arvensis, 329

Colletotrichum, 219, 392393

circinans, 389

gloeosporioides, 20

lagenarium, 389

trifolii, 404

Collybia, 360

conigena, 281

Colus, 379

Comatrichia, 52 typhoides, 50

Commelinaceae, 343

Completoria complens, 128, 132

Compositae, 332

Conidiobolus, 128 utriculosus, 131 villosus, 131

Conifers, 313, 351

Conioplora cerebella, 281, 282, 344 Coniothyrizm, 182, 390 pyrina, 389

Convolvulaceae, 105

Coprinus, 277, 357, 358, 360 atramentarius, 23,361

\section{Coprimus}

comatus, 354

ephemerus, 280

fimetarius, 281

lagopus, 281, 283, 284, 345

micaceus, 23,281

narcoticus, 281, 282

niveus, 281

radians, 284

rostrupianus, 282, 284

stercorarius, 281

Coprobia granulata, 250

Coprophilous fungi, 116, 118, 127, $128,152,153,200,270$

Coral fungi, 276, 345-346

Cordyceps, 161, 186, 187, 385

agariciformia, 191, 197

capitata, 191

clavulata, 189, 197

-militaris, 191, 198, 400, 404

spbingum, 191

Coreopsis, 337

Corn, 66, 70, 71, 72, 300, 303. 307, 336,390

Corticium, 50, 291, 393, 401

bombycinum, 281, 282

calceum, 283

effuscatum, 283

koleroga, 344, 401, 402, 403, 404

polygonium, 281

roseo-pallens, 283

stevensii, 402,403

vagum, 343, 401

varians, 281

Cortinarius, 356,358

pholideus, 363

Corylus avellana, 175

Coryneum, 392 beijerinckii, 394

Cotoneaster, 336

Cotton, 127, 141, 189, 220, 397

Cowpea, 116, 127, 189, 392

Cranberry, 67, 202, 222, 341

Crataegus, 78, 336

Craterellus, 288 borealis, 362

Crepidotus, 353

Cribraria, 53

Cronartieae, 335

Cronartium, 315, 319, 323, 326, 330 asclepiadium, 331

cerebrum, 337

coleosporoides, 313, 337

barknessii, 337 


\section{Cronartium}

quercumm, 313, 329, 337

ribicola, 313, 316, 318, 322

Crucibulum, 381

vulgare, $371,380,382$

Crucifers, 44, 105

Cryptococcus fagi, 188, 197

Cryptomycina, 257 pteridis, 259, 266

Cryptoporus volvatus, 352

Ctenomyces serratus, 152

Cucumbers, 176, 261, 397

Cucurbitaria, 138

Cucurbitariaceae, 199, 207

Cucurbits, 109, 127

Cudonia lutea, 266

Cudonieae, 266

Cultivation of fungi, 21-27

media, 21, 22

agar, 21

pH, 22

temperature, 25

Cumninghamella

bertbolletiae, 119

ecbinulata, 119

Cupressineae, 332

Currant, 169, 187

Cyatbus, 380, 381

fascicularis, 382

stercoreus, 371, 381

striatus, 382

Cydonia, 336

Cylindrocarpon, 187, 385

Cylindrosporium, 253, 259, 307, 385, 392,394

juglandis, 399

Cymadothea trifolii, 182, 183, 184

Cystobasidium, 292

Cystopsora, 328

Cystopus candidus, 108

Cytospora, 225, 390

Dacryomyces, 280

deliquescens, 285, 286

Dacryomycetaceae, 285

Dacryomycetales, 38, 279, 284-287

Dactylis, 191

Daedalea

confragosa, 350

juniperina, 23

quercina, 349

unicolor, 281

Daldinia, 228

Dandelion, 173
Darling's disease, 143

Darluca filum, 390

Dasyscy pha, 247

ellisiana, 259, 266

pini, 259, 266

willkommii, 259

Dasyspora faceolata, 319, 320

Delacroixia coronata, 131

Dematiaceae, 387, 394, 397-400

Dematophora, 203

Dendrochium, 189

Dendrophoma, 390

Dermateaceae, 246, 251-257

Dermatophytes, 11, 152, 153

Deuteromycetes, 32, 33, 383-404 classification, 386-387

development of pycnidia and acervuli, 387-390

Sphaeropsidales, 390-392

Melanconiales, 392-394

Moniliales, 394-401

Mycelia Sterila, 401-402

Dewberry, 222

Diachaea, 46

Dianthus caryopbyllus, 398

Diaporthaceae, 199, 224-226, 228

Diaporthe, 385

citri, 20, 220, 225

parasitica, 226

phaseolorum, 225, 231

sojae, 225,226

Diatrypaceae, 227

Diatrype, 228

Diatrypella, 228

Dibotryon norbosum, 180, 181, 186

Dicranophora fulia, 121

Dictydiaetbalium plumbeum, 48, 50, 54

Dictydium cancellatum, 48

Dictyophora, 377, 378

Dictyosporeae, 387

Dictyosteliaceae, 42

Dictyostelium

discoideunn, 41, 42, 43, 55

mucoroides, 42

pupureum, 42

Dictyuchus, 58, 60, 93, 95

monosporus, 95

Dicyma ampullifera, 200

Didymella, 170

Didymellina macrospora, 398

ornitbogali, 398 
Didymizm

difforme, 50

nigripes var. xantloopus, 50

Didymosporeae, 387

Diplocarpon, 138, 253

earliana, 253, 25+, 255, 385

rosae, $253,255,385$

soraneri, 253, 256

Diplocladium minnus, 188

Diplodia, 219, 390

gossypina, 218

manilliana, 389

natalensis, 218

zeae, 390

Dipodascus, 139

albidus, 140, 142

Diptera, 233

Discedera pedicellata, 371

Discella platani, 225

Discellaceae, 387

Discomycetes, 5, 19, 31, 37, 50, 150, $236,243,245-275$

Inoperculates, 251-268

Helotiales, 251-267

Ostropales, 267-268

Operculates, 268-275

Pezizales, 268-272

Tuberales, 272-275

Discosia, 392

artocreas, 399

Dispira cormuta, 116, 126, 127

Distichlis spicata, 338

Doassansia, 302

martianoffiana, 306

sagittariae, 305

Dothichloe, 188, 191, 385, 392

Dothideaceae, 180, 182-186

Dothideales, 37, 179, 180-186, 237

Dotbidella ulmi, 186

Dothiora, 167

Dothioraceae, 163, 167-169

Dothiorella, 169

Downy mildews, 114

Draba, 105

Drepanapezizoideae, 253

Durandiomyces plillipsii, 268

Dutch elm disease, 203, 205, 400

Earthstars, 376

"Earth tongues," 266

Ebony, 222

Eccrina, 134

Ẽccrinales, 62, 134-136
Eccrinella gammari, 135, 136

Eccrinoides bemegnyi, 135, 136

Eccrinopsis bydropbilorum, 135

Echidnodella, 239

Echidnodes, 239

Echinodontum tinctorizm, 346

Ectrogellaceae, 69

Eidamella spinosa, 152

Elaphomyces cervinus, 161, 191 gramulatus, 161, 191

Elaphomycetaceae, 152, 161, 274

Elephantopus, 337

Elm, 140, 182, 187, 203, 205, 220, 400

Elsinoe, 385,397

australis, 167, 171

canavaliae, 167

fawcetti, 167, 171

piri, 167

veneta, 166

Elsinoeaceae, 163, 165-167

Elvella, 32, 248, 268, 271

elastica, 269

Elvellaceae, 246, 268

Elyminus canadensis, 192

Elytroderma deformans, 242, 243

Empusa

fumosa, 130

muscae, 132

Endoconidia, 160

Endogonaceae, 62, 133-134

Endogone malleola, 133, 134

pisiformis, 133

Endomyces decipiens, 143

mali, 143

Endomycetaceae, 140, 143-144

Endomycetales, 37, 139, 140-146

Endophyllum euphorbiae-syliaticae, 313, 321, 326

sempervizi, 326, 327, 338

Endoptychum agaricoides, 370

Endosporeae, 35, 48

Endotbia, 138 parasitica, 221, 223, 224, 226, 232, 388,389

Englerulaceae, 178

Englerulaster, 239

Enteridinm, 52 splendens, 50

Enterobrus attemuatus, 134, 136 


\section{Enterobrus}

elegans, 134, 136

spiralis, 134, 136

Enterobryus, 134

Entomopeziza, 255 soraueri, 253,256

Entomoplothora, 57, 128, 130

fumosa, 129, 133

muscae, 128,130

pseudococci, 132

sciarae, 129

sphaerosperma, 129, 132, 133

Entomophthorales, 36, 61, 62, 74, 128-132

Entomosporium maculatum, 255, 256

Entophlyctis, 73

Entyloma, 301 ellisii, 307 nymphaeae, 299, 306

Eocronartium muscicola, 294, 298, 299

Ephelis, 188, 191, 385, 392

Epicbloe, 188, 385, 392 typhina, 191, 194

Eremascaceae, 143

Eremascaceae Imperfectae, 143

Eremascus, 138, 139 albidus, 141,143

Ergot, 191, 195, 196, 197

Ericaceae, 341

Erysiphaceae, 171-176, 177

Erysiphales, 37, 171-179, 237

Erysiphe, 138, 172, 174, 175

cichoracearum, 173, 176

galiopsidis, 173, 175

graminis, 171, 173, 174, 176

polygoni, 172, 176

tortilis, 175

Escherichia coli, 42

Euascomycetes, 37, 139, 140, 141, $150-275$

Euglena, 70

Euphorbia, 313

Eurotiales, 37, 152-162

Eurotium, 154, 394 berbariorum, 154

Eusclerotinia, 259, 260

Euthamia, 337

Eutuberaceae, 274

Excipulaceae, 387, 390, 392

Exidia, 287, 288, 289

Exoascales, 37, 139
Exoascus, 149 deformans, 150

Exobasidiaceae, 341-343

Exobasidinum discoideum, 341

rhododendri, 280, 341, 342

symploci, 341

vaccinii, 341

Exosporeae, 35, 48

Fabric, mildew of, 395

Fairy rings, 361

Favus, 152

Feathers, 152, 160, 395

Fendlera, 336

Fermentation, Aspergillus oryzae, 157

germ theory of, 2, 7

Mucorales, 118

yeasts, $144-145$

Ferns, 99, 259, 294, 309, 323, 331, 337

prothallia, 128, 132

Festuca, 195

Ficus carica, 211

Figs, 145, 222, 337, 398

Fimetariaceae, 198, 199, 200-203

Fir, 331, 337

Douglas, 178, 259

white, 266

Fish, 94

Fistulina bepatica, 281, 351

Fistulineae, 348, 351

Flax, 337

Florideae, 139

Fomes

annosus, 283, 351, 363

applanatus, 23, 350, 353

igniarius, 351

obioense, 350

pini, 351

pinicola, 23

robineae, 23

robustus, 351

roseus, 23, 281

subroseus, 281

texamus, 23

Fonsecaea, 397

Fracchiaea, 207

Fraxinus, 212

Frogs, 128, 132

Fuligo septica, 40, 46, 48, 49, 50

Fungi Imperfecti, 32, 33, 35, 39, 50, $343,383-404$ 
Fungi Imperfecti, classification, 386387

development of pycnidia and acervuli, $387-390$

Sphaeropsidales, 390-392

Melanconiales, 392-394

Moniliales, 394-401

Mycelia Sterila, 401-402

Fur, 395

Fusarium, 187, 188, 19t, 385, 396, 400 oxysporum, 401

Elegans, 401

Martiella, 401

solani, 401

vasinfectum, 189

Fusicladium, 385

dendriticum, 215, 217

Fusidium, 307

\section{Galactinia}

proteana, 250

saniosa, 250

Galera silignea, 280

Gallic acid, 395

Gallowaya pinicola, 315

Gannnarus locusta, 135

Ganoderma, 280

applanatum, 363

curtisii, 23

Gasterella lutophila, 367, 368

Gastromycetes, 30, 32, 38, 46, 133, $272,276,279,280,281,298$, 364-382

Hymenogastrales, 367-369

Podaxales, 369-372

Sclerodermatales, 372-374

Lycoperdales, 374-377

Phallales, 377-380

Nidulariales, 380-382

Gautieria, 366, 369

graveolens, 368

Geaster, 4, 277, 365

fornicatus, 371

bygrometricus, 371

velutinus, 376

Geastraceae, 374

Genea, 274 ierrucosa, 273

Geoglossaceae, 246, 251, 266, 268

Geoglosseae, 266

Geoglossum, 248 difforme, 250

Geolegnia, 95
Geopyxis, 248

Geotrichum, 144

Geranizum robertianum, 237

Gibberella, 138, 385

saubinettii, 188, 194, 401

zeae, 188

Gill fungi, 276, 353-364

Gills, 357, 360

Ginseng, 398

Gleditsia

japonica, 189

triacantbos, 189

Gleotulasnella, 290

Gloeodes, 392

Gloeosporium, 219, 222, 307, 385, 392, 393

caulivorum, 394

cingulatum, 222

musarum, 389

nervisequnm, 222, 225

rufomaculans, 389

venetum, 167, 171

Glomerella, 138, 219, 220, 385

cingulata, 220

glycines, 220, 224

gossypii, 220

lagenaria, 220

lindemutbiana, 220

Glonium, 245

Gluconic acid, 395

Glyceria fluctans, 196

Gnomonia, 219, 385

dispora, 199

erythrostoma, .219, 220, 230

leptostyla, 220, 222, 385

ulmea, 220, 221, 232

veneta, 220, 222, 225

Gnomoniaceae, 199, 219-224

Gnomoniopsis, 222

Goldenrod, 337

Gonapodya, 87 polymorpha, 87

prolifera, 59

siliquaeformis, 86

Gooseberries, 176

Goplana, 295

mirabilis, 313, 328

Gossypium, 212

Grapes, 109, 176, 214, 215, 222, 393

Grapbiola phoenicis, 305, 308

Graphiolaceae, 305

Graphium, 400

ulmi, 203, 230, 400 
Grasses, 170, 171, 182, 186, 191, 193, $195,219,299,302,332,391,392$, 397

Grossularia, 336

Guepinia, 285 spatbularia, 286

Guignardia, 208, 214-215, 385, 390 baccae, 215

bidwellii, 214

Guttulinaceae, 42

Gymnoascaceae, 152-153

Gymmoascus, 152 candidus, 153

g^psenm, 162

reesii, 153

setosus, 153

Gymnoconia interstitialis, 313, 316, 318,333

Gymnomyces, 369

Gymmosporangium, 4, 315, 317, 319, $321,330,331$

bermmidianum, 336

clavariaeforme, 316

clavipes, 313, 327, 336

globosum, 336

jumiperi-virginianae, 312, 336

nidus-avis, 313

nootkatense, 336

sabinae, 330,336

yamadae, 336

Gypsum blocks, 145

Gyrocephalus, 288

Gyrostroma, 189

Hamanelis virginiana, 176

Haplosporangium, 118, 120

bisporale, 120

Harpocbytrium bedeni, 65

Hazel nuts, 145

Helicobasidium purpureum, 292, 298

Helicona curtisii, 399, 400

Helicoon reticulatum, 399

Helicosporeae, 387

Helicosporium, 400

Helmintbosporium, 171, 176

clavariorum, 203

ravenelii, 397, 399

Helotiaceae, 246, 251, 259-266, 268

Helotiales, 37, 246, 247, 251-267

Helotium, 247

Helvellaceae, 246

Helvellales, 38, 247, 274
Hemiascomycetes, 37, 133, 139-150

Hemileia vastatrix, 323, 337

Hemisphaeriaceae, 236, 237, 241

Hemisphaeriales, 37, 152, 180, 236241

Hemitricloia, 52

clavata, 50

serpula, 46, 48, 49

vesparium, 40, 50

Hempseed, 92, 100

Hendersonia opuntiae, 389

Hepatica, 336

Herbalists, 4

Hericium, 346

Hermaphroditism, 200, 201, 202, 262

Herpobasidium filicinum, 294, 298

Heterobasidiomycetes, 276, 279, 284341

Dacryomycetales, 284-287

Tremellales, 287-291

Auriculariales, 291-299

Ustilaginales, 299-309

Uredinales, 309-341

Heteroecism, 262, 312, 314, 328-332

Heterosporium, 398

ecbinulatum, 398

iridis, 398

ornithogali, 398

plolei, 398

variabile, 398

Heterothallism, 121, 281, 288, 318

Hieracium boreale, 211

Higginsia, 253, 385

biemalis, 253, 394

lutescens, 394

prunophorae, 394

Hirneola, 294

Histoplasma capsulatum, 143

History of mycology, among Greeks, Romans, 2, 3

influence of "authority," 1

invention of microscope, 2

morphologic approach, 9

Hoebneliomyces delectans, 298

Holcus, 195

Hollyhocks, 338

Homobasidiomycetes, 38, 276, 291, 341-381

Agaricales, 341-364

Gastromycetes, 364-382

Hymenogastrales, 367-369

Podaxales, 369-372

Sclerodermatales, 372-374 
Homobasidiomycetes, Lycoperdales, 374-377

Phallales, 377-380

Nidulariales, $380-382$

Homothallism, 121

"Honey dew," 193, 195, 196, 208

Hops, 109, 176

Hormodendrun, 181, 182, 397

Humaria, 247

Humarieae, 268

Hyalocyphaceae, 246

Hyalodictyae, 387

Hyalodidymae, 387

Hyalophragmiae, 387

Hyaloria, 290 pilacre, 289

Hyaloriaceae, 287, 289

Hyalospora, 323, 331

Hyalosporeae, 387

Hydnaceae, 341, 346-347

Hydnangium carneum, 280, 368, 369

Hydnobolites californicus. 273

Hydnotrya tulasnei, 273

Hydnum, 32, 288

coralloides, 346

erinaceus, 346,352

septentrionale, 347

Hydrophilus piceus, 135

Hygrophorus, 357

Hymeniales, 38

Hymenochaete, 343

Hymenogaster, 369, 372

bebrii, 368

luteus, 368

Hymenogastraceae, 368

Hymenogastrales, 38, 366, 367-369

Hymenomycetes, 11, 18, 20, 32, 50, $186,276,279,280,282,283$, 295, 341-364

Hymenoptera, 233, 297

Hyphal bodies, 129, 130

Hyphochytriaceac, 72

Hypholoma perplexum, 281

Hyphomycetes, 31, 32, 39, 386

Hypocbnus, 128, 401 sasakii, 403

terrestris, 281

Hypocreaceae, 187

Hypocreales, 37, 179, 186-198, 392

Hypocrella, 392

Hypoderma deformans, 243, 245

Hypodermataceae, 243, 392
Hypomyces, 186, 190, 194

chrysospermus, 188

lateritius, 188

ochraceus, 188

rosellus, 188

solani, 401

Hypoxylon, 228

Hysterangiaceae, 368

Hysterangium, 369

stoloniferum var. annericanum, 368

Hysteriaceae, 243, 244

Hysteriales, 37, 208， 241， 243-245, 268

Hysterium pulicare, 244

Hysterograpbium, 245

fraxini, 244

Hysterothecium, 151, 243, 244

Industrial uses of fungi, 11

Inoperculatae (chytrids), 64

Inoperculates (Discomycetes), 246, 251-268

Helotiales, 251-267

Ostropales, 267-268

Insects, 99, 186, 191, 233, 400

beetle, 233

beetle larvae, 128

butterfly larvae, 128, 191

flies, 128

plant lice, 128, 208

scale insects, 128, 163, 178, 188, 191, 292, 295, 296, 297, 392

termites, 131

International Congress, 30

lola

bookerianum, 294

javensis, 294, 298

Ipomoea purpurea, 222

Iris, 398

Irpex lacteus, 23

Isaria, 385, 400

farinosa, 400, 404

Isoachlya, 94

Isolation methods, 15-21

acidulated media, 17

contaminants, 17

dilution method, 16-17

monosporic isolations, 17-19

streak method, 16

surface disinfection, 15

Itbyphallus, 377

impudicus, 378

Iulus pusillus, 134 
Jasminum grandiflorum, 321, 338 Jelly fungi, 276, 282, 283, 284-295 Juniperus, 270, 313, 331 comminunis, 257 mexicana, 207 virginiana, 258, 312, 351

Kabatiella, 392 caulivora, 394, 404

Kalchbrennera, 379

Keitbia, 257 clbamaec y parissi, 258 juniperi, 257, 258 tetraspora, 257, 258 thujina, 258 tsugae, 258

Keys, 34-39

Ascomycetes, 37, 38 Basidiomycetes, 38, 39 classes of fungi, 34,35 Fungi Imperfecti, 39 Myxomycetes, 35 Phycomycetes, 35, 36 Kordyana polliae, 343 Kuebneola uredinis, 324 Kunkelia nitens, 313, 324, 326

\section{Laboulbenia} chaetophora, 235, 236 gyrinidarum, 235, 236

Laboulbeniaceae, 233

Laboulbeniales, 37, 152, 179, 180, 233236

Labyrintbula macrocystis, 43

Labyrinthulales, 35, 43

Laccaria, 360

Lachnea, 248

Lachneeae, 268

Lachnella, 248 pini, 259

Lactarius, 125, 280, 283, 356, 357, 360 deliciosus, 2

Lagena radicicola, 76

Lagenidiales, 36, 62, 69, 74-77

Lagenidium, 61, 75, 76 americanum, 75 entophytum, 76 giganteum, 75 rabenlborstii, 75

Lagerstroemia indica, 173

Lambertella, 263, 265

Lamproderma, 52 Lamprospora areolata, 269
Larch, 259, 337

Larkspur, 401

Lasiobolus, 292

Lasiobotrys, 176

Lasiosphaeria pezizula, 400

Late blight of potato, 102, 104

Leather, 152, 395

Lecanium, 189

Lecanosticta, 392 acicola, 184, 185

Ledum palustre, 261, 262

Leersia, 307

Legumes, 302

Leiotheca, 114

Lembosia, 239

Lentimus lepideus, 23

Lenzites abietinus, 281

saepiaria, 23, 281

trabea, 281

Leocarpus fragilis, 48, 50 .

Leotia, 289

Lepidoptera, 191

Lepiota, 356, 357, 358 clypeolaria, 361

Leptolegnia, 58, 93, 94, 95, 97 candata, 97

Leptomitales, 36, 62, 72, 87, 88-91, 98

Leptomitus, 87,88 lacteus, 89, 90, 91

Leptosphaeria, 170 avenaria, 391

Leptostroma camelliae, 381

Leptostromataceae, 251, 386, 390, 392

Leptothyrium pomi, 392

Lettuce, 109, 114, 261, 394

Leucogaster, 369

Leucophlebs, 369

Leucosporae, 358

Leveillula, 172 taurica, 173

Licea, 53

Liceales, 35, 45

Lichens, 251

Ligniera, 44, 45

Lime-sulphur sprays, 148

Liquidambar, 346

Liver fluke, 66

Liverworts, 99

Lizards, 128, 132

Logoglomeris rugifera, 135

Lophiostomataceae, 199, 208, 243 
Lopbodermium

laricimum, $2+2$

nitens, $2+2$

pinastri, 243, 245

Loquat, 222

Lychnis dioica, 300

Lycogala, 52 epidendrum, 40, 50

Lycoperdaceae, 4, 366, 374

Lycoperdales, 38, 366, 374-377, 380

Lycoperdon, 4, 32, 277, 364, 365, 373 genmmatum, 374, 375, 376

pulcherrimum, 374

pyriforme, 282, 371, 375

wrigbtii, 375

Macowanites, 369

Macrocbytrium botrydioides, 68, 72

Macropboma, 169, 390 citrulli, 389

Macrophomina phaseoli, 401, 403

Macrosporium, 170, 385, 398

Magicicada septemdecim, 132

Magnusiella, 148

Maleae, 332

Mallows, 315

Malus, 336

Mango, 222

Manina cordiformis, 346, 352

Maples, 176, 187, 188, 257, 347

Marasmius, 357

crinis-equi, 354

sacchari, 354

saramentosus, 354

Marssonia, 209, 219, 253, 392, 394

fragariae, 385

fraxini, 212

juglandis, 222, 385

rosae, 385

Marssonina

juglandis, 385

panattoniana, 394

Massospora cicadina, 129, 130, 131, 132,133

Megachytriaceae, 64

Melampsora, 314, 319, 326, 330

abietis-canadensis, 324

bigelowii, 337

caryopbyllacearum, 315

farlowii, 315, 337

lini, 318, 323, 325, 337

medusae, 327, 337

pinitorqua, 313
Melampsora rostrupii, 333

Melampsoraceae, 326, 335

Melampsoreae, 335

Melampsorella, 323, 330 caryophyllacearum, 331 elatina, 325

Melampsoridium, 323, 330

Melanconiaceae, 387, 392

Melanconiales, 39, 386, 387, 392-394

Melanconis, 226

Melanconium, 392 fuligenum, 393

Melanosporae, 358

Melasmia, 257, 258, 385, 392

Melia azadarrach, 114

Meliola, 177, 241

camelliae, 389

circinans, 177, 179

corallina, 177

Meliolaceae, 171, 176-179

Melons, 220

Meristogenous origin, 387, 388

Meruleae, 348

Merulius, 288

lacrymans, 281, 348

Micbelia velutina, 313,328

Microglossum viride, 250

Micromanipulator, 18

Microsphaera, 171, 172 berberidis, 175

grossulariae, 176

Microstronna, 343

juglandis, 364, 393, 404

Microthyriaceae, 236, 237-241, 253

Milesia, 317, 323, 331, 337

marginalis, 316

polypodopbila, 324, 327

Milium effusum, 196

Mites, 26-27

Mitrula

cucullata, 266

muscicola, 266

pusilla, 250

Molinia coerulea, 192

Mollisia, 247

Mollisiaceae, 268

Mollisioideae, 251

Monilia, 144, 260, 385

cinerea, 261

laxa, 261

sitopbila, 25

Moniliaceae, 387, 394

Moniliales, 39, 386, 387, 394-401 
Monilinia, 260, 261

fructicola, 261, 265

Monobleplarella, 85

taylori, 85,88

Monoblepharidales, 36, 62, 83-88

Monobleplaaris, 61, 82, 83, 84

fasciculata, 85

insignis, 85

macrandra, 84

origera, 85

polymiorplaa, $84,85,86$

regignens, 85

splaarica, 84,86

Monochaetia mali, 399

Monostyla, 101

Morchella, 4, 248, 271, 277

crassipes, 268

esculenta, 264, 268

bybrida, 264

Morenoella

mollenideae, 241

quercina, 238, 239, 241

Morning glory, 105

Mortierella, 120, 139

bainieri, 116

niveo-velutina, 116

Mortierellaceae, 118, 124, 133

Morus rubra, 176, 189, 212

Mosses, 266, 294

Mucedinaceae, 387

Mucilago spongiosa, 48

Mucor, 4, 25, 32, 57, 58, 118, 121, 123 biemalis, 116

javanicus, 116

mucedo, 116, 119, 122, 123

simplex, 116

Mucoraceae, 124

Mucorales, 5, 11, 36, 50, 58, 61, 62, 116-128, 133

key to families, 124

Mulberry, 397

Mushrooms, 190, 287, 289, 369

Mutinus, 377, 378 caninus, 377, 378, 379

Mycelia Sterila, 39, 386, 387, 401-402

Mycena

alkalina, 280

atkinsoni, 280

capillaris, 280

cholea, 280

citrinomarginata, 280

dissiliens, 280
Mycena

bemisploaerica, 280

lasiosperma, 280

leptocephala, 280

metata, 279

murina, 280

polygramma var. albida, 280

roseo-pallens, 280

rubromarginata var. laricis, 280

sanguineolenta, 280

stannea, 280

subalkalina, 354

viscosa, 280

vitilis, 280

Mycenastrum, 366

Mycetozoa, 40, 41

Mycochytridineae, 36, 64

Mycoderma, 144

Mycogone

perniciosa, 188, 399

rosea, 188

Mycoplasm hypothesis, 11, 333, 334

Mycorrhiza, 10, 99, 161, 272, 345, 352,354

Mycosphaerella, 138, 208-214, 385, 390, 398

aracbidicola, 212

aracbnoidea, 212

areola, 212

berkeleyi, 212

bolleana, 138, 209, 210, 211

cerasella, 211, 231

cercidicola, 212, 214

confusa, 212

cruenta, 212

effigurata, 212

fraxinicola, 209, 212, 213

bieracii, 211

bippocastani, 211

lytbracearum, 211

mori, 216, 397

nigerristigma, 211

nyssaecola, 209, 212

persicae, 212

personata, 211

polymorpha, 212

punctiformis f. tiliae, 211

rubi, 391

Mycosphaerellaceae, 199, 208-219

Mycotypha microspora, 120, 128

Myriangiaceae, 163-165, 167

Myriangiales, 37, 152, 163-171, 180, 208, 237 
Myriangium curtisii, 163, 165 duriaei, 163, 164

Mytilidion scolecosporum, 244

Myxamoebae, 40, 41, 47

Myxochytridineae, 36, 64

Myxogastres, 35, 45-53

Myxomycetes, 30, 32, 33, 34, 35, 4056

artificial culture, 50-51

capillitium, 51-53

classification, 53

feeding of plasmodia, 49-50

fusion of swarmers, 49

spore germination, 47-49

taxonomy, 41

Myxosporium, 392, 393

valsoideum, 222, 225

Myzocytium, 75, 76

vermicolum, 76

Naucoria lenticeps, 280

Nectria, 188, 385

cinnabarina, 187

coccinea, 187, 188

ditissima, 188

galligena, 188, 197

ipomoeae, 187

Nectriaceae, 187

Nectrioidaceae, 386

Needle cast, 244

Nematospora

coryli, 145

lycopersici, 145

phaseoli, 144, 145, 146

Nematosporangium, 100

Neocosmospora, 188

vasinfecta, 188, 189, 197

Nephrochytrium aurantium, 66, 74

Net plasmodia, 43

Neurospora, 11 sitophila, 202, 230

tetrasperma, 199, 202, 230

Nidula, 380,381

Nidularia, 380, 381

Nidulariales, 39, 366, 373, 380-382

Nitschkieae, 207

Nomenclature, 30, 31

generic and specific names, 31

Latin descriptions, 31

Gastromycetes, 30

Myxomycetes, 30
Nomenclature, Uredinales, 30

Ustilaginales, 30

Nummilaria discreta, 227

Nyctalis

asterophora, 283, 354

parasitica, 283, 354

Nyssa, 212, 346

sylvatica, 163

Nyssopsora echinata, 327

Oak, 146, 187, 203，222，239，272, $337,345,351,354$

Oats, 114, 195, 300, 302, 307, 336, 391

Ochrospora, 326

Ochrosporae, 358

Octavinia ravenelii, 371

Oedocephalum, 283 globuliferum, 351

Oedogonium, 69, 85

Oidiopsis taurica, 173, 179

Oidium, 173, 174

tuckeri, 176

Oleander, 208

Olivea capituliformis, 323

Olpidiaceae, 58, 64, 66-67, 69

Olpidiopsidaceae, 69

Olpidiopsis, 61, 63, 69 acblyae, 66, 69, 73

luxurians, 63, 69

saprolegnieae, 69, 73

Olpidium, 58

brassicae, 66, 67

viciae, 60,67

Ombrophiloideae, 265

Omphalia flavida, 283

Onion, 66, 109

Onygena, 160 equina, 162

Onygenaceae, 152,160

Oomycetes, 36, 60, 83-116

Operculatae (chytrids), 64

Operculates (Discomycetes), 245 246, 268-275

Pezizales, 268-272

Tuberales, 272-275

Opbiobolus, 208

cariceti, 229, 231

cariceti var. graminis, 219

graminis, 231

Opbioceras albicedrae, 207

Orbiliaceae, 246

Orchestia gammarella, 135

Oryza sativa, 308 
Ostropa, 268

Ostropaceae, 246, 267

Ostropales, 246, 267-268

Otideeae, 268

Otomycosis, 157, 395

Ovularia, 209

Oculinia, 262, 263

azaleae, 263

Oxalis stricta, 336

Oxycoccus macrocarpon, 341

Ozonium onmivorum, 402

Pachyma cocos, 364, 402, 404

Panaeolus campanulatus, 281

Panopeus herbstii, 135

Paper, 152, 159, 200

Papulospora, 245

Paradichlorobenzene, 115

Parasitella simplex, 116

Parthenium, 337

Parthenogenesis, 97, 143, 145, 228, 280

Paspalum

dilatatum, 196

floridanum, 196

laeve, 196

Passalus cornutus, 134

Patella

abundans, 270

scutellata, 269, 271

Patellina fragariae, 389

Paxina fusicarpa, 269

Peaches, 176, 207, 261, 336, 394, 397

Peach-leaf curl, 146

Peanuts, 189, 398

Pear, 187, 188, 253, 336, 395

Peas, 94, 337

Pedicularis, 337

Penicillin, 11, 160

Penicillium, 25, 50, 154, 157, 158, 394, 395

avellaneum, 158

brefeldianum, 158

camemberti, 159

crustaceum, 158, 158

digitatum, 159, 395

expansum, 159

glabrum, 116

glaucum, 158, 395

italicum, 159, 395

javanicum, 158

luteum, 158

notatum, 116, 160
Penicillium

pfefferianum, 116

purpurogenum, 159

roqueforti, 116, 158, 159

spiculisporum, 158

Peniopbora, 343

allescheri, 283, 284

gigantea, 281, 344

sambuci, 281

Peraphyllum, 336

Peridermium, 318, 319, 383

Periplasm, 89, 91, 92, 100, 107, 111

Perisporiaceae, 171

Perisporiales, 37, 150, 171

Perithecium, 150, 151

Peronea minuta, 132

Peronoplasmopara, 111

celtidis, 114

cubensis, 109

bumuli, 109

meliae, 114

Peronospora, 110, 111

alsinearum, 109

destructior, 109, 115

effusa, 109

ficariae, 115

parasitica, 116

schacbtii, 109

tabacina, 24, 59, 60, 62, 109, 111, $112,113,114,115$

viciae, 109

Peronosporaceae, 58

Peronosporales, 36, 61, 62, 98, 108-116

Pestalotia, 394

Pestalozzia, 392, 394

guepini, 389

palmarum, 389

uvicola, 399

Peyritschiellaceae, 233

Peziza, 32, 248

aurantia, 248, 250

badia, 271

repanda, 270

venosa, 271

vesiculosa, 269, 270, 271

Pezizaceae, 4, 246, 268

Pezizales, 38, 246, 247, 257. 268-272, 274

Pezizeae, 268

Pezizella, 248

Phacidiaceae, 246, 251, 257-259, 392

Phacidiales, 37, 236, 243, 247

Phaeodictyae, 387 
Phaeodidymae, 387

Phaeophragmiae, 387

Phaeosporeae, 387

Phakosporeae, 335

Phalaris arundinacea, 331

Phallaceae, 4, 377

Phallales, 38, 366, 377-380

Phallogaster, 369 saccatus, 368, 371

Phalloids, 377-380

Phallus, 4, 32, 377, 378

Phaseolus lunatus, 167

Phialophora, 397

Philadelphus, 336

Pbilocopra coeruleotecta, 201, 231

Pbleogena, 279 faginea, 298

Phleogenaceae, 290, 292, 297-298

Phleospora, 208

Pbleum, 191 pratense, 398

Phlyctidiaceae, 64

Phoenix dactylifera, 305

Plooliota, 360 praecox, 281

Ploma, 208, 390

cichorii, 389

destructiva, 389

berbarum, 388, 389

lingam, 390, 403

pyrina, 389

richardii, 388, 389, 403

subcincta, 225, 226

Phomaceae, 386

Phomales, 39, 386

Phomopsis, 225, 226, 385, 390

citri, 220, 225

juniperovora, 399

Phragmidieae, 335

Plsragmidium, 4, 326, 338

americanum, 327

incrassatum, 328

potentillae-canadensis, 333

rubi, 320

speciosum, 333

subcorticinum, 313, 323

violaceum, 316, 332

Phragmosporeae, 387

Pbycomyces, 124

nitens, 118, 122, 123, 126, 127, 128

Phycomycetes, 31, 32, 33, 34, 35, 36, $57-136,140,383$

classification, 61-62
Phycomycetes, origin, 62

repetitional development, 59-60

sexual spores, 60-61

sporangium, 58-59

thallus, 57-58

zoospores, 61

Chytridiales, 63-74

Lagenidiales, 74-77

Blastocladiales, 77-82

Monoblepharidales, $83-88$

Leptomitales, 88-91

Saprolegniales, 92-98

Pythiales, 98-105

Albuginales, 105-108

Peronosporales, 108-116

Mucorales, 116-128

Entomophthorales, 128-132

Endogonaceae, 133-134

Eccrinales, 134-136

Pbyllachora graminis, 182

Phyllachoraceae, 180, 182

Pbyllactinia, 172

corylea, 173, 174, 175, 176, 179

Plbyllosticta, 208, 211, 251, 385, 390 nyssae, 209, 212

phaseolina, 226

solitaria, 390

viridis, 209, 212, 232

Phyllostictales, 39, 386

Phyllostictina, 215, 385, 390

Phymatotrichum omnivorum, 402

Physalospora, 208, 217, 219

cydoniae, 217, 218, 219

fusca, 217, 218

gossypina, 218

rbodina, 217, 218, 219

Physarales, 35, 45

Physarella mirabilis, 52, 53

Physarum, 52

compressum, 48

connatum, 48

leucopus, 48, 49

polycephalum, 47, 49, 50, 53, 54

serpula, 49

virescens, 49

viride, 50

Physoderma, 72

zeae-maydis, 70, 71

Physodermataceae, 64

Plbysopella fici, 324

Phytophthora, 57, 58, 98, 99, 102

cactorum, 60

citropbthora, 104 
Ploytoplotbora

infestans, 8, 60,102, 104, 105, 115 nicotianae, 104 palmivora, 59, 104 parasitica, 104 phaseoli, 60

Picea, 316 engelmanni, 346 morinda, 326

Picbia mandshuricus, 145

Piersonia alveolata, 273

Piggotia fraxini, 212, 232

Pilacre, 279 faginea, 298, 299

Pileolaria toxicodendri, 324

Pileus, 359

Piline, 176

Pilobolaceae, 124

Pilobolus, 116, 127 crystallinus, 118 oedipus, 118

Pines, 182, 243, 257, 259, 265, 313, $336,337,344,392$

Pinus

monticola, 346

ponderosa, 243

sylvestris, 331

rirginiana, 315

Piptocephalidaceae, 124

Piptocephalis, 59, 139

freseniana, 116, 122

tieghemiana, 116

Piricularia

grisea, 397

ory $\approx$ ae, 397

Pisolithus, 364, 380

tinctorius, 371, 373

Pitby a cupressi, 269, 270

Plasmodiocarp, 46, 49

Plasmodiophora brassicae, 9, 13, 44, $52,54,55,56$

Plasmodiophorales, 35, 43-45, 69

Plasmodium, 40, 41, 44, 45, 46

Plasmopara, 110 riticola, 109, 112, 115

Platannıs, 346 occidentalis, 212

Platygloea, 293

Plectania coccinea, 271

Plectascales, 152-162, 200

Plectodiscella

piri, 167, 171

veneta, 167
Plectodiscellaceae, 165, 167

Plectomycetes, 37, 150, 152-179

Plectospira, 95

Pleomorphism, 31

Pleosphaeria citri, 208

Pleospora, 138, 170, 385, 398

Pleosporaceae, 208

Pleurage, 11

anserina, 138, 199, 200, 201, 230

caeruleotecta, 199

zygospora, 199, 201, 232

Pleurotus, 277, 353, 356, 357

corticatus, 283

ostreatus, 23

pinsitus, 283

Plowriglotia morbosum, 180, 181

Plum pockets, 146

Plums, 180, 253, 261, 336

Poa, 191, 195 compressa, 334 pratensis, 192

Podaxaceae, 370

Podaxales, 38, 366, 369-372

Podaxis, 370

Podaxon, 370

Podocrea alutacea, 188

Podosploaera, 172 biuncinata, 176

leucotricha, 173

oxyacantbae, 173, 176

Polygonum

chinense, 300

viviparum, 316

Polyphagus, 61 euglenae, 70

Polyporaceae, 4, 22, 50, 341, 347352,347

Polyporeae, 348, 349-351

Polyporus

abietinus, 349

anceps, 23

cinnabarinus, 23, 349

dryoploilus, 23

farlowii, 23

mylittiàe, 350, 402

obtusus, 23

pargamemus, 349

perennis, 23

sapurema, 350, 402

sulpbureus, 23, 349

tuberaster, 402

tuckaboe, 402

versicolor, 349 
Polysphondylinm purpureum, 42

Polystictus

birsutus, 23

versicolor, 23

Polystigma, 191 rubrum, 190, 197

Polystomellaceae, 236, 241

Polytbrincium trifolii, 183, 184

Pomegranate, 398

Poplar, yellow, 188

Populus, 337 deltoides, 222

Pore fungi, 276, 347-352

Poria, 349 $\operatorname{cocos}, 350,364,402,404$ incrassata, 349, 363 vaporaria, 349

Porteranthus, 336

Portulaca oleracea, 105

Potato, 45, 67, 261, 292, 398

Pourthiaea, 336

Powdery mildews, 171-176

Privet, 222

Prospodium badhamiense, 323 plagiopus, 323

Prosthecium, 226

Protoachlya, 95

Protocoronospora, 392 nigricans, 393, 394

Protodontia, 288

Protogaster rbizoplilus, 368

Protogastraceae, 368

Protohydnum, 287

Protomerulius, 288

Protozoa, 62

Prunes, 207

Prumus, 394

americana, 253

avium, 253

cerasus, 211,253

domestica, 253

pennsylvanica, 211, 253

persica, 212

serotina, 253

virginiana, 253

Psalliota, 357, 358

campestris, 279, 280, 284, 355, 362

Pseudococcus calceolariae, 132

Pseudopeziza, 385

medicaginis, 257, 267

trifolii, 257, 267

Pseudopezizoideae, 257
Pseudoplasmodium, 41, 43

Pseudoplectania nigrella, 269

Pseudosphaeriaceae, 163, 169-171, 208

Pseudotsuga taxifolia, 259, 346

Pseudovalsa, 226

Psychotria, 295

Pteridium

aquilinium, 337

latiusculum, 259

Pteris biaurita, 146

Puccinastreae, 335

Puccinia, 4 adoxae, 333

antirrbini, 338

asparagi, 337

caricis, 313

chrysanthenin, 324, 338

claytoniata, 319

coronata, $317,318,324,327,331$, 336,338

deformans, 333

dispersa, $315,336,340$

fraxinata, 323

glumtarumm, 336

gramininella, 330

graminis, 309, 310, 314, 317, 318, $323,324,328,334,335,336$, $338,339,340$

agrostidis, 334

airae, 334

avenae, 334, 336

poae, 334

secalis, 334, 336

tritici, 334, 336

grindeliae, 318, 327

belianthi, 317, 318, 339

malvacearum, 315, 329, 333, 338

mesneriana, 331

monopora, 323

peckiana, 340

perplexans, 323

poarum , 323, 333

podopbylli, 324, 327, 331, 341

pringsheinniana, 317, 318

rubigo-rera, 336

senecionis, 321

seymouriana, 323

sorghi, 318, 336, 338

subnitens, 337, 338

triticina, 318, 324, 336, 338

verbenicola, 323

vexans, 312 
Puccinia

vivipari, 316

xantbi, 318

Pucciniaceae, 326, 335

Pucciniastrum, 314, 323, 330

Puffballs, 4, 40, 276, 361, 364-369, 372-377

Pulvinula constellatio, 250

Punica granatum, 211

Pure culture, disadvantages of, 14 hanging-drop cultures, 21

Pycnia, 315-318

Pycnidium, 384, 387-390, 388, 391

Pyronema confluens, 138, 246, 248, $268,270,271,272$

Pyrenomycetes, 5, 19, 31, 37, 50, 150, $179-245,257$

Dothideales, $180-186$

Hypocreales, 186-198

Sphaeriales, 198-232

Laboulbeniales, 232-236

Hemisphaeriales, 236-241

Hysteriales, 243-245

Pyrenopeziza, 248, 251

medicaginis, 251, 267

Pyreinophora, 170, 171

tritici-repentis, 165

Pyrus, 336

Pythiacystis citrophtbora, 104

Pythiales, 36, 62, 69, 98-105

Pytliomorpha gonapodioides, 59, 60, 104

Pythiopsis, 58, 93, 94

Pythinm, 58, 61, 98, 100, 103, 104 aphanidermatum, 101

de baryanum, 100, 101, 103, 105

diacarpum, 60

echimulatum, 103

proliferum, 59, 60

ultimum, 101

Queletia, 373

Quercus, 346

agrifolia, 272

Questieria, 239

Quince, 336

Radish, 94, 101

Raisins, 145

Rammularia, 208, 209, 211, 385, 395 areola, 212, 397

Ramularisphaerella, 209

Ranunculaceae, 317, 331, 332

Ranunculus ficaria, 260
Raphanus, 105

Raspberry, 167

Ravenelia, 326, 329

cassiaecola, 327

pygmea, 313

volkesnii, 313

Ravenelia, 326, 329

Relative sexuality, 89, 95

Resistant sporangia, 77

Reticularia lycoperdon, 50

Rhamnus, 324, 331, 336

Rheosporangium aphanidermatum, 101, 104

Rbinosporidium seeberi, 143

Rhinotrichum, 298

Rbipidium, 88, 89, 91

europaeum, 91

Rhizidiaceae, 58, 64, 69-70, 72

Rhizidiomyces apophysatus, 19, 61, 65,66

Rbizina inflata, 250, 269

Rbizoclonium, 101

Rbizoctonia

bataticola, 403

crocorum, 292, 298, 299

solani, 25, 344, 399, 401

Rbizophidium

carpopbilum, 19, 66

globosum, 65

multiporum, 19, 66

ovatum, 69

pollinis-pini, 69

Rbizopogon, 133, 369

nigrescens, 371

Rbizopus, 4, 118, 124

nigricans, 61, 116, 117, 118, 122,

124,128

oryzae, 116

sexualis, $121,122,127$

Rbodochytrizm spilantbidis, 73

Rbododendron, 263

catawbiense, 341

maximum, 341

Rhodophyceae, 139, 235

Rhodosporae, 358

Rbopobata vacciniana, 132

Rbynchophoromyces rostratus, 234, 235

Rbyparobius, 268, 270

Rhytisma, 257, 385, 392

acerinum, 257, 258, 267

Ribes, 266, 336

grossularia, 176 
Rice, 114, 307, 397, 401

Ricinus commmunis, 261

Robergea, 268

Roestelia, 318, 319, 321, 383 cancellata, 330

Rosaceae, 317

Rosellinia

clavariae, 203 quercina, 203

Roses, 176，253，313，328，338，394

Rotifers, 101

Rozella, 69

Rubus, 212, 313, 391

Russula, 125, 280, 283, 356, 357, 360

Rusts, 276, 279，281，283，291，295, 309-341, 390

Rutstroemia, 262, 263, 265

Rye, 192, 195, 196, 303, 307, 315, 328, 336,391

Sabina sabinoides, 231

Sabouraudites gypseum, 162

Saccardiaceae, 163

Saccharomyces

cerevisiae, 144, 145

ellipsoideus, 144, 145

mellacei, 145

piriformis, 145

pombe, 145

sake, 145

Saccharomycetaceae, 140

Saccharomycetales, 37, 139, 144-145

Saccoblastia intermedia, 293, 299

Saccobolus violascens, 248

Sake, 145

Salamanders, 132

Salix, 337

Salsify, 105

Saprolegnia, 57, 58, 61, 69, 93, 94, 97

ferax, 98

monoica, 59, 96

parasitica, 94, 98

Saprolegniales, 19, 22, 36, 60, 61, 62, $69,89,92-98,134,141$

Sapromyces, 88, 89, 91 androgynus, 89, 90 reinschii, 89,91

Sarcoscypha, 248

Sarcoscypheae, 268

Scale insects, $128,163,178,188,191$, $292,295,296,297,392$

Schizomycetes, 32
Schizopbyllum commune, 281, 354

Schizosaccharomyces

ludwigii, 145

octosporus, 14t, 145

Scbizoxylon, 268

sepincola, 268

Schnallenzellen, 281

Scirrbia acicola, 182

Scleroderis

abieticola, 266

ribis, 266

Scleroderma, 364, 366

bovista, 372

geaster, 366, 371, 373

Sclerodermataceae, 373, 380

Sclerodermatales, 39, 366, 372-374, 380

Sclerospora, 110

graminicola, 23, 28, 109, 112, 114, 115,116

macrospora, 114

Sclerotia, 191, 192, 193, 195, 260

Sclerotinia, 11, 248, 259-262, 265, 385, 395

antericana, 261

cinerea, 261

fructicola, 261

fructigena, 261

gladioli, 262, 263, 266

beteroica, 261, 267

ricini, 261

sclerotionum, 261

trifoliorum, 260

utrnula, 260, 261

Sclerotiniaceae, 265

Sclerotium, 391

bataticola, 401

delphinii, 401

oryzae, 401

rolfsii, 25, 401

Scolecosporeae, 387

Scorias spongiosa, 178

Scrophulariaceae, 331, 337

Sebacina, 287, 288

prolifera, 290

Secale cereale, 334

Secotiaceae, 370

Secotium, 372 agaricoides, 370, 372

Sedges, 332

Senecio, 337

Sepedonium, 194

chrysospermum, 188 
Septobasidiaceae, 292, 295-297

Septobasidium, 279, 295 pseudopedicellatum, 296

Septonema, 245

Septoria, 208, 385, 386 apii, 391

avenae, 391

glycines, 399

beliantloi, 389

lycopersici, 390, 391

nodorum, 391

polygonorum, 388, 389

rubi, 391

scrophulariae, 389

secalis, 391

tritici, 391

Septoriosphaerella, 209

Septotinia, 262 podopbyllina, 265

Serratia marcescens, 42

Sesleria coerulea, 196

Setaria viridis, 115

Shot-hole diseases, 253

Shropshiria, 305

Sida spinosa, 127

Simblum sphaeroceplaalum, 378, 379

Sirobasidiaceae, 287, 290

Sirobasidium, 290

Sirolpidiaceae, 69

Slime flux, 140

Slime molds, 40-56

Smuts, 276, 283, 299-309

Snapdragons, 338

Sommerstorffia, 95 spinosa, 101

Sonchus, 337

Sooty molds, 171, 176-178

Sorbus, 336

Sordariaceae, 198, 200-203

Sorghum, 307

Sorocarp, 41, 42

Sorodiscus, 44,45

Sorosplacera, 44,45 veronicae, 53

Sorosporium, 306 reilianum, 308

Soybeans, 189, 220, 226

Sparassis

crispa, 346

radicata, 346, 364

Spartina, 323

Spermogonia, 315-318
Spermopbthora gossypii, 140, 141, 142

Sphacelia, 187

Splaceloma, 167, 385, 397

perseae, 167,171

Sphacelotheca, 301, 306

reiliana, 307

sorghi, 307

Spbaerella nigerristigma, 389

Sphaeria

bidrvellii, 215

cariceti, 219

Sphaeriaceae, 198, 203, 207

Sphaeriales, 37, 169, 179, 180, 182, $198-232,243$

Chaetomiaceae, 200

Fimetariaceae (Sordariaceae), 200203

Sphaeriaceae, 203

Ceratostomataceae, 203-207

Cucurbitariaceae, 207

Amphisphaeriaceae, 207-208

Lophiostomataceae, 208

Mycosphaerellaceae, 208-219

Gnomoniaceae, 219-224

Diaporthaceae, 224-226

Allantosphaeriaceae, 227-228

Xylariaceae, 228-230

Sphaerobolaceae, 373

Sphaerobolus, 366, 380 iowensis, 373, 374, 382

stellatus, 373, 374, 382

Sphaerocladia, 81

Spbaeronema fimbriata, 205

Splaaeronemella fragariae, 389

Sphaeropsidaceae, 31, 386, 390-392

Sphaeropsidales, 39, 386, 390-392

Splaaeropsis, 219

citricola, 389

malorum, 218, 389

Sphaerosporangium, 100

Sphaerosporeae, 268

Sphaerostilbe, 186

Sphaerotbeca, 172, 175, 179

castagnei, 173

bummli, 172, 176

mors-uvae, 176

pannosa, 176

Sphagnum, 307

Spinacea oleracea, 109, 398

Spinach, 105, 307

Spiraea, 323

Spirobolus marginatus, 134 
Spirogyra, 65, 69

Spongospora subterranea, 44, 45, 51, 55

Spontaneous generation, 1, 2, 300

Spores, types of, 32, 37

Sporobolus, 323

Sporodesmium, 245

Sporodinia, 124 grandis, 118, 121, 122, 123, 125

Sporodochium, 384

Sporonema

pbacidioides, 251

platani, 222

Sporormia, 199

coeruleotecta, 201

Sporotrichum, 200

globuliferum, 399

Sporozoa, 45

Squash, 116, 176

Staurosporeae, 387

Stellaria media, 109

Stemonitales, 35, 45

Stemonitis

ferruginea, 50

fusca $, 50,52,53$

splendens var. flaccida, 50

Stemphylium botryosum, 399

Stereum, 344

frustulosum, 345, 351

gausapatum, 345

birsutum, 282

Sterigmatocystis, 154

Stictidaceae, 268

Stictis, 268

Stigeoclonium, 69

Stigmatea, 255

potentillae, 237

robertiani, 237, 239, 241

Stigmateaceae, 236, 237

Stigmatomyces baeri, 237, 235

Stigmina polymorpha, 212

Stilbaceae, 387, 394, 400

Stilbella, 189

Stilbum, 283 vulgare, 297, 299

Stinkhorns, 276, 377-380

Stipa, 330

Stomatogene, 176

Strawberries, 253, 255, 394

Streptotheca, 268 crouani, 269

Strobilomyces strobilaceus, 352

Stromatinia, 259, 260
Stylina, 305

"Substitute sexuality," 202

Sugar beets, 398

Sugar cane, 354

Sunflower, 317,337

Swarm cells, 47

Sweet potato, 105, 116, 188, 205

Sycamore, 220, 222

Symphogenous origin, 387,388

Symplocus tinctoria, 341

Syncephalastrum, 119

Syncephalis, 59, 119

Synchytriaceae, 58, 64, 67-68

Synchytrium, 61

endobioticum, 60, 66, 67, 68, 71, 73

fulgens, 66, 73

vaccinii, 67

Synnema, 384

Systremma

acicola, 182, 184, 185, 392

ulmi, 182, 184

Taeniellopsis flexilis, 135

Taka diastase, 395

Tapbrina, 342

aurea, 149

carnea, 148

cerasi, 146

coerulescens, 146

coryli, 148, 150

deformans, 26, 149, 147, 148, 149, 150

epiphylla, 149

jobansonii, 148

klebabni, 149

mirabilis, 146

pruni, 146

sadebeckii, 149

tosquinetii, 149, 150

Taphrinales, 37, 139, 140, 146-150

Taphrinopsis laurencia, 146, 148

Tar spot, 257

"Target spot," 188

Tea, 222

Telia, 325-328

Teosinte, 71

Terfeziaceae, 152, 161, 274

Testicularia, 302

Tetramyxa, 44

Texas root-rot fungus, 402

Thalictrum, 336

Thamnidiaceae, 124 
Thamnidium, 58 elegans, 118

Thecoplora, 301 deformans, 302, 304

Thekopsora areolata, 329

Thelephora fimbriata, 344 terrestris, 344

Thelephoraceae, 22, 291, 341, 343-345

Theotheca, 268

Thielaria

basicola, 159, 160, 162

sepedonium, 160

terricola, 160

Thraustotbeca, 93, 95, 97 clarata, 98

Thuja occidentalis, 258

Thvriothecia, 236

Tbyronectria, 188 austro-annericana, 189

Tilia cordata, 211

Tilletia, 301

corona, 307

borrida, 307

levis, 307

splaagni, 307

tritici, 300, 302, 303, 305, 307

Tilletiaceae, 302, 305

Titania, 226

Tobacco, 66, 101, 104, 109, 155, 160, 398,400

Tolyposporella, 306

Tolyposporium, 302

Tomato, 45, 101, 145, 391, 392

Tomentella

flava, 283

granulata, 283

Trannetes

annericana, 281

peckii, 23

serialis, 23

Tranzschelia pruni-spinosae, 323, 324, 336

Tremella, 288, 290

fuciformis, 287

lutescens, 290

mesenterica, 289

mycetopbila, 287

Tremellaceae, 287

Tremellales, 38, 279, 284, 286, 287291

Tremellineae, 31

Tremellodendron, 287, 288
Tremellodon, 287

Triclia floriformis, 50

Trichiales, 35, 45

Trichocyphella, 259

Trichocyphelloideae, 259

Trichoderma, 25

viride, 399

Trichoglossum birsutum, 250

Tricholoma, 356

Trichopeltaceae, 236, 237

Trichophytoneae, 152

Trichospora, 326

Trichotbecium candidum, 188

Trichothyriaceae, 241

Trichotbyrium sarciniferum, 241

Triploragmium ulmariae, 323, 333

Triticum vulgare, 334

Truffles, 4, 133, 161, 272-275

Tsuga, 346

canadensis, 258, 315

Tuber, 4

aestivum, 274

brumale, 273, 274

dryopbilum, 274

excaratum, 274

magnatum, 274

melanosporum, 274

nitidum, 274

Tuberales, 38, 152, 161, 272-275

Tubercularia, 385

vulgaris, 187

Tuberculariaceae, 38, 394, 400-401

Tuburcinia, 302

trientalis, 300

Tulasnella, 290, 291

Tulasnellaceae, 290

Tulostoma, 279, 373

Tulostomataceae, 373, 374

Tylostoma, 373

campestre, 371

manmosim, 371

Tympanis pinastri, 257

Typlusula, 391

gramineum, 392

idaboensis, 392, 404

itoana, 392, 404

Ulmes crassifolia, 270

Uncinula, 172

circinata, 176

clandestina, 175

geniculata, 176

lagerstroemiae, 173 


\section{Uncinula}

necator, 176

salicis, 173

Underwoodia columinaris, 269

Uredinales, 30, 38, 262, 278, 282, 292, 309-341, 383

classification, 335

heteroecism, 328-332

important species, 335-338

mycoplasm hypothesis, 333-334

sexuality, 332-333

sori and spore forms, $315-328$

specialization, 334-335

Uredinella coccidoploaga, 295 spinulosa, 295

Uredinia, 321-324

Uredinopsis, 323, 331

macrosperma, 337

mirabilis, 324

osmundae, 327

Uredo, 383

dispersa, 341

linearis, 328

rosae, 328

Urmula

craterium, 2'71

geaster, 268, 269, 270

Urocystis, 302

occulta, 303, 306, 307

Uromyces, 314, 330

appendiculatus, 318, 328, 329, 337,

caladii, $313,333,340$

caryophyllinus, 327,338

cunninghamianus, 321, 338

dactylidis, 323

erytbronii, 320

fabae, 318, 324, 337

ficariae, 333

levis, 327

poae, 333

scutellatus, 327

trifolii, 313

trifolii-bybridi, 318

vignae, 318,338

Uromycladium

maritimum, 315

notabile, 312,315

robinsoni, 315

tepperianum, 312

Urophlyctis alfalfae, 72, 73

Uropyxis amorphae, 327

Urtica parviflora, 313

Ustilaginaceae, 278, 302, 305
Ustilaginales, 30, 38, 278, 282, 299309

Ustilago, 301, 306

avenae, 300, 302, 307, 308

bromivora, 302, 304, 308

esculenta, 300, 308

grandis, 308

beufleri, 299

bordei, 299, 300, 304, 307

levis, 300, 304, 307, 308

longissima, 304

nuda, 302, 303, 304, 307

olivaceae, 302

panici-frumentacei, 304

scabiosae, 301, 303

treubii, 300

tritici, 299, 300, 303, 304, 307

violacea, $300,304,306,308$

zeae, 26, 299, 300, 302, 303, 304, 306, 307, 308, 309

Vaccinium, 313, 341

uliginosum, 261, 262

vitis-idaea, 261

"Valley fever," 143

Valsa, 225

leucostoma, 225, 226

Valsaceae, 227

Van Tieghem cells, 20, 21

Vaucheria, 43

Venturia, 138, 208, 215-217, 385 inaequalis, 215, 217, 231

Verbena, 323

Verbenaceae, 331

Vermicularia, 392, 393

Veronica chamaedrys, 53

Verticillium, 188, 200 globuligerum, 188

Vetch, 394

Vibrissea, 268

Vicia

faba, 50

sativa, 393

sepium, 109

Vigna sinensis, 212

Vitis, 211 vinifera, 109

Volatile fungicides, 114-115

Volutella circinans, 389

fructi, 389

Volva, 356

Volvoboletus, 352 
Walnut, 188,220

Watermelon, 222

Wheat, 114, 195, 300, 302, 303, 307, $309,328,329,330,336,391$, 401

"White rusts," 105, 107

IVillia anomala, 144, 145

Witches' broom, 243, 313

IVojnowicia graminis, 391, 404

Woronina, 69

Woroninaceae, 64, 66, 69

IV ymea annericana, 269

Xenodochus carbonarius, 327

Xenosporella, 400

Xylaria

bypoxylon, 228

mali, 228

Xylaria

polymorpha, 228

tentaculata, 228

Xylariaceae, 199, 228-230

Yeasts, 9, 10, 11, 50, 144-146, 283, 299, 342

Zea mays, 115

Zizania latifolia, 300

Zoophagus, 99

insidians, 101, 105

Zostera marina, 43, 55

Zygomycetes, 36, 60, 116-134

Zygorbynchus, 121

dangeardi, 122

beteroganmus, 60, 122

Zythiaceae, 386, 390, 392 



